\title{
LOS ÁCIDOS APLICADOS COMO HERRAMIENTA DE MODIFICACIÓN DEL COLOR EN LOS ACABADOS DE LAS MADERAS DE CONSTRUCCIÓN.
}

\section{TESIS DOCTORAL}

\author{
AUTOR DE LA TESIS: \\ D. FRANCISCO LORA TORO \\ Arquitecto por la Universidad Politécnica de Madrid
}

\begin{abstract}
DIRECTORES DE TESIS:
Dr. D.ALFONSO GARCÍA SANTOS

Doctor Arquitecto por la Universidad Politécnica de Madrid

Y

Dr. D.ANTONIO RODRÍGUEZ RODRÍGUEZ.

Doctor Arquitecto por la Universidad Politécnica de Madrid
\end{abstract}



Tribunal nombrado por el Sr. Rector Magfco. de la Universidad Politécnica de Madrid, el día. de. de $20 \ldots$.

Presidente:

Vocal:

Vocal:

Vocal:

Secretario:

Suplente:

Suplente:

Realizado el acto de defensa y lectura de la Tesis el día de. .de $20 \ldots$ en la E.T.S.I. /Facultad.

Calificación

EL PRESIDENTE

LOS VOCALES

EL SECRETARIO 



\section{AGRADECIMIENTOS}

Al final del camino vuelves la mirada atrás y puedes contemplar todas las personas que te han ayudado a recórrelo, sin ellas no hubiese sido posible recorrerlo, y ni siquiera hubiese existido ese camino, por lo que dedico esta tesis a todas ellas.

A mis Padres, Crista y Bartolomé, ellos me dieron el mejor de los regalos, su amor, me apoyaron en todo, toda su vida, y sin ellos ni esta tesis ni vida hubiese sido posible.

A mi novia Teresa, que con su ejemplo de esfuerzo, voluntad, paciencia y generosidad, me ha ayudado en esta tesis aconsejándome y apoyándome, tanto desde el punto de vista humano como el técnico en lo concerniente a la química, y también a su familia Alicia, Belén, Sergio, Federico y Samantha, que han apoyado en cuestiones técnicas y a David Padre e hijo, María Jesús y María, por estar ahí.

A mis hermanos Marian, Inmaculada, Silvia, Bartolomé y Mercedes, que recibieron la misma educación de mis padres y gracias a su generosidad, apoyo y cariño he podido realizar esta tesis, y también a sus parejas Antonio, Manuel, Pedro, Celia y Enrique, que siempre han estado ahí también apoyándome.

A todos mis sobrinos, en especial a Rocío, Samuel, Aarón, David, porque me han ayudado, con todo su cariño en cuestiones técnicas y a mi sobrino Jonathan y a Belén García Francoy por su inestimable ayuda en la traducción de artículos indexados.

A mis directores de tesis, Antonio Rodríguez Rodríguez y Alfonso García Santos, que siempre me han dado ánimos y apoyo, además de darme consejos útiles para realizar esta tesis, donde Antonio me ha apoyado solucionando necesidades logísticas y de medios y también en lo referente a lo profesional y personal y Alfonso con sus reflexiones sobre la tesis, apoyo en lo personal y sentido de la vida, y mostrándome como resolver estrategias, publicaciones y congresos.

A mis compañeros de tesis Rebeca, Jorge y Pablo, que con su apoyo personal y profesional me han ayudado en esta tesis.

Y por encima de todo, mi agradecimiento a Dios, que hizo posible su comienzo y terminación. 



\section{ÍNDICE}

1. RESUMEN

2. HIPÓTESIS

3. OBJETIVOS

4. ESTADO DEL ARTE

5. INTRODUCCIÓN y METODOLOGÍA

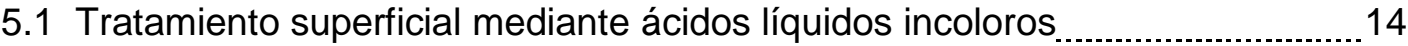

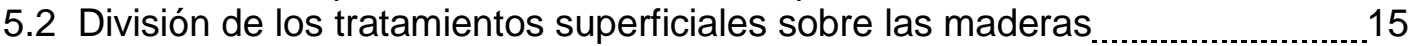

5.3 Tratamiento tradicional químico 15

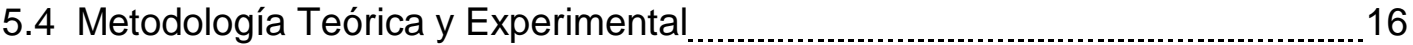

5.5 Conclusiones al capítulo

6. ESTUDIO DEL ANÁLISIS DEL COLOR y LA IMAGEN DIGITAL $\ldots \ldots \ldots \ldots \ldots \ldots \ldots . . . . . .19$

6.1 El espacio de color

6.2 El espacio de color CIELAB

6.3 El espacio de color RGB

6.4 El espacio de color CMYK 24

6.5 Imagen digital, parámetros de utilización e Histogramas 25

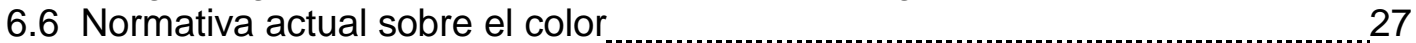

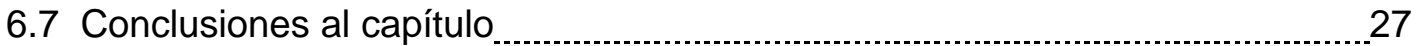

7. ELECCIÓN DEL ESPACIO DE COLOR RGB

7.1 Espacio RGB y transformación con otros espacios .......................................30

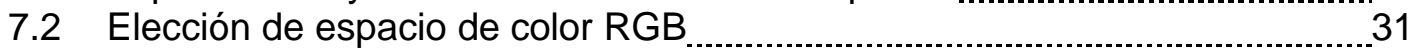

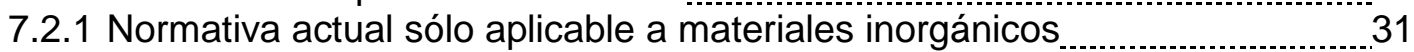

7.2.2 Determinantes de la elección del espacio RGB

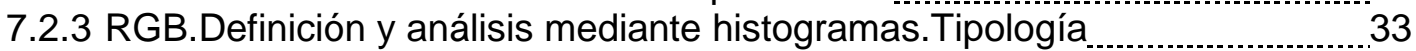

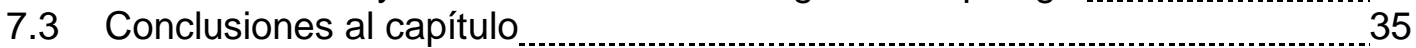

8. CLASIFICACIÓN BOTÁNICA y MORFOLOGÍA DE LAS MADERAS. PRODUCTOS DE MADERAS DE CONSTRUCCIÓN …............................... 37

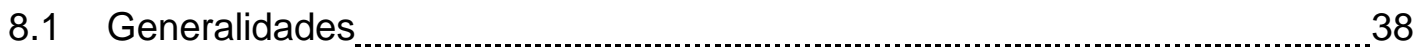

8.2 División XVI - Gimnospermas (Coníferas)

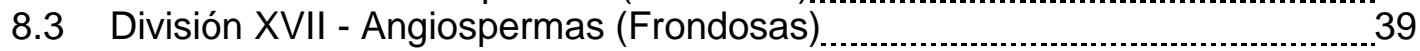

8.4 Estructura general de la madera

8.5 Propiedades generales de la madera

8.5.1 Humedad en la Madera

8.5.2 Secado de la madera

8.5.3 Propiedades Físicas y mecánicas

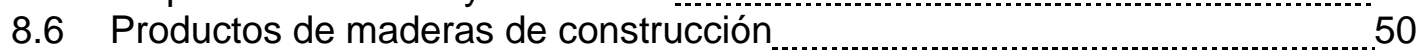

8.7 Conclusiones al capítulo 
9. CLASIFICACIÓN y DESCRIPCIÓN QUÍMICA DE LOS ÁCIDOS

9.1 Generalidades de la materia

9.2 Propiedades generales de los ácidos

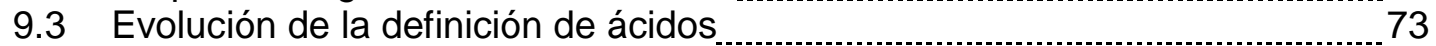

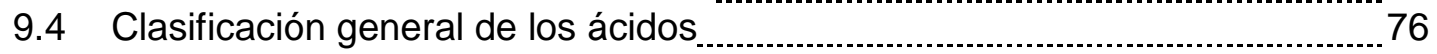

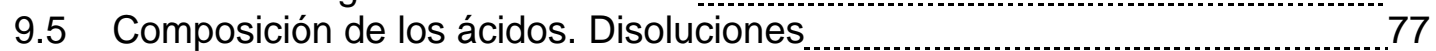

9.6 Fuerza de los ácidos

9.7 Constante de acidez $\mathrm{Ka}$ e índice $\mathrm{Pka}$.Indice de acidez en agua $\mathrm{PH} \ldots \ldots \ldots . . . . . . .80$

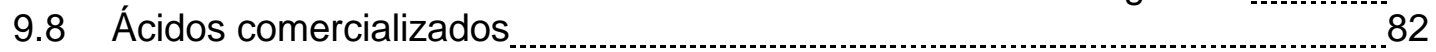

9.9 Conclusiones al capítulo

10. FASE EXPERIMETAL

11. PARÁMETROS DE ELECCIÓN DE MATERIALES

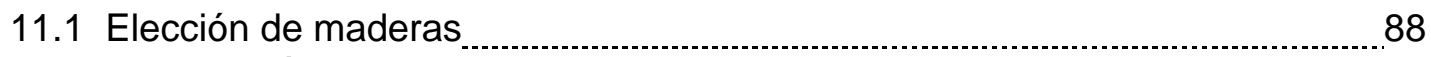

11.2 Localización de maderas

11.3 Parámetros por orden de importancia de elección de maderas $\ldots$

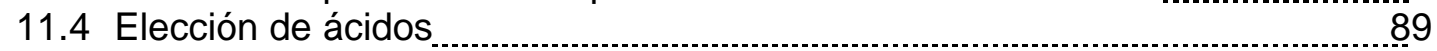

11.5 Localización de ácidos

11.6 Parámetros por orden de importancia de elección de ácidos

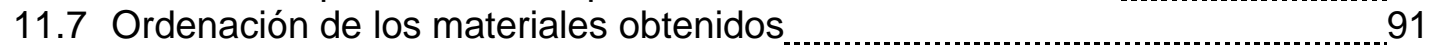

11.8 Fichas de los ácidos y maderas

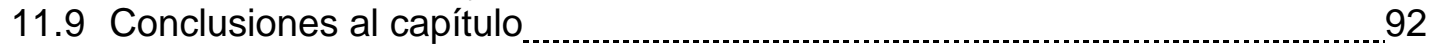

12. ELECCIÓN DE LABORATORIO y CONDICIONES AMBIENTALES ..............93

12.1 Elección de Laboratorio. Medios ……......................................................94

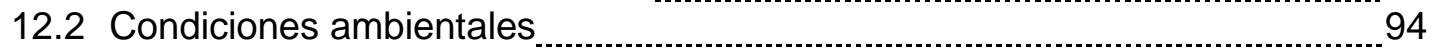

12.3 Condiciones de las muestras

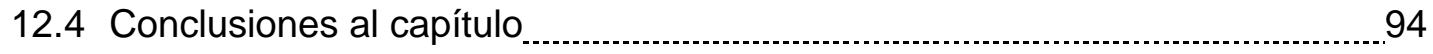

13. ELECCIÓN DE MEDIOS y ALMACENAMIENTO

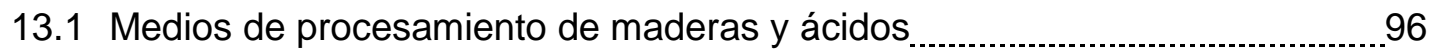

13.2 Medios de procesamiento de las maderas

13.3 Medios de procesamiento de los ácidos líquidos incoloros

13.4 Medios para el procesamiento de imágenes. Mesa de Reproducción ...............98

13.5 Medios para el almacenamiento de los materiales .........................................99

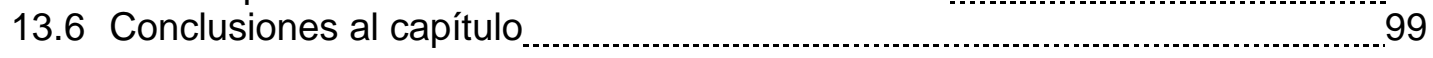

14. ELECCIÓN DE CÓDIGOS y ORDENACIÓN DE LAS MUESTRAS $\ldots \ldots \ldots \ldots \ldots . . . .101$

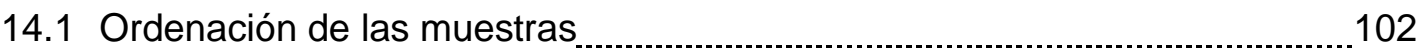

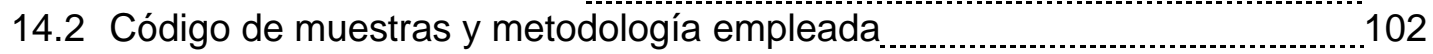

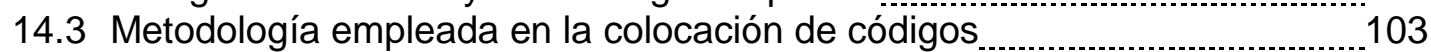

14.4 Conclusiones al capítulo 
15.1 Descripción de los ensayos 106

15.2 Aplicación de ácidos 106

15.3 Procesamiento de imágenes 107

15.4 Obtención de Histogramas

15.5 Ordenación de resultados

15.6 Conclusiones al capítulo.

16. RESULTADOS DE LOS ENSAYOS DE VARIACIÓN CROMÁTICA 113

16.1 Ensayo de Ácido A01. Ácido Acético Glacial con 34 especies de maderas

16.1.1. Histogramas de maderas aplicadas antes y después de aplicar superficialmente el ácido.

16.2 Ensayo de Ácido A02. Ácido Acrílico con 34 especies de maderas. 149

16.2.1. Histogramas de maderas aplicadas antes y después de aplicar superficialmente el ácido.

16.3 Ensayo de Ácido A03. Ácido Clorhídrico con 34 especies de maderas 183

16.3.1. Histogramas de maderas aplicadas antes y después de aplicar superficialmente el ácido.

16.4 Ensayo de Ácido A04. Ácido Fluorhídrico con 34 especies de maderas 217

16.4.1. Histogramas de maderas aplicadas antes y después de aplicar superficialmente el ácido.

16.5 Ensayo de Ácido A05. Ácido Fórmico con 34 especies de maderas 251

16.5.1. Histogramas de maderas aplicadas antes y después de aplicar superficialmente el ácido.

16.6 Ensayo de Ácido A06. Ácido Fosfórico con 34 especies de maderas 285

16.6.1. Histogramas de maderas aplicadas antes y después de aplicar superficialmente el ácido.

16.7 Ensayo de Ácido A07. Ácido Láctico con 34 especies de maderas

16.7.1. Histogramas de maderas aplicadas antes y después de aplicar superficialmente el ácido.

16.8 Ensayo de Ácido A08. Ácido Nítrico con 34 especies de maderas

16.8.1. Histogramas de maderas aplicadas antes y después de aplicar superficialmente el ácido.

16.9 Ensayo de Ácido A09. Ácido Octanónico con 34 especies de maderas

16.9.1. Histogramas de maderas aplicadas antes y después de aplicar superficialmente el ácido.

16.10 Ensayo de Ácido A10. Ácido Oléico con 34 especies de maderas 421

16.10.1. Histogramas de maderas aplicadas antes y después de aplicar superficialmente el ácido. 
16.11 Ensayo de Ácido A11. Ácido Oxálico con 34 especies de maderas 455

16.11.1. Histogramas de maderas aplicadas antes y después de aplicar superficialmente el ácido.

16.12 Ensayo de Ácido A12. Ácido Pirúvico con 34 especies de maderas 489

16.12.1. Histogramas de maderas aplicadas antes y después de aplicar superficialmente el ácido.

16.13 Ensayo de Ácido A13. Ácido Propiónico con 34 especies de maderas 523

16.13.1. Histogramas de maderas aplicadas antes y después de aplicar superficialmente el ácido.

16.14 Ensayo de Ácido A14. Ácido Tioglicólico con 34 especies de maderas. 557

16.14.1. Histogramas de maderas aplicadas antes y después de aplicar superficialmente el ácido.

16.15 Ensayo de Ácido A15. Ácido 2- Etilhexanóico con 34 especies de Maderas 591

16.15.1. Histogramas de maderas aplicadas antes y después de aplicar superficialmente el ácido.

17. ANÁLISIS DE LOS RESULTADOS y DISCUSIÓN 625

17.0 Planteamiento de Gráficas y Tablas _................................ 626

17.0.1 Análisis de tablas

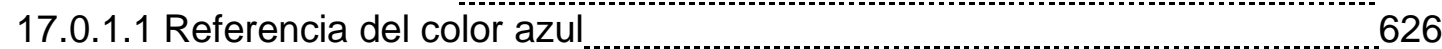

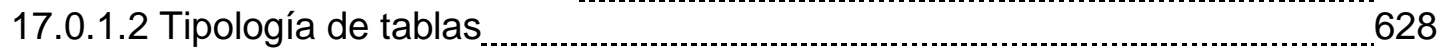

17.0.2 Análisis de gráficas por ácidos.

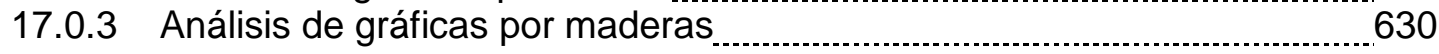

17.1 Análisis de Tablas y Gráficas por Ácidos .................................................... 631

17.1.1 Ácido A01. Ácido Acético Glacial con 34 especies de maderas .................631

- Tabla de Ácido A01.Valores porcentuales.

- Gráfica general de valores de Histogramas.

- Gráfica de valores de diferencia por continentes.

17.1.2 Ensayo de Ácido A02. Ácido Acrílico con 34 especies de maderas 641

- Tabla de Ácido A02.Valores porcentuales.

- Gráfica general de valores de Histogramas.

- Gráfica de valores de diferencia por continentes.

17.1.3 Ensayo de Ácido A03. Ácido Clorhídrico con 34 especies

de maderas

- Tabla de Ácido A03.Valores porcentuales.

- Gráfica general de valores de Histogramas.

- Gráfica de valores de diferencia por continentes.

17.1.4 Ensayo de Ácido A04. Ácido Fluorhídrico con 34 especies de maderas

- Tabla de Ácido A04.Valores porcentuales. 
- Gráfica general de valores de Histogramas.

- Gráfica de valores de diferencia por continentes.

17.1.5 Ensayo de Ácido A05. Ácido Fórmico con 34 especies de maderas

- Tabla de Ácido A05.Valores porcentuales.

- Gráfica general de valores de Histogramas.

- Gráfica de valores de diferencia por continentes.

17.1.6 Ensayo de Ácido A06. Ácido Fosfórico con 34 especies de maderas 681

- Tabla de Ácido A06.Valores porcentuales.

- Gráfica general de valores de Histogramas.

- Gráfica de valores de diferencia por continentes.

17.1.7 Ensayo de Ácido A07. Ácido Láctico con 34 especies de maderas 691

- Tabla de Ácido A07.Valores porcentuales.

- Gráfica general de valores de Histogramas.

- Gráfica de valores de diferencia por continentes.

17.1.8 Ensayo de Ácido A08. Ácido Nítrico con 34 especies de maderas 701

- Tabla de Ácido A08.Valores porcentuales.

- Gráfica general de valores de Histogramas.

- Gráfica de valores de diferencia por continentes.

17.1.9 Ensayo de Ácido A09. Ácido Octanónico con 34 especies de maderas

- Tabla de Ácido A09.Valores porcentuales.

- Gráfica general de valores de Histogramas.

- Gráfica de valores de diferencia por continentes.

17.1.10 Ensayo de Ácido A10. Ácido Oléico con 34 especies de maderas 721

- Tabla de Ácido A10.Valores porcentuales.

- Gráfica general de valores de Histogramas.

- Gráfica de valores de diferencia por continentes.

17.1.11 Ensayo de Ácido A11. Ácido Oxálico con 34 especies de maderas 731

- Tabla de Ácido A11.Valores porcentuales.

- Gráfica general de valores de Histogramas.

- Gráfica de valores de diferencia por continentes.

17.1.12 Ensayo de Ácido A12. Ácido Pirúvico con 34 especies de maderas

- Tabla de Ácido A12.Valores porcentuales.

- Gráfica general de valores de Histogramas.

- Gráfica de valores de diferencia por continentes.

17.1.13 Ensayo de Ácido A13. Ácido Propiónico con 34 especies

de maderas

- Tabla de Ácido A13.Valores porcentuales.

- Gráfica general de valores de Histogramas.

- Gráfica de valores de diferencia por continentes. 
17.1.14 Ensayo de Ácido A14. Ácido Tioglicólico con 34 especies de maderas 761

- Tabla de Ácido A14.Valores porcentuales.

- Gráfica general de valores de Histogramas.

- Gráfica de valores de diferencia por continentes.

17.1.15 Ensayo de Ácido A15. Ácido 2- Etilhexanóico con 34 especies de maderas 771

- Tabla de Ácido A15.Valores porcentuales.

- Gráfica general de valores de Histogramas.

- Gráfica de valores de diferencia por continentes.

17.2 Análisis de Tablas y Gráficas por Maderas

- Tablas de maderas ensayadas. Valores porcentuales.

- Gráficas de maderas ensayadas de valores iniciales, resultados y diferencias.

17.2.1 Ensayo de Madera M01. Abeto Douglas con 15 Ácidos 781

17.2.2 Ensayo de Madera M02. Arce Blando Americano con 15 Ácidos …............. 786

17.2.3 Ensayo de Madera M03. Arce Blando Americano con 15 Ácidos ....................791

17.2.4 Ensayo de Madera M04. Ayous con 15 Ácidos

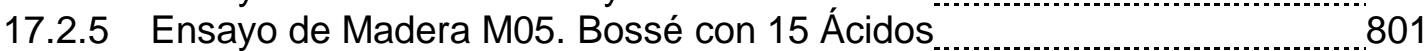

17.2.6 Ensayo de Madera M06. Bubinga con 15 Ácidos

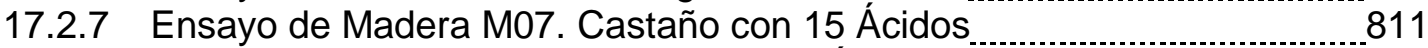

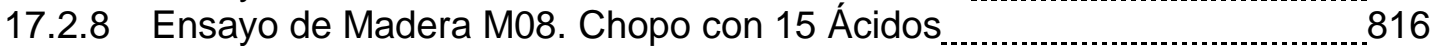

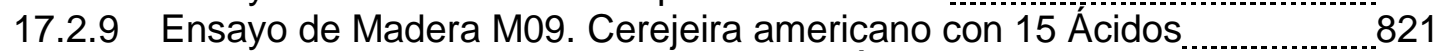

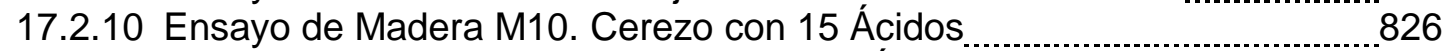

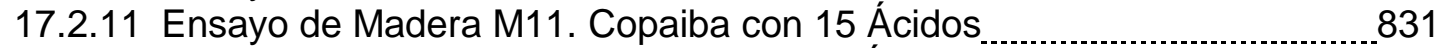

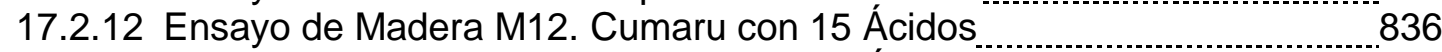

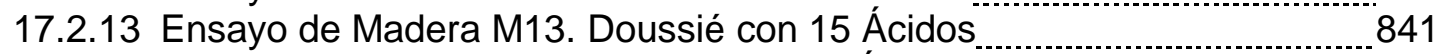

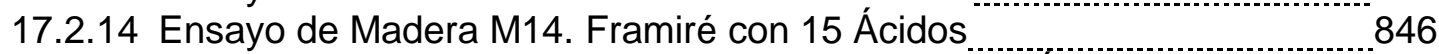

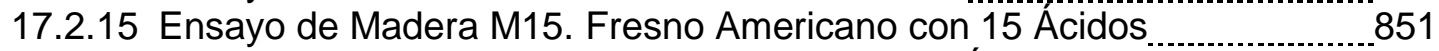

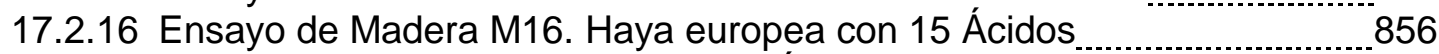

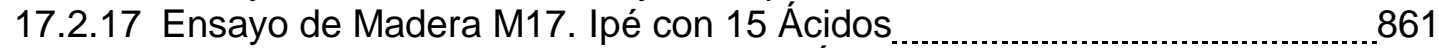

17.2.18 Ensayo de Madera M18. Iroko con 15 Ácidos

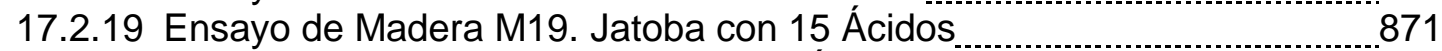

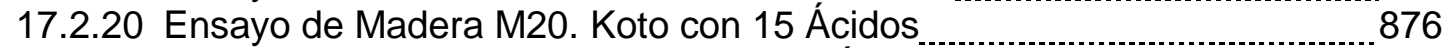

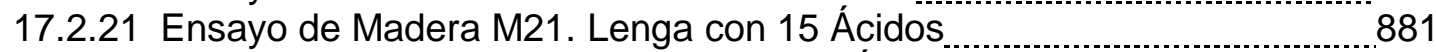

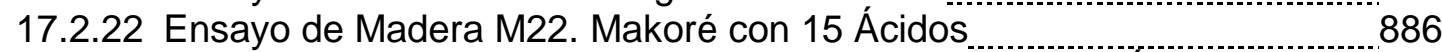

17.2.23 Ensayo de Madera M23. Nogal negro americano con 15 Ácidos ...................891

17.2.24 Ensayo de Madera M24. Okumé con 15 Ácidos.....................................896 896

17.2.25 Ensayo de Madera M25. Pino Amarillo del Sur con 15 Ácidos...........................

17.2.26 Ensayo de Madera M26. Pino Radiata con 15 Ácidos ................................906

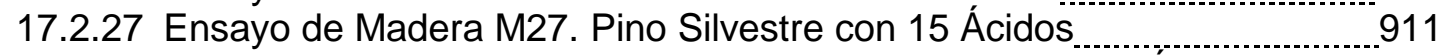

17.2.28 Ensayo de Madera M28. Roble Blanco Americano con 15 Ácidos …............916

17.2.29 Ensayo de Madera M29. Roble Europeo con 15 Ácidos ……...................921

17.2.30 Ensayo de Madera M30. Roble Rojo Americano con 15 Ácidos.......................926

17.2.31 Ensayo de Madera M31. Sapelli con 15 Ácidos

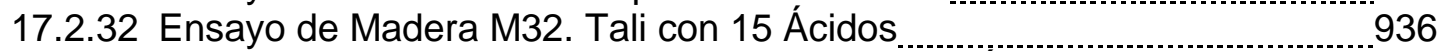

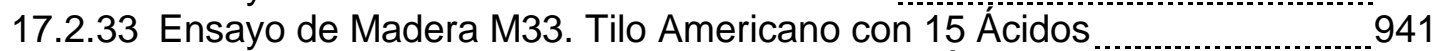

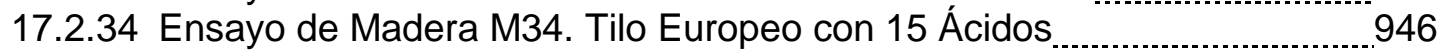




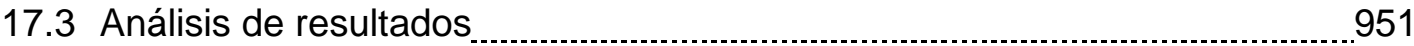

17.4 Publicación y estimación de patente

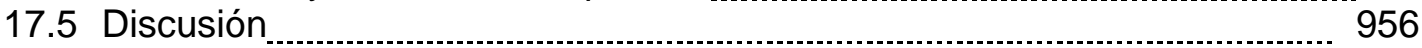

17.5.1 Planteamientos generales 956

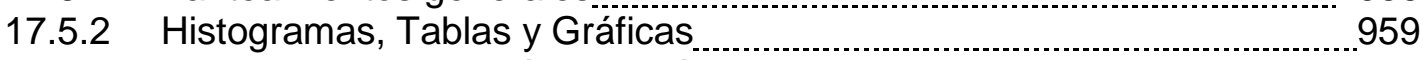

17.5.2.1 Forma, curvas, posición, relación y distancia entre las curvas de histogramas. Uniformidad y Expresividad...................................... 959

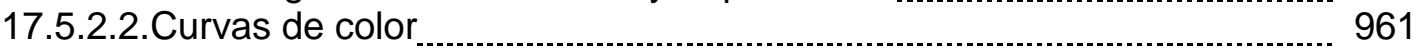

17.6 Variación cromática porcentual según escala de grises

17.7 Modelo Predictivo mediante ábacos _.................................................. 979

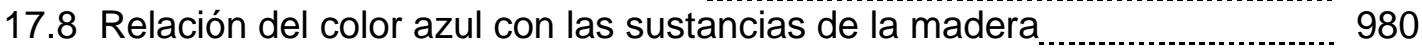

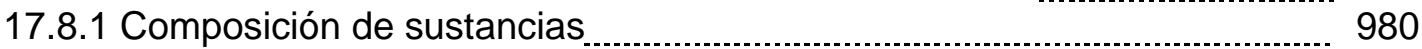

17.8.2 Exudación de las sustancias de la madera

17.9 Densidad de las maderas

17.10 Tipología de la ampliación de la gama cromática................................... 984

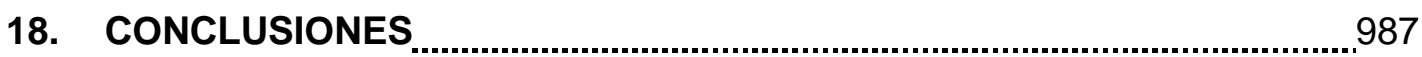

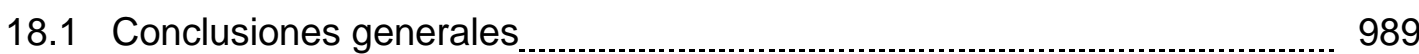

18.2 Modelo Predictivo mediante ábacos

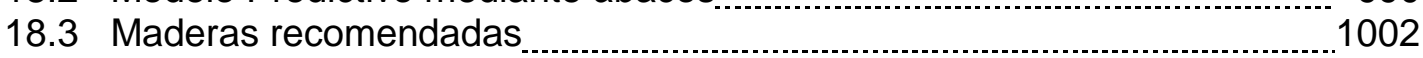

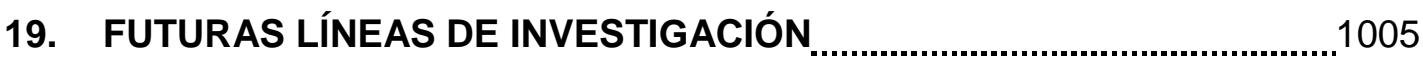

19.1 Aplicación superficial de Ácidos en estado sólido sobre maderas _.......... 1006

19.2 Aplicación superficial de Ácidos en maderas de Asia

19.3 Variación cromática en espacio CIELAB de la aplicación superficial de ácidos sobre maderas.

1006

19.4 Relación entre el color azul del histograma en el espacio RGB y los taninos en la aplicación superficial de Ácidos en estado sólido sobre maderas

19.5 Recuperación de maderas e impacto ecológico mediante la aplicación superficial de ácidos sobre maderas 1006

19.6 Impacto económico en función del cambio de aspecto de la aplicación superficial de ácidos sobre maderas

19.7 Variación del olor en las maderas de construcción mediante la aplicación superficial de ésteres derivados de la combinación de ácidos y alcoholes

19.8 Relación entre la composición del suelo de las maderas y su

Aclaramiento por la aplicación superficial de ácidos.

19.9 Relación entre el número de oxidación de elementos

NO Metales y la variación cromática

19.10 Herramientas de cuantificación de la Uniformidad y

Expresividad de la Madera.

20. BIBLIOGRAFÍA

21. ANEXOS

21.1 Fichas de maderas seleccionadas

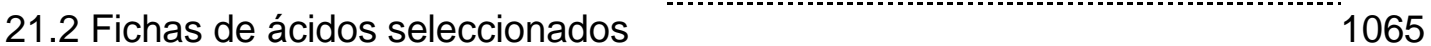

21.3 Normativa de color

21.4 Esquema de gráficas de 34 especies.

Universidad Politécnica de Madrid - Escuela Técnica Superior de Arquitectura - Departamento de Construcción y Tecnología Arquitectónica Directores: Dr. Alfonso García Santos y Dr. Antonio Rodríguez Rodríguez. Doctorando: D. Francisco Lora Toro 



\section{1.}

\section{RESUMEN}

Esta tesis estudia la variación de color obtenida mediante la aplicación superficial de ácidos incoloros en estado líquido sobre las maderas de construcción.

La modificación cromática de la superficie de las maderas de construcción, mediante la aplicación superficial de ácidos en estado líquido, potencia la expresividad de la madera, a través del cambio de color, diferenciándola, personalizándola, permitiendo su reutilización y posibilitando su retorno al mercado.

El objetivo es obtener nuevas tonalidades en las maderas, mediante una ampliación de la gama de color, potenciando su expresividad y proporcionando estabilidad, durabilidad y sostenibilidad, proyectándola al resto de elementos conformadores del espacio arquitectónico, mejorando su aspecto, cuyo reflejo expresivo suponga un valor añadido a la arquitectura, conectando con los parámetros de referencia que actualmente están en vigor de ecología, sostenibilidad, ahorro y eficiencia energética.

La metodología empleada en el laboratorio cumple con este objetivo, mediante el control de los diferentes aspectos en la aplicación superficial de los ácidos, ampliando las posibilidades formales de las muestras y ofreciendo la posibilidad de obtener una protección de la madera de construcción de forma natural, sin necesidad de aplicar posteriormente productos adicionales.

Los ácidos tradicionalmente se utilizan como compuestos que mejoran las características de las maderas, pero no se ha observado se utilicen como medio para obtener colores y texturas. También permite la reutilización de las maderas y su retorno al mercado, al posibilitar la mejora de su aspecto y en algunos casos, generar un subproducto superficial que cambia su aspecto.

La posibilidad de la variación de color en las maderas implica la posibilidad de obtener aspectos similares entre maderas de diferente origen e importancia desde el punto de vista económico y de sostenibilidad de las masas forestales.

Actualmente el mercado de la madera español carece en general de una diversidad de especies en sus almacenes, sin descontar que numerosos proveedores que tradicionalmente disponían de estas especies han desaparecido, tienen poco género ó están en vías de desaparecer, por lo que la aplicación de ácidos incoloros en estado líquido ofrecería la posibilidad a estas empresas de ampliar su gama de productos a sus clientes, ampliando sus perspectivas de negocio al disponer de una variedad adicional de colores y texturas. 


\section{ABSTRACT}

This thesis studies the color variation obtained by the application of colorless acids in liquid state on the construction timbers surface.

The chromatic modification of the surface of the construction timber, through the surface application of acids in a liquid state, enhances the expressiveness of the wood through color change, distinguishing it, customizing it, allowing its reuse and making possible for it to return to the market.

The goal is to obtain new shades in the timber, through a wider color range, enhancing its expressiveness and providing stability, durability and sustainability, projecting it to the rest of the elements that shape the architectural space, improving its appearance so its expressive reflection supposes an added value to the architecture, at the same time as is connects with the current reference parameters of ecology, sustainability, saving and energy efficiency.

The methodology used in the laboratory fulfills this objective, by controlling the different aspects in the surface application of the acids, expanding the formal possibilities of the samples and offering the possibility of providing the timber with a natural protection without the need to apply any additional products.

Acids are traditionally considered compounds that improve the characteristics of timbers, but have not been used as a means to obtain colors and textures.

It also allows the re-use of the timber and its return to the market, making it possible to improve its appearance and, in some cases, to generate a surface byproduct with a different appearance.

The possibility of color variation in the timber implies the possibility of obtaining similar aspects between woods of different importance and origin, an important improvement from an economic point of view and that of the sustainability of the forest areas.

Currently, the Spanish timber market lacks a diversity of species in its warehouses, providing that many suppliers that traditionally had those species have disappeared, are disappearing or have less stock, so the application of colorless acids in liquid state would offer these companies the possibility to expand the range of products they offer to their customers, expanding their business prospects by having an additional variety of colors and textures. 


\section{2.}

HIPÓTESIS

\section{EXISTE UN MODELO PREDICTIVO EN LA OBTENCIÓN DE NUEVOS COLORES EN LAS MADERAS DE CONSTRUCCIÓN MEDIANTE LA APLICACIÓN DE ÁCIDOS LÍQUIDOS INCOLOROS.}

La madera es un material anisótropo y por extensión conceptualmente los resultados de los ensayos se deben entender desde el punto de vista de los valores relativos (porcentajes) y no absolutos (números), aunque estos últimos se utilicen como referencia para obtener conclusiones, por lo que el modelo predictivo propuesto se basa en ábacos, que establecen un valor porcentual de la variación cromática de las maderas afectadas por la aplicación de ácidos incoloros en estado líquido en función de su clasificación y fuerza y del origen, especie y densidad de la madera, permitiendo establecer un valor porcentual predictivo. 


\section{3.}

OBJETIVOS

\section{OBJETIVOS}

- Analizar los diferentes espacios de color y la imagen digital...........(Capítulo 6).

- Elegir el espacio de color donde se desarrollan los ensayos ...........(Capítulo 7).

- Analizar la clasificación botánica y morfología de las maderas y los productos de maderas de construcción

- Analizar la clasificación y descripción química de los ácidos (Capítulo 9).

- Elegir los parámetros de elección de maderas y ácidos (Capítulo 11).

- Elegir el laboratorio y condiciones ambientales (Capítulo 12).

- Elegir los medios de procesamiento y almacenamiento (Capítulo 13).

- Sistematizar los códigos y ordenación de las muestras (Capítulo 14).

- Sistematizar la metodología de los ensayos (Capítulo 15).

- Obtener resultados de los ensayos de variación cromática (Capítulo 16).

- Analizar los resultados y su discusión (Capítulo 17).

- Obtener conclusiones (Capítulo 18).

- Proponer futuras líneas de investigación (Capítulo 19). 


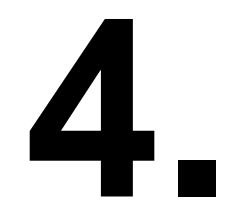

ESTADO DEL ARTE

El estado de la cuestión respecto a la variación color superficial en las maderas de construcción por la aplicación superficial de ácidos incoloros en estado líquido. 


\section{ESTADO DEL ARTE}

Para afrontar el estado del arte de esta tesis doctoral, se utilizan cuatro parámetros de búsqueda que sirvan de acotación del ámbito de la investigación, estos parámetros se resumen en:

- Ampliación de la gama de color.

- Madera de construcción maciza.

- Ácido aplicado superficialmente.

- Espacio de color RGB.

Estos parámetros de búsqueda se utilizan tanto individualmente como conjuntamente y en sus posibles variantes.

Adicionalmente, se tiene en cuenta que las maderas utilizadas en esta tesis, dentro de un proceso productivo normal de la madera, para la realización de los ensayos, se eligen después de su periodo de almacenamiento natural y antes de ser tratadas para su comercialización.

De esta forma las búsquedas realizadas, arrojaron los siguientes resultados porcentuales agrupadas en función de áreas temáticas o grupos de investigación y cuyo porcentaje reflejado representa su porcentaje respecto al total de las búsquedas realizadas. Los resultados estructurados en grupos son los siguientes:

\section{PRODUCTOS DE MADERAS DE CONSTRUCCIÓN.}

2. FORESTAL Y VITIVINÍCOLA.

3. QUÍMICA DE LA MADERA DE CONSTRUCCIÓN.

\section{ESPACIOS DE VARIACIÓN CROMÁTICA.}

A continuación, se pormenorizan cada unos de los grupos mencionados en relación con los subgrupos que integran cada uno de ellos:

\section{1.- PRODUCTOS DE MADERAS DE CONSTRUCCIÓN}

Este grupo representa el $60 \%$ del total de las investigaciones que están relacionadas con la temática de la tesis.

Son investigaciones relacionadas con los productos de las maderas de construcción, desde las maderas almacenadas hasta maderas como producto finalista, así como también productos derivados como tableros, etc. 
Estas investigaciones se pueden dividir porcentualmente en:

\section{1.a.- Secado de la madera.}

Este subgrupo representa el $40 \%$ del total de las investigaciones que están relacionadas con la temática de la tesis.

Son investigaciones donde se estudia el color, pero no se utiliza ningún producto superficialmente y sólo se utilizan técnicas de secado, por lo que este subgrupo no coincide con los parámetros de búsqueda definidos en el capítulo 4 "Estado del arte" de esta tesis doctoral, por lo tanto, no se tiene en cuenta en el ámbito de esta investigación.

\section{1.b.- Ataque de agentes biológicos.}

Este subgrupo representa el $10 \%$ del total de las investigaciones que están relacionadas con la temática de la tesis.

Son investigaciones sobre maderas donde se estudia el ataque de agentes biológicos, como termitas, carcoma, etc. o incluso que pueden estar puestas en su destino final y a las que se les aplica ácidos normalmente inyectados o por inmersión, que afectan a todo su volumen, pero donde no se estudia el color ni una ampliación de la gama de color, por lo tanto, al igual que en el punto anterior, no se tiene en cuenta en el ámbito de esta investigación.

\section{1.c.- Tableros, adhesivos y celulosa.}

Este subgrupo representa el $10 \%$ del total de las investigaciones que están relacionadas con la temática de la tesis.

Son investigaciones sobre derivados de la madera, donde se estudian los diversos compuestos que conforman o unen estos derivados, incluidos los ácidos, y que dadas sus características no entran dentro del ámbito de esta investigación, debido a que estos derivados de la madera poseen componentes diversos como adhesivos de urea, urea-formol, fenol-formaldehído, etc., por otro lado, tampoco hablan de color ni de espacios de color y no son maderas macizas, por lo tanto, al igual que en el punto anterior, no se tiene en cuenta en el ámbito de esta investigación.

\section{2.- FORESTAL Y VITIVINÍCOLA.}

Este grupo representa el $30 \%$ del total de las investigaciones que están relacionadas con la temática de la tesis. 
Son investigaciones relacionadas con masas forestales, plantaciones o pequeñas agrupaciones de árboles ya sean de forma natural o realizadas para investigaciones forestales y por otro lado investigaciones relacionadas con el mundo del vino y el almacenamiento de éste en barricas o toneles de madera. Estas investigaciones se pueden dividir porcentualmente en:

\section{2.a.- Masas forestales "in situ".}

Este subgrupo representa el $20 \%$ del total de las investigaciones que están relacionadas con la temática de la tesis.

Son investigaciones donde se realizan plantaciones "in situ", donde se estudian una o varias especies de madera y observan los cambios de color en función de los cambios ambientales o meteorológicos, entre otros la influencia del sol, pero sin aplicar ningún tipo de producto y eligen las maderas después de ser extraídas de los árboles y cortadas, pero antes de su almacenamiento en el proceso de producción de la madera, por lo que este subgrupo no coincide con los parámetros de búsqueda definidos en el capítulo 4 "Estado del arte" de esta tesis doctoral, por lo tanto, no se tiene en cuenta en el ámbito de esta investigación.

2.b.- Influencia de los compuestos de la madera en los vinos.

Este subgrupo representa el $10 \%$ del total de las investigaciones que están relacionadas con la temática de la tesis.

Son investigaciones que estudian el cambio de color del vino por varias causas, incluyendo entre ellas el cambio de color por la traslación de ácidos presentes en la madera de los toneles ó barricas de vinos, los cuales han sido sometidos a hidrólisis térmica o tostado de la madera, que conjuntamente con los compuestos del vino y la adición de oxígeno influyen sobre el cambio de color del vino, pero donde no se estudia el cambio de color de la madera del tonel y el número de especies empleado es muy bajo, por lo tanto, al igual que en el punto anterior, no se tiene en cuenta en el ámbito de esta investigación.

\section{3.- QUÍMICA DE LA MADERA DE CONSTRUCCIÓN.}

Este grupo representa el $8,5 \%$ del total de las investigaciones que están relacionadas con la temática de la tesis.

Son investigaciones donde se estudian los compuestos que están presentes en las maderas de construcción, donde se estudian estos compuestos de forma individualizada y para un fin concreto y como parte de sus características se menciona el color, el más conocido de estos compuestos son los taninos (polifenoles), relacionados con el color de la madera y no estudian la ampliación de la gama de color, ni el espacio de color donde se produciría, por lo que este grupo no coincide con los parámetros de búsqueda definidos en el capítulo 4 "Estado del arte" de esta tesis doctoral, por lo tanto, no se tiene en cuenta en el ámbito de esta investigación. 


\section{4.- ESPACIOS DE VARIACIÓN CROMÁTICA.}

Este grupo representa el 1,5\% del total de las investigaciones que están relacionadas con la temática de la tesis.

Son investigaciones donde se estudia el cambio de color de diversos tipos de materiales, para diversos fines. Estas investigaciones se pueden dividir porcentualmente en:

\section{4.a.- Materiales inorgánicos.}

Este subgrupo representa el $0,5 \%$ del total de las investigaciones que están relacionadas con la temática de la tesis.

Estas investigaciones estudian espacios de color, pero no la ampliación de la gama de color y al ser materiales inorgánicos, este grupo no coincide con los parámetros de búsqueda definidos en el capítulo 4 "Estado del arte" de esta tesis doctoral, por lo tanto, no se tiene en cuenta en el ámbito de esta investigación.

4.b.-Materiales orgánicos.

Este subgrupo representa el $0,5 \%$ del total de las investigaciones que están relacionadas con la temática de la tesis.

Estas investigaciones estudian espacios de color, pero no la ampliación de la gama de color y no utilizan ácidos incoloros en estado líquido aplicados superficialmente sobre las maderas de construcción macizas y normalmente no utilizan el espacio de color RGB, por lo tanto, al igual que en el punto anterior, no se tiene en cuenta en el ámbito de esta investigación.

4.c.- Inspección de la madera.

Este subgrupo representa el $0,5 \%$ del total de las investigaciones que están relacionadas con la temática de la tesis.

Estas investigaciones estudian espacios de color, pero no la ampliación de la gama de color, estudian por medios informáticos la selección de la madera sin defectos al salir del aserradero, y por lo tanto, al igual que en el punto anterior, no se tiene en cuenta en el ámbito de esta investigación.

Conclusiones de este capítulo:

En función de los resultados de las búsquedas realizadas, se llega a las siguientes conclusiones, en lo relativo al estado del arte: 
- Las investigaciones encontradas hasta el momento desarrollan temas en líneas de investigación tangenciales a los propuestos en esta tesis.

- Las investigaciones encontradas, relacionadas principalmente con temas forestales eligen las maderas después de ser extraídas de los árboles y cortadas, pero antes de su almacenamiento en el proceso de producción de la madera.

- Los ácidos tradicionalmente se utilizan como compuestos que se circunscriben a mejorar las características de las maderas a efectos estabilidad dimensional ó de protección ante agentes atmosféricos, biológicos, protección al fuego ó limpieza, normalmente no aplicándose superficialmente y no siendo su objetivo el color ó la textura de la madera.

- No se encontraron investigaciones sobre ácidos incoloros en estado líquido cuyo objetivo sea investigar la variación cromática superficial producida por la aplicación superficial de estos ácidos sobre las maderas de construcción, cuyo objetivo sea ampliar la gama de color superficial de las maderas de construcción.

En resumen, debido a todas estas circunstancias, se llega a la conclusión respecto a la búsqueda del estado del arte, que esta investigación es novedosa, y que no se encuentran otras investigaciones parecidas a ella, en función de los parámetros presentados y sus características adicionales. 


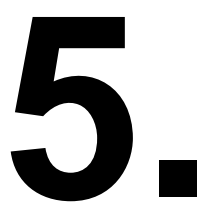

\section{INTRODUCCIÓN y METODOLOGÍA}

La madera desde el punto de vista arquitectónico es un material definido como noble por sus propiedades y por su historia. Este capítulo describe de forma generalizada, los diferentes tipos de tratamientos superficiales de las maderas de construcción y la división de la metodología empleada. 


\section{INTRODUCCIÓN y METODOLOGÍA}

La madera en su estructura interna dependiendo de la especie posee ácido oleico, acético, ascórbico, oxálico, fórmico, tánico, etc, los cuales proporcionan a las maderas diversas características, dentro de la amplia variedad existente.

La madera en términos generales es resistente a los ácidos y por extensión la aplicación de ácidos supone un tratamiento natural de la madera de construcción.

Los ácidos tradicionalmente se utilizan como compuestos que se aplican en muchos casos mediante "inyecciones" o por "inmersión" de las maderas de construcción de exterior o de estructuras y se circunscribe a mejorar las características de las maderas, a efectos estabilidad dimensional o de protección ante agentes atmosféricos, biológicos, protección al fuego (ácido bórico) o limpieza (ácido oxálico), normalmente no aplicándose superficialmente y no siendo su objetivo el color o la textura de la madera.

Los ácidos incoloros en estado líquido aplicados superficialmente sobre las maderas obtienen una ampliación de las gamas de colores y texturas de las maderas, potenciando su expresividad y proporcionando estabilidad, durabilidad y sostenibilidad. Debido a la gran variedad de ácidos y de maderas, en esta tesis se fijan unos parámetros de elección de estos materiales, que se comentarán más adelante.

\subsection{Tratamiento superficial mediante ácidos líquidos incoloros.}

El tratamiento que se propone en esta tesis mediante ácidos líquidos incoloros en estado líquido aplicados superficialmente tiene como objeto el cambio y ampliación de la gama de colores y texturas de las maderas de construcción.

En el caso de ácidos líquidos incoloros, se consigue una homogeneización en la aplicación sobre la superficie de la madera de construcción y además no necesitan una aplicación posterior con otro tratamiento de protección para la madera.

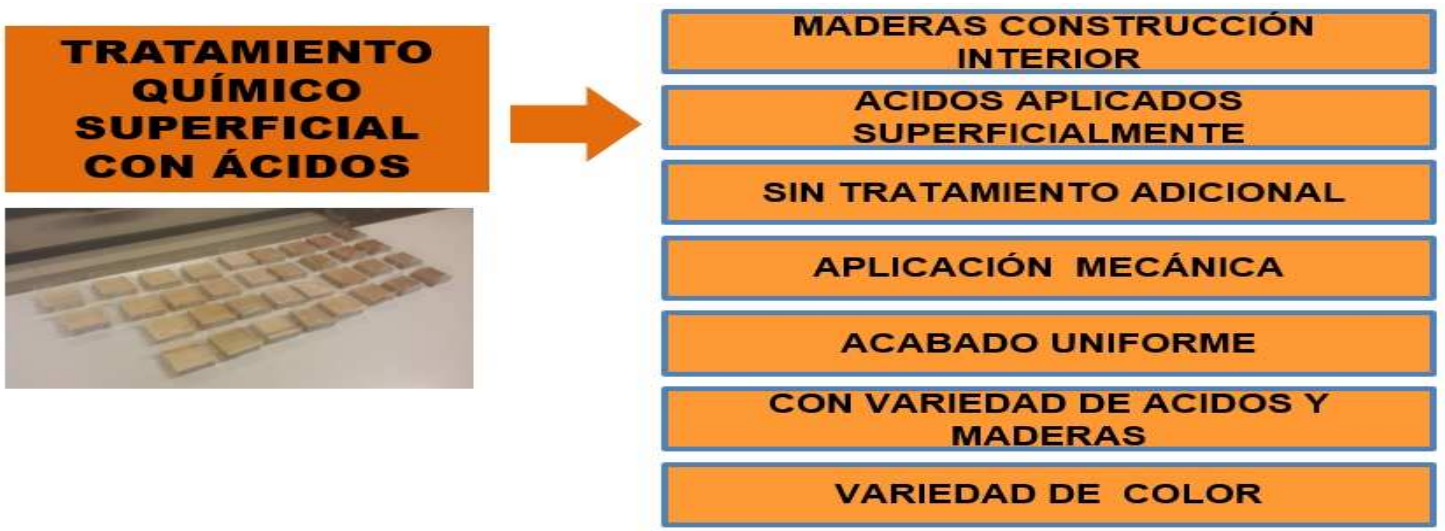

Figura 1. Tratamiento ácidos líquidos incoloros. Elaboración propia.

El ácido se aplica de forma controlada superficialmente proporcionando una capa de protección adicional de forma natural cambiando el color de la madera y mejorando su aspecto, de modo que se garantiza la homogeneidad en la modificación del color en toda la superficie de la madera tratada. 
Esta tesis se centra en la aplicación superficial de ácidos líquidos incoloros sobre maderas de construcción de interior.

\subsection{División de los tratamientos superficiales sobre las maderas.}

La división de los tratamientos superficiales de las maderas de construcción las expongo a continuación, en función de si modifican o no su estructura superficial.

En términos generales el tratamiento superficial de la madera, se puede dividir en tres grupos, los productos aplicados mediante capa superficial externa como pinturas, lacados, barnices, aceites, ceras y tintes (existen diversos productos para obtener el cambio de color de la madera de construcción, incluso siendo algunos denominados "incoloros", también hay otros autores que han estudiado el cambio de color en otros materiales), los productos aplicados que penetran en la capa superficial externa como los lasures y los que modifican la estructura de la capa superficial externa donde se puede incluir la acción de la naturaleza como son el quemado o carbonizado tradicional, el tostado tradicional y el tostado químico.

El primer y segundo grupo requiere un alto mantenimiento dado que los acabados poseen una baja dureza superficial y durabilidad y se pueden degradar por la acción de los rayos ultravioleta (uv), por el contrario, el tercer grupo tiene un mantenimiento bajo y una alta dureza superficial y durabilidad.

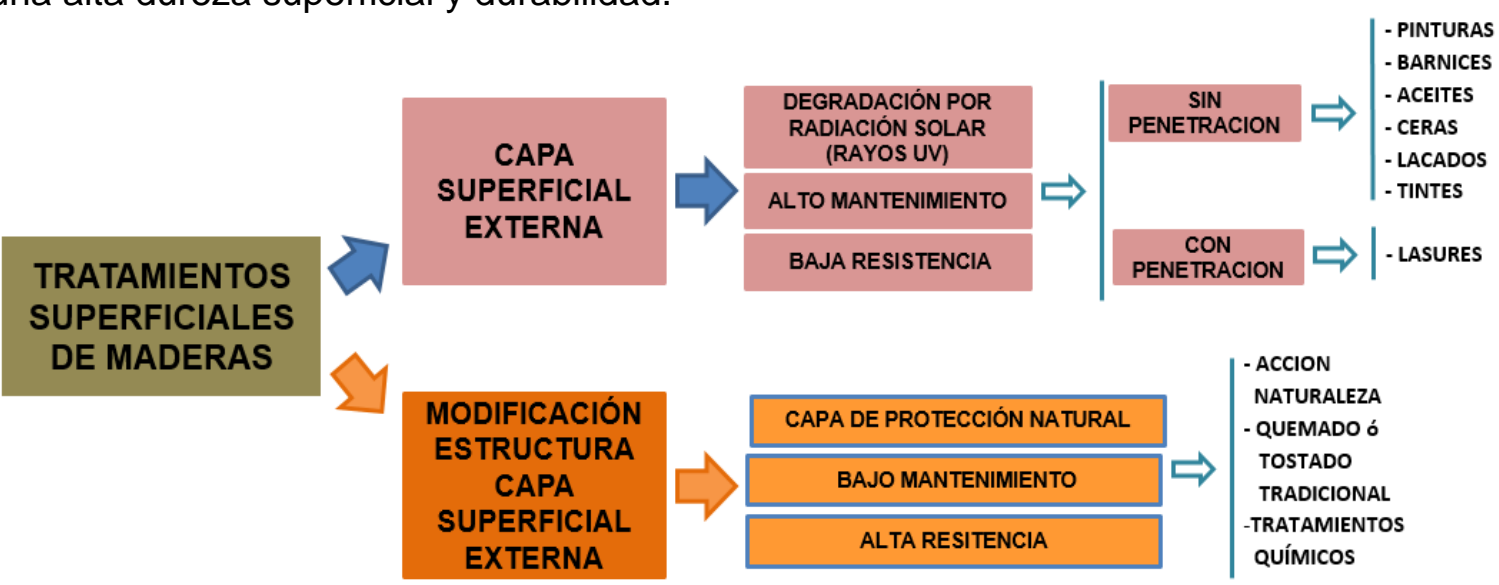

Figura 2. Tratamientos superficiales. División. Elaboración propia

\subsection{Tratamiento tradicional químico.}

Los ácidos tradicionalmente se utilizan como compuestos que mejoran las características de las maderas, a efectos de protección ante agentes biológicos, protección al fuego y limpieza.

La protección biológica se realiza mediante inyectado del ácido elegido en diversos puntos de la madera que impregna todo el volumen de esta, aplicando posteriormente capas de protección, cuyo objetivo es proteger la madera, estas técnicas suelen aplicarse a estructuras de maderas o puntos singulares, que requieren cuidados, 
conservación y protección a efectos de evitar patologías futuras contraproducentes, que afecten a la seguridad constructiva, por ejemplo, de un edificio.

Otros tratamientos químicos de la madera son la obtención de la celulosa o soluciones para la formación de tableros laminados mediante adhesivos, influidos por la forma de distribución de las fibras o el número de capas constitutivas del producto y el destino o función que pueda tener el tablero, que normalmente busca una mejora de la resistencia, la conservación y una larga vida útil.

Como se ha comentado, los tratamientos químicos que se utilizan en general para las maderas van en función de los procesos industriales de los que se quiere obtener un producto como el caso de la celulosa o que se emplea en la formación de tableros laminados en donde se emplean adhesivos químicos, además de los procesos tradicionales de la aplicación de ácidos como protección ante agentes externos. Todos estos procesos no están asociados a la variación del color objeto de esta tesis.

La madera en términos generales es resistente a los ácidos y por extensión la aplicación de ácidos, que supone un tratamiento natural de la madera de construcción.

\subsection{Metodología Teórica y Experimental}

La metodología empleada en esta tesis se divide en metodología teórica, que estudia los materiales empleados y sus propiedades y metodología experimental, donde se establece los parámetros empleados para la realización de los ensayos, incluidos los resultados, el análisis y las conclusiones.

La metodología teórica comprende los capítulos:

- Estudio del análisis del color y la imagen digital (Capítulo 6)

- Elección del espacio de color RGB

- Clasificación botánica y morfología de las maderas

Productos de maderas de construcción (Capítulo 7)

- Clasificación y descripción química de los ácidos

La metodología experimental comprende los capítulos:

- Fase Experimental (Capítulo 10)

- Parámetros de elección de materiales (Capítulo 11)

- Elección de laboratorio y condiciones ambientales (Capítulo 12)

- Elección de medios y almacenamiento (Capítulo 13)

- Elección de códigos y ordenación de las muestras (Capítulo 14)

- Metodología de los ensayos (Capítulo 15)

- Resultados de los ensayos de variación cromática (Capítulo 16)

- Análisis de los resultados y discusión (Capítulo 17)

- Conclusiones (Capítulo 18) 


\subsection{Conclusiones al capítulo}

La madera desde el punto de vista arquitectónico es un material definido como noble por sus propiedades y por su historia, con una variación enorme en sus piezas aun cuando proceda del mismo árbol, fácilmente manipulable y flexible, lo que implica gran variedad de formas, sin grandes variaciones en sus propiedades mecánicas en condiciones normales, está asociado a la percepción sensorial de los seres humanos, por su color, olor, brillo y de tacto cálido, que siempre ha formado parte de nuestro entorno próximo y es un referente de la naturaleza a la que pertenecemos.

La elección de la madera como material para la aplicación superficial de ácidos incoloros en estado líquido, nace de las posibilidades que como material natural ofrece a la hora de tratarlo de forma sencilla, con productos naturales como los ácidos (incluso en procesos industriales), que permiten una ampliación de la gama de colores de las maderas, recuperando incluso maderas deterioradas como las provenientes de restos de obras o aquellas que por tener defectos superficiales de color como vetas, nudos, fendas, cambios de color, etc, se descartan para ser utilizados como materiales destinados a los espacios arquitectónicos, la aplicación superficial de ácidos permitiría la recuperación de estas maderas y un nuevo empleo de las mismas, contribuyendo al sostenimiento de las masas forestales, permitiendo una diferenciación desde el punto de vista comercial, recuperando este material a efectos de potenciación de los elementos conformadores del espacio arquitectónico como revestimientos interiores, particiones, celosías, etc, aportando nuevas cualidades a los elementos del espacio arquitectónico y el respeto por el medio ambiente.

Este capítulo actúa como punto de partida de los diferentes tipos de tratamientos superficiales de la madera, desde un punto de vista general, que sirve a efectos de posicionamiento en la aplicación superficial de ácidos incoloros en estado líquido, que supone una modificación de la estructura de la capa superficial externa de las maderas respecto a otros tipos de tratamientos superficiales, procesos, o la acción de la propia naturaleza.

Se presenta la división y organización de la metodología teórica y experimental empleada en la tesis. 


\section{ESTUDIO DEL ANÁLISIS DEL COLOR y LA IMAGEN DIGITAL}

La percepción del color y su traslación a los diferentes modelos de espacio de color y su ámbito de aplicación, representación e interrelación, que por medios informáticos son a su vez captados y almacenados por medios digitales. 


\section{ESTUDIO DEL ANÁLISIS DEL COLOR y LA IMAGEN DIGITAL}

\subsection{El espacio de color}

Percibimos los colores a través de nuestros ojos, que son capaces de distinguir las diferentes longitudes de onda que reciben desde el exterior, seleccionando el "color" reflejado por un objeto, identificándolo a un color conocido determinado, gracias a que el objeto que observamos absorbe el resto de las longitudes de onda del resto de colores. El color, asimismo, es una característica de la luz. Según el Diccionario de la Real Academia de la Lengua el color se define como "Sensación producida por los rayos luminosos que impresionan los órganos visuales y que depende de la longitud de onda", y define La luz como "Agente físico que hace visible los objetos" y "claridad que irradian los cuerpos en combustión, ignición o incandescencia", otras definiciones de la luz son "la forma de la energía radiante que es capaz de estimular la retina del ojo humano provocando un proceso consciente que da lugar a las sensaciones visuales".

Estas definiciones están supeditadas al criterio del observador, que también estará influenciado según pertenezca a un campo u otro, desde el punto de vista de los físicos lo aplican a las variaciones en las distribuciones espectrales de las luces, tanto si son emitidas directamente por fuentes como si lo son indirectamente reflejadas o transmitidas por objetos, desde el punto de vista de los químicos utilizan la palabra color para referirse a diferencias espectrales debidas a variaciones en la composición molecular o en las configuraciones de los compuestos químicos, desde el punto de vista de la sociología, color significa un aspecto de la respuesta de un observador humano, una percepción que tiene lugar en el cerebro del observador como resultado de la estimulación visual, desde el punto de vista coloquial, el color se asocia con objetos cotidianos, como verde manzana o el azul cielo.

La retina del ojo humano capta la luz que refleja un objeto a través de sus sensores. Los sensores de luz se dividen en células bastón y células de cono, Las células bastón son más sensibles a la intensidad de la luz, permiten distinguir la luz de la oscuridad en condiciones de poca luz, gracias a estas células, podemos ver con poca luz y detectar distintos tonos de grises. En condiciones de luz normales, los ojos sólo utilizan células de cono, dependiendo de la luz que reciben los ojos, las células bastón y de cono envían señales al cerebro y este las procesa para crear la percepción de color, en términos generales, el ojo humano dispone de tres tipos de conos sensitivos que se corresponden con los colores primarios, correspondiendo a una población del $2 \%$ los sensibles al azul, un $33 \%$ los sensibles al verde y un $65 \%$ los que son sensibles al rojo, sin embargo los más sensibles son los azules, la combinación de los tres tipos de conos dan como resultado un amplio abanico de colores resultantes, entre ellos la mezcla de rojo puro y verde claro producen amarillo, rojo y azul producen magenta, verde y azul combinados crean cian y los tres juntos mezclados a máxima intensidad, crean el blanco intenso. Los conos rojos y verdes están dentro de la fóvea central (zona con mayor nitidez visual) y el azul fuera de ella.

El color exacto que se percibe depende de la composición de las longitudes de onda de la luz. Si los sensores detectan a la vez todas las longitudes de onda visibles, el cerebro percibirá luz blanca. Si la vista detecta una longitud de onda alrededor de 450nm veremos "azul", si es 525 veremos "verde" y si es entorno a 700 nm, veremos "rojo", si no hay luz, no se procesa ninguna longitud de onda y el cerebro percibe negro. 
Estas longitudes de onda están representadas en la curva de sensibilidad del ojo humano (que puede encontrarse en cualquier manual de luminotecnia) y que establece que la mayor sensibilidad del ojo se produce en la zona verde-amarilla, en torno a los $550 \mathrm{~nm}$ de longitud de onda, es decir el color se entiende de forma diferente según las circunstancias que rodean o en las que está interesado el observador, son en realidad las normativas UNE y CIE (Comisión Internacional de lluminación), las que definen un "observador colorimétrico patrón", que es un receptor teórico de radiación, y un "observador suplementario", adoptados por acuerdos internacionales.

Un espacio de color es una variante de un modelo de color que tiene una gama (rango) específica de colores, por ejemplo, el espacio RGB, estos espacios tienen en diversos programas con diferentes denominaciones, gamas diferentes de colores, pero estos espacios definen el color en los mismos tres ejes ( $R, G$ y $B$ ). Existen diversos tipos de modelos, los más comunes son el CIELAB, RGB y el CMYK, que a continuación explicaremos.

\subsection{El espacio de color CIELAB}

La CIE (Comisión Internacional de lluminación), desarrollo desde comienzos de los años 30 del siglo pasado diversos sistemas de color, definiendo el espectador estándar, a partir de una amplia muestra de pruebas realizas a personas. Observando tres tipos de sensores de color que corresponden a diferentes gamas de longitud de onda. Fue en 1931 cuando desarrolló su primer modelo basado en tres colores primarios imaginarios que son los que representan todas las gamas de color mediante combinación de sus variables $X Y Z$.

Para representar una gama de colores tridimensional sobre una hoja de papel bidimensional, representada mediante la transformación en dos dimensiones artificiales de color y una de intensidad, esto dio lugar al "diagrama de cromaticidad CIE xyY". Los dispositivos empleados para obtener imágenes son los que determinan los colores representados. La representación se organiza distribuyendo los colores del espectro visible para el ojo humano en la zona curvada, dejando la zona recta a los colores fuera del espectro visible y a los menos saturados en el centro.
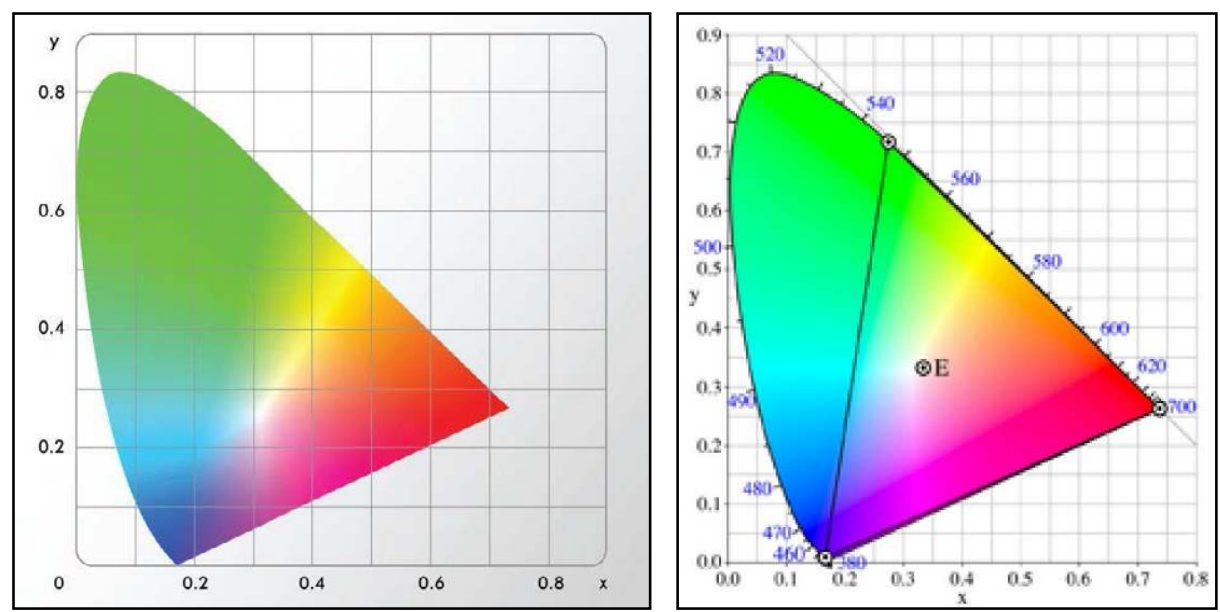

Figura 3. Diagrama de cromaticidad CIE xyY (imagen izq.); CIE L*a*b* (imagen dcha.). Fuente: Lacie-Libro blanco de la gestión de color 
Se puede dar la circunstancia de longitudes de onda hasta $810 \mathrm{~nm}$ con sensibilidades mucho más bajas que con luz verde. Dado que los puntos de corte en el diagrama se eligen arbitrariamente, hay que tener en cuenta que el diagrama expuesto representa como el ojo humano percibe la luz de un determinado espectro, pero no puede determinar el color de los objetos de la misma forma que los colores resultantes al imprimir, debido a que un objeto está influenciado directamente por la luz que recibe un observador para que pueda verla, además de otros parámetros

\section{El espacio de color CIE L*a*b*}

Actualmente el espacio utilizado por CIE es el espacio de color $L^{*} a^{*} b^{*}$, más completo, donde " $L$ " representa la luminosidad, siendo $L^{*}=0$ para el negro y $L^{*}=100$ para el blanco, "a" y "b" representan los valores de los diferentes colores, variando de rojo a verde, donde para "a" los valores negativos indican verde mientras los positivos indican rojo y para "b" los valores negativos indican azul y los positivos amarillo, estableciendo un valor delta $E(\Delta E)$, para la diferencia o distancia existente entre dos puntos dentro del espacio de color $L^{*} a^{*} b^{*}$.

En el espacio de color CIELAB, la luminosidad (L) varía entre 0 y 100. En el Selector de color y la paleta de colores de Adobe, el componente a (eje verde-rojo) y el componente b (eje azul-amarillo) pueden estar comprendidos entre +127 y -128 .

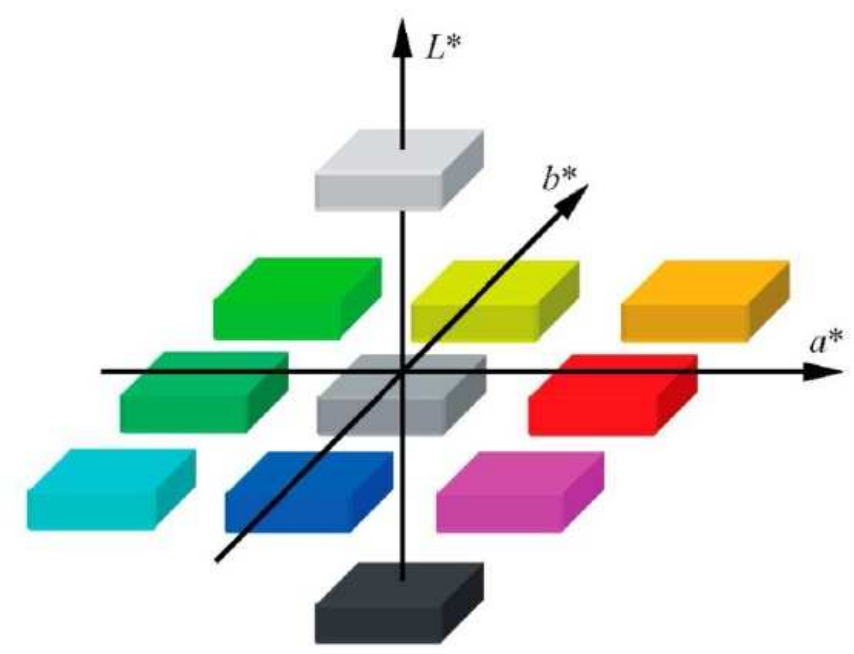

Figura 4. Espacio de color CIE L*a*b* - Norma UNE-EN 1588/2011

CIELAB es un espacio de color teórico, lo que implica que no puede ser utilizado por ningún dispositivo, pero es muy importante porque se inspira en la forma en que los seres humanos percibimos los colores y es capaz de codificar más tonos que los espacios RGB y CMYK.

\subsection{El espacio de color RGB}

La denominación RGB procede de las utilizar las iniciales en inglés de los colores primarios "Red, Green, Blue" (Rojo, Verde, Azul), se define mediante un sistema aditivo que puede obtener cualquier color del espectro visible, mediante la suma de las 
frecuencias de los colores primarios, que son percibidas por el ojo humano y en ausencia de estos lo que se percibe es el negro. Los histogramas de los programas que utilizan RGB, utilizan el valor tonal de cada pixel que se obtiene mediante un promedio ponderado de los tres canales, esta ponderación aproximadamente asume que el verde representa el $59 \%$ de la luminosidad percibida, mientras que a los canales rojo y azul les asigna un peso del $30 \%$ y el $11 \%$ respectivamente, que se corresponde con la curva de sensibilidad del ojo humano, dado que aunque el ojo disponga por ejemplo de menos conos de azul, sin embargo estos tienen la mayor sensibilidad.

Este Sistema se utiliza en dispositivos que trabajan directamente con la luz, como son monitores, proyectores, además de cámaras fotográficas o televisores u otros sistemas que permitan percibir estos colores primarios.

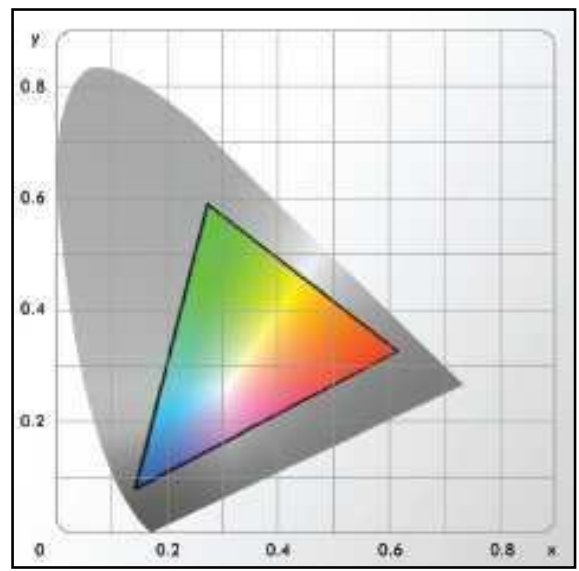

Figura 5.Diagrama de cromaticidad RGB

Fuente: Lacie-Libro blanco de la gestión de color

El diagrama RGB se define como un triángulo debido a que se basa en los tres colores primarios, la zona en gris corresponde a colores puros.

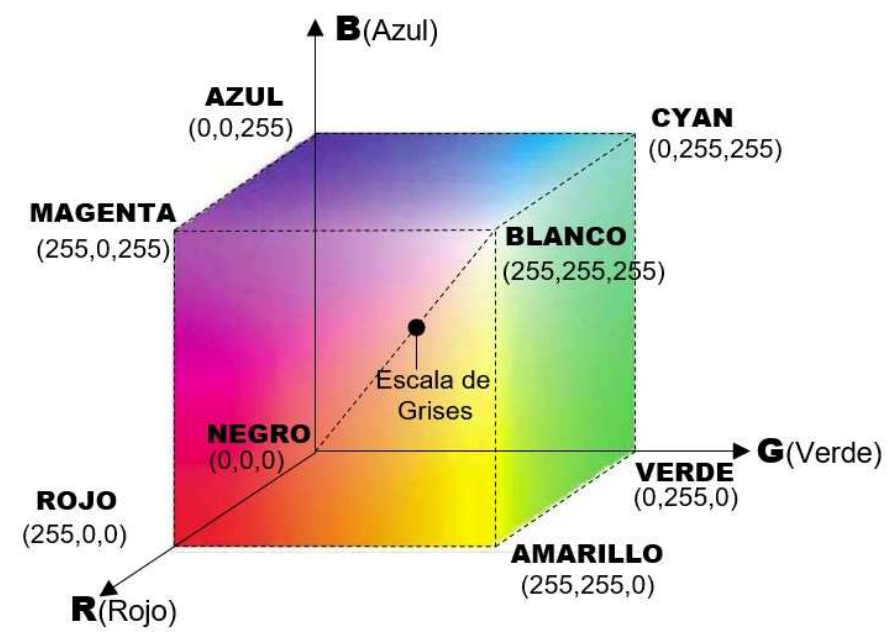

Figura 6. Modelo de color RGB/3D (color representado en caras externas).

Elaboración Propia. 
Esta Tesis utiliza el sistema de color RGB, cuya elección se explica más adelante, donde se utilizan los histogramas correspondientes a los colores básicos, que nos sirven para obtener datos de las diferencias porcentuales de los colores obtenidos.

\subsection{El espacio de color CMYK}

El espacio de color CMYK, es en realidad el espacio CMY, al que se le añade la $\mathrm{K}$ (Black), para obtener mejores resultados, sus siglas corresponden en inglés a "Cian, Magenta; Yellow; Black" (Cian, Magenta; Amarillo, Negro), a diferencia del RGB, se apoya en la teoría de los colores primarios sustractivos o modelo de color sustractivo.

Esto significa que los colores no son el resultado, de la mezcla de luz roja, verde y azul en distinta proporción, sino de la combinación de unos pigmentos capaces de absorber distintas longitudes de onda de la luz. La teoría defiende que podemos obtener prácticamente cualquier color absorbiendo de la luz blanca distintas proporciones de cian (C), magenta (M) y amarillo (Y). El negro se obtiene de al mezclar todos los colores y el blanco se obtiene por ausencia de cualquier color, pensando que la base donde encontremos los colores sea un papel blanco. La K del nombre de este espacio de color procede del negro (se utiliza la K de black y no la B para no confundirlo con el azul), es un pigmento que se emplea para corregir la desviación que se produce debido a la dificultad que entraña fabricar pigmentos cian, magenta y amarillo perfectos y cuya combinación no daría un negro perfecto. Algo que a tener en cuenta es que cuando trabajamos en el espacio de color CMYK debemos indicar el porcentaje de absorción de cada uno de los canales. Esto significa que con un 100\% de cian, magenta y amarillo obtendremos el color negro.

Los dispositivos que recurren a la manipulación de pigmentos, como las impresoras, los sistemas de fabricación de planchas de impresión o los plóter, utilizan el espacio de color CMYK, dado que es más preciso a efectos de mezclas de pigmentos.

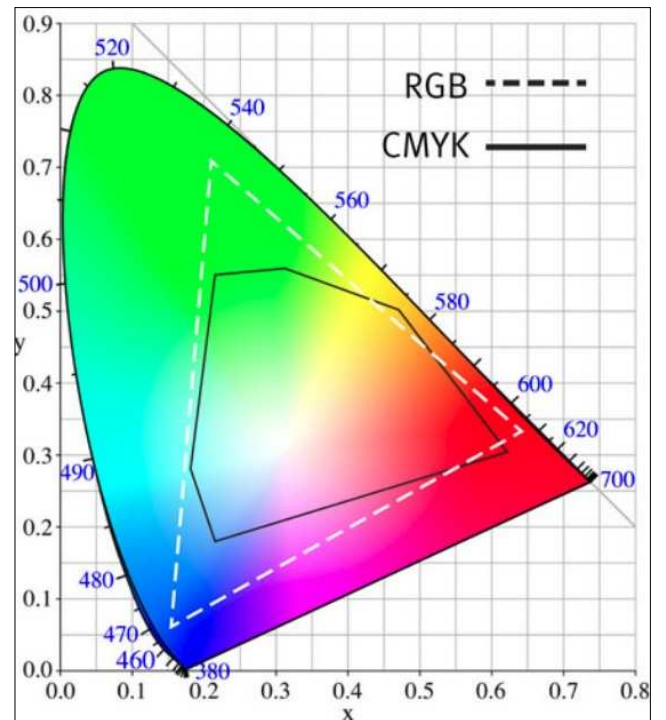

Figura 7. Circulo cromático CMYK. Fuente: foroalfa.org

Se debe tener en cuenta que sólo con unos colores "primarios" ficticios se puede llegar a conseguir todos los colores posibles. Estos "primarios" son conceptos arbitrarios utilizados en modelos de color matemáticos que no representan las sensaciones de 
color reales o incluso los impulsos nerviosos reales o procesos cerebrales. En otras palabras, todos los colores "primarios" perfectos son completamente imaginarios, lo que implica que todos los colores primarios que se utilizan en las mezclas son incompletos o imperfectos.

\subsection{Imagen digital, parámetros de utilización e Histogramas}

El avance tecnológico de las últimas décadas, ha propiciado un salto en la forma de entender la imagen, de la misma forma que anteriormente supuso el paso de la imagen pictórica (producida mediante pigmentos fabricados por los propios pintores, obteniendo colores muy particulares) a la imagen fotográfica tradicional o analógica (formada por granos irregulares y situados de forma aleatoria), lo que supuso también un cambio sustancial en los materiales empleados para su reproducción, la tecnología ha propiciado el nacimiento de la imagen digital, produciendo dispositivos tanto para capturar las imágenes como para reproducirlas, basados en conceptos diferentes de los anteriores y en el cálculo binario utilizado por los ordenadores, es decir sólo emplean el valor 0 ó 1, su unidad mínima de información es el bit, que al ser muy pequeña, se combina en grupos denominados bytes, donde 1 Byte son 8 bits, y que normalmente conocemos por los valores de 1 Kilobyte $(k)=1024$ bytes; 1 Megabyte $(M B)=1024 \mathrm{~Kb}$; 1 Gigabyte $(\mathrm{GB})=1024 \mathrm{MB}$.

El elemento básico del que se compone una imagen digital es el "pixel" (picture element), está basado en un código numérico que interpreta el ordenador, cuya forma es cuadrada, teniendo el conjunto de todos los pixeles que forman una imagen el mismo tamaño, dispuestos mediante una matriz de filas y columnas, cuyo número influye en la nitidez y detalle de final de la imagen, dado que puede tener hasta 16,7 millones de colores, almacenan la información en formato binario, relativa a su tono o luminosidad variando desde el valor 255 (blanco) al valor 0 (negro).

Existen 2 tipos de imágenes digitales:

-Imagen Vectorial:

Son imágenes basadas en puntos donde sus parámetros geométricos, se definen mediante coordenadas, ya sean cartesianas o polares, siempre referidas a un origen, lo que permite representaciones en 3 dimensiones (3D), y cuyos elementos geométricos que conforman como por ejemplo rectas, curvas, superficies de revolución, regladas o volúmenes, pueden a su vez estar dotadas de propiedades como el color o el espesor, permitiendo una imagen detallada y de calidad, que aunque se manipule ya sea por aumento de escala o por deformación, sus puntos siguen disponiendo de coordenadas, permitiendo tratar el color y la textura de sus superficies en 3D.

\section{-Imagen de Mapa de Bits}

También llamadas imágenes Raster o bitmap, están basadas como antes se ha explicado, mediante pixeles, que no disponen de coordenadas geométricas, lo que supone, que se dispongan en 2 dimensiones (2D), otra cosa es que en función del número de pixeles, se pueda llegar a dar la sensación de que está en $3 \mathrm{D}$, como es el caso del cine, pero realmente la imagen es en 2D y no permite cambiar su escala, dado que se puede comprobar realizando un zoom sobre la imagen, que pierde su forma. 
El detalle o nitidez de la imagen de mapa de bits, se basa en el concepto de "resolución" asociada al número de pixeles, medida en pixeles por pulgada (ppp), cuyo aumento implica mayor volumen de bytes, siendo aplicada en todo tipo de dispositivos periféricos de los ordenadores, como monitores, impresoras o escáneres, aunque las imágenes se expresen en $\mathrm{cm}$ o $\mathrm{mm}$, los programas informáticos suelen reflejarlas en pixeles, pero se pueden convertir multiplicando los valores de $\mathrm{cm}$ por la resolución en pixeles por $\mathrm{cm}$ (pasando las pulgadas a $\mathrm{cm}$ ).

La composición de las imágenes digitales en color se realiza mediante síntesis aditiva de los colores primarios R, G,B, cada uno de ellos con una gama de 256 tonos, cuya multiplicación nos da el valor de 16,7 millones de pixeles.

A esto hay que añadir la escala de grises, se utiliza para obtener profundidad, almacenando el valor correspondiente de cada punto en 1 byte, que puede variar en 256 valores posibles de tonos de grises.

Los ficheros creados por los programas de ordenador a partir de los volúmenes de información en pixeles, para imágenes de mapas de bits, se diferencian en que unos permiten más colores o más compresión.

Los principales formatos de imagen digital son los siguientes:

\section{-Fichero con extensión JPG (Joint Photographic Experts Group)}

Con una distribución de 24 bits/pixel, que es un formato flexible, pero con un tipo de compresión que pierde algo de nitidez respecto a la imagen original, dividiendo los datos en color y luminosidad y permite escala de grises, pero es muy usado por que su volumen es mucho menor que el de otros formatos de ficheros de imágenes digitales.

\section{-Fichero con extensión GIF (Graphic Interchange Format)}

Es un formato poco utilizado, empleado para pequeñas imágenes, dado que permite almacenar poca información, aunque se pueden concatenar imágenes en los llamados "GIF animados", debido a un indexado del color y traduciéndolos a una tabla de 256 colores y disponiendo de poca profundidad de color de 8 bits, por razones comerciales se ha sustituido por el formato PNG.

\section{-Fichero con extensión PNG (Portable Network Graphic)}

Es un formato que comprime mejor que el GIF, con mayor profundidad de color de 24 bits, con un sistema de compresión sin pérdidas, permitiendo fundir la imagen con el fondo, pero su volumen de datos es alto.

\section{-Fichero con extensión BMP (BitMap)}

Es el formato más extendido en los programas informáticos y aplicaciones de sistemas operativos y permite más profundidad de color de 24bits y 16,7 millones de colores, con una tasa de compresión baja lo que implica un volumen alto de datos, lo que él hace a efectos de almacenamiento o tratamiento de imágenes, una mayor complejidad. 


\subsection{Normativa actual sobre el color}

Se consulta la normativa sobre color AENOR existente, aplicable a otros tipos de procesos. Esta normativa se adjunta en el capítulo de anexos.

\subsection{Conclusiones al capítulo}

Este capítulo sirve de punto de partida para conocer los diferentes espacios de color que se utilizan normalmente en la captación y procesamiento de imágenes, en especial el RGB, y que responden cada uno a una gama de colores determinada y como se obtienen los colores por adición o por sustracción, partiendo de colores abstractos determinados matemáticamente como CIELAB y si se utilizan para observar los colores mediante dispositivos que emplean la luz o para la impresión de colores como CMYK, además de los diferentes tipos de formato en las que se almacenan las imágenes y sus diferencias, y la normativa existente, relacionada con el cambio cromático de color de forma superficial. 


\section{ELECCIÓN DEL ESPACIO DE COLOR RGB}

Las características del espacio de color RGB y la falta de normativa específica, respecto al espacio de color aplicable a la variación superficial del color en materiales orgánicos, conduce a elegir este espacio para esta tesis. 


\section{ELECCIÓN DEL ESPACIO DE COLOR RGB}

\subsection{Espacio RGB y transformación con otros espacios.}

Los dispositivos actuales que nos permiten tratar imágenes son muy diversos, lo que implica la necesidad de convertir la información obtenida de los colores de una imagen, entre los diferentes espacios comentados anteriormente, debido a que existen diferencias de representación de los colores según el dispositivo y el correspondiente espacio de color con el que se trabaje.

Los programas de tratamiento de imágenes nos permiten realizar esta conversión automáticamente, basados en algoritmos establecidos, incluso existen páginas web que realizan la conversión numérica de los valores obtenidos.

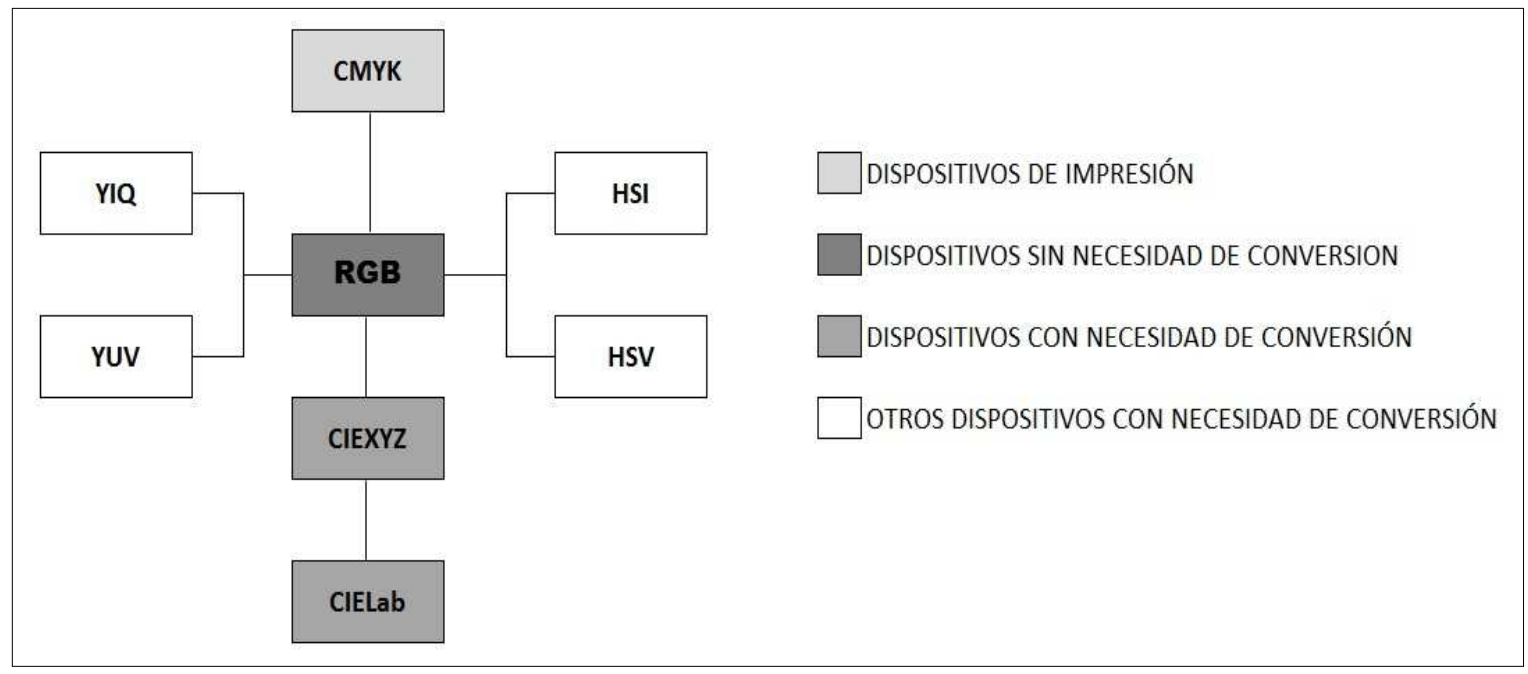

Figura 8. Relación entre espacios de color. Conversión. Elaboración Propia

Como se puede observar en la figura anterior, el espacio de color RGB, aún teniendo un ámbito más reducido de variaciones de color (figura 8), es el que se sitúa como referencia de los demás espacios de color, en especial el CIELab, los dispositivos y los programas en general utilizan el RGB como conversor universal, es decir se puede guardar una imagen en CIELab, pero a la hora de editarla, los programas la convierten en RGB y los dispositivos también, aunque después se pueda guardar en un formato CIELab.

A través del espacio RGB se obtiene por transformación lineal el espacio CMYK, lo que implica menores errores a la hora de convertir la información.

La función del espacio CIExyz es como vehículo de transformación lineal del espacio RGB a algunas coordenadas del espacio CIELab, no siendo utilizado normalmente en el tratamiento de imágenes, pero la transformación de RGB a CIELab no es lineal, lo que implica variaciones en la conversión entre ambos sistemas.

En resumen, el espacio RGB, es un sistema universal tanto para otros espacios de color como para los dispositivos y programas de tratamiento de imágenes. 


\subsection{Elección de espacio de color RGB}

Hay que tener en cuenta que el espacio CIELab no deja de ser un espacio nacido de un cálculo matemático, partiendo de parámetros abstractos de colores, que aunque el ojo humano pueda observar, en su configuración se definen por ejemplo colores puros, que no existen en la naturaleza o que no son percibidos de forma universal, es como cuando se tiene un equipo de música que por muy bueno que sea y con una gran amplitud de frecuencias con posibilidad de ser escuchadas sin embargo, normalmente no podemos oír todas estas frecuencias porque nuestro oído sólo escucha una fracción mucho menor de esas frecuencias, que son las que podemos diferenciar y apreciar, por eso se fija el parámetro Delta E para poder diferenciar colores y comparar con otros sistemas, sin embargo el espacio de color RGB, al ser un espacio de color más restrictivo, permite al ojo humano diferenciar mejor el color que unido a su cualidad de universal y de una transformación lineal de sus parámetros a otros sistemas y dispositivos le permite no perder información.

Se presenta a continuación, los determinantes o razones por los cuales se opta por el espacio de color RGB, frente a los demás sistemas de espacio de color, en especial el CIELab.

\subsubsection{Normativa actual sólo aplicable a materiales inorgánicos}

La referencia de Normativa referente al color más próxima en el tiempo es la UNE- EN 15886 de Enero de 2011 que se titula "Conservación del patrimonio Cultural. Métodos de ensayo. Medición del color de superficies.", en cuyo objeto y campo de aplicación de la norma se especifica que "...Esta norma europea describe un método de ensayo para medir el color de la superficie de materiales inorgánicos porosos, y sus posibles cambios cromáticos. No se hace referencia al aspecto de las superficies brillantes. El método puede aplicarse a materiales inorgánicos porosos, tanto tratados como no sometidos a tratamiento o envejecimiento alguno...".

El objeto de esta tesis es la variación de color que produce la aplicación superficial de ácidos líquidos incoloros en estado líquido sobre las maderas de construcción, lo que implica que al ser un material orgánico la madera, la normativa anterior comentada no es de aplicación, la cual se aplica específicamente a materiales inorgánicos porosos, de la misma forma se ha investigado si existe normativa al respecto, referente a la variación de color en la superficie de materiales orgánicos pero no se ha encontrado ninguna normativa aplicable.

\subsubsection{Determinantes de la elección del espacio RGB.}

En el espacio CIELab, como se ha comentado, aunque abarque toda la posibilidad cromática de colores, hay zonas que el ojo humano no puede diferenciar.

Como se ha comentado en esta Tesis, se estudia la variación del color que produce la aplicación superficial de ácidos líquidos incoloros en estado líquido sobre las maderas de construcción, pero esta variación de color entendida desde el punto de vista de un arquitecto, debe ser una variación apreciable y diferenciable para el ojo humano, que permita observar la variación cromática producida en las diferentes especies de madera, para convertirse en un valor añadido de las mismas, por lo que en esta Tesis esta variación se estudia porcentualmente y no en valores absolutos, que aun siendo correctos, para el caso del espacio CIELab se podría diferenciar una variación cromática en una madera que a efectos prácticos un observador normal no distinguiría. 
En el sistema CIELab , la normativa solo se aplica a materiales inorgánicos (inertes), como pinturas, plásticos, vidrios, paneles, cerámica u otros tipos de materiales susceptibles por su condición de inertes de poder establecer un color determinado para su comercialización por ejemplo como parte de la imagen corporativa de una marca (los rótulos de las entidades bancarias) o para distinguirse de la competencia, al disponer de un producto que en el mercado sólo tiene una empresa, en esa obtención de un color determinado, se utiliza el espacio CIELab, porque elige 5 puntos de referencia determinados que después compara estadísticamente sobre una superficie uniforme perfecta, es decir se entiende que CIELab es más adecuado utilizarlo cuando se busca un color determinado para un producto determinado que permita una industrialización donde todos los materiales mantengan el mismo color, aunque disponga de la posibilidad de observar la variación cromática de los mismos, utilizada precisamente para mantener el mismo color.

Un ejemplo donde se utiliza CIELab para materiales orgánicos, es en los vinos, donde se pretende que el color del vino sea uniforme para toda la producción y que sea un color distintivo, el vino es precisamente por su condición, un material virtualmente "uniforme" al ser líquido. CIELab, en el campo de los materiales inorgánicos, sería difícil de utilizar por ejemplo en mármoles con vetas u otros tipos de piedras naturales.

En los materiales orgánicos dispones de una amplia gama de color en la superficie debido a su anisotropía y a su textura, lo que en términos formales arquitectónicos se denomina expresividad, cuyo origen es natural, si utilizáramos el sistema CIELab, podríamos tener variaciones sustanciales, debido a que se necesitarían muchas mediciones parciales para obtener estadísticamente un valor determinado, se determinaría una nube de puntos con una recta de regresión, como resultado de los experimentos.

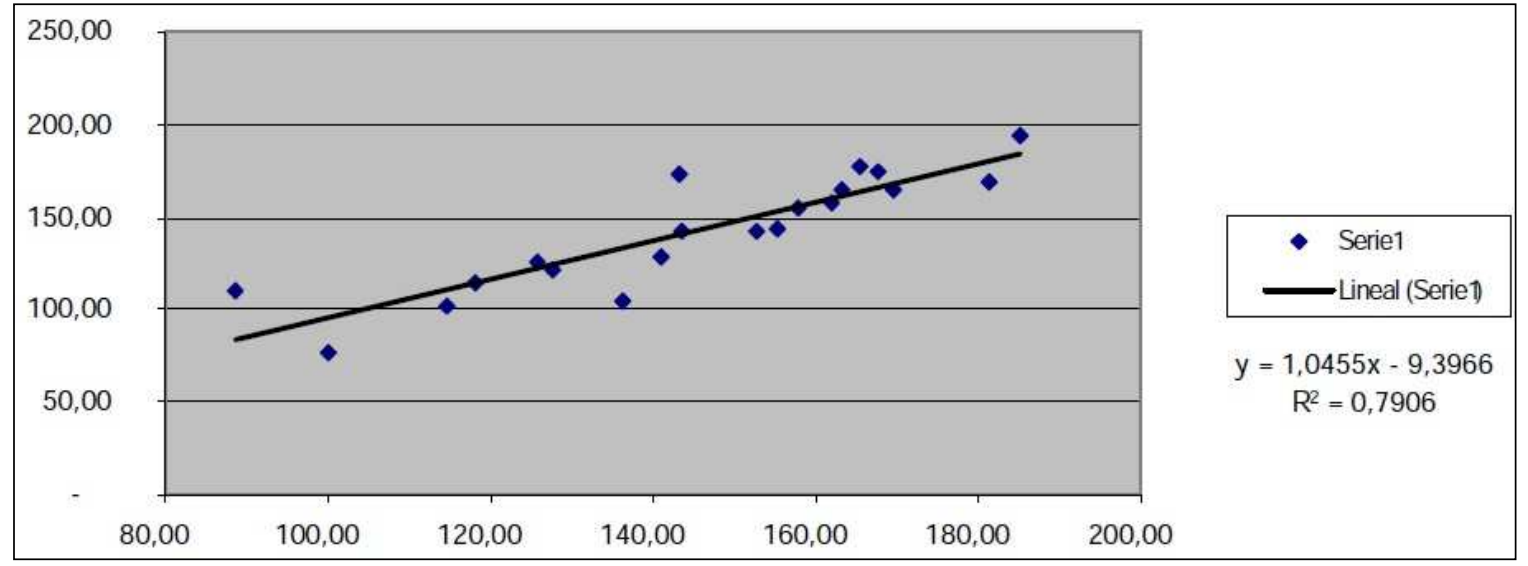

Figura 9. Ejemplo. CIELab. Recta de regresión. Fuente : Rodriguez, A

Sin embargo, en el sistema RGB, se observan curvas obtenidas a partir de toda la muestra, basadas en volúmenes de pixeles en función de su luminosidad y de los colores básicos, cuyo resultado es un conjunto homogéneo de curvas y superficies a estudiar, aunque los valores obtenidos puedan ser más relativos desde el punto de vista científico que los del sistema CIELab que serían valores más absolutos. Dentro del ámbito de la arquitectura el sistema RGB se acerca más a los intereses de esta disciplina interesada más en los cambios perceptivos de los materiales mediante el cambio de color, textura y líneas de expresión, como es el caso de las maderas. 
La aplicación superficial de ácidos líquidos incoloros sobre maderas de construcción permite un sistema industrializado, pero no para obtener todos los materiales iguales, sino para utilizarlo en las maderas para ampliar su gama de colores y texturas que les permitan diferenciarse dentro del mercado, manteniendo la naturaleza de la madera.

Es decir CIELab, es un sistema más científico, basado en colores abstractos difíciles de diferenciar por un observador, y representado mediante nubes de puntos con una recta de regresión, cuya observación es difícil de entender y por extensión sus conclusiones, aplicado a materiales inorgánicos, isótropos y de color uniforme, pensado para observar impurezas en procesos productivos, mientras que el RGB es un sistema de valores más relativos, basado en colores primarios, universal, convertible linealmente a otros sistemas de color o dispositivos sobre los que no influye, con histogramas que derivan en curvas y superficies que son más intuitivas, con el que es más fácil de observar patrones de comportamiento de los materiales orgánicos y anisótropos o de aquellos inorgánicos como los mármoles cuyo color o aspecto no es uniforme, por lo que se entiende que por esta razón sólo exista normativa parcial para materiales inorgánicos, utilizando el sistema CIELab, y no para materiales orgánicos o aquellos inorgánicos, que por su composición y forma, no pueda aplicarse.

\subsubsection{RGB. Definición y análisis mediante histogramas. Tipología.}

En estadística un histograma describe de forma gráfica el número de píxeles que hay por cada nivel de intensidad de color o tono de color, que normalizado a la unidad, puede entenderse como la probabilidad de que un valor de un nivel de intensidad de color determinado aparezca en la imagen y permite ofrecer una imagen rápida de la tonalidad de la imagen, es decir, el programa informático compara el nivel de intensidad de color o tono de color del pixel de la imagen con el nivel de intensidad o tono de color más aproximado de la paleta universal de colores del espacio RGB.

El histograma de una imagen digital con $L$ niveles de intensidad de color y rango [0, $L-1]$ es una función discreta de la forma:

$$
h(r k)=n k / n
$$

$$
\begin{array}{ll}
h(r k) & =\text { Función de distribución del histograma } \\
r k & =\text { k-ésimo nivel de intensidad de color } \\
n k & =\text { Número de pixeles en la imagen de un } r k \text { determinado } \\
n & =\text { Número total de pixeles de una imagen } \\
k & =0,1,2 \ldots . . . \mathrm{L}-1
\end{array}
$$

El número de pixeles o frecuencia de repetición de un nivel de intensidad de color se representa en el eje vertical y el nivel de intensidad de color o tono de color se representa en el eje horizontal, donde el histograma también tiene en cuenta las coordenadas de posición del pixel en una imagen.

En el programa informático se emplean los parámetros de número de pixeles, escala de niveles de intensidad de color o tono de color entre 0 y 255 , el valor promedio, la desviación estadística y la mediana, donde estos valores estadísticos se presentan debajo de la gráfica del histograma. (Figura 10, izq.) 

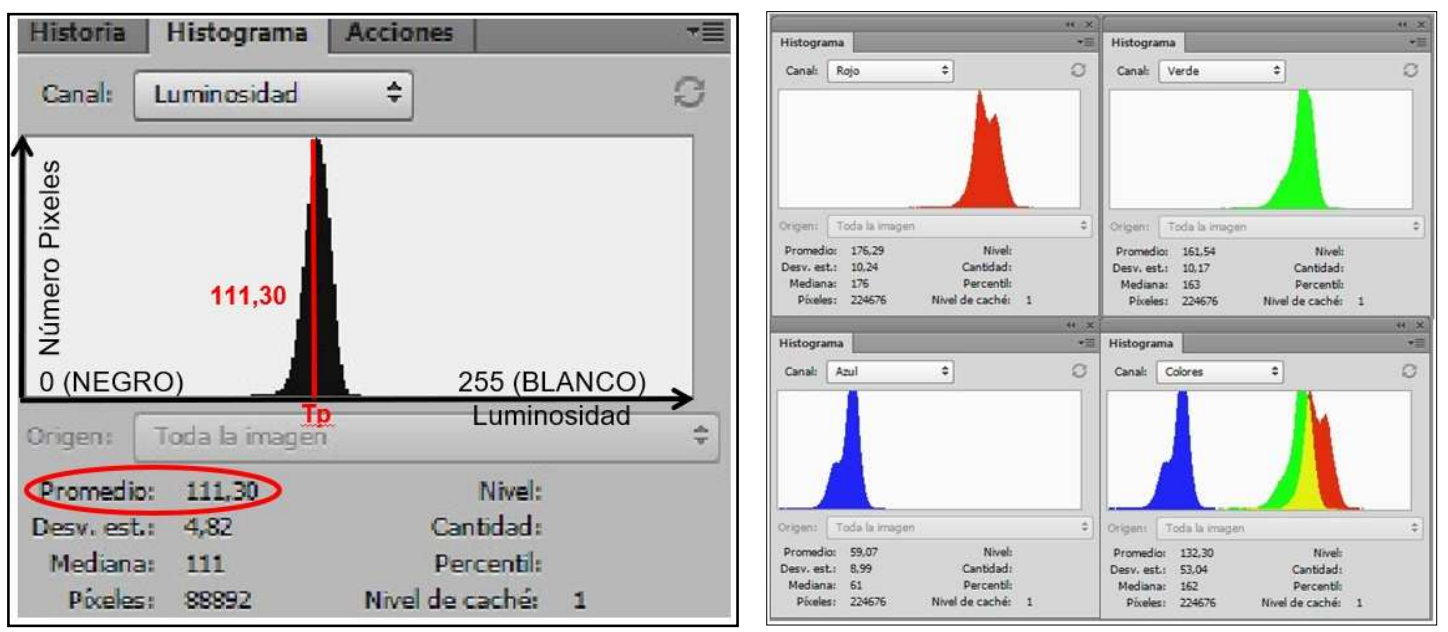

Figura 10. Representación Histograma de Luminosidad (izquierda). Ejemplo Histogramas, Rojo, Verde, Azul y Promedio (derecha). Fuente: Adobe

El espacio de color RGB, que también se elige porque ofrece mayor independencia de dispositivos, pues no depende de los monitores o las tintas, analiza su variación del color de una materia mediante la realización de histogramas, representados mediante ejes de coordenadas cartesianas, donde se dibuja una gráfica de barras que representa el número de pixeles de la imagen por cada valor de nivel de intensidad de color o tono de color, situando en el eje de abscisa (horizontal) las diferentes intensidades de color 0 tonos de color divididas en 256 columnas, y situándose el "negro" con valor (0) a la izquierda y el "blanco" con valor (255) a la derecha y en el eje de ordenadas (vertical) donde la altura de cada una de las columnas determina el número de píxeles que hay por cada uno de los valores de nivel de intensidad de color o tono de color, y obteniendo tanto el promedio (valor medio del tono de color del conjunto de pixeles), como los valores de luminosidad, rojo, verde y azul, por separado y en el conjunto. Los valores del histograma de Promedio son una media de los valores de Rojo, Verde y Azul.

Esta tesis utiliza los valores promedio que detalla el programa informático en el histograma (Figura 10), para utilizarlos como "valor promedio de nivel de intensidad de color de referencia" o "tono de color promedio de referencia" y poder comparar posteriormente maderas de construcción y ácidos ensayados, con maderas y ácidos no ensayados.

Los colores son representados, mediante otros histogramas de las mismas características. La variación de color se obtiene al estudiar las muestras de madera antes y después de ser tratadas, comparando la diferencia observada en los histogramas correspondientes.

El histograma de luminosidad muestra una mezcla de los valores tonales de cada uno de los canales RGB, pero a diferencia del histograma RGB, no asigna el mismo peso a cada uno de ellos, ponderando el verde que representa el $59 \%$ de la luminosidad percibida, mientras que a los canales rojo y azul les asigna un peso del $30 \%$ y el $11 \%$ respectivamente, que se corresponde con la curva de sensibilidad del ojo humano (donde la máxima zona de visibilidad es la zona verde-amarilla). 
Es decir una cosa es la representación de la curva del histograma de Luminosidad, que responde a la curva de sensibilidad del ojo humano (que puede encontrarse en cualquier manual de luminotecnia) y que establece que la mayor sensibilidad del ojo se produce en la zona verde-amarilla (en RGB la suma de Verde y Rojo da Amarillo), en torno a los 550nm de longitud de onda, y otra la población de conos en el ojo humano (fundamentalmente en la fóvea central, donde se concentran conos de rojo y verde y en el exterior conos de azul) que corresponde a conos sensibles al azul (2\%), conos sensibles al verde (33\%) y conos sensibles al rojo (65\%), donde los conos azules son los más sensibles y después los verdes.

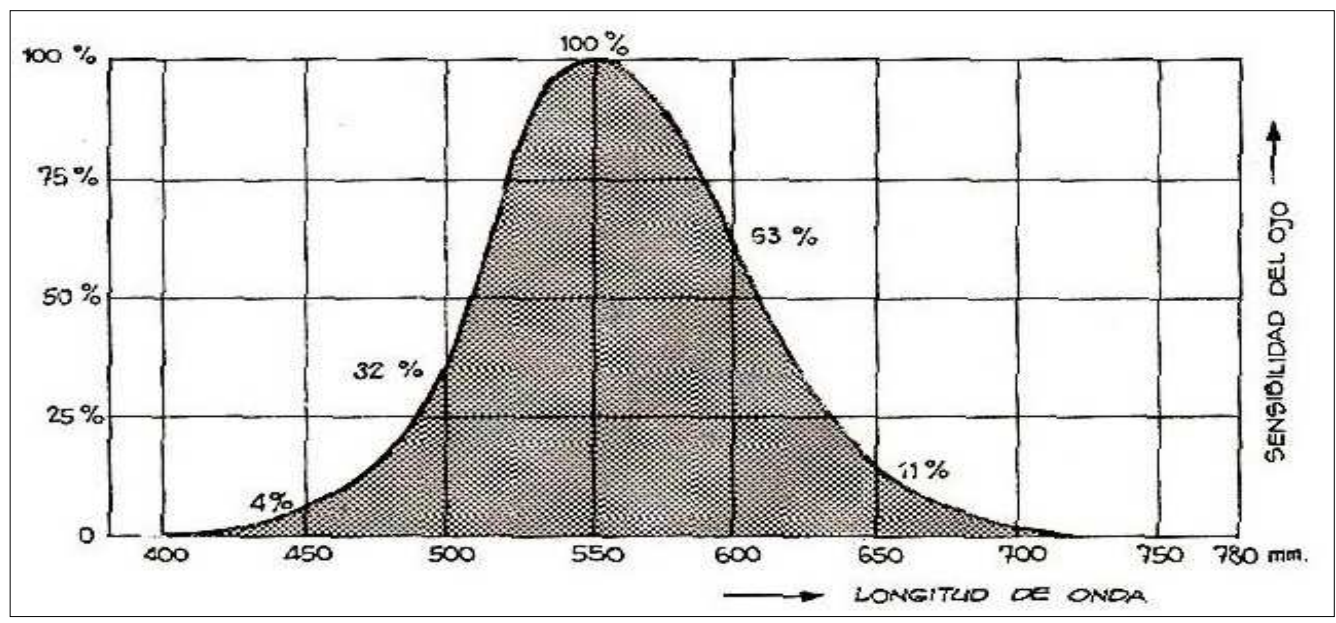

Figura 11. Curva de sensibilidad del ojo humano con respecto a las longitudes de onda dentro del campo visible. Fuente: Arizmendi

En la figura, los tanto por ciento son simétricos respecto al eje del $100 \%$ de sensibilidad del ojo humano.

La curva de sensibilidad del ojo relaciona los colores desde el punto de vista fisiológico percibidos por nuestro ojo con las longitudes de onda desde el punto de vista físico. Esta escala (Arizmendi) es: Radiación Ultravioleta<400nm (color mu frío); Violeta de 380 a 400nm; Azul 450nm; Azul-Verde 500nm (color frío); Verde $525 \mathrm{~nm}$; VerdeAmarillo 550nm; Amarillo 575nm; Naranja 600 nm (color cálido); Rojo 650 a 780nm; Radiación Infrarroja < 780nm (color muy cálido).

\subsection{Conclusiones al capítulo}

Esta tesis utiliza los valores promedio que detalla el programa informático en el histograma (Figura 10), para utilizarlos como "valor promedio de nivel de intensidad de color de referencia" o "tono de color promedio de referencia" y poder comparar posteriormente maderas de construcción y ácidos ensayados con maderas y ácidos no ensayados.

La elección en esta Tesis del espacio de color RGB, respecto a otros espacios de color como CIELAB (que también sería válido para utilizarla) se basa en que el espacio de color RGB al ser un espacio más restrictivo en cuanto a gama de colores, permite mejor la diferenciación de los colores para el ojo humano, partiendo de colores primarios, dado que para esta Tesis interesa aquellas diferencias de color que sean claramente perceptibles para el ojo humano, mientras que en CIELAB se representan todos los 
colores de un modelo matemático, siendo difícil su diferenciación entre colores parecidos o muy próximos (para eso emplea el Delta E).

Como se puede observar en la figura de abajo, además el espacio CMYK, que es el que se emplea en los dispositivos de impresión se adecua más al espacio RGB, no pudiendo abarcar una amplia zona de colores del espacio CIELAB.

También porque RGB es el sistema más universal de intercambio entre los diversos espacios de color, siendo su conversión lineal con los demás espacios de color e independiente de los dispositivos en los que se utiliza, además no existe una normativa específica aplicable a la variación de color superficial en las maderas.

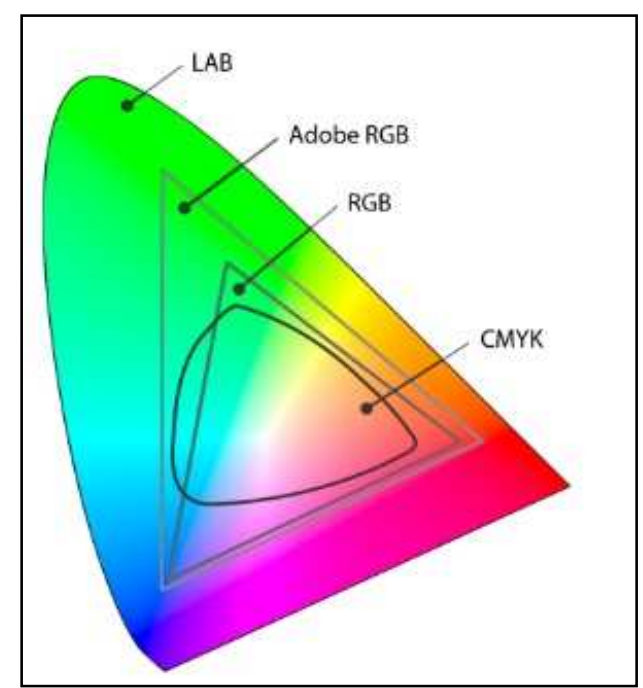

Figura 12. Espacios de Color. Fuente: Wordpress

No existe una norma que detalle un método de ensayo para medir el color de la superficie de materiales orgánicos porosos, y sus posibles cambios cromáticos. 


\section{CLASIFICACIÓN BOTÁNICA y MORFOLOGÍA DE LAS MADERAS. PRODUCTOS DE LAS MADERAS DE CONSTRUCCIÓN.}

Las diferentes divisiones de la clasificación botánica de la madera, su estructura macroscópica y microscópica, y en función de las divisiones su morfología y propiedades.

El procesamiento de la madera y los productos de la construcción asociados a ella. 


\section{CLASIFICACIÓN BOTÁNICA y MORFOLOGÍA DE LAS MADERAS. PRODUCTOS DE MADERAS DE CONSTRUCCIÓN}

\subsection{Generalidades}

La madera es un material orgánico de origen vegetal, de composición y estructura compleja y anisótropo, lo que le confiere propiedades diferentes a otros materiales de la construcción.

De las 17 divisiones que establece Enger en la división "Sylabus", sólo dos de estas divisiones son apropiadas para el proceso natural de la formación o generación de la madera y por extensión para la producción de la madera de construcción. Las divisiones I a XV incluyen las especies más antiguas del planeta.

Las divisiones $\mathrm{XVI}$ y XVII son las que generan madera, para posteriormente producir productos manufacturados de madera para la construcción.

La división XVI son las GIMNOSPERMAS, del griego gymnos, desnudo, sin protección y de speirein, sperma, semilla. Quiere decir: plantas con semillas que no están protegidas por una envoltura, es decir, sus semillas están desnudas, comúnmente se las denomina Coníferas.

La división XVII son las ANGIOSPERMAS, del griego angion, vaso y de speirein, sperma, semilla, sembrar. Plantas con semillas desarrolladas dentro de una envoltura, es decir "semillas incluidas en un vaso", comúnmente denominadas frondosas.

Estas dos divisiones se dividen según el siguiente cuadro.

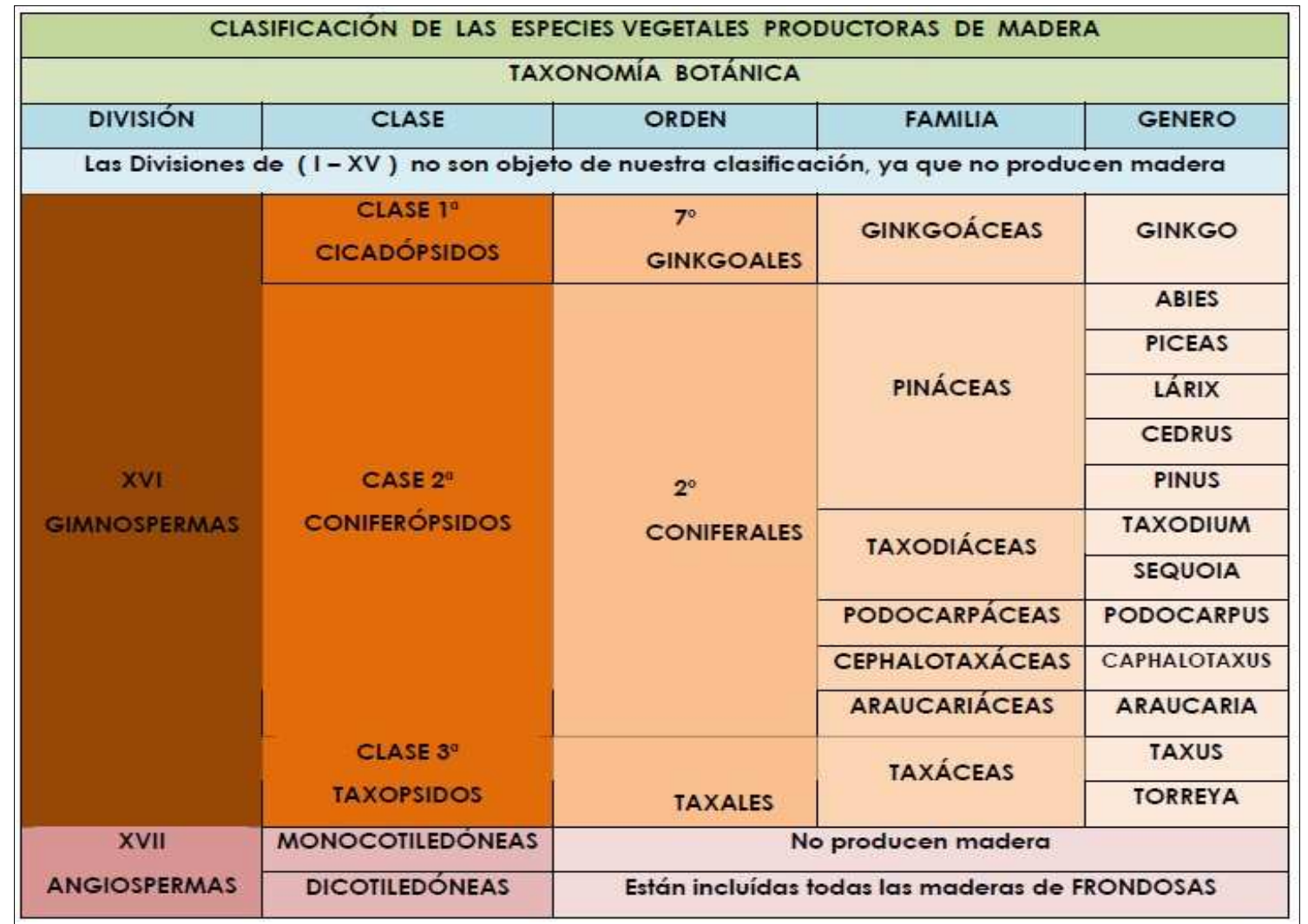

Figura 13. Clasificación especies vegetales productoras de madera.Fuente:Rodríguez,A. 


\subsection{División XVI - Gimnospermas (Coníferas)}

De las cuatro clases que componen las Gimnospermas, sólo tres generan madera, como se puede observar en el cuadro anterior y de estas clases, solo los órdenes mencionados en el cuadro generan madera, la especie más utilizada desde el punto de vista de las maderas de construcción son el orden 2 que son los coniferales, comúnmente denominados Coníferas, la cual dispone de las siguientes familias: "PINÁCEAS".Géneros:Abies(Abetos),Picea(Piceas), Lárix(Alerce),Cedrus(Cedros),Pinus( Pinos),etc;"TAXODIÁCEAS". Géneros, Taxodium (Ciprés de los pantanos, Ciprés calvo),Sequoia,Sequoiadendron,etc,"PODOCARPÁCEAS”.Géneros:Podocarpus (podos) ,y Saxegotháceas (Mañiu),etc,;“CEPHALOTAXÁCEAS”. Comprende a su vez, los siguientes géneros, Cephalotaxus. "ARAUCARIÁCEAS". Géneros: Araucaria. Como se puede observar, en el cuadro anterior, aunque sólo una, de estas clases son propiamente coníferas, comúnmente el nombre se amplía a todas las demás clases.

\subsection{División XVII - Angiospermas (Frondosas)}

De las dos clases de esta división, las Angiospermas Monocotiledóneas no generan madera, así pues, las maderas que generan madera son las Angiospermas Dicotiledóneas, a las cuales comúnmente, se las denomina Frondosas.

Dentro de las Frondosas, se pueden encontrar las especies Boreales, localizadas entre el trópico de Cáncer y el Círculo Polar Ártico, las especies Australes localizadas entre el Trópico de Capricornio y el Círculo Polar Antártico y las especies Tropicales localizadas entre el Trópico de Cáncer y el Trópico de Capricornio.

\subsection{Estructura general de la madera}

La estructura general de la madera se puede observar desde el punto de vista macroscópico, que correspondería a la percepción a simple vista de los elementos de la estructura del tronco de un árbol y desde el punto de vista microscópico.

\section{a) Estructura Macroscópica}

La organización de las diversas células que constituyen un árbol se agrupan en conjuntos morfológicamente muy diferentes, cuya organización varía de unas especies a otras y especialmente entre coníferas y frondosas.

Desde el punto de vista macroscópico si partiéramos desde el centro, observaríamos la médula o xilema, de forma poligonal o estrellada, es la responsable del crecimiento del árbol debido al meristemo apical, que en arboles de cierto grosor o edad, tienen en la zona central lo que se denomina duramen, que también es la madera más dura del árbol. Alrededor del xilema se van disponiendo anillos de crecimiento, formados inicialmente por un anillo de células claras que constituyen la madera temprana o de primavera y posteriormente un anillo de células oscuras que constituyen la madera tardía o de verano, por último en la corona más externa, normalmente de color claro se sitúa la albura, la albura y duramen, tienen diferentes propiedades, por ejemplo por la albura se distribuye la savia bruta (cuando se secan se convierten en conductos), también a la albura y al duramen se le denomina generalmente como tejido xilemático o madera. 


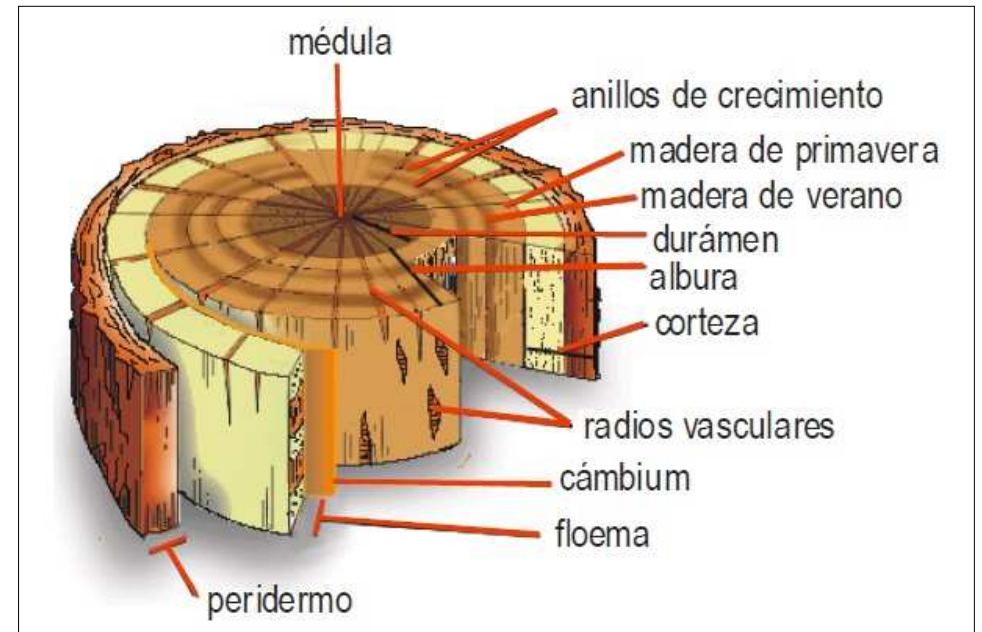

Figura 14. Estructura macroscópica de la madera. Fuente: C.Gracia

El Cambium es una fina capa blanquecina después de la capa más exterior que es la corteza o peridermo, desde él parte la estructura radial de la madera, responsable del crecimiento secundario de la madera, que aunque se separen al crecer, nacen de nuevo otros radios para que la distancia entre ellos sea constante, desde el cambium se forman células internamente que forman el Floema o líber constituido por una capa delgada que es el responsable de la distribución de la savia elaborada, que parte de las hojas hacia el centro del árbol y hacia el exterior del cambium se forman los nuevos anillos de crecimiento del árbol, y mediante las células externas que genera el floema por suberificación van formado la corteza o peridemo.

\section{b) Estructura Microscópica}

Desde el punto de vista microscópico, se puede estudiar la pared celular de las maderas, después que se produzca la división del cambium y cuando las células se expanden, se forma una nueva pared conocida como pared secundaria que se deposita internamente y que suele ser una pared muy gruesa, como por ejemplo en las traqueidas y fibras y confiere una gran resistencia al árbol, dispone de una lámina media que está formada por material amorfo, con una elevada proporción de ligninas que mantiene unidas a las células adyacentes.
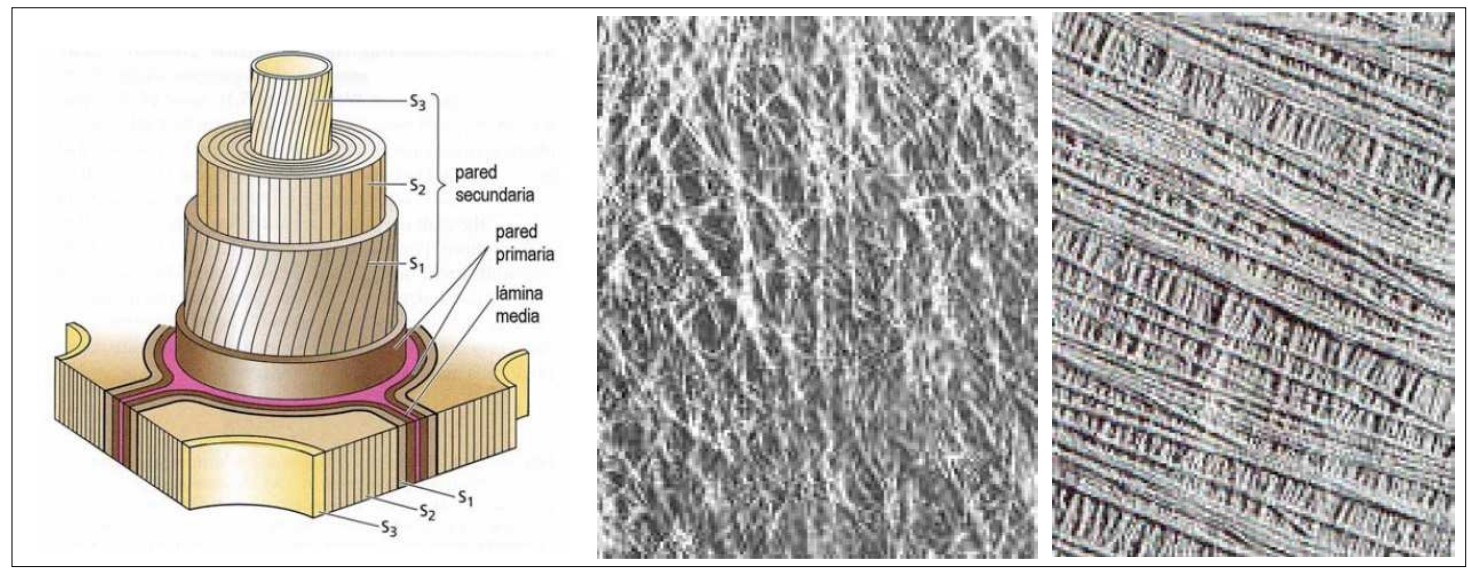

Figura 15. Estructura microscópica de la madera (izquierda). Microfotografía electrónica de la pared primaria (centro). Microfotografía de la pared secundaria (derecha). Fuente: C.Gracia 
La pared celular de las maderas, se compone de dos paredes, por un lado está la pared primaria, con una organización de las fibras amorfa y de espesor fino, y dentro de esta se dispone la pared secundaria, formada por tres capas $\mathrm{S} 1$, que se compone de microfibrillas de celulosa orientadas de forma paralela y con desviación angular respecto a la dirección longitudinal de la célula; la S2 es la más gruesa de las tres capas y prácticamente las microfibrillas son paralelas a la dirección longitudinal de la célula: la capa S3 vuelve a comportarse como la capa S1, estas microfibrillas están compuestas por moléculas de celulosa, que mantienen su estructura, por la malla formada por las moléculas de hemicelulosa y ligninas.

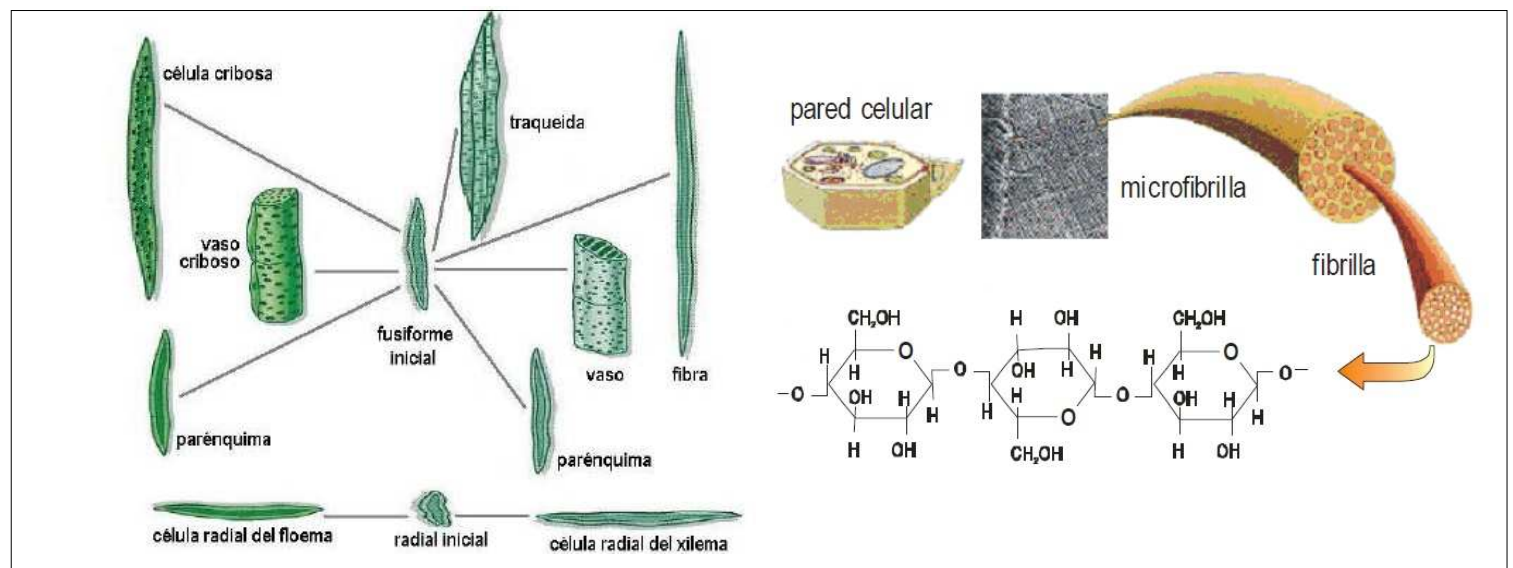

Figura 16. Tipos de células. Microfibrillas. Fuente: C.Gracia

En cuanto a los tipos de células, existen dos tipos de tejidos en las maderas que las defienden, las denominadas parénquimas que están formadas por células aproximadamente isodiamétricas que disponen de membranas muy finas y que no presentan lignificación y donde el protoplasma ocupa una posición parietal y las denominadas prosénquimas que están constituidas por células alargadas fusiformes generalmente unidas por sus extremos que presentan membranas de cierto espesor y prácticamente no tienen protoplasma, por otro lado las células se generan a partir de dos tipos de células indiferenciadas iniciales, que son las células radiales y las células fusiformes, que tienen un origen común.

Las células fusiformes iniciales producen células alargadas verticalmente que, en las coníferas representan más del 90 por ciento de la madera y del floema, y las células radiales iniciales generan células alargadas radialmente que se conocen como fibras radiales, se sabe que en muchas coníferas con estructura sencilla, sólo se observan un tipo de células fusiformes y en las demás coníferas se generan (a parte de las traqueídas) puntualmente algunas células parenquimatosas, aunque inicialmente parezca que los dos tipos de células son parecidas, no es así porque las células parenquimatosas no generan la pared secundaria y además algunas coníferas generan otro tipo de conducto denominado canales resiníferos. 


\begin{tabular}{|lll|}
\hline Características & Gimnospermas & Angiospermas \\
\hline Leño & homoxilo y simple & heteroxilo y complejo \\
Elementos de conducción & traqueidas & $\begin{array}{l}\text { traqueidas y vasos } \\
\text { fibras libriformes y } \\
\text { Elementos de sostén }\end{array}$ \\
$\begin{array}{l}\text { Almacenamiento y transporte a corta } \\
\text { distancia }\end{array}$ & parénquima axial escaso y & parénquima axial \\
Radios & canales resiníferos & paratraqueal o apotraqueal \\
\hline
\end{tabular}

Figura 17. Características de Gimnospermas y Angiospermas. Fuente: C.Gracia

En la figura anterior se definen aquellos aspectos más significativos de la división XVI Ginospermas (coníferas) y de la división XVII Angiospermas (frondosas). Las células cribosas y los elementos de los vasos liberianos son los elementos especializados en el transporte del floema y los vasos son las células encargadas del transporte de agua, y las fibras son las que confieren resistencia a la madera. Las traqueídas disponen de estas propiedades, resistencia y capacidad de transporte, y, por último, las células del parénquima acumulan carbohidratos de reserva.

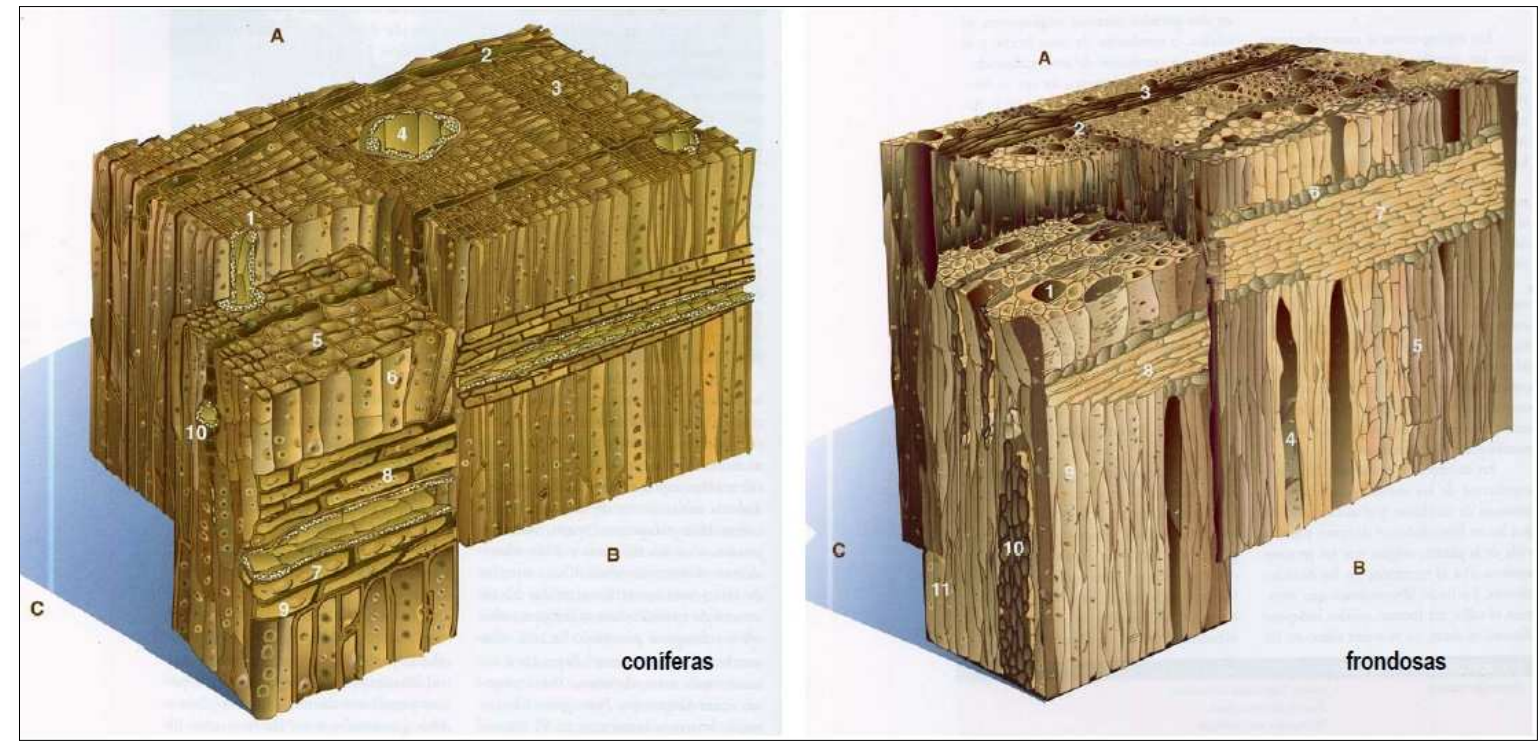

Figura 18. En ambas figuras: A: sección transversal. B: sección radial. C: sección tangencial. Coníferas: A: 1:canal resinífero longitudinal, 2:radio leñoso, 3:traqueidas longitudinales, 4: células epiteliales resinógenas, 5: sección de punteadura areolada. B: 6:punteaduras areoladas en traqueidas longitudinales, 7: punteduras en los campos de cruce, 8: traqueidas radiales, 9:células del parénquima radial. C: 10: canal resinífero transversal. Frondosas: A: 1: vaso 2: parénquima longitudinal, 3: radio leñoso, B: 4: elemento vasal, 5:parénquima longitudinal, 6: células erectas, 7: células procumbentes, 8: radio leñoso heterogéneo, 9:fibrotraqueidas. C: 10: radio leñoso multiseriado, 11: fibrotraqueidas. Fuente: De García. 
8.5 Propiedades generales de la madera, Humedad, Secado; Dureza; Mecánicas; Acústicas; Térmicas y Eléctricas.

\subsubsection{Humedad en la Madera}

La madera contiene gran cantidad de agua que varía en función de la especie, procedencia y época de corte, como material poroso dispone de estructuras que permiten su distribución, siendo por ejemplo más presente en la albura que en el duramen y se encuentra dentro de la madera bajo diferentes formas:

\section{a) Agua de Constitución}

Constituye parte de la materia celular de la madera que no puede ser eliminada utilizando las técnicas comunes de secado, su eliminación implicaría la destrucción de la madera, que es también conocida como agua de sorción, es decir es aquella agua retenida debida a fuerzas de cohesión de los grupos polares activos de la pared celular, por lo tanto como se ha dicho es la que queda más adherida a las paredes celulares, lo que supone supone un $7 \%$ del peso de agua respecto del peso de la madera seca.

\section{b) Agua Libre o capilar}

Está presente ocupando cavidades celulares o el lumen de los elementos vasculares, dando a la madera lo que comúnmente se denomina la "condición verde" y, al iniciarse el secado, el agua libre de los poros se va perdiendo fácilmente por evaporación ya que es retenida por fuerzas capilares muy débiles, hasta el momento en que ya no contiene más agua de este tipo. En este punto, la madera estará en lo que se denomina "punto de saturación de las fibras", que corresponde a un contenido de humedad que fluctúa entre 20-30 \%. A partir de esta condición, se producen modificaciones en las propiedades físicas - mecánicas, eléctricas, de secado y trabajabilidad de la madera.

\section{b) Agua de Saturación o Higroscópica}

Se encuentra presente en las paredes celulares y se la conoce también como: agua de imbibición o agua absorbida, la eliminación de esta agua ocurre con mayor lentitud, hasta lograr su estado de equilibrio higroscópico (12-18\%) de humedad, dependiendo el lugar donde se realice el secado.

\section{d) Variación de volumen}

Se produce una variación del volumen de la madera en función que la madera absorba o ceda agua, para determinar los fenómenos asociados, se parte del concepto de agua libre o capilar, esta agua aunque se elimine, no produce modificaciones significativas en las propiedades físico-mecánicas de la madera y llega aproximadamente a un $30 \%$ de la madera, que es el contenido mínimo de agua también llamado punto de saturación de las fibras, si la madera absorbe agua estará por encima del punto de saturación y entonces se produce el fenómeno de hinchazón y si se produce por debajo entonces se denomina al fenómeno merma. 


\subsubsection{Secado de la madera}

En términos generales, se denomina secado de la madera al proceso de eliminación del agua que existe en exceso en la madera recién cortada cuyo objetivo es la optimización y obtención del material finalista para su procesamiento y transporte con destino a usos específicos. Los sistemas tradicionales de secado son:

- Secado natural al aire libre

- Secado mediante autoclave, hornos o cámaras

- Secado mixto primero al aire llegando al punto de saturación y después en horno

También existen otros métodos más modernos de producción industrial para obtener en un corto periodo de tiempo el secado de un volumen considerable de madera empleando técnicas como bombas de calor, el secado al vacío mediante vapor sobrecalentado, lámparas de infrarrojos, ultrasonidos.

Estos métodos están influenciados por diversos aspectos como son la elección del tipo de secado y su forma de eliminación de la humedad, la especie de la madera, el tamaño de la misma y el nivel de degradación o elementos singulares como vetas, nudos, fendas, grietas, etc que puedan tener.

\begin{tabular}{|l|c|l|}
\hline \multicolumn{1}{|c|}{ ESTADO DE LA MADERA } & $\begin{array}{c}\text { PORCENTAJE DE } \\
\text { HUMEDAD }(\&)\end{array}$ & \multicolumn{1}{c|}{$\begin{array}{c}\text { LUGAR DE CORTE DE LA MADERA } \\
\text { LOCALIZACIÓN DONDE SE PROUCE }\end{array}$} \\
\hline Madera Verde & $200 \%$ a $80 \%$ & Bajo cubierta en bosque \\
Madera Húmeda & $80 \%$ a $25 \%$ & Recién cortada en Patio de fábrica ó al aire libre \\
Madera poco seca & $25 \%$ a $20 \%$ & Al aire libre \\
Madera secada al aire & $20 \%$ a $15 \%$ & En Almacén Bajo techo \\
Madera muy seca & $15 \%$ a $12 \%$ & En destinos de interiores \\
Madera anhidra & $12 \%$ a $0 \%$ & En destinos de laboratorio \\
\hline
\end{tabular}

Figura 19. Secado madera. Contenido de humedad. Elaboración propia

\subsubsection{Propiedades Físicas y mecánicas}

Las propiedades físicas y mecánicas de las maderas pueden variar en función de la especie, contenido de humedad y procedencia. 


\section{a) Anisotropía}

En la estructura de la madera tanto desde el vista de vista macroscópico como microscópico, se observa que la madera no es un material homogéneo y por extensión sus propiedades tampoco lo son en función de las diferentes direcciones, normalmente identificadas en función del elemento a estudiar, se considera eje longitudinal a la dirección con mayor longitud del elemento y eje axial, perpendicular al anterior y referido al espesor del elemento, en el caso de la madera, como ejemplo, se podría considerar que el elemento estudiado es un cilindro, donde en cuyo centro se dispondría su eje longitudinal, normalmente el $Z$ (por ejemplo, coincidente con el eje del árbol), que sería paralelo a las generatrices del cilindro, el eje $Y$, sería el eje axial o radial (por ejemplo, coincidente con los radios de espesor del árbol) y el eje $X$ sería el eje tangencial perpendicular a ambos, y también existirían esfuerzos tangenciales en las perpendiculares a las diferentes generatrices de la superficie del cilindro, de esta forma podríamos estudiar, en cualquiera de las secciones del árbol, sus esfuerzos, tensiones, deformaciones o momentos de inercia, por ejemplo mediante el circulo de Mohr.

\section{b) Densidad}

Densidad es la relación entre la masa o cantidad de materia (leñosa en este caso) y el volumen de un cuerpo, debida a las características de la madera, esta densidad a su vez hay que distinguirla entre densidad absoluta y densidad aparente.

La densidad absoluta teórica (que es la propia de la masa celular o leñosa), es casi idéntica en todas las especies, con un valor aproximado de $1.560 \mathrm{Kg} / \mathrm{m}^{3}$, donde no se tiene en cuenta los poros o huecos, y se considera como si fuera un elemento macizo.

La densidad aparente de la madera anhidra depende del volumen de huecos o poros, lo que implica una variación en función del contenido de agua, sin descartar que existen factores como la especie o el lugar de origen, que pueden suponer variaciones entorno al $20 \%$ de las densidades atribuidas según la especie.

Las maderas más ligeras tienen densidades aparentes entre 100 y $300 \mathrm{Kg} / \mathrm{m}^{3}$ y las maderas más pesadas tiene densidades entre 1.200 y $1.400 \mathrm{Kg} / \mathrm{m}^{3}$.

\section{c) Dureza}

La dureza es la resistencia superficial que ofrece la madera al rayado, corte o penetración mediante otro material normalmente pulido en situación localizada en la madera, por lo que se puede considerar que es una propiedad donde intervienen propiedades físicas y mecánicas, por lo que en ella influye la cohesión existente entre las fibras de la madera, su localización en el árbol (duramen o albura) y contenido de humedad que influye sobre la propiedad mecánica a efectos del material que se emplee para medir la dureza y si el corte es radial o tangencial. En España se utiliza la Norma UNE-56.540, que establece una clasificación según la división botánica.

En el ensayo Monnin (Chalais-Meudon), se establece en la Norma UNE-56.534, que define el método mediante la aplicación de una carga de $100 \mathrm{Kp}$ por $\mathrm{cm}$ de anchura de la probeta, a través de un cilindro de acero de $30 \mathrm{~mm}$ de diámetro, los valores referenciados en esta Tesis corresponden a los de este método. 


\begin{tabular}{|c|c|c|}
\hline & DUREZA (dureza monnin) & CLASE \\
\hline RESINOSAS & $1-2$ & BLANDAS \\
\hline RESINOSAS & $2-4$ & SEMDURAS \\
\hline RESINOSAS & $4-20$ & DURAS \\
\hline FRONDOSAS & $0,2-1,5$ & MUY BLANDAS \\
\hline FRONDOSAS & $1,5-3,0$ & BLANDAS \\
\hline FRONDOSAS & $3,0-6,0$ & SEMIDURAS \\
\hline FRONDOSAS & $6,0-9,0$ & DURAS \\
\hline FRONDOSAS & $9,0-20$ & MUY DURAS \\
\hline
\end{tabular}

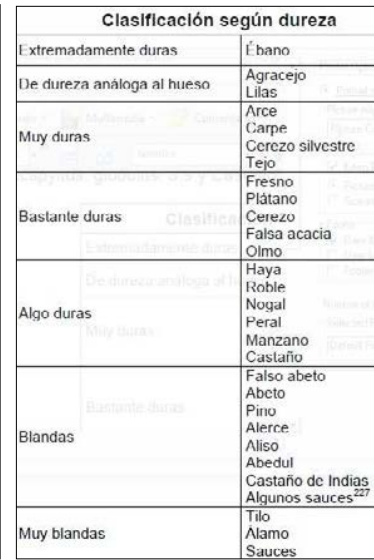

Figura 20. Dureza UNE-56.540. Fuente A. Rodríguez (izquierda); Dureza Monnin UNE-56.534. Fuente j.García

Aunque la dureza se pueda obtener mediante ensayos, normalmente se utilizan los valores utilizados en normativas o clasificaciones existentes.

Por ejemplo, la dureza Brinell, las clasifica como

-Muy duras: Akoga boj, encina, bongossi.

-Duras: Ébano, haya, olivo.

-Medias: Acacia, alerce, aliso, amaranto, caoba, acacia, alerce, aliso, amaranto, caoba, cedro, cerezo, fresno, manzano, nogal, olmo, peral, teka.

-Blandas: Abedul, abeto, avellano, ciprés, pino norte, pino silvestre, chopo y okumé.

D) Resistencia

La resistencia es la capacidad de oposición que ofrece un material frente a la acción de una fuerza exterior.

Pero la madera es un material anisótropo, lo que implica que en función de la dirección en que estén situadas sus fibras respecto a la fuerza exterior, opondrá mayor o menor resistencia, como se indica en el manual de Camuñas.

Añadiendo además que la resistencia se reduce en función de la humedad, por lo que, si aumenta un $1 \%$ su humedad, disminuye un $2 \%$ su resistencia, y también influyen otras variables en función de la forma del elemento como el módulo de elasticidad.

\section{- Resistencia a compresión}

La resistencia a compresión es la oposición a una fuerza exterior que comprime o reduce el volumen de un elemento y varía en función de la dirección de las fibras, siendo mayor si coincide con la dirección longitudinal coincidente con las fibras del elemento de madera y por extensión obtendrá los mayores valores de compresión. 


\section{- Resistencia a tracción}

La resistencia a tracción es la oposición a una fuerza exterior y es el esfuerzo producido por dos fuerzas opuestas que actúan en sentido axial sobre un elemento y tienden a provocar un alargamiento longitudinal y una disminución de la tensión transversal, siendo menor si coincide con la dirección longitudinal coincidente con las fibras del elemento de madera y mayor si se produce perpendicularmente.

- Resistencia a flexión

La resistencia a flexión es la oposición a una fuerza exterior que deforma o curva el elemento y varía en función de la dirección de las fibras, siendo mayor si coincide con la dirección perpendicular a la dirección longitudinal de las fibras y menor si es perpendicular.

La madera es un elemento flexible o de comportamiento elástico, lo que significa que cuando una carga desaparece tiende a recuperar su forma, pero si se mantiene el elemento se deforma y su comportamiento es plástico.
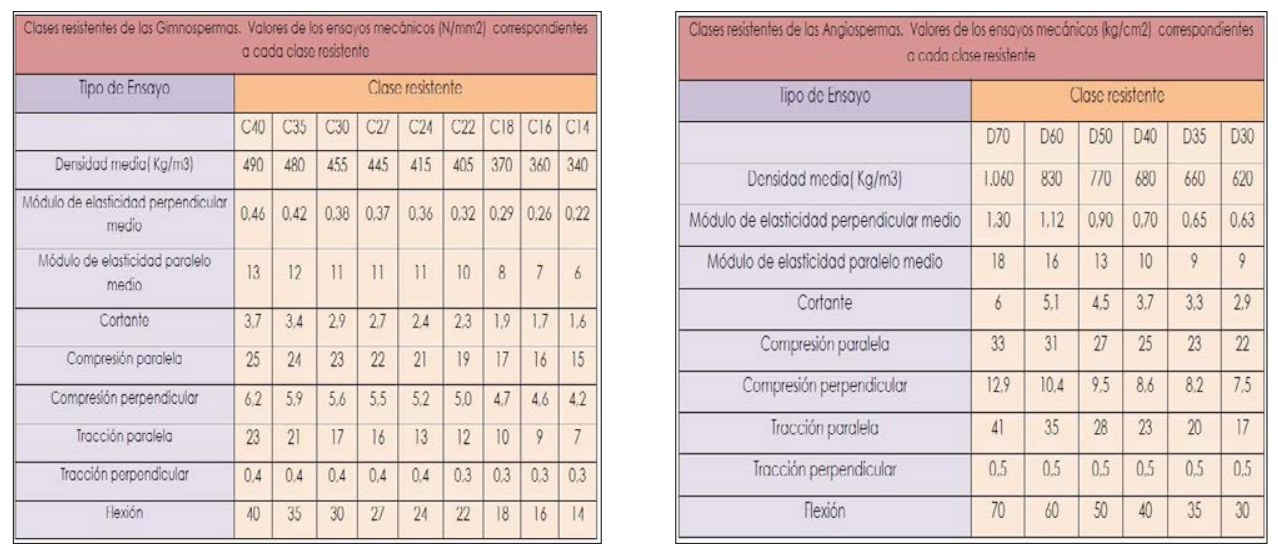

Figura 21. Valores de las maderas en N/mm2. Fuente A. Rodríguez

En las fichas de esta tesis se indica los valores de compresión, tracción y flexión, de las diferentes especies de madera.

e) Térmicas

A efectos de temperatura, es menos evidente a simple vista, que afecte a la madera, dado que lo que le sucede es que desciende su humedad interna. Cuando la madera está sometida a un aumento de temperatura ambiente el efecto es que se dilata, debido a su masa leñosa, y cuando el ambiente es húmedo también se dilata por el aumento de humedad en el ambiente, y se contrae por pérdida de humedad, esta contracción siempre es superior a la dilatación por calor.

La madera tiene una baja conductividad térmica, lo que implica por un lado que es un buen aislante y por otro que es un mal conductor de calor, esta propiedad también es aplicable a sus derivados como el papel o el cartón. 
Otros aspectos son su condición de material orgánico y poroso, además de contener celulosa y ligninina, lo que refuerza su capacidad aislante, y también se puede utilizar con otros materiales también aislantes inorgánicos, pero su capacidad aislante varía según el tipo de material y especie, los paneles, estructuras y tableros tienen una capacidad menor, debido a que son muy porosos y debido a como son realizados, que los materiales más densos que son menos porosos, son más secos y por lo tanto la fuga de calor es menor, y en el caso de la especie vegetal, influye su densidad y por lo tanto el volumen de poros que tenga, a parte de la dirección de sus fibras y grado de humedad que al aumentar también aumenta la emisión del calor, mientras que una madera seca trasmite el calor menos.

El poder calorífico de la madera varía en función de la especie a la que pertenezcan, siendo el caso de las Angiospermas menor que el de las Gimnospermas, debido a que contienen cantidades elevadas de resinas.

La velocidad con que un material se calienta, puesto en contacto con una fuente de calor es lo que se llama difusividad térmica, es debido a esta condición, las maderas al tocarlas dan una sensación térmica cálida.

\section{f) Fuego}

En el análisis del comportamiento de la madera frente al fuego deben tenerse en cuenta algunos factores como son la densidad de la madera que varía en función de su especie, siendo las mayores densidades las que tiene un mejor comportamiento frente al fuego, siendo su inicio y combustión más lentos. En la relación entre la superficie y volumen de la pieza de madera se incrementa la probabilidad de propagación del fuego, donde esta circunstancia se advierte al comparar el comportamiento de astillas con piezas de tronco de árboles y las irregularidades presentes en la madera, ya que al ser la madera un material anisótropo, sus condiciones no son uniformes por lo que la existencia de hendiduras, fendas, nudos, etc. son un factor desfavorable en caso de contacto con el fuego, sobre todo si las irregularidades van en la misma dirección de las fibras de la madera.

Las temperaturas que se pueden alcanzar al estar la madera en contacto con el fuego son de unos $270^{\circ} \mathrm{C}$ que es cuando se empiezan a desprender vapores de la madera, con llama directa la madera comienza a arder con $300^{\circ} \mathrm{C}$, y a $400^{\circ} \mathrm{C}$ sin llama directa.

La madera al ser un material de conductividad baja no arde rápidamente y es esta baja conductividad térmica la que transmite en el caso de un carbonizado superficial de la madera una baja proporción de calor hacia el interior de la madera que la protege en el futuro de agresiones.

Esta capa exterior carbonizada actúa de aislante protegiendo el interior de la pieza de madera, actuando como aislante y manteniendo sus propiedades físicas y mecánicas. La madera es un material combustible en su reacción con el fuego, pero debido a su gran diversidad de especies, existen algunas que se queman tan lentamente que parecen incombustibles como el Eucaliptus Jarrah (Eucaliptus marginata Sm.) de Australia, también las propiedades de las maderas ante el fuego hacen que desde el punto de vista de las estructuras no se deforme, como le puede ocurrir al metal. 


\section{e) Eléctricas}

La madera si está protegida con parafina o aceite de linaza y si tiene bajo contenido de humedad (madera anhidra) actúa como un buen aislante, pero la resistividad eléctrica decrece si aumenta su humedad, si esta madera se encuentre secada al aire actúa como semiconductora por contener más humedad que la anhidra, pero si llegáramos a un $100 \%$ de humedad la madera sería conductora, la resistividad también dependerá de la especie de madera, peso específico aparente, del contenido de aceites y resinas y de la dirección de las fibras que puede llegar a tener diferencias entre 2 y 4 veces en función de la dirección de la que se trate.

\section{g) Acústicas}

El aislamiento acústico que ofrece la madera, en el caso de paneles va en función del peso del mismo y de las capas que pueda tener o por el cambio de material a otras maderas más blandas.La madera suele ir asociada a otros tipos de productos, cuando la intención del proyectista es obtener un aislamiento acústico, por ejemplo en revestimientos de teatros, salas de conciertos, etc que en el caso de paneles va en función del peso del mismo y de las capas que pueda tener o por el cambio de material a otras maderas más blandas o tableros derivados intercalados o troquelados o emplear corcho que tiene un buen aislamiento acústico.

\section{h) Durabilidad}

La durabilidad de las maderas se entiende como la duración natural de las maderas que mantenga la calidad de la madera durante su conservación para un uso definido y sin haberle aplicado ningún tipo de protección, las normas UNE hablan de durabilidad natural y lo definen como la resistencia intrínseca de la madera a los ataques de los organismos destructores.

En términos generales la madera desde el punto de vista químico es estable en el ambiente en el que crece, dado que tiene una capacidad de resistencia a la corrosión considerable y permite que la capacidad de conservarse ya sea al aire libre o en el agua pueda llegar a considerarse ilimitada, siempre y cuando no le afecten agentes biológicos como parásitos, otras plantas que puedan influir en su entorno o los animales.

Tiene una gran capacidad de duración en ambientes secos y cerrados, siempre que no existan agentes que causen su degradación, por lo que su capacidad de conservación es casi ilimitada, prueba de ello es la multitud de piezas de madera encontradas en las excavaciones en Egipto y especialmente sus sarcófagos.

En el caso de estar enterrada en terrenos arcillosos, tiene un grado de conservación muy bueno, pero en terrenos calizos se conserva muy mal. Por lo tanto, en términos generales la durabilidad de la madera va a depender principalmente de dos factores, por un lado, de los compuestos químicos de los que dispone internamente según su especie y del entorno donde se encuentre, pero no de la estructura que tenga. 


\begin{tabular}{|c|c|c|c|c|}
\hline Especies. & $\begin{array}{c}\text { Traviesas } \\
\text { de } \\
\text { ferrocarril. }\end{array}$ & $\begin{array}{l}\text { Permanentemente a } \\
\text { la intemperie, sin } \\
\text { protección. }\end{array}$ & $\begin{array}{l}\text { A la intemperie, bajo } \\
\text { cubierta. }\end{array}$ & $\begin{array}{l}\text { En ambiente } \\
\text { siempre seco. }\end{array}$ \\
\hline Abeto rojo & 4 a 5 & 40 a 55 a 70 & 50 a 60 a 75 & 120 a 900 \\
\hline $\begin{array}{l}\text { Pino } \\
\text { silvestre }\end{array}$ & 7 a 8 & 40 a 60 a 85 & 90 a 100 a 120 & 120 a 1.000 \\
\hline Alerce & 9 a 10 & 40 a 65 a 90 & 90 a 120 a 150 & $<1.800$ \\
\hline Pinabete & 4 a 5 & $<50$ & $<50$ & $<900$ \\
\hline Abedul & - & 3 a 20 a 40 & 3 a 20 a 40 & $<500$ \\
\hline Haya & 2,5 a 3 & 10 a 35 a 60 & 5 a 50 a 100 & 300 a 800 \\
\hline Roble & 14 a 16 a 20 & 50 a 85 a 120 & 100 a 150 a 200 & 300 a 800 \\
\hline Aliso & - & 3 a 20 a 40 & 3 a 20 a 40 & $<400$ \\
\hline Fresno & - & 15 a 40 a 60 & 30 a 60 a 100 & 300 a 800 \\
\hline $\begin{array}{l}\text { Chopo } \\
\text { (Populus } \\
\text { nigra) }\end{array}$ & - & 3 a 20 a 40 & 3 a 20 a 40 & $<500$ \\
\hline Olmo & - & 60 a 80 a 100 & 80 a 130 a 180 & $<1.500$ \\
\hline Sauce & - & 5 a 15 a 30 & 5 a 20 a 40 & $<600$ \\
\hline
\end{tabular}

Figura 22. Durabilidad. Fuente J. García

\subsection{Productos de maderas de construcción}

En este punto se desarrolla los materiales que normalmente se producen con madera.

a) Elementos básicos

Desde el punto de vista constructivo y siempre orientado a los productos de la madera de construcción se presenta la siguiente figura, donde se detallan los productos derivados básicos de la industria maderera y su destino a efectos de productos de la madera con destino a la construcción.

\begin{tabular}{|c|c|c|c|c|c|}
\hline $\begin{array}{c}\text { Orden: } \\
\text { descendente } \\
\text { de tamaños }\end{array}$ & Elementos & $\begin{array}{l}\text { Posibilidad } \\
\text { de obtención } \\
\text { a partir de } \\
\text { residuos }\end{array}$ & $\begin{array}{l}\text { Elementos más } \\
\text { empleados en la } \\
\text { fabricación de } \\
\text { soportes rígidos }\end{array}$ & $\begin{array}{c}\text { Productos } \\
\text { obtenidos de } \\
\text { estos } \\
\text { elementos. }\end{array}$ & $\begin{array}{c}\text { Elementos } \\
\text { intermedios en la } \\
\text { fabricación de } \\
\text { otros elementos }\end{array}$ \\
\hline 1 & Trozas & NO & & $\begin{array}{l}\text { Todos los } \\
\text { demás } \\
\text { elementos }\end{array}$ & \\
\hline 2 & Madera aserrada & NO & $\mathrm{X}$ & $\begin{array}{l}\text { En tableros, } \\
\text { bastidores, } \\
\text { refuerzos, etc. }\end{array}$ & \\
\hline 3 & $\begin{array}{l}\text { Tablas delgadas (chapas } \\
\text { gruesas) }\end{array}$ & NO & $\times$ & Embalaje. & \\
\hline 4 & Chapas & NO & $\times$ & $\begin{array}{l}\text { En tableros, } \\
\text { chapeados, etc. }\end{array}$ & \\
\hline 5 & $\begin{array}{l}\text { Hojuelas largas (chapas } \\
\text { cortas) }\end{array}$ & Si & & $\begin{array}{l}\text { Waferboard, } \\
\text { OSB, etc. }\end{array}$ & \\
\hline 6 & Astillas & Si & & & $\begin{array}{l}\text { De este } \\
\text { elemento se } \\
\text { obtienen } \\
\text { elementos de } \\
\text { tamaño menor. }\end{array}$ \\
\hline 7 & Hojuelas & SI & $\times$ & $\begin{array}{l}\text { Waferboard, } \\
\text { OSB, etc. }\end{array}$ & \\
\hline 8 & $\begin{array}{l}\text { Virutillas de madera o } \\
\text { excelsio } \text { r }^{370}\end{array}$ & SI & 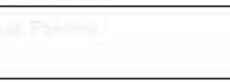 & $\begin{array}{l}\text { Embalaje, } \\
\text { tableros } \\
\text { aislantes, etc. } \\
\end{array}$ & \\
\hline 9 & Hebras de madera & SI & & Embalaje. & \\
\hline 10 & Particulas de madera & Si & $\times$ & $\begin{array}{l}\text { Tableros } \\
\text { aglomerados } \\
\text { de particulas. }\end{array}$ & \\
\hline 11 & Haces de fibras & Si & $x$ & $\begin{array}{l}\text { Tableros de } \\
\text { fibras. }\end{array}$ & \\
\hline 12 & Fibra de papel & SI & & $\begin{array}{l}\text { Papel, cartón, } \\
\text { trillajes, etc }\end{array}$ & \\
\hline 13 & $\begin{array}{l}\text { Polvo de madera(harina } \\
\text { de madera) }\end{array}$ & S1 & & $\begin{array}{l}\text { En perfiles, } \\
\text { masillas, etc. }\end{array}$ & \\
\hline 14 & Celulosa & Si & & Papel, etc. & \\
\hline
\end{tabular}

Figura 23. Elementos básicos. Madera de construcción Fuente G.G. Marra

Universidad Politécnica de Madrid - Escuela Técnica Superior de Arquitectura - Departamento de Construcción v Tecnología Arquitectónica Directores: Dr. Alfonso García Santos y Dr. Antonio Rodríguez Rodríguez. Doctorando: D. Francisco Lora Toro 
Esta descripción, se desarrolla a continuación con los productos específicos de la madera de construcción.

b) Madera aserrada.

Es madera maciza de volúmenes en forma de paralepípedo, que pueden producirse en instalaciones fijas o móviles.

- Instalaciones fijas: Son aquellas instalaciones de ubicación permanente, con ciclos de producción completos.

- Instalaciones móviles: Aquellas montadas sobre sistema de tracción móvil, que se desplazan a las fuentes de abastecimiento de la materia prima, y necesitan entre otras, la industria auxiliar como las reaserradoras, disponen de la facilidad de dejar en el mismo lugar los desperdicios derivados de su actividad, salvo en el caso que se trate de tableros de partículas.
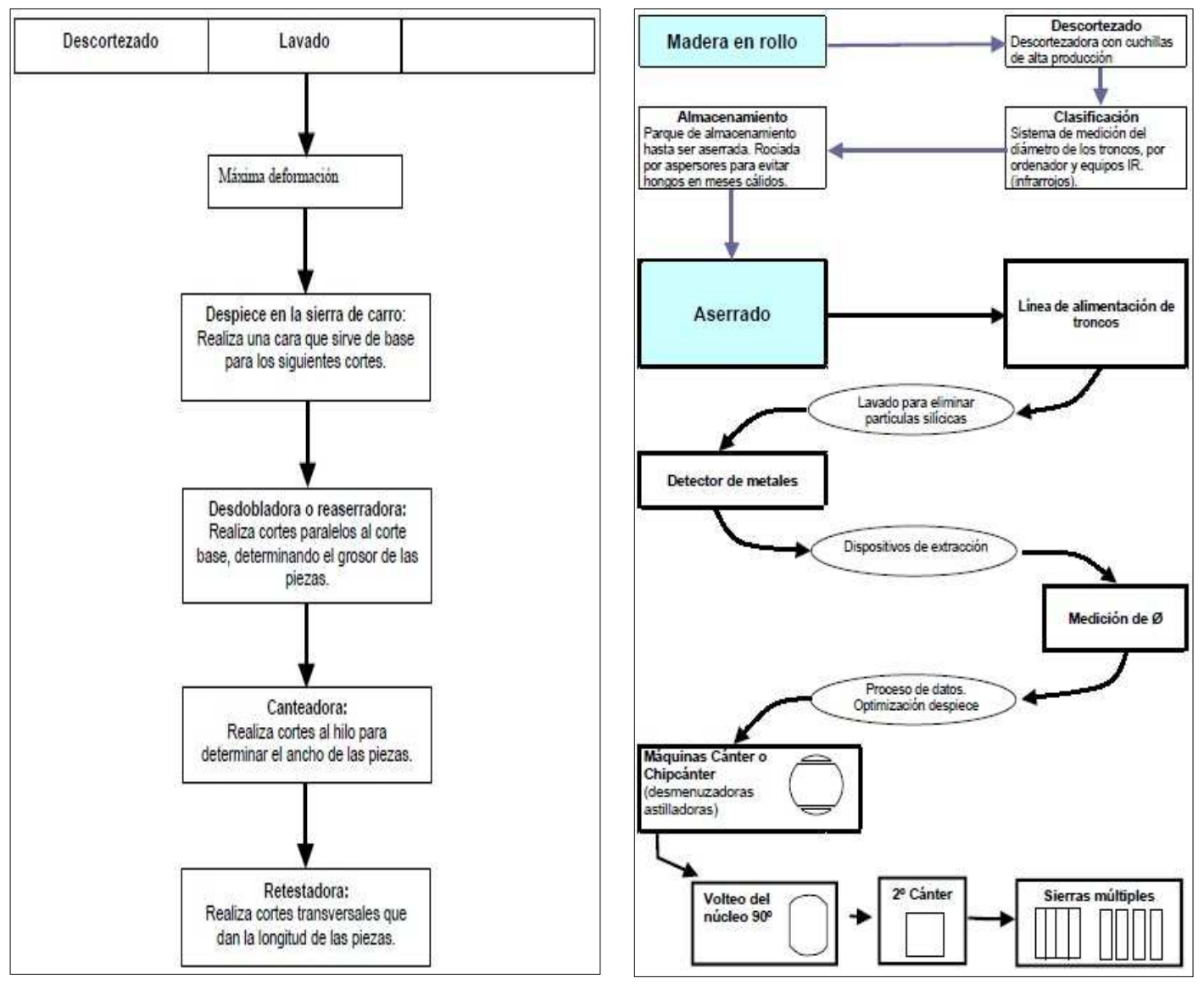

Figura 24. Madera Aserrada. Producción tradicional (izquierda). Producción moderna (derecha) Fuente J.García 


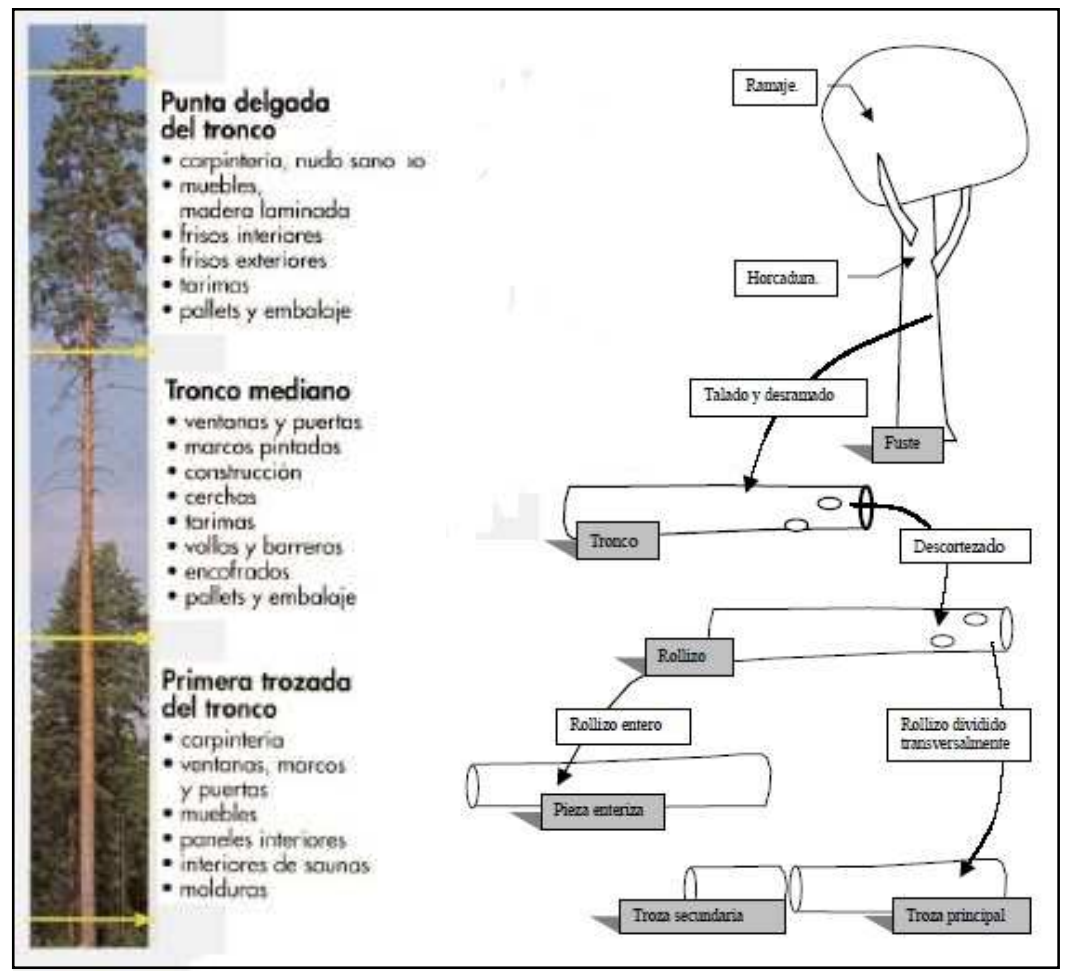

Figura 25. Partes del árbol y destino de productos. Fuente J.García

Las figuras representan los sistemas industrializados tradicional y moderno, obsérvese como el moderno incorpora elementos como la detección de metales y aprovecha más los restos del árbol mediante las máquinas Cánter o Chipcanter, que trituran los laterales o costeros por medio de cuchillas y los convierten en astillas.

-Corte de la madera. Métodos de despiece según el corte.

La importancia del corte de la madera deriva de la necesidad de despiezar la madera de un tronco o troza en piezas más pequeñas, que suelen ser tablones o tablas, siempre buscando con el corte realizado obtener el máximo de piezas útiles reduciendo al máximo los residuos no aprovechables.

Los métodos de despiece según el corte son:

A un tronco o troza se le pueden efectuar dos tipos generales de despiece, despiece tangencial y despiece radial.

El despiece radial proporciona piezas con una mayor estabilidad en el proceso de secado, en cambio el aserrado tangencial proporciona, en algunas especies, veteados más atractivos.

Cuando se desea obtener piezas con un mejor comportamiento físico, con mejores calidades estéticas o con un aprovechamiento máximo de la madera se suelen efectuar los siguientes despieces particulares: 
a) Despiece pieza enteriza: Es el que aprovecha todo el rollizo (tronco), utilizando toda su longitud, se descorteza con la sierra, dando hilos que se disponen perpendiculares entre sí, los lados costeros se utilizan para piezas más pequeñas, como tablas, virotillos, etc, también pueden obtenerse piezas de aristas vivas o no, según si se apura o no el corte, si se apura mucho se produce lo que se denomina piezas a gema o de cantos imperfectos (también se da en las tablas), este corte se emplea en elementos portantes o que trabajen a compresión: vigas, mástiles, andamios, etc, si se dan uno o dos cortes perpendiculares al corazón a la pieza enteriza se obtienen vigas o viguetas de menor escuadría en función de las necesidades, a la pieza enteriza, de la madera de hilo a dos caras y a estos maderos medios y cuartones se les denomina "madera escuadrada" para diferenciarlas de la madera de sierra que obtiene escuadrías mucho menores y tiene la arista perfectamente a escuadra y sin gema.

b) Despiece común o en hilos paralelos: es un método empleado para maderas de poca calidad, se disponen cortes paralelos, donde la tabla central incluye la médula, de esta forma se obtienen tablas de igual anchura y sin rastro de corteza; el inconveniente es que produce fuertes contracciones en sentido contrario a los anillos de crecimiento y cuanto mayor es el radio de los anillos, mayor es la contracción, se distinguen por el dibujo crestado que ofrece, en forma de triángulos o pirámides superpuestas.

c) Despiece en cortes paralelos: Es una alternativa del anterior donde se obtienen tablones de igual ancho al tronco, pero la pieza central se hiende con facilidad, además las restantes tablas tienden a curvarse hacia la zona periférica en donde aumenta la savia y la humedad.

d) Despiece tangencial o Floreado: Se obtienen tablas por cortes al hilo, donde cada nueva tabla se obtiene por un corte perpendicular al anterior.

e) Despiece, Despiece de Paris: Consiste en obtener una gruesa tabla con el corazón en el centro y varias laterales de menor escuadría.

f) Despiece en cruz o encuaternado: Es una alternativa al de Paris, donde se dispone una pieza central gruesa, pero con el corazón, y dos piezas más pequeñas perpendiculares a la anterior y varias tablas de menor escuadría, pero radiales.

g) Despiece en cortes radiales: es, en teoría, el mejor método para eliminar fendas y alabeos, este corte sigue los radios medulares, pero es el método con mayor pérdida si se trata de obtener piezas de sección rectangular, las piezas así obtenidas conservan las vetas en toda su viveza.

h) Despiece alternado o por hilos encontrados: Se realizan cortes alternativos en cada cuadrante, paralelamente a los ejes del tronco, reduciendo al mínimo la posibilidad de las deformaciones de las tablas.

i) Despiece Canadiense: Es para trozas de mucho diámetro, pero genera muchos desechos

j) Despiece Cantibay: Es el método más indicado para eliminar el corazón cuando éste se encuentra alabeado o marchito, se obtienen tablas anchas con un mínimo de desperdicio, se emplea en las maderas exóticas. 
k) Despiece Holandés: es un método muy empleado en maderas de alta calidad ya que se consigue un dibujo y la malla en toda la superficie, representa una pérdida de madera bastante considerable, pero se obtienen tablas de mejores resultados en cuanto a la calidad.

I) Despiece variable: Son otros tipos de despiece donde se procede cortando primero un grueso tablón de corazón y el resto puede dejarse como tablones de buena escuadría o seguir dividiéndolos según necesidades, siendo válido para obtener vigas o viguetas.

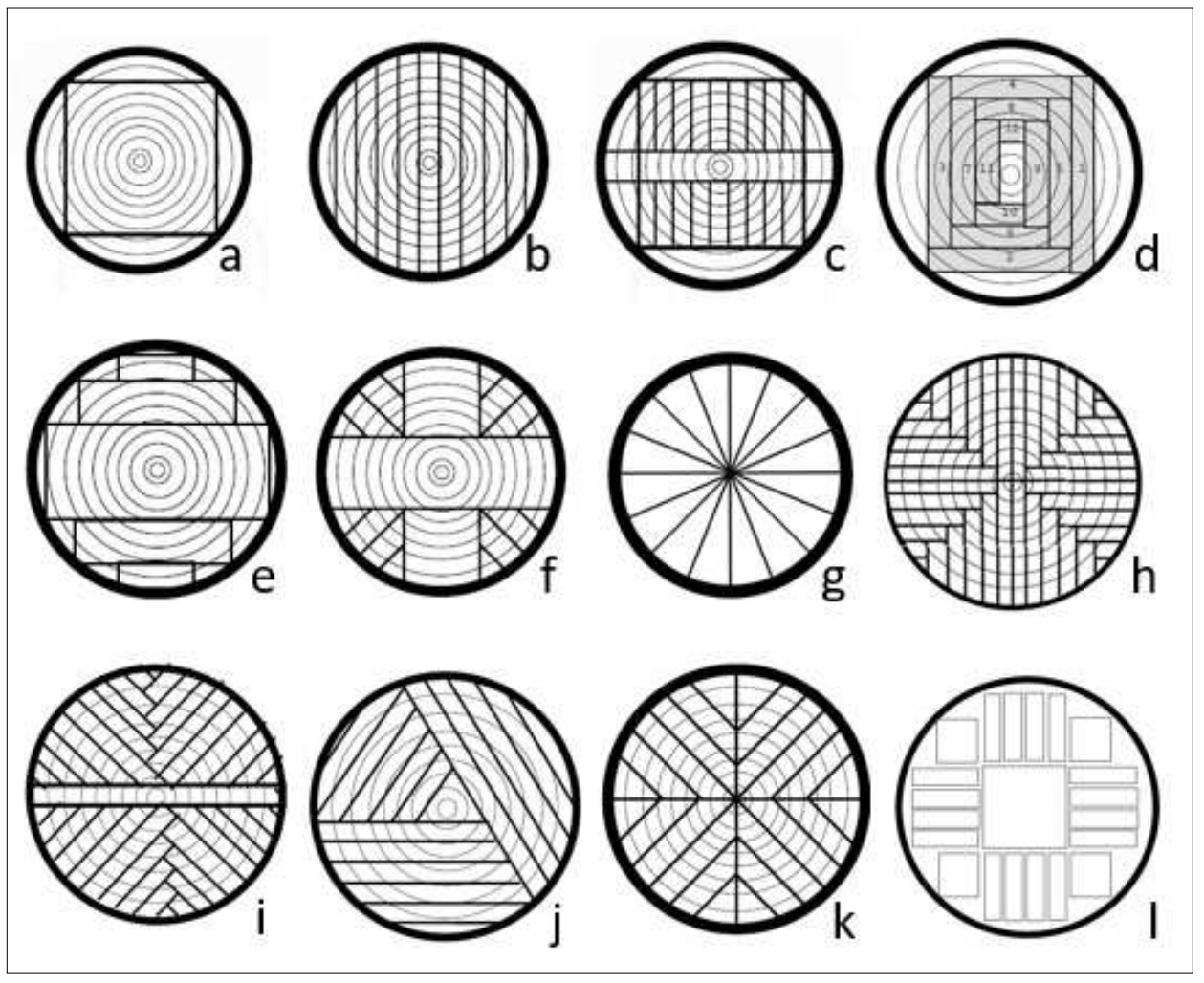

Figura 26. Tipos de corte de la madera aserrada. Elaboración propia.

\section{c) Tableros}

En términos generales podemos utilizar la Norma UNE 56700: 1992, "Tableros de maderas. Definiciones y clasificación.", como punto de partida a efectos de conocer el amplio abanico de posibilidades de los tableros, donde dicha norma define el tablero como "...aquella pieza en que predominan dos dimensiones, longitud y anchura, sobre la tercera, el grosor y en la que el elemento constitutivo principal es madera de medidas variables, o elementos estructurales de la misma..."

Las líneas de producción, dentro del sector de la transformación de la madera, más importantes en el mundo están relacionadas con los tableros alistonados, los OSB y LVL, que se comentarán más adelante.

En la figura siguiente se indica los posibles usos o destinos de los tableros. 


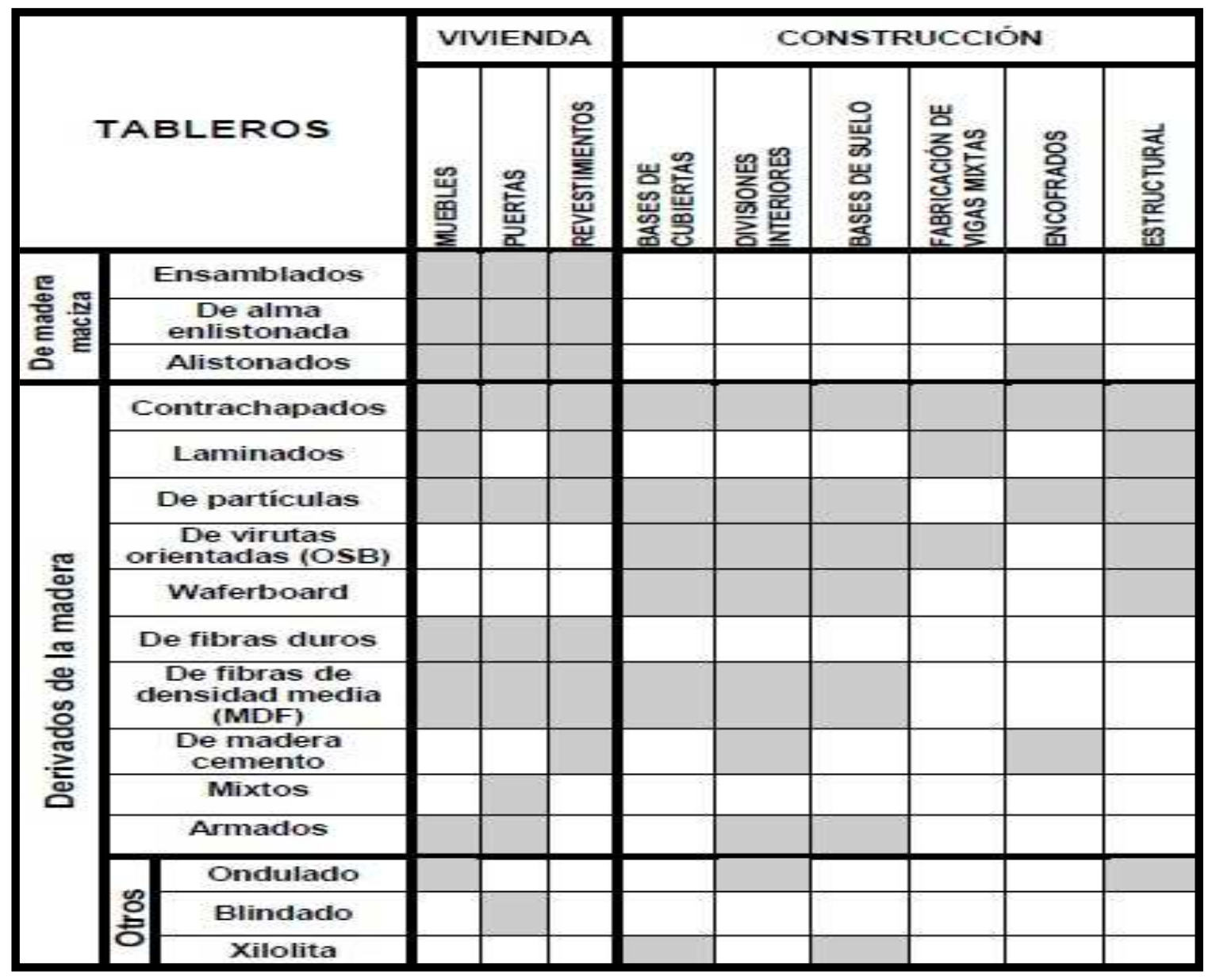

Figura 27. Destino de tipos de tableros. Fuente Aitim 1994

d) Tableros de madera maciza.

Son todos aquellos tableros de madera compuestos por uno o varios paneles o tablas de madera natural no reconstituida, donde una de sus dimensiones predomina sobre las demás, siendo normalmente la longitud sobre la sección constituida por el espesor y la anchura.

-Tableros machihembrados o ensamblados:

Este tipo de tableros es el que tradicionalmente se ha utilizado, realizados en madera maciza, donde se utilizaban diferentes tipos de sistemas de ensamblaje, desde ensamblajes machihembrados o lambetados a uniones encoladas, que desde el punto de vista comercial se les denomina tableros de madera.

\section{-Tableros de alma enlistonada}

Son tableros constituidos por un alma o núcleo grueso (también llamada ciega o madera de soporte) que está formada por listones o trozos de listones de madera maciza, yuxtapuestos, sujetos entre sí por encolado u otros sistemas, y cubiertos por chapas que forman las caras, normalmente de la misma especie que el alma, colocados 
perpendicularmente a la fibras si se trata de 3 piezas (alma más dos chapas) y paralelas si se trata de 5 piezas ( dos almas más 3 chapas).

\section{-Tableros alistonados}

El tablero alistonado es todo aquel tablero formado por listones de madera maciza encolados o unidos por adhesivos entre sí, con uniones dentadas o lisas sin empalmar donde los listones pueden tener longitudes iguales o diferentes, siempre y cuando sus anchuras y grosores sean iguales. Su proceso de fabricación es sencillo, pero con control exhaustivo de sus materias primas y proceso de aplicación, por ejemplo, su secado depende del uso y destino del tablero y dependiendo del tipo de adhesivo se utilizan para exterior o interior y normalmente para muebles y encofrados.

e) Tableros derivados de la madera

Los tableros derivados de la madera aparte de que predominen su longitud respecto a su anchura y espesor y donde su elemento principal sea la madera, se diferencia de los anteriores en que se utilizan tecnologías avanzadas. Estas tecnologías basadas en la innovación, donde se utilizan nuevos productos y también utilizan restos desechados de madera desde los usados por el hombre a los obtenidos por aclareos o podas de árboles, pero siempre controlando el origen de la madera, para la realización de este tipo de tableros.

La tipología de estos tableros se detalla a continuación:

\begin{tabular}{|c|c|c|c|c|}
\hline Familia & Productos & Subproductos & $\begin{array}{l}\text { Denominación } \\
\text { inglesa }\end{array}$ & $\begin{array}{l}\text { Acrónimos o } \\
\text { siglas más } \\
\text { conocidas }\end{array}$ \\
\hline \multirow{9}{*}{$\begin{array}{c}\text { Perfiles } \\
\text { estructurales de } \\
\text { productos } \\
\text { derivados de la } \\
\text { madera } \\
\text { Engineered } \\
\text { Wood Products } \\
\text { (EWP) }\end{array}$} & $\begin{array}{l}\text { Perfiles estructuralesde } \\
\text { madera reconstituida. }\end{array}$ & & $\begin{array}{l}\text { Structural Composite } \\
\text { Lumber }\end{array}$ & SCL \\
\hline & \multirow{4}{*}{$\begin{array}{c}\text { Perfiles de madera } \\
\text { reconstituida para la } \\
\text { construcción. }{ }^{176 s} \\
\text { Construction Strand } \\
\text { Lumber } \\
\text { (CSL) }\end{array}$} & $\begin{array}{l}\text { Perfiles de madera } \\
\text { microlaminada }\end{array}$ & Laminated Veneer Lumber & LVL \\
\hline & & $\begin{array}{c}\text { Perfiles de astillas } \\
\text { paralelas }\end{array}$ & Parallel Strand Lumber & $\mathrm{P} \mid \mathrm{SL}$ \\
\hline & & & Laminated Strand Lumber & LSL \\
\hline & & $\begin{array}{l}\text { Perfiles de astillas } \\
\text { orientadas }\end{array}$ & Oriented Strand Lumber & OSL \\
\hline & Viguetas en doble $T^{1771}$ & & Wood $\mathrm{I}$ - Beams ( $\mathrm{T}$ joist) & \\
\hline & & & $\begin{array}{c}\text { I- Beams } \\
\text { (Space Joist) }\end{array}$ & I - Beams \\
\hline & $\begin{array}{l}\text { Unión madera-metal en } \\
\text { la formación de } \\
\text { viguetas con alma de } \\
\text { celosía metálica. } \\
\text { (Vigueta Solivide). }\end{array}$ & & Space Joist & \\
\hline & $\begin{array}{l}\text { Madera laminada } \\
\text { encolada }\end{array}$ & & Glued Laminated Timber & Glulam \\
\hline \multirow{10}{*}{$\begin{array}{c}\text { Tableros } \\
\text { derivados de la } \\
\text { madera } \\
\text { Wood Based } \\
\text { Panels } \\
(\text { WBP) } \\
\text { (1772 }\end{array}$} & $\begin{array}{c}\text { Tableros } \\
\text { contrachapados }\end{array}$ & & Plywood & \\
\hline & Tableros de partículas & & Particleboards & $\mathrm{PB}$ \\
\hline & $\begin{array}{l}\text { Tableros de fibras de } \\
\text { densidad media }\end{array}$ & & Medium Density Fiberboard & MDF \\
\hline & $\begin{array}{c}\text { Tableros de Fibras de } \\
\text { Alta Densidad }\end{array}$ & & High Density Fiberboard & $\begin{array}{l}\text { HDF } \\
\text { HFH }\end{array}$ \\
\hline & $\begin{array}{c}\text { Tableros de fibras } \\
\text { duros }\end{array}$ & & Hardfiberboard & HF \\
\hline & $\begin{array}{c}\text { Tablero de Fibras de } \\
\text { Baja Densidad }\end{array}$ & & Low Density Fiberboard & \\
\hline & $\begin{array}{c}\text { Tableros de virutas } \\
\text { orientadas }\end{array}$ & & Oriented Strand Board & osB \\
\hline & Tableros alistonados ${ }^{1773}$ & & Solid Wood Panels & \\
\hline & $\begin{array}{c}\text { Tablero contrachapado } \\
\text { de alma alistonada. }\end{array}$ & & & \\
\hline & $\begin{array}{l}\text { Tableros de Madera- } \\
\text { cemento }\end{array}$ & & Cement Panels & \\
\hline
\end{tabular}

Figura 28. Tableros derivados de la madera. Fuente J.García 
-Tableros contrachapados.

El tablero contrachapado es un material constituido por chapas de madera, superpuestas y yuxtapuestas, encoladas entre sí, prensadas y con las fibras orientadas habitualmente, de forma alterna, formando $90^{\circ}$, que permiten tener mayor resistencia mecánica muy parecida en todas sus direcciones (largo y ancho) y también resistencia al alabeo, son bastante estables y rígidos y con la disposición del cruce entre chapas se mejora la resistencia transversal.

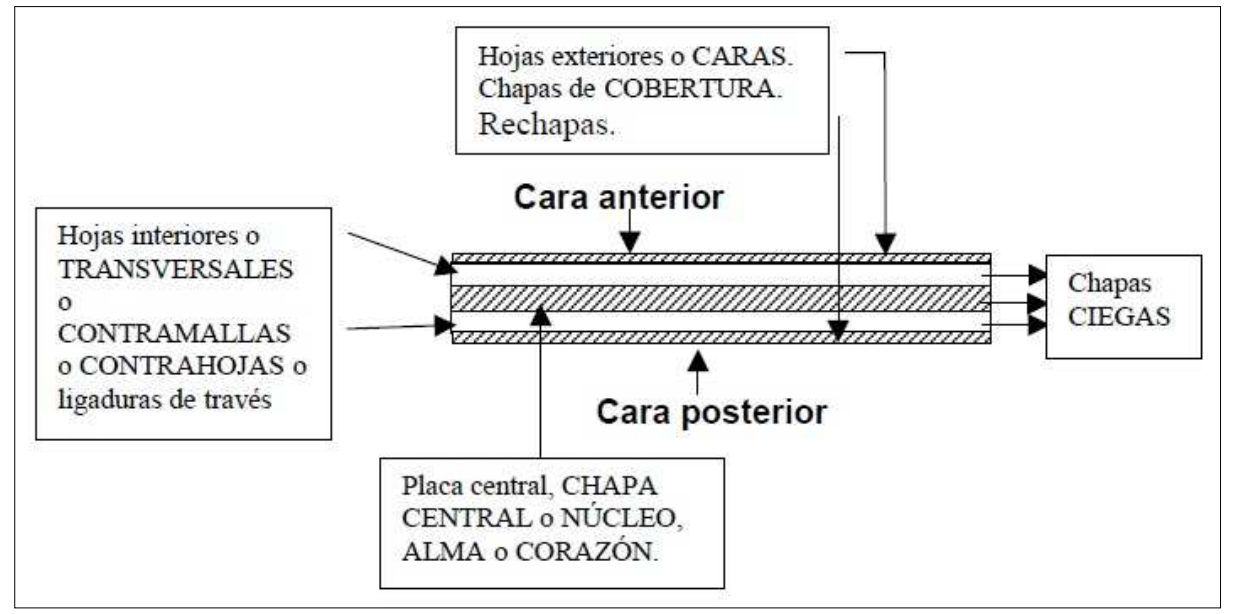

Figura 29. Sección tablero chapado. Fuente J.García

-Tableros laminados $(\mathrm{SCH})$

Son tableros formados por diferentes chapas cuyas fibras se sitúan paralelamente, es decir todas las fibras de la chapa tienen la misma orientación, a este tipo de tableros se les denomina $\mathrm{SCH}$ (Schichtholzplatten). Surge de la necesidad que se tenía en la construcción de conseguir tirantes de madera que tuvieran las ventajas de los contrachapados y sin los movimientos resistentes del mismo, es decir poca resistencia a los esfuerzos de tracción, debido a que tienen chapas con la veta en dirección perpendicular a esos esfuerzos, lo que implica que es un tablero muy apto para el esfuerzo a flexión.

Como se ha comentado se fabrica, superponiendo varias hojas con las fibras en la misma dirección encolándolas con resinas fenólicas y sometiéndolas posteriormente a presiones de $30 \mathrm{~kg} / \mathrm{cm} 2$, es aquí donde se produce la diferencia con la madera laminada y comprimida, ya que para esta las presiones más comunes son de 140 $\mathrm{kg} / \mathrm{cm} 2$ y unas temperaturas de $160^{\circ} \mathrm{C}$, durante unos minutos.

-Tableros microlaminados (LVL).

Los tableros microlaminados LVL (Laminated Veener Lumber), se obtiene mediante piezas de madera laminada a partir de chapas, de estructura homogénea muy estable, con la misma dirección de las fibras, es decir, todas son paralelas entre sí, fue concebido para la ingeniería aeronáutica de los años 40 , por lo que es muy sofisticado, en su fabricación se utiliza la ISO 9001, con unas propiedades a la flexión, tracción y 
compresión con prestaciones extremadamente elevadas y próximas entre ellas, lo que permite la optimización del dimensionamiento de las estructuras, en comparación con el acero y el hormigón es más ligero, con una resistencia mayor que la madera maciza en escuadrías similares.

Una de las más importantes propiedades de este material es que sus movimientos son menores lo que le hace más estable a la humedad que la madera maciza, debido al diseño de las chapas que al tener todas la misma dirección y un escaso grosor minimiza estos movimientos higroscópicos, lo que implica que es más estable dimensionalmente. Además, se pueden reducir o eliminar los problemas derivados de nudos, fendas, bolsas de resina, etc y puede cortarse a cualquier tamaño, al igual que la madera maciza, pero con la ventaja de disponer de una exactitud en cuanto a medidas y rectitud.

-Tableros aglomerados de partículas.

Este tipo de tableros son elaborados a partir de partícula de madera como el serrín, virutas, hojuelas u otros materiales leñosos de forma aglomerada y cohesionados mediante adhesivos normalmente sintéticos mediante la aplicación de presión y temperatura, donde al ser partículas mayores que en los tableros de fibras, la madera conserva más sus propiedades, y son rígidos, densos, resistentes y no muy manejables debido a un peso considerable. Para su formación, se utilizan maderas no muy densas, y se eligen coníferas frente a frondosas, y en el diseño se utiliza una densidad de madera que sea inferior a la del tablero deseado, debido a que si la densidad es alta es más difícil transformar y preparar las partículas.

-Tableros de virutas no orientadas (Waferboard).

Se utilizan con especies de crecimiento rápido con virutas de tamaño grande no orientadas, es el predecesor del OSB y con él satisfacen los requisitos de la C.S.A. (Asociación canadiense de Normalización), estableciendo por norma un grado para este tipo de tablero denominado tablero al aza" R-1, está muy presente en América del Norte, se utilizan para interior y exterior y para estructura.

-Tableros de virutas orientadas (OSB).

Es un tablero del tipo composite compuesto por madera o un derivado, producido por la rotura de madera sólida y su posterior conversión en virutas rebanadas de troncos, más o menos rectangulares, colocadas en capas, que luego son aglutinadas entre sí, por medio de un adhesivo resistente a la intemperie, dentro de una forma fija, que posteriormente se prensan con el concurso de una temperatura determinada, existen dos tipos, el O-1 que presenta las virutas de la superficie del tablero, orientadas según la dirección longitudinal del mismo y las del núcleo dispuestas aleatoriamente y el O-2 que está formado por capas sucesivas virutas orientadas tanto en la dirección longitudinal como en la transversal, formando entre sí ángulos de 90ํㅡㄴ

El producto acabado es un panel estructural parecido al contrachapado, cuya resistencia viene de la "continuidad" de la fibra al entrelazarse fibras largas entre sí y la gran orientación que éstas tienen en la superficie, también satisfacen los requisitos de la C.S.A, prácticamente es un tablero de madera "isótropo", aprovechando el $90 \%$ de la madera. 
-Tableros de madera-cemento.

El tablero de partículas-cemento es fabricado mediante la aplicación de una elevada presión sobre partículas de madera u otras de naturaleza vegetal, aglomerados con cemento tipo Portland, pudiendo llevar otros aditivos, acabados lisos y duros y con excepcional comportamiento al fuego, resistencia al choque, durabilidad y aislamiento acústico.

-Tableros de fibras duros.

Son realizados con fibra de madera fieltrada con densidades entre 0,8 y $1,2 \mathrm{~g} / \mathrm{cm}^{3}$, pudiendo si su sistema de fabricación es en seco, se añaden adhesivos, en caso contrario la cohesión se obtiene mediante las propias sustancias de la madera.

-Tableros de fibras de densidad media (MDF).

Formados mediante fibras lignocelulósicas unidas con adhesivo de resina sintética y se prensan en caliente con densidades que varían entre 600 y $800 \mathrm{Kg} / \mathrm{m}^{3}$ uniforme en todo el tablero, y disposición de fibras homogénea, fabricado en seco con la posibilidad de añadir aditamentos diferentes durante el proceso, de superficies lisas y textura de grano fina, pudiendo ser chapado, pintado, lacado, etc.

En función de su destino se denominan, MDF Tableros para uso general en ambiente seco; MDF.H Tableros para uso general en ambiente húmedo; MDF. LA Tableros estructurales para uso en ambiente seco y MDF.HLS Tableros estructurales para uso en ambiente húmedo, recogidos en la norma UNE EN 622-5.

f) Estructuras de madera.

Históricamente, se ha utilizado la madera como material estructural, en todo tipo de situaciones y de usos desde el punto de vista de una amplia gama de la actividad del ser humano, viviendas, industria, agricultura, marítima, etc, incluso llegando en diversos momentos históricos a estructuras mixtas con hierro o acero, según las diferentes soluciones constructivas del momento.

A nivel europeo se aplica el Eurocódigo 5 y desde 2006 en España se utiliza el CTE (Código Técnico de la Edificación) y sus modificaciones posteriores, para estructuras de madera, definido en el Documento Básico para Estructuras de Madera DB - SEM, donde se define en función del tipo de madera, especie y producto, según sus propiedades, destino y uso, las condiciones técnicas, protecciones, fichas de producto, etc, en función cada uno de estos elementos de madera y organizadas por clases resistentes.

Dentro de las estructuras de madera, encontramos elementos cuya definición podemos dividir según su destino. Elementos verticales como pilares o algunos tipos de entramados y tableros (muros de diafragma en CTE), arcos, pórticos; elementos horizontales como vigas, viguetas, tableros o entrevigados etc; elementos de cubierta como cerchas (estructuras triangulares o celosías en CTE), tirantes, pares, parecillos y tableros o entrevigados. 


\section{-Estructuras de madera maciza}

Son las estructuras más relacionadas, con las que históricamente conocemos y que actualmente están reguladas por las normativas comentadas anteriormente, con los mismos tipos de elementos comentados y clase resistente aplicable.

\section{-Estructuras de madera laminada encolada.}

En estas estructuras se tiene en cuenta los tipos de adhesivos empleados y sus correspondientes fichas técnicas aplicadas a los diferentes elementos comentados y clase resistente aplicable.

\section{-Estructuras de madera microlaminada}

Al igual que la anterior, son estructuras en las que se tiene en cuenta los tipos de adhesivos empleados y sus correspondientes fichas técnicas aplicadas a los diferentes elementos comentados y clase resistente aplicable.

\section{-Tableros estructurales}

Tableros contrachapados, de fibras duros y semiduros y por proceso en seco (MDF). Donde se tiene en cuenta sus correspondientes fichas técnicas aplicadas a los diferentes elementos comentados y clase resistente aplicable.

g) Pavimentos de madera.

Existen diversos tipos de pavimento de madera, que se definen por su solución constructiva y diseño empleado en la confección de los diferentes productos de madera. En cuanto a su solución constructiva, tenemos:

Entablado: Tablas unidas por sus cantos y clavadas 0 atornilladas a viguetas de madera del elemento resistente de madera.

Tarima: Tablas machiembradas, clavadas a rastreles también clavados o encolados a recrecidos o plastones de morteros de cemento o yeso, también sueltos para superficies de dimensiones importantes.

Parquet tipo mosaico, Tablillas adosadas formando dibujos, que según sus dimensiones se denominan taraceado o lamparquet, adherido al soporte normalmente de mortero de cemento mediante colas o adhesivos.

Parquet flotante: Tablas o tablillas machiembradas, con dos 0 varias capas contrapeadas formando un machiembrado y con el espesor de la cara vista variable, apoyadas sobre lámina de espuma de plástico o fieltro elástico directamente sobre el soporte de apoyo.

Parquet industrial: Tablas o tablillas de especies de coste bajo, apoyadas directamente sobre sus cantos, siendo el canto no apoyado el utilizado como servicio del área destinada, actuando para soportar el desgaste de la actividad de destino, ya sea industrial o zonas de uso público en general. 
Parquet hidráulico: Tablas o tablillas formado figuras geométricas, unidas a loseta de mortero hidráulico, sistema en desuso.

Entarugado: Tacos adosados a hueso con la testa a cara vista y sus fibras perpendiculares al soporte de base para usos con grandes cargas o gran uso.

Tarima de composite (WPC): La tarima de composite WPC (Wood Plastic Composite), son tarimas producidas normalmente para exterior, que se diseñan en planchas 0 plaquetas o losetas, en diversos colores, compuestas por la mezcla de $70 \%$ de fibra de Bambú y un $30 \%$ de resinas fenólicas o fibras naturales de bambú y polvo de madera, mezclado con polietileno de alta densidad y otros aditivos químicos.

En cuanto a los diseños, podemos encontrar tablas en paralelo, espiga, formando dameros de diferentes tipos como el encuadrado, chantilly o versalles.

h) Puertas de madera.

Las puertas de madera pueden dividirse entre las de exterior, de acceso a los edificios o a viviendas, locales, oficinas, etc, que en función de la seguridad de la que dispongan pueden variar desde las que son denominadas puertas de seguridad, que pueden estar realizadas en su totalidad en madera con los correspondientes herrajes de seguridad y las denominadas puertas blindadas o acorazadas que incorporan en mayor o menor medida panelados de diferentes especies de madera, después están las puertas de interior que pueden estar compuestas de partes o piezas de madera en su totalidad o diseñadas con diferentes materiales ya sea en sus acabados (cuarterones) o el acabado o composición en el diseño de los productos, como melaninas (oficinas), vidrios y lacados (viviendas), etc, ofreciendo posibilidades con diferentes funcionalidades según sus dimensiones y el número de hojas del que dispongan.

\section{i) Ventanas de madera.}

De la misma manera que con las puertas, existen diferentes tipos de ventanas de madera, a la que se pueden sumar las contraventanas de madera normalmente macizas, muy utilizadas en localizaciones de montaña o sierra, se diferencian sobre todo en su funcionalidad, como practicables, correderas u oscilobatientes, con sellado o no de puente térmico, y diferentes configuraciones de vidrios.

\section{j) Revestimientos de madera.}

Los revestimientos de maderas suelen ser panelados para zonas de interior de estancias, cuya función o diseño lo indiquen, se pueden realizar con todo tipo de formas y especies, ya sean en techos (que también pueden ser artesonados que implican mayor complejidad y utilizan diferentes formatos de madera), paredes o zonas puntuales como pilares, también en exterior o interior.

k) Edificaciones de madera.

Existen edificaciones en madera, normalmente aplicadas a viviendas unifamiliares, aunque también existen otros tipos de edificios, del sector terciario (hoteles), industria (naves) o agrícolas (almacenes o cobertizos) que están realizados en madera, en cualquier caso, las edificaciones en madera son más utilizadas en otras partes del 
mundo que en España, debido a la propia demanda del mercado (en España es baja en el mercado de vivienda unifamiliar y casi inexistente en otros sectores) y por las propias circunstancias de nuestro clima, la adaptación y exigencias a la normativa española técnica y urbanística.

\subsection{Conclusiones al capítulo}

En esta tesis se elige la madera aserrada cortada al hilo para la realización de las muestras, en su estado natural, dado como se ha detallado otros tipos de productos de la madera, disponen de aditivos como los tableros que disponen de adhesivos que podrían influir en el color de la madera en su combinación con los ácidos incoloros en estado líquido aplicados superficialmente sobre ella.

Las maderas utilizadas en esta investigación, dentro de un proceso productivo normal de la madera, para la realización de los ensayos, se eligen después de su periodo de almacenamiento natural y antes de ser tratadas para su comercialización, otras investigaciones eligen las maderas después de ser extraídas de los árboles y cortadas, pero antes de su almacenamiento en el proceso de producción de la madera.

La madera aserrada permite con cualquier tipo de despiece obtener muestras de madera uniforme y después de ser procesadas y obtener una base homogénea y adecuada para la aplicación superficial de ácidos líquidos incoloros, que permitió la alteración de la estructura de la capa superficial de las muestras de madera y por extensión generar una capa de protección y una variación en el color de la madera.

Como se ha podido observar en este capítulo la madera es un material natural anisótropo y orgánico complejo, tanto desde el punto de vista macroscópico como microscópico, con diversas propiedades, que le hacen ser un material utilizado históricamente, con infinidad de productos realizados con ella y para todo tipo de aplicaciones tanto para interior como para exterior, y con una versatilidad de combinación con otros materiales, permitiendo muchos tipos de uniones y combinaciones, con una variación enorme en sus piezas, fácilmente manipulable y flexible, lo que implica gran variedad de formas, sin grandes variaciones en sus propiedades mecánicas en condiciones normales, y debido a las múltiples especies de las que dispone con gran una variedad cromática.

Es por estas razones que esta Tesis elige este material para estudiar la variación y ampliación de la gama de colores de las especies de madera mediante la aplicación superficial de ácidos incoloros en estado líquido, con la posibilidad de recuperar incluso maderas deterioradas o desechadas, permitiendo proyectar un valor añadido a los elementos que definen los espacios en la arquitectura y sin perder las propiedades naturales de las maderas, que las convierten en un material singular y apreciado. 


\section{CLASIFICACIÓN y DESCRIPCIÓN QUÍMICA DE LOS ÁCIDOS}

Para abordar la relación de los ácidos y su aplicación hemos de definir, clasificar y entender la química de los ácidos más utilizados comercialmente. 


\section{CLASIFICACIÓN y DESCRIPCIÓN QUÍMICA DE LOS ÁCIDOS}

Como punto de partida se establece un resumen de los elementos químicos y su clasificación y comportamiento, para de esta forma comprender el comportamiento de los ácidos.

\subsection{Generalidades de la materia}

Si buscamos la definición de materia en el diccionario de la Real Academia de la Lengua (RAE), dice que es "la realidad primaria de la que están hechas las cosas", por extensión podríamos definirla como todo aquello que tiene masa y ocupa un lugar en el espacio.

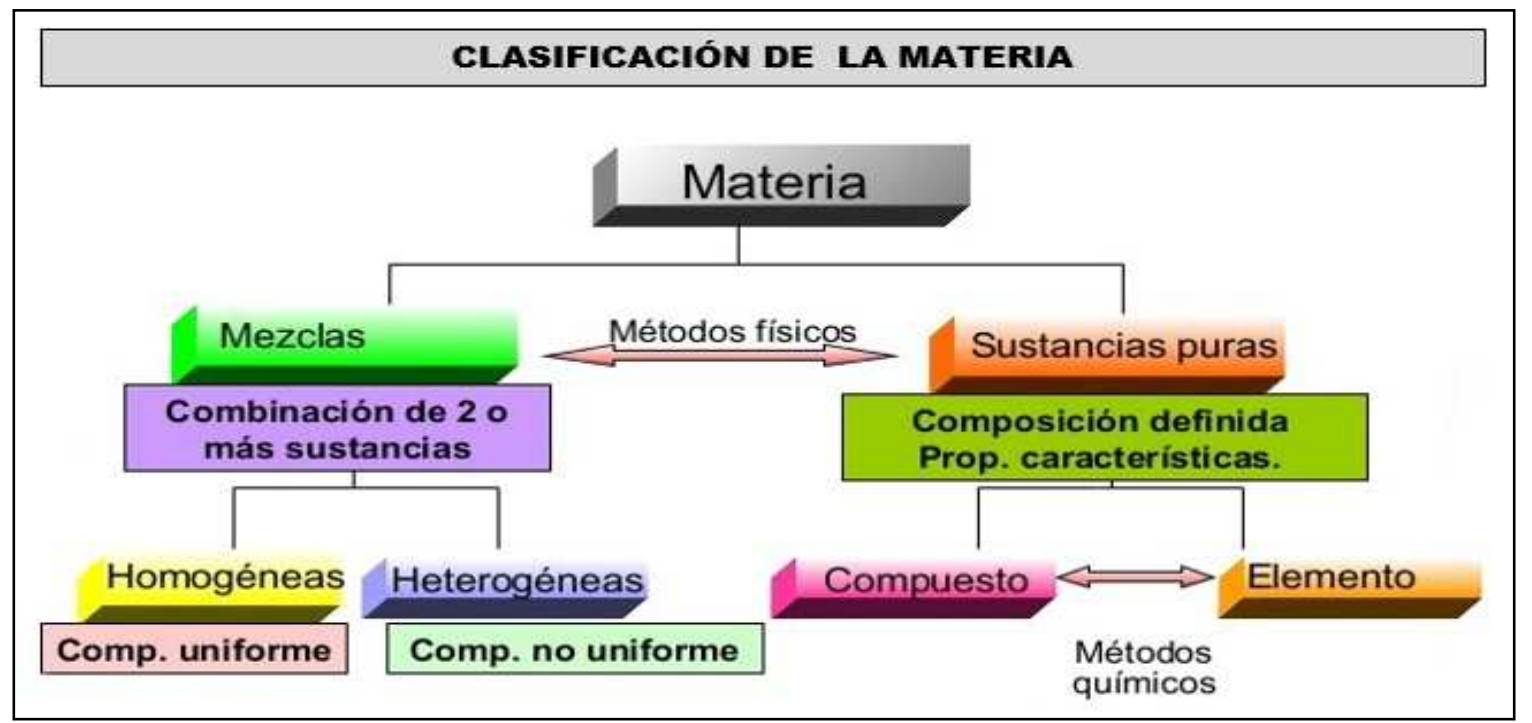

Figura 30. Clasificación de la materia. Elaboración propia.

En la figura superior se observa la división de la materia. La materia la encontramos en la naturaleza en forma de sustancias puras y mezclas.

Sustancias puras: son aquellas cuya naturaleza y composición no varían sea cual sea su estado, no cambian sus propiedades (densidad, temperatura de ebullición, etc) y no se pueden separar en otras sustancias por métodos físicos (tamización, decantación,filtración,etc). Se dividen en dos grandes grupos: Elementos y Compuestos.

a) Elementos: Son sustancias puras que no pueden descomponerse en otras sustancias puras más sencillas por ningún procedimiento. Un ejemplo lo forman todos los elementos de la tabla periódica, que se representan por su símbolo químico (Ej, carbono $(\mathrm{C})$, oxigeno(O)).

b) Compuestos: Son sustancias puras compuestas por 2 o más elementos combinados en proporciones fijas, se pueden descomponer mediante procedimientos químicos en los elementos que los constituyen: Por ejemplo, el agua de fórmula, $\mathrm{H}_{2} \mathrm{O}$ está constituida por los elementos hidrogeno $(\mathrm{H})$ y oxigeno $(\mathrm{O})$, y los compuestos se representan mediante su fórmula química que nos especifica los elementos que los forman y el número de átomos de cada uno de ellos 


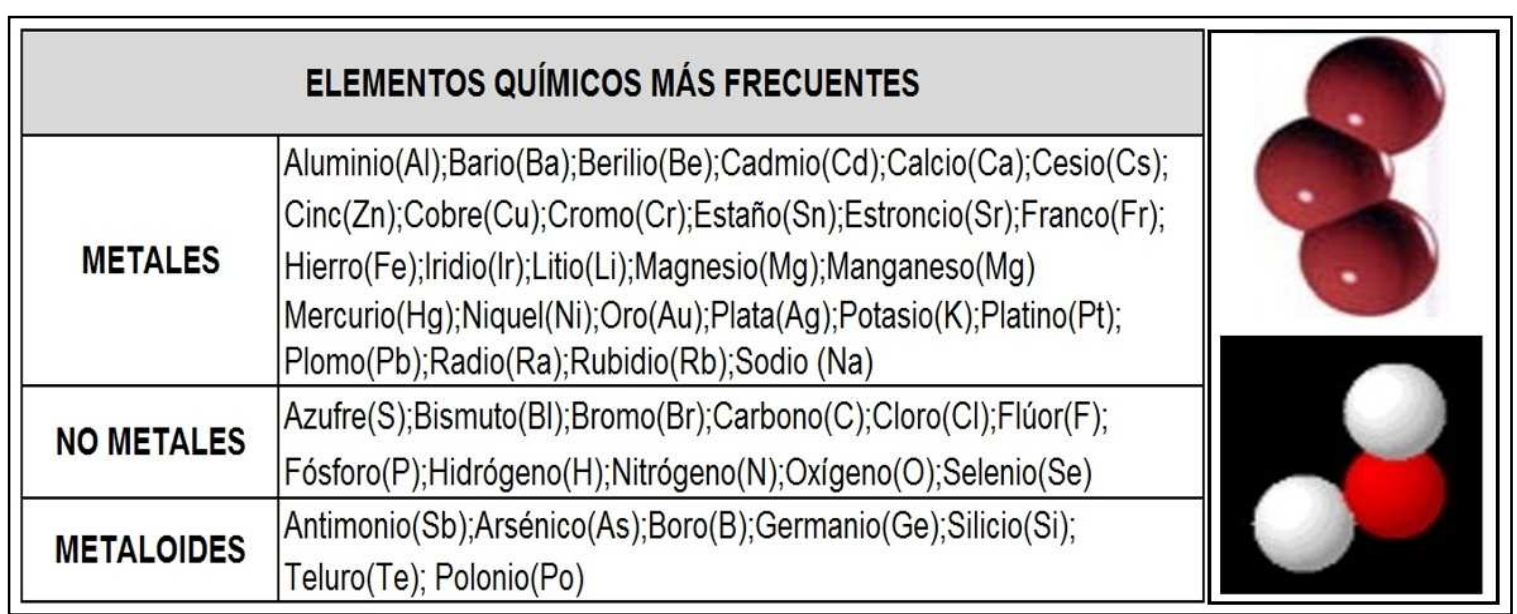

Figura 31. Tabla de elementos químicos más frecuentes. Representación (abajo) de la molécula de agua $\left(\mathrm{H}_{2} \mathrm{O}\right)$ y del Ozono $\left(\mathrm{O}_{3}\right)$. En rojo los átomos de oxígeno y en blanco los de hidrógeno. Elaboración propia.

Cuando una sustancia pura está formada por un solo tipo de elemento se dice que es una sustancia simple, lo que ocurre cuando la molécula tiene varios átomos, pero todos de un mismo elemento. Por ejemplo: oxígeno gaseoso $\left(\mathrm{O}_{2}\right)$ y el ozono $\left(\mathrm{O}_{3}\right)$ formados por varios átomos de oxígeno.

Mezclas: se encuentran formadas por 2 o más sustancias puras. Su composición es variable. Se distinguen dos grandes grupos: Mezclas homogéneas y Mezclas heterogéneas.

a) Mezclas homogéneas: También llamadas Disoluciones. Son mezclas en las que no se pueden distinguir sus componentes a simple vista. Ejemplo: Disolución de sal en agua, el aire, una aleación de oro y cobre, etc.

b) Mezclas heterogéneas: Son mezclas en las que se pueden distinguir a los componentes a simple vista. Ejemplo: Agua con aceite, granito, arena en agua, etc.

\section{a) Elementos Químicos}

En el sistema periódico actual figuran 118 elementos químicos diferentes, algunos de los cuales han recibido nombre definitivo por la IUPAC desde 1998, en concreto los elementos metálicos sintéticos, son materiales no presentes en la naturaleza creados por el hombre, basados en polímeros y en condiciones controladas, como por ejemplo plásticos y metales (aleaciones) pueden ser sintetizados en laboratorio o en la industria por medio de procesos como laminaciones extrusiones o en caso de los metales fundiciones para mejorar las propiedades mecánicas químicas o físicas de los materiales, normalmente superconductores y suelen aplicarse a la industria de la automoción, los últimos metales sintéticos son los designados en la tabla periódica con número atómico: 104 Rutherfordio (Rf),105 Dubnio (Db),106 Seaborgio(Sg),107 Bohrio (Bh), 108 Hasio (Hs),109 Meitnerio (Mt) y 110 Darmstadio (Ds), 111 Roentgenio (Rg), 112 Copernicio (Cn), 113 Ununtrio (Uut), 114 Flerovio (FI), 115 Unumpentio (Uup), 116 Livermorio (Lv), 117 Ununseptio (Uus) y 118 Ununoctio (Uuo).

Los elementos químicos que forman las sustancias, que tradicionalmente se estudian, se pueden dividir en Metales, No Metales, Metaloides, Gases Nobles, Lantánidos y 
Actínidos. En la tabla periódica los Metales se encuentran a la izquierda y centro, y a la derecha los No Metales y los Metaloides como el Boro, Silicio, Germanio, Arsénico Antimonio, Teluro y Polonio

Los Metales se diferencian por:

- Aspecto y brillo metálico

- Densidad elevada (gran empaquetamiento de partículas)

- Son dúctiles, maleables y tenaces, buenos conductores térmicos y eléctricos

- Se combinan con el oxígeno formando óxidos básicos

- No forman moléculas en sentido estricto p.ej: Na,Fe.Co,K (un elemento metálico se considera monoatómico)

- Son sólidos a temperatura ordinaria menos el mercurio (líquido)

- Muestran poca tendencia a combinarse con el hidrógeno.

- Son poco electronegativos, tienden a perder electrones y originar iones positivos.

Los No Metales se diferencian por:

- No tienen brillo metálico

- Su densidad suele ser inferior a la de los metales

- No son dúctiles ni maleables, no son buenos conductores térmicos ni eléctricos

- Se combinan con el oxígeno formando óxidos ácidos (anhidros)

- Excepto los gases nobles que son monoatómicos, los no metales presentan en general agrupaciones moleculares bi,tri o poliatómicas. p.ej: $\mathrm{O}_{2}, \mathrm{Cl}_{2}, \mathrm{P}_{4} ; \mathrm{S}_{8}$

- Son sólidos o gaseosos a temperatura ordinaria, excepto el bromo (líquido)

- Muestran mucha tendencia a combinarse con el hidrógeno

- Son electronegativos, captan electrones y originan iones negativos

b) Generalidades de conceptos de la estructura atómica.

Las combinaciones químicas que se producen entre los elementos químicos obteniendo diferentes tipos de compuestos, conlleva a efectos de compresión, tener en cuenta algunos conceptos de la estructura atómica, que a continuación se exponen:

- Molécula (del nuevo latín molécula, que es un diminutivo de la palabra moles, 'masa') En química, es un grupo eléctricamente neutro y suficientemente estable de al menos dos átomos en una configuración definida, unidos por enlaces químicos fuertes (covalentes o enlace iónico). Las moléculas de sustancias simples, como oxígeno, cloro, nitrógeno, etc están constituidas por átomos de la misma especie, y las moléculas de sustancias compuestas como el ácido nítrico, carbonato cálcico, etc están constituidas por átomos diferentes, en función del número de átomos, las moléculas puedes ser diatómicas $\left(\mathrm{Cl}_{2}, \mathrm{O}_{2}, \mathrm{~N}_{2}, \mathrm{H}_{2}, \mathrm{~F}_{2}, \mathrm{Br}_{2}, \mathrm{I}_{2}\right)$, triatómicas, tetraatómicas y poliatómicas , en función de 2,3,4 o varios átomos.

- Átomo: En griego significa "indivisible" que es la parte más pequeña de un elemento que puede entrar en combinación química para formar un compuesto químico.

El átomo se subdivide en el núcleo y la "corteza" o periferia (algunos autores la denominan nube), en el núcleo tenemos los neutrones con carga eléctrica neutra (que le da su nombre) y con masa parecida a los protones con unidad de carga positiva (+) y una masa 2.000 veces mayor a los electrones con carga negativa (-) y masa despreciable que se encuentra en la "corteza" o periferia. A protones y neutrones se les llama nucleones, por encontrarse en el núcleo del átomo, en un átomo neutro el número 
de electrones o cargas negativas debe ser igual al número de protones o cargas positivas. La última capa se la denomina capa de valencia.

Número atómico (Z), número de protones que posee un átomo en su núcleo igual al número de electrones para ser un átomo neutro.

Número másico $(A)$, número de nucleones de un átomo (protones y neutrones).

Unidad de masa atómica $(u)$, es la doceava parte de la masa de un átomo de carbono12 , que contiene 6 protones y 6 electrones. Es una unidad arbitraria, que se establece para comparar diferentes elementos y obtener la masa atómica relativa que es la masa de un átomo, medida en unidades de masa atómica, equivalente aproximadamente a la suma de las masas de los protones y neutrones del núcleo (nucleones) y coincide prácticamente con el número atómico y por extensión la masa molecular relativa de una sustancia simple o compuesta igual a la suma de las masas atómicas relativas de los átomos que contiene la sustancia. La masa atómica del calcio Ca es 40 unidades de masa atómica, es decir $40 u$.

Isótopos: (significa igual lugar), presentan el mismo número atómico $\mathrm{Z}$, y diferente número másico $\mathrm{A}$, cuando un elemento presenta varios isótopos, se le llama pléyade.

La pléyade del Hierro sería:

$$
{ }^{54} \mathrm{Fe} \rightarrow 8,10 \% ;{ }^{56} \mathrm{Fe} \rightarrow 91,01 ;{ }^{77} \mathrm{Fe} \rightarrow 0,88 \% ;{ }^{58} \mathrm{Fe} \rightarrow 0,01 \% ;
$$

Esto significa que el $8,10 \%$ de los átomos de hierro tiene una masa atómica de $54 \mathrm{u}$ y así sucesivamente, para hallar la masa de un átomo de un elemento químico, que aparece en la tabla periódica, se utiliza la media ponderada de los diferentes isótopos.

Mol (mol): Cantidad de sustancia que tiene un sistema que contiene tantas entidades elementales como átomos de carbono hay en 0,012 kilogramos de carbono-12. Es decir, se utiliza para determinar la cantidad de átomos o moléculas que contiene una determinada sustancia. Cuando se mide en moles hay que especificar a que nos referimos átomos, moléculas, iones, electrones o partículas. El mol determina por un lado la cantidad de masa de una sustancia expresada en el número de kilogramos de sustancia y el número de entidades elementales (átomos, moléculas, iones, electrones o partículas) que hay en esa sustancia. Experimentalmente se determinó que el número de entidades elementales (número de carbonos) contenidas en 0,012 kilogramos de carbono-12 es igual a 6,022 × $10^{23}$ que es la constante de Avogadro $\left(\mathrm{N}_{\mathrm{A}}\right)$.

Para cualquier elemento, como por ejemplo:

\begin{tabular}{|c|c|c|c|}
\hline Moles & Átomos & & $\begin{array}{l}\text { Gramos } \\
\text { (Masa atómica) }\end{array}$ \\
\hline $1 \mathrm{~mol}$ de $\mathrm{S}$ & $6.022 \times 10^{23}$ & átomos de S & $32.06 \mathrm{~g}$ de $\mathrm{S}$ \\
\hline $1 \mathrm{~mol}$ de $\mathrm{Cu}$ & $6.022 \times 10^{23}$ & átomos de $\mathrm{Cu}$ & $63.55 \mathrm{~g}$ de $\mathrm{Cu}$ \\
\hline $1 \mathrm{~mol}$ de $\mathrm{N}$ & $6.022 \times 10^{23}$ & átomos de $\mathrm{N}$ & $14.01 \mathrm{~g}$ de $\mathrm{N}$ \\
\hline $1 \mathrm{~mol}$ de $\mathrm{Hg}$ & $6.022 \times 10^{23}$ & átomos de $\mathrm{Hg}$ & $200.59 \mathrm{~g}$ de $\mathrm{Hg}$ \\
\hline 2 moles de $\mathrm{K}$ & $1.2044 \times 10^{23}$ & átomos de $\mathrm{K}$ & $78.20 \mathrm{~g}$ de $\mathrm{K}$ \\
\hline 0.5 moles de $P$ & $3.0110 \times 10^{23}$ & átomos de $\mathrm{P}$ & $15.485 \mathrm{~g}$ de $\mathrm{P}$ \\
\hline
\end{tabular}

Universidad Politécnica de Madrid - Escuela Técnica Superior de Arquitectura - Departamento de Construcción y Tecnología Arquitectónica Directores: Dr. Alfonso García Santos y Dr. Antonio Rodríguez Rodríguez. Doctorando: D. Francisco Lora Toro 
Masa molar de los compuestos:

Un mol de un compuesto contiene el número de Avogadro de unidades fórmula (moléculas o iones) del mismo. Los términos peso molecular, masa molecular, peso fórmula y masa fórmula se han usado para referirse a la masa de $1 \mathrm{~mol}$ de un compuesto. El término de masa molar es más amplio pues se puede aplicar para todo tipo de compuestos. A partir de la fórmula de un compuesto, podemos determinar la masa molar sumando las masas atómicas de todos los átomos de la fórmula. Si hay más de un átomo de cualquier elemento, su masa debe sumarse tantas veces como aparezca. Ej.KOH (hidróxido de potasio):

$\mathrm{K}=1 \times 39.10=39.10 ; \mathrm{O}=1 \times 16.00=16.00 ; \mathrm{H}=1 \times 1.01=1.01 ;$ Total $=56.11 \mathrm{~g}$

En el caso de los compuestos también podemos establecer una relación entre moles, moléculas y masa molar. $1 \mathrm{MOL}=6.022 \times 10^{23}$ MOLÉCULAS $=$ MASA MOLAR (gramos).

Estructura electrónica de la corteza del átomo: Las propiedades químicas de los elementos dependen de esta estructura y de la distribución en que se dispongan, en la corteza del átomo, los electrones se disponen en función del número de niveles electrónicos de diferente energía.

Número cuántico principal $(n)$ : Fija el número de niveles de diferente energía, con valores de 1 hasta $(n)$ designados los diferentes niveles electrónicos de energía por las letras $K, L, M, N, O, P \ldots y$ en cada nivel caben $2 n^{2}$ electrones. A su vez cada nivel de energía dispone de 2 subniveles, donde sólo caben 2 electrones con spin antiparalelo, según el principio de exclusión de Pauli, el sentido de llenado de los electrones es siempre de menor a mayor nivel de energía, que se detalla mediante el diagrama de Möller, obteniendo la configuración electrónica del elemento, dicha configuración tiene una forma reducida en función del gas noble anterior al elemento estudiado, dado que las configuraciones puede llegar a ser largas, obsérvese en el ejemplo del cloro $(\mathrm{Cl})$ que la suma de los superíndices de los subniveles dan el número 17 igual al número $Z$.

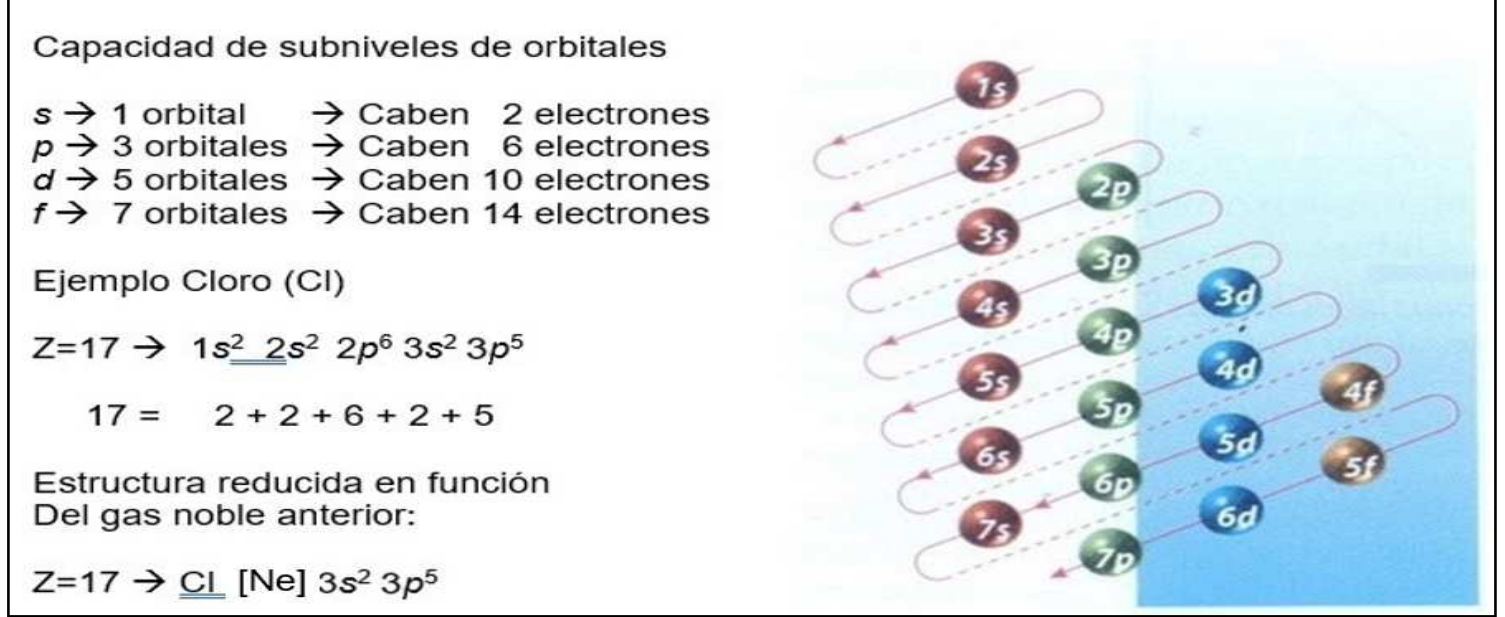

Figura 32.Configuración electrónica (izq.)Diagrama de Möller (dcha). Elaboración propia

Valencia: Capacidad de un elemento de combinarse con otro. Se toma como referencia el hidrógeno al que se le asigna la valencia 1, que viene dada por el número de electrones captados, cedidos o compartidos con un átomo de dicho elemento al formar un enlace. 
Número de oxidación: Suele coincidir con el número de electrones que le faltan o sobran al átomo del elemento para adquirir la estructura externa propia de los gases nobles, es decir ocho electrones en el último nivel (estructura de octeto). En general a los metales le sobran electrones y a los no metales le faltan electrones, lo que implica que los metales presentan tendencia a perder electrones y los no metales a adquirirlos. Ejemplo: El cloro tiene 7 electrones en el último nivel ( $3 s^{2} 2 p^{5} \rightarrow 2+5=7$ ), le falta un electrón para alcanzar la estructura de gas noble (estructura de octeto), por tanto, su número de oxidación es $(-1)$, negativo pues le falta un electrón, que lo captaría en la capa más externa o capa de valencia.

Fórmulas de los compuestos: Los compuestos se expresan mediante fórmulas, donde se indica con que elementos están constituidos, donde se expresa el número de átomos de los diferentes elementos, la masa molecular es la suma de las masas de sus elementos en $(\mathrm{u})$, la relación ponderal de sus elementos (como se combinan) y el porcentaje en masa de los elementos que la constituyen (porcentaje de masas).
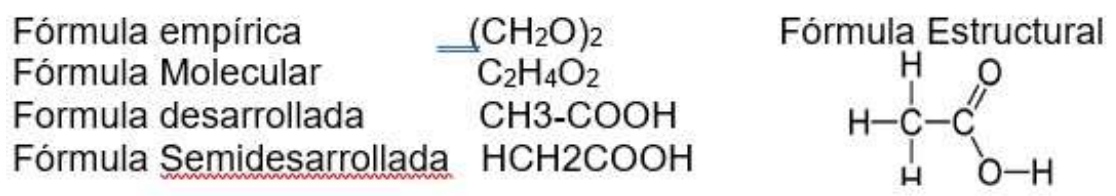

Enlaces: Los enlaces son las relaciones que se producen entre los elementos, para formar una molécula, en función de su capacidad de ceder o tomar electrones, los elementos se unen porque los compuestos resultantes tienen menos energía y por lo tanto son más estables, para romper un enlace habría que aportar energía. Existen 3 tipos de enlaces:

Enlace iónico: Es un enlace donde un número de aniones de un elemento se compensa con un número igual de cationes de otro elemento como es el caso del cloruro sódico que sería $\mathrm{Na}^{+} \mathrm{Cl}^{-}$.

Enlace covalente: Es un enlace donde los elementos de una molécula comparten los electrones, es el caso de muchos compuestos, como por ejemplo el metano $\mathrm{CH}_{4}$, donde el carbono necesitaría mucha energía para ganar o perder 4 electrones y poder tener una estructura de gas noble (estructura de octeto), así que lo que hace es compartirlos con 4 hidrógenos.

Enlace covalente polarizado: Es igual al anterior, pero en este caso uno de los elementos es más fuerte que el otro, es un enlace típico dado que muchos enlaces ni son totalmente covalentes (como el del etano C-C) ni son totalmente iónicos. Los enlaces covalentes polarizados suponen que la estructura de la molécula se asimétrica, de esta circunstancia se producen los momentos dipolares. Los enlaces covalentes se suelen representar como una línea continua entre 2 elementos (representación de Kekulé), pero también se pueden representar por punto-electrón (Brönsted-Lowry) o combinaciones de los dos. También se representan enlaces en 3 dimensiones (química orgánica), donde se representan los enlaces covalentes polarizados.

Orbital molecular: Son los orbitales resultantes que se producen por la combinación de los diferentes elementos que la componen, debida a una combinación matemática de orbitales atómicos (funciones de onda). Estos orbitales describe una región del espacio que rodea al átomo donde es más probable que se puedan encontrar los electrones y al 
igual que el orbital atómico tienen tamaño, forma y energía específica. Existen dos formas en que se combinan los orbitales atómicos de forma aditiva que lleva a un orbital en forma de huevo y de menor energía o de forma sustractiva que es un orbital de mayor energía y que forma un nodo entre los núcleos.

Sistema periódico: El sistema periódico se resume en la tabla periódica, se ordena por el número atómico (número de protones) de izquierda a derecha y de arriba abajo y donde se forman filas horizontales llamados periodos (mismo número de capas de electrones) y columnas verticales denominadas grupos o familias (mismo número de capas en la última capa), donde se encuentran los metales, metaloides con propiedades intermedias entre metales y no metales, gases nobles, lantánidos y actínidos, durante los últimos años se ha añadido los compuestos sintéticos como los metales sintéticos.

Los elementos con propiedades químicas similares se encuentran en el mismo grupo del sistema periódico, donde se observa un periodo en dichas propiedades químicas y físicas (grupos), debidas a las semejanzas y diferencias entre las estructuras electrónicas de los diferentes elementos. Existen 7 periodos y 18 grupos o familias.

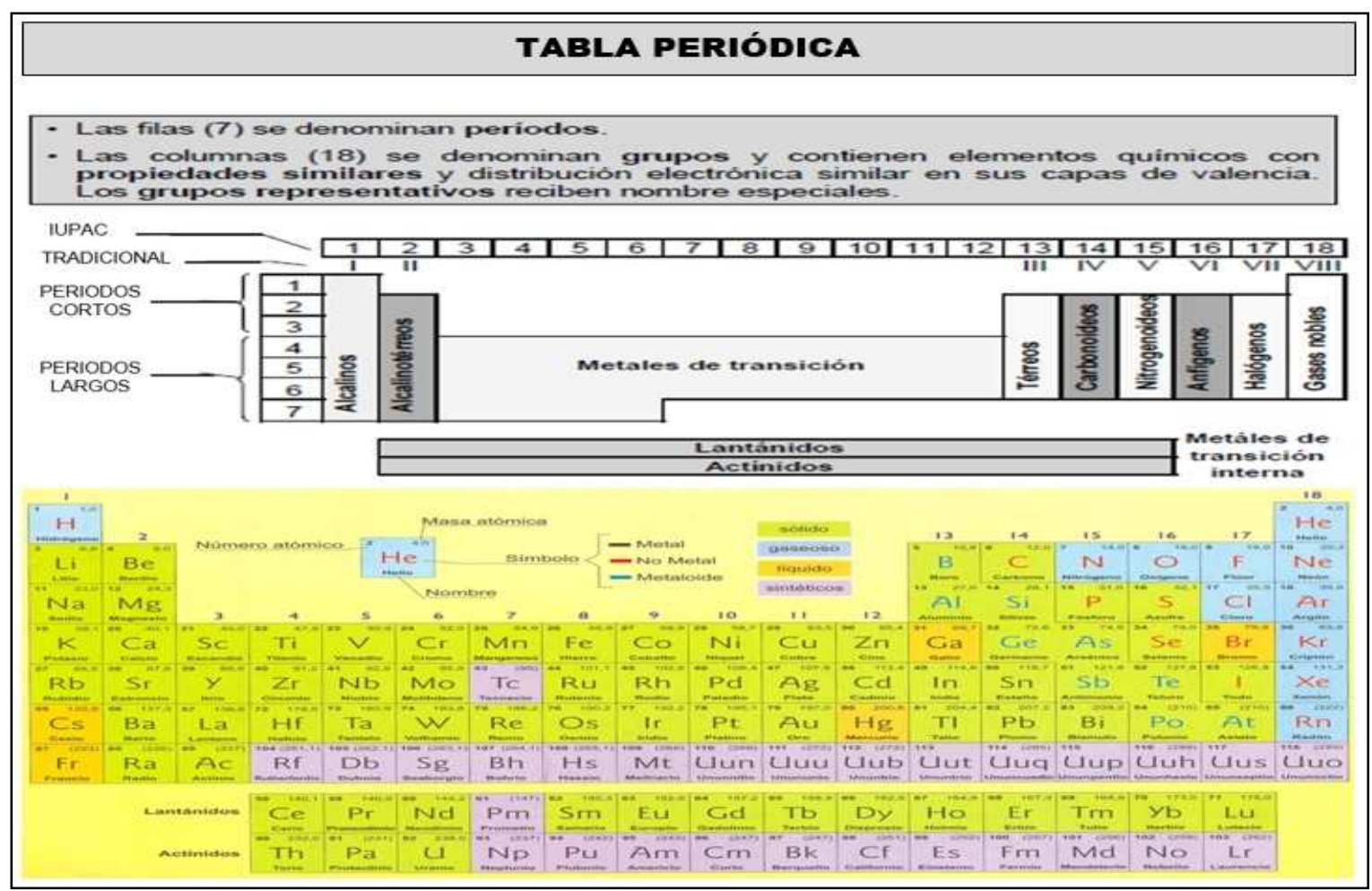

Figura 33. Sistema periódico. Elaboración propia.

c) División de la química

La materia desde el punto de vista químico se puede dividir en Química orgánica, y Química inorgánica, el nexo de unión entre ambas es la Química Organometálica donde existen restos orgánicos unidos por un carbono o un metal a través de enlaces covalentes con carácter más o menos iónico. El organismo que unifica los criterios a efectos de designación de compuestos, formulación, valores, etc es la International Union of Pure and Applied Chemestry (IUPAC), que traducido es la unión internacional de química pura y aplicada. 
d) Química Inorgánica

Parte de la química que estudia la formación, estructura, composición y reacciones de aquellas sustancias simples o compuestas que NO disponen de enlaces de carbono e hidrógeno en sus elementos.

\begin{tabular}{|c|c|c|c|}
\hline \multicolumn{4}{|c|}{ CLASIFICACIÓN DE COMPUESTOS INORGÁNICOS } \\
\hline \multirow{9}{*}{$\begin{array}{l}\text { COMPUESTOS } \\
\text { BINARIOS } \\
\text { (2 Elementos } \\
\text { diferentes } \\
\text { combinados) }\end{array}$} & \multirow{2}{*}{ SALES } & Metal + NO Metal & Sales Neutras \\
\hline & & NO Metal + NO Metal & Sales volátiles \\
\hline & \multirow{3}{*}{ OXÍGENO } & \multirow{2}{*}{ + Metal } & Óxidos básicos \\
\hline & & & Peróxidos \\
\hline & & + NO Metal & Óxidos ácidos \\
\hline & \multirow{3}{*}{ HIDRÓGENO } & + Metal & Hidruros metálicos \\
\hline & & + Metaloide & Hidrúros volátiles \\
\hline & & + NO Metal & Haluros de Hidrógeno \\
\hline & HIDRÁCIDOS & \multicolumn{2}{|c|}{ Haluros de Hidrógeno + agua } \\
\hline \multirow{3}{*}{$\begin{array}{c}\text { COMPUESTOS } \\
\text { TERNARIOS } \\
\text { (3 Elementos } \\
\text { diferentes } \\
\text { combinados) }\end{array}$} & $\begin{array}{c}\text { ÁCIDOS } \\
\text { OXÁCIDOS }\end{array}$ & \multicolumn{2}{|c|}{ Óxidos ácidos + agua } \\
\hline & $\begin{array}{l}\text { HIDRÓXIDOS } \\
\text { BASES }\end{array}$ & \multicolumn{2}{|c|}{ Óxidos Básicos + agua } \\
\hline & \multicolumn{3}{|c|}{ SALES NEUTRAS (Oxisales) } \\
\hline \multirow{4}{*}{$\begin{array}{c}\text { COMPUESTOS } \\
\text { CUATERNARIOS } \\
\text { (4 Elementos } \\
\text { diferentes comb.) }\end{array}$} & \multicolumn{3}{|c|}{ SALES ÁCIDAS } \\
\hline & \multicolumn{3}{|c|}{ SALES BÁSICAS } \\
\hline & \multirow{2}{*}{\multicolumn{2}{|c|}{ SALES DOBLES }} & Con varios cationes \\
\hline & & & Con varios aniones \\
\hline
\end{tabular}

Figura 34. Química Inorgánica. Clasificación. Elaboración propia

Los compuestos pueden ser binarios, ternarios o cuaternarios, en función de si en su composición contienen 2,3 o 4 elementos, que combinados con metales o no metales, oxigeno o hidrogeno, conforman diferentes tipos de compuestos complejos.

En el caso de esta Tesis, interesada por los ácidos, observamos que: La combinación de oxígeno con un No Metal da un Óxido ácido (compuesto binario), también denominado Anhídrido ácido, que al añadirles agua, se convierten en un compuesto ternario denominado Ácido oxácido, o simplemente Oxácido.

La combinación de hidrógeno con un No Metal da un Haluro de hidrógeno (compuesto binario), que combinado con agua, se convierten en un compuesto también binario también denominado Hidrácido. 
e) Química Orgánica

Llamada química del carbono es la parte de la química que estudia la formación, estructura, composición y reacciones de aquellas sustancias simples o compuestas que disponen de enlaces de carbono-carbono y carbono-hidrógeno en sus elementos. Además del carbono, los compuestos que normalmente se asocian en la química orgánica son Nitrógeno, Fósforo, Oxígeno, Azufre, Flúor, Cloro, lodo y Bromo.

\begin{tabular}{|c|c|c|c|}
\hline \multicolumn{4}{|c|}{ CLASIFICACIÓN DE COMPUESTOS ORGÁNICOS } \\
\hline \multirow{15}{*}{$\begin{array}{l}\text { HIDROCARBUROS } \\
\text { (2 ó } 3 \text { Elementos } \\
\text { Hidrógeno(H) y } \\
\text { Carbono(C)) }\end{array}$} & \multirow{3}{*}{$\begin{array}{c}\text { ALIFÁTICOS (Acíclicos) } \\
\text { Cadenas Lineales ó } \\
\text { Ramificadas }\end{array}$} & Saturados & Alcano(parafina)/Enlace 1 \\
\hline & & \multirow{2}{*}{ Insaturados } & Alqueno(olefinas)/Enlace 2 \\
\hline & & & Alquino(aceitilenos)/Enlace 3 \\
\hline & \multirow{3}{*}{$\begin{array}{c}\text { CíCLICOS } \\
\text { Cadenas cerrada con } 2 \\
\text { atomos extremos }\end{array}$} & Saturados & Alcano/Enlace 1 \\
\hline & & \multirow{2}{*}{ Insaturados } & Alqueno/Enlace 2 \\
\hline & & & Alquino/Enlace 3 \\
\hline & \multirow{3}{*}{$\begin{array}{c}\text { ALICÍCLICOS } \\
\text { Cadenas cerrada (+) de } 2 \\
\text { atomos extremos }\end{array}$} & Saturados & Alcano/Enlace 1 \\
\hline & & \multirow{2}{*}{ Insaturados } & Alqueno/Enlace 2 \\
\hline & & & Alquino/Enlace 3 \\
\hline & \multirow{3}{*}{$\begin{array}{c}\text { AROMÁTICOS } \\
\text { Cad.cerrada Base Anillo } \\
\text { Benceno } 6 \text { atomos }\end{array}$} & Saturados & Alcano/Enlace 1 \\
\hline & & \multirow{2}{*}{ Insaturados } & Alqueno/Enlace 2 \\
\hline & & & Alquino/Enlace 3 \\
\hline & \multirow{3}{*}{$\begin{array}{l}\text { DERIVADOS HALOGENADOS } \\
\text { (Fluor(F),Cloro(Cl), Bromo( } \\
\text { Br); Yodo }(\mathrm{l}))\end{array}$} & Saturados & Alcano/Enlace 1 \\
\hline & & \multirow{2}{*}{ Insaturados } & Alqueno/Enlace 2 \\
\hline & & & Alquino/Enlace 3 \\
\hline \multirow{12}{*}{$\begin{array}{c}\text { COMPUESTOS } \\
\text { OXIGENADOS } \\
\text { (3 Elementos } \\
\text { Hidrógeno(H), } \\
\text { Carbono(C) y } \\
\text { Oxígeno(O) }\end{array}$} & \multirow{2}{*}{ ALCOHOL } & Alifático & Cadena abierta \\
\hline & & Aromático & Cadena cerrada \\
\hline & FENOL & Aromático & Cadena cerrada \\
\hline & \multirow{2}{*}{ ÉTER } & Alifático & Cadena abierta \\
\hline & & Aromático & Cadena cerrada \\
\hline & ALDEHÍDO & Alifático & Cadena abierta \\
\hline & CETONA & Alifático & Cadena abierta \\
\hline & \multirow{3}{*}{$\begin{array}{c}\text { ÁCIDOS CARBOXÍlICOS } \\
\text { Grupo } \mathrm{COOH} \\
\text { (Carbonilo+Hidroxilo) }\end{array}$} & Monocarboxílicos & 1 grupo $\mathrm{COOH}$ \\
\hline & & \begin{tabular}{|l|} 
Dicarboxílicos \\
\end{tabular} & 2 grupo $\mathrm{COOH}$ \\
\hline & & Policarboxílicos & Más de 2 grupos $\mathrm{COOH}$ \\
\hline & ÉSTERES & Alifático & Cadena Abierta (Enlace Covalente) \\
\hline & SALES ión $(\mathrm{Na}),(\mathrm{K})$,etc & Aromático & Cadena Cerrada (Enlace iónico) \\
\hline \multirow{6}{*}{$\begin{array}{c}\text { COMPUESTOS } \\
\text { NITROGENADOS (3ó4 } \\
\text { Elem. Incluye Nitrógeno } \\
\text { (N) y (H), } \quad \text { (C) y } \\
\text { (O) no siempre }\end{array}$} & \multirow{2}{*}{ AMINA } & Alifático & Cadena abierta \\
\hline & & Aromático & Cadena cerrada \\
\hline & AMIDA & Alifático & Cadena abierta \\
\hline & NITRILO (Cianuros) & Alifático & Cadena abierta (3 Enlace $(\mathrm{N})$ ) \\
\hline & \multirow{2}{*}{$\begin{array}{l}\text { NITROCOMPUESTOS } \\
\text { (Nitroderivados) }\end{array}$} & Alifático & Cadena abierta \\
\hline & & Aromático & Cadena cerrada \\
\hline
\end{tabular}

Figura 35. Química Orgánica. Clasificación. Elaboración propia

La química orgánica se organiza mediante grupos funcionales, son grupos de átomos que tiene un comportamiento químico característico en todas las moléculas que aparece unido mediante enlaces al resto de la molécula (suelen denominarse con la letra $\mathrm{R}$ de radical).

En el caso de esta Tesis, interesada por los ácidos, observamos que el grupo funcional donde se encuentran los ácidos orgánicos es en el grupo carboxilo $(\mathrm{COOH})$. 


\subsection{Propiedades generales de los ácidos}

A principios del s.XIX en la química se tendía a observar los compuestos y observar sus diferencias, de ahí que dividieran, en tres grandes grupos, en función de sus propiedades, ácidos, álcalis y sales. La denominación de ácido proviene del latín "agrio" y álcali del árabe "al kali" que era una planta que atacaba los ácidos.

En química la forma tradicional de definir los ácidos es mediante su comparación con sus compuestos opuestos, las bases. A principios del s.XIX, se definieron como:

a) Propiedades de los Ácidos:

- Aquellas sustancias que tenían un sabor agrio.

- En disolución acuosa cambiaban el color de los colorantes vegetales.

- Disolvían muchas sustancias.

- Contenían hidrógeno, que podía liberarse en forma de gas, cuando en disoluciones acuosas con metales liberaban gas.

- Perdían sus propiedades características cuando reaccionaban con otras sustancias denominadas bases.

b) Propiedades de las Bases:

- Aquellas sustancias que tenían un sabor amargo.

- Disponen de suavidad al tacto, actualmente se deduce que es por la facilidad de hidrolizar las proteínas de la piel.

- En disolución acuosa cambiaban el color de los colorantes vegetales, con color diferente al de los ácidos.

- Precipitaban muchas sustancias que eran solubles en ácidos.

- Perdían sus propiedades características cuando reaccionaban con otras sustancias denominadas ácidos.

Todas estas características de los ácidos tenían que ver con la forma con la que se usaban o mezclaban las sustancias, pero no hacían referencia a la estructura molecular de ácidos y bases.

\subsection{Evolución de la definición de ácidos}

Por ser la definición de las propiedades, sólo basadas en cuestiones más operacionales que desde el punto de vista de comprender que intervenía para que se produjeran esos resultados, se comenzó a desarrollar, entre el s.XIX y s.XX, diferentes teorías.

Existen 3 definiciones de ácidos que han evolucionado a lo largo del tiempo: 
a) Definición de Arrhenius

A principios del s.XIX, Arrhenius, definió los ácidos.

Según Arrhenius:

Ácido es toda sustancia que contiene hidrógeno y que en su disolución acuosa que se ioniza dando lugar a iones de hidrógeno $\mathrm{H}^{+}$y Base es toda sustancia que en disolución acuosa que se ioniza dando lugar a iones hidroxilo $\mathrm{OH}^{-}$.

Los siguientes ácidos en disolución o disociación acuosa (ac) o (aq) forman iones negativos para el anión ácido e iones positivos para el catión $\mathrm{H}^{+}$.

Ácido Clorhídrico ClH (disolución acuosa) $\leftrightarrow \mathrm{Cl}^{-}(\mathrm{ac})+\mathrm{H}^{+}$(ac)

Ácido Sulfúrico $\mathrm{SO}_{4} \mathrm{H}_{2}$ (disolución acuosa) $\leftrightarrow \mathrm{SO}_{4}{ }^{{ }^{-}}(\mathrm{ac})+2 \mathrm{H}^{+}$(ac)

Ácido Acético $\mathrm{CH}_{3} \mathrm{COOH}$ (disolución acuosa) $\leftrightarrow \mathrm{CH}_{3} \mathrm{COO}^{-}(\mathrm{ac})+\mathrm{H}^{+}$(ac)

De la misma forma sucede con las bases:

Hidróxido Sódico $\mathrm{NaOH}$ (disolución acuosa) $\leftrightarrow \mathrm{Na}^{+}(\mathrm{ac})+\mathrm{OH}^{-}(\mathrm{ac})$

Hidróxido Cálcico $\mathrm{Ca}(\mathrm{OH})_{2}$ (disolución acuosa) $\leftrightarrow \mathrm{Ca}^{2}(\mathrm{ac})+2 \mathrm{OH}^{-}(\mathrm{aq})$

El resultado son iones Hidróxidos $\mathrm{OH}^{-}$y cationes para los metales $\mathrm{Ca}$ y $\mathrm{Na}$.

Esta definición era restrictiva porque lo que se hacía era sumar o restar iones al estar los elementos de ácido y base en agua y en su reacción formar moléculas de agua, pero no valía para otros tipos de ácidos.

$\mathrm{ClH}(\mathrm{ac})+\mathrm{NaOH}(\mathrm{ac}) \longleftrightarrow \mathrm{NaCl}(\mathrm{ac})+\mathrm{H}_{2} \mathrm{O}$ (líquido)

Es decir, la conocida fórmula de Ácido + Base = Sal + Agua, en nuestro caso Cloruro de Sodio más agua.

b) Definición de Brönsted-Lowry

A principios del s.XX, se estableció la definición de Brönsted-Lowry, también llamada teoría protónica de ácidos y bases.

Según Brönsted-Lowry:

Ácido es cualquier sustancia molecular o iónica, que pueda ceder protones a otra sustancia que actué como base, es decir por extensión significa que el concepto de base es cualquier sustancia que pueda aceptar protones de un ácido.

Esto significa que la definición protónica es válida para cualquier disolvente (no sólo agua) o incluso en ausencia de disolvente. 


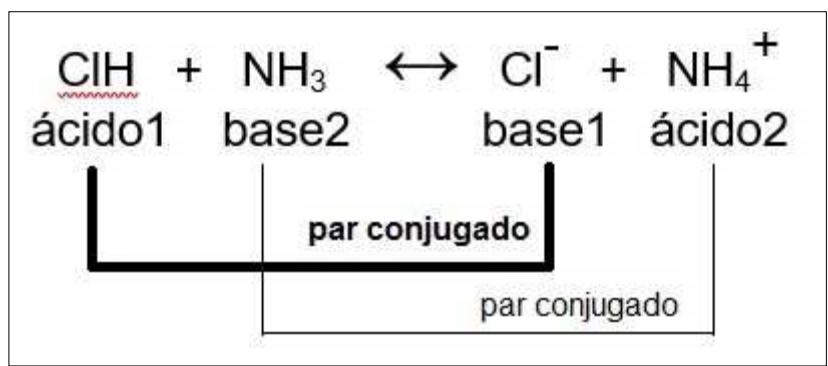

Figura 36. Ácidos y Bases conjugadas. Elaboración propia

Cuando sumamos el ácido $1 \mathrm{ClH}$ (ácido clorhídrico) con la base $2 \mathrm{NH}_{3}$ (amoniaco); obtenemos el ion $\mathrm{Cl}^{-}$que se convierte en base 1, pero podría volver a recupera el protón cedido, por eso a la base 1 se la denomina "base conjugada del ácido", igualmente cuando una base $2 \mathrm{NH}_{3}$ (amoniaco) acepta un protón se convierte en un ácido 2 $\mathrm{NH}_{4}{ }^{+}$(ion amonio), al que se le denomina "ácido conjugado de la base".

Esto significa que todas las reacciones ácido-base de Brönsted-Lowry, implican la presencia de dos pares de ácidos-bases en equilibrio. En función de la capacidad de ceder protones, en la definición de Brönsted-Lowry, los ácidos podrían dividirse en monopróticos, dipróticos o polipróticos, si ceden 1,2 o más protones. De forma reducida podemos expresar que para Brönsted-Lowry

$$
\text { ácido }+ \text { base } \leftrightarrow \text { base conjugada + ácido conjugado }
$$

\section{c) Definición de Lewis}

Casi al mismo tiempo que la anterior apareció la definición de Lewis, aunque la definición más completa fue posterior, también descrita como teoría electrónica de ácidos y bases.

Según Lewis:

Ácido es todo átomo, molécula o ion que es capaz de aceptar la compartición de un par de electrones que procede de otro átomo, molécula o ion que se llama base.

Esta definición amplía considerablemente las sustancias consideradas ácidos, pero mantiene todas las bases que consideraba la definición de Brönsted-Lowry. La teoría electrónica de ácidos y bases incluye las de Arrhenius y Brönsted-Lowry, y es la más general pero también la más compleja.

Como se ha comenta anteriormente, la definición de Arrhenius es más restrictiva desde el punto de vista de los ácidos y sólo se refiere a disoluciones acuosas, pero la de Brönsted-Lowry habla de la cesión u obtención de protones que cumpliría con los ácidos de una forma más amplia incluso sin disolventes y la de Lewis es la más general de todas pero también la más compleja y suele aplicarse a situaciones particulares como los metales de transición y los iones complejos, en función de estas definiciones, ésta tesis utiliza la teoría de Brönsted-Lowry. 


\subsection{Clasificación general de los ácidos}

La clasificación de ácidos no viene detallada en la documentación encontrada, por lo que se ha realizado una división de los ácidos, en función de las clasificaciones generales expuestas de la química orgánica y la química inorgánica.

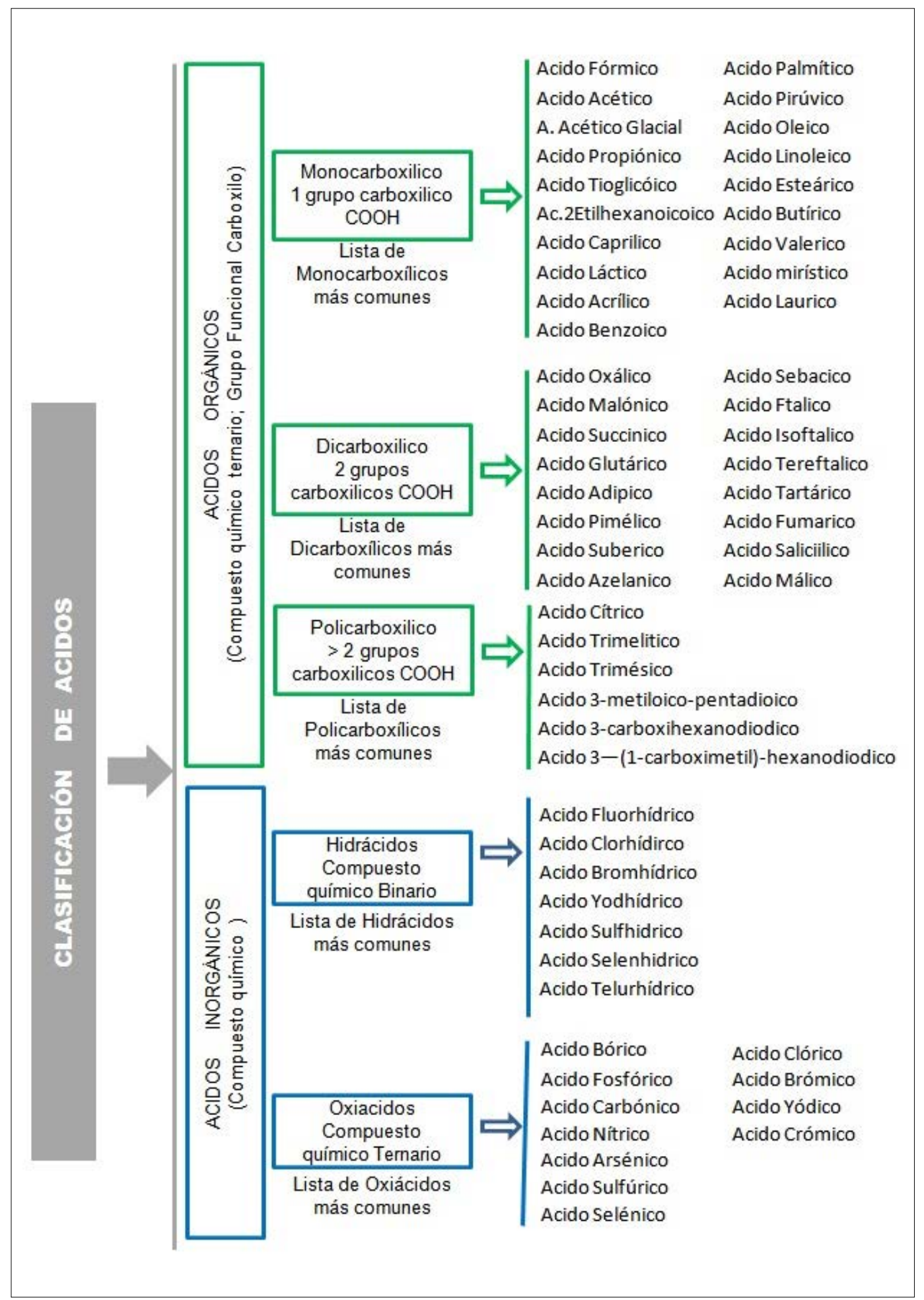

Figura 37. Ácidos más comunes. Clasificación. Elaboración propia 
Dentro de los ácidos carboxílicos también se incluyen:

Los Ácidos Grasos, como los ácidos palmítico y esteárico que son saturados (enlaces simples entre carbonos), el ácido oleico es monoinsaturado (un enlace doble entre un par de carbonos), y los ácidos linoleico y linolénico son poliinsaturados (más de dos enlaces dobles entre carbonos). En la mayoría de los aceites vegetales predominan los ácidos grasos insaturados, con algunas excepciones como el aceite de palma y el de coco. El ácido graso predominante en el aceite de oliva que es el ácido oleico, con mayor proporción que cualquiera de los otros aceites vegetales.

Los Aminoácidos, son ácidos con dos grupos funcionales el grupo carboxilo $(\mathrm{COOH})$ y el grupo Amino $\left(\mathrm{NH}_{2}\right)$, se clasifican en Aminoácidos ácidos con 20 más grupos carboxilos y 1 grupo amino; Aminoácidos neutros con 1 grupos carboxilo y 1 grupo Amino; Aminoácidos con 1 grupo carboxilo y 1 o más grupos Aminos. A nivel celular se encontrarían dentro de estos los ácidos nucleicos (ADN y ARN), dado que una secuencia de tres nucleótidos conforma un aminoácido de una proteína. El grupo de los aminoácidos no se ha contemplado en esta tesis, por varias razones, porque se entiende o que no tiene repercusión a efectos el cambio de la variación de color de las maderas si los aplicáramos superficialmente, por otro lado, es un material biológico relacionado con el mundo animal y porque en su composición entran 2 grupos funcionales el carboxilo y el amino.

\subsection{Composición de los ácidos. Disoluciones}

Como se ha indicado en la Química inorgánica, sabemos que:

a) Hidrácido (compuesto binario):

Se produce por la combinación de Haluro de hidrógeno (combinación de hidrógeno con un No Metal, compuesto binario) y añadiendo agua.

b) Ácido oxácido, o simplemente Oxácido (compuesto ternario):

Se produce por la combinación de un Óxido ácido o Anhídrido ácido (combinación de oxígeno con un No Metal, compuesto binario), y añadiendo agua

En la combinación de 1,2 o 3 moléculas de agua con el Anhídrido ácido se obtiene las diferentes nomenclaturas de los diferentes compuestos, por ejemplo:

Óxido de fósforo (Anhidro, No Metal más oxígeno) $\rightarrow$ fórmula $\rightarrow \quad \mathrm{P}_{2} \mathrm{O}_{3}$

Si sumamos una molécula de agua:

$\mathrm{P}_{2} \mathrm{O}_{3}+\mathrm{H}_{2} \mathrm{O} \leftrightarrow \mathrm{HPO}_{2} \rightarrow$ Ácido Metafosforoso o Metafosfónico

Si sumamos 2 moléculas de agua:

$\mathrm{P}_{2} \mathrm{O}_{3}+2 \mathrm{H}_{2} \mathrm{O} \leftrightarrow \mathrm{H}_{4} \mathrm{P}_{2} \mathrm{O}_{5} \rightarrow$ Ácido Pirofosforoso o Difosfónico

Si sumamos 3 moléculas de agua:

$\mathrm{P}_{2} \mathrm{O}_{3}+3 \mathrm{H}_{2} \mathrm{O} \leftrightarrow \mathrm{H}_{3} \mathrm{PO}_{3} \rightarrow$ Ácido (orto)Fosforoso o Ortofosfónico 
En la Química Orgánica los ácidos se encuentran en el grupo funcional carboxilo $(\mathrm{COOH})$, donde los ácidos se caracterizan por la presencia de un átomo de hidrógeno polarizado positivamente y son de 2 tipos principales, los que contienen un átomo de hidrógeno unido a un átomo de oxígeno electronegativo $(\mathrm{O}-\mathrm{H})$ y otros que contienen un átomo de hidrógeno unido a un átomo de carbono al lado de un enlace $(\mathrm{C}=\mathrm{O})$.

Los ácidos carboxílicos forman puentes de hidrógeno con el agua, y los de peso molecular más pequeño son miscibles en agua. A medida que aumenta la longitud de la cadena de carbono disminuye la solubilidad en agua; los ácidos con más de diez átomos de carbono son esencialmente insolubles.

Este tipo de ácidos, no siempre se pueden disolver con agua, más bien en ocasiones se busca quitarle el agua para obtener el compuesto anhídrido, mediante condensación, lo que requiere un largo tiempo y un considerable calentamiento. Como por ejemplo:

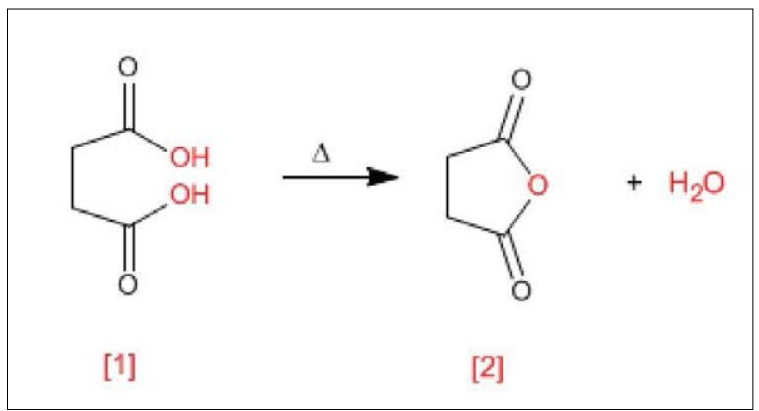

Figura 38. Ácidos carboxílicos. Conversión en anhídridos. Fuente: quimicaorganica.org

El calentamiento del ácido butanodioico [1] produce anhídrido butanodioico (anhídrido succínico) [2]. Este tipo de ciclación requiere anillos de 5 o 6 elementos.

Los anhídridos de ácido se derivan de dos moléculas de ácido carboxílico por eliminación de un equivalente de agua.

Los ácidos carboxílicos son muy solubles en los alcoholes, porque forman enlaces de hidrógeno con ellos. Además, los alcoholes no son tan polares como el agua, de modo que los ácidos de cadena larga son más solubles en ellos que en agua. La mayor parte de los ácidos carboxílicos son bastante solubles en solventes no polares como el cloroformo porque el ácido continúa existiendo en forma de dímero en el solvente no polar. Así, los puentes de hidrógeno de dímero cíclico no se rompen cuando se disuelve el ácido en un solvente polar.

En el caso de las bases orgánicas se caracterizan por la presencia de un átomo, con un par de electrones no enlazado que pueden enlazar al $\mathrm{H}^{+}$.

Los compuestos que tienen nitrógeno son las bases orgánicas más comunes, pero los compuestos que tiene oxigeno también pueden actuar como bases cuando reacciona con un ácido lo suficientemente fuerte, y también hay que tener en cuenta que algunos compuestos que contienen oxígeno pueden actuar como ácidos o como bases según las circunstancias, al igual que en el caso del agua, por ejemplo el metanol y la acetona actúan como ácidos cuando donan un protón pero actúan como bases cuando su átomo de oxígeno acepta un protón. 


\subsection{Fuerza de los ácidos.}

En función de la teoría protónica de Brönsted-Lowry, podemos deducir que un ácido fuerte será aquel con una gran tendencia a ceder protones a otra sustancia, mientras que una base será la que tenga gran tendencia a coger protones, es decir, si partimos de una ecuación general del tipo:

$$
\underset{\text { ácido } 1}{\mathrm{AH}}+\underset{\text { base } 2}{\mathrm{~B}} \leftrightarrow \underset{\text { base } 1}{\mathrm{~A}^{-}}+\underset{\text { ácido } 2}{\mathrm{BH}^{+}}
$$

Si la reacción estuviera desplazada fuertemente hacia la derecha, querría decir que el ácido 1 es más fuerte que el ácido 2, como sabemos la fuerza de un ácido es opuesta a su base conjugada, por lo que si un ácido es muy fuerte tenderá a ceder el mayor número de protones y su base conjugada tendera a coger pocos protones, es decir un ácido muy fuerte implica una base muy débil. El agua es un disolvente único que dispone de la capacidad de actuar como un ácido o como una base, el agua funciona como una base en reacciones con ácidos como el ácido clorhídrico $\mathrm{ClH}$ o el ácido acético $\mathrm{CH}_{3} \mathrm{COOH}$ y funciona como base con el amoniaco $\mathrm{NH}_{3}$. El agua es un electrolito muy débil y por lo tanto un mal conductor de electricidad, pero experimenta una ligera ionización a la que se le suele denominar autoionización del agua que aplicando el esquema de Brönsted-Lowry, tendríamos 2 moléculas en estado líquido de agua:

$$
\underset{\text { ácido 1 }}{\mathrm{H}_{2} \mathrm{O}}+\underset{\text { base 2 }}{\mathrm{H}_{2} \mathrm{O}} \leftrightarrow \underset{\text { base 1 }}{\mathrm{H}_{3} \mathrm{O}^{+}}+\underset{\text { ácido } 2}{\mathrm{OH}^{-}}
$$

Donde los pares conjugados ácido-base son en estado líquido $\mathrm{H}_{2} \mathrm{O}$ (ácido) y $\mathrm{OH}^{-}$(base), que supondrían 2 moléculas de agua $\left(2 \mathrm{H}_{2} \mathrm{O}\right.$ ) y $\mathrm{H}_{3} \mathrm{O}^{+}$(ácido) y $\mathrm{H}_{2} \mathrm{O}$ (base). La posibilidad a través de una reacción ácido-base de generar un producto no sólo dependerá de la

\begin{tabular}{|c|c|c|c|}
\hline \multirow{17}{*}{ 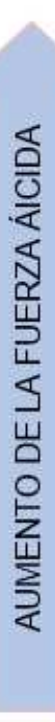 } & ÁCIDO & BASE CONJUGADA & \multirow{17}{*}{ 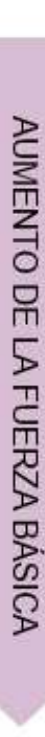 } \\
\hline & $\mathrm{HClO}_{4}$ (ácido perclórico) & $\mathrm{ClO}_{4}^{-}$(ion perclorato) & \\
\hline & HI (ácido yodhídrico) & $I^{-}$(ion yoduro) & \\
\hline & $\mathrm{HBr}$ (ácido bromhidrico) & $\mathrm{Br}^{-}$(ion bromuro) & \\
\hline & $\mathrm{HCl}$ (ácido clorhídrico) & $\mathrm{Cl}^{-}$(ion cloruro) & \\
\hline & $\mathrm{H}_{2} \mathrm{SO}_{4}$ (ácido sulfúrico) & $\mathrm{HSO}_{4}^{-}$(ion hidrógeno sulfato) & \\
\hline & $\mathrm{HNO}_{3}$ (ácido nítrico) & $\mathrm{NO}_{3}^{-}$(ion nitrato) & \\
\hline & $\mathrm{H}_{3} \mathrm{O}^{+}$(ion hidronio) & $\mathrm{H}_{2} \mathrm{O}$ (agua) & \\
\hline & $\mathrm{HSO}_{4}^{-}$(ion hidrógeno sulfato) & $\mathrm{SO}_{4}^{2-}$ (ion sulfato) & \\
\hline & HF (ácido fluorhidrico) & $\mathrm{F}^{-}$(ion fluoruro) & \\
\hline & $\mathrm{HNO}_{2}$ (ácido nitroso) & $\mathrm{NO}_{2}^{-}$(ion nitrito) & \\
\hline & $\mathrm{HCOOH}$ (ácido fórmico) & $\mathrm{HCOO}^{-}$(ion formiato) & \\
\hline & $\mathrm{CH}_{3} \mathrm{COOH}$ (ácido acético) & $\mathrm{CH}_{3} \mathrm{COO}^{-}$(ion acetato) & \\
\hline & $\mathrm{NH}_{4}^{+}$(ion amonio) & $\mathrm{NH}_{3}$ (amoniaco) & \\
\hline & $\mathrm{HCN}$ (ácido cianhidrico) & $\mathrm{CN}^{-}$(ion cianuro) & \\
\hline & $\mathrm{H}_{2} \mathrm{O}$ (agua) & $\mathrm{OH}^{-}$(ion hidróxido) & \\
\hline & $\mathrm{NH}_{3}$ (amoniaco) & $\mathrm{NH}_{2}{ }^{-}$(ion amida) & \\
\hline
\end{tabular}
tendencia de los ácidos a perder un protón sino también de las bases a ganarlo, lo cual implica que el modelo más adecuado para comparar las fuerzas de los ácidos y las bases es medirlo con una sustancia de referencia.

Figura 39. Fuerza de algunos ácidos y bases. Elaboración propia 
9.7 Constante de acidez Ka e índice Pka. Índice de acidez en agua PH.

a) Constante de acidez Ka e índice Pka

La forma de cuantificar la fuerza de un ácido en solución es mediante la constante de disociación ácida, $\mathrm{Ka}$, (también conocida como constante de acidez, o constante de ionización ácida) es la constante de equilibrio de la reacción conocida como disociación para reacciones ácido-base. La ecuación de equilibrio de un ácido puede escribirse como:

$$
\mathrm{AH}+\mathrm{H}_{2} \mathrm{O} \leftrightarrow \mathrm{A}^{-}+\mathrm{H}_{3} \mathrm{O}^{+}
$$

Como ejemplo podemos pensar en el ácido acético que es un ácido débil, donde AH es $\mathrm{CH}_{3} \mathrm{COOH} ; \mathrm{A}^{-}$es el anión acético $\mathrm{CH}_{3} \mathrm{COO}^{-}$y el catión o ion hidronio es $\mathrm{H}_{3} \mathrm{O}^{+}$, se dice que la reacción está en equilibrio cuando sus concentraciones no cambian con el paso del tiempo, donde la concentración de agua cambia muy poco por la variación del soluto, por lo que suele tomarse como constante (aprox. 55,5 Moles) y se incluye en la constate de disociación ácida $\mathrm{Ka}$ que se formula como un cociente entre concentraciones, tomando como unidades $\mathrm{mol} / \mathrm{L}$, según la expresión:

$$
\mathrm{Ka}=\left[\mathrm{K} \mathrm{H}_{2} \mathrm{O}\right]=\frac{\left[\mathrm{A}^{-}\right]\left[\mathrm{H}_{3} \mathrm{O}^{+}\right]}{[\mathrm{AH}]}
$$

Hay que tener en cuenta que el ejemplo se realiza en disolución acuosa, pero podría utilizarse cualquier otro disoluto, que variaría el valor de Ka.

Normalmente se dice que un ácido es muy fuerte si está entorno a Ka $\boldsymbol{\sim}_{1 \times 10^{3}}$; es fuerte si Ka entre $1 \times 10^{3}$ y $1 \times 10^{-2}$; débil entre $1 \times 10^{-2}$ y $1 \times 10^{-7}$ y muy débil menos de $1 \times 10^{-7}$.

La fórmula Ka genera variaciones de magnitud lo suficientemente importantes, como que por facilidad en su uso, se establezca una escala logarítmica y que también suele llamarse constante de disociación ácida, cuya fórmula es:

$$
\mathrm{pKa}=-\log _{10} \mathrm{Ka}
$$

Al igual que la fórmula anterior, dicha fórmula es igual para calcular la acidez de una base y se suele representar simplemente cambiando el sufijo "a" por "b".

En términos generales, un ácido muy fuerte tiene un valor de pKa negativo, fuerte, entorno a 2, y medio, entorno a 4 y débil de 8 en adelante, un ácido fuerte está casi completamente disociado en solución acuosa, en la medida en que la concentración del ácido no disociado es indetectable. Los valores de pKa para los ácidos fuertes, pueden ser estimados por medios teóricos o por extrapolación de medidas en otro tipo de disolutos no acuoso, en donde la constante de disociación Ka es menor.

b) Índice y escala $\mathrm{PH}$.

El agua es una sustancia que está ligeramente disociada debido a la conductividad eléctrica que presenta incluso en el agua más pura, que puede representarse como:

$$
\mathrm{H}_{2} \mathrm{O}+\mathrm{H}_{2} \mathrm{O} \leftrightarrow \mathrm{OH}^{-}+\mathrm{H}_{3} \mathrm{O}^{+}
$$


Donde una de las moléculas de agua actúa como si fuera un ácido y cede un protón a la otra molécula, y hay que tener en cuenta que la proporción de moléculas ionizadas es muy pequeña incluso elevando la temperatura, la concentración de la molécula de agua puede considerarse constante e incluirse en la constante de equilibrio por lo que:

$$
\mathrm{Kw}=\left[\mathrm{H}_{3} \mathrm{O}^{+}\right]\left[\mathrm{OH}^{-}\right]
$$

Donde Kw es el producto iónico del agua, que sí depende de la temperatura, en el agua pura las concentraciones de $\mathrm{OH}^{-}$y $\mathrm{H}_{3} \mathrm{O}^{+}$son iguales., debido a que existen numerosos procesos químicos en todas las áreas de la ciencia donde se calcula concentraciones de estos elementos y como las concentraciones son muy pequeñas, a efectos de simplificación que como en los casos anteriores de $\mathrm{Ka}$, era mejor establecer una escala logarítmica por lo que en 1909, el químico danés Sorensen definió el potencial hidrógeno $(\mathrm{pH})$ como :

$$
\mathrm{pH}=-\log \left[\mathrm{H}_{3} \mathrm{O}^{+}\right]
$$

El término $\mathrm{pH}$ ha sido universalmente utilizado por la facilidad de su uso, evitando así el manejo de cifras largas y complejas, como ejemplo decir que una concentración de $[\mathrm{H}+]$ $=1 \times 10-8 \mathrm{M}(0.00000001)$ es simplemente un $\mathrm{pH}$ de 8 ya que $: \mathrm{pH}=-\log \left[10^{-8}\right]=8$. La escala de $\mathrm{pH}$ se establece en una recta numérica que va desde el 0 hasta el 14, donde el valor 14 es para un valor como la base de Hidróxido de Sodio $\mathrm{NaOH}$, el 7 es para la neutra agua destilada y el valor 0 es para un valor como el Ácido Clorhídrico $\mathrm{ClH}$.

En esta tesis, no se pretende realizar disoluciones en agua por varias razones:

- El agua según el concepto de ácido-base conjugados, puede ser considerada ácido o base según las circunstancias.

- Los ácidos inorgánicos en su composición ya poseen agua y en función del número de moléculas, según la nomenclatura se obtendrían ácidos diferentes al inicial.

- Los ácidos orgánicos, no siempre son solubles en agua, por lo que la comparación entre unos y otros a igual disolución, no podría realizarse porque con unos se podría realizar y con otros no, lo que implicaría que los ensayos no serían comparables y por extensión los datos obtenidos.

- La disolución de ácidos implicaría que habría que fijar un tanto por ciento de agua, cuyo resultado no sería un ácido normalmente comercializado.

- Los ácidos líquidos incoloros comercializados y utilizados en esta tesis, responden a una concentración determinada y a una composición determinada, según sus fichas técnicas, dado que se pretende utilizarlos en un futuro en procesos industrializados para obtener una ampliación de la gama de colores de las especies de madera de forma mecánica y como forma de utilizar un patrón de comparación, con otros posibles ensayos, por ejemplo en futuras líneas de investigación.

- Las disoluciones de ácidos, sólo podrían reducir su fuerza, lo que implicaría que no se observarían modificaciones o ampliaciones en el color de las maderas de construcción que fueran útiles desde el punto de vista perceptivo de un observador normal. 


\section{8 Ácidos comercializados}

Dentro de los compuestos comercializados por las diferentes empresas químicas, que abarcan gran parte de las ciencias, se encuentran los ácidos.

Se detallan a continuación los ácidos más comunes comercializados, separando entre los que se encuentran en estado sólido, 160 y los ácidos en estado líquido 70, en total 230 ácidos.

\section{a) Ácidos sólidos}

\begin{tabular}{|c|c|c|c|c|c|c|c|c|c|}
\hline CD & NOMBRE & \%Riqueza & Fórmula & Estado & $C D$ & NOMBRE & \%Riqueza & Fórmula & Estado \\
\hline 7 & Acido Acetilsalicílico & 99,50 & $\mathrm{CH} 3 \mathrm{COOC6H} 4 \mathrm{COOH}$ & Sólido & 41 & Acido mono-Cloroacético PRS & 98,50 & $\mathrm{C} 2 \mathrm{H} 3 \mathrm{ClO} 2$ & Sólido \\
\hline & (ver Acido 4-Acetilbenzoico) & 98,00 & $\mathrm{CPH} 803$ & Sólido & 42 & Acido 5-Cloroantranílico & 98,00 & C7H6CINO2 & Sólido \\
\hline 3 & (ver Acido Acetilsalicílico) & 99,50 & $\mathrm{CH} 3 \mathrm{COOC6H} 4 \mathrm{COOH}$ & Sólido & 43 & Acido 2-Clorocinámico & 99,00 & $\mathrm{C} 9 \mathrm{H} 7 \mathrm{CIO} 2$ & Sólido \\
\hline & Acido Adípico & 99,00 & $(\mathrm{CH} 2 \mathrm{CH} 2 \mathrm{COOH}) 2$ & Sólido & 44 & Acido 4-Cloro-3,5-Dinitrobenzoico & 99,00 & C7H3CIN2O6 & Sólido \\
\hline 5 & Acido Alizarín-3-Metilamino-N,N-Diacético & 98,00 & $\begin{array}{l}\text { C19H15NOB } \\
\text { L }\end{array}$ & Sólido & 45 & Acido Cólico Sal Sódica & 98,00 & $\mathrm{C} 24 \mathrm{H} 39 \mathrm{NaO5}$ & Sólido \\
\hline 6 & (ver Acido Sulfámico) & 99,50 & H3NO3S & Sólido & 46 & Acido Crómico & 98,50 & $\mathrm{CrO} 3$ & Sólido \\
\hline 7 & (uer Acido Sulfańlilioo) & 99,00 & C6H7NO3S & Sólido & 47 & Acido Cromotrópico Sal Disódica 2-hidrato & 98,00 & $\mathrm{C} 10 \mathrm{H} 6 \mathrm{Na} 2 \mathrm{O} 8 \mathrm{~S} 2.2 \mathrm{H} 2 \mathrm{O}$ & Sólido \\
\hline 8 & Acido 6-Aminocaproico & 99,50 & $\mathrm{C} 6 \mathrm{H} 13 \mathrm{NO} 2$ & Sólido & 48 & Acido 1,2-Diaminociclohexano-N,N,N? & 97,50 & C14H22N2O8.H2O & Sólido \\
\hline 9 & Acido 2-Amino-5-Clorobenzoico & 99,00 & $\mathrm{H} 2 \mathrm{NCH} 2 \mathrm{CH} 2 \mathrm{SO} 3 \mathrm{H}$ & Sólido & 49 & Tetraacético 1-hidrato (Reag. Pr & 97,50 & C14H22N2O8.H2C & \\
\hline 10 & Acido 2-Ámino-5-Fluorobenzoi & 97,00 & C7H6FNO2 & Sólido & 50 & Acido 2,3-Dibromopropiónico & 98,00 & $\mathrm{C} 3 \mathrm{H}_{4} \mathrm{Br}_{2}$ & Sóli \\
\hline 11 & (ver Acido Glutámico) & 99,00 & C5H10N2O3 & Sólido & 51 & Acido 3,4-Diclorocinámico & 97,00 & $\mathrm{C} 9 \mathrm{H} 6 \mathrm{Cl}$ & Sólido \\
\hline 12 & Acido 5-Amino-2-Hidroxibenzoico & 99,00 & C4H9NO3 & Sólido & 52 & Acido 5,5-Dietilbarbitúrico & 99,00 & $\mathrm{C} 8 \mathrm{H} 12 \mathrm{~N} 2 \mathrm{O} 3$ & Sólido \\
\hline 13 & (ver Acido 1-Ämino-2-Naftol-4-Sulfónico) & 98,50 & C3H7NO3 & Sólido & 53 & Acido Dietilentriaminopentaacético & 99,00 & $\mathrm{C} 14 \mathrm{H} 23 \mathrm{~N} 3010$ & Sólido \\
\hline 14 & (ver Acido Alizarín-3-Metilamino-N,N-Diacético) & 98,50 & C5H11NO2 & Sólido & 54 & (ver Acido Bencílico) & 99,00 & $\mathrm{C} 14 \mathrm{H} 12 \mathrm{O} 3$ & Sólido \\
\hline 15 & Acido 1-Amino-2-Naftol-4-Sulfónico & 98,00 & C1OHONO4S & Sólido & 55 & Acido 3,4-Dihidroxibenzoico & 98,00 & $\mathrm{C} 7 \mathrm{H} 604$ & Sólido \\
\hline 16 & Acido 2-Ámino-5-Nitrobenzoico & 97,00 & $\mathrm{C} 7 \mathrm{H} 6 \mathrm{~N} 2 \mathrm{O} 4$ & Sólido & 56 & (ver Acido Cafeico) & 99,00 & $\mathrm{C9H} 8 \mathrm{O} 4$ & Sólido \\
\hline 17 & (ver Acido 5-Amino-2-Hidroxibenzoico) & 97,00 & C7H7NO & Sólido & 57 & (ver Acido Citracínico) & 97,00 & C6H5NO4 & Sólido \\
\hline 18 & (ver Acido 4-Metoxibenzoico) & 99,00 & $\mathrm{C} 8 \mathrm{H} 8 \mathrm{O} 3$ & Sólido & 58 & (ver Acido D(-)-Tartárico) & 99,00 & $\mathrm{CO} 2 \mathrm{HCH}(\mathrm{OH}) \mathrm{CH}(\mathrm{OH}) \mathrm{CO} 2 \mathrm{H}$ & Sólido \\
\hline 19 & Acido Antranílico & 99,50 & $\mathrm{C} 7 \mathrm{H} 7 \mathrm{NO2}$ & Sólido & 59 & Acido 2,5-Dimetilbenzoico & 98,00 & C9H10O2 & Sólido \\
\hline 20 & AcidoL-Áspártico & 97,00 & C6H7As03 & Sólido & 60 & Acido 2,3-Dimetoxicinámico & 97,00 & $\mathrm{C} 11 \mathrm{H} 1204$ & Sólido \\
\hline & (ver Acido Fenilarsónico) & 97,00 & $\mathrm{C} 6 \mathrm{H} 7 \mathrm{~A}$ & Sólido & 61 & Acido 3,5-Dinitrobenzoico & & C7H4N2O6 & Sól \\
\hline & Acida $\mathrm{B}$ & 99,00 & $\mathrm{C} 14 \mathrm{H}$ & Sólido & 62 & Acido 3,5-Dinitrosalic & & C7HAN2O7 & Sólido \\
\hline 23 & AcidoBenzo: & 99,95 & $\mathrm{CEH} 5 \mathrm{C}$ & Sólido & 63 & Acido Dipicolínico & & C7H5NO4 & Sólido \\
\hline 24 & Acido N-Boo & 98,00 & C9H15 & Sólic & 64 & lver $\mathrm{Acic}$ & & $\mathrm{CH} 3(\mathrm{CH} 2) 10 \mathrm{COOH}$ & Sollido \\
\hline 25 & Do-L-Glutámico & 98,00 & $\mathrm{C1OH}$ & & 65 & Acido & & $\mathrm{C} 10 \mathrm{H} 1$ & Sólit \\
\hline 26 & Acido & 99,80 & $\mathrm{H} 3 \mathrm{BC}$ & Sólido & 66 & Acido Esteárico & & $\mathrm{C} 18 \mathrm{H} 36 \mathrm{C}$ & Sólido \\
\hline 27 & Acido & 99,00 & & Sólido & 67 & Acido Extilendiaminotetraacético & 99,40 & $\mathrm{C} 10 \mathrm{H} 16 \mathrm{~N} 2 \mathrm{O} 8$ & Sollido \\
\hline & Acido 2 & & & & 68 & Acido Fenilacético & 99,00 & & \\
\hline 29 & (ver Acido Su & 99,50 & $\mathrm{HOOC}$ & & 69 & no) Bencenosulfónico & & BaN2O652 & \\
\hline 30 & Acido 1-Butano Sulfónico Sal Sódica (HPLC)PAI & & & & 70 & & & & \\
\hline 31 & (ver Acido Fumár & & & & 71 & & & & \\
\hline 32 & Ílico Sal Sódica 3-hidrato & & $\mathrm{NaO2} .3 \mathrm{H} 2 \mathrm{O}$ & & 72 & & & & Sól \\
\hline 33 & Acido Cafeico & & & & 73 & & & $\mathrm{C} 7 \mathrm{H} 5 \mathrm{FO} 2$ & Sóli \\
\hline 34 & Acido Calconcarbosílico (Reag. Ph. Eur.)PA & & 2075 & & 74 & Aci & & $\mathrm{C} 9 \mathrm{H} 7 \mathrm{FO}$ & Sólido \\
\hline 35 & Acido Carmínico & 90, & $\mathrm{C} 22 \mathrm{H} 20013$ & Sólido & 75 & Acido N-Fmoc-L-Aspártico & 98,00 & $\mathrm{C} 19 \mathrm{H} 17 \mathrm{NO} 6$ & Sólido \\
\hline 36 & Acido Carmínico Natural & 10,00 & $\mathrm{C} 22 \mathrm{H} 20013$ & Sólido & 76 & Acido Fólico (USP, BP, Ph. Eur.)PRS-CODEX & 98,00 & $\mathrm{C} 19 \mathrm{H} 19 \mathrm{~N} 706$ & Sólido \\
\hline 37 & Acido a-Cetoglutárico & 99,00 & $\mathrm{C} 5 \mathrm{H} 605$ & Sólido & 77 & Acido Fosfomolíbdico $x$-hidrato PA-ACS & 89,00 & $\mathrm{H} 3[\mathrm{P}(\mathrm{M} 03 \mathrm{O} \mathrm{O10}) 4] \times \mathrm{H} 2 \mathrm{O}$ & Sólido \\
\hline 38 & Acido Cianoacético & 98,00 & C3H3NO2 & Sólido & 78 & Acido meta-Fosfórico estabilizado con $\mathrm{NaPO3}$ & 33,50 & (HPO3)n & Sólido \\
\hline 39 & Acido Cítrico anhidro PA-ACS & 99,50 & $\mathrm{C} 6 \mathrm{H} 807$ & Sólido & 79 & Acido Fosforoso & 98,50 & $\mathrm{H} 3 \mathrm{PO} 3$ & Sólido \\
\hline 40 & Acido Cítrico 1-hidrato PA-ACS-ISO & 99,50 & С6H807.H2O & Sólido & 80 & Acido Fosfotúngstico hidrato & 99,00 & $\mathrm{H} 3[\mathrm{P}(\mathrm{W} / 3 \mathrm{O} 10) 4] \times \mathrm{H} 2 \mathrm{O}$ & Sólido \\
\hline
\end{tabular}

\begin{tabular}{|c|c|c|c|c|c|c|c|c|c|}
\hline$C D$ & NOMBRE & \%Riqueza & Fórmula & Estado & $\mathrm{CD}$ & NOMBRE & \%Riqueza & Fórmula & Estado \\
\hline 81 & Acido Ftálico & 99,50 & $\mathrm{C} 8 \mathrm{H} 604$ & Sólido & 121 & Acido 2-Nitrocinámico & 98,00 & $\mathrm{C} 9 \mathrm{H} 7 \mathrm{NO} 4$ & Sólido \\
\hline 82 & Acido Fumárico & 99,50 & $\mathrm{HOOCCHCHCOOH}$ & Sólido & 122 & (ver Acido Esteárico) & 96,00 & $\mathrm{C} 18 \mathrm{H} 3602$ & Sólido \\
\hline 83 & Acido 2-Furancarboxilico & 98,00 & $\mathrm{C} 5 \mathrm{H} 403$ & Sollido & 123 & Acido 1-Dotano Sulfónico Sal Sódioa (HPLC)PAl & 99,00 & $\mathrm{C} 8 \mathrm{H} 17 \mathrm{NaO} 3 \mathrm{~S}$ & Sólido \\
\hline 84 & Acido 2-Furoico & 98,00 & $\mathrm{C} 5 \mathrm{H} 403$ & Sólido & 124 & Acido Osmico & 99,80 & & Sólido \\
\hline 85 & Acido Gálioo 1-hidrato & 99,00 & $\mathrm{C} 7 \mathrm{H} 605 . \mathrm{H} 2 \mathrm{O}$ & Sollido & 125 & Acido 2-D*oglutárico & 99,00 & C5H605 & Sólido \\
\hline 86 & Acido Giberélico & 90,00 & $\mathrm{C} 19 \mathrm{H} 22 \mathrm{O} 6 \mathrm{6}$ & Sólido & 126 & Acido Palmítico & 98,00 & $\mathrm{C} 16 \mathrm{H} 32 \mathrm{O} 2$ & Sólido \\
\hline 87 & AcidoL-Glutámico (RFE, BP, Ph. Eur.)PRS-CODEX & 98,50 & C5H9NO4 & Sólido & 127 & Acido 1-Pentano Sulfónico Sal Sódica (HPLC)PAl & 99,00 & $\mathrm{C} 5 \mathrm{H} 11 \mathrm{NaO} 3 \mathrm{~S}$ & Sólido \\
\hline 88 & Acido 1-Heptano Sulfónico Sal Sódica & 99,00 & $\mathrm{C} 7 \mathrm{H} 15 \mathrm{NaO} \mathrm{OSS}$ & Sollido & 128 & Acido Peryódico & 99,00 & H5IOG & Sólido \\
\hline 89 & Acido HexacloroplatínicollV 6 -hidrato & 37,50 & H2Cl6Pt.6H2O & Sólido & 129 & Acido Pícrico humectado con' $33 \%$ de $\mathrm{H} 2 \mathrm{O}$ & 98,00 & $\mathrm{CEH} 3 \mathrm{~N} 3 \mathrm{O} 7$ & Sólido \\
\hline 90 & $\begin{array}{l}\text { (ver Acido Palmítico) } \\
\text { (n) }\end{array}$ & 99,00 & $\mathrm{C}_{16 \mathrm{H} 3202}$ & Sólido & 130 & Aido 3-(2-Piridili-5,6-Difenil-1,2,4-Triacina-4, 4" & 85,00 & $\mathrm{C} 20 \mathrm{H} 12 \mathrm{~N} 4 \mathrm{Na} 2 \mathrm{O} 6 \mathrm{S2} 2$ & Sólido \\
\hline 91 & Acido 1-Hexano Sulfónico Sal Sódica (HPLC) PA) & 99,00 & $\mathrm{C} 6 \mathrm{H} 13 \mathrm{NaO} 3 \mathrm{~S}$ & Sólido & 131 & 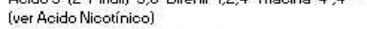 & 99,50 & C6H5NO2 & Sólido \\
\hline 92 & (ver Acido Salicílico) & 99,00 & $\mathrm{CEH} 4(\mathrm{OH}) \mathrm{COOH}$ & Sólido & 132 & Acido Piridin 2,6-Dicarboxilico & 98,00 & C7H5NO4 & Sólido \\
\hline 93 & Acido 4-Hidroxibenzoico & 99,00 & $\mathrm{C} 7 \mathrm{H} 603$ & Sólido & 133 & Acido 3-Piridinosulfónico & 98,00 & C5H5NO3S & Sólido \\
\hline 94 & (ver Acido 3,5-Dinitrosalicílico) & 99,00 & $\mathrm{C} 7 \mathrm{H} 4 \mathrm{~N} 2 \mathrm{O} 7$ & Sólido & 134 & Acido Pirogálico & 99 & $\mathrm{C} 6 \mathrm{H} 3(\mathrm{OH}) 3$ & Sollido \\
\hline 95 & Acido 4-Hidroxifenilacético & 98,00 & $\mathrm{C} 8 \mathrm{H} 803$ & Sólido & 135 & (ver Prolina) & 98 & C5H9I & Sólido \\
\hline & (ver Acido DL-Mandélico) & 99,00 & $\mathrm{C} 6 \mathrm{H} 5 \mathrm{CH}(\mathrm{OH}) \mathrm{COOH}$ & Sólido & 136 & Acido 1-Pirrolidinditiocarbox́lico Sal Amónica PA & 99 , & C5H12N2S2 & Sólido \\
\hline 97 & Acido 2-Hidroxiisobutírico & 99,00 & $\mathrm{C} 4 \mathrm{H} 8 \mathrm{O} 3$ & Sólido & 137 & Acido Polifostórico & 85,00 & $\mathrm{Hn}+2 \mathrm{PnO} n \mathrm{n}+1$ & Sólido \\
\hline 98 & Acido 1H-Indol-3-Acético & 98,00 & $\mathrm{C} 10 \mathrm{HONO} 2$ & Sólido & 138 & Acido Protocatéc & 98,00 & $\mathrm{C} 7 \mathrm{H} 604$ & Sólido \\
\hline 99 & Acido $1 \mathrm{H}$-Indol-3-Butírico & 99,00 & $\mathrm{C} 12 \mathrm{H} 13 \mathrm{NO} 2$ & Sólido & 139 & Acido Rosólico & 98,00 & (C6H4OH)2CC6H4O & Sólido \\
\hline 100 & Acido Kópico & 98,00 & $\mathrm{C} 6 \mathrm{H} 604$ & Sólido & 140 & Acido Rubeánico & 85,00 & $(\mathrm{CSNH} 2) 2$ & Sólido \\
\hline 101 & Acido Láurico & 99,00 & $\mathrm{CH} 3(\mathrm{CH} 2) 10 \mathrm{COOH}$ & Sólido & 141 & Acido Salicílico & 99,00 & $\mathrm{C} 6 \mathrm{H} 4(\mathrm{OH}) \mathrm{COOH}$ & Sólido \\
\hline 102 & Acido Maleico & 99,00 & $\mathrm{HOOCCHCHCOOH}$ & Sólido & 142 & Acido Sórbico & 99,00 & $\mathrm{C} 6 \mathrm{H} 802$ & Sólido \\
\hline 103 & Acido D(+)-Málico & 99,00 & $\mathrm{C} 4 \mathrm{H} 605$ & Sólido & 143 & Acido Succínico & 99,50 & $\mathrm{HOOCCH} 2 \mathrm{CH} 2 \mathrm{COOH}$ & Sollido \\
\hline 104 & Acido Malónico Diamida & 99,00 & C3H6N2O2 & Sólido & 144 & do Sulfámico & 99,50 & H3NO3S & Sólido \\
\hline & Acido DL-Mandélico & 99,00 & $\mathrm{C} 6 \mathrm{H} 5 \mathrm{CH}(\mathrm{OH}) \mathrm{COOH}$ & Sólido & 145 & - Sulfanílico & 99,50 & C6H7NO3S & Sólido \\
\hline 106 & Acido Mercaptúrico & 98,00 & C5H9NO3S & Sólido & 146 & 5-Sulfosalicílico 2-hidrato & 99,00 & $\mathrm{C} 7 \mathrm{H} 606 \mathrm{~S} .2 \mathrm{H} 2 \mathrm{O}$ & Sólido \\
\hline 107 & (ver Acido 3-Metoxi-4-Metilbenzoico) & 96,00 & $\mathrm{C} 9 \mathrm{H} 1003$ & Sólido & 147 & do Tánico & 99,00 & C76H52O46 & Sólido \\
\hline 108 & Acido 4-Metilbencenosulfónico & 98,00 & $\mathrm{CH} 3 \mathrm{CGH} 4 \mathrm{HSO} 3 . \mathrm{H} 2 \mathrm{O}$ & Sólido & 148 & Acido D(-)-Tartárico & 99,00 & $\mathrm{CO} 2 \mathrm{HCH}(\mathrm{OH}) \mathrm{CH}(\mathrm{OH}) \mathrm{CO} 2 \mathrm{H}$ & Sólido \\
\hline 109 & (ver Acido 2-Hidroxilisobutírioo) & 99,00 & $\mathrm{C} 4 \mathrm{H} 8 \mathrm{O} 3$ & Sólido & 149 & Acido $\mathrm{L}(+)-T a r t a ́ r i c o$ & 99,50 & $(\mathrm{CHOH}) 2(\mathrm{COOH}) 2$ & Sólido \\
\hline 110 & Acido 4-Metoxibenzoico & 99,00 & $\mathrm{C} 8 \mathrm{H} 8 \mathrm{O} 3$ & Sólido & 150 & Acido Tetracloroáurico(III) 3-hidrato & 49,00 & $\mathrm{H}(\mathrm{AuCl} / 4) .3 \mathrm{H} 2 \mathrm{O}$ & Sólido \\
\hline 111 & Acido 3-Metoxi-4-Metilbenzoico & 96,00 & $\mathrm{C} 9 \mathrm{H} 1003$ & Sólido & 151 & (ver Acido Mirístico) & 98,00 & $\mathrm{CH} 3(\mathrm{CH} 2) 12 \mathrm{COOH}$ & Sólido \\
\hline 112 & (ver Acido 3-Metoxi-4-Metilbenzoico) & 96,00 & $\mathrm{C} 9 \mathrm{H} 1003$ & Sólido & 152 & Acido 3,3'-Tiodipropiónico & 99,00 & $\mathrm{C} 6 \mathrm{H} 10045$ & Sólido \\
\hline 113 & Acido Mirístico & 98,00 & $\mathrm{CH} 3(\mathrm{CH} 2) 12 \mathrm{COOH}$ & Sólido & 153 & (ver Acido Fenilacético) & 99,00 & $\mathrm{C} 8 \mathrm{H} 8 \mathrm{OO} 2$ & Sólido \\
\hline & Acido Molibdico (contiene amonio molibdato) & 85,00 & MoO4H2+Mo7O24(NH4)6 & Sólido & 154 & Acidop-Toluenosulfónico & 98,00 & $\mathrm{CH} 3 \mathrm{C} 6 \mathrm{H} 4 \mathrm{HSO} 3 . \mathrm{H} 2 \mathrm{O}$ & Sólido \\
\hline 115 & Acido Molibdofostórico & 82,00 & $\mathrm{H} 3[\mathrm{P}(\mathrm{M} 03010) 4] \times \mathrm{H} 2 \mathrm{H} \mathrm{O}$ & Sólido & 155 & Acido 4-Toluenosulfónico 1-hidrato & 98,00 & $\mathrm{CH} 3 \mathrm{C} 6 \mathrm{H} 4 \mathrm{HSO} 3 . \mathrm{H} 2 \mathrm{O}$ & Sollido \\
\hline 116 & Acido 1-Naftaleno & 97,00 & $\mathrm{C}_{2} \mathrm{H} 10 \mathrm{OO} 2$ & Sólido & 156 & Acido Tricloroacético & 99,50 & $\mathrm{CCl} 3 \mathrm{COOH}$ & Sollido \\
\hline & Acido 1-Naftilacéti & 97. & & Sól & 157 & gstofosfórico & 75 & $\mathrm{H} 3[\mathrm{P}(\mathrm{w} / 3010) 4]$ & Sólido \\
\hline 118 & Acido & & & & 158 & & & & \\
\hline 119 & & & & & & & & & \\
\hline 120 & Acido 5-Nitroantranílico & 97,00 & C7HGN2O4 & Sollido & 160 & Acido N-Z-L-Glutámico & 98,00 & C13H15NO6 & Sólido \\
\hline
\end{tabular}

Figura 40. Ácidos en estado sólido más comerciales. Elaboración propia 


\section{b) Ácidos Líquidos}

Esta gran variedad de ácidos, pueden servir de patrón de comparación, para observar en esta tesis la variación de la gama de colores de las maderas de construcción, en especial los ácidos líquidos incoloros utilizados en esta tesis.

\begin{tabular}{|c|c|c|c|c|c|c|c|c|}
\hline $\mathrm{CD}$ & NOMBRE & \%Riqueza & Fórmula & Estado & $C D$ & NOMBRE & \%Riqueza Fórmula & Estado \\
\hline 1 & Acido Acético glacial & 99.8 & $3 \mathrm{CH} 3 \mathrm{COOH}$ & Líquido & 39 & Acido Hexanoico & $98 \mathrm{CH} 3(\mathrm{CH} 2) 4 \mathrm{COOH}$ & Líquido \\
\hline 2 & Acido Acético & $80-96$ & $\mathrm{CH} 3 \mathrm{COOH}$ & Líquido & 40 & Acido Hexanoico Cloruro & $98 \mathrm{C} 6 \mathrm{H} 11 \mathrm{CIO}$ & Líquido \\
\hline 3 & Acido Acético Dimetilamida & 99,9 & 9 C4HONO & Líquido & 41 & (ver Acido Glicólico) & $65 \mathrm{C} 2 \mathrm{H} 403$ & Líquido \\
\hline 4 & Acido 4-Acetilbenzoico & 98 & $3 \mathrm{CH} 3 \mathrm{COCH} 2 \mathrm{COOC} 2 \mathrm{H}$ & I: Líquido & 42 & Acido 4-Hidroxibutírico Lactona & $99 \mathrm{C} 4 \mathrm{H} 6 \mathrm{OC} 2$ & Líquido \\
\hline 5 & Acido 4-Acetoxibenzoico & & $\mathrm{CH} 2=\mathrm{CHCOOCH} 3$ & Líquido & 43 & (ver Acido L(+)-Láctico) & $85 \mathrm{C} 3 \mathrm{H} 603$ & Líquido \\
\hline 6 & Acido Acrílico & 99 & $\mathrm{C} 3 \mathrm{H} 4 \mathrm{O} 2$ & Líquido & 44 & Acido L(+)-Láctico & $85 \mathrm{C} 3 \mathrm{H} 603$ & Líquido \\
\hline 7 & Acido Bromhídrico & 48 & $\mathrm{HBr}$ & Líquido & 45 & Acido Linoleico & $99 \mathrm{C} 18 \mathrm{H} 32 \mathrm{O} 2$ & Líquido \\
\hline 8 & Acido Butanodioico & & - $\mathrm{C} 4 \mathrm{H} 8 \mathrm{O} 2$ & Líquido & 46 & (ver Acido Tioglicólico 80\%) & $79-82 \mathrm{HSCH} 2 \mathrm{COOH}$ & Líquido \\
\hline 9 & Acido Butanoico & & $\mathrm{C} 4 \mathrm{H} 8 \mathrm{OZ}$ & Líquido & 47 & Acido Metanosulfónico & $70 \mathrm{CH} 403 \mathrm{~S}$ & Líquido \\
\hline 10 & Acidon-Butírico & & C $\mathrm{C4} 8 \mathrm{HO} 2$ & Líquido & 48 & Acido D-2-Metilbutírico & $98 \mathrm{C} 5 \mathrm{H} 10 \mathrm{OO} 2$ & Líquido \\
\hline 11 & Acido Butírico Cloruro & & $8 \mathrm{C} 4 \mathrm{H} 7 \mathrm{CIO}$ & Líquido & 49 & Acido 2-Metilbutírico Cloruro & $99 \mathrm{CH} 3 \mathrm{CH} 2 \mathrm{CH}(\mathrm{CH} 3) \mathrm{COCl}$ & Líquido \\
\hline 12 & Acido Cáprico & & $3 \mathrm{CH} 3-(\mathrm{CH} 2) 8-\mathrm{COOH}$ & Líquido & 50 & (ver Acido Metanosulfónico) & $70 \mathrm{CH} 403 \mathrm{~S}$ & Líquido \\
\hline 13 & Acido Cáprico Cloruro & & $3 \mathrm{C} 10 \mathrm{H} 19 \mathrm{CIO}$ & Líquido & 51 & Acido Nítrico & $69 \mathrm{HNO} 3$ & Líquido \\
\hline 14 & Acido Caprílico & & $\mathrm{CH} 3-(\mathrm{CH} 2) 6-\mathrm{COOH}$ & Líquido & 52 & Acido Dotanoico & $99 \mathrm{CH} 3-(\mathrm{CH} 2) 6-\mathrm{COOH}$ & Líquido \\
\hline 15 & Acido Caprílico Cloruro & & $8 \mathrm{C} 8 \mathrm{H} 15 \mathrm{ClO}$ & Líquido & 53 & (ver Acido Heptanoico) & $98,5 \mathrm{C} 7 \mathrm{H} 14 \mathrm{O} 2$ & Líquido \\
\hline 16 & Aoido Caproico & & $3 \mathrm{CH} 3(\mathrm{CH} 2) 4 \mathrm{COOH}$ & Líquido & 54 & Acido Oleico & $89 \mathrm{C} 18 \mathrm{H} 3402$ & Líquido \\
\hline 17 & Acido Caproico Cloruro & & 3 C6H11CIO & Líquido & 55 & Acido Oxalico & $99 \mathrm{C} 2 \mathrm{H} 2 \mathrm{O} 4$ & Líquido \\
\hline 18 & Acido Ciclopropanocarboxílico & 98 & $3 \mathrm{C} 4 \mathrm{H} 6 \mathrm{O} 2$ & Líquido & 56 & Acido Peracético solución $15 \%$ & $15 \mathrm{C} 2 \mathrm{H} 403$ & Líquido \\
\hline 19 & Acido Citracínico & & $7 \mathrm{C} 6 \mathrm{H} 5 \mathrm{NO} 4$ & Líquido & 57 & Acido Perclórico & $70 \mathrm{HCIO} 4$ & Líquido \\
\hline 20 & Aoido Clorhídrico & & $7 \mathrm{HCl}$ & Líquido & 58 & Acido Pirúvico & $98 \mathrm{CH} 3 \mathrm{COCOOH}$ & Líquido \\
\hline 21 & Acido Decanoico & 98 & $3 \mathrm{CH} 3-(\mathrm{CH} 2) 8-\mathrm{COOH}$ & Líquido & 59 & (ver Acido Propiónico) & $99,5 \mathrm{CH} 3 \mathrm{CH} 2 \mathrm{COOH}$ & Líquido \\
\hline 22 & Acido Decanoico Cloruro & 98,5 & $5 \mathrm{C} 10 \mathrm{H} 19 \mathrm{CIO}$ & Líquido & 60 & Acido Propiónico & $99.5 \mathrm{CH} 3 \mathrm{CH} 2 \mathrm{COOH}$ & Líquido \\
\hline 23 & Acido Dicloroacético & & $8 \mathrm{CHCl} 2 \mathrm{COOH}$ & Líquido & 61 & Acido Propiónico Cloruro & $98 \mathrm{C} 3 \mathrm{H} 5 \mathrm{CIO}$ & Líquido \\
\hline 24 & Acido Dicloroetanoico & & $8 \mathrm{CHCl} 2 \mathrm{COOH}$ & Líquido & 62 & Acido Sulfúrico & $93-98 \mathrm{H} 2 \mathrm{SO} 4$ & Líquido \\
\hline 25 & Acido Enántico & 98,5 & $5 \mathrm{C} 7 \mathrm{H} 1402$ & Líquido & 63 & Acido Sulfuroso solución $6 \%$ & $6 \mathrm{H} 2 \mathrm{SO} 3$ & Líquido \\
\hline 26 & Acido Enántico Cloruro & 98.5 & $5 \mathrm{C} 7 \mathrm{H} 13 \mathrm{CIO}$ & Líquido & 64 & Acido Tetrafluorobórico & $35 \mathrm{HBF} 4$ & Líquido \\
\hline 27 & Acido 2-Etilcaproico & & $9 \mathrm{C} 8 \mathrm{H} 1602$ & Líquido & 65 & Acido Tioglicólico & $80 \mathrm{HSCH} 2 \mathrm{COOH}$ & Líquido \\
\hline 28 & Acido 2-Etilhexanoico & & $\mathrm{C} 8 \mathrm{H} 16 \mathrm{O} 2$ & Líquido & 66 & Acido Trílico & 99 CHF303S & Líquido \\
\hline 29 & Acido 2-Etilpropiónico & & $3 \mathrm{C} 5 \mathrm{H} 1002$ & Líquido & 67 & Acido Trifluoroacético & $99,8 \mathrm{C} 2 \mathrm{HF} 3 \mathrm{O} 2$ & Líquido \\
\hline 30 & Acido Fluobórico & & 5 HBF4 & Líquido & 68 & Acido Tríluoroacético-D1 grado de deuteración & $99,5 \mathrm{CF} 3 \mathrm{COOD}$ & Líquido \\
\hline 31 & Acido Fluorhídrico & 50 & $\mathrm{HF}$ & Líquido & 69 & Acido Trifluorometanosulfónico & 99 CHF $303 \mathrm{~S}$ & Líquido \\
\hline 32 & Acido Fórmico & & $3 \mathrm{HCOOH}$ & Líquido & 70 & Acido Yodhídrico & $57 \mathrm{HI}$ & Líquido \\
\hline 33 & Acido Fórmico Dimetilamida & 99.9 & $9(\mathrm{CH} 3) 2 \mathrm{NCHO}$ & Líquido & & & & \\
\hline 34 & Acido orto-Fosfórico & 85 & 5 H3PO4 & Líquido & & & & \\
\hline 35 & Acido Glioólico & & $5 \mathrm{C} 2 \mathrm{H} 403$ & Líquido & & & & \\
\hline 36 & Acido Heptanoico & 98,5 & $5 \mathrm{C} 7 \mathrm{H} 1402$ & Líquido & & & & \\
\hline 37 & Acido Heptanoico Cloruro & 98,5 & 5 C7H13CIO & Líquido & & & & \\
\hline 38 & $\begin{array}{l}\text { Acido Hexacloroplatínico(IV) 6- } \\
\text { hidrato solución }\end{array}$ & & $3 \mathrm{H} 2(\mathrm{PtCl}) .6 \mathrm{H} 2 \mathrm{O}$ & Líquido & & & & \\
\hline
\end{tabular}

Figura 41. Ácidos en estado líquido más comerciales. Elaboración propia

Esta relación de ácidos, sirve de punto de partida, que al estar comercializados y por extensión disponer de fórmulas aceptadas para su realización, permiten servir de punto o patrón de referencia estandarizado, para que sirvan de comparación con estos u otros ensayos, futuras líneas de investigación o futuros procesos industrializados de tratamiento superficial de la madera, disponiendo por extensión de un patrón de comparación estandarizado, disponiendo de fichas técnicas, que aportan datos sobre su configuración. Se entiende, que estos productos comerciales, responden a la mejor forma de presentación, con las mejores propiedades de conservación, traslado y cumplimiento de normativa técnica.

También hay que tener en cuenta que la modificación de estos productos influye sobre la propia denominación de ácidos de los mismos, incluso simplemente con agua, que desde el punto de vista de la formulación química, cambiaría de denominación, aun utilizando variaciones porcentuales contempladas desde el punto de vista lógico, pero que afectaría a estos elementos, perdiendo su referencia, su denominación y el patrón de comparación deseado para futuras investigaciones.

Además, permiten una facilidad de aplicación a efectos de posteriores aplicaciones industriales y la obtención de patentes 


\subsection{Conclusiones al capítulo}

Se detalla la evolución histórica de la definición de ácido y por extensión de la definición de base, para explicar posteriormente, la fuerza de los mismos y los parámetros utilizados para determinar dicha fuerza y poder establecer en el caso de los ácidos un parámetro, que permita diferenciar que ácidos son más fuertes que otros y establecer una escala para los ácidos incoloros en estado líquido utilizados en esta tesis.

Para abordar estas definiciones se parte de la clasificación de la materia, dado el carácter que tiene la química, que se basa en los elementos más pequeños de la materia, definiendo los parámetros generales de estos elementos, detallando los elementos más comunes, posteriormente detallando las clasificaciones de la química inorgánica y orgánica y la situación que dentro de estas se encuentran los ácidos, para después realizar una clasificación sólo de ácidos como los ácidos más utilizados y conocidos.

La facilidad de aplicación de los ácidos líquidos incoloros en estado líquido, que al estar comercializados y por extensión disponer de fórmulas aceptadas para su realización, permiten por un lado un patrón de referencia estandarizado y además un facilidad de aplicación a efectos de posteriores aplicaciones industriales y la obtención de patentes y además que la modificación cromática de la superficie de las maderas de construcción, que mediante la aplicación superficial de ácidos en estado líquido, potencia la expresividad de la madera, a través del cambio de color, ampliando su gama cromática diferenciándola, personalizándola, permitiendo su reutilización y posibilitando su retorno al mercado. 


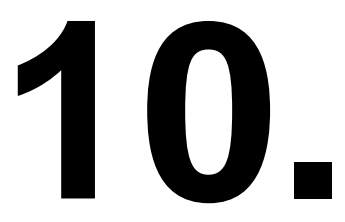

\section{FASE EXPERIMENTAL}

Resumen de las etapas empleadas, para la realización de los ensayos. 


\section{FASE EXPERIMETAL.}

Las etapas realizadas para la realización de los ensayos:

- Parámetros de elección de materiales

Elección, localización y ordenación de maderas y ácidos.

- Elección de laboratorio y condiciones ambientales.

Elección del laboratorio donde se realizan los ensayos y las condiciones ambientales.

- Elección de medios y almacenamiento.

Elección de los medios de almacenamiento, procesamiento de maderas, ácidos e Imágenes.

- Elección de códigos y ordenación de las muestras.

Ordenación de los códigos empleados para identificar maderas y ácidos.

- Metodología de los ensayos

Metodología y descripción de los ensayos, aplicación de ácidos, procesamiento de imágenes, obtención de histogramas, fichas y tablas de resultados de cada ensayo y ordenación de resultados.

- Resultados de los ensayos de variación cromática

Fichas y gráficas de los resultados obtenidos de cada ensayo.

- Análisis de los resultados y discusión

Valoración de datos obtenidos, representación de gráficas de resultados según los valores obtenidos bgr, análisis de resultados obtenidos, discusión, publicación y estimación de patente.

- Conclusiones

- Futuras líneas de investigación 


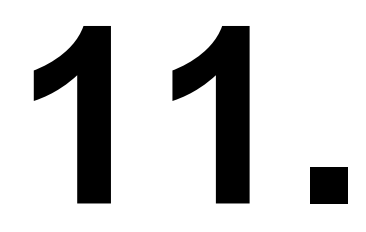

\section{PARÁMETROS DE ELECCIÓN DE MATERIALES}

La diversidad de las especies de maderas y de ácidos, obliga a fijar unos parámetros de elección, debido a diferentes condicionantes como el origen, características, disponibilidad o facilidad de aplicación. 


\section{PARÁMETROS DE ELECCIÓN DE MATERIALES}

\subsection{Elección de maderas}

Las maderas de construcción de esta tesis se eligen en función de las divisiones que realiza la botánica que son: División XVI Gimnospermas (Coníferas) y División XVII Angiospermas (Frondosas), de sus características técnicas y sus propiedades, y de los parámetros de elección de esta tesis. Las divisiones I - XV, no se consideran porque no son especies maderables.

Las maderas elegidas, lo han sido en función de las condiciones que existían en el momento de su elección dentro de la variedad de especies comercializadas en nuestro país, siendo la obtención de las diferentes especies con localizaciones geográficas por continentes, condicionadas por su disponibilidad, esta variedad permite por extensión un abanico de posibilidades lo más amplio posible, fundamentalmente por especie y por comercialización, abarcando maderas de diferentes densidades, texturas y colores.

Las maderas pertenecen a 34 especies diferentes y a las dos divisiones botánicas, según se detalla en la siguiente figura, a estos efectos se presentan las maderas en función del continente de localización de origen y la división botánica.

\begin{tabular}{|c|c|c|c|}
\hline CONTINENTE & DIVISION & MADERAS EMPLEADAS & TIMBERS \\
\hline \multirow[b]{2}{*}{ EUROPA } & CONÍFERAS & $\begin{array}{l}\text { PINO RADIATA } \\
\text { PINO SILVESTRE }\end{array}$ & $\begin{array}{l}\text { RADIATA PINE } \\
\text { SCOTS PINE } \\
\end{array}$ \\
\hline & FRONDOSAS & $\begin{array}{l}\text { CASTAÑO EUROPEO } \\
\text { CHOPO EUROPEO } \\
\text { HAYA } \\
\text { ROBLE BLANCO EUROPEO } \\
\text { TILO EUROPEO } \\
\end{array}$ & $\begin{array}{l}\text { SWEET CHESNUT } \\
\text { WHITE POPLAR } \\
\text { EUROPEAN BEECH } \\
\text { EUROPEAN WHITE OAK } \\
\text { EUROPEAN LIME } \\
\end{array}$ \\
\hline \multirow[b]{2}{*}{ AMÉRICA DEL NORTE } & CONIFERAS & ABETO DOUGLAS & DOUGLAS -FIR \\
\hline & FRONDOSAS & $\begin{array}{l}\text { ARCE BLANDO AMERICANO } \\
\text { ARCE DURO AMERICANO } \\
\text { CEREZO AMERICANO } \\
\text { FRESNO BLANCO AMERICANO } \\
\text { NOGAL NEGRO AMERICANO } \\
\text { ROBLE BLANCO AMERICANO } \\
\text { ROBLE ROJO AMERICANO } \\
\text { TILO AMERICANO } \\
\end{array}$ & $\begin{array}{l}\text { SOFT MAPLE } \\
\text { HARD MAPLE } \\
\text { BLACK CHERRY } \\
\text { PUMPKIN ASH } \\
\text { WALNUT } \\
\text { WHITE OAK } \\
\text { RED OAK } \\
\text { BASSWOOD } \\
\end{array}$ \\
\hline $\begin{array}{l}\text { AMÉRICA CENTRAL Y DEL } \\
\text { SUR }\end{array}$ & FRONDOSAS & $\begin{array}{l}\text { CEREJEIRA } \\
\text { COPAIBA } \\
\text { CUMARÚ } \\
\text { IPÉ } \\
\text { JATOBA } \\
\text { LENGA } \\
\text { PINO AMARILLO DEL SUR - P.MELIX }\end{array}$ & $\begin{array}{l}\text { CEREJEIRA } \\
\text { ETIMOE } \\
\text { CUMARU } \\
\text { IPE } \\
\text { JATOBA } \\
\text { LENGA } \\
\text { SHORTLEAF PINE } \\
\end{array}$ \\
\hline ÁFRICA & $\begin{array}{l}\text { FRONDOSAS } \\
\text { TROPICALES }\end{array}$ & $\begin{array}{l}\text { AYOUS } \\
\text { BOSSÉ } \\
\text { BUBINGA } \\
\text { DOUSSIÉ } \\
\text { FRAMIRÉ } \\
\text { IROKO } \\
\text { KOTO } \\
\text { MAKORÉ } \\
\text { OKUMÉ } \\
\text { SAPELLI } \\
\text { TALI } \\
\end{array}$ & $\begin{array}{l}\text { OBECHE } \\
\text { BOSSE } \\
\text { BUBINGA } \\
\text { DOUSSIE } \\
\text { IDIGBO } \\
\text { IROKO } \\
\text { KOTO } \\
\text { MAKORE } \\
\text { OKUME } \\
\text { SAPELLI } \\
\text { TALI }\end{array}$ \\
\hline
\end{tabular}

Figura 42. Elección de maderas de construcción. Elaboración propia 


\subsection{Localización de maderas.}

El suministro de las maderas se realizó a través de almacén de maderas de reconocido prestigio, donde se suministraron, teniendo en cuenta su denominación botánica.

11.3 Parámetros por orden de importancia de elección de maderas.

Las maderas se eligieron en función de los siguientes parámetros:

- Por ser maderas cuyo uso normal es para madera de construcción

- Por clasificación de la especie frondosas o coníferas.

- Por accesibilidad, comercialización y uso común.

- Por color de la madera

- Por densidad de la madera.

- Por localización geográfica por continentes.

\subsection{Elección de ácidos}

La elección de los ácidos se ha realizado en función de la clasificación general de ácidos, disponibilidad, comercialización, fuerza ácida, características y propiedades, y también en función de los parámetros de elección fijados en la tesis.

Los ácidos seleccionados sirven de punto o patrón de referencia que responden a una concentración determinada y a una composición determinada, según sus fichas técnicas y comparación con estos u otros ensayos, futuras líneas de investigación o futuros procesos industrializados de tratamiento superficial de la madera, disponiendo por extensión de un patrón de comparación estandarizado, para obtener una ampliación de la gama de colores de las especies de madera de forma mecánica

Los ácidos elegidos permiten tener un tiempo corto de obtención de resultados de los ensayos, en vez de utilizar por ejemplo ácidos sólidos, que implicarían para observar mejor su interacción con las muestras de madera, aplicar disoluciones en agua, alcohol u otros compuestos, cuyas concentraciones no estarían estandarizadas, e influirían en la propia denominación del ácido, y si los aplicáramos directamente implicaría la necesidad de mayor tiempo de actuación para observar cambios significativos.

Se han elegido 15 ácidos incoloros en estado líquido, orgánicos e inorgánicos, en las siguientes figuras se detallan la relación de estos, los códigos aplicados para los ensayos y el nombre dado por la IUPAC u otros nombres conocidos. 


\begin{tabular}{|c|c|l||}
\hline CLASIFICACIÓN & COMPUESTO & \multicolumn{1}{|c|}{ ACIDOS EMPLEADOS } \\
\hline \multirow{2}{*}{ QUIMICA } & INORGÁNICO & ACIDO CLORHIDRICO \\
INORGÁNICA & INORGÁNICO & ACIDO FLUORHIDRICO \\
& INORGANICO & ACIDO FOSFORICO \\
& INORGÁNICO & ACIDO NITRICO \\
\hline & ORGANICO & ACIDO ACÉTICO GLACIAL \\
& ORGANICO & ACIDO ACRILICO \\
& ORGANICO & ACIDO FÓRMICO \\
& ORGANICO & ACIDO LÁCTICO \\
QUIMICA & ORGÁNICO & ACIDO OCTANOICO \\
ORGÁNICA & ORGÁNICO & ACIDO OLEICO \\
& ORGÁNICO & ÁCIDO OXÁLICO \\
& ORGÁNICO & ACIDO PIRUVICO \\
& ORGÁNICO & ACIDO PROPIONICO \\
& ORGÁNICO & ACIDO TIOGLICOLICO \\
& ORGÁNICO & ACIDO 2-ETILHEXANOICO \\
\hline
\end{tabular}

Figura 43. Elección de ácidos incoloros en estado líquido. Tipo. Elaboración propia

\begin{tabular}{|c|c|c|c|c|}
\hline № & ACIDOS EMPLEADOS & COD.AC. & IUPAC / OTROS NOMBRES & CTE ACIDEZ (PKa) \\
\hline$\overline{A 01}$ & ACIDO ACÉTICO GLACIAL & AG & ÁCIDO ETANOICO (GLACIAL)/METILENCARBOXILICO & 4,76 \\
\hline $\mathrm{AO} 2$ & ACIDO ACRILICO & $C R$ & ÁCIDO PROPENOICO/A. PROP-2-ENOICO & 4,35 \\
\hline $\mathrm{AO} 3$ & ACIDO CLORHIDRICO & $\mathrm{CL}$ & CLORURO DE HIDROGENO & $-6,22$ \\
\hline A04 & ACIDO FLUORHIDRICO & $\mathrm{FL}$ & FLUORURO DE HIDROGENO & 3,14 \\
\hline A05 & ACIDO FÓRMICO & FM & ÁCIDO METANOICO & 3,75 \\
\hline A06 & ACIDO FOSFORICO & $\mathrm{FF}$ & ÁCIDO ORTOFOSFÓRICO / a.TETRAOXOFOSFÓRICO (V) & 4,10 \\
\hline A07 & ACIDO LÁCTICO & LC & ÁCIDO 2-HIDROXIPROPANOICO & 3,86 \\
\hline A08 & ACIDO NITRICO & NT & & $-1,64$ \\
\hline A09 & ACIDO OCTANOICO & $O C$ & ACIDO CAPRILICO & 4,89 \\
\hline A10 & ACIDO OLEICO & $\mathrm{OL}$ & ÁCIDO CIS-9-OCTADECENOICO & 5,02 \\
\hline A11 & ÁCIDO OXÁLICO & ox & ÁCIDO ETANODIOICO & 4,26 \\
\hline A12 & ACIDO PIRUVICO & PV & ÁCIDO OXOPROPANOICO & 2,49 \\
\hline A13 & ACIDO PROPIONICO & PN & ÁCIDO PROPANOICO & 4,87 \\
\hline A14 & ACIDO TIOGLICOLICO & TG & ÁCIDO MERCAPTOACETICO/ACIDO 2-MERCAPTOETANOIC & 3,60 \\
\hline A15 & ACIDO 2-ETILHEXANOICO & $\mathrm{EH}$ & ÁCIDO 2-ETILCAPROICOIACIDO 3-HEPTANOCARBOXILICO & 4,82 \\
\hline & & & MENOR ACIDEZ (NÚMEROS POSITIVOS) & \\
\hline
\end{tabular}

Figura 44. Elección de ácidos incoloros en estado líquido. PKa. Elaboración propia

Por facilidad de representación en las gráficas y en función del valor de PKa de cada ácido, podemos dividir los ácidos elegidos por su fuerza ácida en:

Ácidos Fuertes: A03 ; A04; A08; A12 y A14

Ácidos Medios: A02 ; A05 ; A06 ; A07 y A11

Ácidos Débiles: A01; A09 ; A10 ; A13 y A15 


\subsection{Localización de ácidos.}

El suministro de ácidos incoloros en estado líquido se realizó a través de laboratorios químicos de reconocido prestigio, donde se suministraron, teniendo en cuenta su denominación química.

11.6 Parámetros por orden de importancia de elección de ácidos.

Los ácidos se eligieron en función de los siguientes parámetros:

- Por ser ácido incoloro en estado líquido.

- Por pertenecer al ámbito de la química orgánica o inorgánica.

- Por pertenecer al ámbito de la clasificación general de ácidos.

- Por accesibilidad, comercialización y uso común.

- Por aplicación del ácido en condiciones normales.

- $\quad$ Por su fuerza ácida.

- Por poder situarse dentro de una escala de ácidos del más fuerte al menos fuerte en función del parámetro de referencia Ka.

- Que puedan servir como patrón de referencia dadas sus características.

- Por pertenencia al grupo, según sus características y aplicables a las maderas de construcción.

\subsection{Ordenación de los materiales obtenidos}

Las maderas obtenidas se tuvieron que ordenar primero mediante tablones, que posteriormente serían procesados, para obtener las correspondientes probetas de madera para realizar los ensayos.

En las maderas se tuvo en cuenta el color, en la figura de abajo, se ordenan según un patrón de luminosidad.

De la misma forma los ácidos inicialmente se reconocieron y ordenaron, de forma conveniente para posteriormente poder procesarlos.

En los ácidos se tuvo en cuenta su acidez, en la figura se ordenan mediante su fuerza.

En ambos materiales se tuvieron en cuenta estas características para disponer de un abanico o espectro de posibilidades a la hora de realizar los ensayos. 


\subsection{Fichas de ácidos y maderas.}

En el anejo de esta tesis, se presentan las fichas de los diferentes materiales empleados, cuyo objetivo es observar la variación del color. En las fichas de las maderas se recoge el aspecto de estas, plano de localización de origen de la especie, nombre científico, propiedades generales y técnicas y usos en que se emplean. En las fichas de ácidos incoloros en estado líquido se recoge, aspecto del envase donde están contenidos, representación gráfica del ácido, nombre científico, descripción y obtención, propiedades generales y técnicas y usos.

\subsection{Conclusiones al capítulo}

La diversidad de las especies de maderas y de ácidos, obliga a fijar unos parámetros de elección, para determinar unos materiales apropiados para los ensayos realizados en esta tesis y por extensión su localización.

En ambos materiales se tuvieron en cuenta estas características para disponer de un abanico o espectro de posibilidades a la hora de realizar los ensayos.

Para ello en este capítulo se fijan los parámetros de elección de los materiales, por un lado las maderas, que aún influenciadas por su disponibilidad en el mercado de madera español, se ha podido dar un amplio abanico de especies, con diferentes características y localizaciones de diferentes continentes y por otro lado los ácidos, elegidos por sus características de ser incoloros, para influir lo menos posible en el color a la hora de aplicarlos superficialmente, y en estado líquido por su facilidad de aplicación, en ambos materiales se utilizan los parámetros de elección debida a la gran cantidad de productos de esta naturaleza que se pueden encontrar y ordenarlos desde el punto de vista de los posteriores ensayos a realizar, pensando en una lógica que permita desarrollar la tesis. 


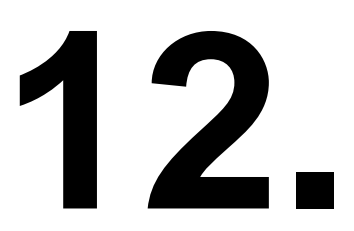

\section{ELECCIÓN DE LABORATORIO y CONDICIONES AMBIENTALES}

Se detallan las condiciones de laboratorio y de almacenamiento que se utilizaron como punto de partida, para posteriormente procesar las probetas. 


\section{ELECCIÓN DE LABORATORIO y CONDICIONES AMBIENTALES.}

\subsection{Elección de Laboratorio. Medios.}

Se elige el laboratorio de materiales de construcción de la Escuela Técnica Superior de Arquitectura de Madrid (ETSAM), perteneciente a la Universidad Politécnica de Madrid (UPM) como lugar de realización de los ensayos y almacenamiento y conservación de las muestras. Para ello se utilizó la sala de química, donde se encuentra el almacén de productos químicos y la campana de laboratorio, y donde se aplicaban los ácidos superficialmente sobre las maderas. También se dispone de pila de agua y mesas de trabajo.

\subsection{Condiciones ambientales.}

Las condiciones ambientales donde se desarrollan, depositan y estudian las muestras de madera es en ambiente de laboratorio en interior (laboratorio de materiales de construcción ETSAM). Se depositan las probetas de madera en zona designada por el responsable del Laboratorio de Materiales de Construcción de ETSAM. Las condiciones de conservación y ubicación designada cumplen con los siguientes criterios:

a) Las condiciones serán de interior con una temperatura media entre $18^{\circ}$ y $23^{\circ} \mathrm{C}$ y humedad relativa entre el $30 \%$ y el $50 \%$, no permitiéndose ambientes húmedos para garantizar la estabilidad dimensional de las muestras.

b) Las muestras serán depositadas en cajas de cartón convenientemente ventiladas y rotuladas.

c) Se dispondrán en estanterías o armarios destinados a tal efecto, con ventilación directa o forzada, según el caso.

d) No se apilarán más de tres cajas por grupo de ensayos.

e) No estarán situadas cerca de focos de calor, iluminación, líneas o tomas de fuerza, ni expuestas a la acción de la luz solar, ni en zonas cercanas a condiciones ambientales de exterior o acceso de carga y descarga de materiales diversos para el laboratorio.

f) No podrán ser dañadas, golpeadas o "contaminadas" por agua, otros productos o las muestras de otros ensayos que puedan afectar a la integridad de estas.

Su acceso será limitado dentro de las condiciones de seguridad del laboratorio

\subsection{Condiciones de las muestras.}

Las muestras dispondrán de las siguientes condiciones: de dimensiones aproximadas

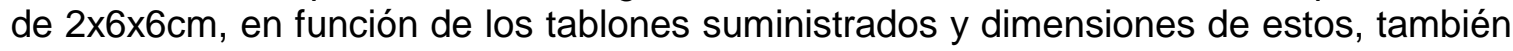
disponen de marcado de la probeta, tipo de madera y ácido líquido incoloro.

\subsection{Conclusiones al capítulo}

La determinación de las condiciones de laboratorio y de almacenamiento, influyen sobre la conservación de las muestras de maderas y ácidos. 


\section{ELECCIÓN DE MEDIOS y ALMACENAMIENTO}

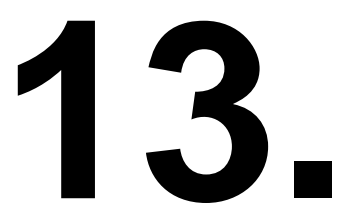

Se detalla una enumeración de los medios de los que se disponía para realizar los ensayos de esta tesis, así como las descripciones técnicas de algunos de estos medios. 


\section{ELECCIÓN DE MEDIOS y ALMACENAMIENTO.}

13.1 Medios de procesamiento de maderas y ácidos.

Las maderas y los ácidos empleados necesitan medios para su procesamiento, mediante maquinas, mesas de trabajo, material, etc.

13.2 Medios de procesamiento de las maderas.

Para el procesamiento de las maderas se empleó diversa maquinaria que se detalla a continuación:

- Máquina desbastadora: Empleada para eliminar la primera capa de los tablones de Madera.

- Máquina de Corte Lineal: Empleada para adecuar las dimensiones de los tablones a las muestras que se querían obtener.
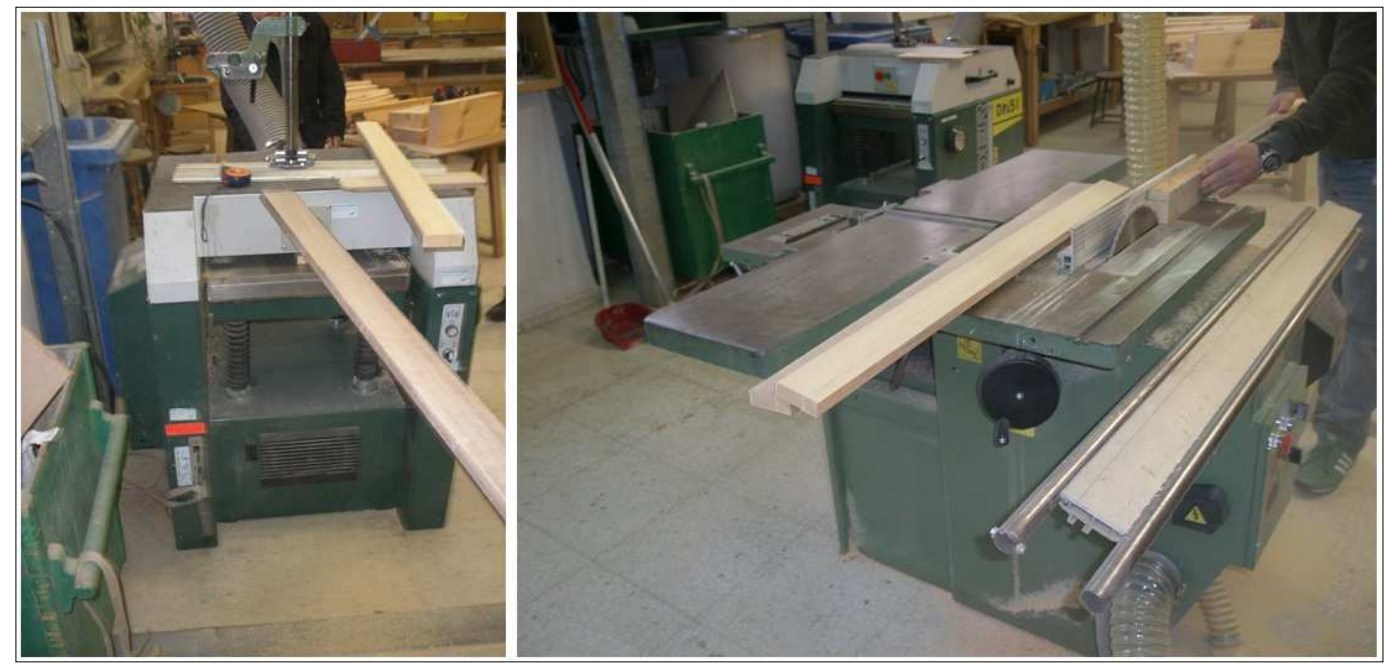

Figura 45. Desbastadora (izquierda). Corte Lineal (derecha). Elaboración propia

- Máquina de Corte Trasversal: Empleada para adecuar las dimensiones de los tablones a las muestras que se querían obtener, una vez adecuados los tablones de madera y obtener las muestras deseadas en bruto.

- Máquina de Lijado: Empleada para adecuar y eliminar las impurezas de las caras y comprobar el estado de la madera de las muestras deseadas, para su posterior procesamiento con los ácidos. 


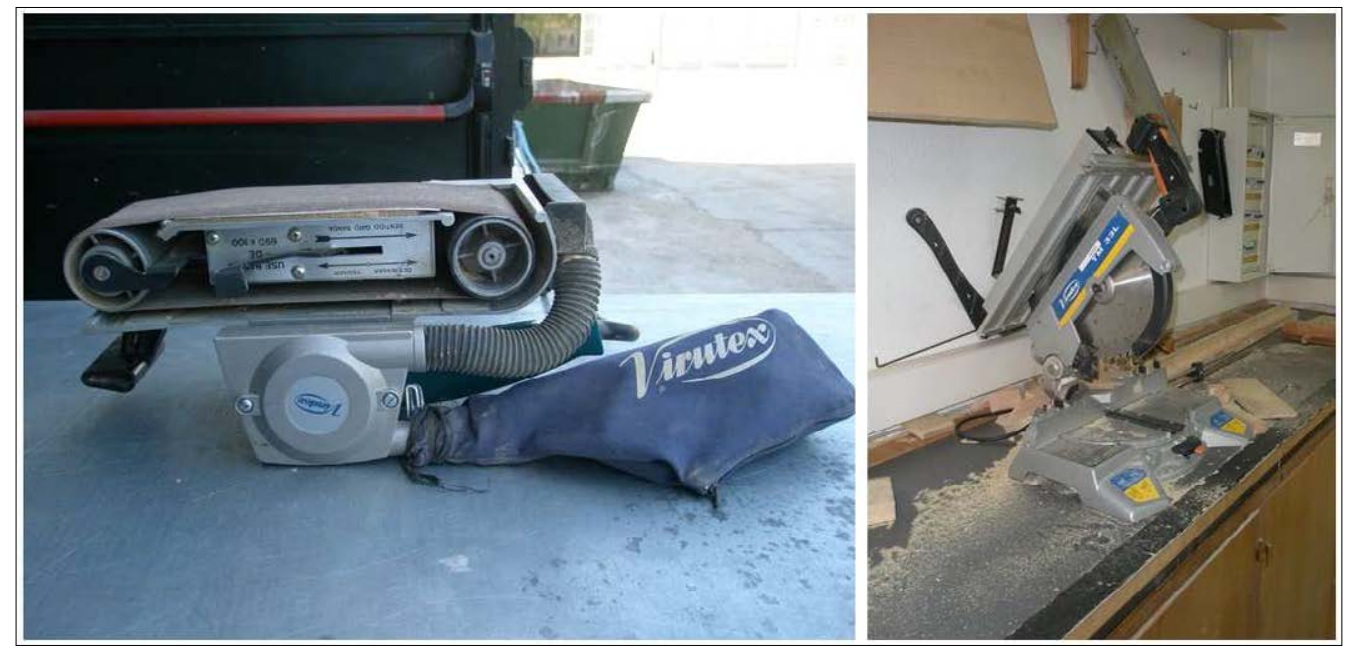

Figura 46. Lijadora (izquierda). Corte Trasversal (derecha). Elaboración propia

\subsection{Medios de procesamiento de los ácidos líquidos incoloros.}

Los medios para el procesamiento de los ácidos incoloros en estado líquido consistían en disponer de una campana de laboratorio como la existente en la sala de química del laboratorio de materiales de la ETSAM, además de pequeño material para la aplicación de los ácidos.

- Campana de laboratorio: Empleada para la aplicación de ácidos incoloros en estado líquido, en condiciones de igualdad de ambiente de interior.

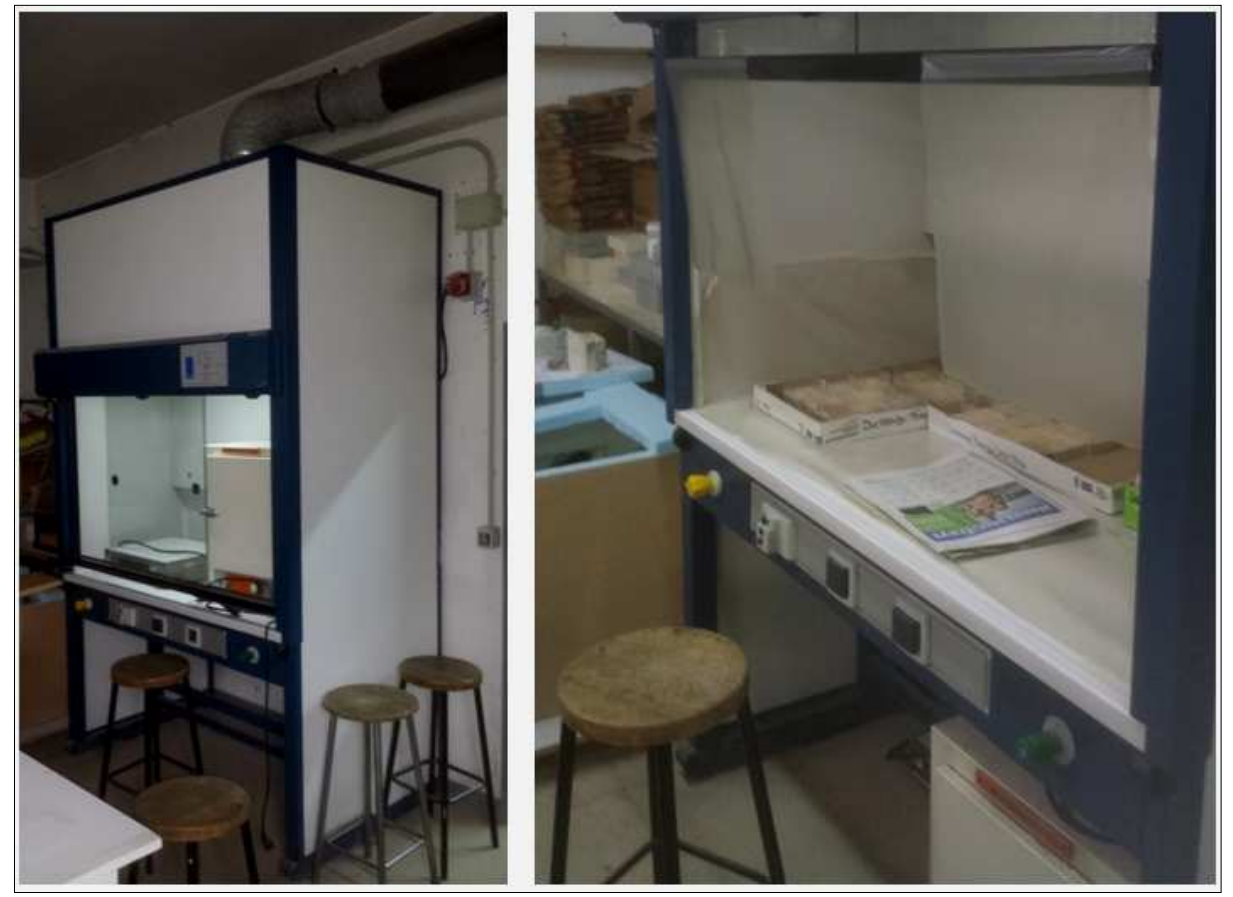

Figura 47. Campana de laboratorio. Sala de química. Elaboración propia

Universidad Politécnica de Madrid - Escuela Técnica Superior de Arquitectura - Departamento de Construcción y Tecnología Arquitectónica Directores: Dr. Alfonso García Santos y Dr. Antonio Rodríguez Rodríguez. Doctorando: D. Francisco Lora Toro 
- Pequeño material de laboratorio: Son las pipetas calibradas empleadas para poder aplicar los ácidos de una forma uniforme y en la cantidad deseada, para ello se empleaba un pipetero (propipeta) para la extracción del ácido por succión de este, desde el contenedor del ácido, además también se incluyen bata, gafas y guantes de nitrilo.

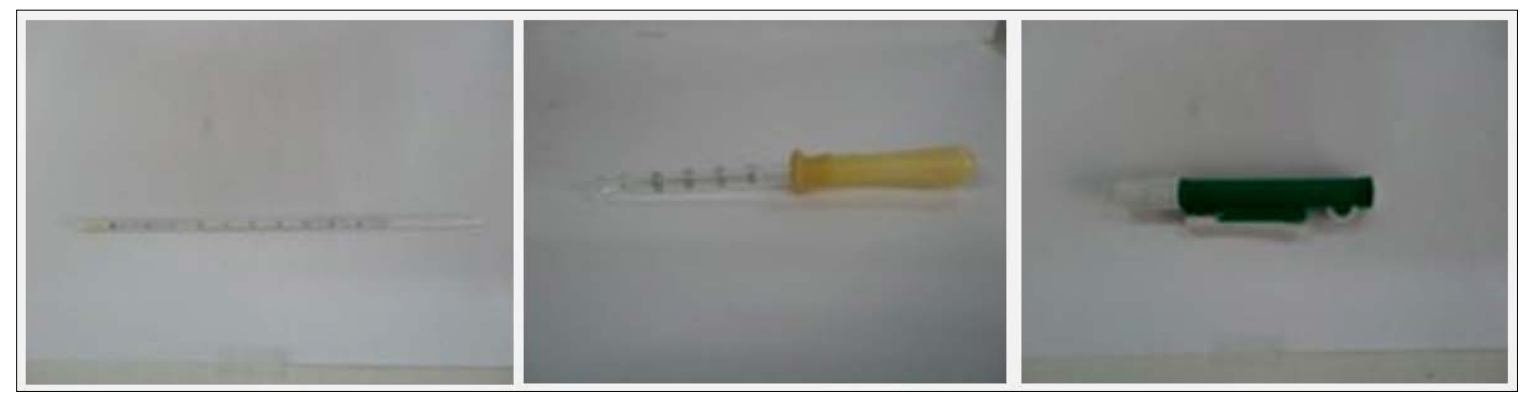

Figura 48. Pipetas calibradas y pipetero. Elaboración propia

\subsection{Medios para el procesamiento de imágenes. Mesa de Reproducción.}

Para el procesamiento de imágenes de esta tesis se ha utilizado una cámara digital Nikon Coolpix P-100, una mesa de reproducción de imágenes, compuesta por tablero con malla de referencia, columna graduada en milímetros, con 4 focos a los que se les añadió cuatro lámparas de Luz de Día (6.400k), 23 w (115w incandescente), además del equipo y programa informático Photoshop CS5 de procesamiento de imágenes.
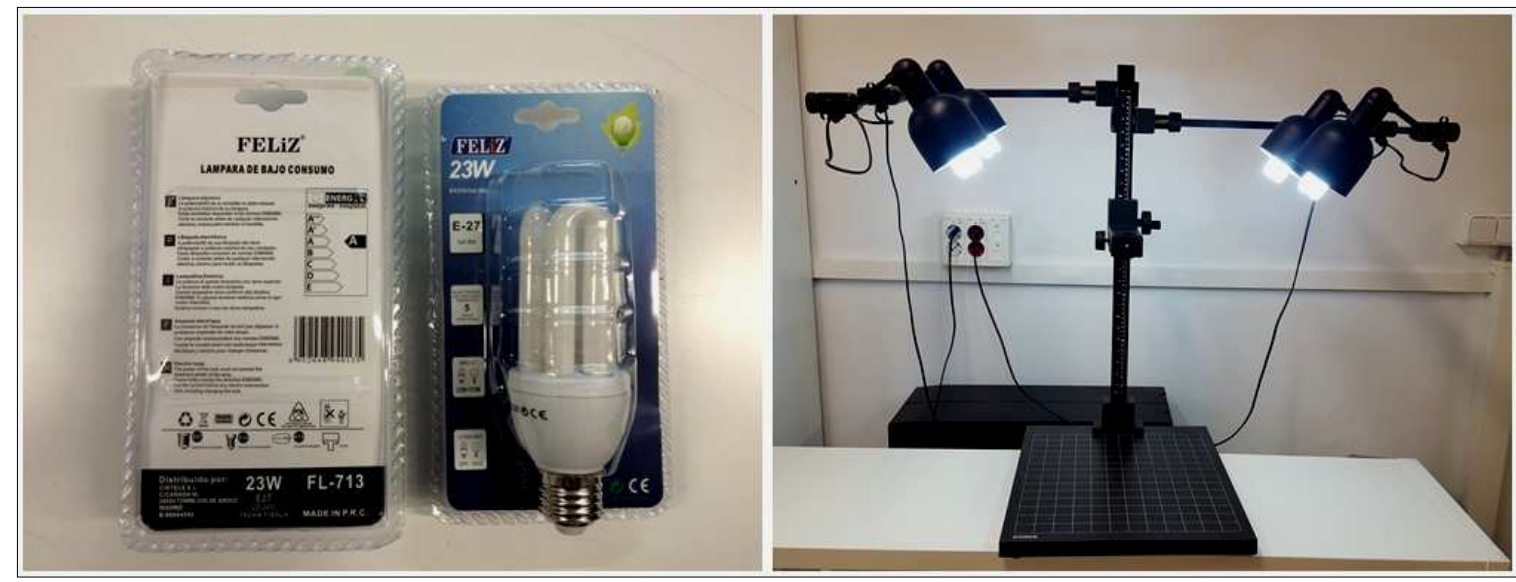

Figura 49. Lámpara y mesa de reproducción. Elaboración propia

Se establecieron las condiciones de iluminación necesarias e iguales para la realización de todas las fotografías fijando, siempre la misma situación de la mesa dentro de la sala del laboratorio empleada para realizar las fotografías.

\subsection{Medios para el almacenamiento de los materiales.}

Se utilizó la misma sala para el almacenamiento de las muestras de ensayo en condiciones de laboratorio de interior y armario de depósito de muestras con cerradura y llave, y cada grupo protegido por una caja de contenedor. 


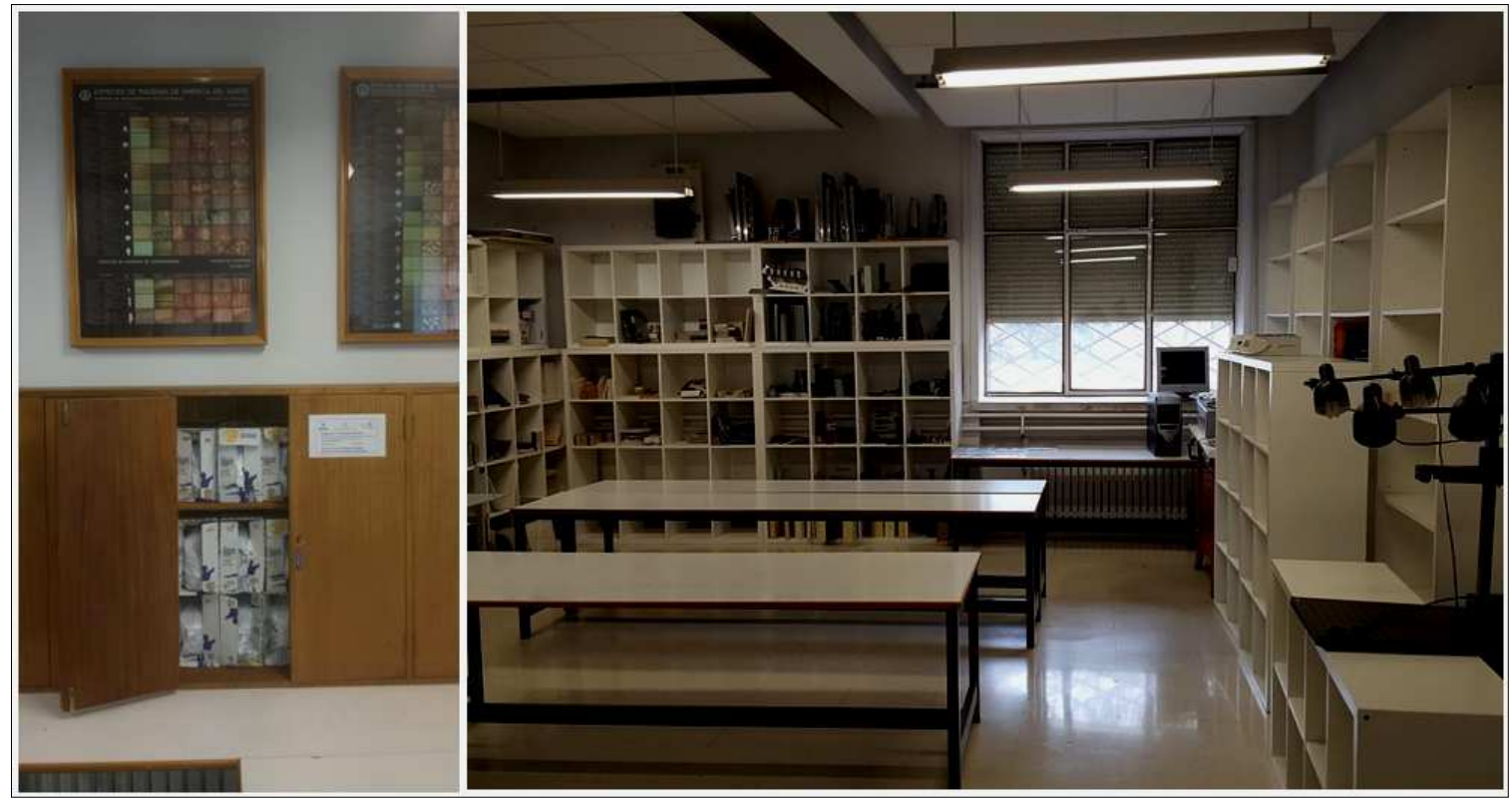

Figura 50. Sala de almacenamiento. Módulo de almacenamiento. Elaboración propia

Para los ácidos se utilizó el almacén de materiales de la sala de química del Laboratorio de Materiales, y se almacenaron en un módulo de acero con cerradura y llave.

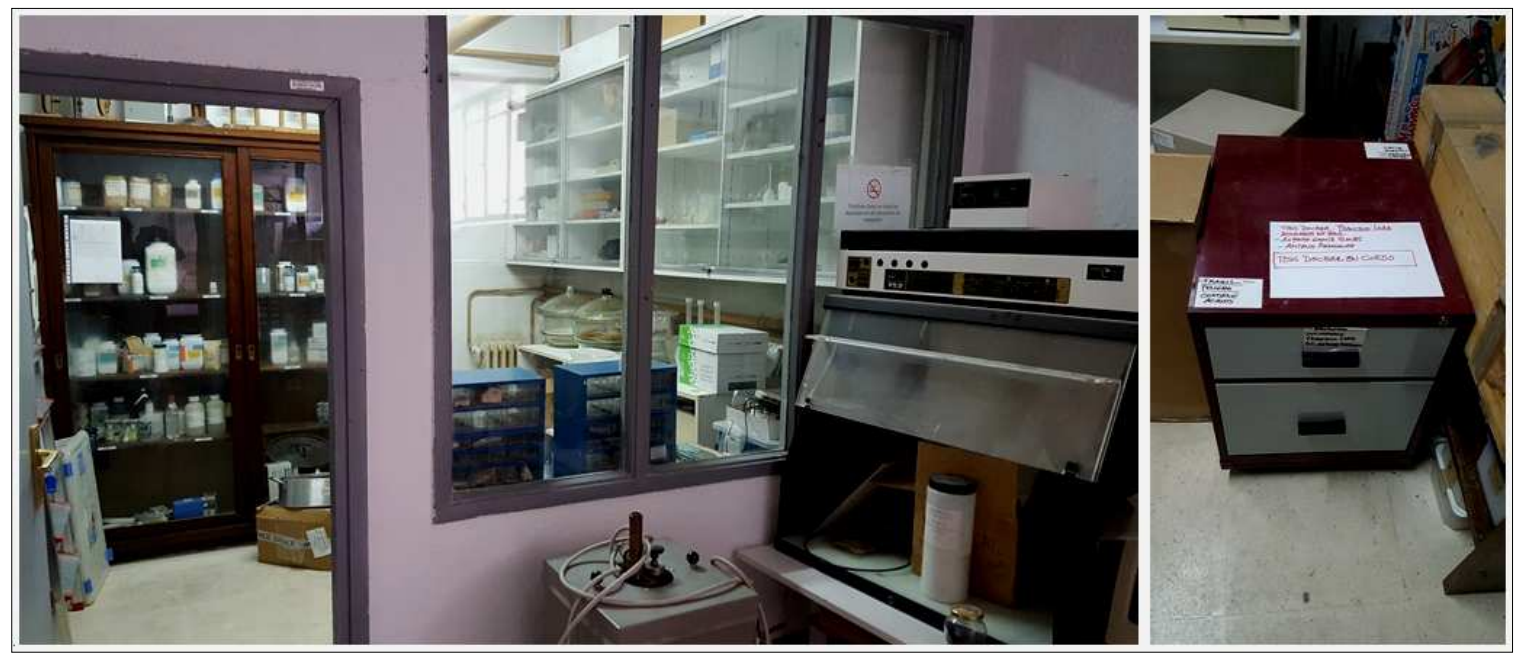

Figura 51. Sala de almacén de ácidos. Módulo de almacenamiento. Elaboración propia

\subsection{Conclusiones al capítulo}

Los medios de procesamiento permiten una uniformidad en la forma en que se obtienen las muestras de madera y un control sobre la aplicación superficial de ácidos, y por extensión una uniformidad en las condiciones en que se realizan los ensayos. 


\section{ELECCIÓN DE CÓDIGOS y ORDENACIÓN DE MUESTRAS}

El volumen de ensayos y las características de los ácidos obligaban a realizar un control exhaustivo de los códigos correspondientes a la identificación de las muestras ensayadas. 


\section{ELECCIÓN DE CÓDIGOS y ORDENACIÓN DE LAS MUESTRAS.}

El volumen tanto de ensayos, como de las propias características del proceso a realizar implica una ordenación de las muestras empleadas, tanto antes como después de ser tratadas superficialmente con los ácidos incoloros en estado líquido.

\subsection{Ordenación de las muestras}

Una vez que se disponían de las muestras, se debía seguir un método para ordenar las muestras tanto antes como después de ser tratadas con los ácidos.

En un primer paso y una vez que se disponía de cada grupo de muestras de cada especie, se las marcó primero con una etiqueta adhesiva para identificar la especie de a la que pertenecía la muestra y todas ellas juntas, en un mismo contenedor.
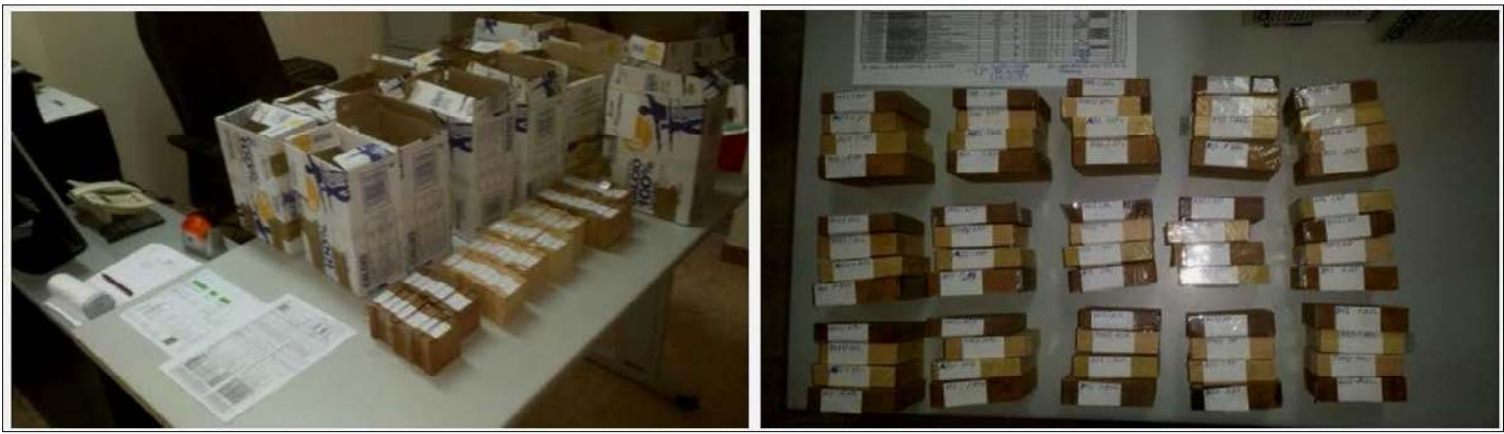

Figura 52. Ordenación inicial de muestras. Elaboración propia.

Debidas a las características de los ensayos posteriormente se empleó una ordenación más detallada en función del código de muestras que se describe en el siguiente punto.

\subsection{Código de muestras y metodología empleada}

Las especies de maderas y los tipos de ácidos se ordenaron alfabéticamente, y se les asignó un código tanto de orden por el listado, como un código por la especie a la que pertenecían, esto permitía que después se aplicará un número al código de especie en función del ensayo correspondiente de ácido que se hubiera realizado.

\begin{tabular}{|c|c|c|c|c|c|c|c|c|}
\hline № & MADERAS EMPLEADAS & COD.MAD. & № & MADERAS EMPLEADAS & COD.MAD. & № & ACIDOS EMPLEADOS & COD.ACD. \\
\hline M01 & ABETO DOUGLAS & $A D$ & M18 & IROKO & $\mathrm{IK}$ & A01 & ACIDO ACÉTICO GLACIAL & $A G$ \\
\hline M02 & ARCE BLANDO AMERICANO & ABA & M19 & JATOBA & $\mathrm{JT}$ & $\mathrm{A} 02$ & ACIDO ACRILICO & $C R$ \\
\hline M03 & ARCE DURO AMERICANO & ADA & M20 & КОто & KT & A03 & ACIDO CLORHIDRICO & CL \\
\hline M04 & AYOUS & AS & M21 & LENGA & LG & A04 & ACIDO FLUORHIDRICO & $\mathrm{FL}$ \\
\hline M05 & BOSSÉ & BS & M22 & MAKORÉ & MK & A05 & ACIDO FÓRMICO & FM \\
\hline M06 & BUBINGA & BG & M23 & NOGAL NEGRO AMERICANO & NGA & A06 & ACIDO FOSFORICO & $\mathrm{FF}$ \\
\hline M07 & CASTAÑO EUROPEO & CÑ & M24 & OKUMÉ & $\mathrm{OK}$ & A07 & ACIDO LÁCTICO & LC \\
\hline M08 & CHOPO EUROPEO & CPE & M25 & PINO AMARILLO DEL SUR - P.MELIX & PX & A08 & ACIDO NITRICO & NT \\
\hline M09 & CEREJEIRA & c) & M26 & PINO RADIATA & $P R$ & AOS & ACIDO OCTANOICO & $O C$ \\
\hline M10 & CEREZO AMERICANO & CZA & M27 & PINO SILVESTRE & PS & A10 & ACIDO OLEICO & $\mathrm{OL}$ \\
\hline M11 & COPAIBA & $C B$ & M28 & ROBLE BLANCO AMERICANO & RBA & A11 & ÁCIDO OXÁLICO & $O x$ \\
\hline M12 & CUMARÚ & CM & M 29 & ROBLE BLANCO EUROPEO & RBE & A12 & ACIDO PIRUVICO & PV \\
\hline M13 & DOUSSIÉ & DS & M30 & ROBLE ROJO AMERICANO & RRA & A13 & ACIDO PROPIONICO & PN \\
\hline M14 & FRAMIRÉ & $F R$ & M31 & SAPELLI & $S P$ & A14 & ACIDO TIOGLICOLICO & TG \\
\hline M15 & FRESNO BLANCO AMERICANO & FBA & M32 & TALI & TL & A15 & ACIDO 2-ETILHEXANOICO & EH \\
\hline M16 & HAYA & $H$ & M33 & TILO AMERICANO & TA & & & \\
\hline M17 & IPÉ & IP & M34 & TILO EUROPEO & $\mathrm{TE}$ & & & \\
\hline
\end{tabular}

Figura 53. Códigos de maderas y ácidos. Elaboración propia. 
El código se detallaba de la siguiente forma primero el número del ácido con su número de orden correspondiente seguido del código del ácido empleado, separados por "/" , después un guion y el número de orden de la madera y el código de la especie de madera con el número de madera de esa especie coincidente con el número del ácido, separados por "l", después un nuevo guion y el año de realización del ensayo.

El ejemplo siguiente, sería Ácido №01 / Acético Glacial (AG) - Madera №01 / Abeto Douglas (AD) muestra nำ1 - año 2015

\section{A01/AG-M01/AD1-2015}

Figura 54. Código de etiquetas. Ejemplo. Elaboración propia.

El total de códigos para un ácido empleado sería:

\begin{tabular}{|c|c|c|c|}
\hline A01/AG-M01/AD1-2015 & A01/AG-M10/CZA1-2015 & A01/AG-M19/JT1-2015 & A01/AG-M27/PS1-2015 \\
\hline A01/AG-M02/ABA1-2015 & A01/AG-M11/CB1-2015 & A01/AG-M20/KT1-2015 & A01/AG-M28/RBA1-2015 \\
\hline A01/AG-M03/ADA1-2015 & A01/AG-M12/CM1-2015 & A01/AG-M21/LG1-2015 & A01/AG-M29/RBE1-2015 \\
\hline A01/AG-M04/AS1-2015 & A01/AG-M13/DS1-2015 & A01/AG-M22/MK1-2015 & A01/AG-M30/RRA1-2015 \\
\hline A01/AG-M05/BS1-2015 & A01/AG-M14/FR1-2015 & A01/AG-M23/NGA1-2015 & A01/AG-M31/SP1-2015 \\
\hline A01/AG-M06/BG1-2015 & A01/AG-M15/FBA1-2015 & A01/AG-M24/OK1-2015 & A01/AG-M32/TL1-2015 \\
\hline A01/AG-M07/CÑ1-2015 & A01/AG-M16/H1-2015 & A01/AG-M25/PX1-2015 & A01/AG-M33/TA1-2015 \\
\hline A01/AG-M08/CPE1-2015 & A01/AG-M17/IP1-2015 & A01/AG-M26/PR1-2015 & A01/AG-M34/TE1-2015 \\
\hline A01/AG-M09/CJ1-2015 & A01/AG-M18/IK1-2015 & &
\end{tabular}

Figura 55. Códigos de etiquetas del Ácido №01. Ejemplo. Elaboración propia.

\subsection{Metodología empleada en la colocación de códigos.}

La metodología empleada en la colocación de las etiquetas de Identificación de los códigos, en el proceso de aplicación superficial de ácidos, se realizó de la siguiente forma, las maderas se encontraban ordenadas y se etiquetaban en el momento que se realizaba un grupo de ensayo y se procesaban las imágenes antes de ser tratadas las maderas.

\subsection{Conclusiones al capítulo}

El método descrito y el control sobre los códigos detallados en las etiquetas de las muestras, permitió la identificación de las muestras en cualquier momento de los ensayos y posteriormente en su almacenamiento. 


\section{METODOLOGÍA DE LOS ENSAYOS}

Se describe la metodología empleada para la realización de los ensayos y la ordenación de los datos obtenidos mediante, fichas, gráficas y tablas. 


\section{METODOLOGÍA DE LOS ENSAYOS}

\subsection{Descripción de los ensayos.}

La metodología de los ensayos se ha desarrollado durante el periodo de tiempo para los ensayos, realizado en el laboratorio de materiales de construcción de la E.T.S. de Arquitectura de Madrid de la UPM, siendo las condiciones ambientales donde se realizan los ensayos en ambiente de laboratorio en interior.

Seleccionadas y procesadas las maderas y los ácidos, con sus correspondientes códigos para la identificación de las muestras y los ácidos a aplicar, se comienza la campaña de ensayos, en total 510 ensayos, correspondientes a la combinación de 34 especies de maderas con 15 ácidos incoloros en estado líquido.

\begin{tabular}{|c|c|c|c|}
\hline CAMPAÑA & № Ensayos & № Especies Madera & № Ácidos \\
\hline TOTAL & 510 & 34 & 15 \\
\hline
\end{tabular}

\subsection{Aplicación de ácidos.}

Dado por ejemplo el grupo de muestras de maderas sin tratar correspondientes al ácido no10 (ácido oleico), se disponían en orden sobre una mesa de laboratorio, donde se colocaba a continuación, de una en una a las muestras, una lámina plástica perimetral, cuya función era contener el ácido n10 sobre la superficie de la muestra a tratar, formando una lámina o película de ácido, definida por el perímetro de la muestra.

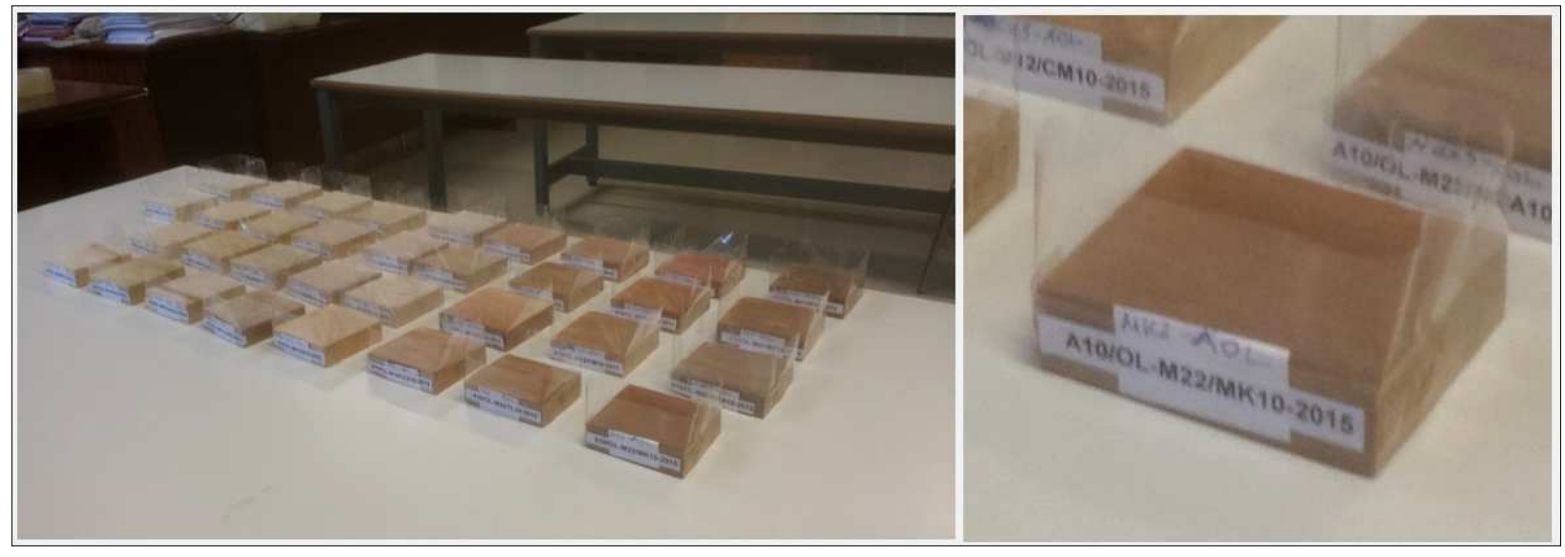

Figura 56. Preparación láminas. Ácido nำ10 (Ácido Oléico). Ejemplo. Elaboración propia.

Una vez colocadas las láminas se colocaban sobre una bandeja, en cuya superficie se disponía una lámina de plástico resistente a los ácidos y se llevaban a la sala de química del laboratorio, donde se depositaban sobre la superficie horizontal de la campana de laboratorio.

Las muestras aún sin tratar se colocaban en un lado de la campana y según se iba vertiendo el ácido incoloro en estado líquido mediante la pipeta graduada, siendo el volumen de ácido que se vertía sobre la cara superior de la muestra de 3 mililitros (cantidad que no empapa la muestra), extraído mediante mecanismo de pipetero (propipeta), el ácido se vertía sobre la superficie de la muestra a tratar de forma uniforme, contenido este por la lámina plástica perimetral dispuesta con anterioridad y 
se disponían las muestras al otro lado de la mesa de la campana, una vez que se observaba que las diferentes muestras depositadas en la campana se habían secado, se procedía a retirarlas, después las muestras se depositan en el espacio reservado en el laboratorio para su almacenamiento, en un contenedor individual y el armario destinado a todas las muestras, para ser por último procesadas las correspondientes imágenes de las muestras tratadas con el ácido correspondiente.
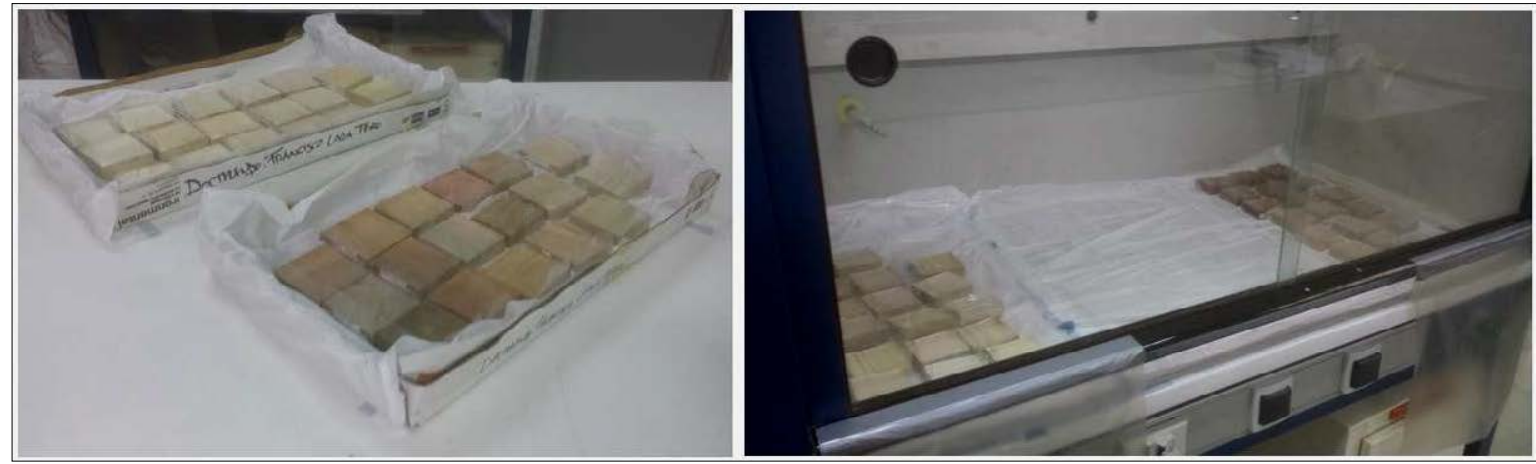

Figura 57. Bandejas y colocación en campana de laboratorio. Elaboración propia.

\subsection{Procesamiento de imágenes.}

Antes de comenzar los ensayos se determinaron las condiciones de iluminación que se utilizarían para la realización de las fotografías, disponiendo la mesa de reproducción siempre en la misma posición dentro de la sala utilizada para tal fin, además ser realizaron diversas pruebas a efectos del control de la cámara fotográfica y la determinación de los parámetros de la misma para la realización de las fotografías de las muestras antes y después de ser tratadas.

Posteriormente se fotografían las muestras tanto originales como las tratadas con los ácidos sobre la mesa de reproducción provista de 4 lámparas laterales de luz de día de $6.400 \mathrm{k}$ de temperatura, 23 watios de bajo consumo correspondientes a 115 watios de una lámpara incandescente, con un valor de luminancia de 1160 lúmenes, para fijar las mismas condiciones en las tomas de las fotos, después se coloca la cámara fotográfica en la mesa de reproducción, en la que, en su base se sitúa la probeta de madera a una distancia de $40 \mathrm{~cm}$ desde la cara superior de ésta hasta el objetivo de la cámara, fijando los valores de la cámara, balance de blancos, diafragma, abertura, velocidad, etc, expuestas en la siguiente figura.

\begin{tabular}{|c|c|c|c|}
\hline \multicolumn{4}{|c|}{ CONDICIONES DE CÁMARA PARA EL PROCESAMIENTO DE IMÁGENES } \\
\hline Descripción & Condiciones & Descripción & Condiciones \\
\hline CÁMARA & Nikon Coolpix P-100 & Medición & Ponderada Central \\
\hline Modo & Manual & Continuo & Sí \\
\hline Flash & Sin Flash & Modo AF & Central \\
\hline Macro & Sin Macro & Autofoco & Sí \\
\hline ISO & 200 & Compensación Flash & $\mathrm{O}$ \\
\hline Balance de Blancos & Luz de Flash & Reducción Ruido & Auto \\
\hline Abertura & 3,5 & Control Distorsión & Off \\
\hline Velocidad & $1 / 60$ & D-Light & Off \\
\hline Calidad Imagen & Fine & Luz Sala & Todas \\
\hline Optimización Imagen & Personalizada & Tamaño Foto & $4 \mathrm{Mb}$ \\
\hline
\end{tabular}

Figura 58. Condiciones de la Cámara Fotográfica. Elaboración propia. 
Posteriormente se pulsa el botón disparador de la cámara fotográfica, realizando la foto sin flash ni zoom y en posición de manual, obteniendo una imagen completa de la muestra, una vez que se dispone de la imagen se procede a visualizar mediante programa informático PhotoShop CS5, recortando la imagen por el perímetro de la muestra, eliminando las zonas no pertenecientes a la muestra.

\subsection{Obtención de Histogramas.}

Una vez que se dispone de la imagen, se proyecta una cuadrícula dispuesta simétricamente sobre la muestra, de la cual se obtienen los datos del histograma pertenecientes a el espacio de color RGB, seleccionado de la cuadrícula un área central de iguales dimensiones en todas las muestras,

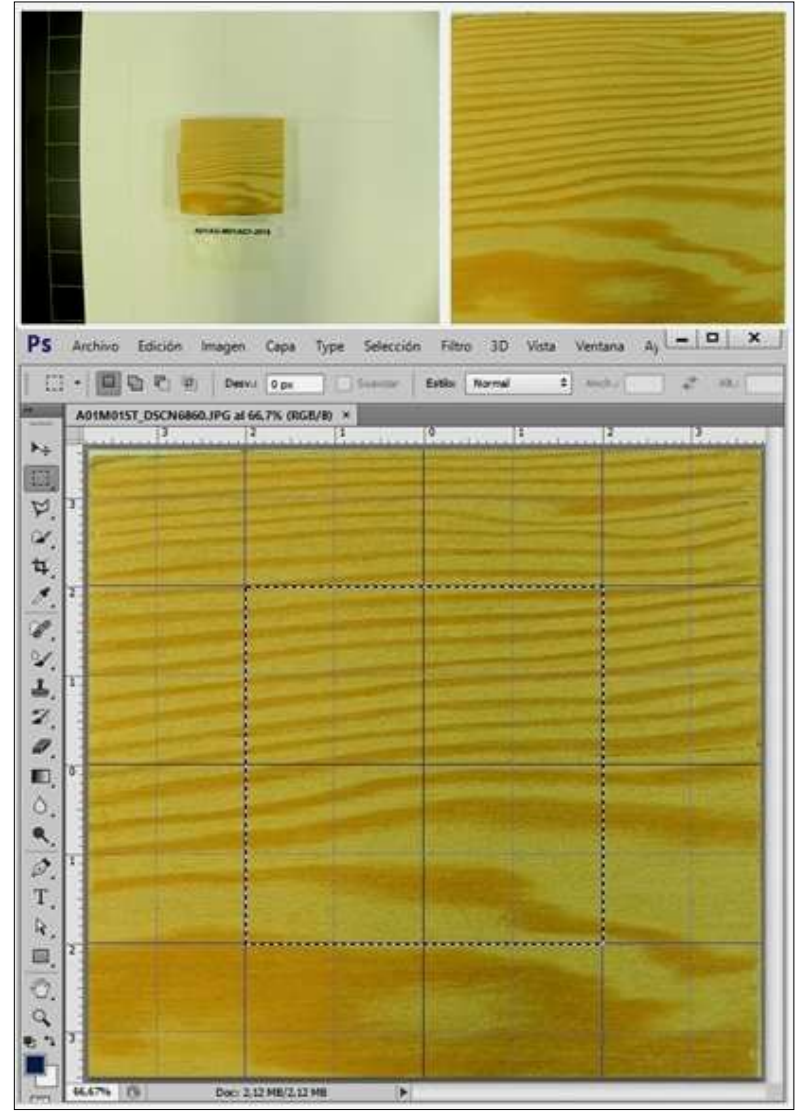

Figura 59. Foto original, recortada y rejilla. Ejemplo. Elaboración propia.

Mediante dicho histograma que se proyecta sobre una representación de coordenadas cartesianas definida por una gráfica de barras que representan el número de pixeles de la imagen por cada valor de luminosidad, situando en el eje de abscisa (horizontal) las diferentes luminosidades divididas en 256 columnas, situándose el "negro" con valor (0) a la izquierda y el "blanco" con valor (255) a la derecha y en el eje de ordenadas (vertical) donde la altura de cada una de las columnas determina el número de píxeles que hay por cada uno de los valores de luminosidad de cada color. 


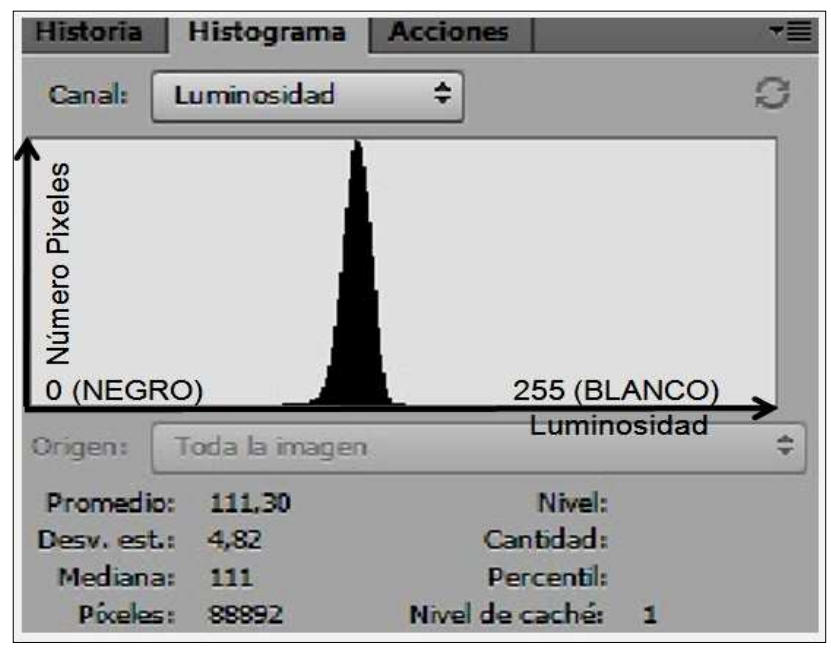

Figura 60. Histograma. Coordenadas. Valores. Elaboración propia

De esta forma se obtienen los histogramas tanto del promedio (valor medio de luminosidad del conjunto de pixeles), como los valores de luminosidad, rojo, verde y azul, por separado, para posteriormente comparar proporcionalmente los valores obtenidos y observar la variación cromática de las muestras, mediante el análisis de los resultados, tanto de las muestras sin tratar como de las mismas muestras después de ser tratadas superficialmente con el correspondiente ácido incoloro en estado líquido

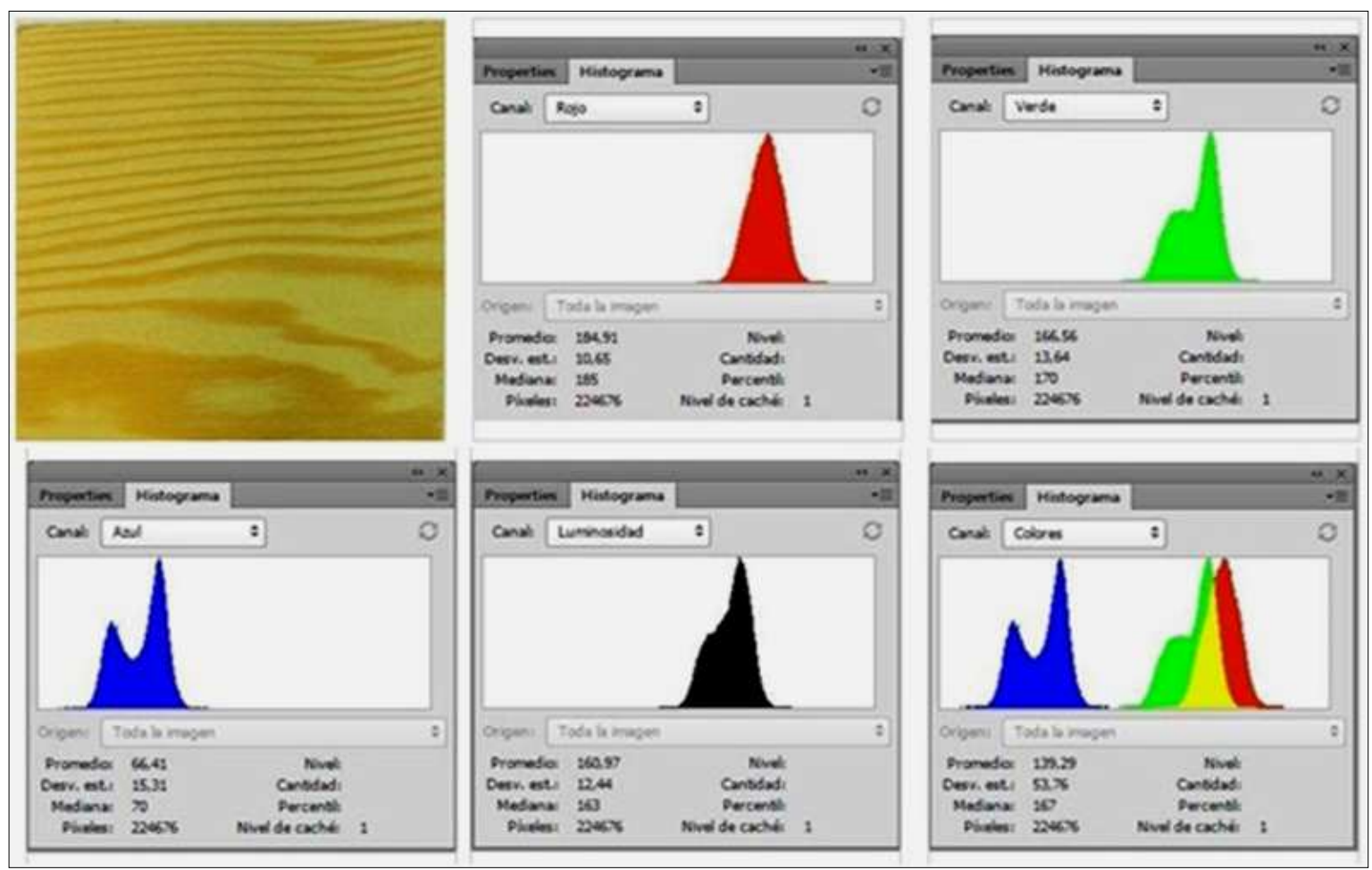

Figura 61.Histograma de Rojo, Verde, Azul, Luminosidad y Promedio. Elaboración propia. 


\subsection{Fichas y Tablas de resultados de cada ensayo.}

Cuando se obtienen los diferentes histogramas, los resultados se organizan en fichas con los diversos valores obtenidos, donde se refleja la gráfica particular del ensayo y dado el volumen de datos, los resultados se organizan en varias gráficas, también en el proceso se utilizan tablas de hoja de datos para obtener otros valores comentados en el punto siguiente.

\subsection{Ordenación de resultados.}

La generación de fichas, gráficas y tablas permite ordenar los resultados, en función de cada uno de los 15 ácidos seleccionados aplicado a las 34 especies de madera seleccionadas, realizadas y ordenadas por ácidos y por maderas.

En las fichas se reflejó la muestra de madera sin tratar detallada como (ST) y la muestra de la madera tratada detallada como (TT), detallando en cada caso los histogramas obtenidos con el valor obtenido y también los valores de diferencia entre cada caso detallados como (DF).

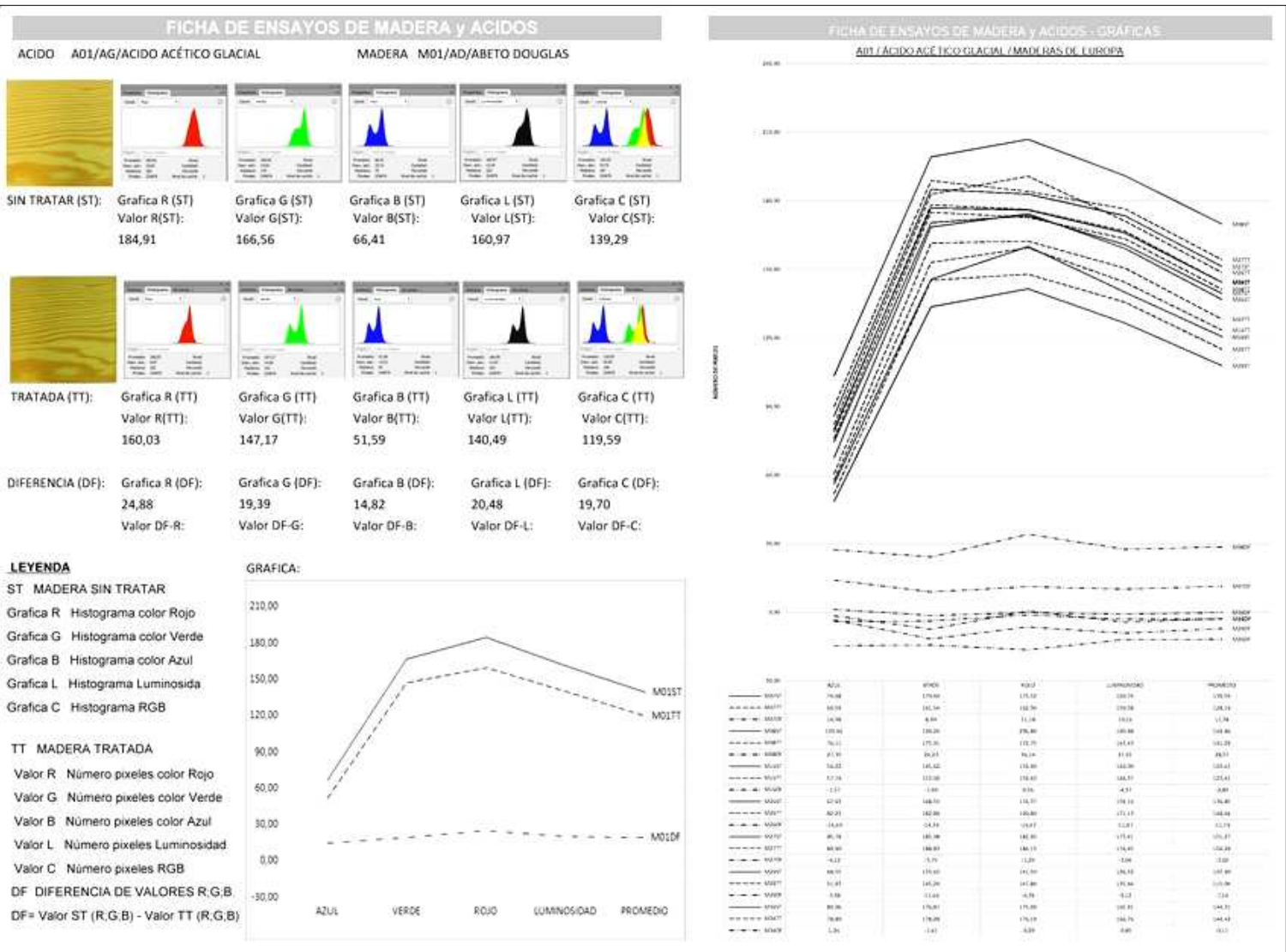

Figura 62.Ficha resultado y Gráfica tipo.Ejemplo gráfica orden ácido.Elaboración propia.

En el caso de las gráficas ordenadas por ácidos, que se subdividen por continentes, se observaran 3 tipos de líneas, las correspondientes a los ensayos de muestras de madera sin tratar se representan mediante una línea continua, las muestras de madera tratadas con ácidos, se representan mediante una línea discontinua de rayas y las 
diferencias de valores, se representan mediante una línea discontinua de rayas y puntos, cada una de las líneas lleva a su lado derecho un código que se compone del código de la madera, seguido del código "ST" para detallar los valores de la madera sin tratar, "TT" para detallar los valores de la madera tratada y "DF" para los valores de diferencia entre las anteriores gráficas, como se observa en la figura siguiente, de la misma forma se realizará para las gráficas ordenadas para cada madera.
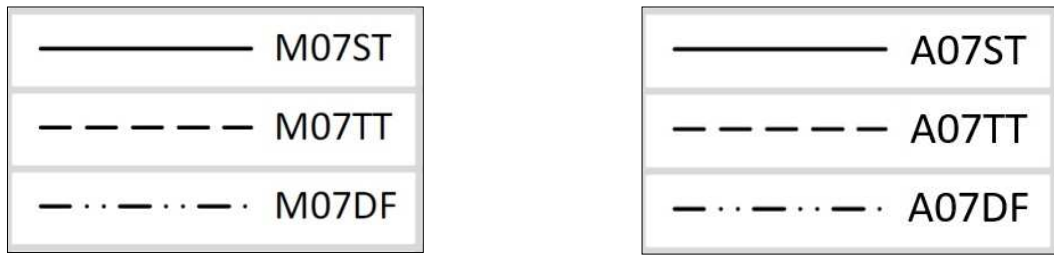

Figura 63. Representación gráfica de valores. Códigos. Ejemplo. Gráfica ácidos / 34 Maderas (izq.). Gráficas Maderas /15 ácidos (dcha.).Elaboración propia.

Por último, debajo de las gráficas se observa una tabla resumen, donde en la columna izquierda se refleja el esquema de la gráfica de la que se trate, seguida en la correspondiente columna de los diferentes valores de rojo, verde, azul, luminosidad y promedio, alineados verticalmente con los correspondientes puntos en la variación de la correspondiente gráfica.

\subsection{Conclusiones al capítulo}

Las muestras de maderas de cada especie pertenecen a la misma tabla de madera y por extensión a la misma parte del árbol, y en todos los casos procedentes del mismo almacén de reconocido prestigio. La madera aserrada permite con cualquier tipo de despiece obtener muestras de madera uniforme y después de ser procesadas obtener una base homogénea y adecuada para la aplicación superficial de ácidos líquidos incoloros, que permitió la alteración de la estructura de la capa superficial de las muestras de madera y por extensión generar una capa de protección y una variación en el color de la madera.

La metodología descrita permitió una uniformidad en la presentación de los datos obtenidos en los ensayos y la comparación entre los mismos, para poder llegar a conclusiones. 


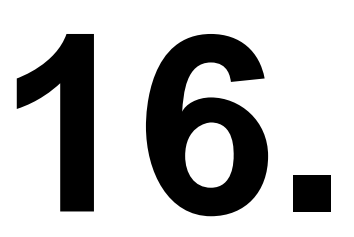

RESULTADOS DE LOS ENSAYOS DE VARIACIÓN CROMÁTICA

Se exponen los resultados obtenidos de variación cromática en los ensayos realizados. 


\section{RESULTADOS DE LOS ENSAYOS DE VARIACIÓN CROMÁTICA.}

Para la presentación de los ensayos de variación cromática de la aplicación superficial de los ácidos incoloros en estado líquido sobre maderas de construcción se han realizado fichas donde se recogen los resultados obtenidos antes y después de ser tratadas las muestras de madera. Dichas fichas se han diseñado de la siguiente forma.

En la parte superior se detalla el ácido aplicado y la madera elegida, después una zona inferior con los resultados de la madera sin tratar (ST), a continuación los resultados de la madera tratada (TT), debajo las diferencias entre los resultados (DF) y por último una representación cartesiana con el eje vertical donde se sitúan los valores de tono de intensidad de color o rango, en el eje horizontal los valores de rojo, verde, azul, luminosidad y promedio y la línea continua de los valores de la madera sin tratar con su código seguido del valor "ST", de la línea discontinua de la madera tratada con su código seguido del valor "TT" y de la línea de punto y raya de la diferencia entre resultados de la madera tratada y sin tratar con su código seguido del valor "DF".

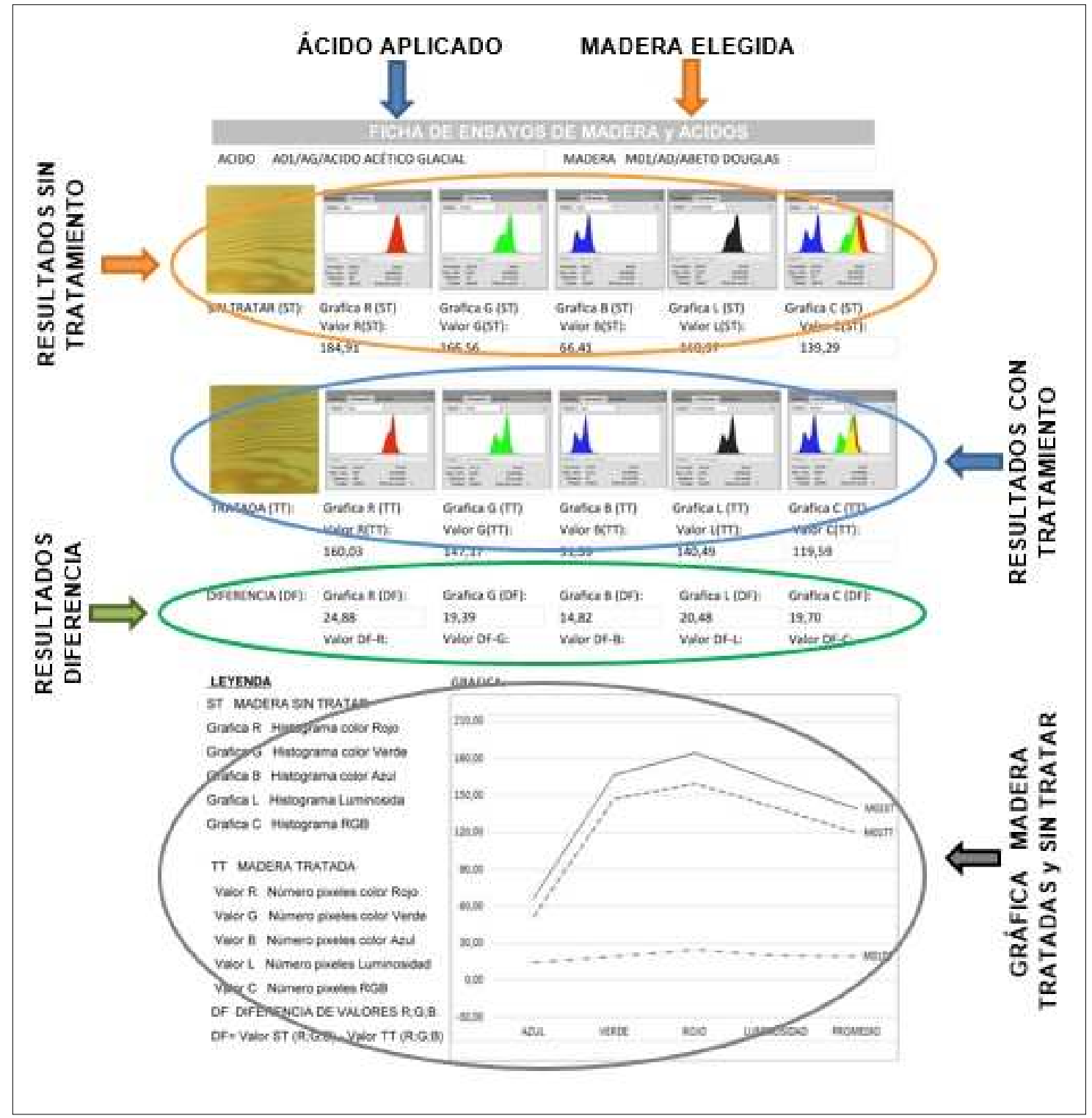

Figura 64. Ejemplo tipo de Ficha de ensayo. Elaboración propia.

Universidad Politécnica de Madrid - Escuela Técnica Superior de Arquitectura - Departamento de Construcción y Tecnología Arquitectónica Directores: Dr. Alfonso García Santos y Dr. Antonio Rodríguez Rodríguez. Doctorando: D. Francisco Lora Toro 


\section{A01 / ÁCIDO ACÉTICO GLACIAL}

\section{FICHA DE ENSAYOS DE MADERA Y ACIDOS}

\section{ACIDO A01/AG/ACIDO ACÉTICO GLACIAL}
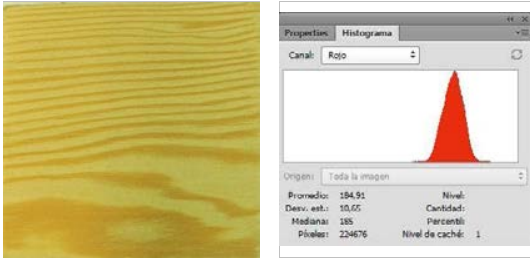

SIN TRATAR (ST): Grafica R (ST)

Valor R(ST):

184,91

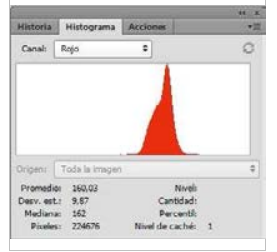

TRATADA (TT): Grafica $R(T T)$

Valor $\mathrm{R}(\mathrm{TT})$ :

160,03

DIFERENCIA (DF) Grafica R (DF): Valor DF-R: 24,88

\section{LEYENDA}

ST MADERA SIN TRATAR

Grafica R Histograma color Rojo

Grafica G Histograma color Verde

Grafica B Histograma color Azul

Grafica L Histograma Luminosidad

Grafica C Histograma RGB

TT MADERA TRATADA

Valor $\mathrm{R}$ Número pixeles color Rojo

Valor $\mathrm{G}$ Número pixeles color Verde

Valor B Número pixeles color Azul

Valor $L$ Número pixeles Luminosidad

Valor C Número pixeles RG

DF DIFERENCIA DE VALORES R;G;

$\mathrm{DF}=$ Valor $\mathrm{ST}(\mathrm{R} ; \mathrm{G} ; \mathrm{B})$ - Valor TT(R;G;B

166,56

147,17 19,39

\section{MADERA M01/AD/ABETO DOUGLAS}
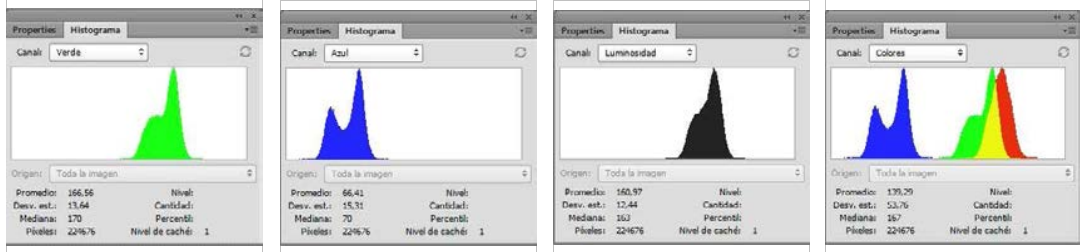

Grafica G (ST)

Grafica B (ST)

Grafica L (ST)

Grafica C (ST)

Valor G(ST):

Valor B(ST):

Valor L(ST):

Valor C(ST):

66,41

160,97

139,29
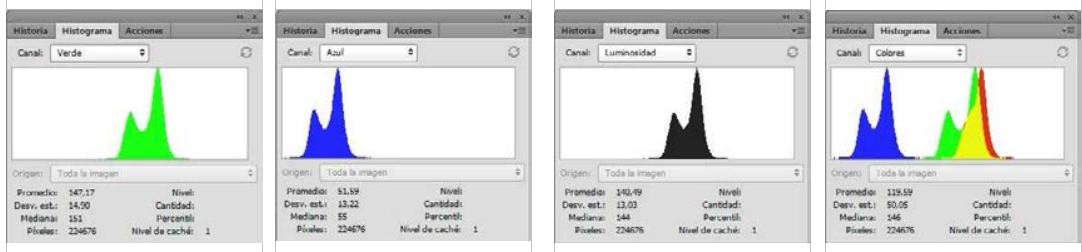

Grafica G (TT)

Grafica B (TT)

Grafica L (TT)

Grafica C (TT)

Valor G(TT):

Valor $\mathrm{B}(\mathrm{TT})$ :

Valor L(TT):

Valor $\mathrm{C}(\mathrm{TT})$ :

51,59

140,49

119,59

Grafica G (DF): Grafica B (DF): Grafica L (DF): Grafica C (DF): Valor DF-G: $\quad$ Valor DF-B: Valor DF-L: Valor DF-C: 14,82 20,48 19,70

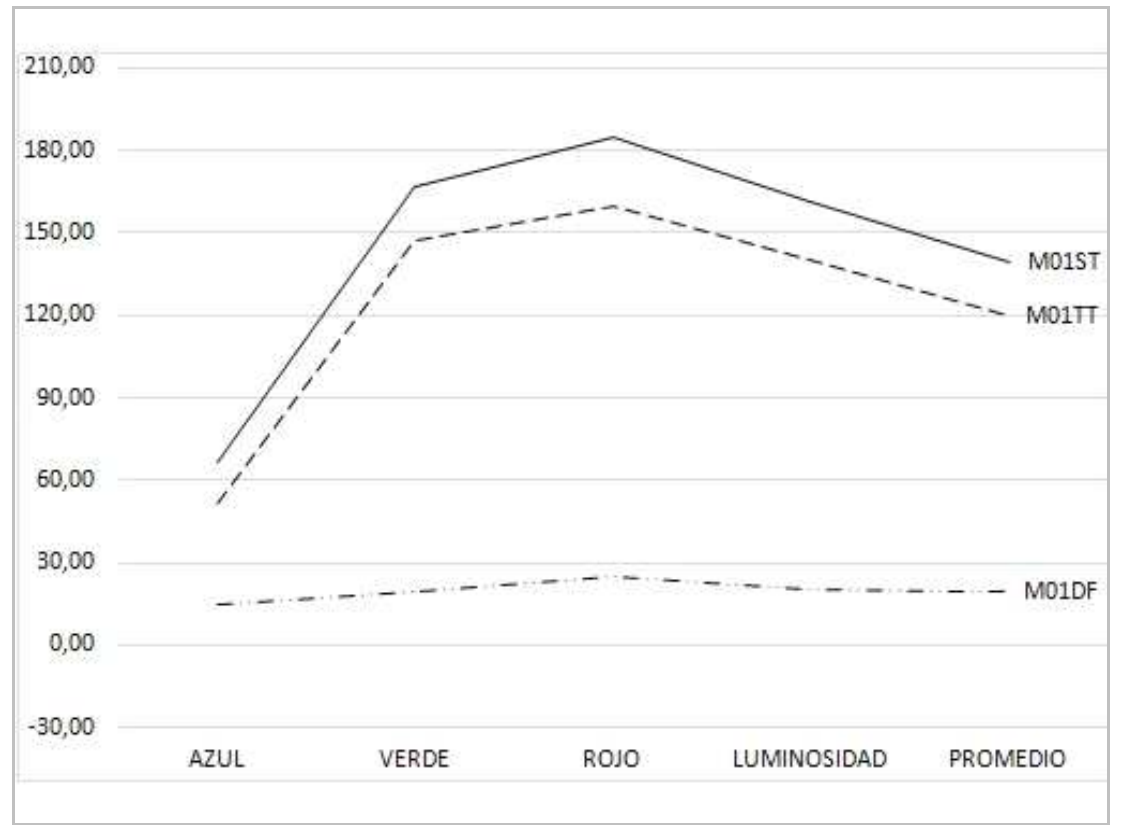

Universidad Politécnica de Madrid - Escuela Técnica Superior de Arquitectura - Departamento de Construcción y Tecnología Arquitectónica Directores: Dr. Alfonso García Santos y Dr. Antonio Rodríguez Rodríguez. Doctorando: D. Francisco Lora Toro 


\section{FICHA DE ENSAYOS DE MADERA Y ACIDOS}

ACIDO A01/AG/ACIDO ACÉTICO GLACIAL

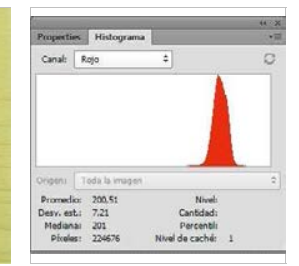

SIN TRATAR (ST): Grafica R (ST)

Valor R(ST):

200,51

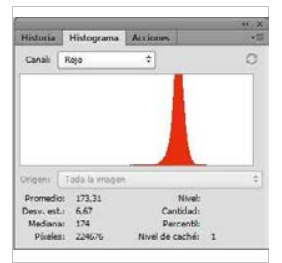

TRATADA (TT): Grafica R (TT)

Valor $\mathrm{R}(\mathrm{TT})$ :

173,31

DIFERENCIA (DF) Grafica R (DF):

Valor DF-R:

27,20

GRAFICA:

\section{LEYENDA}

ST MADERA SIN TRATAR

Grafica R Histograma color Rojo

Grafica G Histograma color Verde

Grafica B Histograma color Azul

Grafica L Histograma Luminosidad

Grafica C Histograma RGB

TT MADERA TRATADA

Valor $R$ Número pixeles color Rojo

Valor $\mathrm{G}$ Número pixeles color Verde

Valor B Número pixeles color Azul

Valor $L$ Número pixeles Luminosidad

Valor C Número pixeles RG

DF DIFERENCIA DE VALORES R;G; $\mathrm{DF}=$ Valor $\mathrm{ST}(\mathrm{R} ; \mathrm{G} ; \mathrm{B})$ - Valor TT(R;G;B 17,18

\section{MADERA M02/ABA/ARCE BLANDO AMERICANO}

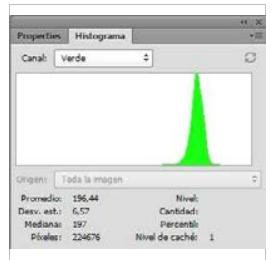

Grafica G (ST)

Valor $\mathrm{G}(\mathrm{ST})$ :

196,44
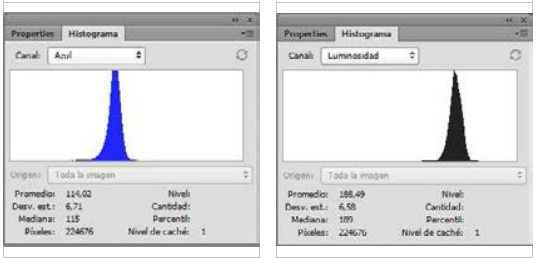

Grafica B (ST)

Grafica L (ST)

Valor B(ST):

Valor L(ST):

188,49

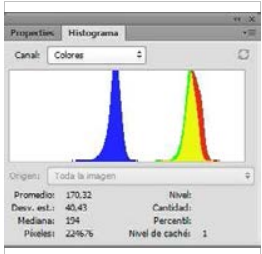

Grafica C (ST)

114,02
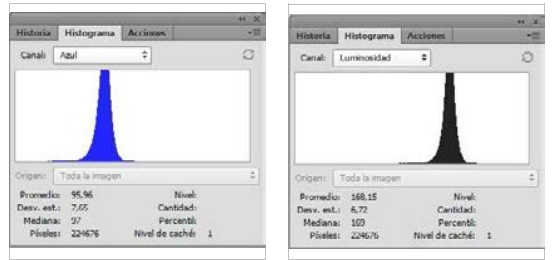

Grafica L (TT)

Valor C(ST):

170,32

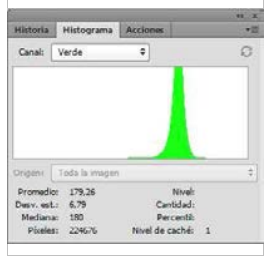

Grafica G (TT)

Grafica B (TT)

Valor L(TT):

168,15

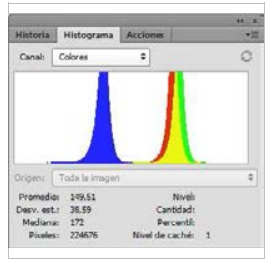

Grafica C (TT)

Valor C(TT):

149,51 179,26

95,96

$\begin{array}{llll}\text { Grafica G (DF): } & \text { Grafica B (DF): } & \text { Grafica L (DF): } & \text { Grafica C (DF): } \\ \text { Valor DF-G: } & \text { Valor DF-B: } & \text { Valor DF-L: } & \text { Valor DF-C: }\end{array}$

$\begin{array}{llll}\text { Grafica G (DF): } & \text { Grafica B (DF): } & \text { Grafica L (DF): } & \text { Grafica C (DF): } \\ \text { Valor DF-G: } & \text { Valor DF-B: } & \text { Valor DF-L: } & \text { Valor DF-C: }\end{array}$ 18,06 20,34 20,81

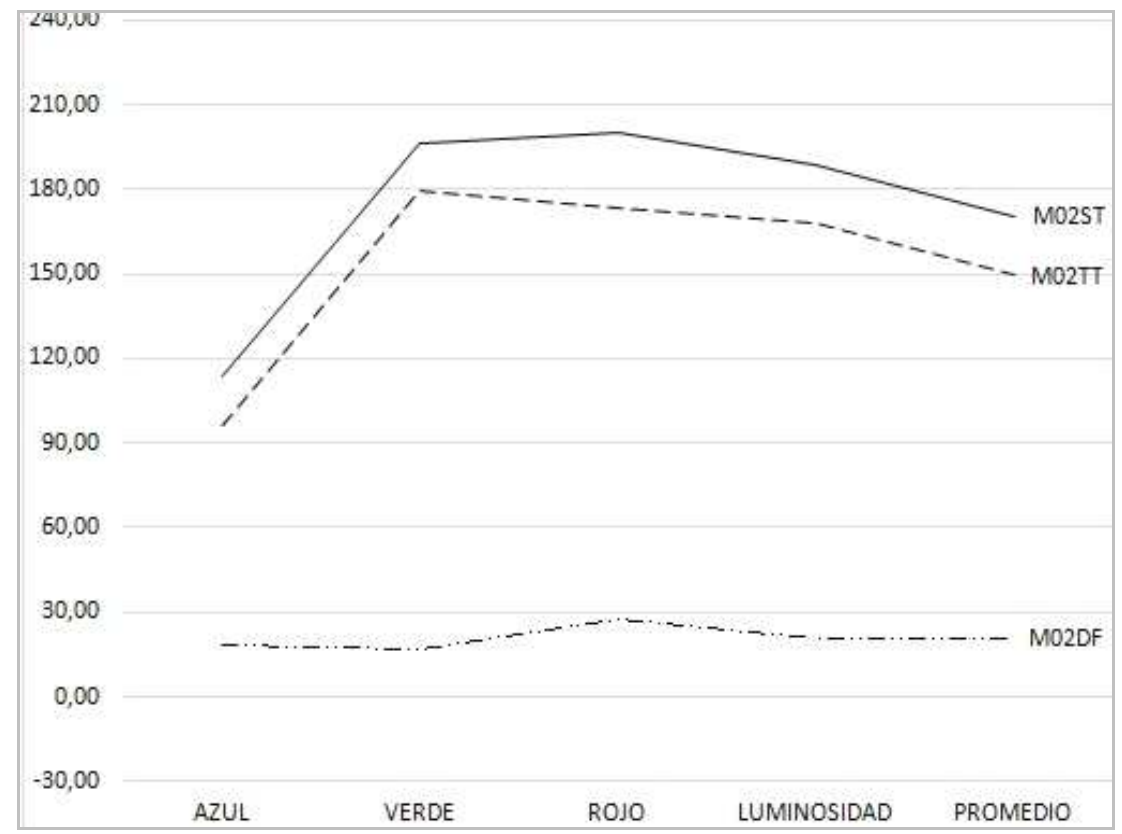

Universidad Politécnica de Madrid - Escuela Técnica Superior de Arquitectura - Departamento de Construcción y Tecnología Arquitectónica Directores: Dr. Alfonso García Santos y Dr. Antonio Rodríguez Rodríguez. Doctorando: D. Francisco Lora Toro 


\section{FICHA DE ENSAYOS DE MADERA Y ACIDOS}

ACIDO A01/AG/ACIDO ACÉTICO GLACIAL
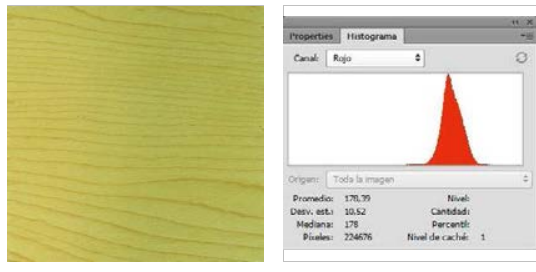

SIN TRATAR (ST): Grafica R (ST)

Valor R(ST):

178,39

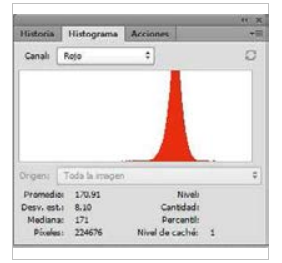

TRATADA (TT): Grafica R (TT)

Valor $\mathrm{R}(\mathrm{TT})$ :

170,91

DIFERENCIA (DF) Grafica R (DF): Valor DF-R: 7,48

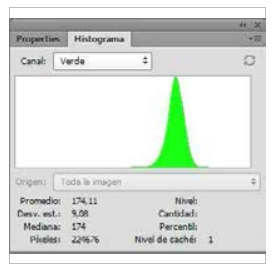

Grafica G (ST)

Valor G(ST):

174,11

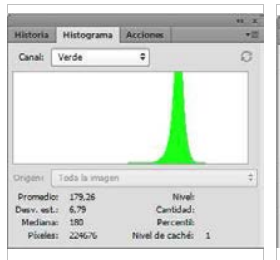

Grafica G (TT)

Valor $\mathrm{G}(\mathrm{TT})$ :

173,55

MADERA MO3/ADA/ARCE DURO AMERICANO

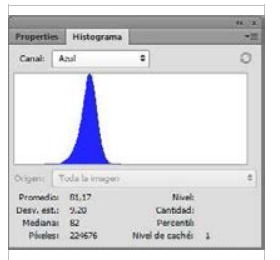

Grafica B (ST)

Valor B(ST):

81,17

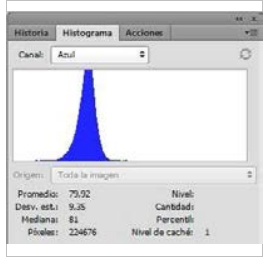

Grafica B (TT)

Valor $\mathrm{B}(\mathrm{TT})$ :

79,92

Grafica G (DF): Grafica B (DF):

Valor DF-B:

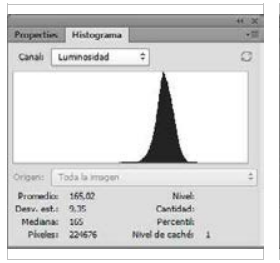

Grafica L (ST)

Valor L(ST):

165,02

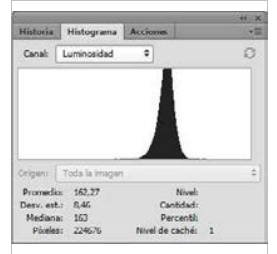

Grafica L (TT)

Valor L(TT):

162,27

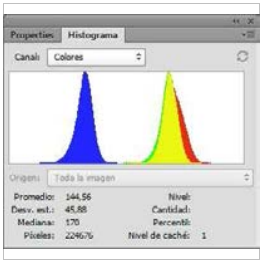

Grafica C (ST)

Valor C(ST):

144,56

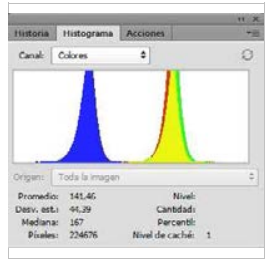

Grafica C (TT)

Valor $\mathrm{C}(\mathrm{TT})$ :

141,46

Grafica L (DF): Grafica C (DF):

Valor DF-L:

Valor DF-C:

$\begin{array}{llll}0,56 & 1,25 & 2,75 & 3,10\end{array}$

GRAFICA:

\section{LEYENDA}

ST MADERA SIN TRATAR

Grafica R Histograma color Rojo

Grafica G Histograma color Verde

Grafica B Histograma color Azul

Grafica L Histograma Luminosidad

Grafica C Histograma RGB

TT MADERA TRATADA

Valor $\mathrm{R}$ Número pixeles color Rojo

Valor $\mathrm{G}$ Número pixeles color Verde

Valor B Número pixeles color Azul

Valor L Número pixeles Luminosidad

Valor C Número pixeles RG

DF DIFERENCIA DE VALORES R;G; $\mathrm{DF}=$ Valor $\mathrm{ST}(\mathrm{R} ; \mathrm{G} ; \mathrm{B})$ - Valor TT(R;G;B

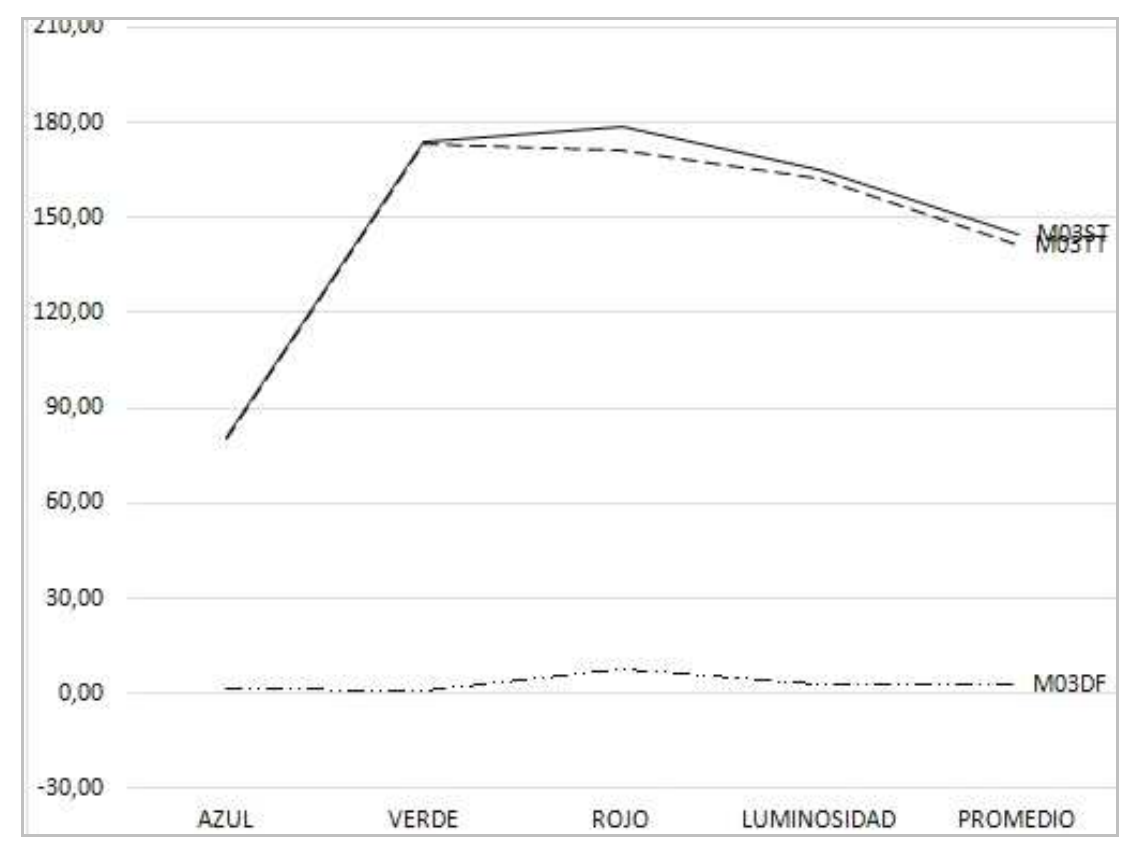

Universidad Politécnica de Madrid - Escuela Técnica Superior de Arquitectura - Departamento de Construcción y Tecnología Arquitectónica Directores: Dr. Alfonso García Santos y Dr. Antonio Rodríguez Rodríguez. Doctorando: D. Francisco Lora Toro 


\section{FICHA DE ENSAYOS DE MADERA Y ACIDOS}

\section{ACIDO A01/AG/ACIDO ACÉTICO GLACIAL}

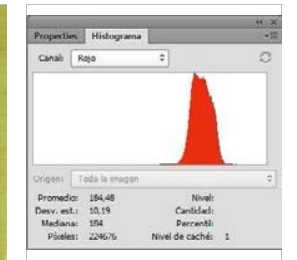

SIN TRATAR (ST): Grafica R (ST)

Valor R(ST):

184,48

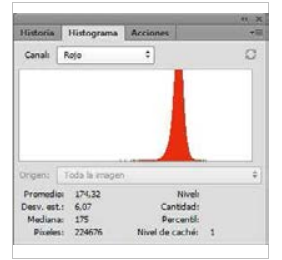

TRATADA (TT): Grafica R (TT)

Valor R(TT):

174,32

DIFERENCIA (DF) Grafica R (DF):

Valor DF-R:

10,16

GRAFICA:

\section{LEYENDA}

ST MADERA SIN TRATAR

Grafica R Histograma color Rojo

Grafica G Histograma color Verde

Grafica B Histograma color Azul

Grafica L Histograma Luminosidad

Grafica C Histograma RGB

TT MADERA TRATADA

Valor $\mathrm{R}$ Número pixeles color Rojo

Valor $\mathrm{G}$ Número pixeles color Verde

Valor B Número pixeles color Azul

Valor $L$ Número pixeles Luminosidad

Valor C Número pixeles RG

DF DIFERENCIA DE VALORES R;G; $\mathrm{DF}=$ Valor $\mathrm{ST}(\mathrm{R} ; \mathrm{G} ; \mathrm{B})$ - Valor TT(R;G;B

\section{MADERA M04/AS/AYOUS}

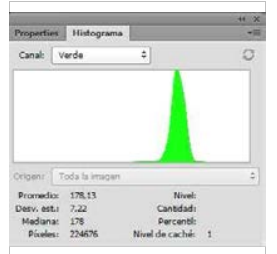

Grafica G (ST)

Valor G(ST):

178,13

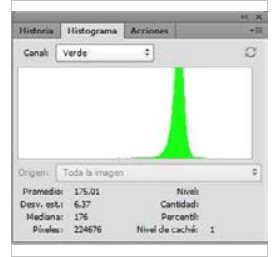

Grafica G (TT)

Valor $\mathrm{G}(\mathrm{TT})$ :

175,01

Grafica G (DF): Grafica B (DF):

Valor DF-G:

Valor DF-B:

7,20

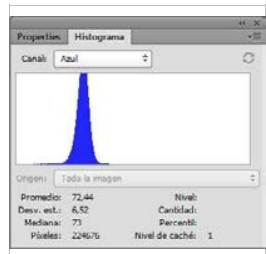

Grafica B (ST)

Valor B(ST):

72,44

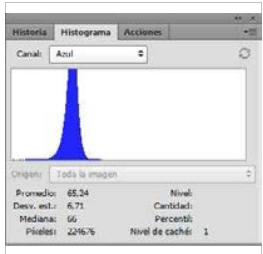

Grafica B (TT)

Valor B(TT):

65,24

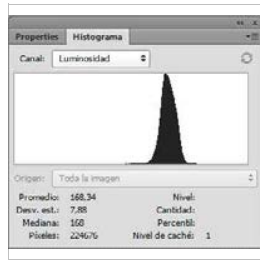

Grafica L (ST)

Valor L(ST):

168,34

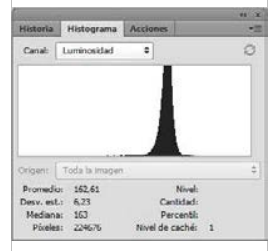

Grafica L (TT)

Valor L(TT):

162,61

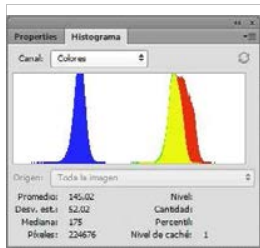

Grafica C (ST)

Valor C(ST):

145,02
3,12

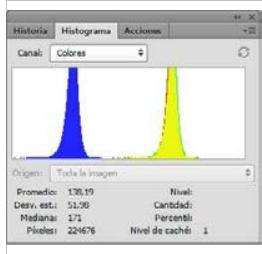

Grafica C (TT)

Valor C(TT):

138,19

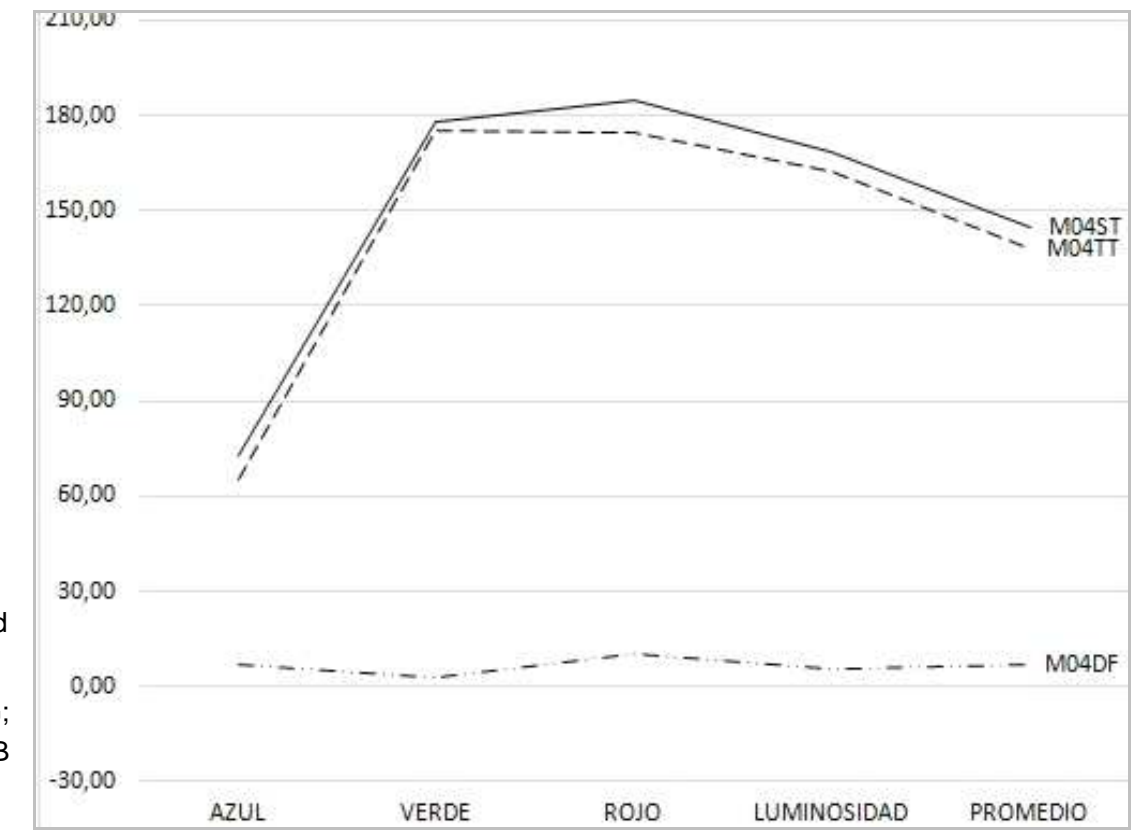

Universidad Politécnica de Madrid - Escuela Técnica Superior de Arquitectura - Departamento de Construcción y Tecnología Arquitectónica Directores: Dr. Alfonso García Santos y Dr. Antonio Rodríguez Rodríguez. Doctorando: D. Francisco Lora Toro 


\section{FICHA DE ENSAYOS DE MADERA Y ACIDOS}

\section{ACIDO A01/AG/ACIDO ACÉTICO GLACIAL}
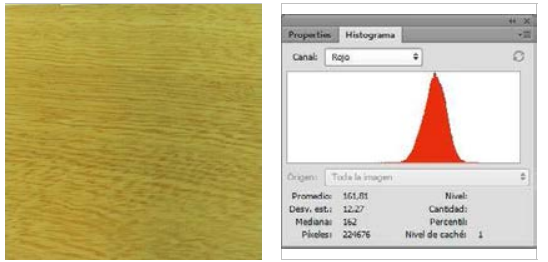

SIN TRATAR (ST): Grafica R (ST)

Valor R(ST):

161,81

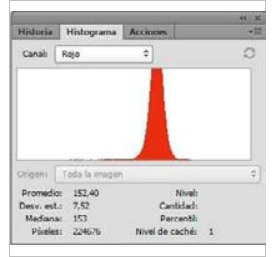

TRATADA (TT): Grafica R (TT)

Valor $\mathrm{R}(\mathrm{TT})$ :

152,40

DIFERENCIA (DF) Grafica R (DF): Valor DF-R:

9,41

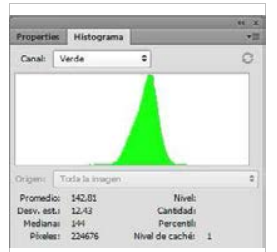

Grafica G (ST)

Valor G(ST):

142,81

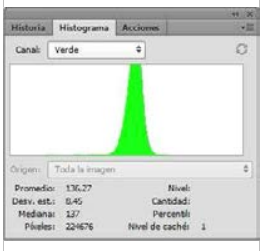

Grafica G (TT)

Valor $\mathrm{G}(\mathrm{TT})$ :

136,27

\section{MADERA M05/BS/BOSSÉ}

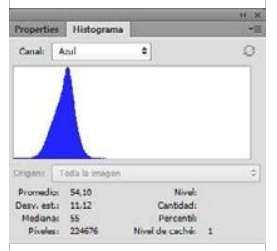

Grafica B (ST)

Valor $\mathrm{B}(\mathrm{ST})$ :

54,10

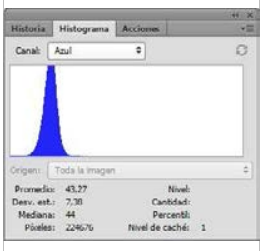

Grafica B (TT)

Valor $\mathrm{B}(\mathrm{TT})$ :

43,27

Grafica G (DF): Grafica B (DF):

Grafica L (DF):

Grafica C (DF):

Valor DF-G: Valor DF-B:

Valor DF-L:

Valor DF-C:

$\begin{array}{llll}6,54 & 10,83 & 7,85 & 8,92\end{array}$

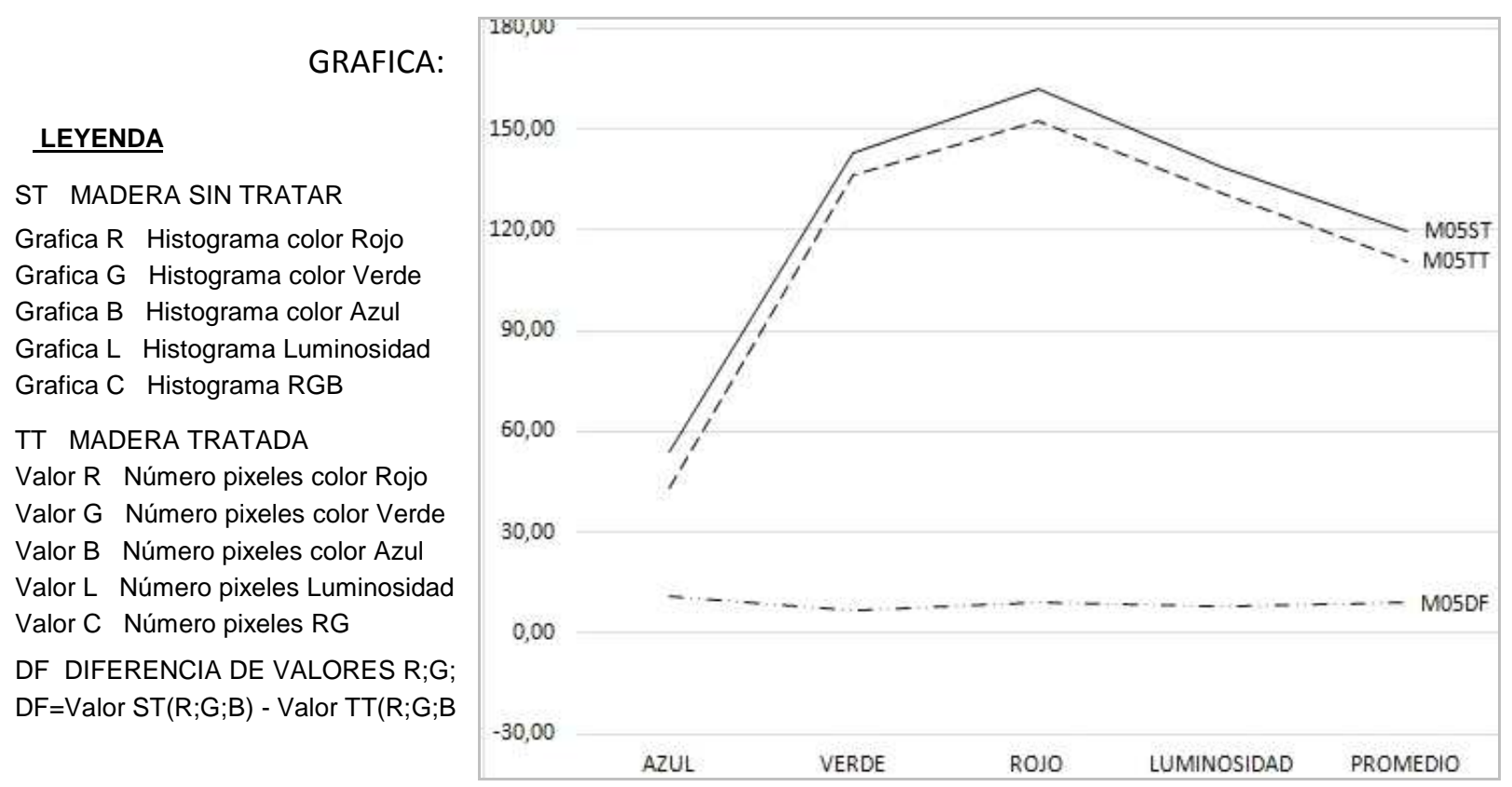

Universidad Politécnica de Madrid - Escuela Técnica Superior de Arquitectura - Departamento de Construcción y Tecnología Arquitectónica Directores: Dr. Alfonso García Santos y Dr. Antonio Rodríguez Rodríguez. Doctorando: D. Francisco Lora Toro 


\section{FICHA DE ENSAYOS DE MADERA Y ACIDOS}

\section{ACIDO A01/AG/ACIDO ACÉTICO GLACIAL}
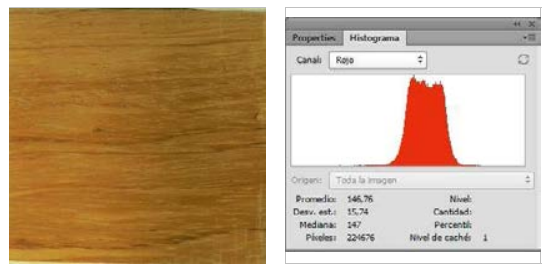

SIN TRATAR (ST): Grafica R (ST)

Valor R(ST):

146,76

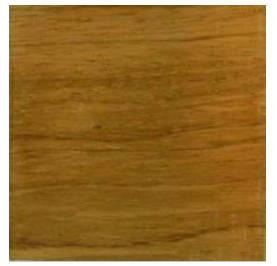

TRATADA (TT):

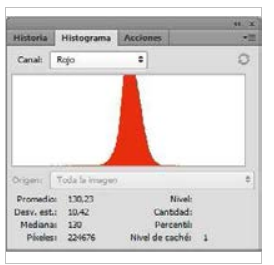

Grafica R (TT)

Valor R(TT):

130,23

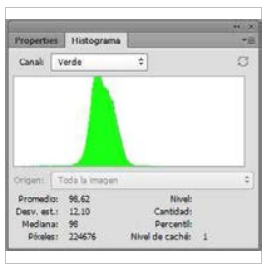

Grafica G (ST)

Valor $\mathrm{G}(\mathrm{ST})$ :

98,62

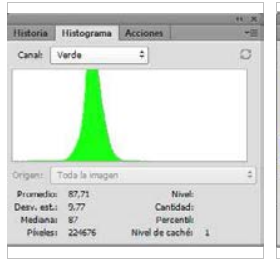

Grafica G (TT)

Valor $\mathrm{G}(\mathrm{TT})$ :

87,71

\section{MADERA M06/BG/BUBINGA}

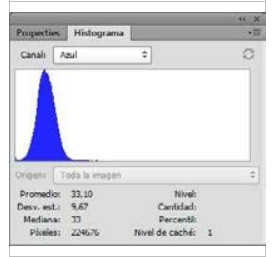

Grafica B (ST)

Valor $\mathrm{B}(\mathrm{ST})$ :

33,10

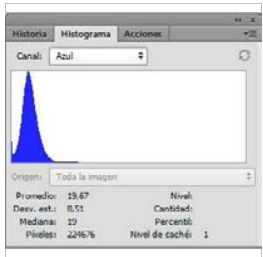

Grafica B (TT)

Valor $\mathrm{B}(\mathrm{TT})$ :

19,67

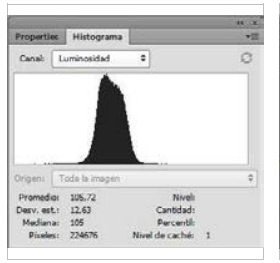

Grafica L (ST)

Valor L(ST):

105,72

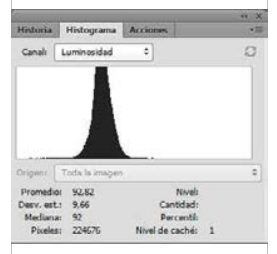

Grafica L (TT)

Valor L(TT):

92,82

Grafica L (DF):

Valor DF-L:

12,90

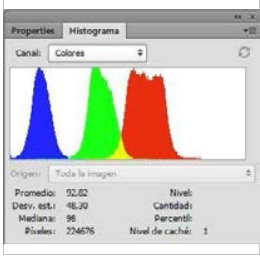

Grafica C (ST)

Valor C(ST):

92,82

DIFERENCIA (DF) Grafica R (DF):

Grafica G (DF): Grafica B (DF): Valor DF-B:

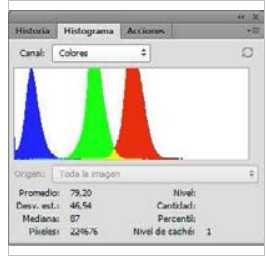

Valor DF-R:

Valor DF-G:

13,43

Grafica C (TT)

Valor $\mathrm{C}(\mathrm{TT})$ :

79,20

16,53

10,91

$12,90 \quad 13,62$

GRAFICA:

\section{LEYENDA}

ST MADERA SIN TRATAR

Grafica R Histograma color Rojo

Grafica G Histograma color Verde

Grafica B Histograma color Azul

Grafica L Histograma Luminosidad

Grafica C Histograma RGB

\section{TT MADERA TRATADA}

Valor $\mathrm{R}$ Número pixeles color Rojo

Valor $\mathrm{G}$ Número pixeles color Verde

Valor B Número pixeles color Azul

Valor L Número pixeles Luminosidad

Valor $C$ Número pixeles $R G$

DF DIFERENCIA DE VALORES R;G; $\mathrm{DF}=$ Valor $\mathrm{ST}(\mathrm{R} ; \mathrm{G} ; \mathrm{B})$ - Valor TT $(\mathrm{R} ; \mathrm{G} ; \mathrm{B}$

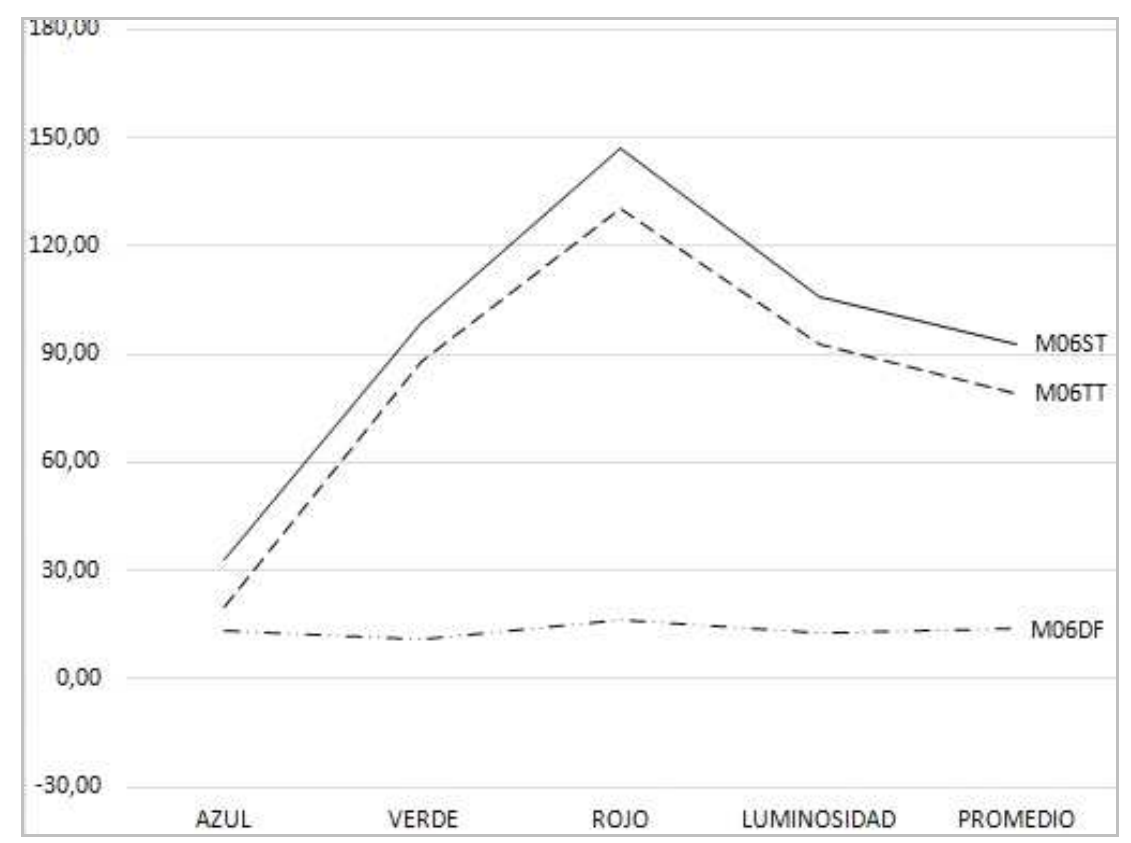

Universidad Politécnica de Madrid - Escuela Técnica Superior de Arquitectura - Departamento de Construcción y Tecnología Arquitectónica Directores: Dr. Alfonso García Santos y Dr. Antonio Rodríguez Rodríguez. Doctorando: D. Francisco Lora Toro 


\section{FICHA DE ENSAYOS DE MADERA Y ACIDOS}

\section{ACIDO A01/AG/ACIDO ACÉTICO GLACIAL}

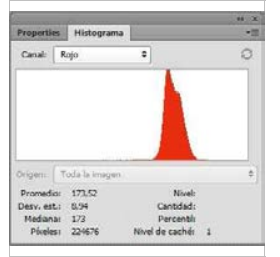

SIN TRATAR (ST): Grafica R (ST)

Valor R(ST):

173,52

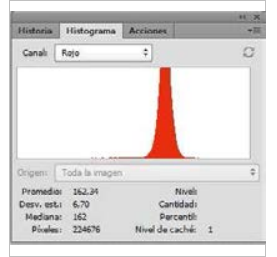

TRATADA (TT): Grafica $R(T T)$

Valor $\mathrm{R}(\mathrm{TT})$ :

162,34

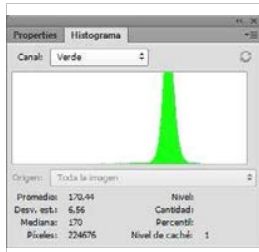

Grafica G (ST)

Valor $\mathrm{G}(\mathrm{ST})$ :

170,44

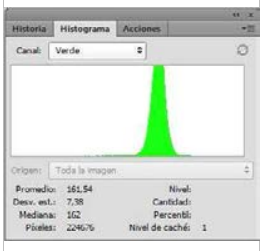

Grafica G (TT)

Valor $\mathrm{G}(\mathrm{TT})$ :

161,54
MADERA MOT/CÑ/CASTAÑO EUROPEO

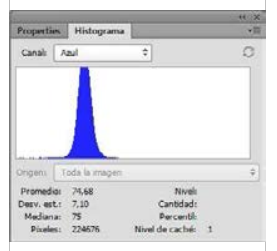

Grafica B (ST)

Valor B(ST):

74,68

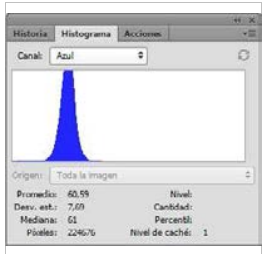

Grafica B (TT)

Valor $\mathrm{B}(\mathrm{TT})$ :

60,59

Grafica G (DF): Grafica B (DF):

Grafica L (DF):

Valor DF-L:

10,16

14,09

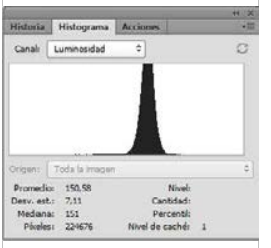

Grafica L (TT)

Valor L(TT):

150,58

or C(TT)

128,16 Valor DF-G: Valor DF-B:

Grafica C (DF):

8,90

Valor DF-C:

DIFERENCIA (DF) Grafica R (DF) 11,18

GRAFICA:

LEYENDA

ST MADERA SIN TRATAR

Grafica R Histograma color Rojo

Grafica G Histograma color Verde

Grafica B Histograma color Azul

Grafica L Histograma Luminosidad

Grafica C Histograma RGB

TT MADERA TRATADA

Valor R Número pixeles color Rojo

Valor $\mathrm{G}$ Número pixeles color Verde

Valor B Número pixeles color Azul

Valor $\mathrm{L}$ Número pixeles Luminosidad

Valor C Número pixeles RG

DF DIFERENCIA DE VALORES R;G;

$\mathrm{DF}=$ Valor $\mathrm{ST}(\mathrm{R} ; \mathrm{G} ; \mathrm{B})$ - Valor TT(R;G;B

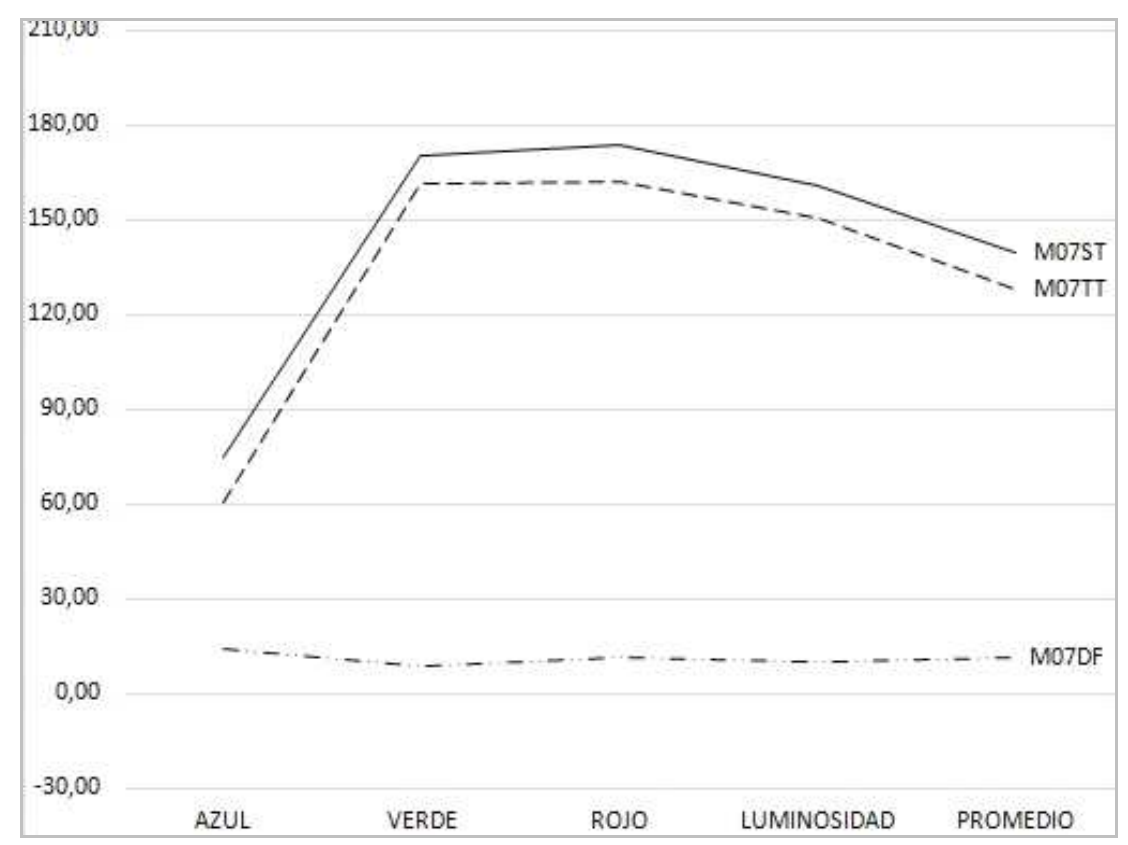

Universidad Politécnica de Madrid - Escuela Técnica Superior de Arquitectura - Departamento de Construcción y Tecnología Arquitectónica Directores: Dr. Alfonso García Santos y Dr. Antonio Rodríguez Rodríguez. Doctorando: D. Francisco Lora Toro 


\section{FICHA DE ENSAYOS DE MADERA Y ACIDOS}

\section{ACIDO A01/AG/ACIDO ACÉTICO GLACIAL}

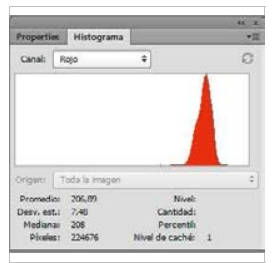

SIN TRATAR (ST): Grafica R (ST)

Valor R(ST):

206,89

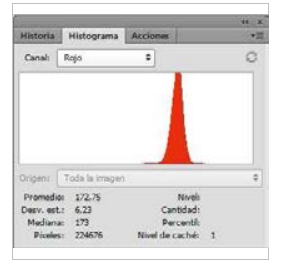

TRATADA (TT): Grafica R (TT) Valor $\mathrm{R}(\mathrm{TT})$ :

172,75

DIFERENCIA (DF) Grafica R (DF): Valor DF-R: 34,14

GRAFICA:

\section{LEYENDA}

ST MADERA SIN TRATAR

Grafica R Histograma color Rojo Grafica G Histograma color Verde Grafica B Histograma color Azul Grafica L Histograma Luminosidad Grafica C Histograma RGB

TT MADERA TRATADA

Valor $R$ Número pixeles color Rojo Valor $\mathrm{G}$ Número pixeles color Verde Valor B Número pixeles color Azul Valor $L$ Número pixeles Luminosidad Valor C Número pixeles RG DF DIFERENCIA DE VALORES R;G; $\mathrm{DF}=$ Valor $\mathrm{ST}(\mathrm{R} ; \mathrm{G} ; \mathrm{B})$ - Valor TT $(\mathrm{R} ; \mathrm{G} ; \mathrm{B}$

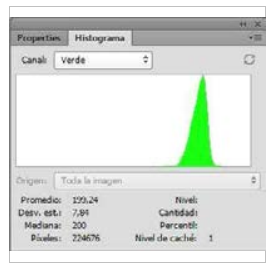

Grafica G (ST)

Valor $\mathrm{G}(\mathrm{ST})$ :

199,24

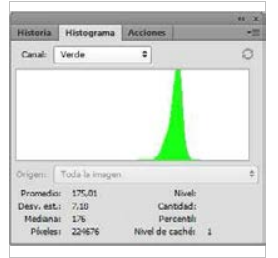

Grafica G (TT)

Valor $\mathrm{G}(\mathrm{TT})$ :

175,01
MADERA M08/CPE/CHOPO EUROPEO

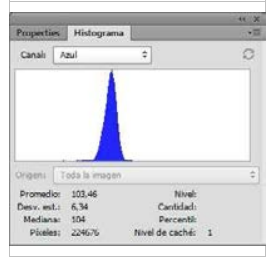

Grafica B (ST)

Valor B(ST):

103,46

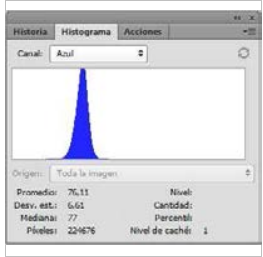

Grafica B (TT)

Valor $\mathrm{B}(\mathrm{TT})$ :

76,11

Grafica G (DF): Grafica B (DF): Valor DF-B: 27,35 24,23

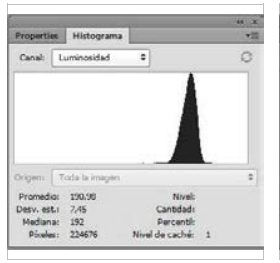

Grafica L (ST)

Valor L(ST):

190,98

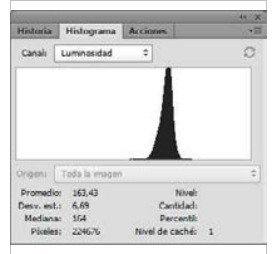

Grafica L (TT)

Valor L(TT):

163,43

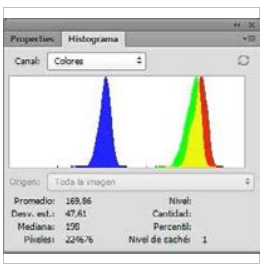

Grafica C (ST)

Valor C(ST):

169,86

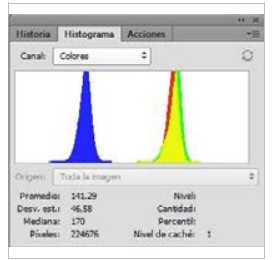

Grafica C (TT)

Valor C(TT):

141,29

Grafica L (DF): Grafica C (DF): Valor DF-L: $\quad$ Valor DF-C: 27,55 28,57

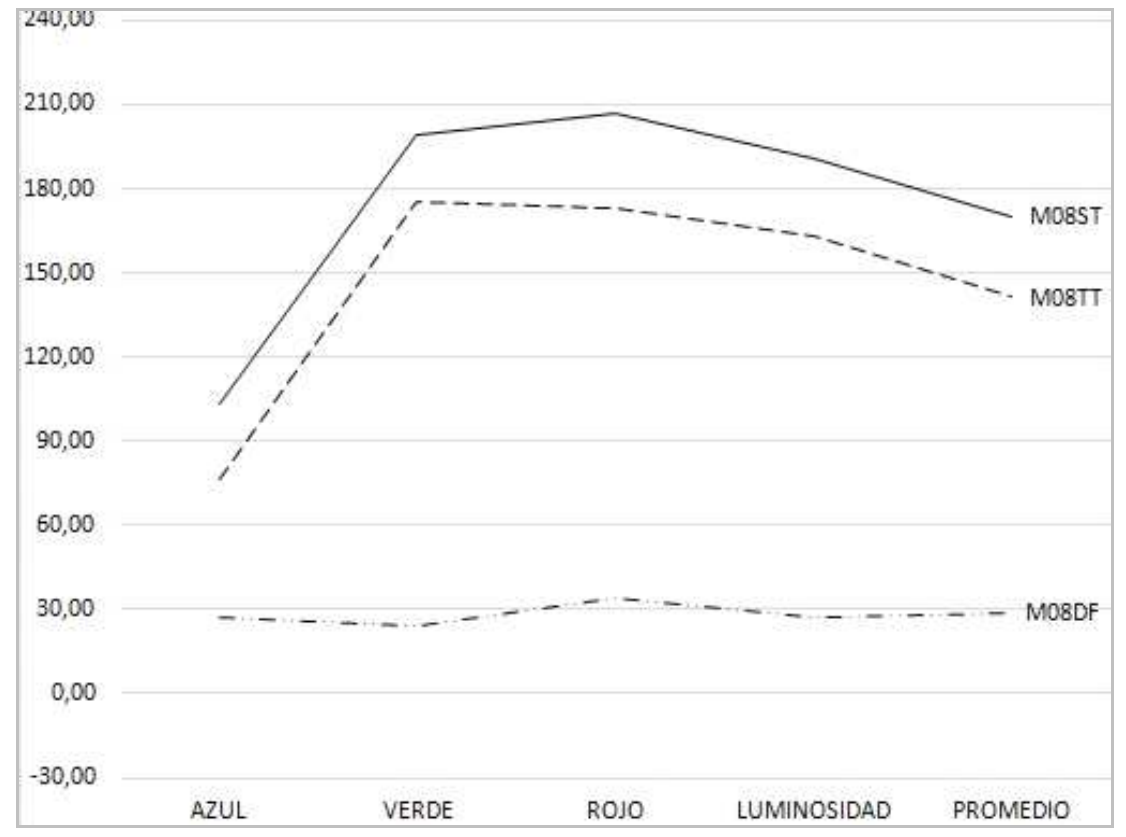

Universidad Politécnica de Madrid - Escuela Técnica Superior de Arquitectura - Departamento de Construcción y Tecnología Arquitectónica Directores: Dr. Alfonso García Santos y Dr. Antonio Rodríguez Rodríguez. Doctorando: D. Francisco Lora Toro 


\section{FICHA DE ENSAYOS DE MADERA Y ACIDOS}

\section{ACIDO A01/AG/ACIDO ACÉTICO GLACIAL}
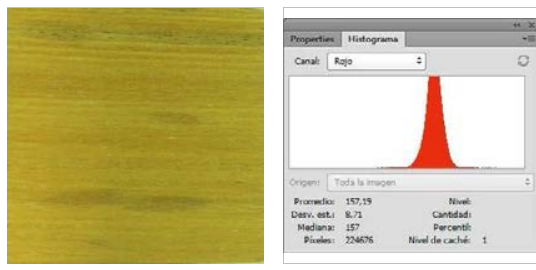

SIN TRATAR (ST): Grafica R (ST)

Valor R(ST):

157,19

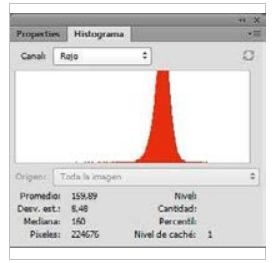

TRATADA (TT): Grafica R (TT)

Valor R(TT):

159,89

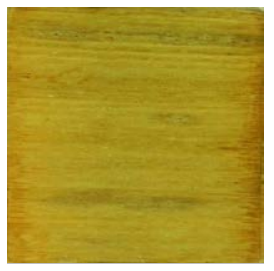

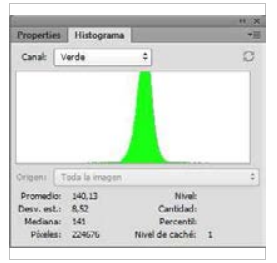

Grafica G (ST)

Valor $\mathrm{G}(\mathrm{ST})$ :

140,13

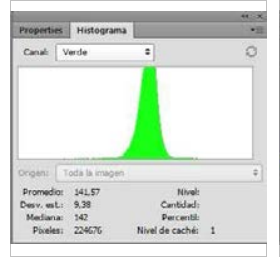

Grafica G (TT)

Valor $\mathrm{G}(\mathrm{TT})$ :

141,57

\section{MADERA M09/CJ/CEREJEIRA}

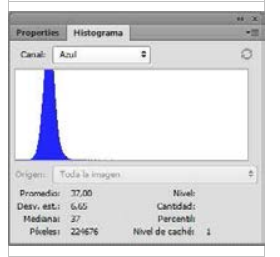

Grafica B (ST)

Valor $\mathrm{B}(\mathrm{ST})$ :

37,00

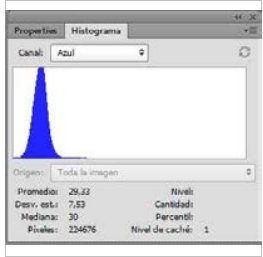

Grafica B (TT)

Valor $\mathrm{B}(\mathrm{TT})$ :

29,33

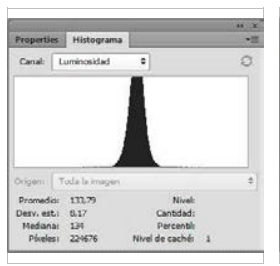

Grafica L (ST)

Valor L(ST):

133,79

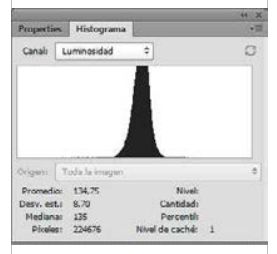

Grafica L (TT)

Valor L(TT):

134,75

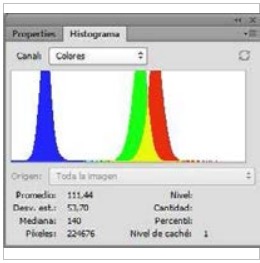

Grafica C (ST)

Valor C(ST):

111,44

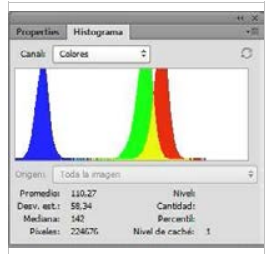

Grafica C (TT)

Valor C(TT):

110,27

DIFERENCIA (DF) Grafica R (DF): Grafica G (DF): Grafica B (DF): Grafica L (DF): Grafica C (DF): Valor DF-R: $\quad$ Valor DF-G: Valor DF-B: Valor DF-L: Valor DF-C:

$\begin{array}{lllll}-2,70 & -1,44 & 7,67 & -0,96 & 1,17\end{array}$

\section{LEYENDA}

ST MADERA SIN TRATAR

Grafica R Histograma color Rojo

Grafica G Histograma color Verde

Grafica B Histograma color Azul

Grafica L Histograma Luminosidad

Grafica C Histograma RGB

\section{TT MADERA TRATADA}

Valor R Número pixeles color Rojo

Valor $\mathrm{G}$ Número pixeles color Verde

Valor B Número pixeles color Azul

Valor L Número pixeles Luminosidad

Valor $C$ Número pixeles $R G$

DF DIFERENCIA DE VALORES R;G; $\mathrm{DF}=$ Valor $\mathrm{ST}(\mathrm{R} ; \mathrm{G} ; \mathrm{B})$ - Valor TT $(\mathrm{R} ; \mathrm{G} ; \mathrm{B}$

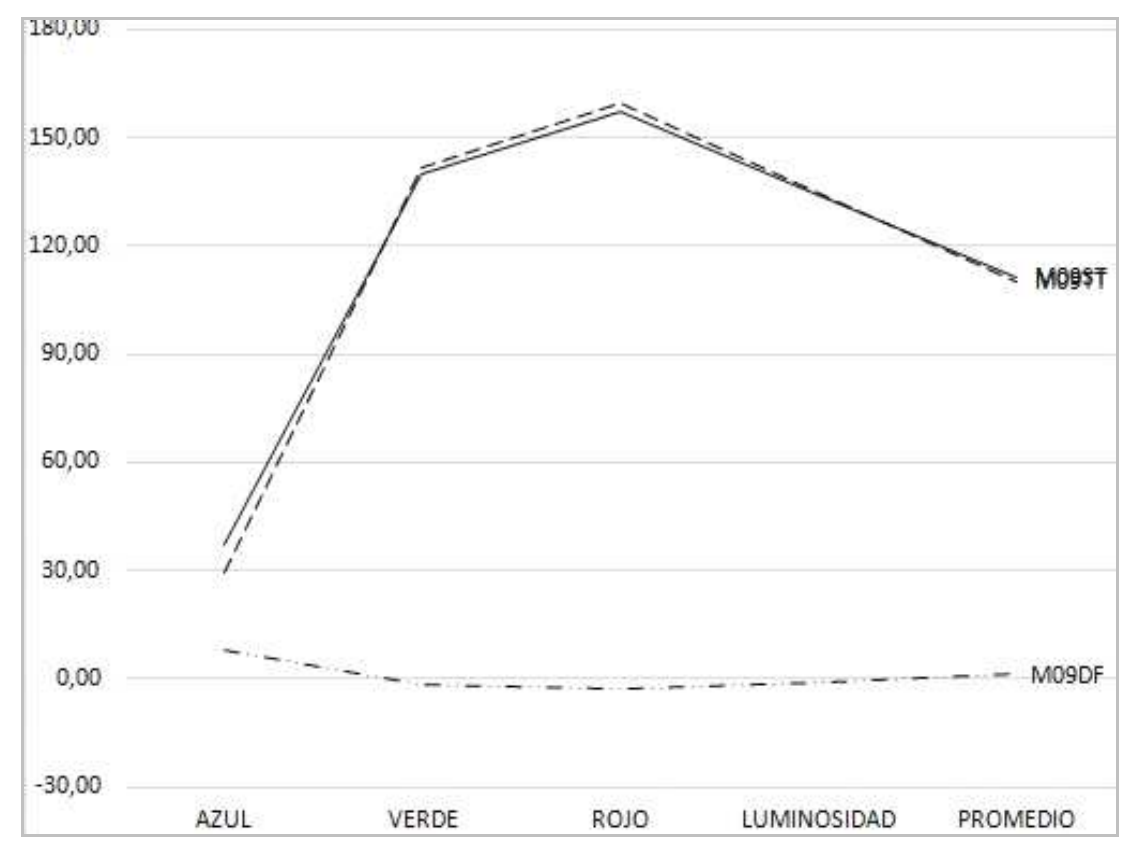

Universidad Politécnica de Madrid - Escuela Técnica Superior de Arquitectura - Departamento de Construcción y Tecnología Arquitectónica Directores: Dr. Alfonso García Santos y Dr. Antonio Rodríguez Rodríguez. Doctorando: D. Francisco Lora Toro 


\section{FICHA DE ENSAYOS DE MADERA Y ACIDOS}

\section{ACIDO A01/AG/ACIDO ACÉTICO GLACIAL}
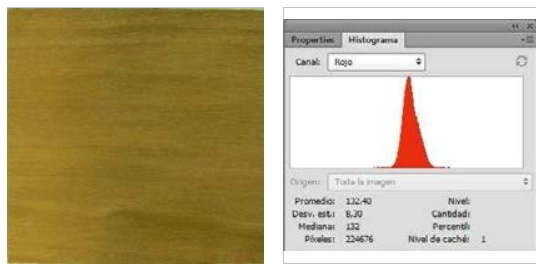

SIN TRATAR (ST): Grafica R (ST)

Valor R(ST):

132,40

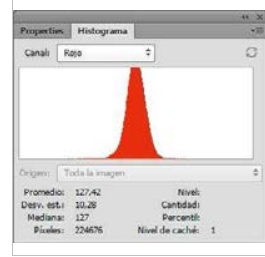

TRATADA (TT): Grafica R (TT)

130,06

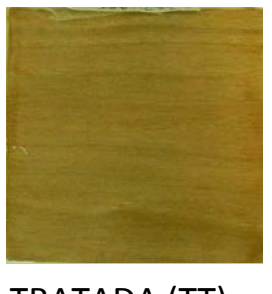

\section{Valor R(TT):}

DIFERENCIA (DF) Grafica R (DF): Valor DF-R: 2,34

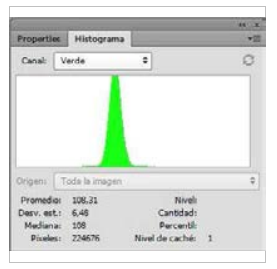

Grafica G (ST)

Valor $\mathrm{G}(\mathrm{ST})$ :

108,31

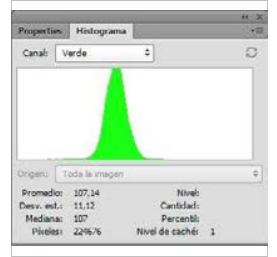

Grafica G (TT)

Valor $\mathrm{G}(\mathrm{TT})$ :

108,50
MADERA M10/CZA/CEREZO AMERICANO

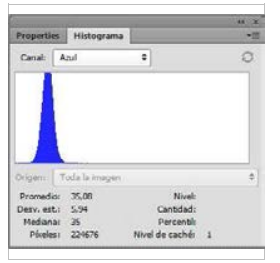

Grafica B (ST)

Valor B(ST):

35,08

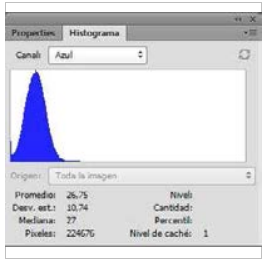

Grafica B (TT)

Valor $\mathrm{B}(\mathrm{TT})$ :

31,02

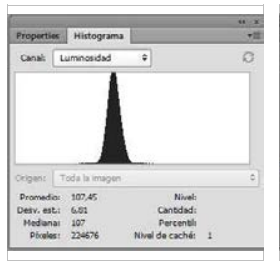

Grafica L (ST)

Valor L(ST):

107,45

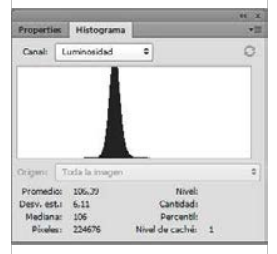

Grafica L (TT)

Valor L(TT):

106,39

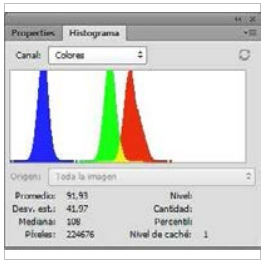

Grafica C (ST)

Valor C(ST):

91,93

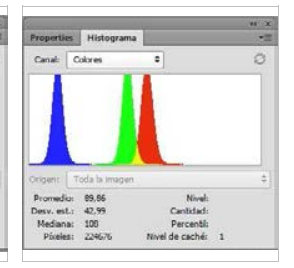

Grafica C (TT)

Valor C(TT):

89,86

\section{Grafica G (DF): Grafica B (DF): Grafica L (DF): Grafica C (DF):}

Valor DF-G: Valor DF-B:

Valor DF-L:

Valor DF-C:

$\begin{array}{llll}-0,19 & 4,06 & 1,06 & 2,07\end{array}$

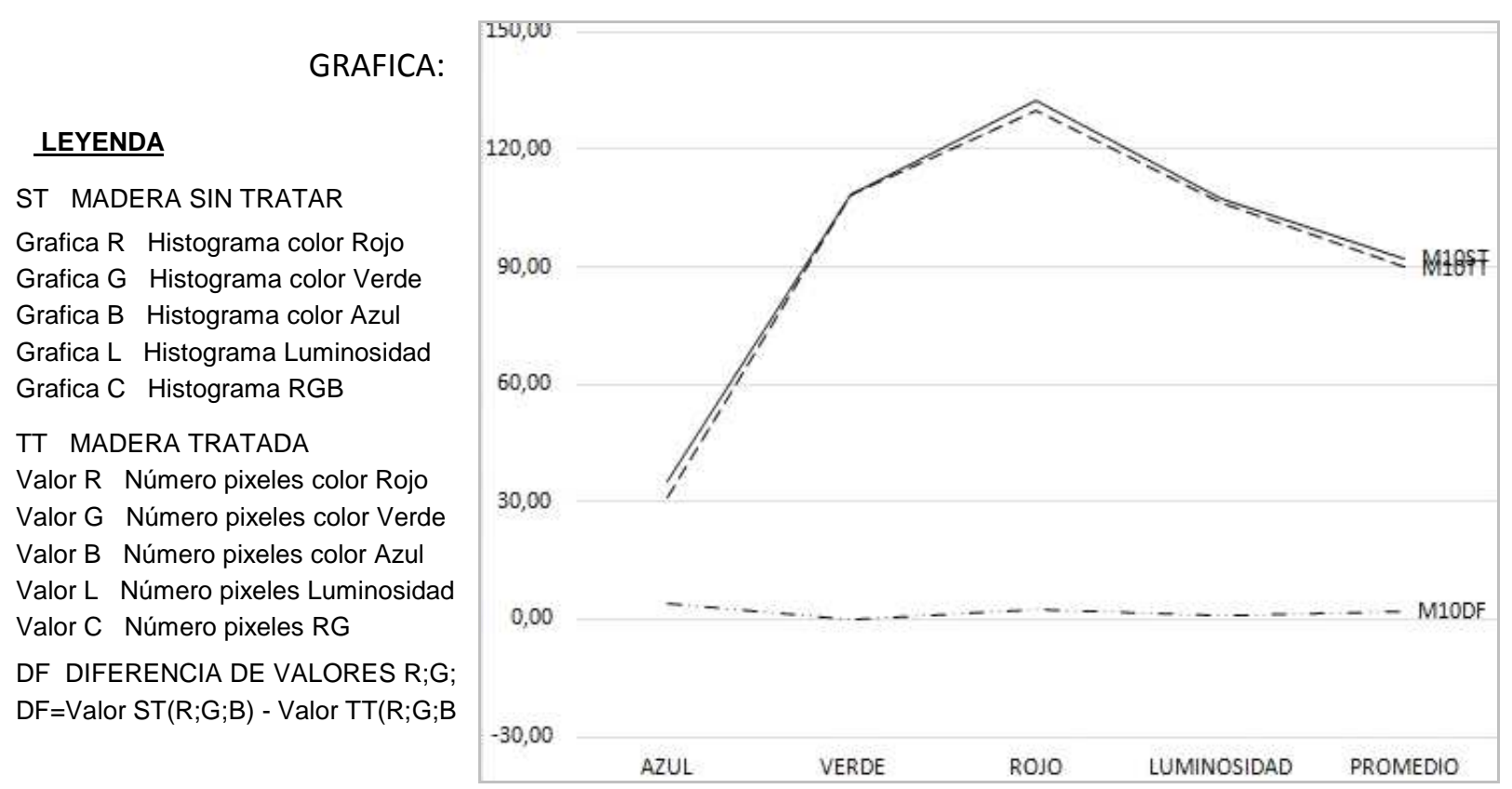

Universidad Politécnica de Madrid - Escuela Técnica Superior de Arquitectura - Departamento de Construcción y Tecnología Arquitectónica Directores: Dr. Alfonso García Santos y Dr. Antonio Rodríguez Rodríguez. Doctorando: D. Francisco Lora Toro 


\section{FICHA DE ENSAYOS DE MADERA Y ACIDOS}

\section{ACIDO A01/AG/ACIDO ACÉTICO GLACIAL}
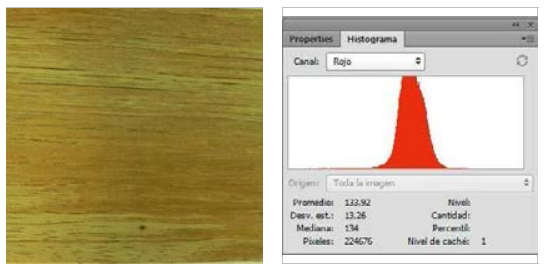

SIN TRATAR (ST): Grafica R (ST)

Valor R(ST):

133,92

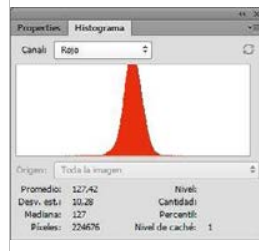

TRATADA (TT): Grafica R (TT)

Valor $\mathrm{R}(\mathrm{TT})$ :

127,42

DIFERENCIA (DF) Grafica R (DF): Valor DF-R: 6,50

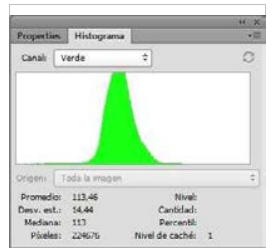

Grafica G (ST)

Valor G(ST):

113,46

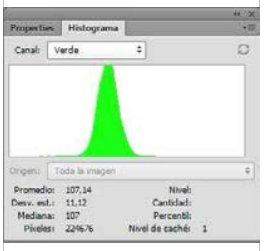

Grafica G (TT)

Valor G(TT):

107,14
MADERA M11/CB/COPAIBA

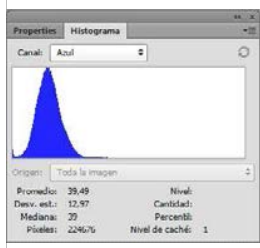

Grafica B (ST)

Valor B(ST):

39,49

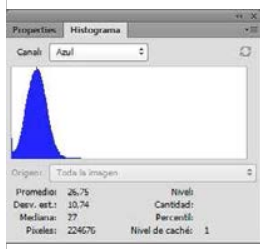

Grafica B (TT)

Valor $\mathrm{B}(\mathrm{TT})$ :

26,75

Grafica G (DF): Grafica B (DF):

Valor DF-B:

12,74

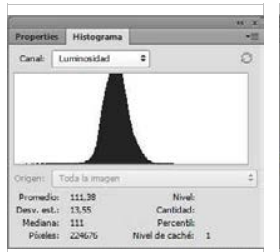

Grafica L (ST)

Valor L(ST):

111,38

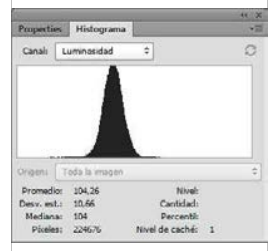

Grafica L (TT)

Valor L(TT):

104,26

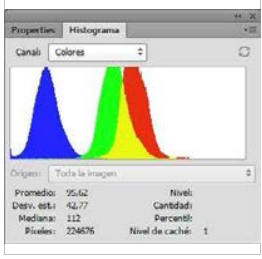

Grafica C (ST)

Valor C(ST):

95,62

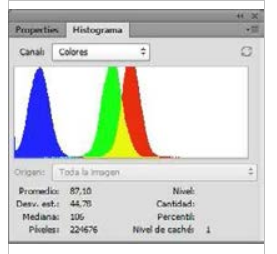

Grafica C (TT)

Valor C(TT):

87,10

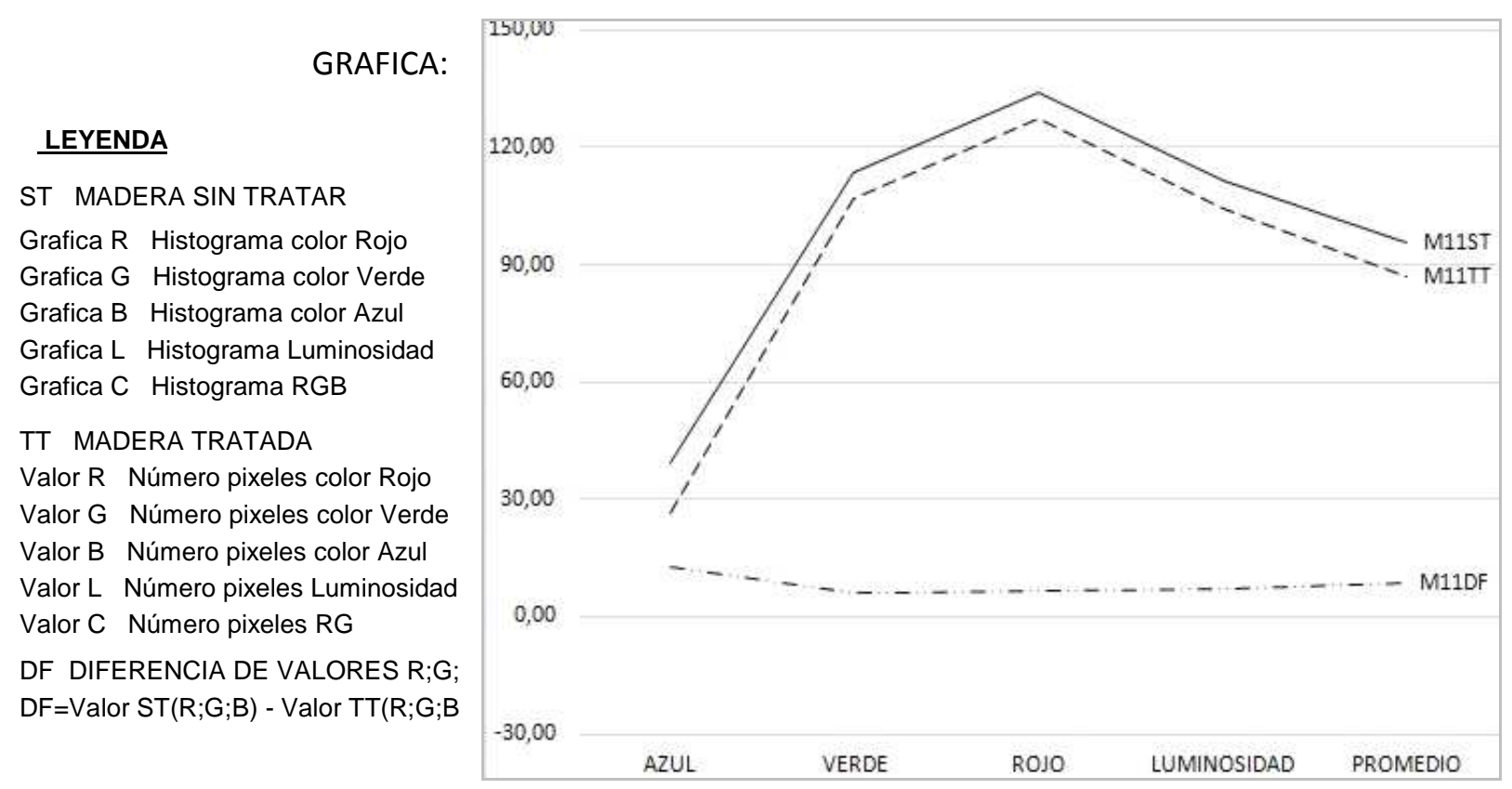

Universidad Politécnica de Madrid - Escuela Técnica Superior de Arquitectura - Departamento de Construcción y Tecnología Arquitectónica Directores: Dr. Alfonso García Santos y Dr. Antonio Rodríguez Rodríguez. Doctorando: D. Francisco Lora Toro 


\section{FICHA DE ENSAYOS DE MADERA Y ACIDOS}

\section{ACIDO A01/AG/ACIDO ACÉTICO GLACIAL}
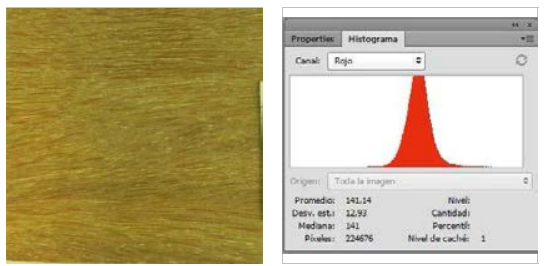

SIN TRATAR (ST): Grafica R (ST)

Valor R(ST):

141,14

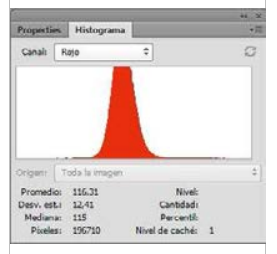

TRATADA (TT): Grafica R (TT)

Valor $\mathrm{R}(\mathrm{TT})$ :

116,31

DIFERENCIA (DF) Grafica R (DF): Valor DF-R: 24,83

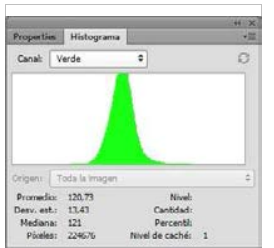

Grafica G (ST)

Valor G(ST):

120,73

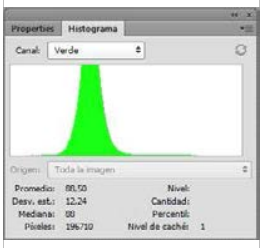

Grafica G (TT)

Valor G(TT):

88,50
MADERA M12/CM/CUMARÚ

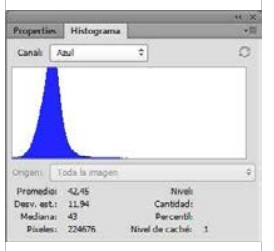

Grafica B (ST)

Valor $\mathrm{B}(\mathrm{ST})$ :

42,45

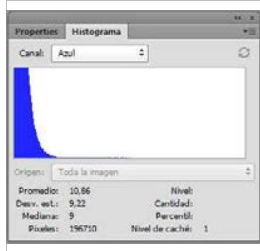

Grafica B (TT)

Valor $\mathrm{B}(\mathrm{TT})$ :

10,86

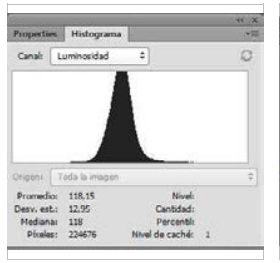

Grafica L (ST)

Valor L(ST):

118,15

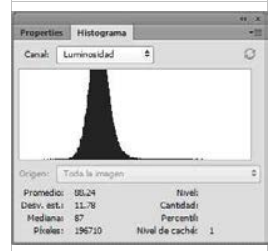

Grafica L (TT)

Valor L(TT):

88,24

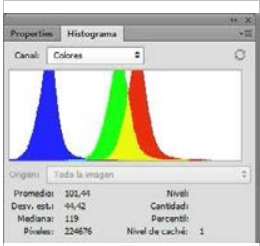

Grafica C (ST)

Valor C(ST):

101,44

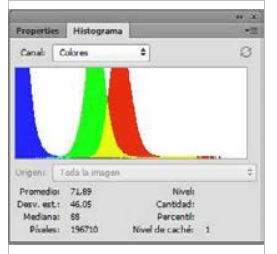

Grafica C (TT)

Valor $\mathrm{C}(\mathrm{TT})$ :

71,89

Grafica G (DF): Grafica B (DF): Grafica L (DF): Grafica C (DF): Valor DF-G: $\quad$ Valor DF-B: $\quad$ Valor DF-L: Valor DF-C:

$\begin{array}{llll}32,23 & 31,59 & 29,91 & 29,55\end{array}$

\section{LEYENDA}

ST MADERA SIN TRATAR

Grafica R Histograma color Rojo

Grafica G Histograma color Verde

Grafica B Histograma color Azul

Grafica L Histograma Luminosidad

Grafica C Histograma RGB

TT MADERA TRATADA

Valor R Número pixeles color Rojo

Valor G Número pixeles color Verde

Valor B Número pixeles color Azul

Valor $L$ Número pixeles Luminosidad

Valor C Número pixeles RG

DF DIFERENCIA DE VALORES R;G; $\mathrm{DF}=$ Valor $\mathrm{ST}(\mathrm{R} ; \mathrm{G} ; \mathrm{B})$ - Valor $\mathrm{TT}(\mathrm{R} ; \mathrm{G} ; \mathrm{B}$

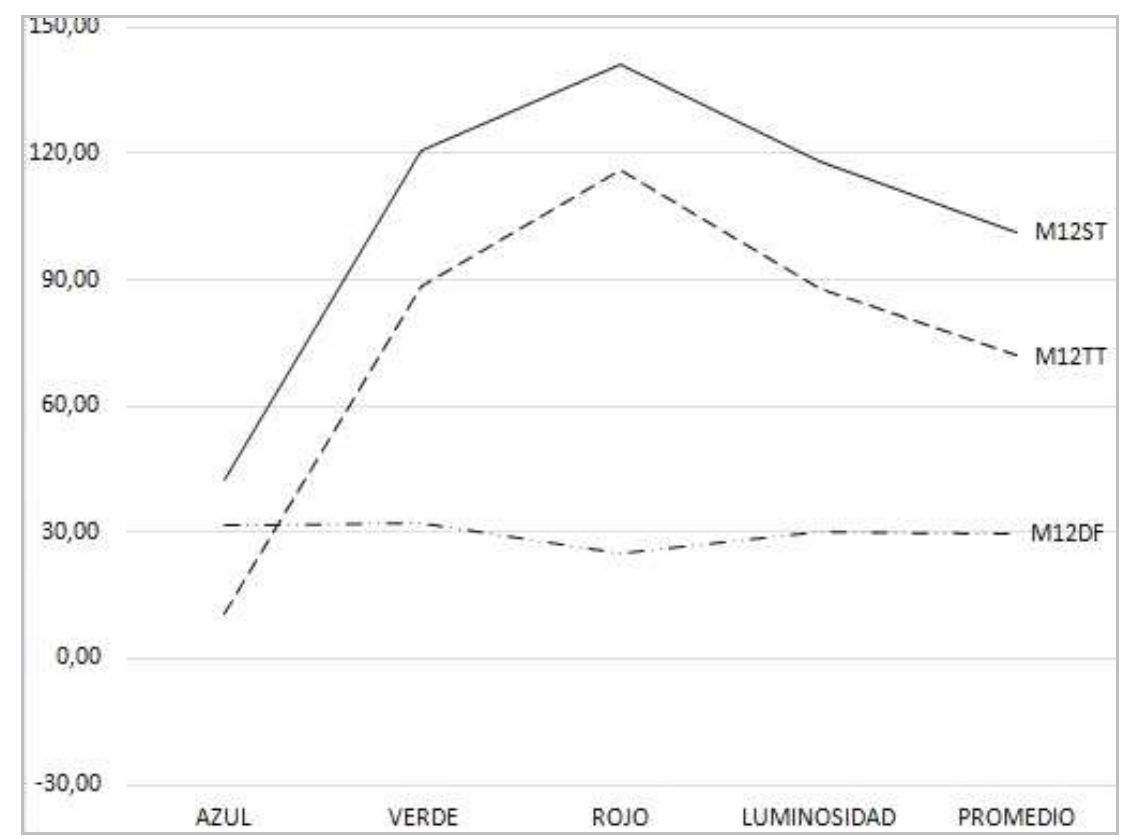

Universidad Politécnica de Madrid - Escuela Técnica Superior de Arquitectura - Departamento de Construcción y Tecnología Arquitectónica Directores: Dr. Alfonso García Santos y Dr. Antonio Rodríguez Rodríguez. Doctorando: D. Francisco Lora Toro 


\section{FICHA DE ENSAYOS DE MADERA Y ACIDOS}

\section{ACIDO A01/AG/ACIDO ACÉTICO GLACIAL}
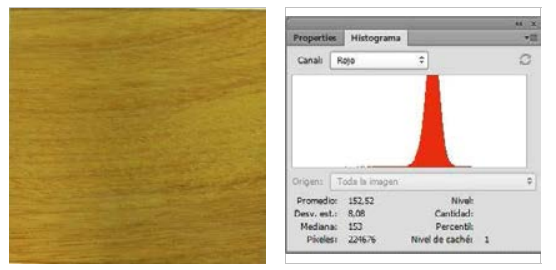

SIN TRATAR (ST): Grafica R (ST)

Valor R(ST):

152,52

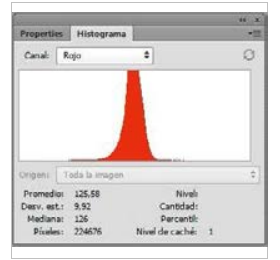

TRATADA (TT): Grafica $R(T T)$

Valor $\mathrm{R}(\mathrm{TT})$ :

125,58

DIFERENCIA (DF) Grafica R (DF): Valor DF-R: 26,94

GRAFICA:

\section{LEYENDA}

ST MADERA SIN TRATAR

Grafica R Histograma color Rojo

Grafica G Histograma color Verde

Grafica B Histograma color Azul

Grafica L Histograma Luminosidad

Grafica C Histograma RGB

\section{TT MADERA TRATADA}

Valor R Número pixeles color Rojo

Valor $G$ Número pixeles color Verde

Valor B Número pixeles color Azul

Valor $L$ Número pixeles Luminosidad

Valor C Número pixeles RG

DF DIFERENCIA DE VALORES R;G; $\mathrm{DF}=$ Valor $\mathrm{ST}(\mathrm{R} ; \mathrm{G} ; \mathrm{B})$ - Valor $\mathrm{TT}(\mathrm{R} ; \mathrm{G} ; \mathrm{B}$
MADERA M13/DS/DOUSSIÉ
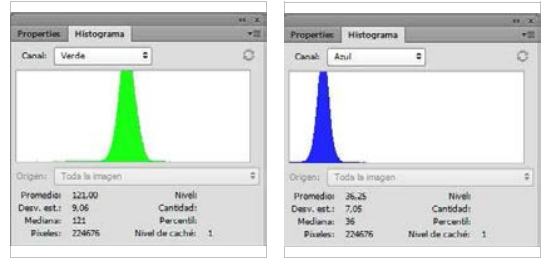

Grafica B (ST)

Valor $\mathrm{B}(\mathrm{ST})$ :

36,25
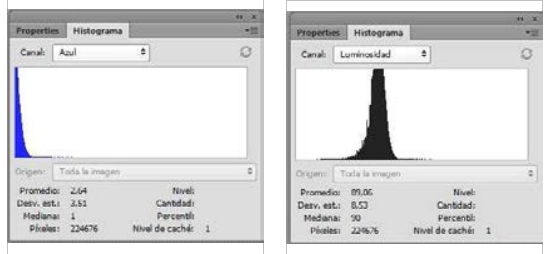

Grafica L (TT)

Grafica C (TT)

Grafica G (TT) Grafica B (TT)

Valor L(TT):

Valor C(TT):

Valor $\mathrm{G}(\mathrm{TT})$ :

Valor $\mathrm{B}(\mathrm{TT})$ :

89,06

71,66

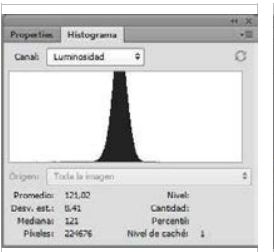

Grafica L (ST)

Valor L(ST):

121,02

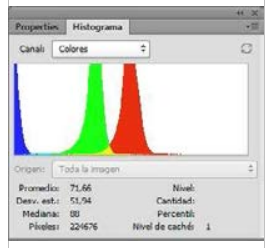

86,76

2,64

Grafica G (DF): Grafica B (DF):

Grafica L (DF):

Grafica C (DF):

Valor DF-G:

Valor DF-B:

33,61
Valor DF-L:

Valor DF-C:

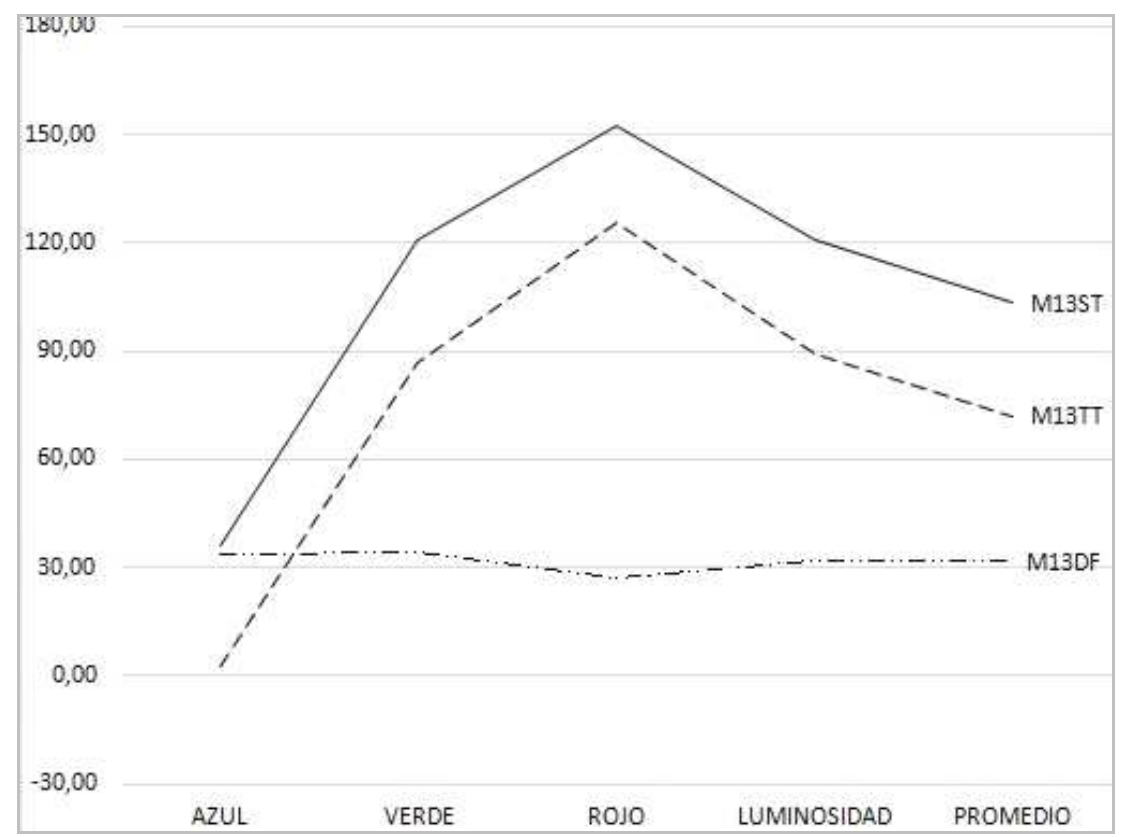

Universidad Politécnica de Madrid - Escuela Técnica Superior de Arquitectura - Departamento de Construcción y Tecnología Arquitectónica Directores: Dr. Alfonso García Santos y Dr. Antonio Rodríguez Rodríguez. Doctorando: D. Francisco Lora Toro 


\section{FICHA DE ENSAYOS DE MADERA Y ACIDOS}

\section{ACIDO A01/AG/ACIDO ACÉTICO GLACIAL}
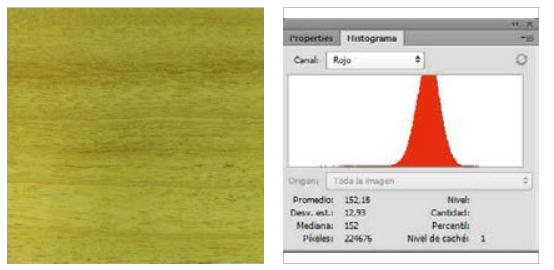

SIN TRATAR (ST): Grafica R (ST)

Valor R(ST):

152,18

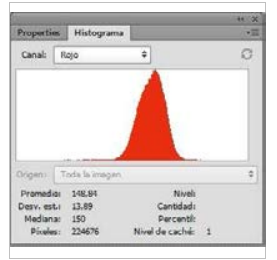

TRATADA (TT): Grafica $R(T T)$

Valor R(TT):

148,84

DIFERENCIA (DF) Grafica R (DF): Valor DF-R:

3,34

GRAFICA:

\section{LEYENDA}

ST MADERA SIN TRATAR

Grafica R Histograma color Rojo

Grafica G Histograma color Verde

Grafica B Histograma color Azul

Grafica L Histograma Luminosidad

Grafica C Histograma RGB

\section{TT MADERA TRATADA}

Valor R Número pixeles color Rojo

Valor $G$ Número pixeles color Verde

Valor B Número pixeles color Azul

Valor $L$ Número pixeles Luminosidad

Valor C Número pixeles RG

DF DIFERENCIA DE VALORES R;G; $\mathrm{DF}=$ Valor $\mathrm{ST}(\mathrm{R} ; \mathrm{G} ; \mathrm{B})$ - Valor $\mathrm{TT}(\mathrm{R} ; \mathrm{G} ; \mathrm{B}$

\section{MADERA M14/FR/FRAMIRÉ}
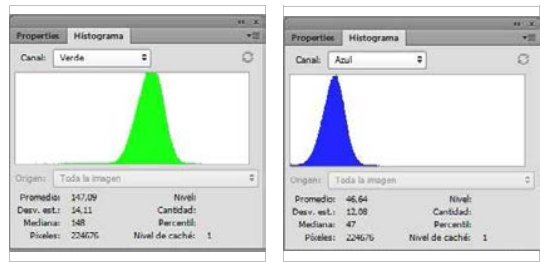

Grafica B (ST)
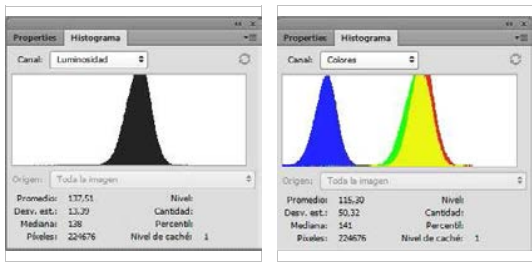

Grafica G (ST)

Valor B(ST):

Grafica L (ST)

Grafica C (ST)

Valor $\mathrm{G}(\mathrm{ST})$ :

46,64

Valor L(ST):

Valor C(ST):

147,09
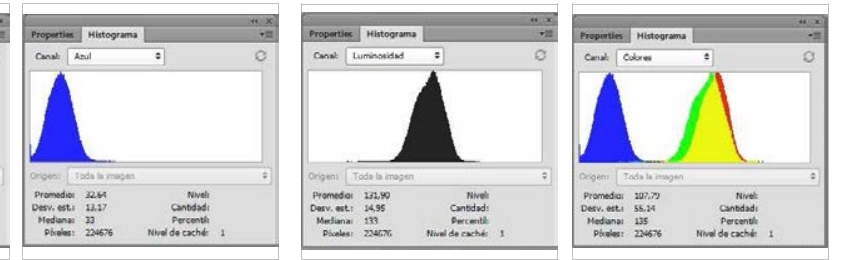

Grafica G (TT)

Grafica B (TT)

Grafica L (TT)

Grafica C (TT)

Valor $\mathrm{G}(\mathrm{TT})$ :

Valor $\mathrm{B}(\mathrm{TT})$ :

Valor L(TT):

Valor C(TT):

141,88

32,64

131,90

107,79

Grafica G (DF): Grafica B (DF): Grafica L (DF): Grafica C (DF): Valor DF-G: Valor DF-B: Valor DF-L: Valor DF-C:

$5,21 \quad 14,00 \quad 5,61 \quad 7,51$

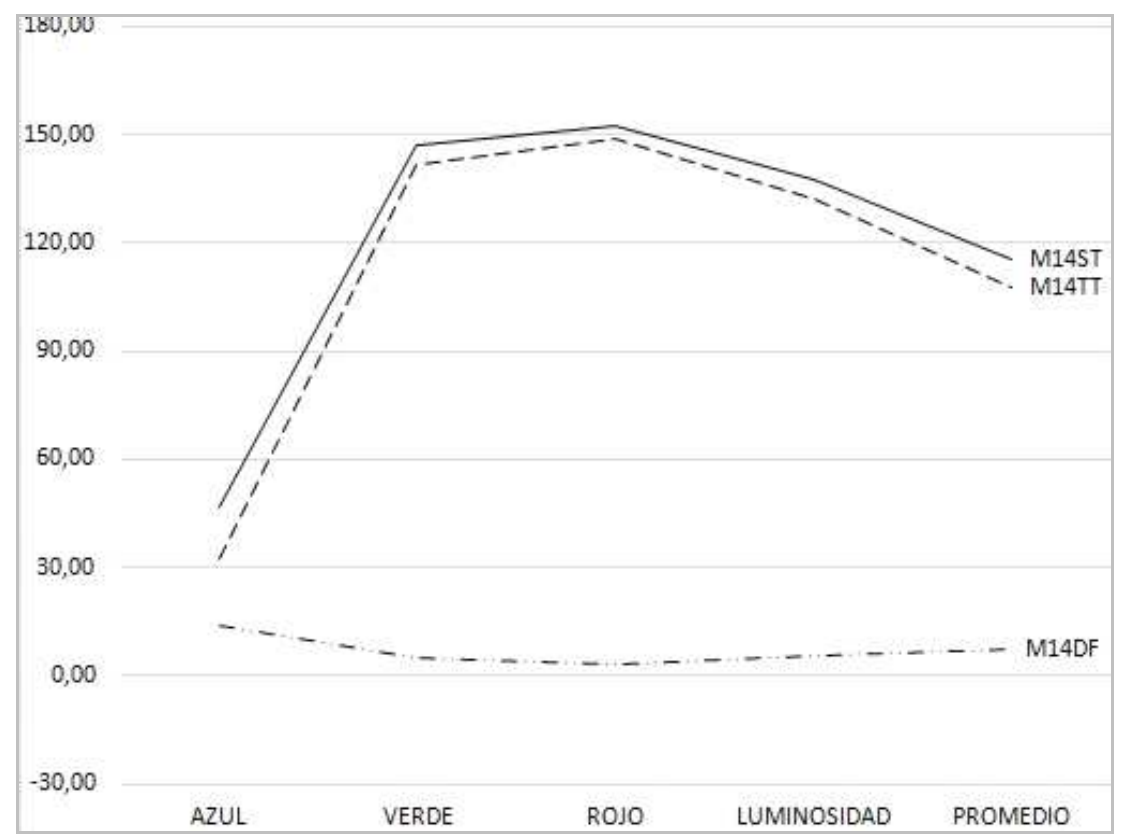

Universidad Politécnica de Madrid - Escuela Técnica Superior de Arquitectura - Departamento de Construcción y Tecnología Arquitectónica Directores: Dr. Alfonso García Santos y Dr. Antonio Rodríguez Rodríguez. Doctorando: D. Francisco Lora Toro 


\section{FICHA DE ENSAYOS DE MADERA Y ACIDOS}

\section{ACIDO A01/AG/ACIDO ACÉTICO GLACIAL}
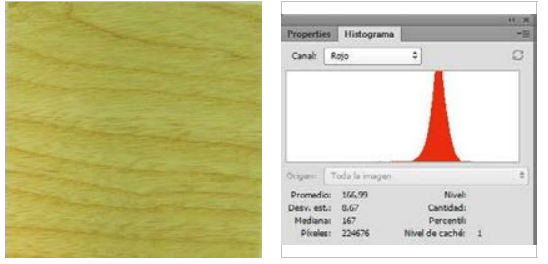

SIN TRATAR (ST): Grafica R (ST)

Valor R(ST):

166,99

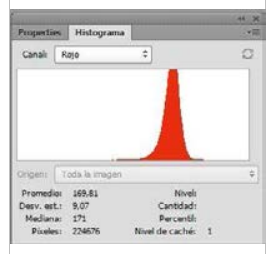

TRATADA (TT): Grafica $R(T T)$

Valor $\mathrm{R}(\mathrm{TT})$ :

169,81

DIFERENCIA (DF) Grafica R (DF): Valor DF-R: $-2,82$

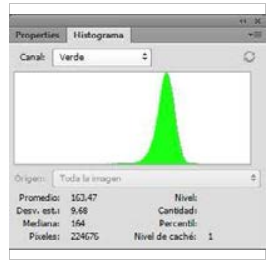

Grafica G (ST)

Valor G(ST):

163,47

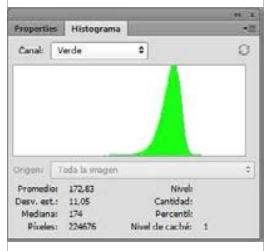

Grafica G (TT)

Valor $\mathrm{G}(\mathrm{TT})$ :

172,83

MADERA M15/FBA/FRESNO BLANCO AMERICAN

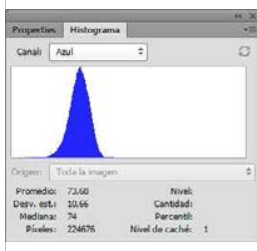

Grafica B (ST)

Valor B(ST):

73,68

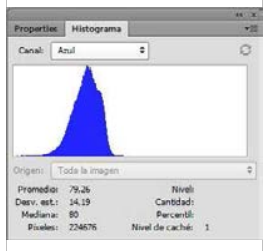

Grafica B (TT)

Valor $\mathrm{B}(\mathrm{TT})$ :

79,26

Grafica G (DF): Grafica B (DF):

Valor DF-B:

$-5,58$

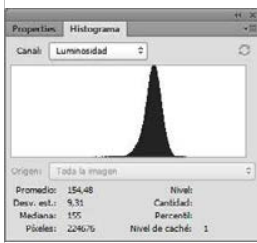

Grafica L (ST)

Valor L(ST):

154,48

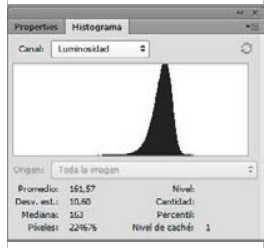

Grafica L (TT)

Valor L(TT):

161,57

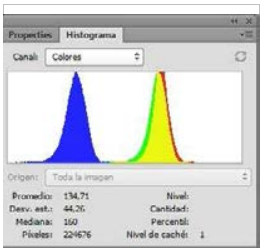

Grafica C (ST)

Valor C(ST):

134,71

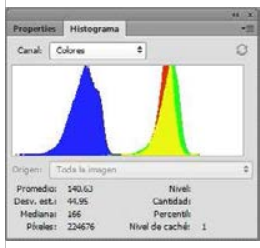

Grafica C (TT)

Valor $\mathrm{C}(\mathrm{TT})$ :

140,63

Grafica L (DF): Grafica C (DF):

Valor DF-L: Valor DF-C:

$\begin{array}{llll}-9,36 & -5,58 & -7,09 & -5,92\end{array}$

GRAFICA :

\section{LEYENDA}

ST MADERA SIN TRATAR

Grafica R Histograma color Rojo

Grafica G Histograma color Verde

Grafica B Histograma color Azul

Grafica L Histograma Luminosidad

Grafica C Histograma RGB

TT MADERA TRATADA

Valor R Número pixeles color Rojo

Valor G Número pixeles color Verde

Valor B Número pixeles color Azul

Valor $L$ Número pixeles Luminosidad

Valor $C$ Número pixeles $R G$

DF DIFERENCIA DE VALORES R;G;

$\mathrm{DF}=$ Valor $\mathrm{ST}(\mathrm{R} ; \mathrm{G} ; \mathrm{B})$ - Valor $\mathrm{TT}(\mathrm{R} ; \mathrm{G} ; \mathrm{B}$

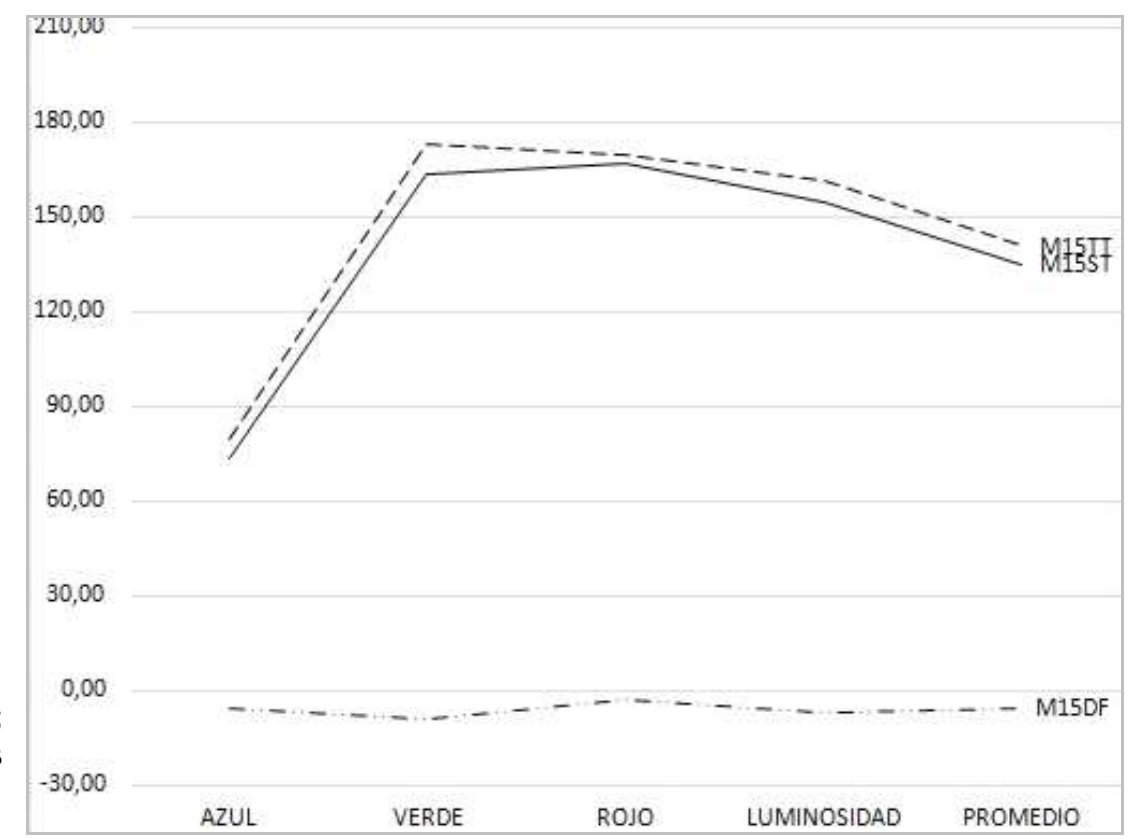

Universidad Politécnica de Madrid - Escuela Técnica Superior de Arquitectura - Departamento de Construcción y Tecnología Arquitectónica Directores: Dr. Alfonso García Santos y Dr. Antonio Rodríguez Rodríguez. Doctorando: D. Francisco Lora Toro 


\section{FICHA DE ENSAYOS DE MADERA Y ACIDOS}

\section{ACIDO A01/AG/ACIDO ACÉTICO GLACIAL}
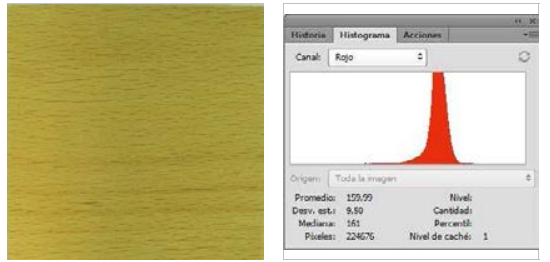

SIN TRATAR (ST): Grafica R (ST)

Valor R(ST):

159,99

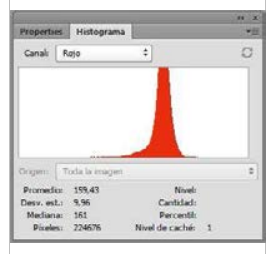

TRATADA (TT): Grafica R (TT)

Valor $\mathrm{R}(\mathrm{TT})$ :

159,43

DIFERENCIA (DF) Grafica R (DF):

Valor DF-R:

0,56

GRAFICA:

\section{LEYENDA}

ST MADERA SIN TRATAR

Grafica R Histograma color Rojo

Grafica G Histograma color Verde

Grafica B Histograma color Azul

Grafica L Histograma Luminosidad

Grafica C Histograma RGB

TT MADERA TRATADA

Valor R Número pixeles color Rojo

Valor $\mathrm{G}$ Número pixeles color Verde

Valor B Número pixeles color Azul

Valor $L$ Número pixeles Luminosidad

Valor $C$ Número pixeles $R G$

DF DIFERENCIA DE VALORES R;G; $\mathrm{DF}=$ Valor $\mathrm{ST}(\mathrm{R} ; \mathrm{G} ; \mathrm{B})$ - Valor TT $(\mathrm{R} ; \mathrm{G} ; \mathrm{B}$

\section{MADERA M16/H/HAYA}
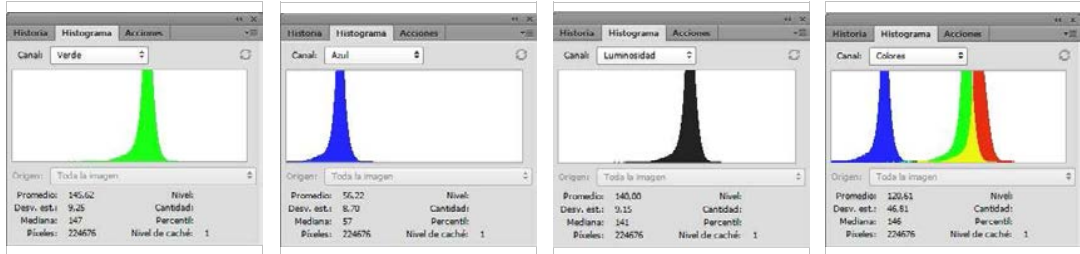

Grafica G (ST)

Grafica B (ST)

Grafica L (ST)

Grafica C (ST)

Valor G(ST):

Valor B(ST):

Valor L(ST):

Valor C(ST):

145,62

56,22

140,00

120,61
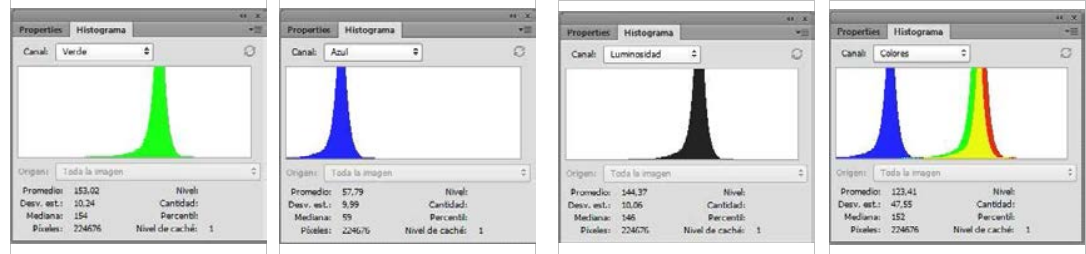

Grafica G (TT)

Grafica B (TT)

Grafica L (TT)

Grafica C (TT)

Valor $\mathrm{G}(\mathrm{TT})$ :

Valor $\mathrm{B}(\mathrm{TT})$ :

Valor L(TT):

Valor C(TT):

153,02

57,79

144,37

123,41

Grafica G (DF): Grafica B (DF): Grafica L (DF): Grafica C (DF): Valor DF-G: Valor DF-B: $\quad$ Valor DF-L: Valor DF-C:

$\begin{array}{llll}-7,40 & -1,57 & -4,37 & -2,80\end{array}$

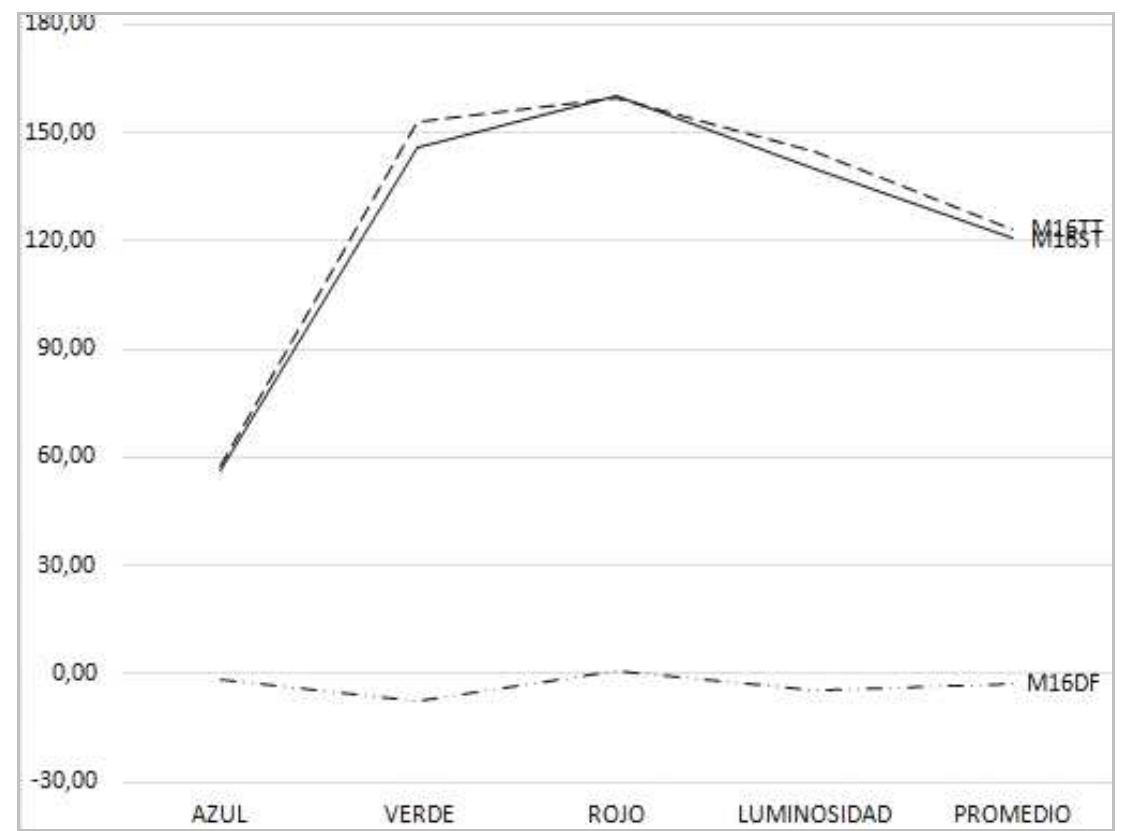

Universidad Politécnica de Madrid - Escuela Técnica Superior de Arquitectura - Departamento de Construcción y Tecnología Arquitectónica Directores: Dr. Alfonso García Santos y Dr. Antonio Rodríguez Rodríguez. Doctorando: D. Francisco Lora Toro 


\section{FICHA DE ENSAYOS DE MADERA Y ACIDOS}

\section{ACIDO A01/AG/ACIDO ACÉTICO GLACIAL}
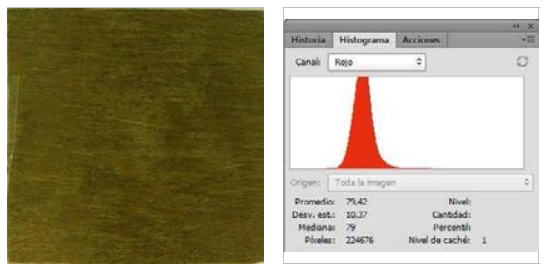

SIN TRATAR (ST): Grafica R (ST)

Valor R(ST):

79,42

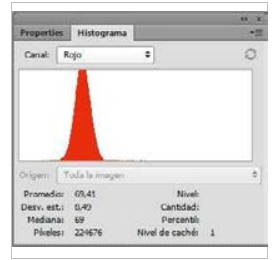

TRATADA (TT): Grafica R (TT)

Valor $\mathrm{R}(\mathrm{TT})$ :

69,41

DIFERENCIA (DF) Grafica R (DF): Valor DF-R: 10,01

GRAFICA:

\section{LEYENDA}

ST MADERA SIN TRATAR

Grafica R Histograma color Rojo Grafica G Histograma color Verde Grafica B Histograma color Azul Grafica L Histograma Luminosidad Grafica C Histograma RGB

TT MADERA TRATADA

Valor $\mathrm{R}$ Número pixeles color Rojo Valor $\mathrm{G}$ Número pixeles color Verde Valor B Número pixeles color Azul Valor $L$ Número pixeles Luminosidad Valor C Número pixeles RG DF DIFERENCIA DE VALORES R;G; $\mathrm{DF}=$ Valor $\mathrm{ST}(\mathrm{R} ; \mathrm{G} ; \mathrm{B})$ - Valor $\mathrm{TT}(\mathrm{R} ; \mathrm{G} ; \mathrm{B}$

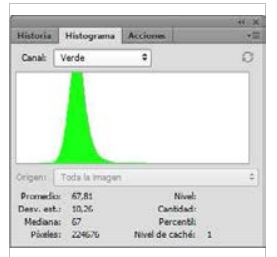

Grafica G (ST) Valor $\mathrm{G}(\mathrm{ST})$ :

67,81

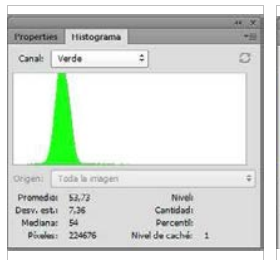

Grafica G (TT)

Valor G(TT):

53,73

\section{MADERA M17/IP/IPÉ}

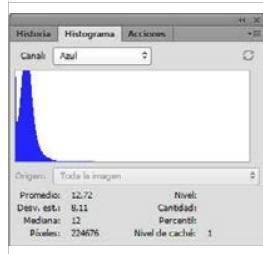

Grafica B (ST)

Valor B(ST):

12,72

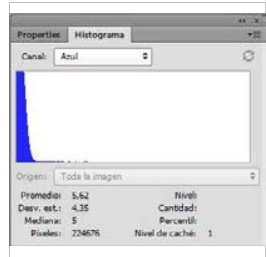

Grafica B (TT)

Valor $\mathrm{B}(\mathrm{TT})$ :

5,62

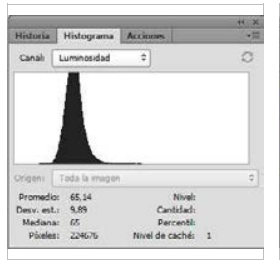

Grafica L (ST)

Valor L(ST):

65,14

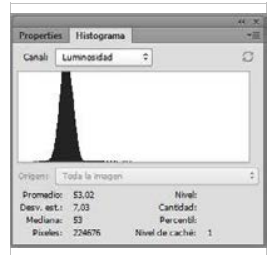

Grafica L (TT)

Valor L(TT):

53,02

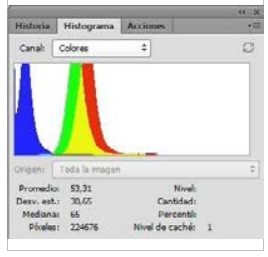

Grafica C (ST)

Valor C(ST):

53,31

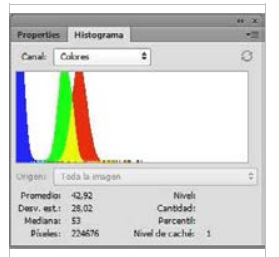

Grafica C (TT)

Valor C(TT):

42,92

\section{Grafica G (DF): Grafica B (DF): Grafica L (DF): Grafica C (DF):} Valor DF-G: Valor DF-B: Valor DF-L: Valor DF-C:

$\begin{array}{llll}14,08 & 7,10 & 12,12 & 10,39\end{array}$

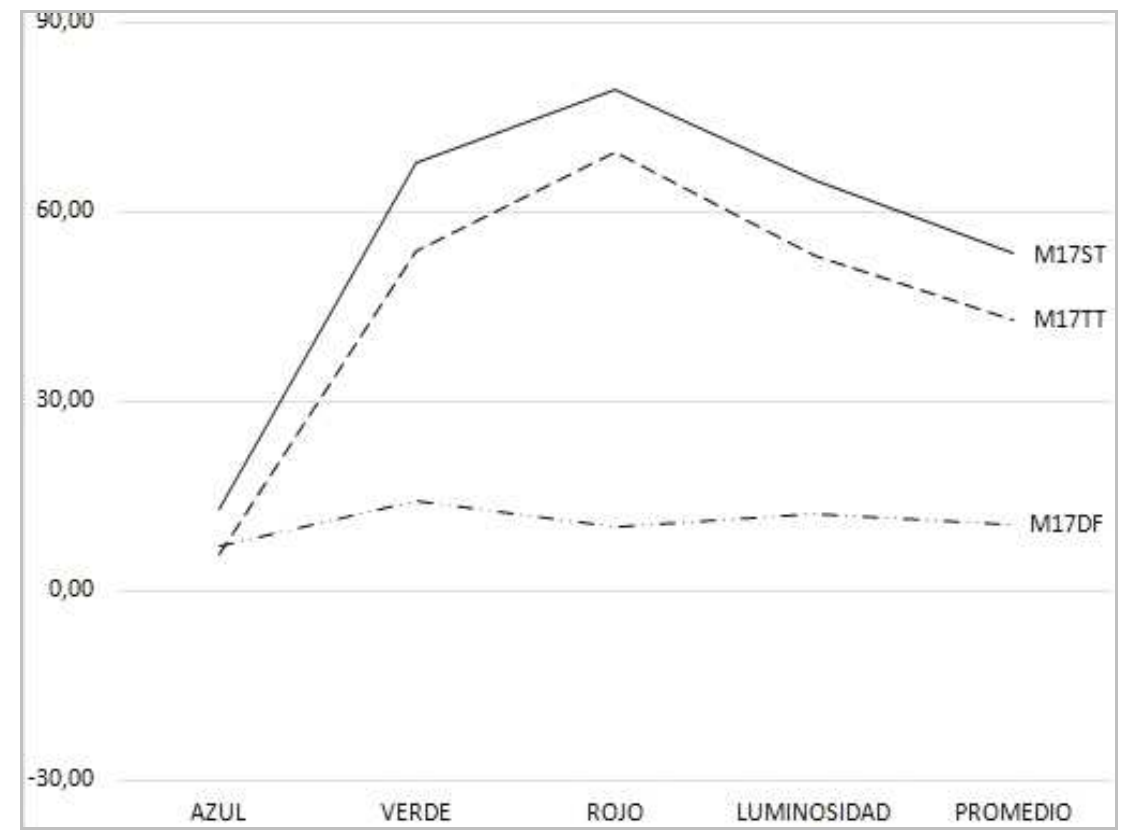

Universidad Politécnica de Madrid - Escuela Técnica Superior de Arquitectura - Departamento de Construcción y Tecnología Arquitectónica Directores: Dr. Alfonso García Santos y Dr. Antonio Rodríguez Rodríguez. Doctorando: D. Francisco Lora Toro 


\section{FICHA DE ENSAYOS DE MADERA Y ACIDOS}

\section{ACIDO A01/AG/ACIDO ACÉTICO GLACIAL}
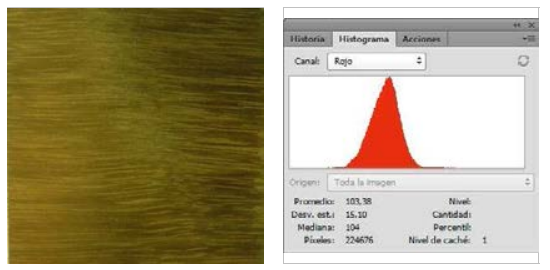

SIN TRATAR (ST): Grafica R (ST)

Valor R(ST):

103,38

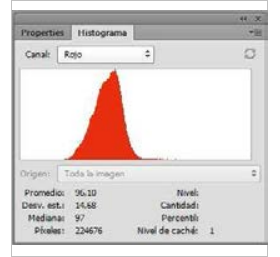

TRATADA (TT): Grafica R (TT)

Valor $\mathrm{R}(\mathrm{TT})$ :

96,10

DIFERENCIA (DF) Grafica R (DF): Valor DF-R:

7,28

6,85

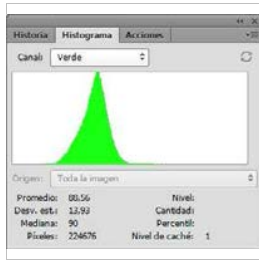

Grafica G (ST)

Valor $\mathrm{G}(\mathrm{ST})$ :

88,56

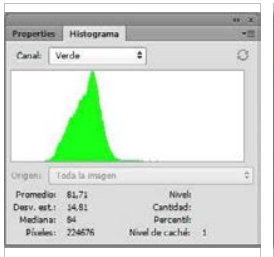

Grafica G (TT)

81,71
Valor $\mathrm{G}(\mathrm{TT})$ :

MADERA M18/IK/IROKO

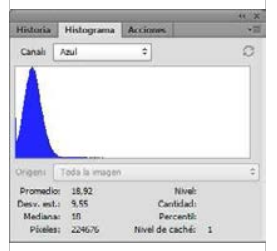

Grafica B (ST)

Valor $\mathrm{B}(\mathrm{ST})$ :

18,92

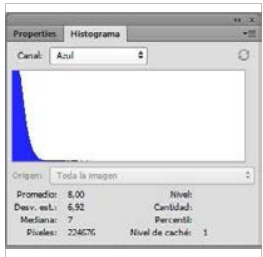

Grafica B (TT)

Valor $\mathrm{B}(\mathrm{TT})$ :

8,00

Grafica G (DF): Grafica B (DF):

Grafica L (DF):

Valor DF-L:

7,40
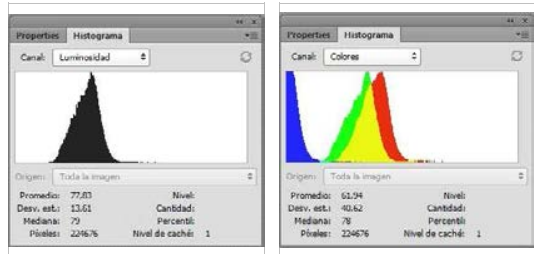

Grafica L (TT)

Grafica C (TT)

Valor L(TT):

Valor C(TT):

61,94

Grafica C (ST)

Valor C(ST):

70,29

Valor DF-G: Valor DF-B:

Grafica C (DF):

10,92

Valor DF-C:

8,35

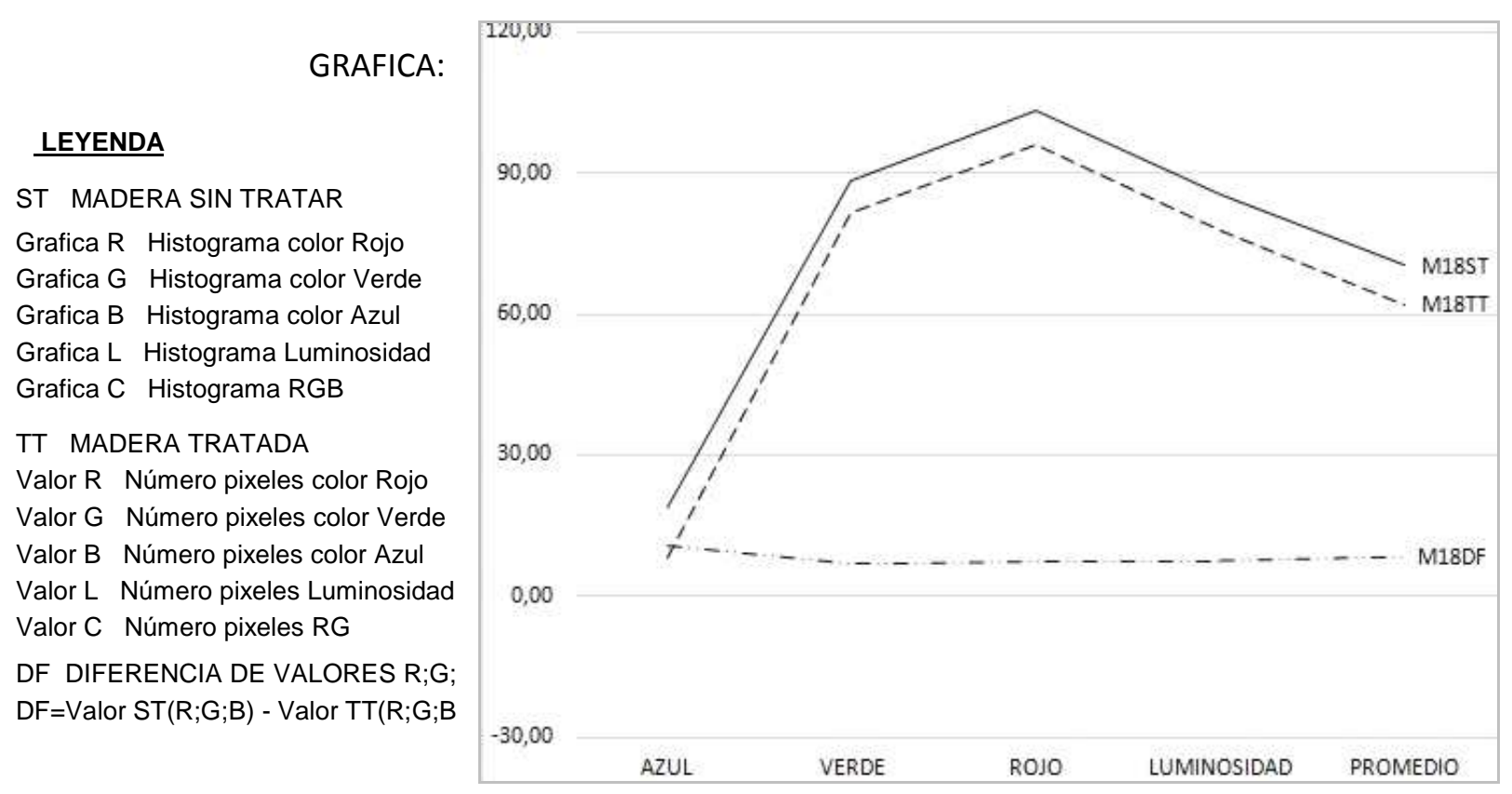

Universidad Politécnica de Madrid - Escuela Técnica Superior de Arquitectura - Departamento de Construcción y Tecnología Arquitectónica Directores: Dr. Alfonso García Santos y Dr. Antonio Rodríguez Rodríguez. Doctorando: D. Francisco Lora Toro 


\section{FICHA DE ENSAYOS DE MADERA Y ACIDOS}

\section{ACIDO A01/AG/ACIDO ACÉTICO GLACIAL}
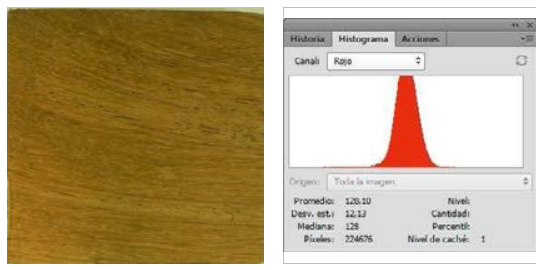

SIN TRATAR (ST): Grafica R (ST)

Valor R(ST):

128,10

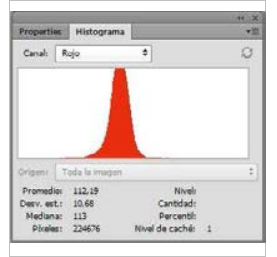

TRATADA (TT): Grafica R (TT)

Valor R(TT):

112,19

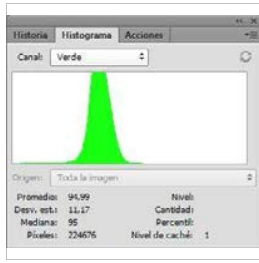

Grafica G (ST)

Valor $\mathrm{G}(\mathrm{ST})$ :

94,99

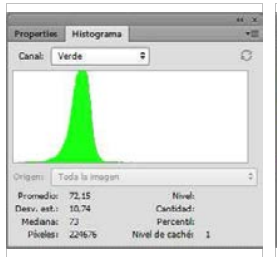

Grafica G (TT)

Valor $\mathrm{G}(\mathrm{TT})$ :

72,15
MADERA M19/JT/JATOBA

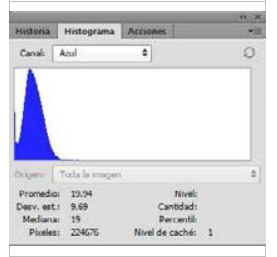

Grafica B (ST)

Valor B(ST):

19,94

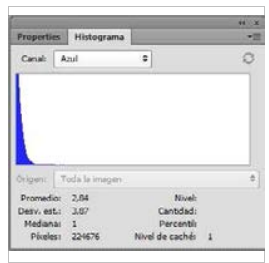

Grafica B (TT)

Valor $\mathrm{B}(\mathrm{TT})$ :

2,84

Valor DF-L:

20,10

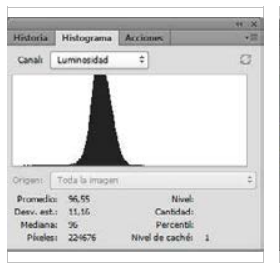

Grafica L (ST)

Valor L(ST):

96,55

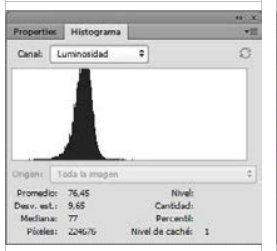

Grafica L (TT)

Valor L(TT):

76,45 17,10

\section{2,84}

DIFERENCIA (DF) Grafica R (DF): Grafica G (DF): Grafica B (DF): Grafica L (DF): Grafica C (DF):

DIFERENCIA (DF) Grafica R (DF): Grafica G (DF): Grafica B (DF): Grafica L (DF): Grafica C (DF):

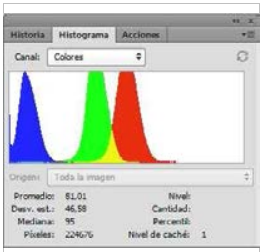

Grafica C (ST)

Valor C(ST):

81,01

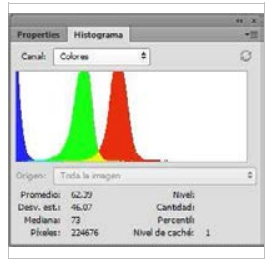

Grafica C (TT)

Valor C(TT):

62,39 Valor DF-R: Valor DF-C: 15,91

18,62

\section{GRAFICA:}

\section{LEYENDA}

ST MADERA SIN TRATAR

Grafica R Histograma color Rojo

Grafica G Histograma color Verde

Grafica B Histograma color Azul

Grafica L Histograma Luminosidad

Grafica C Histograma RGB

\section{TT MADERA TRATADA}

Valor $\mathrm{R}$ Número pixeles color Rojo

Valor $G$ Número pixeles color Verde

Valor B Número pixeles color Azul

Valor $L$ Número pixeles Luminosidad

Valor C Número pixeles RG

DF DIFERENCIA DE VALORES R;G; $\mathrm{DF}=\operatorname{Valor} \mathrm{ST}(\mathrm{R} ; \mathrm{G} ; \mathrm{B})$ - Valor TT(R;G;B

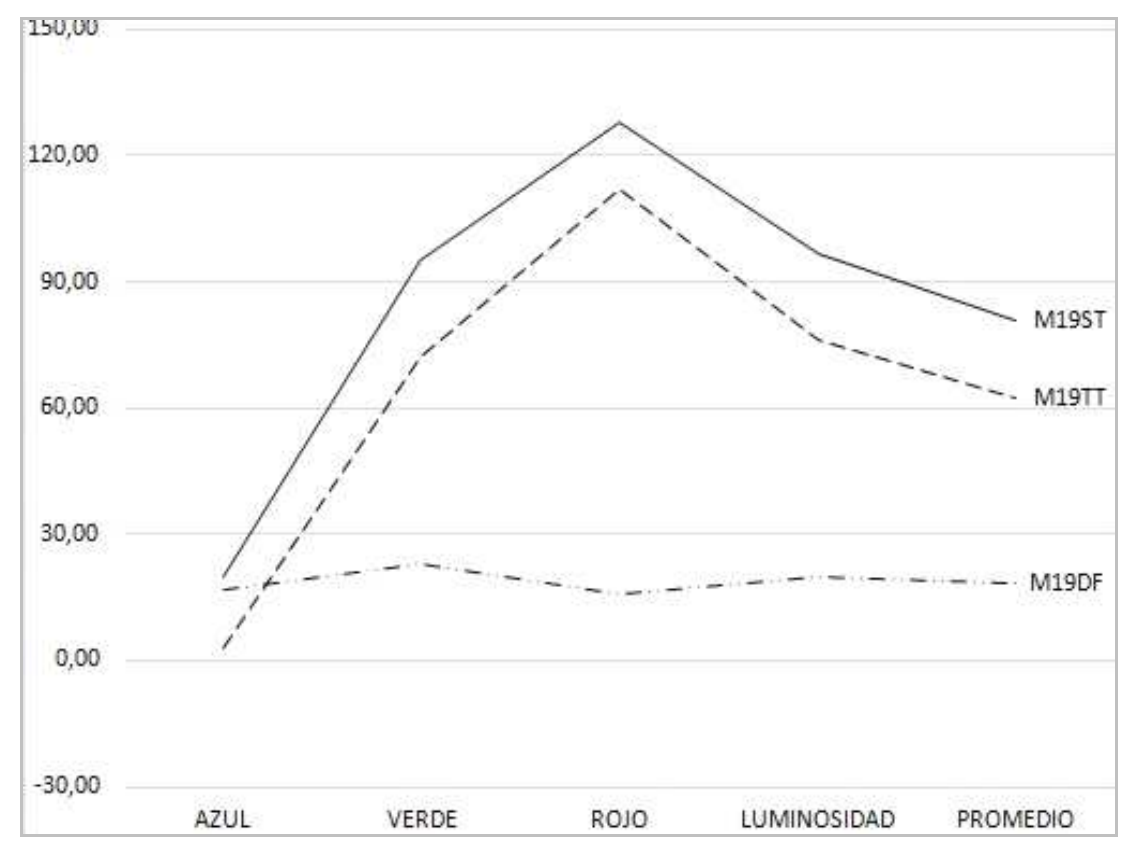

Universidad Politécnica de Madrid - Escuela Técnica Superior de Arquitectura - Departamento de Construcción y Tecnología Arquitectónica Directores: Dr. Alfonso García Santos y Dr. Antonio Rodríguez Rodríguez. Doctorando: D. Francisco Lora Toro 


\section{FICHA DE ENSAYOS DE MADERA Y ACIDOS}

\section{ACIDO A01/AG/ACIDO ACÉTICO GLACIAL}

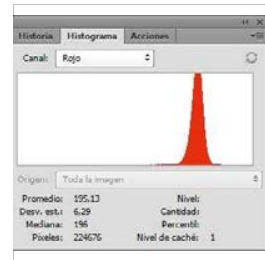

SIN TRATAR (ST): Grafica R (ST)

Valor R(ST):

195,13

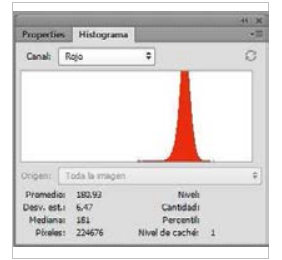

TRATADA (TT): Grafica R (TT) Valor R(TT): 180,93

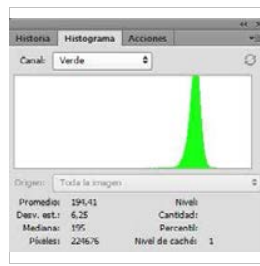

Grafica G (ST) Valor $\mathrm{G}(\mathrm{ST})$ : 194,41

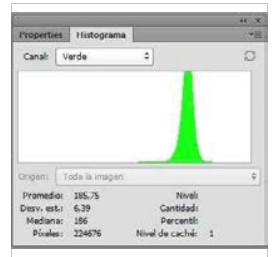

Grafica G (TT)

Valor $\mathrm{G}(\mathrm{TT})$ : 185,75

\section{MADERA M20/KT/KOTO}

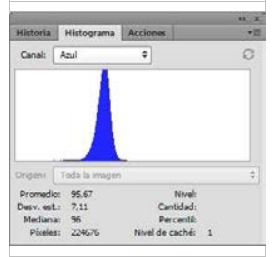

Grafica B (ST)

Valor B(ST):

95,67

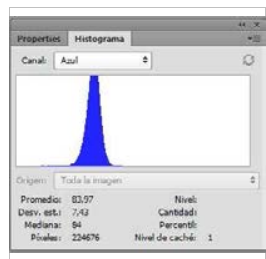

Grafica B (TT)

Valor $\mathrm{B}(\mathrm{TT})$ :

83,97

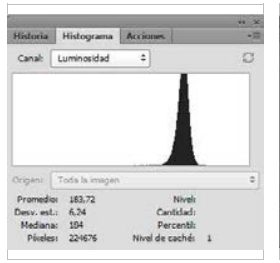

Grafica L (ST)

Valor L(ST):

183,72

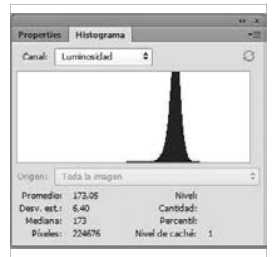

Grafica L (TT)

Valor L(TT):

173,05

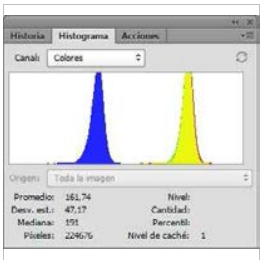

Grafica C (ST)

Valor C(ST):

161,74

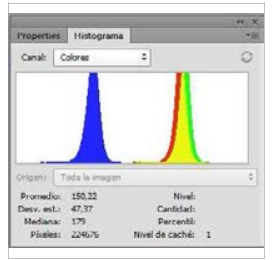

Grafica C (TT)

Valor C(TT):

150,22

DIFERENCIA (DF) Grafica R (DF):

Grafica G (DF): Grafica B (DF):

Grafica L (DF):

Grafica C (DF): Valor DF-R:

Valor DF-G:

Valor DF-B:

Valor DF-L:

Valor DF-C: 14,20

8,66

11,70

10,67

11,52

\section{GRAFICA:}

\section{LEYENDA}

\section{ST MADERA SIN TRATAR}

Grafica R Histograma color Rojo Grafica G Histograma color Verde Grafica B Histograma color Azul

Grafica L Histograma Luminosidad Grafica C Histograma RGB

\section{TT MADERA TRATADA}

Valor $\mathrm{R}$ Número pixeles color Rojo Valor $\mathrm{G}$ Número pixeles color Verde Valor B Número pixeles color Azul Valor L Número pixeles Luminosidad Valor C Número pixeles RG DF DIFERENCIA DE VALORES R;G; $\mathrm{DF}=$ Valor $\mathrm{ST}(\mathrm{R} ; \mathrm{G} ; \mathrm{B})$ - Valor TT(R;G;B

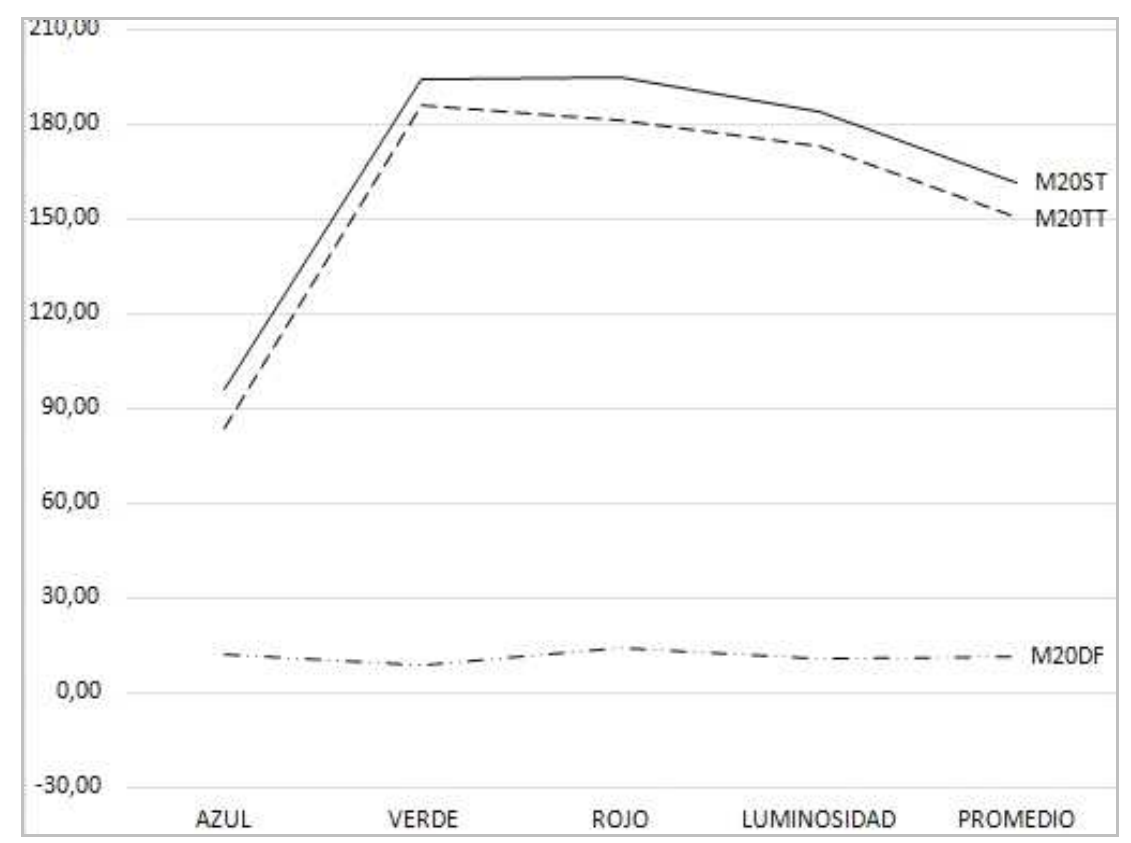

Universidad Politécnica de Madrid - Escuela Técnica Superior de Arquitectura - Departamento de Construcción y Tecnología Arquitectónica Directores: Dr. Alfonso García Santos y Dr. Antonio Rodríguez Rodríguez. Doctorando: D. Francisco Lora Toro 


\section{FICHA DE ENSAYOS DE MADERA Y ACIDOS}

\section{ACIDO A01/AG/ACIDO ACÉTICO GLACIAL}

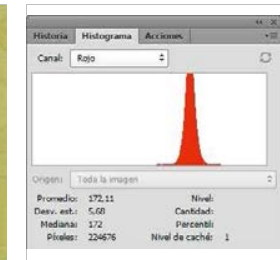

SIN TRATAR (ST): Grafica R (ST)

Valor R(ST):

172,11

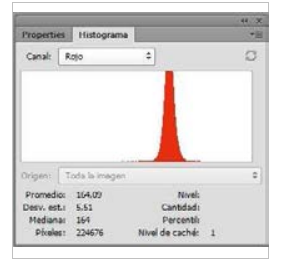

TRATADA (TT): Grafica R (TT)

Valor $\mathrm{R}(\mathrm{TT})$ :

164,09

DIFERENCIA (DF) Grafica R (DF):

Valor DF-R:

8,02

6,88

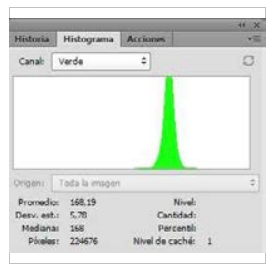

Grafica G (ST)

Valor G(ST):

168,19

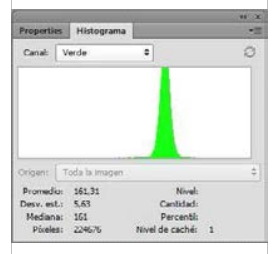

Grafica G (TT)

Valor $\mathrm{G}(\mathrm{TT})$ :

161,31

\section{MADERA M21/LG/LENGA}

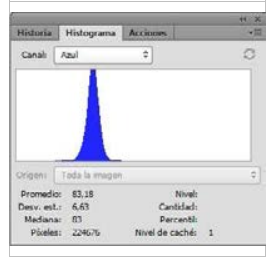

Grafica B (ST)

Valor B(ST):

83,18

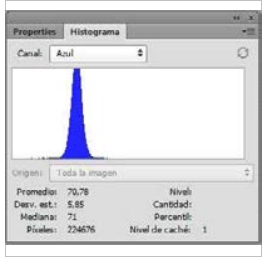

Grafica B (TT)

Valor $\mathrm{B}(\mathrm{TT})$ :

70,78

Grafica G (DF): Grafica B (DF):

Valor DF-G:

Valor DF-B:

12,40

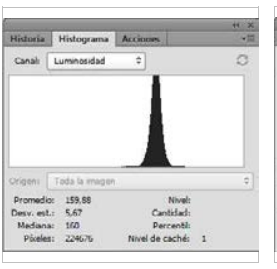

Grafica L (ST)

Valor L(ST):

159,88

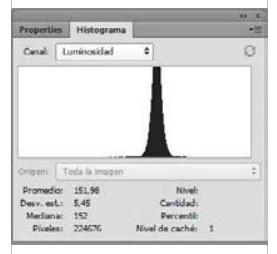

Grafica L (TT)

Valor L(TT):

151,98

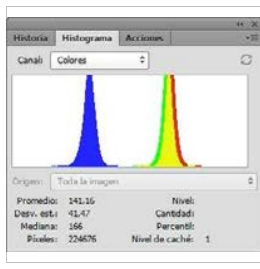

Grafica C (ST)

Valor C(ST):

141,16

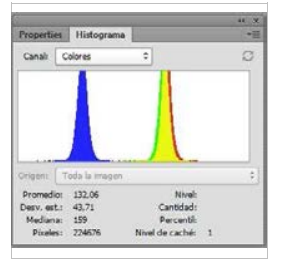

Grafica C (TT)

Valor $\mathrm{C}(\mathrm{TT})$ :

132,06
GRAFICA:

\section{LEYENDA}

ST MADERA SIN TRATAR

Grafica R Histograma color Rojo

Grafica G Histograma color Verde

Grafica B Histograma color Azul

Grafica L Histograma Luminosidad

Grafica C Histograma RGB

\section{TT MADERA TRATADA}

Valor $R$ Número pixeles color Rojo

Valor $\mathrm{G}$ Número pixeles color Verde Valor B Número pixeles color Azul

Valor L Número pixeles Luminosidad

Valor C Número pixeles RG

DF DIFERENCIA DE VALORES R;G; $\mathrm{DF}=$ Valor $\mathrm{ST}(\mathrm{R} ; \mathrm{G} ; \mathrm{B})$ - Valor TT(R;G;B

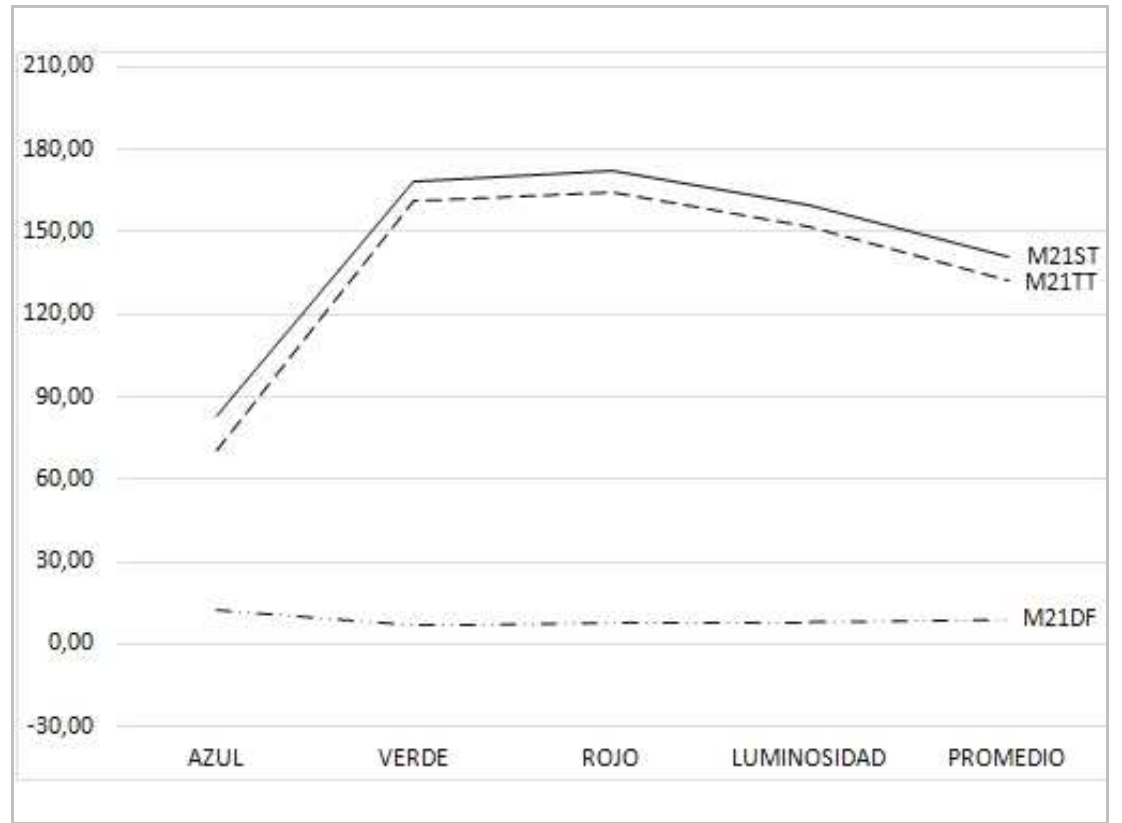

Universidad Politécnica de Madrid - Escuela Técnica Superior de Arquitectura - Departamento de Construcción y Tecnología Arquitectónica Directores: Dr. Alfonso García Santos y Dr. Antonio Rodríguez Rodríguez. Doctorando: D. Francisco Lora Toro 


\section{FICHA DE ENSAYOS DE MADERA y ACIDOS}

\section{ACIDO A01/AG/ACIDO ACÉTICO GLACIAL}
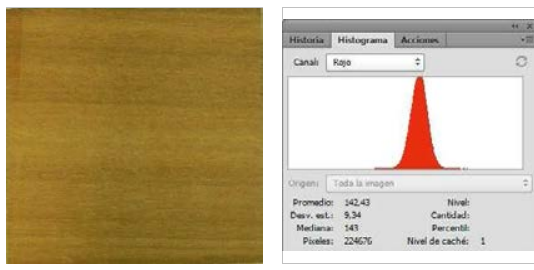

SIN TRATAR (ST): Grafica R (ST)

Valor R(ST):

142,43

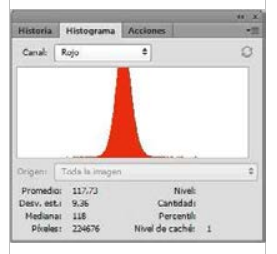

TRATADA (TT): Grafica R (TT)

Valor $\mathrm{R}(\mathrm{TT})$ :

117,73

DIFERENCIA (DF) Grafica R (DF): Valor DF-R: 24,70

GRAFICA:

\section{LEYENDA}

ST MADERA SIN TRATAR

Grafica R Histograma color Rojo

Grafica G Histograma color Verde

Grafica B Histograma color Azul

Grafica L Histograma Luminosidad

Grafica C Histograma RGB

TT MADERA TRATADA

Valor $\mathrm{R}$ Número pixeles color Rojo

Valor $\mathrm{G}$ Número pixeles color Verde

Valor B Número pixeles color Azul

Valor $L$ Número pixeles Luminosidad

Valor $C$ Número pixeles $R G$

DF DIFERENCIA DE VALORES R;G $\mathrm{DF}=$ Valor $\mathrm{ST}(\mathrm{R} ; \mathrm{G} ; \mathrm{B})$ - Valor TT(R;G;B

\section{MADERA M22/MK/MAKORÉ}
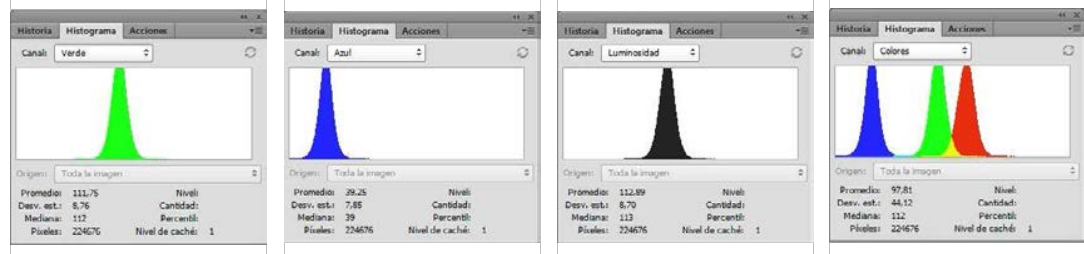

\section{Grafica G (ST)}

Grafica B (ST)

Grafica L (ST)

Grafica C (ST)

Valor G(ST):

Valor B(ST):

Valor L(ST):

Valor C(ST):

39,25

112,89

97,81
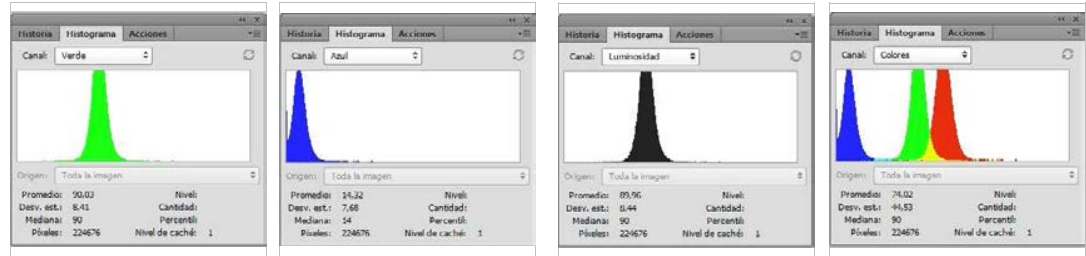

Grafica G (TT)

Grafica B (TT)

Grafica L (TT)

Grafica C (TT)

Valor $\mathrm{G}(\mathrm{TT})$ :

Valor $\mathrm{B}(\mathrm{TT})$ :

Valor L(TT):

Valor $\mathrm{C}(\mathrm{TT})$ :

90,03

14,32

89,96

74,02

Grafica G (DF): Grafica B (DF): Grafica L (DF): Grafica C (DF): Valor DF-G: $\quad$ Valor DF-B: Valor DF-L: Valor DF-C: 21,12 24,93 22,93 23,79

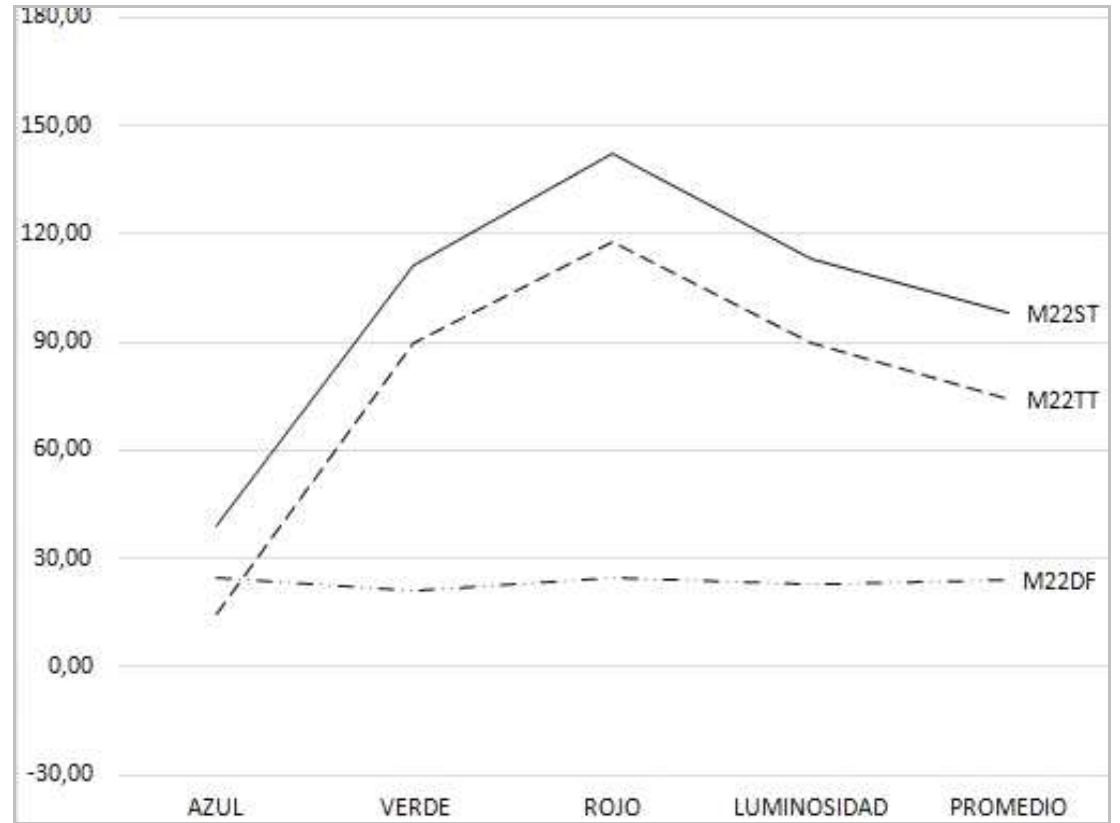

Universidad Politécnica de Madrid - Escuela Técnica Superior de Arquitectura - Departamento de Construcción y Tecnología Arquitectónica Directores: Dr. Alfonso García Santos y Dr. Antonio Rodríguez Rodríguez. Doctorando: D. Francisco Lora Toro 


\section{FICHA DE ENSAYOS DE MADERA Y ACIDOS}

\section{ACIDO A01/AG/ACIDO ACÉTICO GLACIAL}
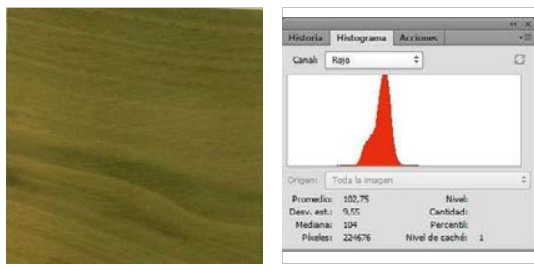

SIN TRATAR (ST): Grafica R (ST)

Valor R(ST):

102,75

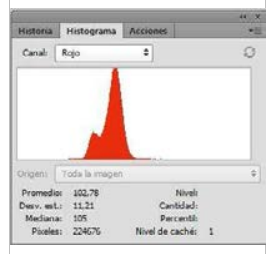

TRATADA (TT): Grafica $R(T T)$

Valor $\mathrm{R}(\mathrm{TT})$ :

102,78

DIFERENCIA (DF) Grafica R (DF): Valor DF-R: $-0,03$

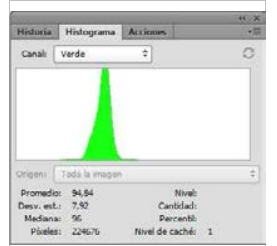

Grafica G (ST)

Valor G(ST):

94,84

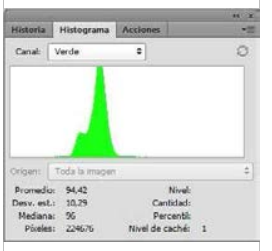

Grafica G (TT)

Valor G(TT):

94,42
MADERA M23/NGA/NOGAL NEGRO AMERICANO

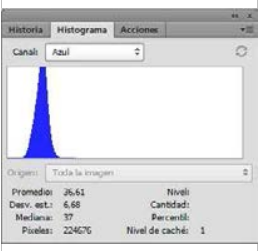

Grafica B (ST)

Valor $\mathrm{B}(\mathrm{ST})$ :

36,61
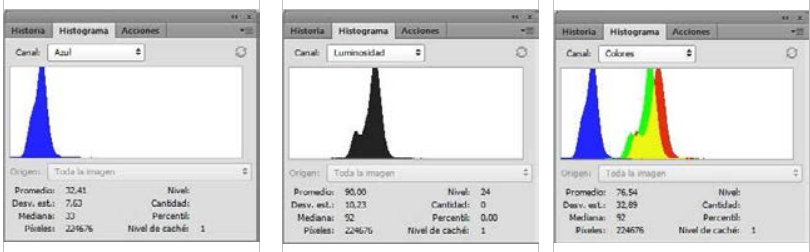

Grafica B (TT)

Grafica L (TT)

Grafica C (TT)

Valor $\mathrm{B}(\mathrm{TT})$ :

Valor L(TT):

Valor $\mathrm{C}(\mathrm{TT})$ :

90,00

76,54

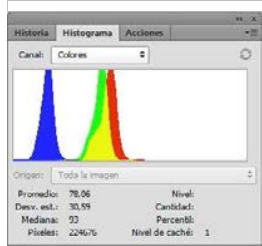

Grafica C (ST)

Valor C(ST):

78,06
Grafica G (DF): Grafica B (DF):

Valor DF-G:

0,42
4,20
Grafica L (DF):

Valor DF-L:

0,68

GRAFICA:

\section{LEYENDA}

ST MADERA SIN TRATAR

Grafica R Histograma color Rojo

Grafica G Histograma color Verde

Grafica B Histograma color Azul

Grafica L Histograma Luminosidad

Grafica C Histograma RGB

TT MADERA TRATADA

Valor R Número pixeles color Rojo

Valor G Número pixeles color Verde

Valor B Número pixeles color Azul

Valor $\mathrm{L}$ Número pixeles Luminosidad

Valor $C$ Número pixeles $R G$

DF DIFERENCIA DE VALORES R;G; $\mathrm{DF}=$ Valor $\mathrm{ST}(\mathrm{R} ; \mathrm{G} ; \mathrm{B})$ - Valor $\mathrm{TT}(\mathrm{R} ; \mathrm{G} ; \mathrm{B}$

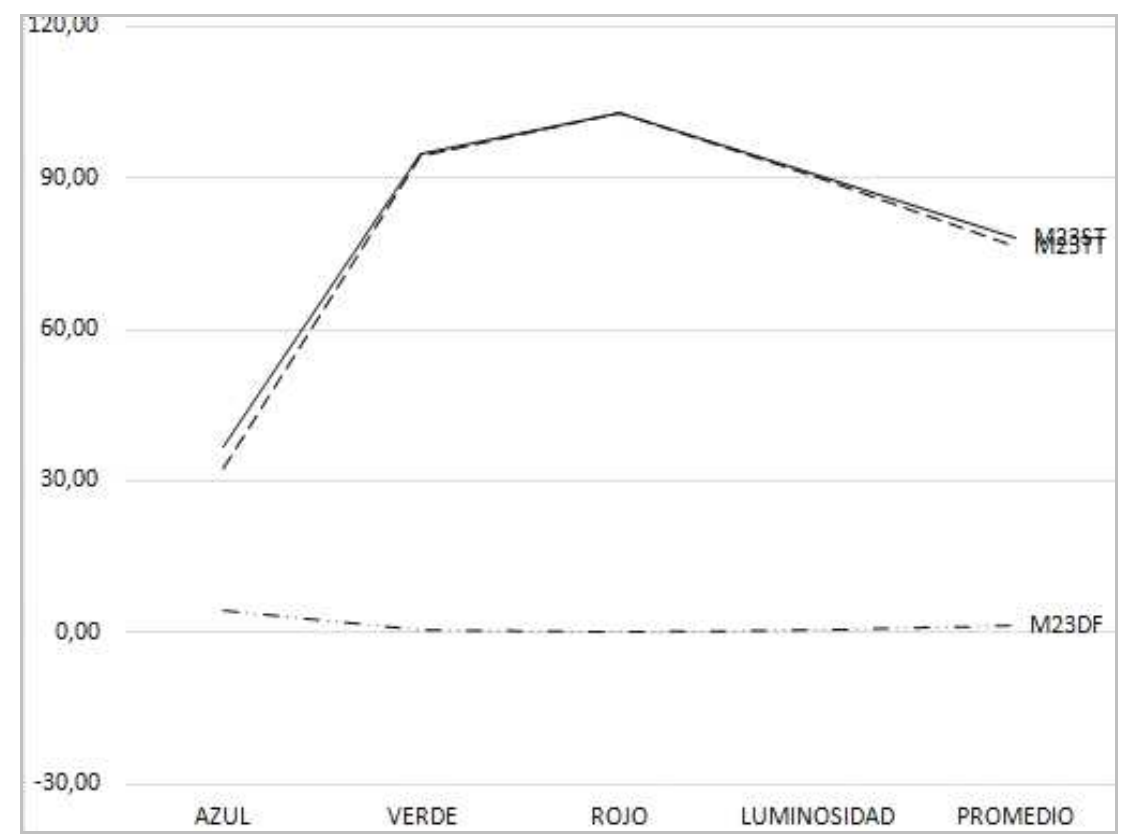

Universidad Politécnica de Madrid - Escuela Técnica Superior de Arquitectura - Departamento de Construcción y Tecnología Arquitectónica Directores: Dr. Alfonso García Santos y Dr. Antonio Rodríguez Rodríguez. Doctorando: D. Francisco Lora Toro 


\section{FICHA DE ENSAYOS DE MADERA Y ACIDOS}

\section{ACIDO A01/AG/ACIDO ACÉTICO GLACIAL}
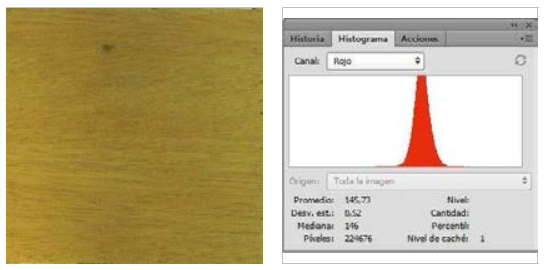

SIN TRATAR (ST): Grafica R (ST)

Valor R(ST):

145,73

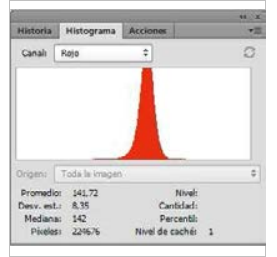

TRATADA (TT): Grafica R (TT)

Valor $\mathrm{R}(\mathrm{TT})$ :

141,72

DIFERENCIA (DF) Grafica R (DF): Valor DF-R:

4,01

GRAFICA:

\section{LEYENDA}

ST MADERA SIN TRATAR

Grafica R Histograma color Rojo

Grafica G Histograma color Verde

Grafica B Histograma color Azul

Grafica L Histograma Luminosidad

Grafica C Histograma RGB

TT MADERA TRATADA

Valor R Número pixeles color Rojo

Valor $\mathrm{G}$ Número pixeles color Verde

Valor B Número pixeles color Azul

Valor $L$ Número pixeles Luminosidad

Valor $C$ Número pixeles $R G$

DF DIFERENCIA DE VALORES R;G; $\mathrm{DF}=$ Valor $\mathrm{ST}(\mathrm{R} ; \mathrm{G} ; \mathrm{B})$ - Valor $\mathrm{TT}(\mathrm{R} ; \mathrm{G} ; \mathrm{B}$

\section{MADERA M24/OK/OKUMÉ}
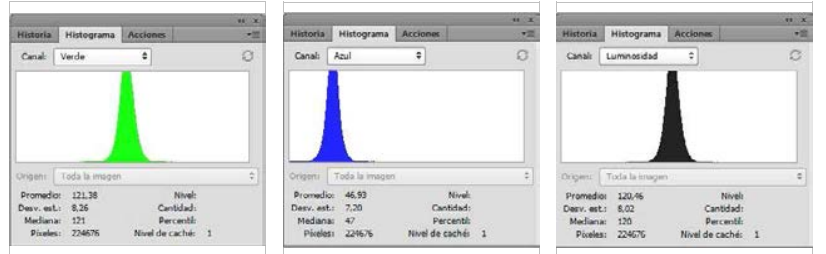

Grafica G (ST)

Grafica B (ST)

Grafica L (ST)

Valor L(ST):

120,46

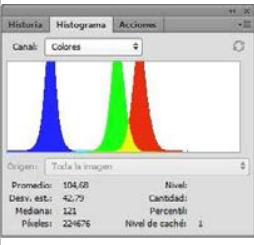

Valor G(ST):

Valor $\mathrm{B}(\mathrm{ST})$ :

46,93
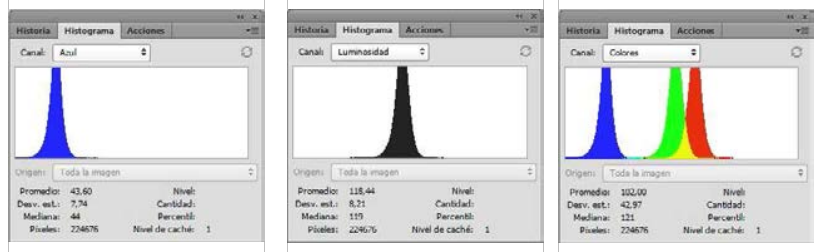

\section{Grafica G (TT)}

Grafica B (TT)

Grafica L (TT)

Grafica C (TT)

Valor $\mathrm{B}(\mathrm{TT})$ :

Valor L(TT):

Valor C(TT):

43,60

118,44

102,00

Valor C(ST):

104,68

$$
120,66
$$

Grafica G (DF): Grafica B (DF):

Grafica L (DF):

Grafica C (DF):

Valor DF-G:

Valor DF-B:

Valor DF-L:

Valor DF-C:

$\begin{array}{llll}0,72 & 3,33 & 2,02 & 2,68\end{array}$

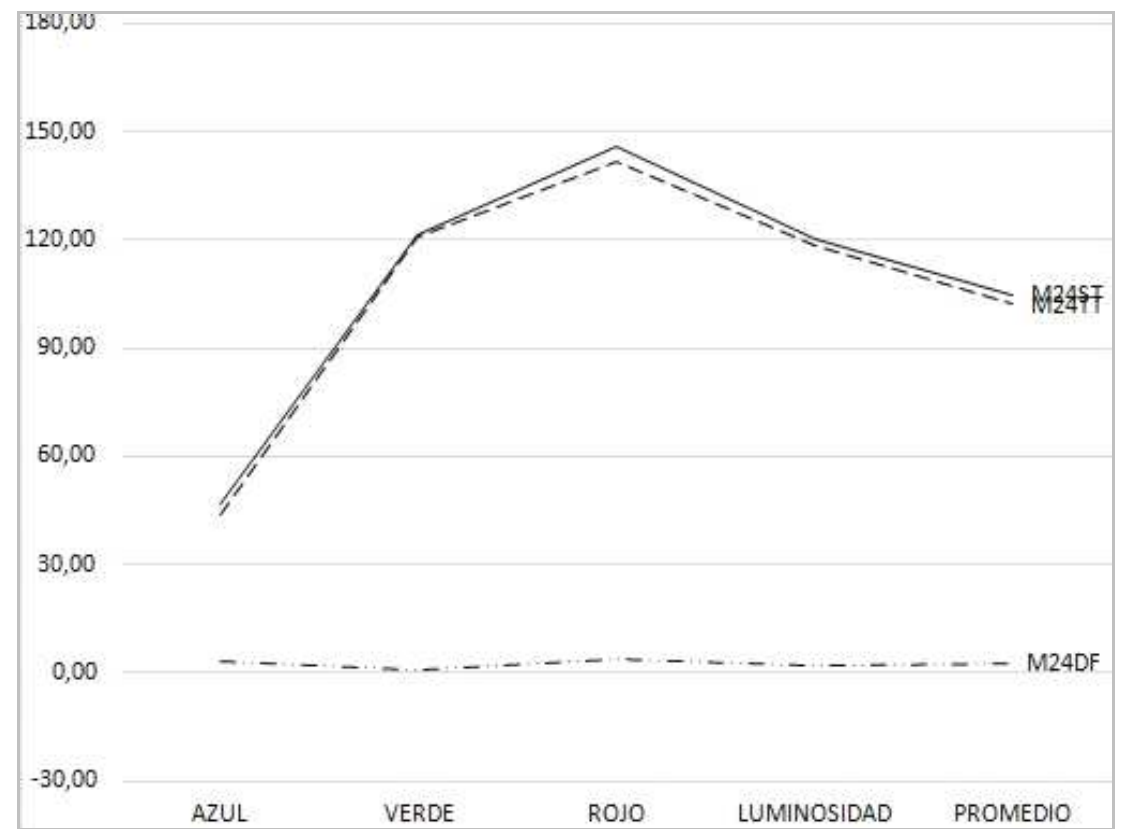

Universidad Politécnica de Madrid - Escuela Técnica Superior de Arquitectura - Departamento de Construcción y Tecnología Arquitectónica Directores: Dr. Alfonso García Santos y Dr. Antonio Rodríguez Rodríguez. Doctorando: D. Francisco Lora Toro 


\section{FICHA DE ENSAYOS DE MADERA Y ACIDOS}

\section{ACIDO A01/AG/ACIDO ACÉTICO GLACIAL}
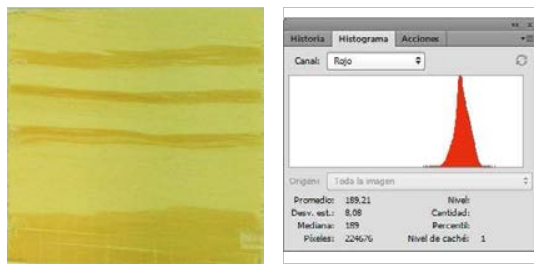

SIN TRATAR (ST): Grafica R (ST)

Valor R(ST):

189,21

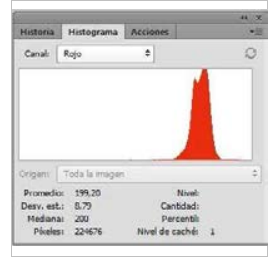

TRATADA (TT): Grafica R (TT)

Valor $\mathrm{R}(\mathrm{TT})$ :

199,20

DIFERENCIA (DF) Grafica R (DF): Valor DF-R: $-9,99$

GRAFICA:

\section{LEYENDA}

ST MADERA SIN TRATAR

Grafica R Histograma color Rojo

Grafica G Histograma color Verde

Grafica B Histograma color Azul

Grafica L Histograma Luminosidad

Grafica C Histograma RGB

TT MADERA TRATADA

Valor $R$ Número pixeles color Rojo

Valor $\mathrm{G}$ Número pixeles color Verde

Valor B Número pixeles color Azul

Valor $L$ Número pixeles Luminosidad

Valor $C$ Número pixeles $R G$

DF DIFERENCIA DE VALORES R;G; $\mathrm{DF}=$ Valor $\mathrm{ST}(\mathrm{R} ; \mathrm{G} ; \mathrm{B})$ - Valor $\mathrm{TT}(\mathrm{R} ; \mathrm{G} ; \mathrm{B}$

\section{MADERA M25/PX/PINO AMARILLO DEL SUR}

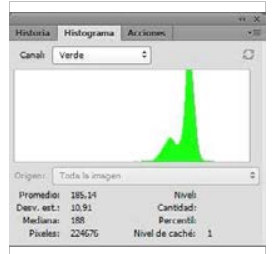

Grafica G (ST)

Valor G(ST):

185,14

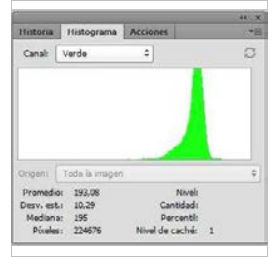

Grafica G (TT)

Valor $\mathrm{G}(\mathrm{TT})$ :

193,08
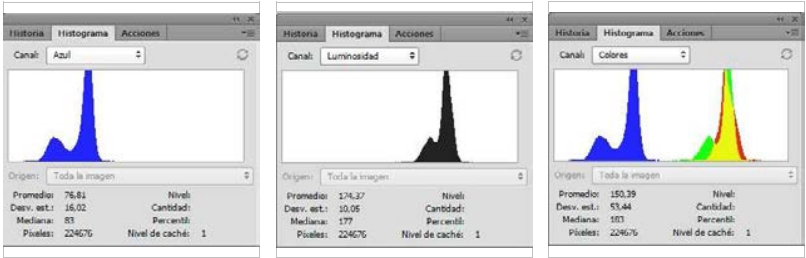

Grafica B (ST)

Grafica L (ST)

Grafica C (ST)

Valor B(ST):

Valor L(ST):

Valor C(ST):

76,81

174,37

150,39
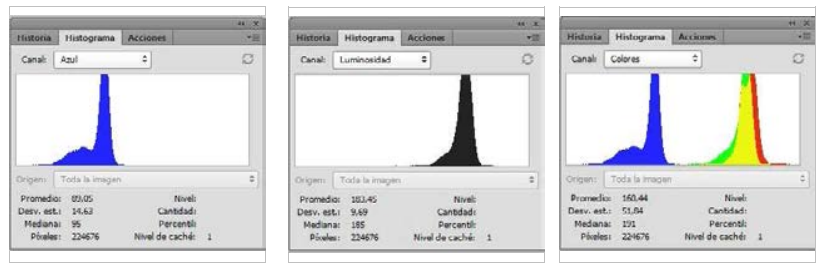

Grafica B (TT)

Grafica L (TT)

Grafica C (TT)

Valor B(TT):

Valor L(TT):

Valor C(TT):

89,05

183,45

160,44

Grafica G (DF): Grafica B (DF): Grafica L (DF): Grafica C (DF): Valor DF-G: Valor DF-B: Valor DF-L: Valor DF-C:

$\begin{array}{llll}-7,94 & -12,24 & -9,08 & -10,05\end{array}$

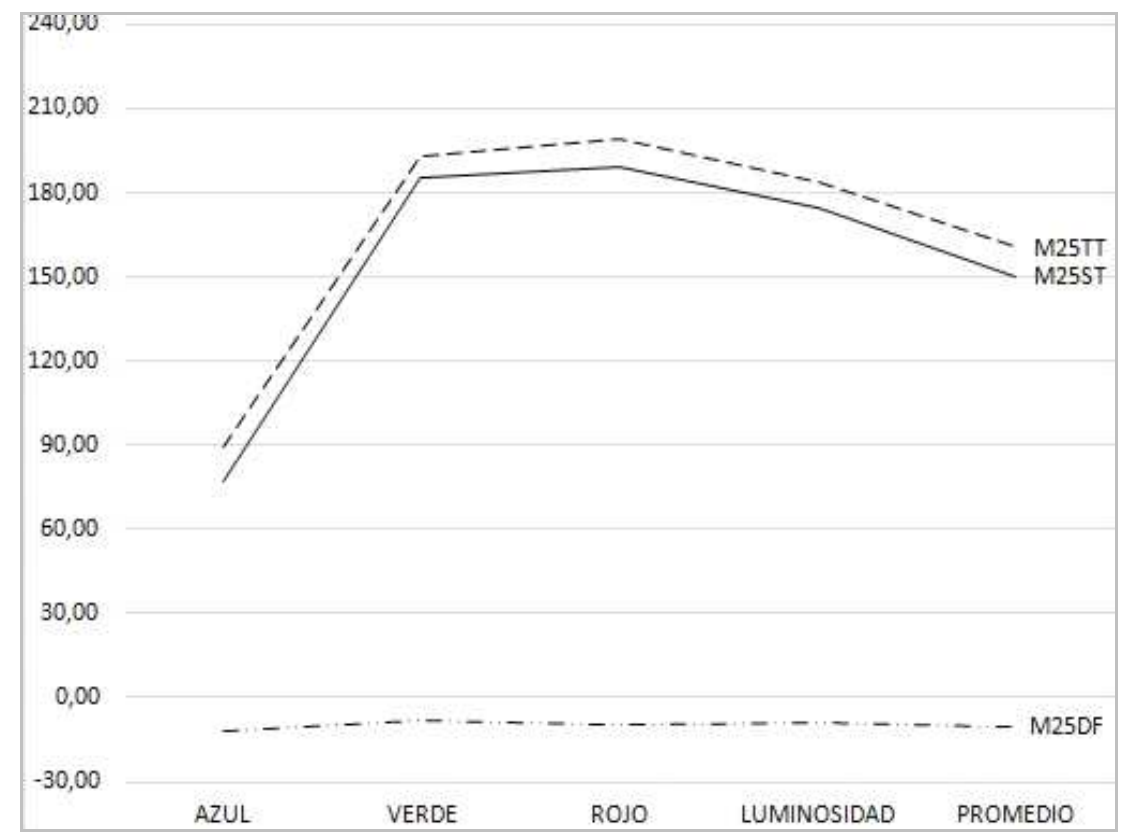

Universidad Politécnica de Madrid - Escuela Técnica Superior de Arquitectura - Departamento de Construcción y Tecnología Arquitectónica Directores: Dr. Alfonso García Santos y Dr. Antonio Rodríguez Rodríguez. Doctorando: D. Francisco Lora Toro 


\section{FICHA DE ENSAYOS DE MADERA Y ACIDOS}

\section{ACIDO A01/AG/ACIDO ACÉTICO GLACIAL}

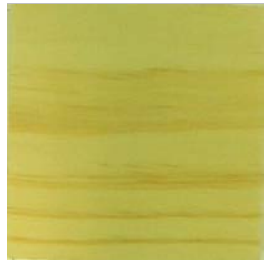

SIN TRATAR (ST): Grafica R (ST)

Valor R(ST):

174,37

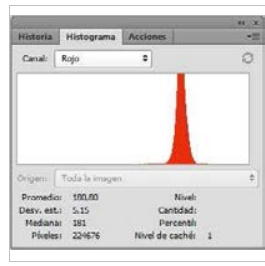

TRATADA (TT): Grafica R (TT)

Valor $\mathrm{R}(\mathrm{TT})$ :

190,80

DIFERENCIA (DF) Grafica R (DF):

Valor DF-R:

$-16,43$

GRAFICA:

\section{LEYENDA}

ST MADERA SIN TRATAR

Grafica R Histograma color Rojo

Grafica G Histograma color Verde

Grafica B Histograma color Azul

Grafica L Histograma Luminosidad

Grafica C Histograma RGB

\section{TT MADERA TRATADA}

Valor R Número pixeles color Rojo

Valor $\mathrm{G}$ Número pixeles color Verde

Valor B Número pixeles color Azul

Valor $L$ Número pixeles Luminosidad

Valor C Número pixeles RG

DF DIFERENCIA DE VALORES R;G;

$\mathrm{DF}=$ Valor $\mathrm{ST}(\mathrm{R} ; \mathrm{G} ; \mathrm{B})$ - Valor $\mathrm{TT}(\mathrm{R} ; \mathrm{G} ; \mathrm{B}$

\section{MADERA M26/PR/PINO RADIATA}
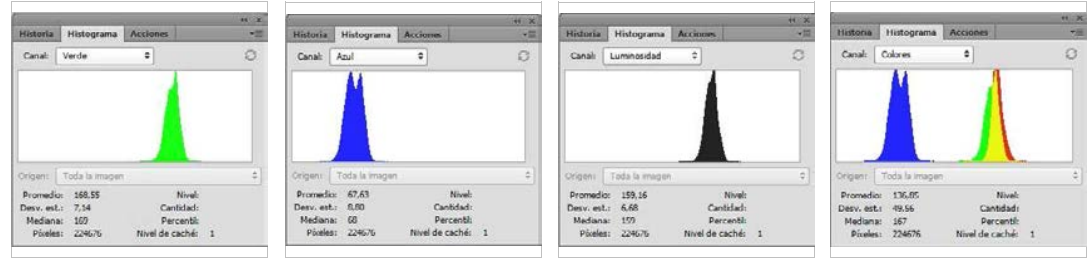

Grafica G (ST)

Grafica B (ST)

Grafica L (ST)

Grafica C (ST)

Valor G(ST):

Valor B(ST):

Valor L(ST):

Valor C(ST):

168,55

67,63

159,16

136,85
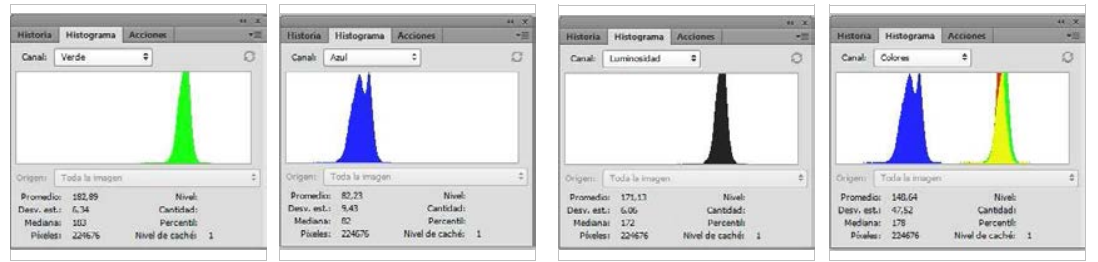

Grafica G (TT)

Grafica B (TT)

Grafica L (TT)

Grafica C (TT)

Valor G(TT):

Valor $\mathrm{B}(\mathrm{TT})$ :

Valor L(TT):

Valor C(TT):

182,89

82,23

171,13

148,64

Grafica G (DF): Grafica B (DF): Grafica L (DF):

Grafica C (DF):

Valor DF-G:

Valor DF-B:

Valor DF-L:

Valor DF-C:

$-14,34$

$-14,60$

$-11,97$

$-11,79$

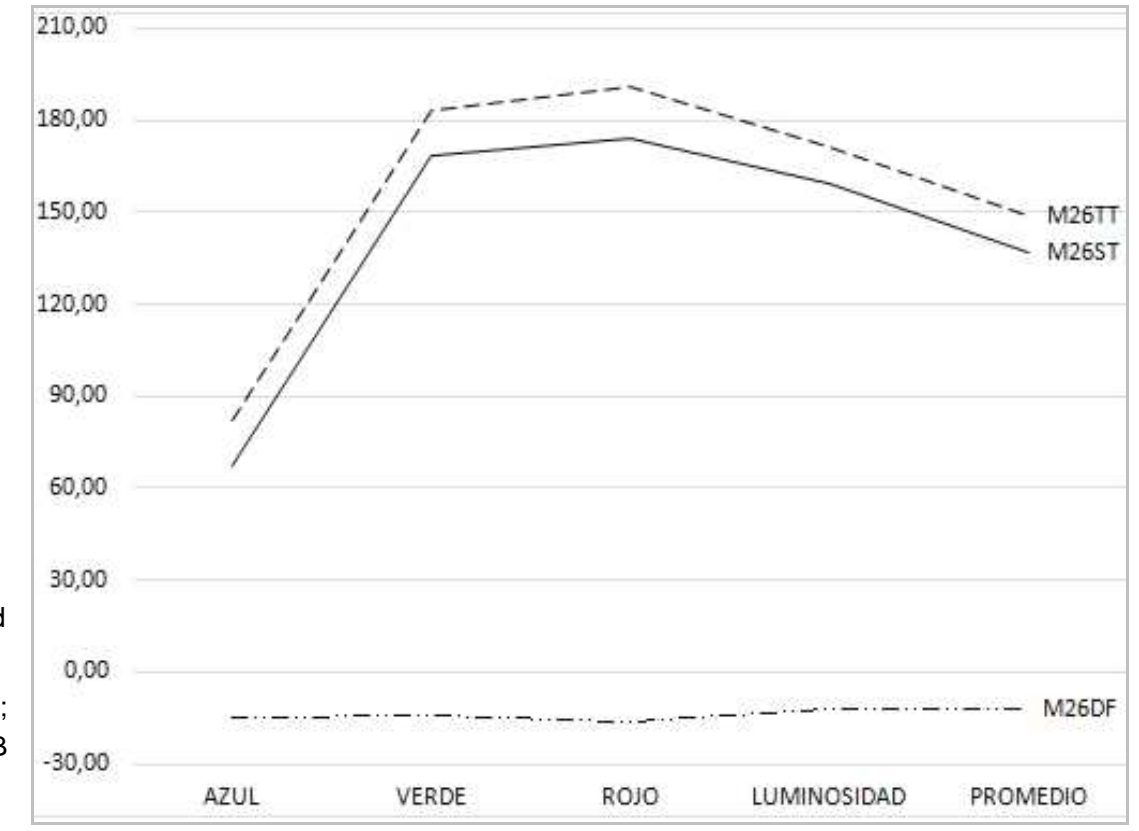

Universidad Politécnica de Madrid - Escuela Técnica Superior de Arquitectura - Departamento de Construcción y Tecnología Arquitectónica Directores: Dr. Alfonso García Santos y Dr. Antonio Rodríguez Rodríguez. Doctorando: D. Francisco Lora Toro 


\section{FICHA DE ENSAYOS DE MADERA Y ACIDOS}

\section{ACIDO A01/AG/ACIDO ACÉTICO GLACIAL}

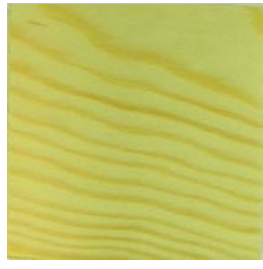

SIN TRATAR (ST): Grafica R (ST)

Valor R(ST):

182,95

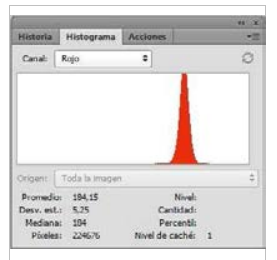

TRATADA (TT): Grafica R (TT) Valor $\mathrm{R}(\mathrm{TT})$ : 184,15

DIFERENCIA (DF) Grafica R (DF): Valor DF-R: $-1,20$

GRAFICA:

\section{LEYENDA}

ST MADERA SIN TRATAR

Grafica R Histograma color Rojo Grafica G Histograma color Verde Grafica B Histograma color Azul Grafica L Histograma Luminosidad Grafica C Histograma RGB

\section{TT MADERA TRATADA}

Valor $\mathrm{R}$ Número pixeles color Rojo Valor $G$ Número pixeles color Verde Valor B Número pixeles color Azul Valor $L$ Número pixeles Luminosidad Valor C Número pixeles RG DF DIFERENCIA DE VALORES R;G; $\mathrm{DF}=$ Valor $\mathrm{ST}(\mathrm{R} ; \mathrm{G} ; \mathrm{B})$ - Valor $\mathrm{TT}(\mathrm{R} ; \mathrm{G} ; \mathrm{B}$

185,08

188,83

\section{MADERA M27/PS/PINO SILVESTRE}
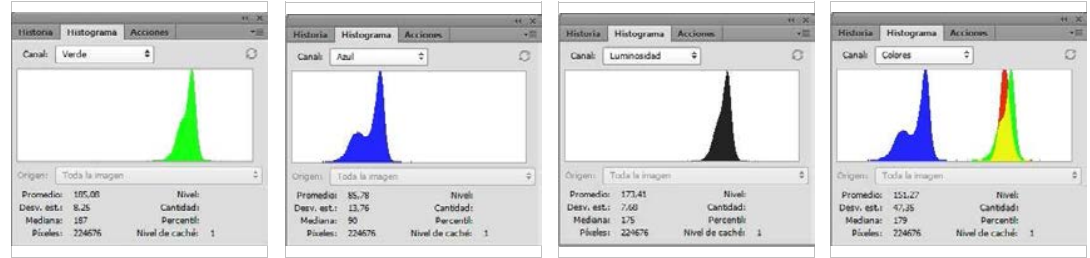

Grafica G (ST)

Grafica B (ST)

Grafica L (ST)

Grafica C (ST)

Valor G(ST):

Valor B(ST):

Valor L(ST):

Valor C(ST):

85,78

173,41

151,27
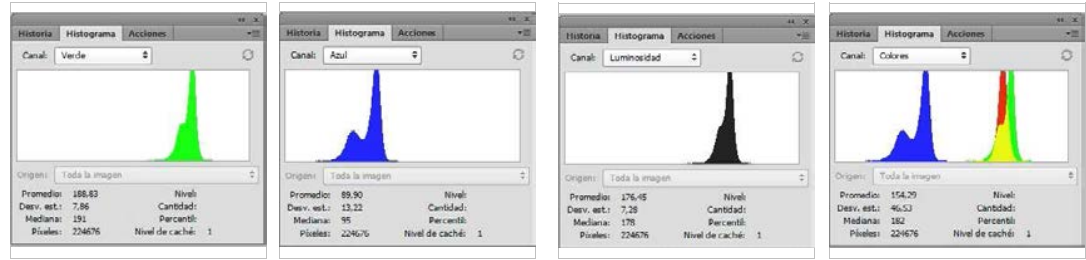

Grafica G (TT)

Grafica B (TT)

Grafica L (TT)

Grafica C (TT)

Valor $\mathrm{G}(\mathrm{TT})$ :

Valor $\mathrm{B}(\mathrm{TT})$ :

Valor L(TT):

Valor C(TT):

89,90

176,45

154,29

Grafica G (DF): Grafica B (DF): Grafica L (DF):

Grafica C (DF):

Valor DF-G:

Valor DF-B:

Valor DF-L:

Valor DF-C:
$-3,75$
$-4,12$
$-3,04$
$-3,02$

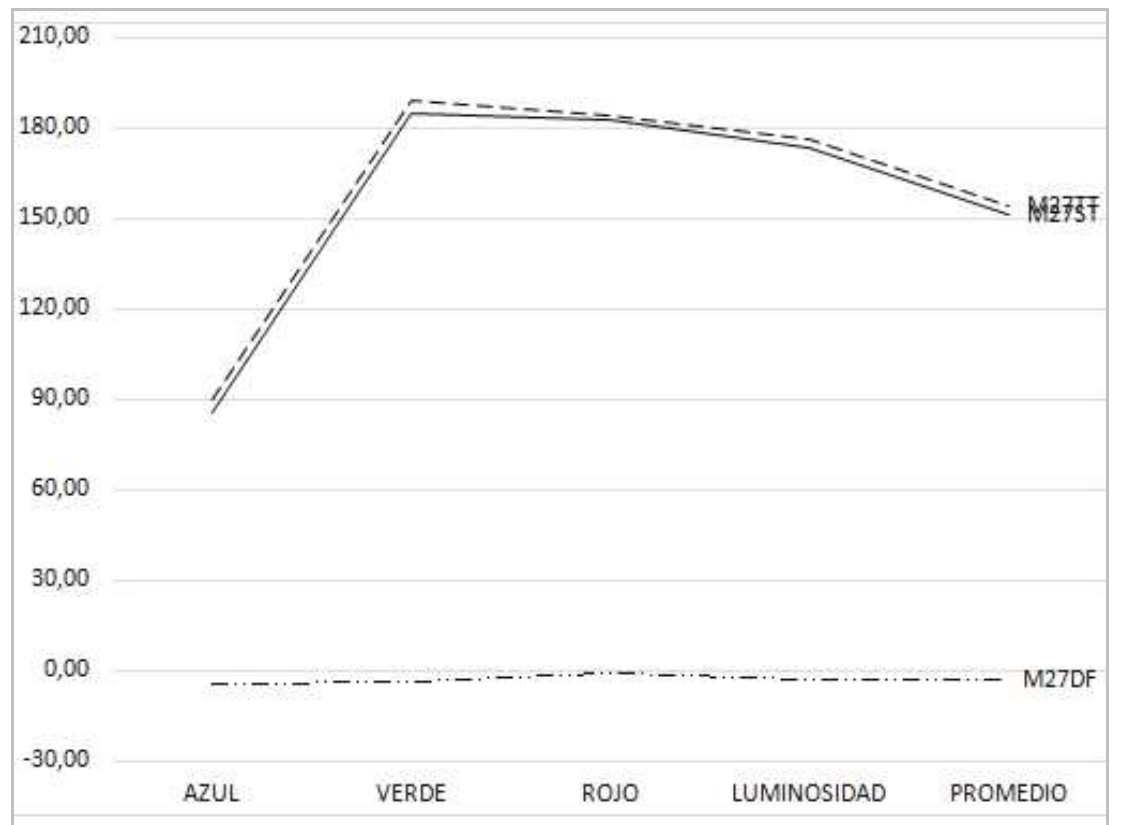

Universidad Politécnica de Madrid - Escuela Técnica Superior de Arquitectura - Departamento de Construcción y Tecnología Arquitectónica Directores: Dr. Alfonso García Santos y Dr. Antonio Rodríguez Rodríguez. Doctorando: D. Francisco Lora Toro 


\section{FICHA DE ENSAYOS DE MADERA Y ACIDOS}

ACIDO A01/AG/ACIDO ACÉTICO GLACIAL
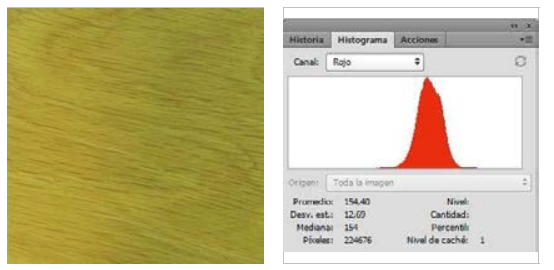

SIN TRATAR (ST): Grafica R (ST)

Valor R(ST):

154,40

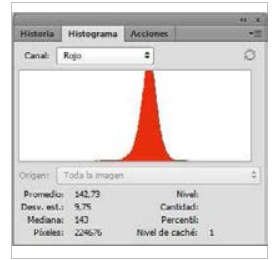

TRATADA (TT): Grafica R (TT)

Valor $\mathrm{R}(\mathrm{TT})$ :

142,73

DIFERENCIA (DF) Grafica R (DF): Valor DF-R: 11,67

GRAFICA :

\section{LEYENDA}

ST MADERA SIN TRATAR

Grafica R Histograma color Rojo Grafica G Histograma color Verde Grafica B Histograma color Azul Grafica L Histograma Luminosidad Grafica C Histograma RGB

TT MADERA TRATADA

Valor R Número pixeles color Rojo Valor $\mathrm{G}$ Número pixeles color Verde Valor B Número pixeles color Azul Valor $L$ Número pixeles Luminosidad Valor C Número pixeles RG DF DIFERENCIA DE VALORES R;G; $\mathrm{DF}=$ Valor $\mathrm{ST}(\mathrm{R} ; \mathrm{G} ; \mathrm{B})$ - Valor TT(R;G;B
MADERA M28/RBA/ROBLE BLANCO AMERICANO

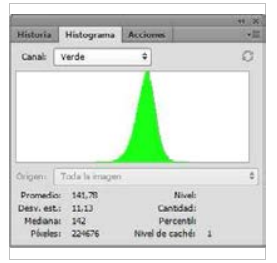

Grafica G (ST)

Valor $\mathrm{G}(\mathrm{ST})$ :

141,78

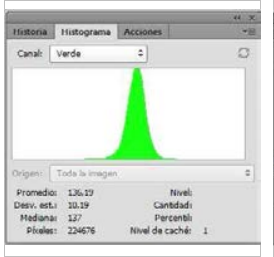

Grafica G (TT)

Valor $\mathrm{G}(\mathrm{TT})$ :

136,19

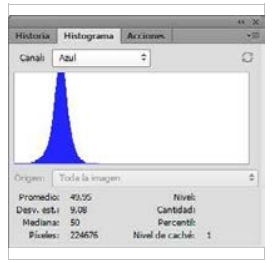

Grafica B (ST)

Valor B(ST):

49,95

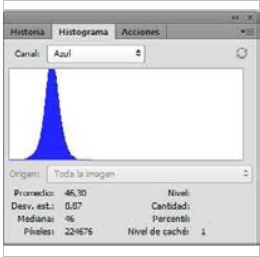

Grafica B (TT)

Valor $\mathrm{B}(\mathrm{TT})$ :

46,30

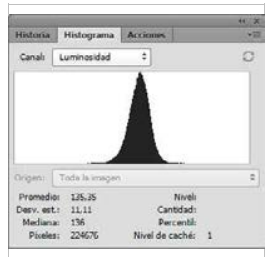

Grafica L (ST)

Valor L(ST):

135,35

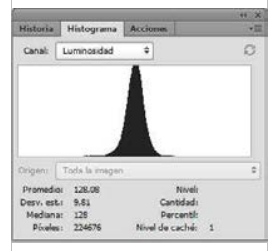

Grafica L (TT)

Valor L(TT):

128,08

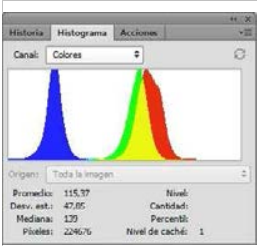

Grafica C (ST)

Valor C(ST):

115,37

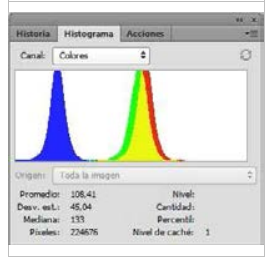

Grafica C (TT)

Valor C(TT):

108,41

Grafica G (DF): Grafica B (DF): Grafica L (DF): Grafica C (DF): Valor DF-G: Valor DF-B: Valor DF-L: Valor DF-C: $\begin{array}{llll}5,59 & 3,65 & 7,27 & 6,96\end{array}$

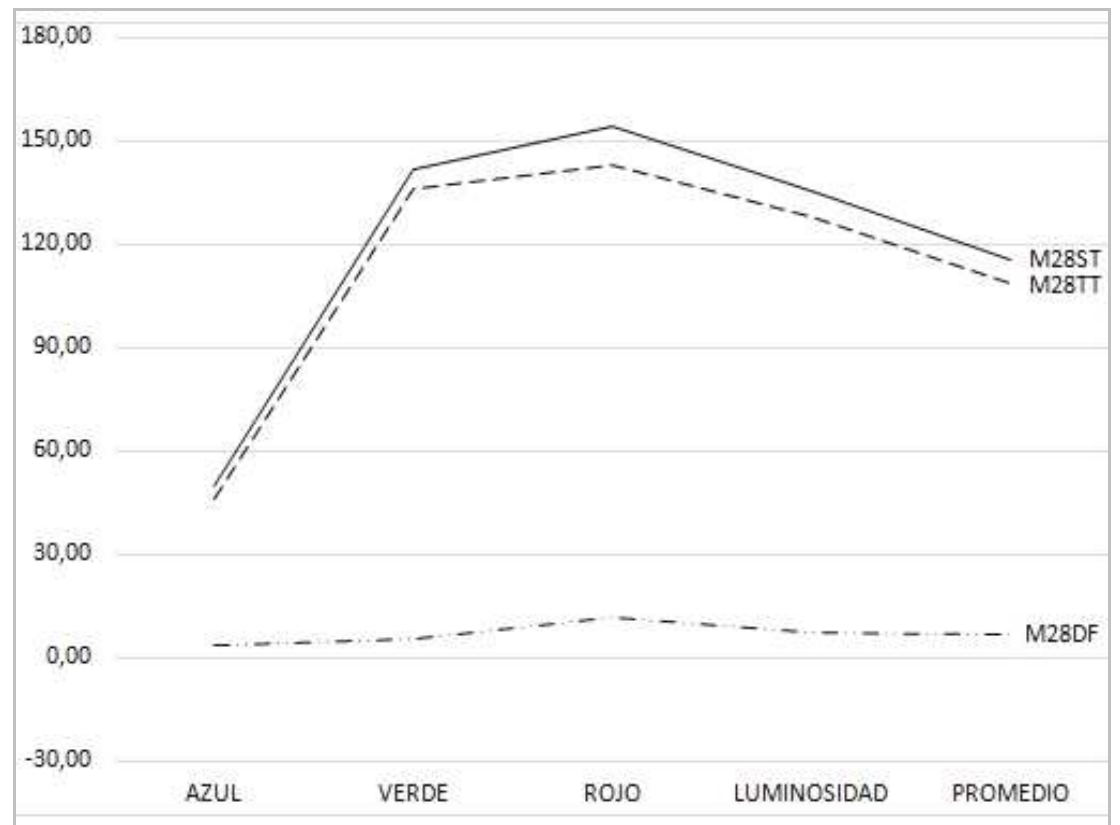

Universidad Politécnica de Madrid - Escuela Técnica Superior de Arquitectura - Departamento de Construcción y Tecnología Arquitectónica Directores: Dr. Alfonso García Santos y Dr. Antonio Rodríguez Rodríguez. Doctorando: D. Francisco Lora Toro 


\section{FICHA DE ENSAYOS DE MADERA Y ACIDOS}

\section{ACIDO A01/AG/ACIDO ACÉTICO GLACIAL}
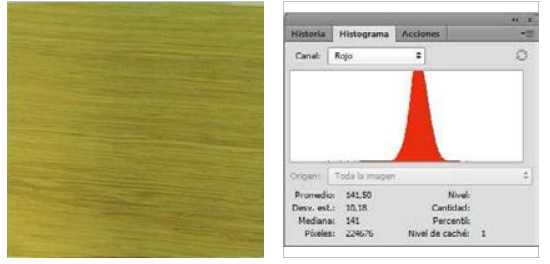

SIN TRATAR (ST): Grafica R (ST)

Valor R(ST):

141,50

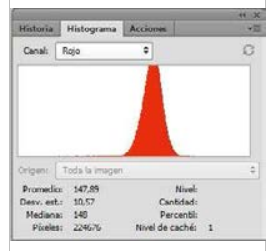

TRATADA (TT): Grafica $R(T T)$

Valor $\mathrm{R}(\mathrm{TT})$ :

147,89

DIFERENCIA (DF) Grafica R (DF): Valor DF-R: $-6,39$

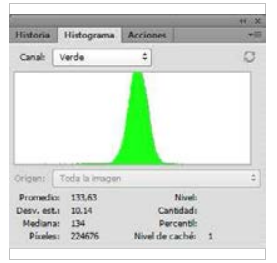

Grafica G (ST)

Valor G(ST):

133,63

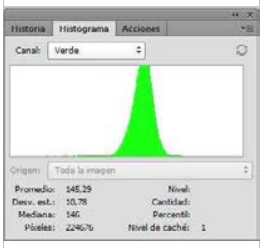

Grafica G (TT)

Valor G(TT):

145,29
MADERA M29/RBE/ROBLE BLANCO EUROPEO

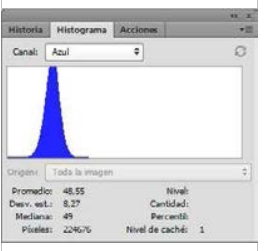

Grafica B (ST)

Valor B(ST):

48,55

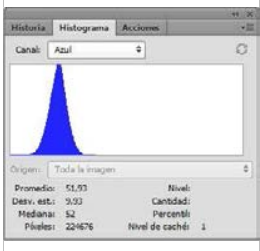

Grafica B (TT)

Valor $\mathrm{B}(\mathrm{TT})$ :

51,93

Grafica G (DF): Grafica B (DF):

Valor DF-B:

$-3,38$

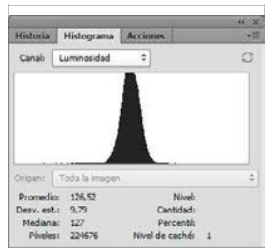

Grafica L (ST)

Valor L(ST):

126,52

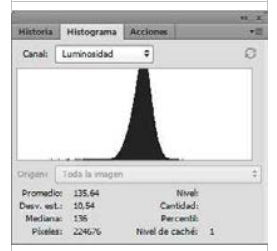

Grafica L (TT)

Valor L(TT):

135,64
Grafica C (TT)

Valor C(TT):

115,04

Grafica L (DF): Grafica C (DF):

Valor DF-L: $\quad$ Valor DF-C:

$-9,12$

$-7,14$

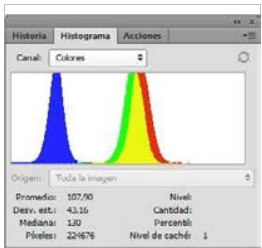

Grafica C (ST)

Valor C(ST):

107,90

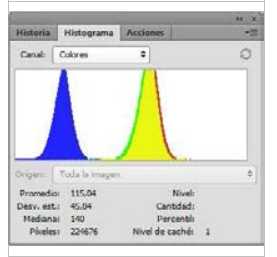

\section{LEYENDA}

ST MADERA SIN TRATAR

Grafica R Histograma color Rojo

Grafica G Histograma color Verde

Grafica B Histograma color Azul

Grafica L Histograma Luminosidad

Grafica C Histograma RGB

TT MADERA TRATADA

Valor R Número pixeles color Rojo

Valor G Número pixeles color Verde

Valor B Número pixeles color Azul

Valor L Número pixeles Luminosidad

Valor $C$ Número pixeles $R G$

DF DIFERENCIA DE VALORES R;G;

$\mathrm{DF}=$ Valor $\mathrm{ST}(\mathrm{R} ; \mathrm{G} ; \mathrm{B})$ - Valor TT $(\mathrm{R} ; \mathrm{G} ; \mathrm{B}$

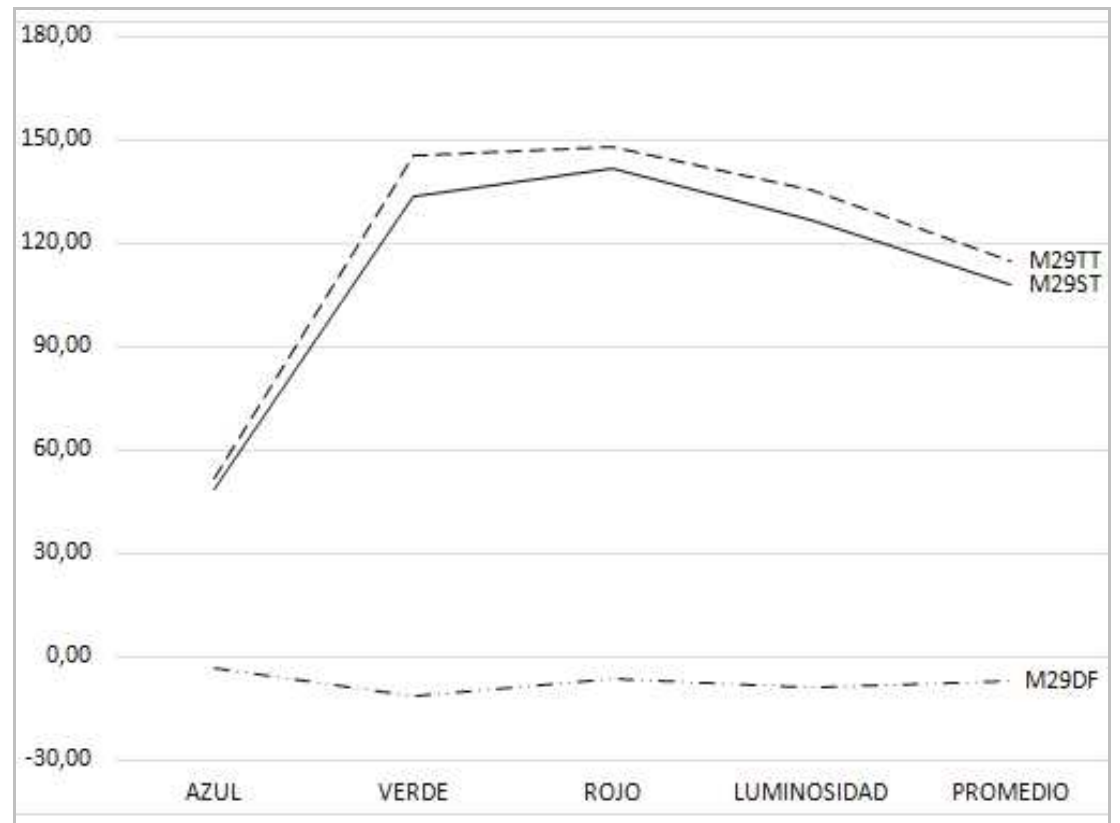

Universidad Politécnica de Madrid - Escuela Técnica Superior de Arquitectura - Departamento de Construcción y Tecnología Arquitectónica Directores: Dr. Alfonso García Santos y Dr. Antonio Rodríguez Rodríguez. Doctorando: D. Francisco Lora Toro 


\section{FICHA DE ENSAYOS DE MADERA Y ACIDOS}

\section{ACIDO A01/AG/ACIDO ACÉTICO GLACIAL}

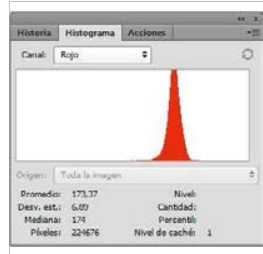

SIN TRATAR (ST): Grafica R (ST)

Valor R(ST):

173,37

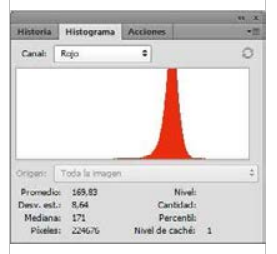

TRATADA (TT): Grafica $R(T T)$

Valor $\mathrm{R}(\mathrm{TT})$ :

169,83

DIFERENCIA (DF) Grafica R (DF): Valor DF-R:

3,54

3,97

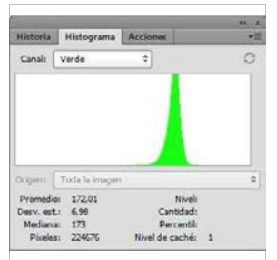

Grafica G (ST)

Valor G(ST):

172,01

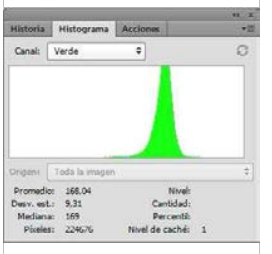

Grafica G (TT)

Valor $\mathrm{G}(\mathrm{TT})$ :

168,04
MADERA M30/RRA/ROBLE ROJO AMERICANO

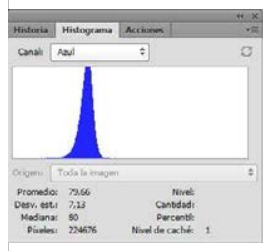

Grafica B (ST)

Valor B(ST):

79,66

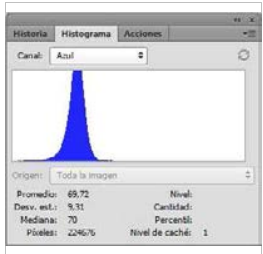

Grafica B (TT)

Valor $\mathrm{B}(\mathrm{TT})$ :

69,72

Grafica G (DF): Grafica B (DF):

Grafica L (DF):

Grafica C (DF):

Valor DF-G:

Valor DF-B:

Valor DF-L:

Valor DF-C:

9,94

4,36

5,82
GRAFICA:

\section{LEYENDA}

ST MADERA SIN TRATAR

Grafica R Histograma color Rojo

Grafica G Histograma color Verde

Grafica B Histograma color Azul

Grafica L Histograma Luminosidad

Grafica C Histograma RGB

\section{TT MADERA TRATADA}

Valor $R$ Número pixeles color Rojo

Valor $G$ Número pixeles color Verde

Valor B Número pixeles color Azul

Valor L Número pixeles Luminosidad

Valor C Número pixeles RG

DF DIFERENCIA DE VALORES R;G; $\mathrm{DF}=$ Valor $\mathrm{ST}(\mathrm{R} ; \mathrm{G} ; \mathrm{B})$ - Valor $\mathrm{TT}(\mathrm{R} ; \mathrm{G} ; \mathrm{B}$

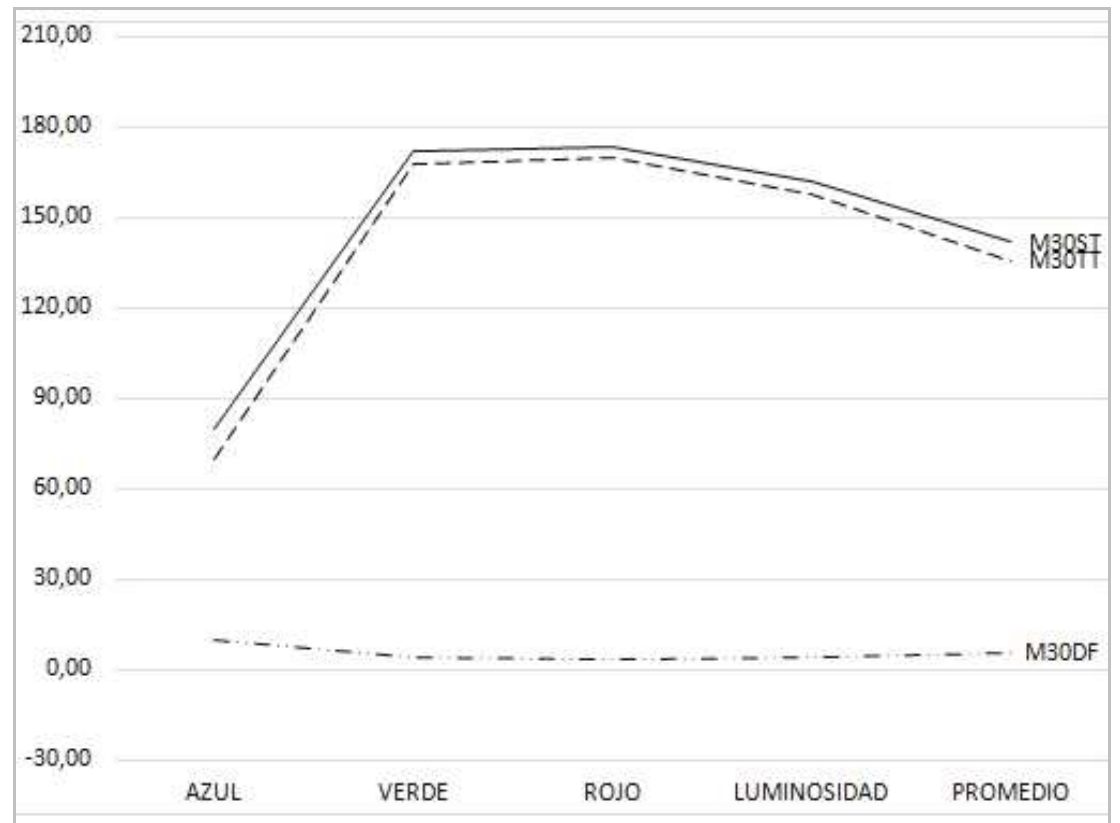

Universidad Politécnica de Madrid - Escuela Técnica Superior de Arquitectura - Departamento de Construcción y Tecnología Arquitectónica Directores: Dr. Alfonso García Santos y Dr. Antonio Rodríguez Rodríguez. Doctorando: D. Francisco Lora Toro 


\section{FICHA DE ENSAYOS DE MADERA Y ACIDOS}

\section{ACIDO A01/AG/ACIDO ACÉTICO GLACIAL}
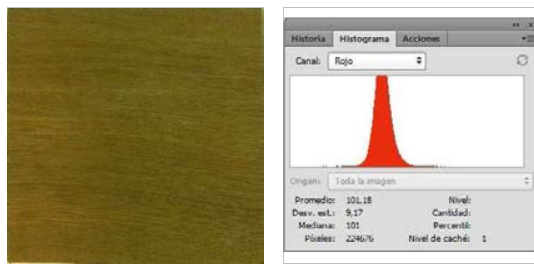

SIN TRATAR (ST): Grafica R (ST)

Valor R(ST):

101,18

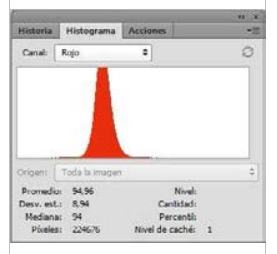

TRATADA (TT): Grafica $R(T T)$

Valor $\mathrm{R}(\mathrm{TT})$ :

94,96

DIFERENCIA (DF) Grafica R (DF): Valor DF-R:

6,22

10,90

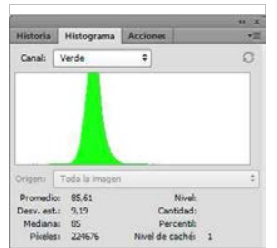

Grafica G (ST)

Valor G(ST):

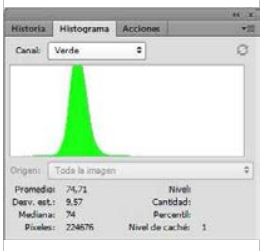

Grafica G (TT)

Valor $\mathrm{G}(\mathrm{TT})$ :

74,71
85,61

MADERA M31/SP/SAPELLI

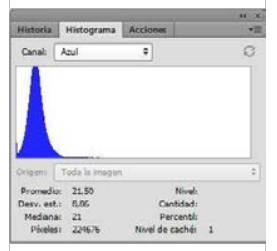

Grafica B (ST)

Valor B(ST):

21,50

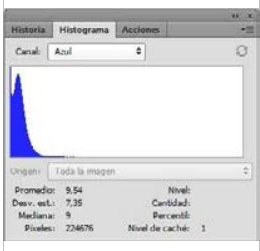

Grafica B (TT)

Valor $\mathrm{B}(\mathrm{TT})$ :

9,54

Grafica G (DF): Grafica B (DF):

Grafica L (DF):

Grafica C (DF):

Valor DF-G:

Valor DF-B:

Valor DF-L:

Valor DF-C:

11,96

9,69

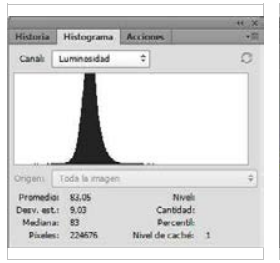

Grafica L (ST)

Valor L(ST):

83,05

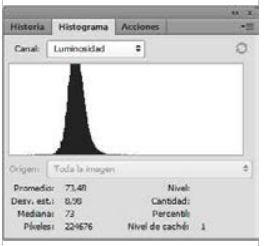

Grafica L (TT)

Grafica C (TT)

Valor $\mathrm{C}(\mathrm{TT})$ :

59,74

GRAFICA:

\section{LEYENDA}

ST MADERA SIN TRATAR

Grafica R Histograma color Rojo

Grafica G Histograma color Verde

Grafica B Histograma color Azul

Grafica L Histograma Luminosidad

Grafica C Histograma RGB

TT MADERA TRATADA

Valor $\mathrm{R}$ Número pixeles color Rojo

Valor $\mathrm{G}$ Número pixeles color Verde

Valor B Número pixeles color Azul

Valor L Número pixeles Luminosidad

Valor $C$ Número pixeles $R G$

DF DIFERENCIA DE VALORES R;G;

$\mathrm{DF}=$ Valor $\mathrm{ST}(\mathrm{R} ; \mathrm{G} ; \mathrm{B})$ - Valor TT $(\mathrm{R} ; \mathrm{G} ; \mathrm{B}$

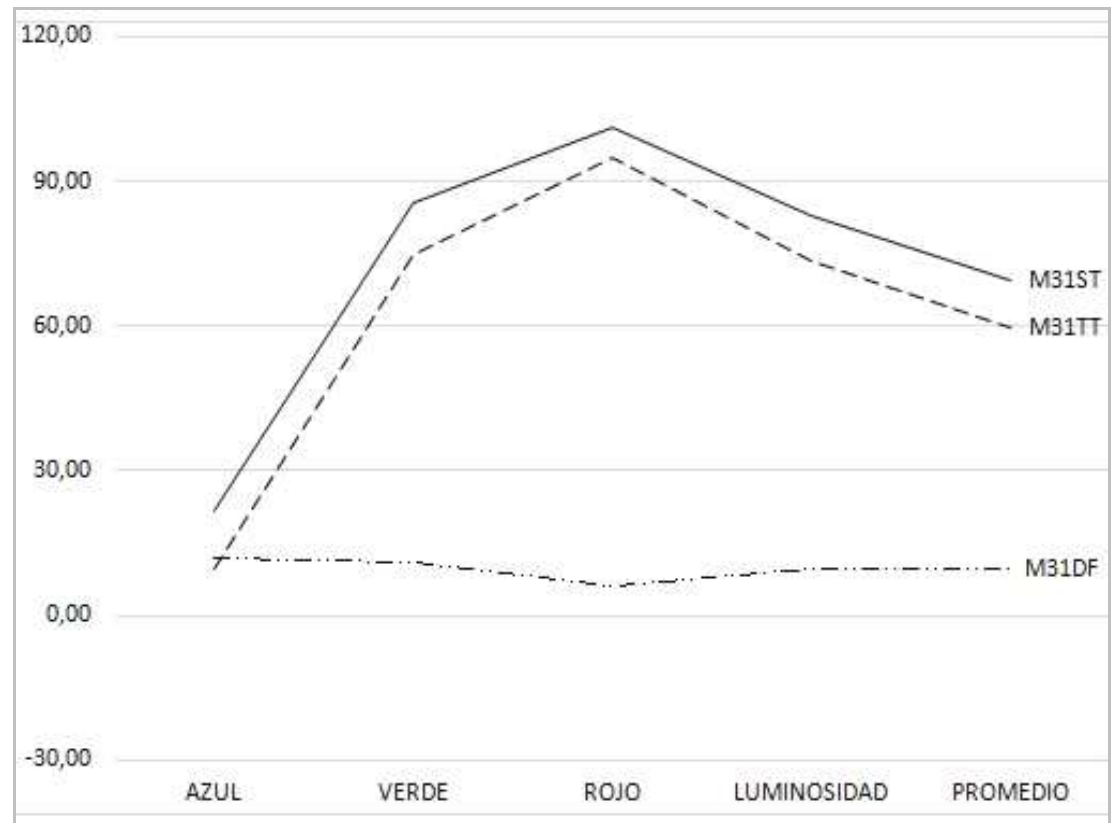

Universidad Politécnica de Madrid - Escuela Técnica Superior de Arquitectura - Departamento de Construcción y Tecnología Arquitectónica Directores: Dr. Alfonso García Santos y Dr. Antonio Rodríguez Rodríguez. Doctorando: D. Francisco Lora Toro 


\section{FICHA DE ENSAYOS DE MADERA Y ACIDOS}

\section{ACIDO A01/AG/ACIDO ACÉTICO GLACIAL}

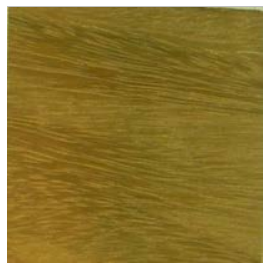

SIN TRATAR (ST): Grafica R (ST)

Valor R(ST):

124,12
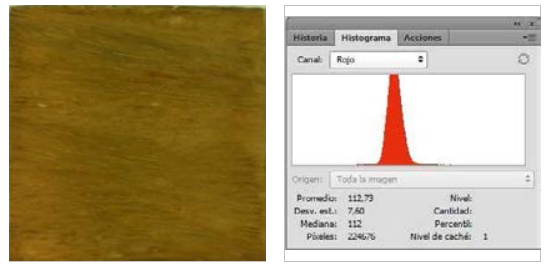

TRATADA (TT): Grafica R (TT)

Valor $\mathrm{R}(\mathrm{TT})$ :

112,73

DIFERENCIA (DF) Grafica R (DF): Valor DF-R: 11,39

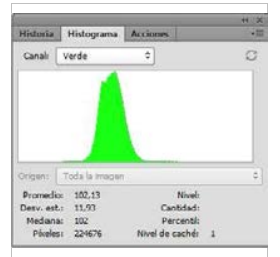

Grafica G (ST)

Valor $\mathrm{G}(\mathrm{ST})$ :

102,13

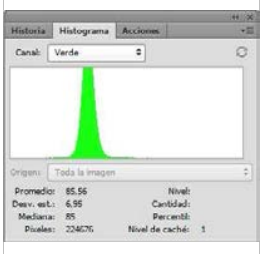

Grafica G (TT)

Valor G(TT):

85,56

\section{MADERA M32/TL/TALI}

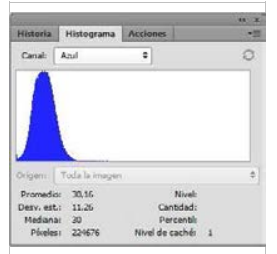

Grafica B (ST)

Valor $\mathrm{B}(\mathrm{ST})$ :

30,16

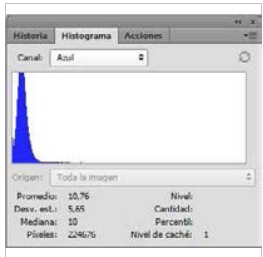

Grafica B (TT)

Valor $\mathrm{B}(\mathrm{TT})$ :

10,76

Grafica G (DF): Grafica B (DF):

Valor DF-G:

Valor DF-B:

19,40

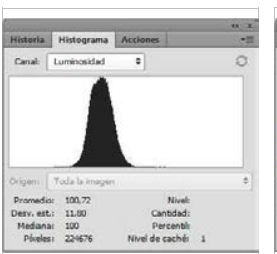

Grafica L (ST)

Valor L(ST):

100,72

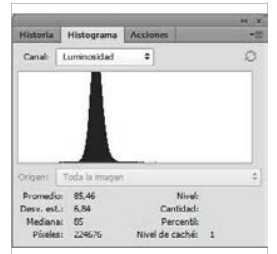

Grafica L (TT)

Valor L(TT):

85,46

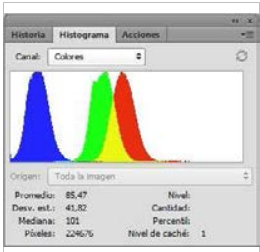

Grafica C (ST)

Valor C(ST):

85,47

\section{GRAFICA:}

\section{LEYENDA}

ST MADERA SIN TRATAR

Grafica R Histograma color Rojo

Grafica G Histograma color Verde

Grafica B Histograma color Azul

Grafica L Histograma Luminosidad

Grafica C Histograma RGB

\section{TT MADERA TRATADA}

Valor R Número pixeles color Rojo

Valor $\mathrm{G}$ Número pixeles color Verde

Valor B Número pixeles color Azul

Valor $L$ Número pixeles Luminosidad

Valor C Número pixeles RG

DF DIFERENCIA DE VALORES R;G; $\mathrm{DF}=$ Valor $\mathrm{ST}(\mathrm{R} ; \mathrm{G} ; \mathrm{B})$ - Valor $\mathrm{TT}(\mathrm{R} ; \mathrm{G} ; \mathrm{B}$

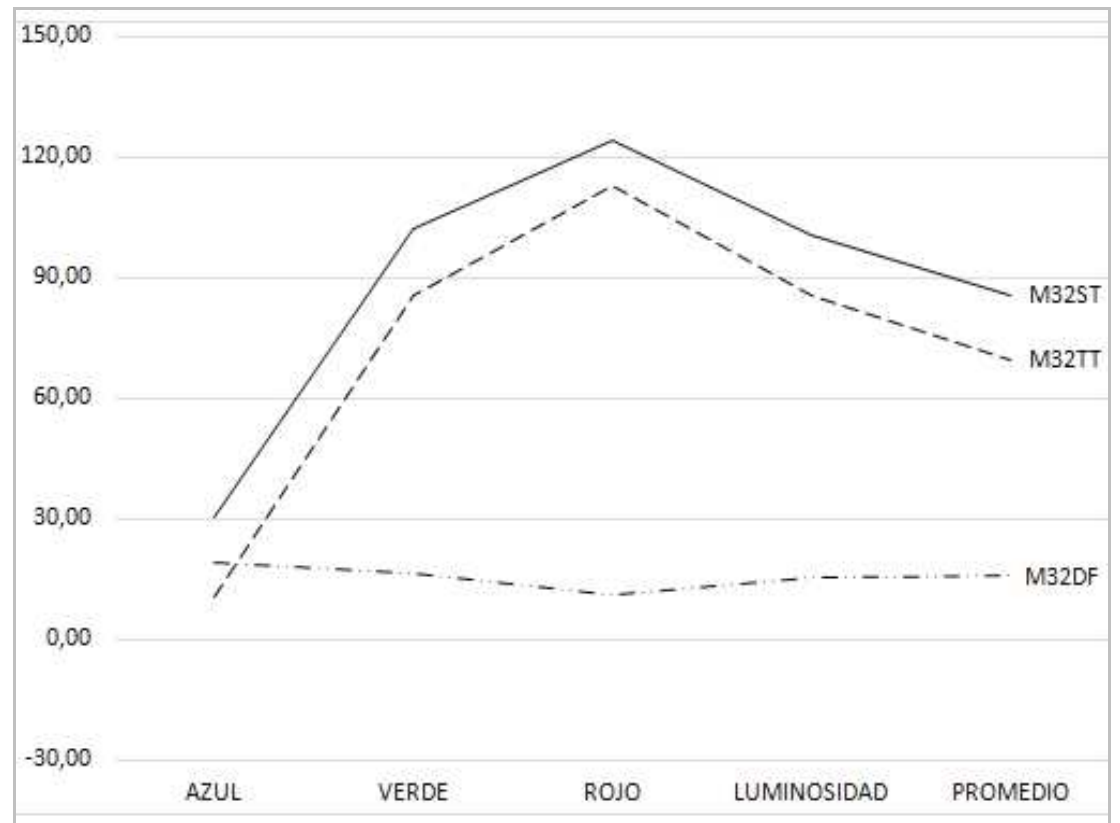

Universidad Politécnica de Madrid - Escuela Técnica Superior de Arquitectura - Departamento de Construcción y Tecnología Arquitectónica Directores: Dr. Alfonso García Santos y Dr. Antonio Rodríguez Rodríguez. Doctorando: D. Francisco Lora Toro 


\section{FICHA DE ENSAYOS DE MADERA Y ACIDOS}

ACIDO A01/AG/ACIDO ACÉTICO GLACIAL

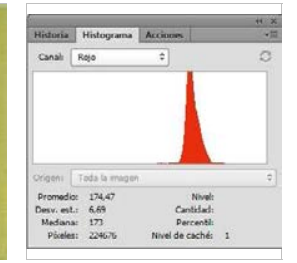

SIN TRATAR (ST): Grafica R (ST)

Valor R(ST):

174,47

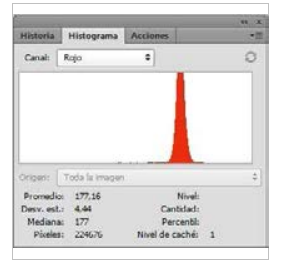

TRATADA (TT): Grafica R (TT) Valor $\mathrm{R}(\mathrm{TT})$ :

177,16

DIFERENCIA (DF) Grafica R (DF): Valor DF-R: $-2,69$

GRAFICA :

\section{LEYENDA}

ST MADERA SIN TRATAR

Grafica R Histograma color Rojo Grafica G Histograma color Verde Grafica B Histograma color Azul Grafica L Histograma Luminosidad Grafica C Histograma RGB

\section{TT MADERA TRATADA}

Valor R Número pixeles color Rojo Valor $\mathrm{G}$ Número pixeles color Verde Valor B Número pixeles color Azul Valor $L$ Número pixeles Luminosidad Valor C Número pixeles RG DF DIFERENCIA DE VALORES R;G; $\mathrm{DF}=$ Valor $\mathrm{ST}(\mathrm{R} ; \mathrm{G} ; \mathrm{B})$ - Valor $\mathrm{TT}(\mathrm{R} ; \mathrm{G} ; \mathrm{B}$

\section{MADERA M33/TA/TILO AMERICANO}
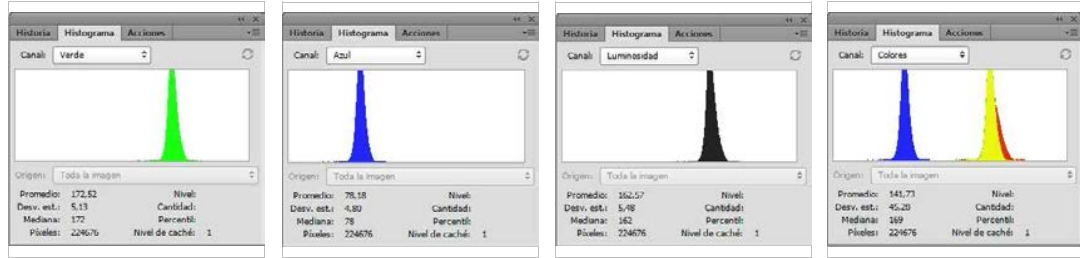

Grafica G (ST)

Grafica B (ST)

Grafica L (ST)

Grafica C (ST)

Valor $\mathrm{G}(\mathrm{ST})$ :

Valor B(ST):

Valor L(ST):

Valor C(ST):

78,18

162,57

141,73
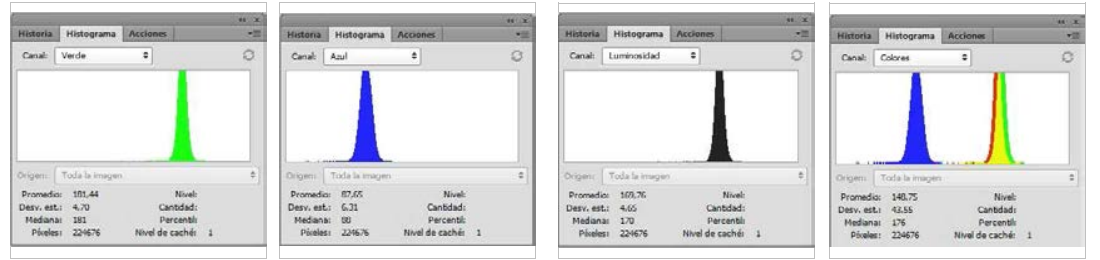

Grafica G (TT)

Grafica B (TT)

Grafica L (TT)

Grafica C (TT)

Valor $\mathrm{G}(\mathrm{TT})$ :

Valor $\mathrm{B}(\mathrm{TT})$ :

Valor L(TT):

Valor C(TT):

181,44

87,65

169,76

148,75

Grafica G (DF): Grafica B (DF): Grafica L (DF): Grafica C (DF): Valor DF-G: Valor DF-B: Valor DF-L: Valor DF-C: $\begin{array}{llll}-8,92 & -9,47 & -7,19 & -7,02\end{array}$

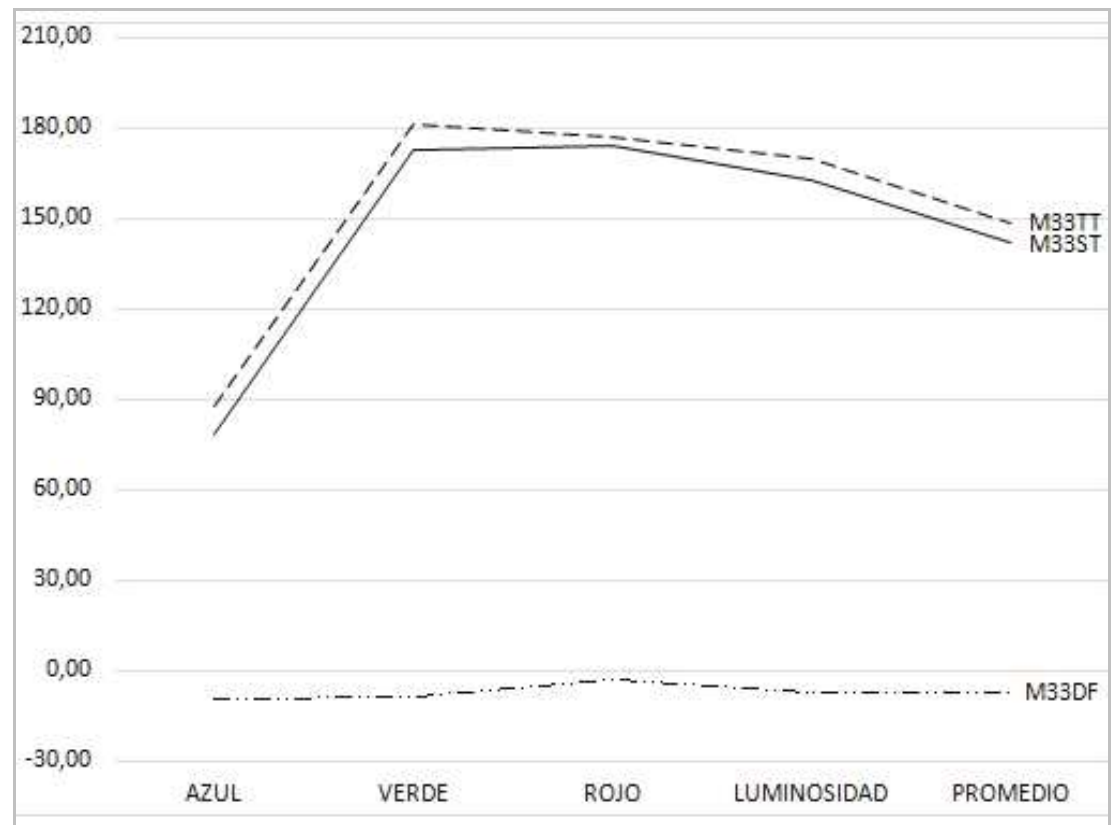

Universidad Politécnica de Madrid - Escuela Técnica Superior de Arquitectura - Departamento de Construcción y Tecnología Arquitectónica Directores: Dr. Alfonso García Santos y Dr. Antonio Rodríguez Rodríguez. Doctorando: D. Francisco Lora Toro 


\section{FICHA DE ENSAYOS DE MADERA Y ACIDOS}

ACIDO A01/AG/ACIDO ACÉTICO GLACIAL

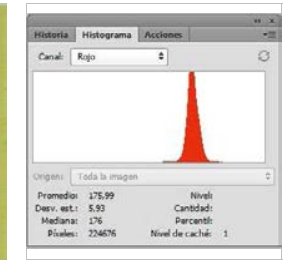

SIN TRATAR (ST): Grafica R (ST)

Valor R(ST):

175,99

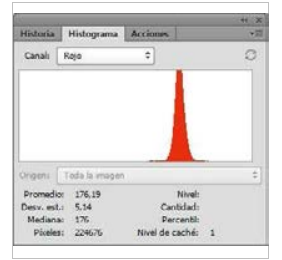

TRATADA (TT): Grafica R (TT) Valor $\mathrm{R}(\mathrm{TT})$ :

176,19

DIFERENCIA (DF) Grafica R (DF): Valor DF-R: $-0,20$

\section{GRAFICA:}

\section{LEYENDA}

ST MADERA SIN TRATAR

Grafica R Histograma color Rojo Grafica G Histograma color Verde Grafica B Histograma color Azul Grafica L Histograma Luminosidad Grafica C Histograma RGB

\section{TT MADERA TRATADA}

Valor R Número pixeles color Rojo Valor $\mathrm{G}$ Número pixeles color Verde Valor B Número pixeles color Azul Valor $\mathrm{L}$ Número pixeles Luminosidad Valor C Número pixeles RG DF DIFERENCIA DE VALORES R;G; $\mathrm{DF}=$ Valor $\mathrm{ST}(\mathrm{R} ; \mathrm{G} ; \mathrm{B})$ - Valor TT(R;G;B

176,87

178,28

\section{MADERA M34/TE/TILO EUROPEO}
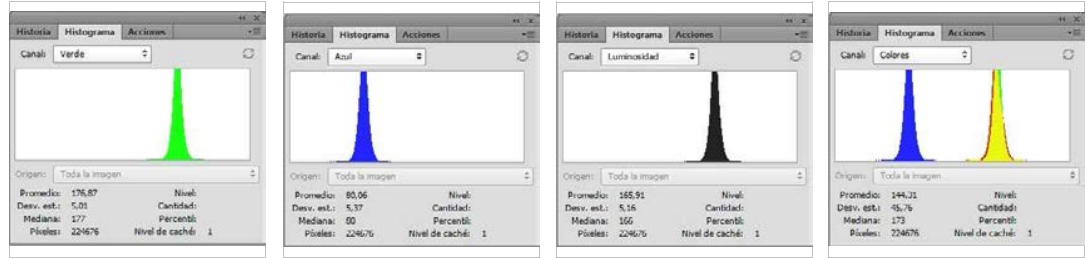

Grafica G (ST)

Grafica B (ST)

Grafica L (ST)

Grafica C (ST)

Valor $\mathrm{G}(\mathrm{ST})$ :

Valor B(ST):

Valor L(ST):

Valor C(ST):

80,06

165,91

144,31
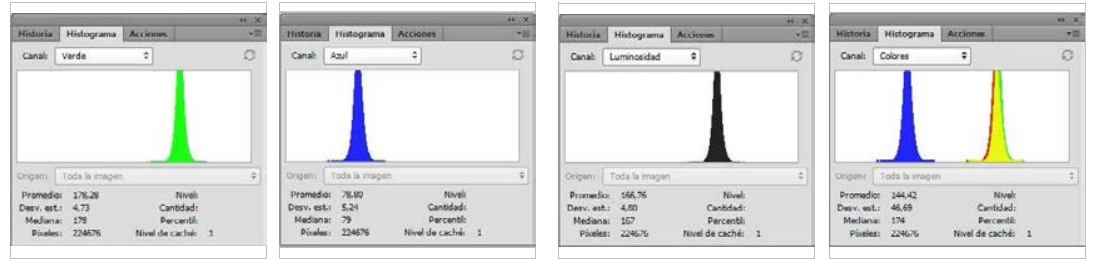

\section{Grafica G (TT)}

Grafica B (TT)

Grafica L (TT)

Grafica C (TT)

Valor $\mathrm{G}(\mathrm{TT})$ :

Valor $\mathrm{B}(\mathrm{TT})$ :

Valor L(TT):

Valor C(TT):

78,80

166,76

144,42

Grafica G (DF): Grafica B (DF): Grafica L (DF):

Grafica C (DF):

Valor DF-G:

Valor DF-B:

Valor DF-L:

Valor DF-C:
$-1,41$
1,26
$-0,85$
$-0,11$

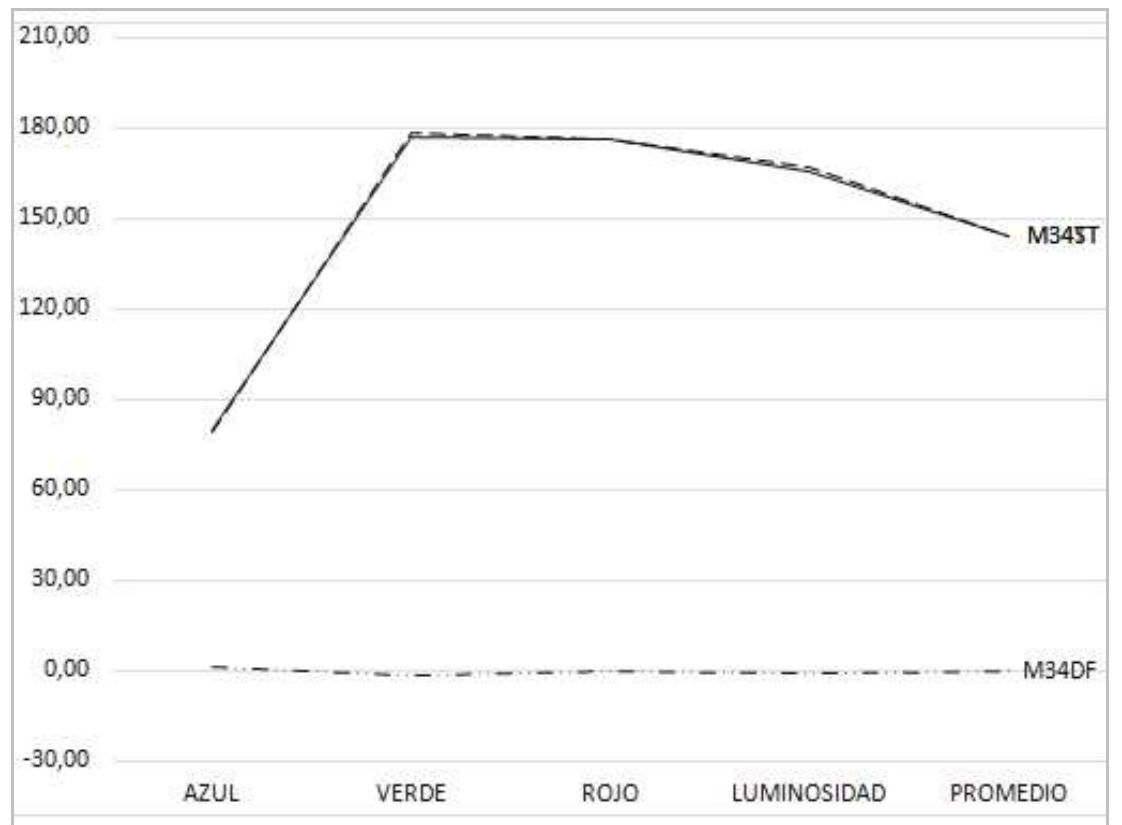

Universidad Politécnica de Madrid - Escuela Técnica Superior de Arquitectura - Departamento de Construcción y Tecnología Arquitectónica Directores: Dr. Alfonso García Santos y Dr. Antonio Rodríguez Rodríguez. Doctorando: D. Francisco Lora Toro 


\section{A02 / ÁCIDO ACŔLILCO}

\section{FICHA DE ENSAYOS DE MADERA Y ACIDOS}

\section{ACIDO A02/CR/ACIDO ACRILICO}
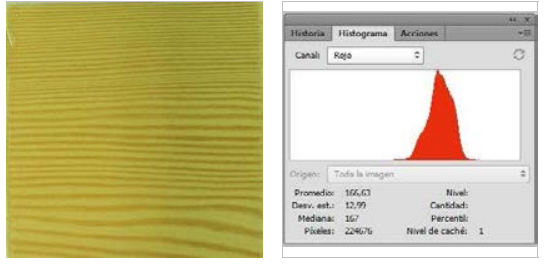

SIN TRATAR (ST): Grafica R (ST)

Valor R(ST):

166,33

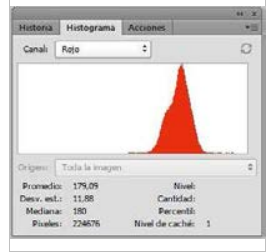

TRATADA (TT): Grafica $R(T T)$

Valor $\mathrm{R}(\mathrm{TT})$ :

179,09

DIFERENCIA (DF) Grafica R (DF): Valor DF-R:

$-12,76$

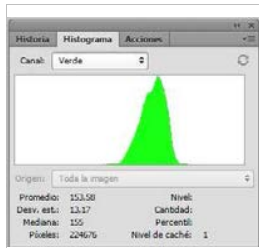

Grafica G (ST)

Valor G(ST):

153,88

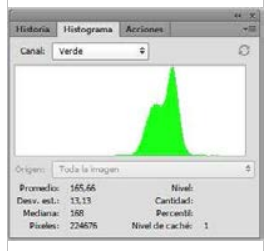

Grafica G (TT)

Valor G(TT):

165,66
MADERA M01/AD/ABETO DOUGLAS
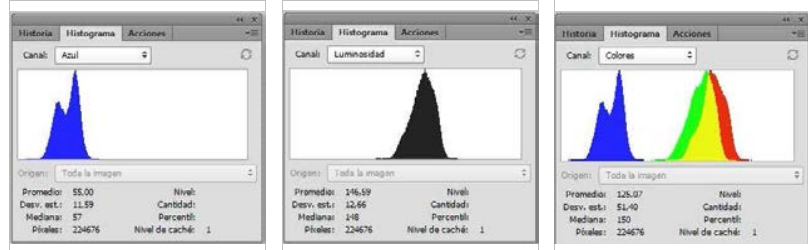

Grafica B (ST)

Grafica L (ST)

Grafica C (ST)

Valor $\mathrm{B}(\mathrm{ST})$ :

Valor L(ST):

Valor C(ST):

55,00

146,59

125,07
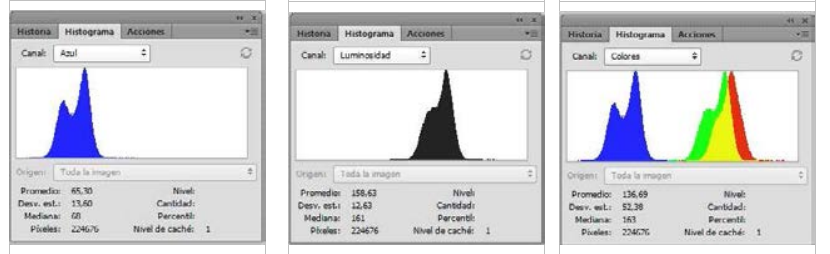

Grafica B (TT)

Grafica L (TT)

Grafica C (TT)

Valor $\mathrm{B}(\mathrm{TT})$ :

Valor L(TT):

Valor C(TT):

65,30

158,63

136,69

Grafica G (DF): Grafica B (DF): Grafica L (DF): Grafica C (DF): Valor DF-G: Valor DF-B: Valor DF-L: Valor DF-C: $-11,78$ $-10,30$ $-12,04$ $-11,62$

GRAFICA:

\section{LEYENDA}

ST MADERA SIN TRATAR

Grafica R Histograma color Rojo Grafica G Histograma color Verde Grafica B Histograma color Azul Grafica L Histograma Luminosidad Grafica C Histograma RGB

TT MADERA TRATADA

Valor R Número pixeles color Rojo Valor G Número pixeles color Verde Valor B Número pixeles color Azul Valor L Número pixeles Luminosidad Valor C Número pixeles RG DF DIFERENCIA DE VALORES R;G; $\mathrm{DF}=$ Valor $\mathrm{ST}(\mathrm{R} ; \mathrm{G} ; \mathrm{B})$ - Valor TT(R;G;B

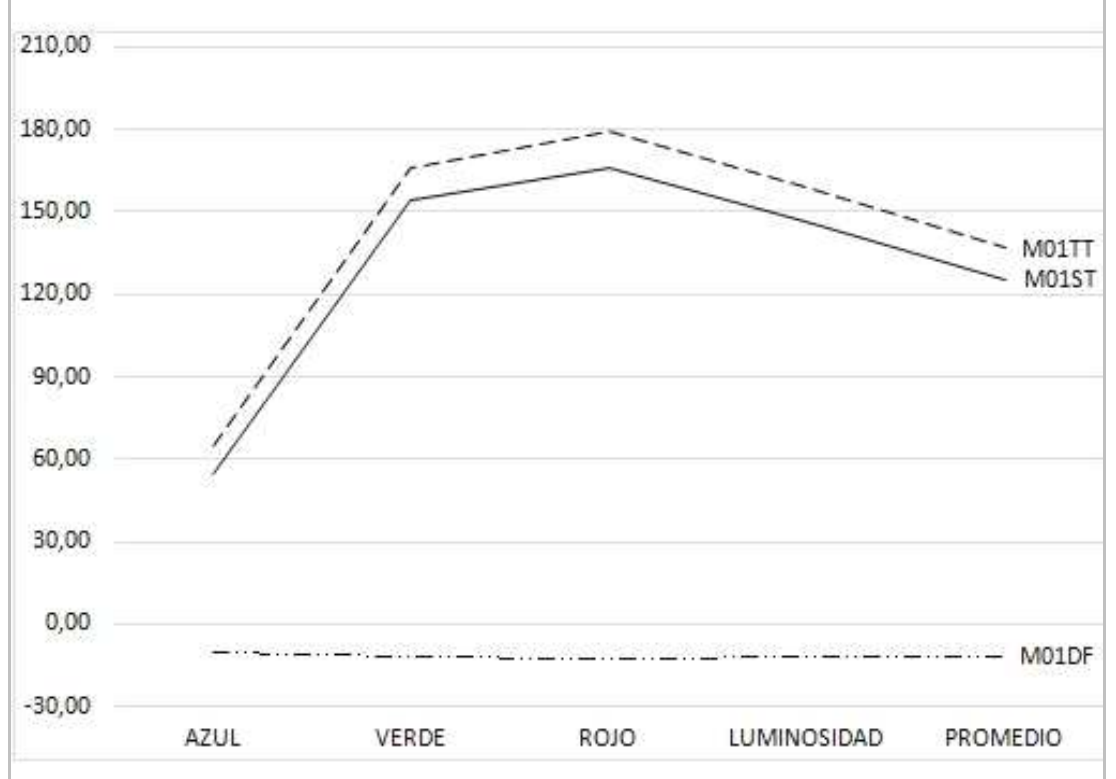

Universidad Politécnica de Madrid - Escuela Técnica Superior de Arquitectura - Departamento de Construcción y Tecnología Arquitectónica Directores: Dr. Alfonso García Santos y Dr. Antonio Rodríguez Rodríguez. Doctorando: D. Francisco Lora Toro 


\section{FICHA DE ENSAYOS DE MADERA Y ACIDOS}

\section{ACIDO A02/CR/ACIDO ACRILICO}
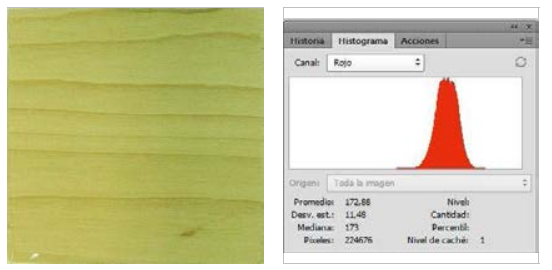

SIN TRATAR (ST): Grafica R (ST)

Valor R(ST):

172,88

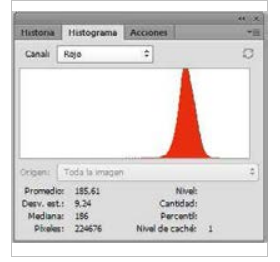

TRATADA (TT): Grafica R (TT) Valor R(TT): 185,61

DIFERENCIA (DF) Grafica R (DF): Valor DF-R: $-12,73$ GRAFICA:

\section{LEYENDA}

ST MADERA SIN TRATAR

Grafica R Histograma color Rojo Grafica G Histograma color Verde Grafica B Histograma color Azul Grafica L Histograma Luminosidad Grafica C Histograma RGB

\section{TT MADERA TRATADA}

Valor R Número pixeles color Rojo Valor $\mathrm{G}$ Número pixeles color Verde Valor B Número pixeles color Azul Valor $L$ Número pixeles Luminosidad Valor C Número pixeles RG DF DIFERENCIA DE VALORES R;G; $\mathrm{DF}=$ Valor $\mathrm{ST}(\mathrm{R} ; \mathrm{G} ; \mathrm{B})$ - Valor TT $(\mathrm{R} ; \mathrm{G} ; \mathrm{B}$

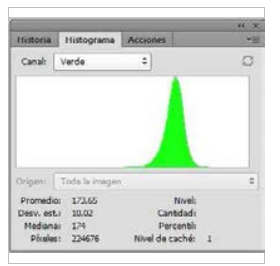

Grafica G (ST)

Valor G(ST):

173,65

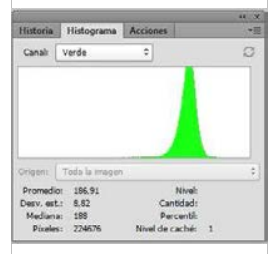

Grafica G (TT)

Valor $\mathrm{G}(\mathrm{TT})$ :

186,91
MADERA M02/ABA/ARCE BLANDO AMERICANO

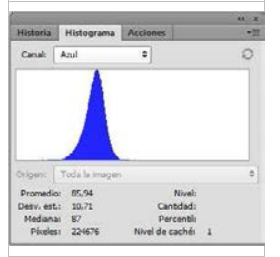

Grafica B (ST)

Valor B(ST):

85,94

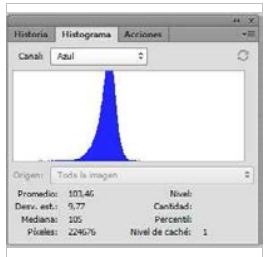

Grafica B (TT)

Valor $\mathrm{B}(\mathrm{TT})$ :

103,46

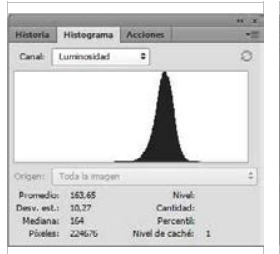

Grafica L (ST)

Valor L(ST):

163,65

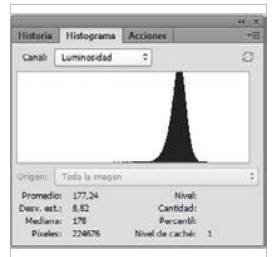

Grafica L (TT)

Valor L(TT):

177,24

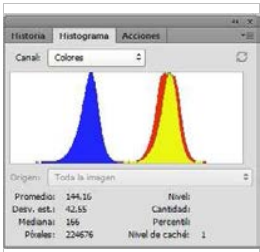

Grafica C (ST)

Valor C(ST):

144,16

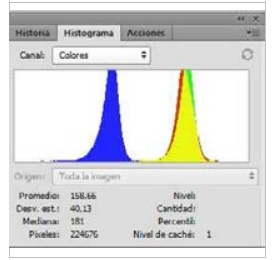

Grafica C (TT)

Valor C(TT):

158,66

Grafica G (DF): Grafica B (DF): Grafica L (DF): Grafica C (DF): Valor DF-G: Valor DF-B: Valor DF-L: Valor DF-C:

$-13,26-17,52 \quad-13,59 \quad-14,50$

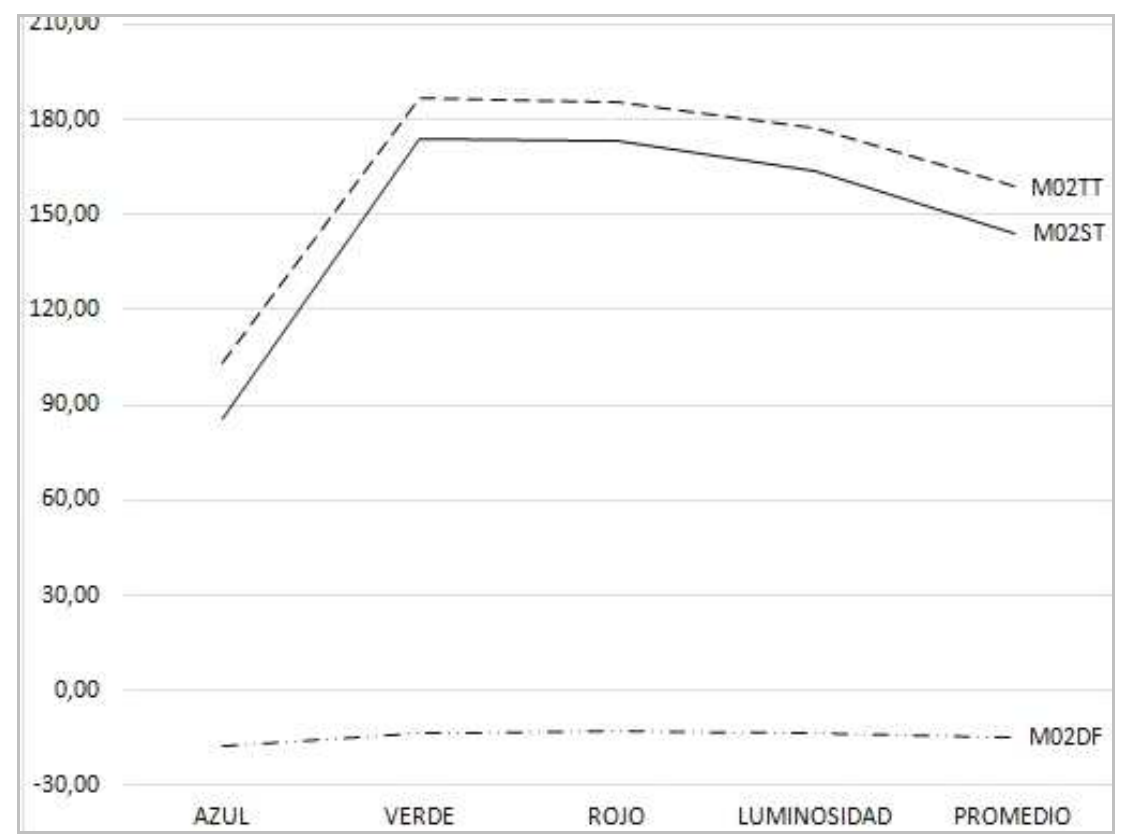

Universidad Politécnica de Madrid - Escuela Técnica Superior de Arquitectura - Departamento de Construcción y Tecnología Arquitectónica Directores: Dr. Alfonso García Santos y Dr. Antonio Rodríguez Rodríguez. Doctorando: D. Francisco Lora Toro 


\section{FICHA DE ENSAYOS DE MADERA y ACIDOS}

\section{ACIDO A02/CR/ACIDO ACRILICO}
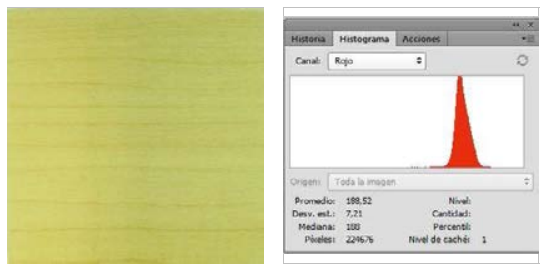

SIN TRATAR (ST): Grafica R (ST)

Valor R(ST):

188,52

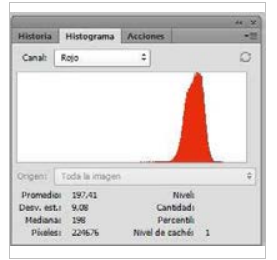

TRATADA (TT): Grafica $R(T T)$ Valor R(TT): 197,41

DIFERENCIA (DF) Grafica R (DF): Valor DF-R: $-8,89$

GRAFICA:

\section{LEYENDA}

ST MADERA SIN TRATAR

Grafica R Histograma color Rojo Grafica G Histograma color Verde Grafica B Histograma color Azul Grafica L Histograma Luminosidad Grafica C Histograma RGB

\section{TT MADERA TRATADA}

Valor R Número pixeles color Rojo Valor G Número pixeles color Verde Valor B Número pixeles color Azul Valor $L$ Número pixeles Luminosidad Valor C Número pixeles RG DF DIFERENCIA DE VALORES R;G; $\mathrm{DF}=$ Valor $\mathrm{ST}(\mathrm{R} ; \mathrm{G} ; \mathrm{B})$ - Valor $\mathrm{TT}(\mathrm{R} ; \mathrm{G} ; \mathrm{B}$

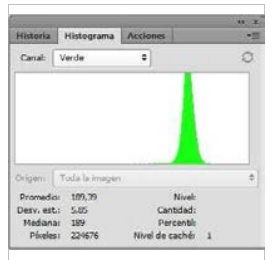

\section{Grafica G (ST)}

Valor G(ST):

189,39

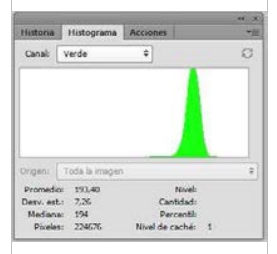

Grafica G (TT)

Valor G(TT):

193,40

Grafica G (DF)

Valor DF-G:

$-4,01$

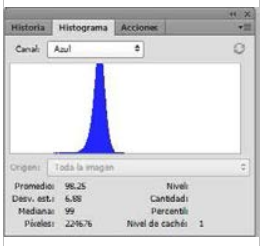

Grafica B (TT)

Valor $\mathrm{B}(\mathrm{TT})$ :

98,25

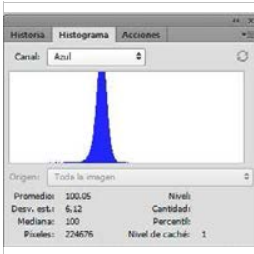

Grafica B (ST)

Valor $\mathrm{B}(\mathrm{ST})$ :

100,05

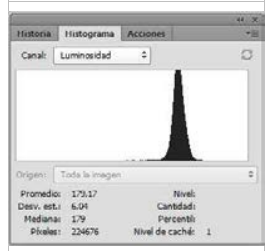

Grafica L (ST)

Valor L(ST):

179,17

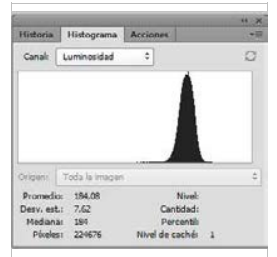

Grafica L (TT)

Valor L(TT):

184,08

Grafica L (DF):

Valor DF-L:

$-4,91$

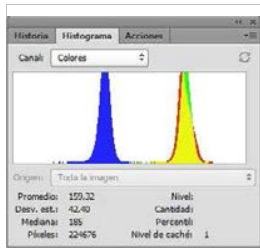

Grafica C (ST)

Valor C(ST):

159,32

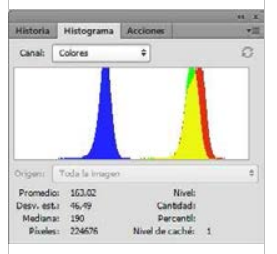

Grafica C (TT)

Valor C(TT):

163,02

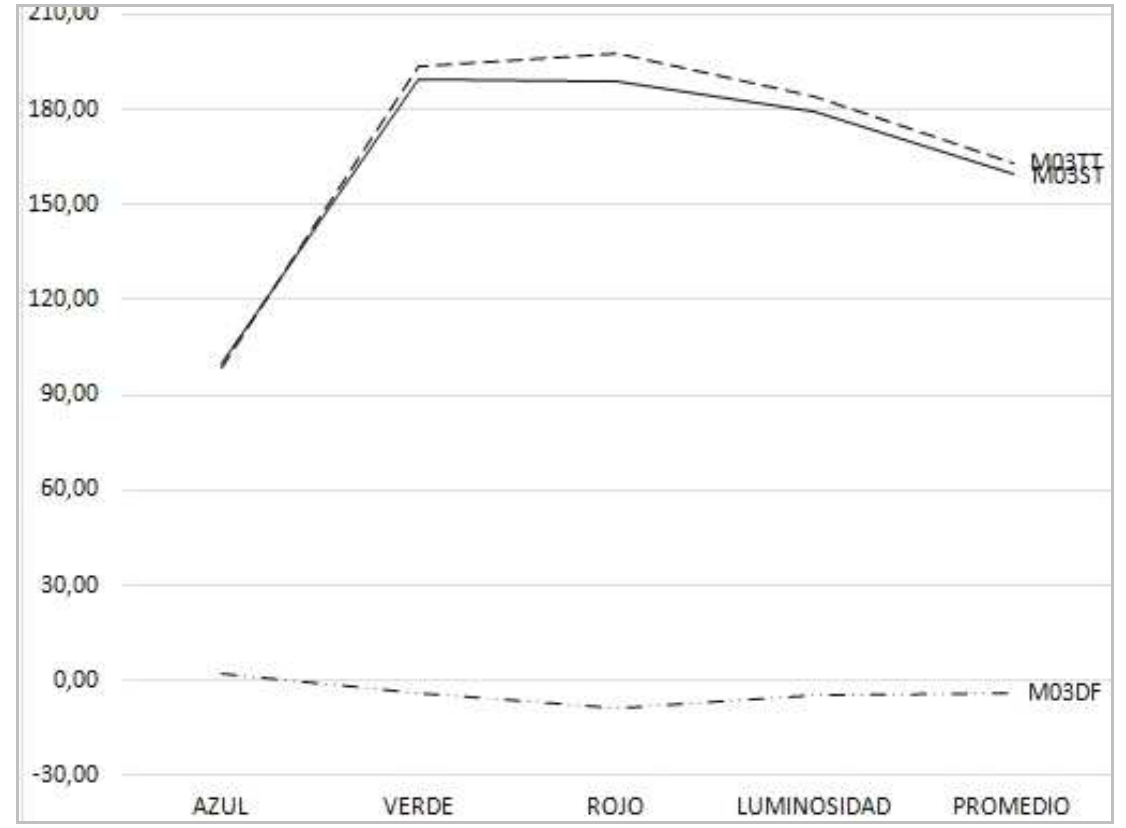

Universidad Politécnica de Madrid - Escuela Técnica Superior de Arquitectura - Departamento de Construcción y Tecnología Arquitectónica Directores: Dr. Alfonso García Santos y Dr. Antonio Rodríguez Rodríguez. Doctorando: D. Francisco Lora Toro 


\section{FICHA DE ENSAYOS DE MADERA Y ACIDOS}

\section{ACIDO A02/CR/ACIDO ACRILICO}
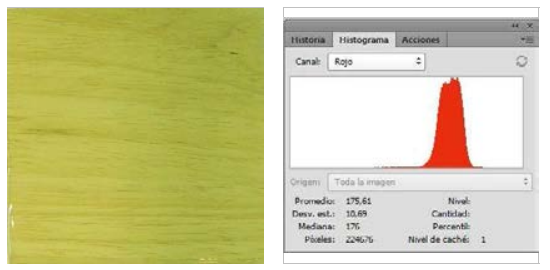

SIN TRATAR (ST): Grafica R (ST)

Valor R(ST):

175,61

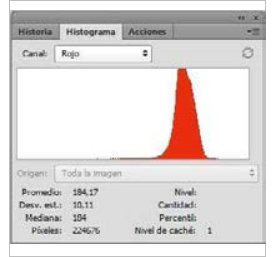

TRATADA (TT): Grafica $R(T T)$

Valor R(TT):

184,17

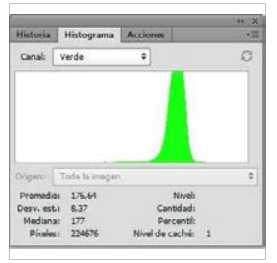

Grafica G (ST)

Valor G(ST):

176,64

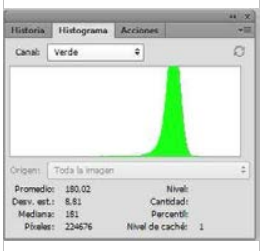

Grafica G (TT)

Valor $\mathrm{G}(\mathrm{TT})$ :

180,02

\section{MADERA M04/AS/AYOUS}

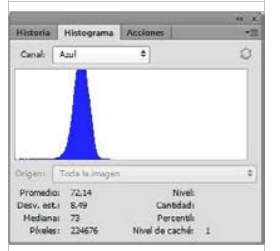

Grafica B (ST)

Valor B(ST):

72,14

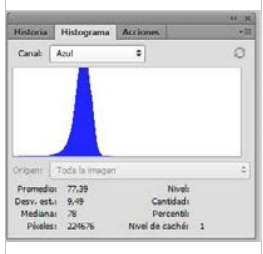

Grafica B (TT)

Valor $\mathrm{B}(\mathrm{TT})$ :

77,39

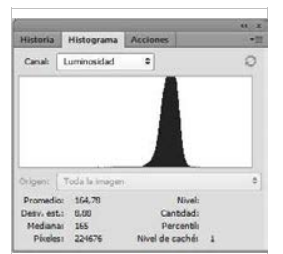

Grafica L (ST)

Valor L(ST):

164,78

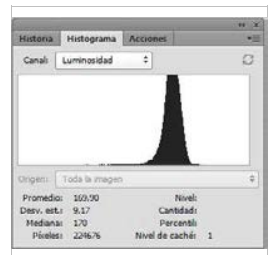

Grafica L (TT)

Valor L(TT):

169,90

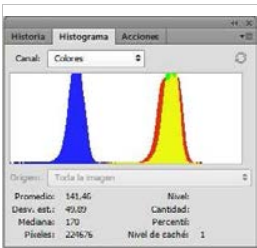

Grafica C (ST)

Valor C(ST):

141,46

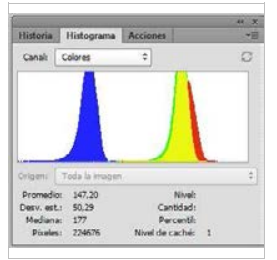

Grafica C (TT)

Valor C(TT):

147,20

DIFERENCIA (DF) Grafica R (DF):

Grafica G (DF): Grafica B (DF):

Grafica L (DF):

Grafica C (DF):

Valor DF-R:

Valor DF-G:

Valor DF-B:

Valor DF-L:

Valor DF-C:

$-8,56$

$-3,38$

$-5,25$

$-5,12$

$-5,74$

\section{GRAFICA:}

\section{LEYENDA}

\section{ST MADERA SIN TRATAR}

Grafica R Histograma color Rojo

Grafica G Histograma color Verde

Grafica B Histograma color Azul

Grafica L Histograma Luminosidad

Grafica C Histograma RGB

\section{TT MADERA TRATADA}

Valor R Número pixeles color Rojo

Valor $\mathrm{G}$ Número pixeles color Verde

Valor B Número pixeles color Azul

Valor $L$ Número pixeles Luminosidad

Valor C Número pixeles RG

DF DIFERENCIA DE VALORES R;G; $\mathrm{DF}=$ Valor $\mathrm{ST}(\mathrm{R} ; \mathrm{G} ; \mathrm{B})$ - Valor $\mathrm{TT}(\mathrm{R} ; \mathrm{G} ; \mathrm{B}$

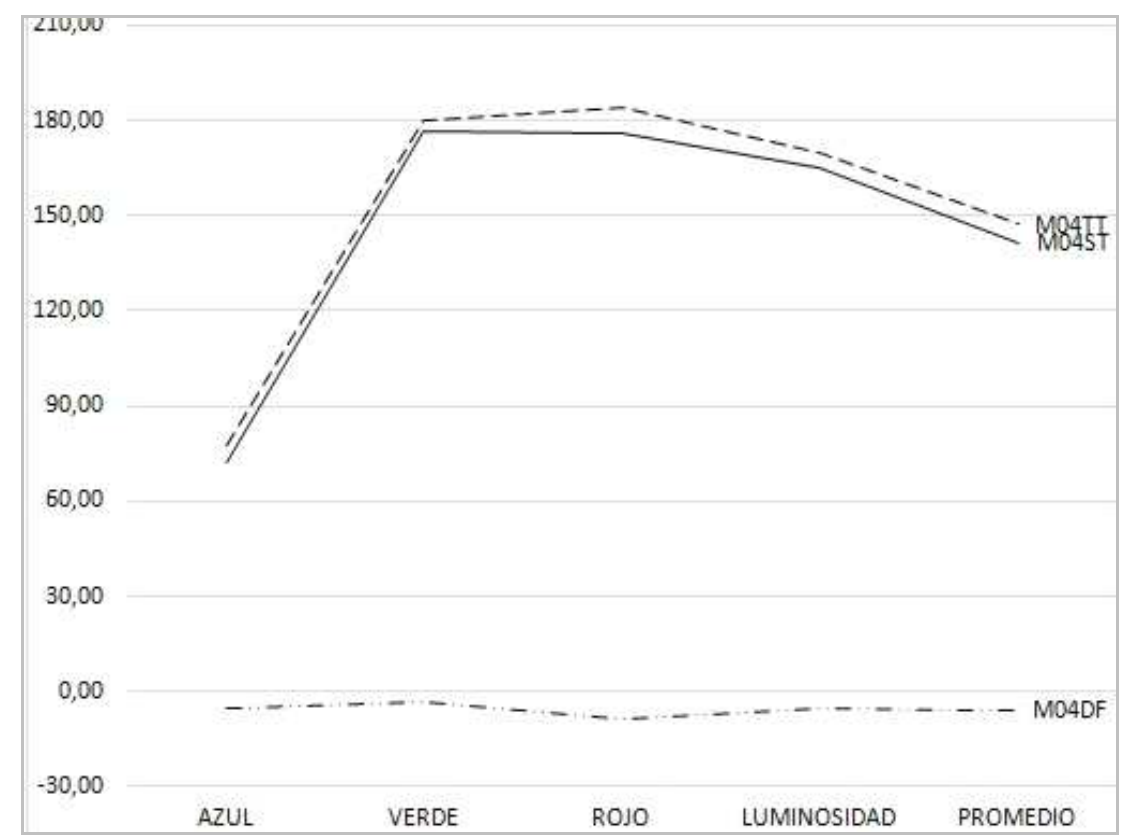

Universidad Politécnica de Madrid - Escuela Técnica Superior de Arquitectura - Departamento de Construcción y Tecnología Arquitectónica Directores: Dr. Alfonso García Santos y Dr. Antonio Rodríguez Rodríguez. Doctorando: D. Francisco Lora Toro 


\section{FICHA DE ENSAYOS DE MADERA Y ACIDOS}

\section{ACIDO A02/CR/ACIDO ACRILICO}
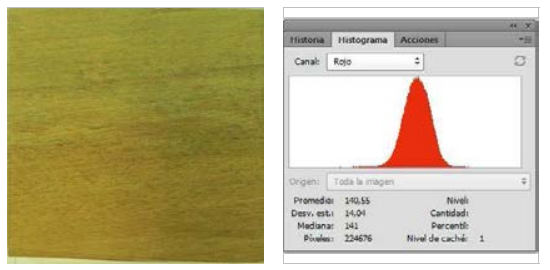

SIN TRATAR (ST): Grafica R (ST)

Valor R(ST):

140,55

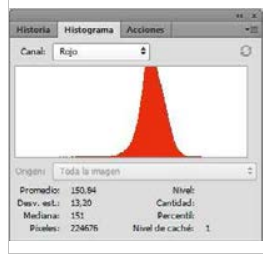

TRATADA (TT): Grafica $R(T T)$

Valor R(TT):

150,84

DIFERENCIA (DF) Grafica R (DF):

Valor DF-R:

$-10,29$

GRAFICA:

\section{LEYENDA}

ST MADERA SIN TRATAR

Grafica R Histograma color Rojo

Grafica G Histograma color Verde

Grafica B Histograma color Azul

Grafica L Histograma Luminosidad

Grafica C Histograma RGB

\section{TT MADERA TRATADA}

Valor R Número pixeles color Rojo

Valor $G$ Número pixeles color Verde

Valor B Número pixeles color Azul

Valor $L$ Número pixeles Luminosidad

Valor C Número pixeles RG

DF DIFERENCIA DE VALORES R;G; $\mathrm{DF}=$ Valor $\mathrm{ST}(\mathrm{R} ; \mathrm{G} ; \mathrm{B})$ - Valor $\mathrm{TT}(\mathrm{R} ; \mathrm{G} ; \mathrm{B}$

\section{MADERA M05/BS/BOSSÉ}

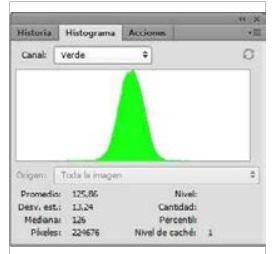

Grafica G (ST)

Valor G(ST):

125,86
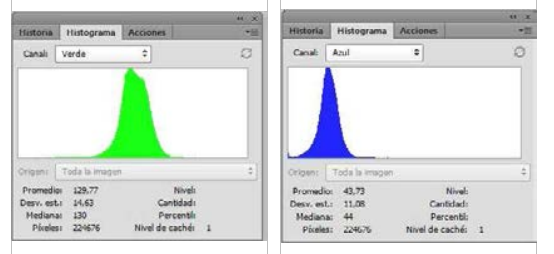

Grafica G (TT)

Grafica B (TT)

Valor $\mathrm{B}(\mathrm{TT})$ :

43,73

129,77

Grafica G (DF): Grafica B (DF):

Valor DF-G:

Valor DF-B:

Valor DF-L:

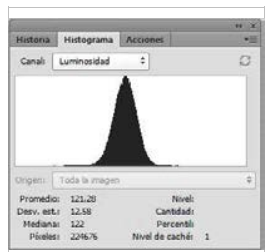

Grafica L (ST)

Valor L(ST):

121,28

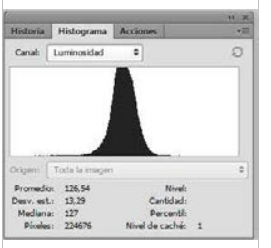

Grafica L (TT)

Valor L(TT):

126,54

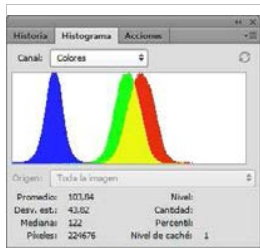

Grafica C (ST)

Valor C(ST):

103,84

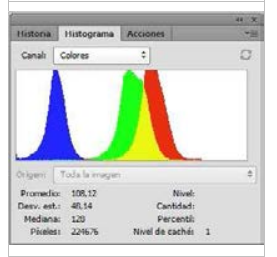

Grafica C (TT)

Valor C(TT):

108,12
1,38
$-3,91$
$-4,28$

1,38

Grafica L (DF):

Grafica C (DF):

Valor DF-C:

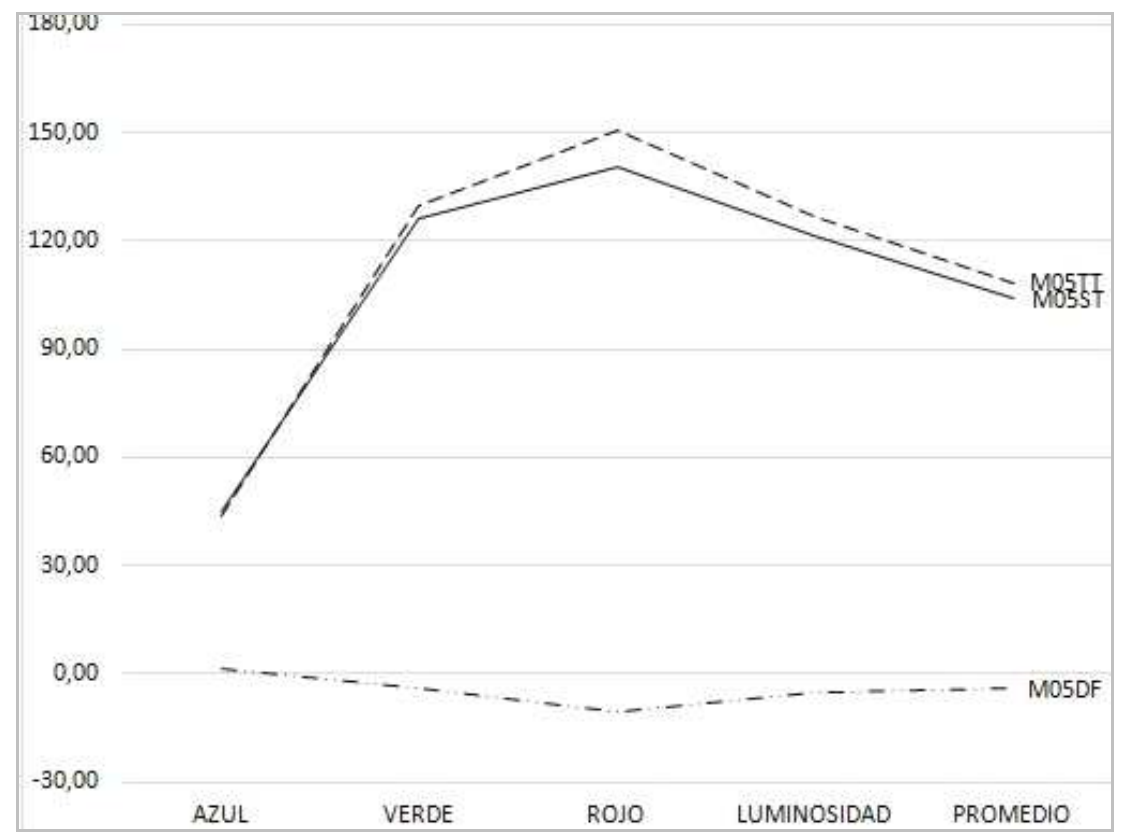

Universidad Politécnica de Madrid - Escuela Técnica Superior de Arquitectura - Departamento de Construcción y Tecnología Arquitectónica Directores: Dr. Alfonso García Santos y Dr. Antonio Rodríguez Rodríguez. Doctorando: D. Francisco Lora Toro 


\section{FICHA DE ENSAYOS DE MADERA Y ACIDOS}

\section{ACIDO A02/CR/ACIDO ACRILICO}
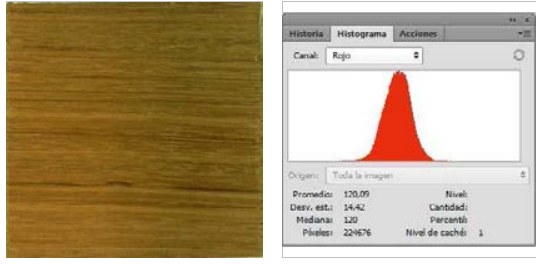

SIN TRATAR (ST): Grafica R (ST)

Valor R(ST):

120,09
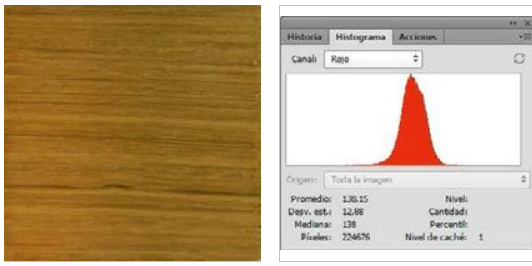

TRATADA (TT): Grafica $R(T T)$

Valor $\mathrm{R}(\mathrm{TT})$ :

138,15

DIFERENCIA (DF) Grafica R (DF): Valor DF-R: $-18,06$

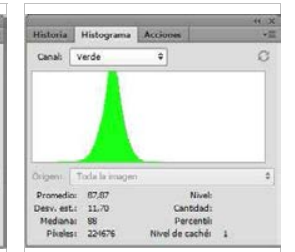

Grafica G (ST)

Valor G(ST):

87,87

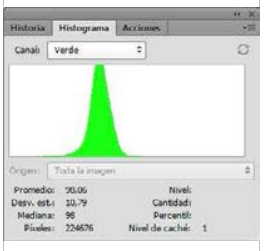

Grafica G (TT)

Valor $\mathrm{G}(\mathrm{TT})$ :

98,06

\section{MADERA M06/BG/BUBINGA}
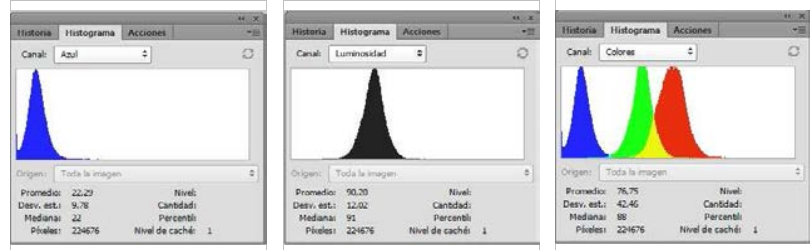

Grafica B (ST)

Grafica L (ST)

Grafica C (ST)

Valor B(ST):

Valor L(ST):

Valor C(ST):

22,29

90,20

76,75
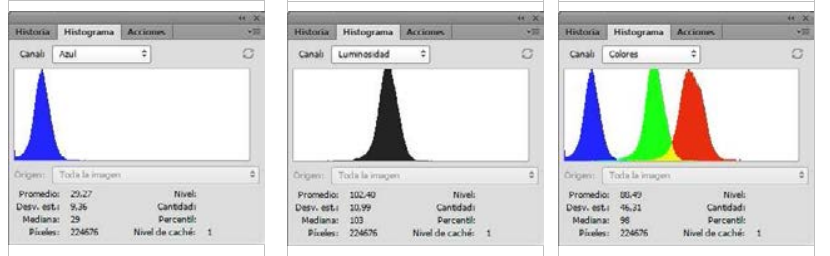

Grafica B (TT)

Grafica L (TT)

Grafica C (TT)

Valor B(TT):

Valor L(TT):

Valor $\mathrm{C}(\mathrm{TT})$ :

29,27

102,40

88,49

Grafica G (DF): Grafica B (DF): Grafica L (DF): Grafica C (DF): Valor DF-G: Valor DF-B: Valor DF-L: Valor DF-C: $-10,19$ $-6,98$ $-12,20$ $-11,74$

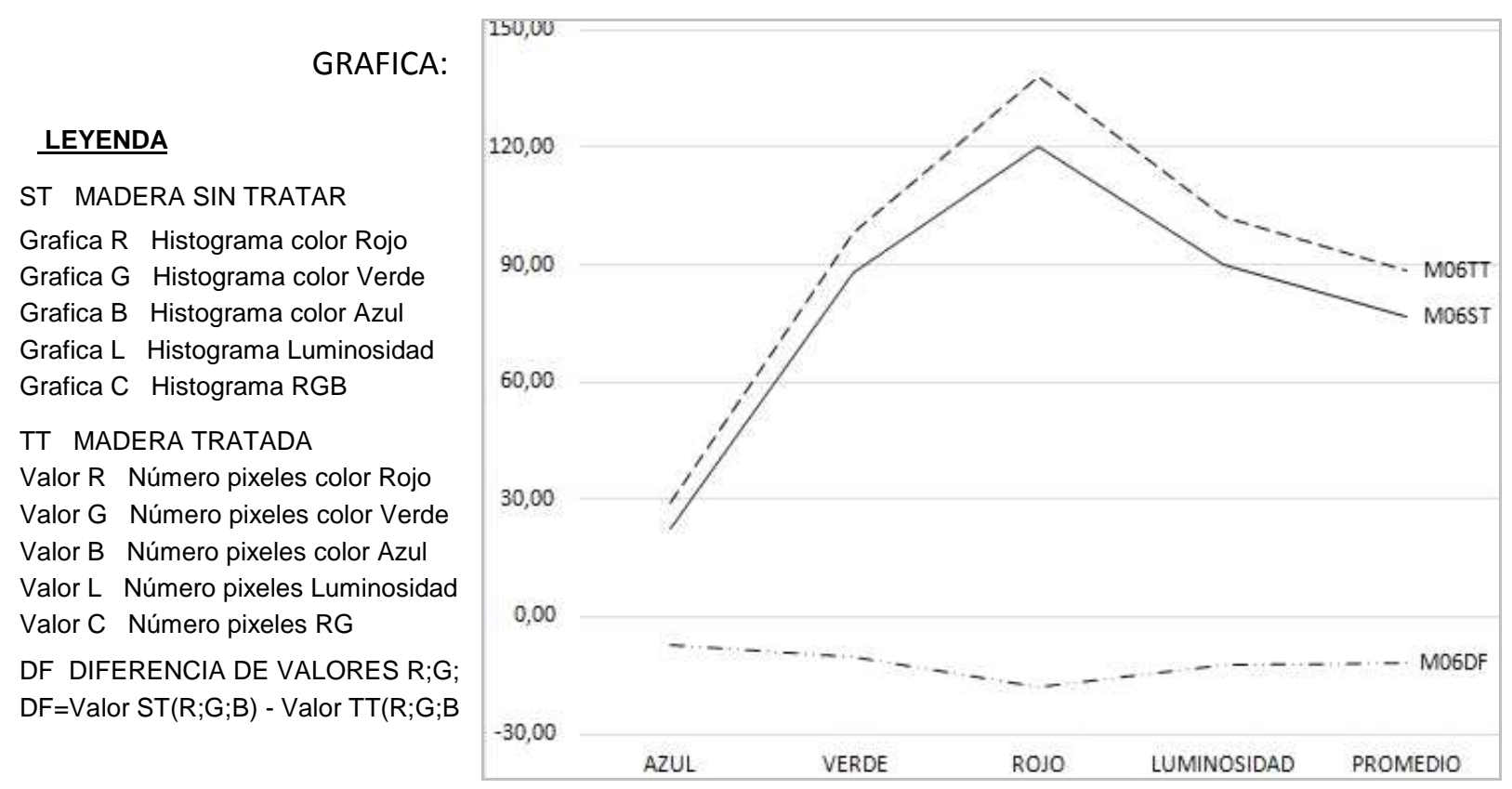

Universidad Politécnica de Madrid - Escuela Técnica Superior de Arquitectura - Departamento de Construcción y Tecnología Arquitectónica Directores: Dr. Alfonso García Santos y Dr. Antonio Rodríguez Rodríguez. Doctorando: D. Francisco Lora Toro 


\section{FICHA DE ENSAYOS DE MADERA Y ACIDOS}

\section{ACIDO A02/CR/ACIDO ACRILICO}
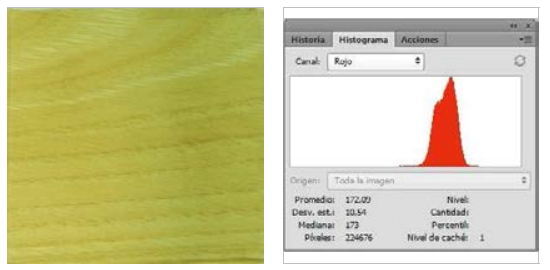

SIN TRATAR (ST): Grafica R (ST)

Valor R(ST):

172,09

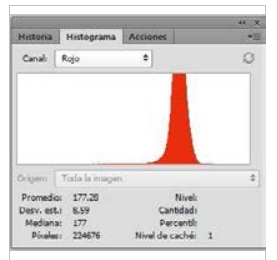

TRATADA (TT): Grafica R (TT) Valor R(TT):

177,28

DIFERENCIA (DF) Grafica R (DF): Valor DF-R: $-5,19$ GRAFICA:

\section{LEYENDA}

ST MADERA SIN TRATAR

Grafica R Histograma color Rojo Grafica G Histograma color Verde Grafica B Histograma color Azul Grafica L Histograma Luminosidad Grafica C Histograma RGB

\section{TT MADERA TRATADA}

Valor R Número pixeles color Rojo Valor $\mathrm{G}$ Número pixeles color Verde Valor B Número pixeles color Azul Valor $L$ Número pixeles Luminosidad Valor C Número pixeles RG DF DIFERENCIA DE VALORES R;G; $\mathrm{DF}=$ Valor $\mathrm{ST}(\mathrm{R} ; \mathrm{G} ; \mathrm{B})$ - Valor $\mathrm{TT}(\mathrm{R} ; \mathrm{G} ; \mathrm{B}$

\section{MADERA MO7/CÑ/CASTAÑO EUROPEO}
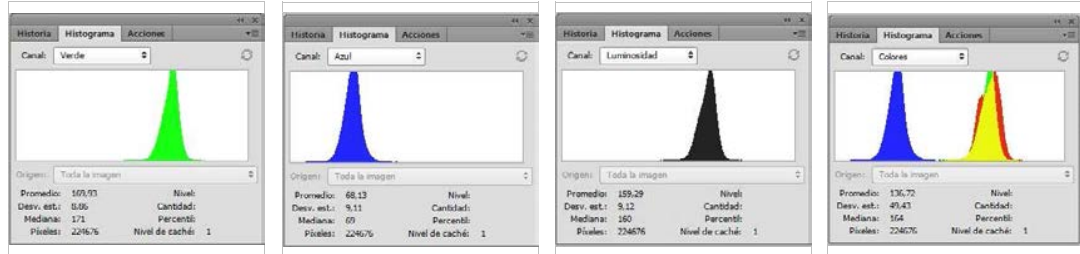

Grafica G (ST)

Grafica B (ST)

Grafica L (ST)

Grafica C (ST)

Valor $\mathrm{G}(\mathrm{ST})$ :

Valor B(ST):

Valor L(ST):

Valor C(ST):

68,13

159,29

136,72
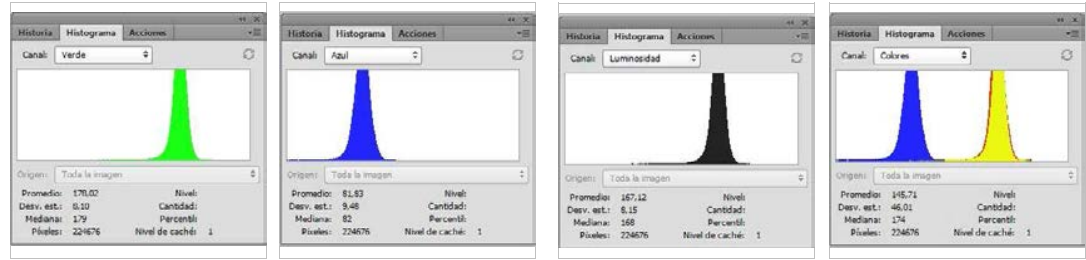

Grafica G (TT)

Grafica B (TT)

Grafica L (TT)

Grafica C (TT)

Valor $\mathrm{G}(\mathrm{TT})$ :

Valor $\mathrm{B}(\mathrm{TT})$ :

Valor L(TT):

Valor C(TT):

178,02

81,83

167,12

145,71

Grafica G (DF): Grafica B (DF): Grafica L (DF): Grafica C (DF): Valor DF-G: Valor DF-B: Valor DF-L: Valor DF-C:

$\begin{array}{llll}-8,09 & -13,70 & -7,83 & -8,99\end{array}$

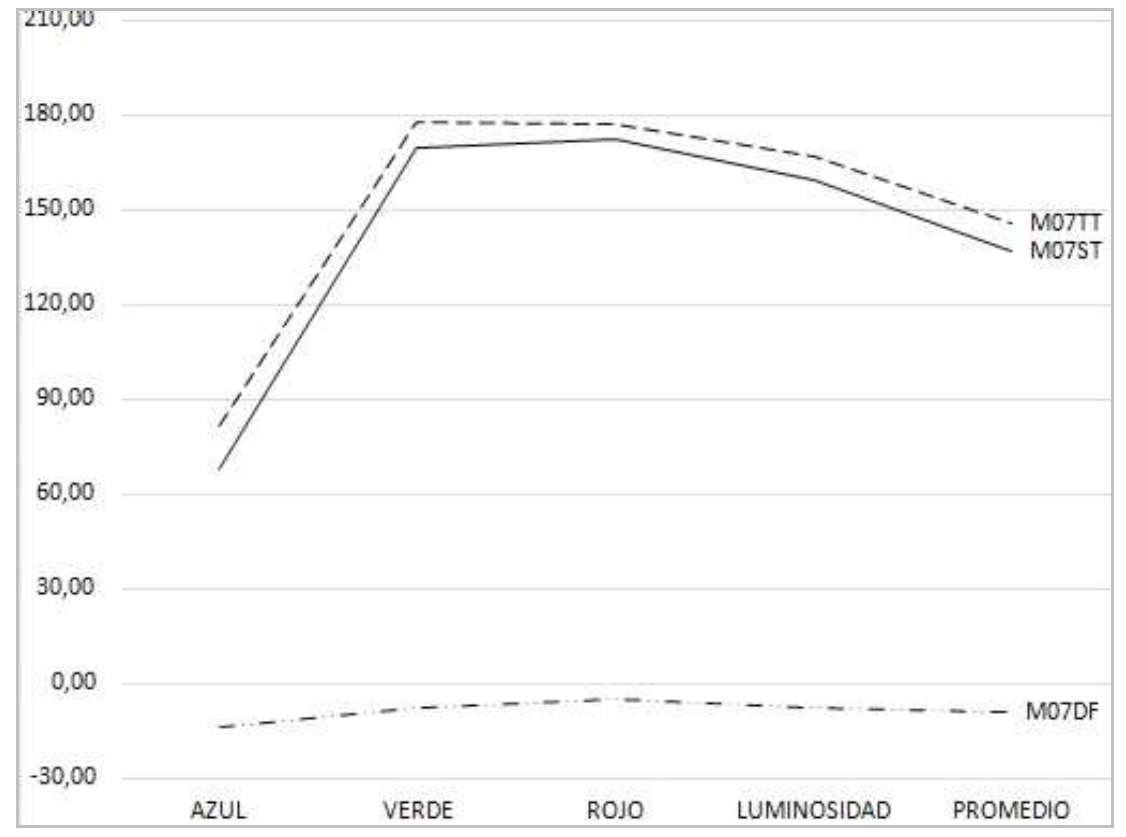

Universidad Politécnica de Madrid - Escuela Técnica Superior de Arquitectura - Departamento de Construcción y Tecnología Arquitectónica Directores: Dr. Alfonso García Santos y Dr. Antonio Rodríguez Rodríguez. Doctorando: D. Francisco Lora Toro 


\section{FICHA DE ENSAYOS DE MADERA Y ACIDOS}

\section{ACIDO A02/CR/ACIDO ACRILICO}
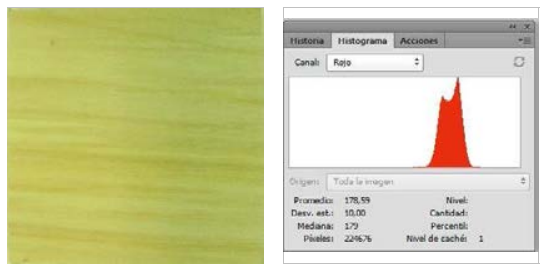

SIN TRATAR (ST): Grafica R (ST)

Valor R(ST):

178,59

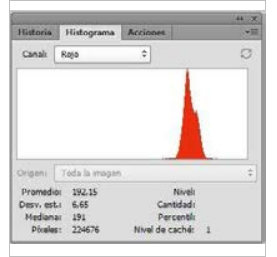

TRATADA (TT): Grafica $R(T T)$ Valor R(TT): 192,15

DIFERENCIA (DF) Grafica R (DF): Valor DF-R: $-13,56$

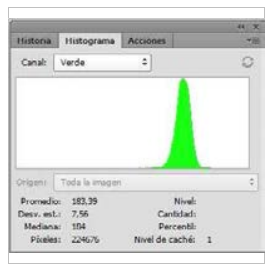

Grafica G (ST)

Valor $\mathrm{G}(\mathrm{ST})$ :

183,39

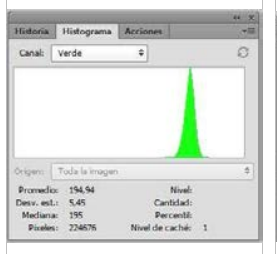

Grafica G (TT)

Valor $\mathrm{G}(\mathrm{TT})$ :

194,94
MADERA M08/CPE/CHOPO EUROPEO

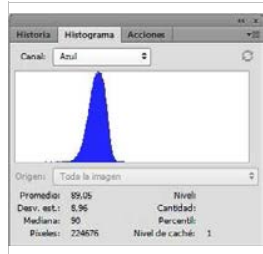

Grafica B (ST)

Valor B(ST):

89,05

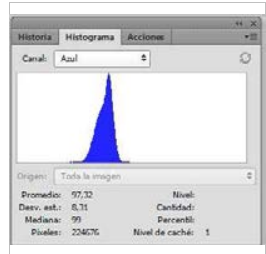

Grafica B (TT)

Valor $\mathrm{B}(\mathrm{TT})$ :

97,32

Grafica G (DF): Grafica B (DF):

Valor DF-G:

Valor DF-B:

$-8,27$

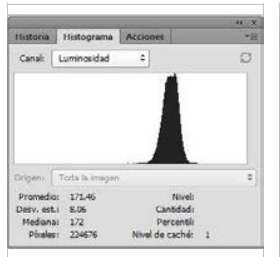

Grafica L (ST)

Valor L(ST):

171,46

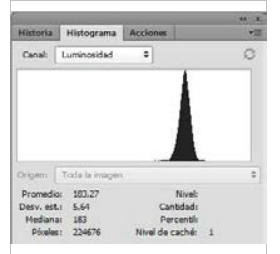

Grafica L (TT)

Valor L(TT):

183,27 $-11,55$

Grafica L (DF): Valor DF-L:

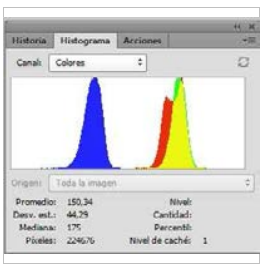

Grafica C (ST)

Valor C(ST):

150,34

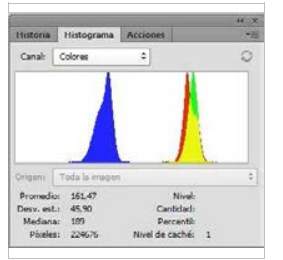

Grafica C (TT)

Valor C(TT):

161,47

Grafica C (DF): Valor DF-C:

GRAFICA

\section{LEYENDA}

ST MADERA SIN TRATAR

Grafica R Histograma color Rojo

Grafica G Histograma color Verde

Grafica B Histograma color Azul

Grafica L Histograma Luminosidad

Grafica C Histograma RGB

TT MADERA TRATADA

Valor R Número pixeles color Rojo

Valor $\mathrm{G}$ Número pixeles color Verde

Valor B Número pixeles color Azul

Valor $\mathrm{L}$ Número pixeles Luminosidad

Valor C Número pixeles RG

DF DIFERENCIA DE VALORES R;G; $\mathrm{DF}=$ Valor $\mathrm{ST}(\mathrm{R} ; \mathrm{G} ; \mathrm{B})$ - Valor TT(R;G;B

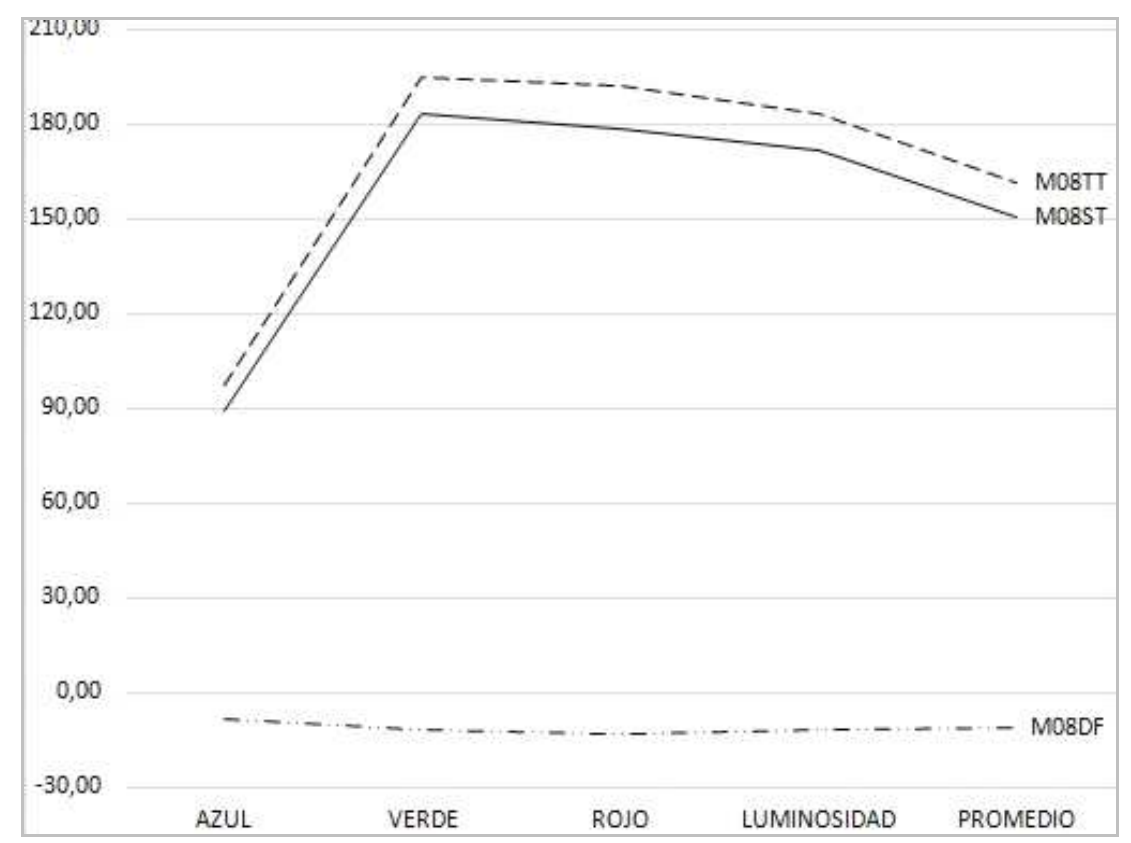

Universidad Politécnica de Madrid - Escuela Técnica Superior de Arquitectura - Departamento de Construcción y Tecnología Arquitectónica Directores: Dr. Alfonso García Santos y Dr. Antonio Rodríguez Rodríguez. Doctorando: D. Francisco Lora Toro 


\section{FICHA DE ENSAYOS DE MADERA Y ACIDOS}

\section{ACIDO A02/CR/ACIDO ACRILICO}
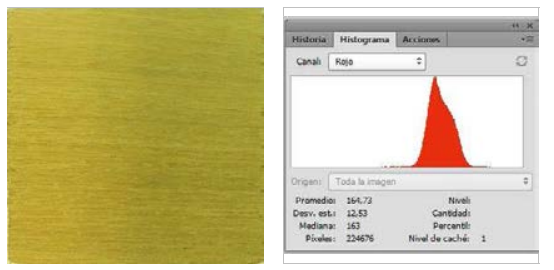

SIN TRATAR (ST): Grafica R (ST)

Valor R(ST):

164,73

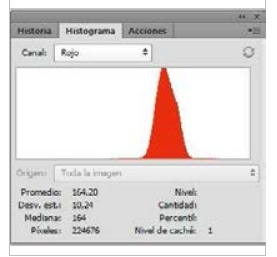

TRATADA (TT): Grafica $R(T T)$

Valor R(TT):

164,20

DIFERENCIA (DF) Grafica R (DF):

Valor DF-R:

0,53

GRAFICA:

\section{LEYENDA}

ST MADERA SIN TRATAR

Grafica R Histograma color Rojo

Grafica G Histograma color Verde

Grafica B Histograma color Azul

Grafica L Histograma Luminosidad

Grafica C Histograma RGB

\section{TT MADERA TRATADA}

Valor R Número pixeles color Rojo

Valor $G$ Número pixeles color Verde

Valor B Número pixeles color Azul

Valor $L$ Número pixeles Luminosidad

Valor C Número pixeles RG

DF DIFERENCIA DE VALORES R;G; $\mathrm{DF}=$ Valor $\mathrm{ST}(\mathrm{R} ; \mathrm{G} ; \mathrm{B})$ - Valor $\mathrm{TT}(\mathrm{R} ; \mathrm{G} ; \mathrm{B}$

\section{MADERA M09/CJ/CEREJEIRA}
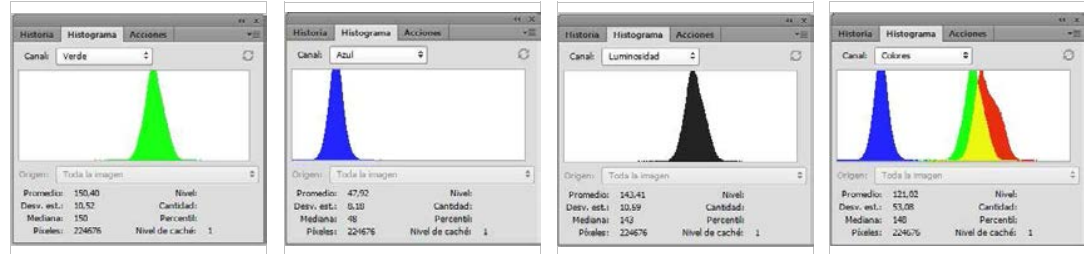

Grafica G (ST)

Grafica B (ST)

Grafica L (ST)

Grafica C (ST)

Valor $\mathrm{G}(\mathrm{ST})$ :

Valor B(ST):

Valor L(ST):

Valor C(ST):

150,40

47,92

143,41

121,02
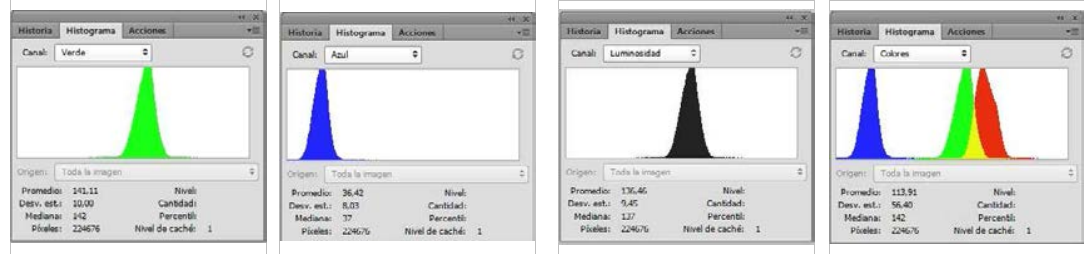

Grafica G (TT)

Grafica B (TT)

Grafica L (TT)

Grafica C (TT)

Valor $\mathrm{G}(\mathrm{TT})$ :

Valor $\mathrm{B}(\mathrm{TT})$ :

Valor L(TT):

Valor C(TT):

141,11

36,42

136,46

113,91

Grafica G (DF): Grafica B (DF): Grafica L (DF): Grafica C (DF): Valor DF-G: Valor DF-B: Valor DF-L: Valor DF-C:

$9,29 \quad 11,50 \quad 6,95 \quad 7,11$

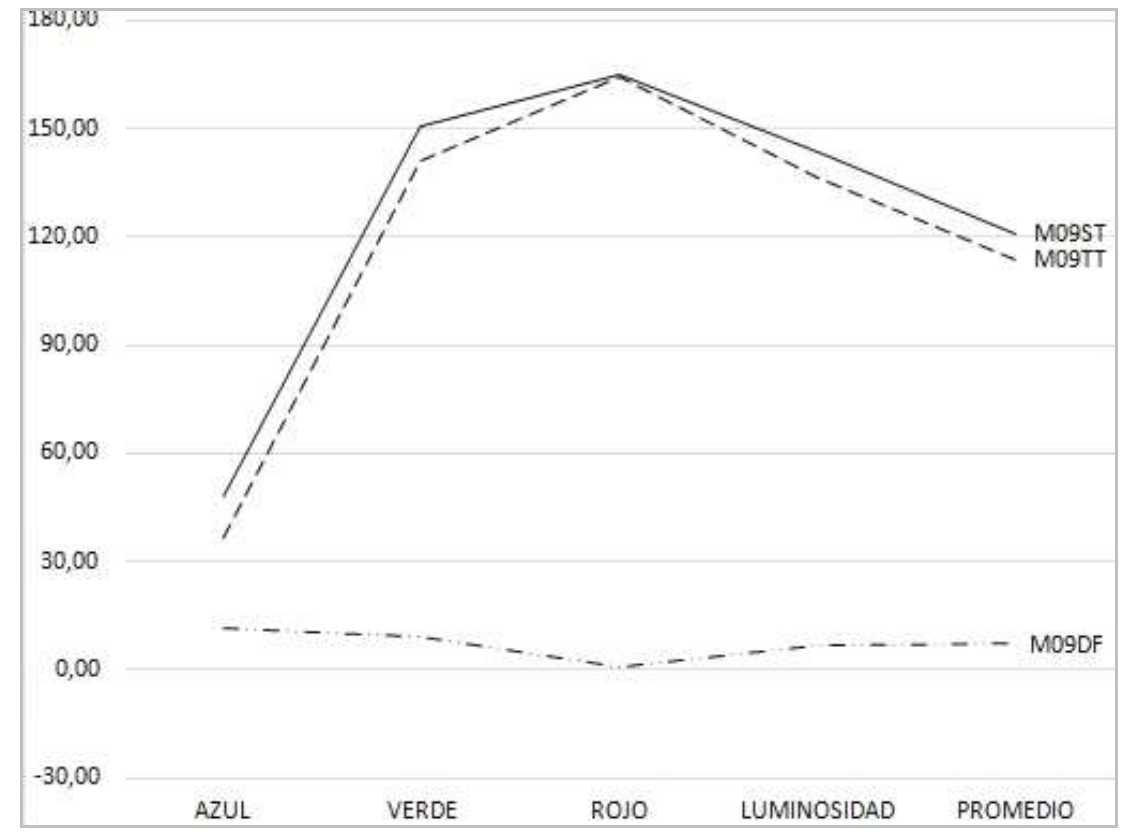

Universidad Politécnica de Madrid - Escuela Técnica Superior de Arquitectura - Departamento de Construcción y Tecnología Arquitectónica Directores: Dr. Alfonso García Santos y Dr. Antonio Rodríguez Rodríguez. Doctorando: D. Francisco Lora Toro 


\section{FICHA DE ENSAYOS DE MADERA Y ACIDOS}

\section{ACIDO A02/CR/ACIDO ACRILICO}
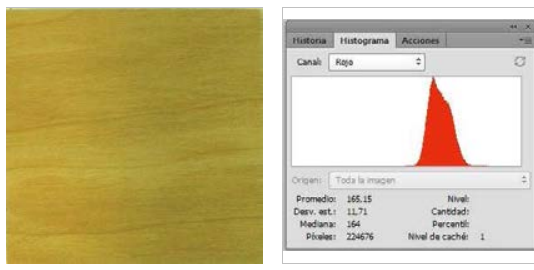

SIN TRATAR (ST): Grafica R (ST)

Valor R(ST):

165,15

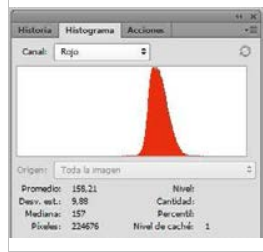

TRATADA (TT): Grafica R (TT)

Valor $\mathrm{R}(\mathrm{TT})$ :

158,21

DIFERENCIA (DF) Grafica R (DF): Valor DF-R:

6,94

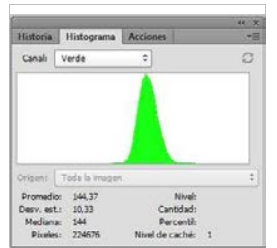

Grafica G (ST)

Valor G(ST):

144,37

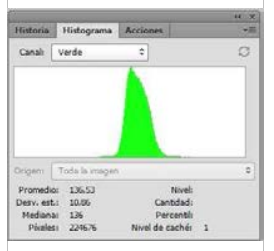

Grafica G (TT)

Valor $\mathrm{G}(\mathrm{TT})$ :

136,53
MADERA M10/CZA/CEREZO AMERICANO
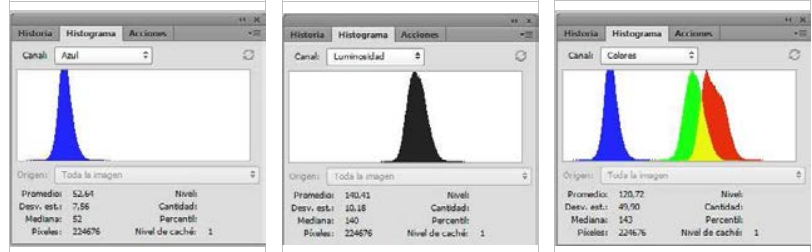

Grafica B (ST)

Grafica L (ST)

Grafica C (ST)

Valor B(ST):

Valor L(ST):

Valor C(ST):

52,64

140,41

120,72
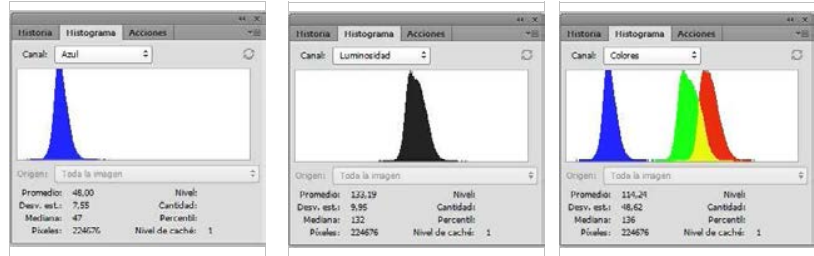

Grafica B (TT)

Grafica L (TT)

Grafica C (TT)

Valor $\mathrm{B}(\mathrm{TT})$ :

Valor L(TT):

Valor $\mathrm{C}(\mathrm{TT})$ :

48,00

133,19

114,24

Grafica G (DF): Grafica B (DF): Grafica L (DF): Grafica C (DF): Valor DF-G: $\quad$ Valor DF-B: Valor DF-L: Valor DF-C:

\section{LEYENDA}

ST MADERA SIN TRATAR

Grafica R Histograma color Rojo

Grafica G Histograma color Verde

Grafica B Histograma color Azul

Grafica L Histograma Luminosidad

Grafica C Histograma RGB

TT MADERA TRATADA

Valor R Número pixeles color Rojo

Valor $\mathrm{G}$ Número pixeles color Verde

Valor B Número pixeles color Azul

Valor $L$ Número pixeles Luminosidad

Valor C Número pixeles RG

DF DIFERENCIA DE VALORES R;G; $\mathrm{DF}=$ Valor $\mathrm{ST}(\mathrm{R} ; \mathrm{G} ; \mathrm{B})$ - Valor $\mathrm{TT}(\mathrm{R} ; \mathrm{G} ; \mathrm{B}$

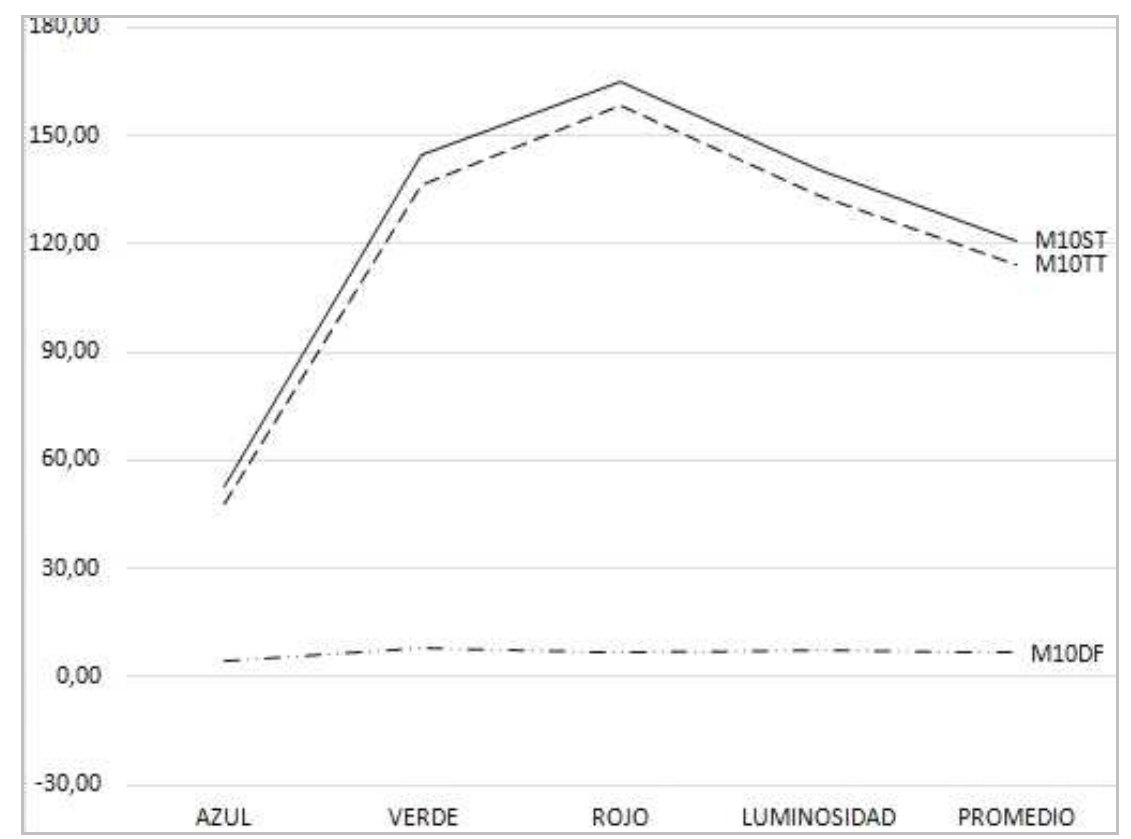

Universidad Politécnica de Madrid - Escuela Técnica Superior de Arquitectura - Departamento de Construcción y Tecnología Arquitectónica Directores: Dr. Alfonso García Santos y Dr. Antonio Rodríguez Rodríguez. Doctorando: D. Francisco Lora Toro 


\section{FICHA DE ENSAYOS DE MADERA Y ACIDOS}

\section{ACIDO A02/CR/ACIDO ACRILICO}
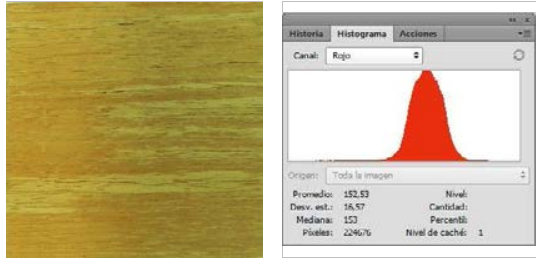

SIN TRATAR (ST): Grafica R (ST)

Valor R(ST):

152,53
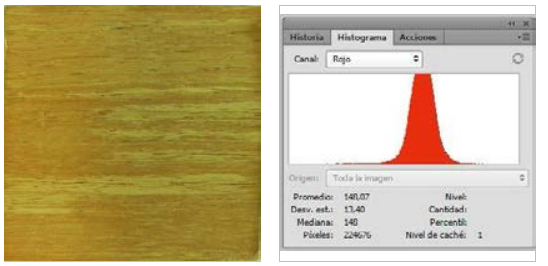

TRATADA (TT): Grafica R (TT)

Valor $\mathrm{R}(\mathrm{TT})$ :

148,07

DIFERENCIA (DF) Grafica R (DF): Valor DF-R:

4,46

GRAFICA:

\section{LEYENDA}

ST MADERA SIN TRATAR

Grafica R Histograma color Rojo

Grafica G Histograma color Verde

Grafica B Histograma color Azul

Grafica L Histograma Luminosidad

Grafica C Histograma RGB

TT MADERA TRATADA

Valor R Número pixeles color Rojo

Valor G Número pixeles color Verde

Valor B Número pixeles color Azul

Valor $L$ Número pixeles Luminosidad

Valor $C$ Número pixeles $R G$

DF DIFERENCIA DE VALORES R;G; $\mathrm{DF}=$ Valor $\mathrm{ST}(\mathrm{R} ; \mathrm{G} ; \mathrm{B})$ - Valor TT $(\mathrm{R} ; \mathrm{G} ; \mathrm{B}$

\section{MADERA M11/CB/COPAIBA}

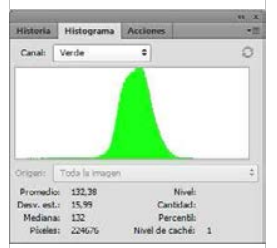

Grafica G (ST)

Valor G(ST):

132,38
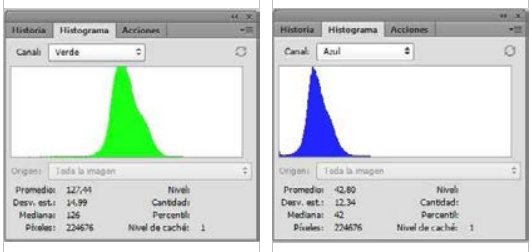

Grafica G (TT)

Grafica B (TT)

Valor $\mathrm{B}(\mathrm{TT})$ :

42,80

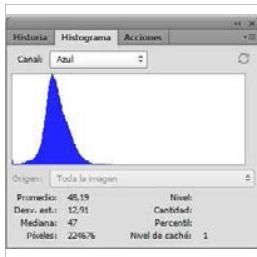

Grafica B (ST)

Valor $\mathrm{B}(\mathrm{ST})$ :

48,19

Valor G(TT):

127,44

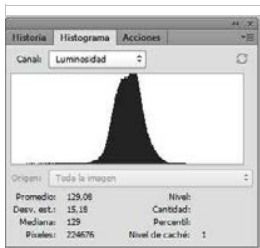

Grafica L (ST)

Valor L(ST):

129,08

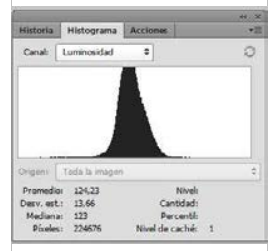

Grafica L (TT)

Valor L(TT):

124,23

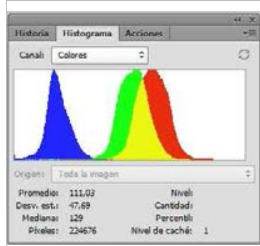

Grafica C (ST)

Valor C(ST):

111,03

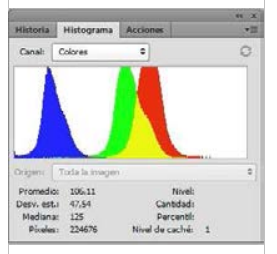

Grafica C (TT)

Valor $\mathrm{C}(\mathrm{TT})$ :

106,11

\section{Grafica G (DF): Grafica B (DF): Grafica L (DF): Grafica C (DF):} Valor DF-G: Valor DF-B: Valor DF-L: Valor DF-C:

$\begin{array}{llll}4,94 & 5,39 & 4,85 & 4,92\end{array}$

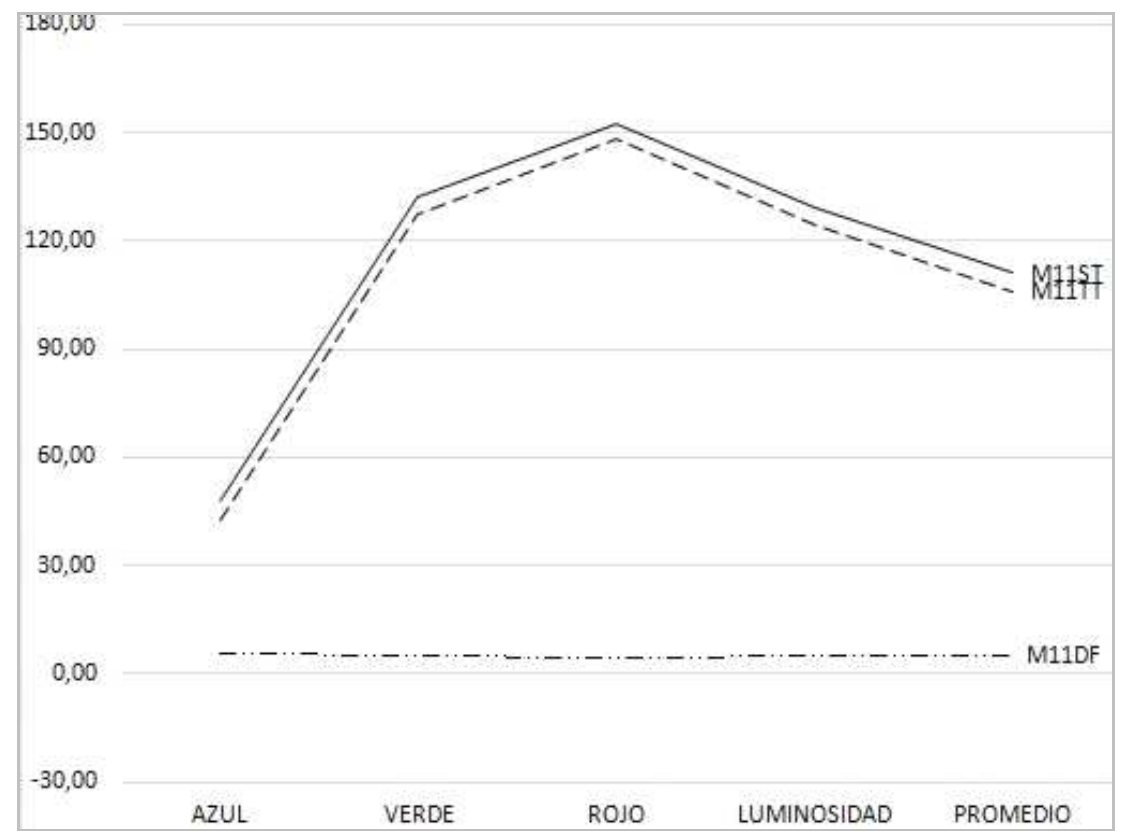

Universidad Politécnica de Madrid - Escuela Técnica Superior de Arquitectura - Departamento de Construcción y Tecnología Arquitectónica Directores: Dr. Alfonso García Santos y Dr. Antonio Rodríguez Rodríguez. Doctorando: D. Francisco Lora Toro 


\section{FICHA DE ENSAYOS DE MADERA Y ACIDOS}

\section{ACIDO A02/CR/ACIDO ACRILICO}
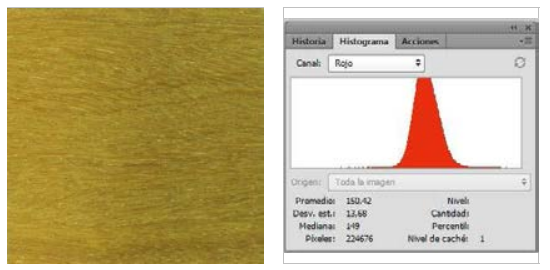

SIN TRATAR (ST): Grafica R (ST)

Valor R(ST):

150,42
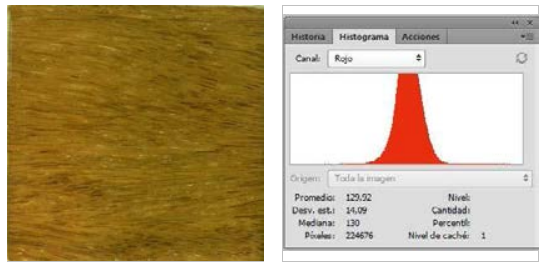

TRATADA (TT): Grafica $R(T T)$

Valor $\mathrm{R}(\mathrm{TT})$ :

129,92

DIFERENCIA (DF) Grafica R (DF): Valor DF-R: 20,50

GRAFICA:

\section{LEYENDA}

ST MADERA SIN TRATAR

Grafica R Histograma color Rojo

Grafica G Histograma color Verde

Grafica B Histograma color Azul

Grafica L Histograma Luminosidad

Grafica C Histograma RGB

\section{TT MADERA TRATADA}

Valor R Número pixeles color Rojo Valor $G$ Número pixeles color Verde Valor B Número pixeles color Azul Valor L Número pixeles Luminosidad Valor C Número pixeles RG DF DIFERENCIA DE VALORES R;G; $\mathrm{DF}=$ Valor $\mathrm{ST}(\mathrm{R} ; \mathrm{G} ; \mathrm{B})$ - Valor $\mathrm{TT}(\mathrm{R} ; \mathrm{G} ; \mathrm{B}$

\section{MADERA M12/CM/CUMARÚ}
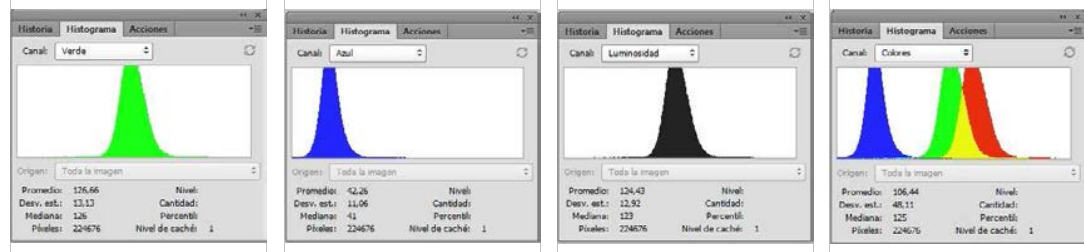

Grafica G (ST)

Grafica B (ST)

Grafica L (ST)

Grafica C (ST)

Valor $\mathrm{G}(\mathrm{ST})$ :

Valor $\mathrm{B}(\mathrm{ST})$ :

Valor L(ST):

Valor C(ST):

126,66

42,26

124,43

106,44
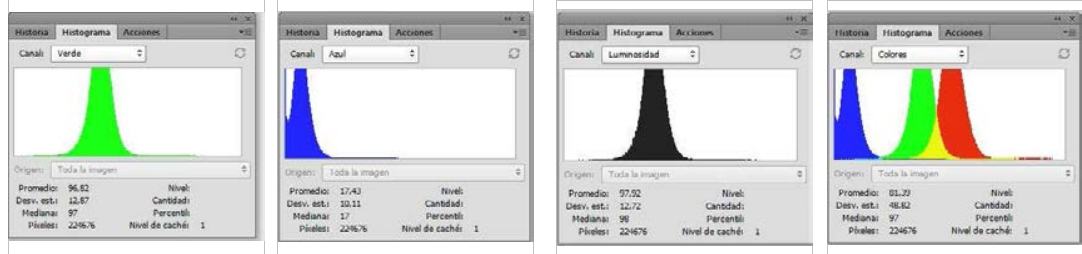

Grafica G (TT)

Grafica B (TT)

Grafica L (TT)

Grafica C (TT)

Valor $\mathrm{G}(\mathrm{TT})$ :

Valor $\mathrm{B}(\mathrm{TT})$ :

Valor L(TT):

Valor C(TT):

96,82

17,43

97,92

81,39

Grafica G (DF): Grafica B (DF): Grafica L (DF): Grafica C (DF): Valor DF-G: Valor DF-B: Valor DF-L: Valor DF-C: 29,84 24,83 26,51 25,05

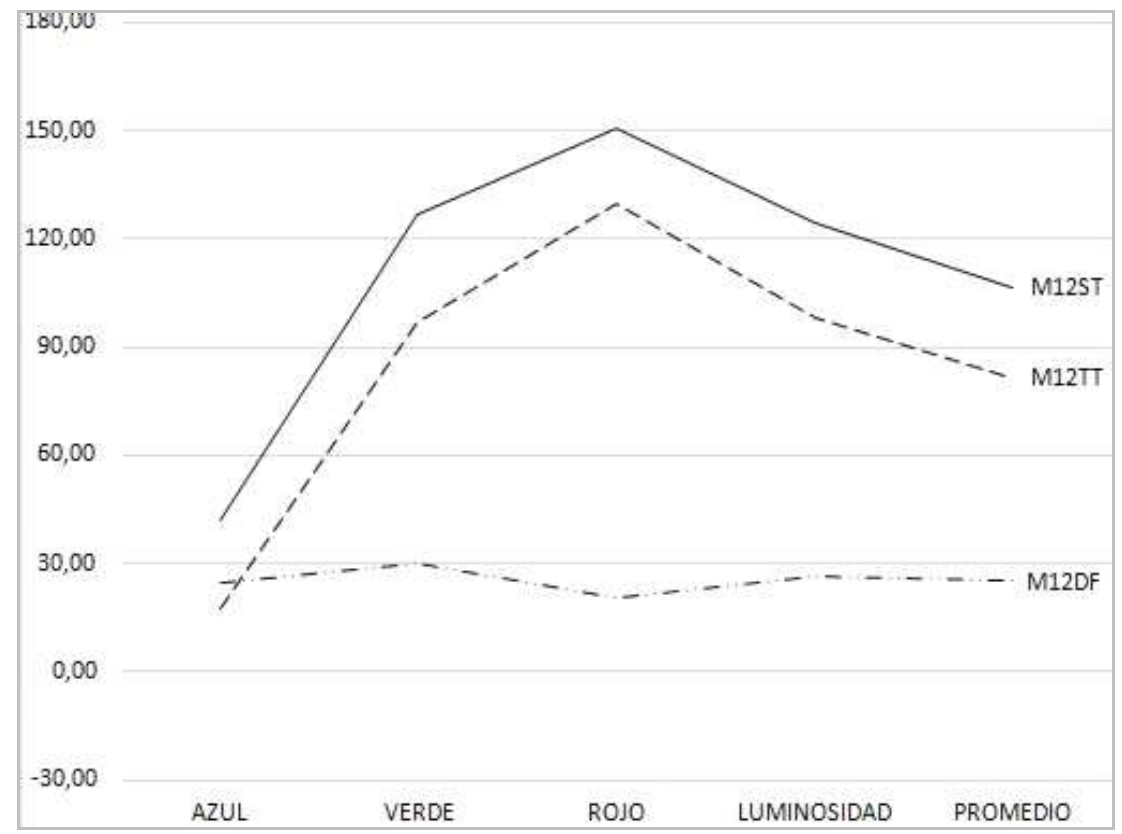

Universidad Politécnica de Madrid - Escuela Técnica Superior de Arquitectura - Departamento de Construcción y Tecnología Arquitectónica Directores: Dr. Alfonso García Santos y Dr. Antonio Rodríguez Rodríguez. Doctorando: D. Francisco Lora Toro 


\section{FICHA DE ENSAYOS DE MADERA Y ACIDOS}

\section{ACIDO A02/CR/ACIDO ACRILICO}
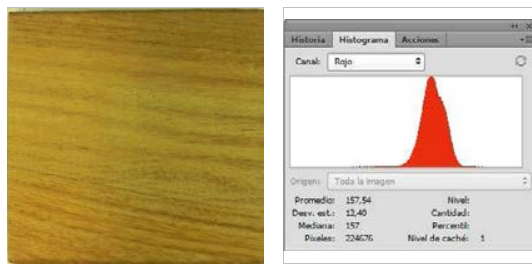

SIN TRATAR (ST): Grafica R (ST)

Valor R(ST):

157,54

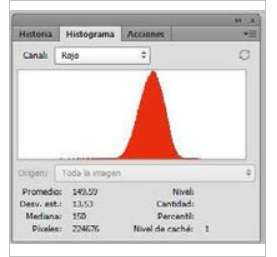

TRATADA (TT): Grafica $R(T T)$

Valor $\mathrm{R}(\mathrm{TT})$ :

149,59

DIFERENCIA (DF) Grafica R (DF): Valor DF-R:

7,95

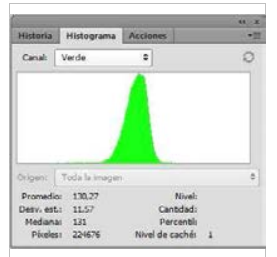

Grafica G (ST)

Valor G(ST):

130,27

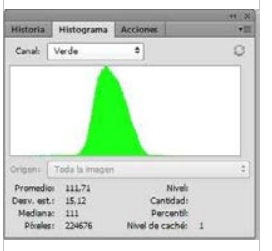

Grafica G (TT)

Valor G(TT):

111,71
MADERA M13/DS/DOUSSIÉ

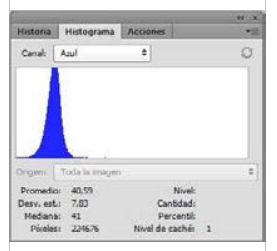

Grafica B (ST)

Valor B(ST):

40,59

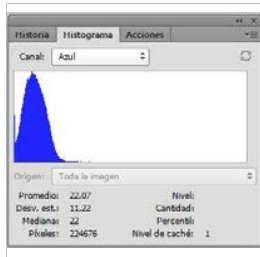

Grafica B (TT)

Valor $\mathrm{B}(\mathrm{TT})$ :

22,07

Grafica G (DF): Grafica B (DF):

Valor DF-B:

18,52 Valor DF-L:

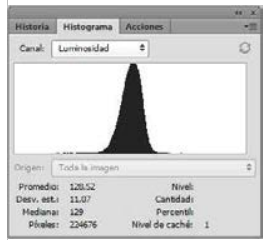

Grafica L (ST)

Valor L(ST):

128,52

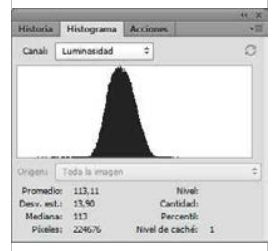

Grafica L (TT)

Valor L(TT):

113,11

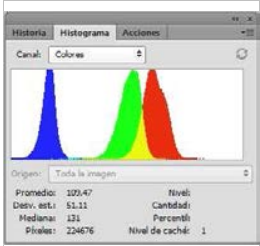

Grafica C (ST)

Valor C(ST):

109,47

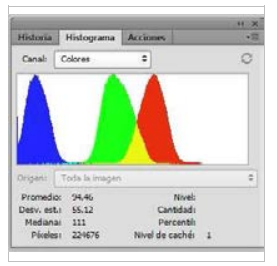

Grafica C (TT)

Valor C(TT):

94,46

Grafica L (DF): Grafica C (DF): Valor DF-C:

$\begin{array}{llll}18,56 & 18,52 & 15,41 & 15,01\end{array}$

GRAFICA:

\section{LEYENDA}

ST MADERA SIN TRATAR

Grafica R Histograma color Rojo

Grafica G Histograma color Verde

Grafica B Histograma color Azul

Grafica L Histograma Luminosidad

Grafica C Histograma RGB

TT MADERA TRATADA

Valor R Número pixeles color Rojo

Valor G Número pixeles color Verde

Valor B Número pixeles color Azul

Valor L Número pixeles Luminosidad

Valor C Número pixeles RG

DF DIFERENCIA DE VALORES R;G; $\mathrm{DF}=$ Valor $\mathrm{ST}(\mathrm{R} ; \mathrm{G} ; \mathrm{B})$ - Valor $\mathrm{TT}(\mathrm{R} ; \mathrm{G} ; \mathrm{B}$

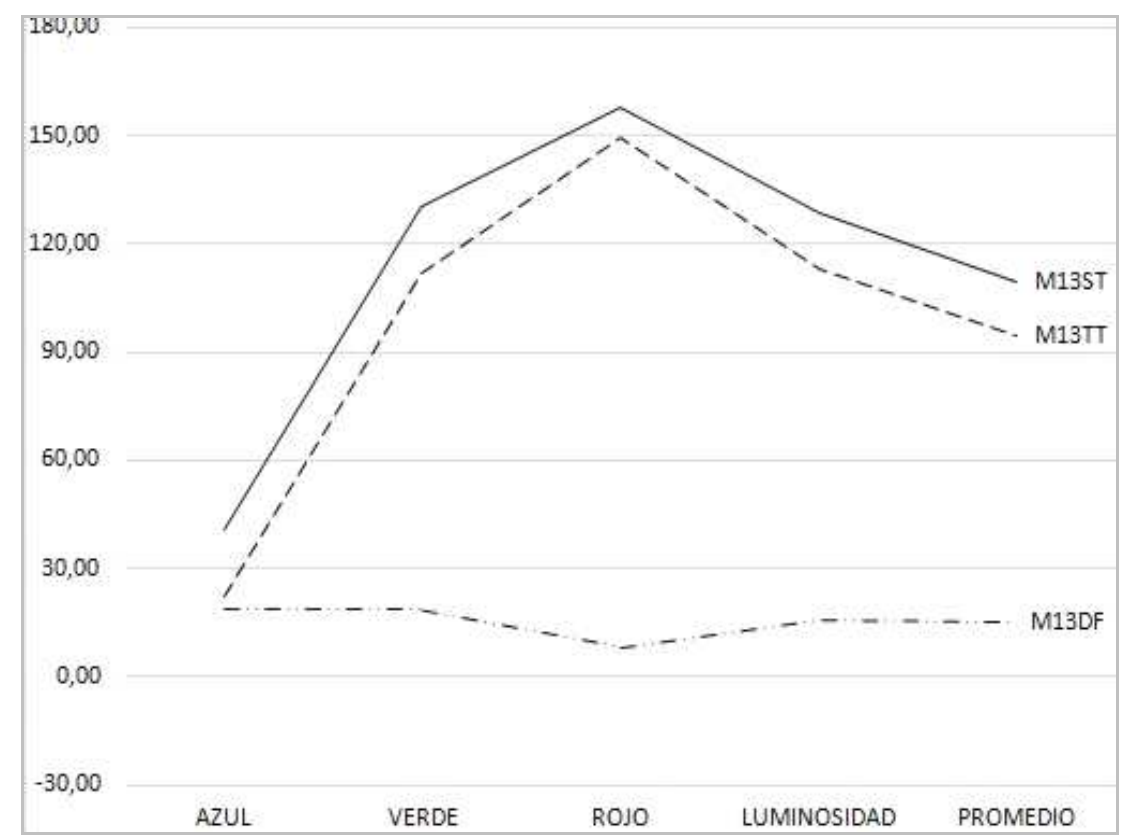

Universidad Politécnica de Madrid - Escuela Técnica Superior de Arquitectura - Departamento de Construcción y Tecnología Arquitectónica Directores: Dr. Alfonso García Santos y Dr. Antonio Rodríguez Rodríguez. Doctorando: D. Francisco Lora Toro 


\section{FICHA DE ENSAYOS DE MADERA Y ACIDOS}

\section{ACIDO A02/CR/ACIDO ACRILICO}
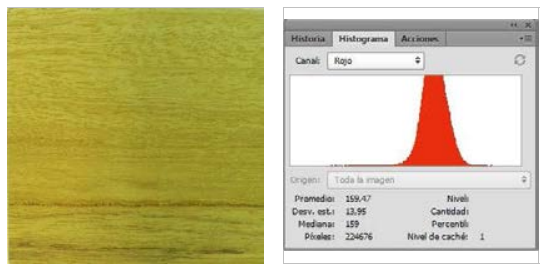

SIN TRATAR (ST): Grafica R (ST)

Valor R(ST):

159,47

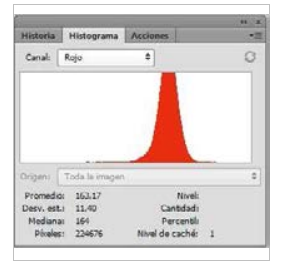

Grafica R (TT)

Valor R(TT):

163,17

DIFERENCIA (DF) Grafica R (DF): Valor DF-R: $-3,70$

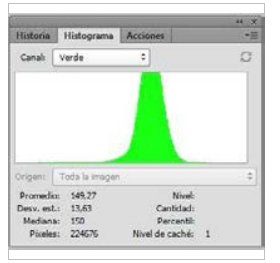

Grafica G (ST)

Valor $\mathrm{G}(\mathrm{ST})$ :

149,27

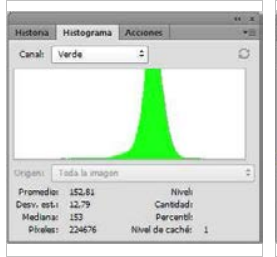

Grafica G (TT)

Valor $\mathrm{G}(\mathrm{TT})$ :

152,81
MADERA M14/FR/FRAMIRÉ

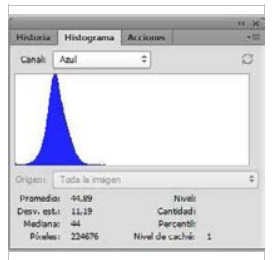

Grafica B (ST)

Valor B(ST):

44,89

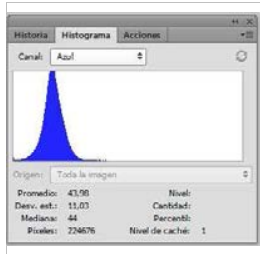

Grafica B (TT)

Valor $\mathrm{B}(\mathrm{TT})$ :

43,98

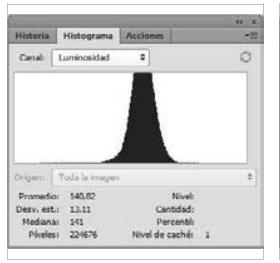

Grafica L (ST)

Valor L(ST):

140,82

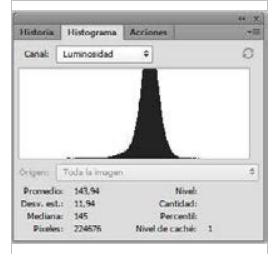

Grafica L (TT)

Valor L(TT):

143,94

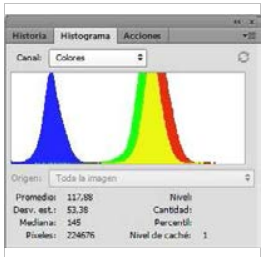

Grafica C (ST)

Valor C(ST):

117,88

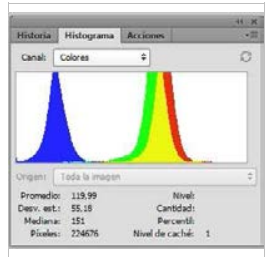

Grafica C (TT)

Valor C(TT):

119,99

Grafica G (DF): Grafica B (DF): Grafica L (DF): Grafica C (DF): Valor DF-G: Valor DF-B: Valor DF-L: Valor DF-C:

$\begin{array}{llll}-3,54 & 0,91 & -3,12 & -2,11\end{array}$

\section{LEYENDA}

ST MADERA SIN TRATAR

Grafica R Histograma color Rojo

Grafica G Histograma color Verde

Grafica B Histograma color Azul

Grafica L Histograma Luminosidad

Grafica C Histograma RGB

\section{TT MADERA TRATADA}

Valor R Número pixeles color Rojo

Valor $\mathrm{G}$ Número pixeles color Verde

Valor B Número pixeles color Azul

Valor L Número pixeles Luminosidad

Valor C Número pixeles RG

DF DIFERENCIA DE VALORES R;G; $\mathrm{DF}=$ Valor $\mathrm{ST}(\mathrm{R} ; \mathrm{G} ; \mathrm{B})$ - Valor TT(R;G;B

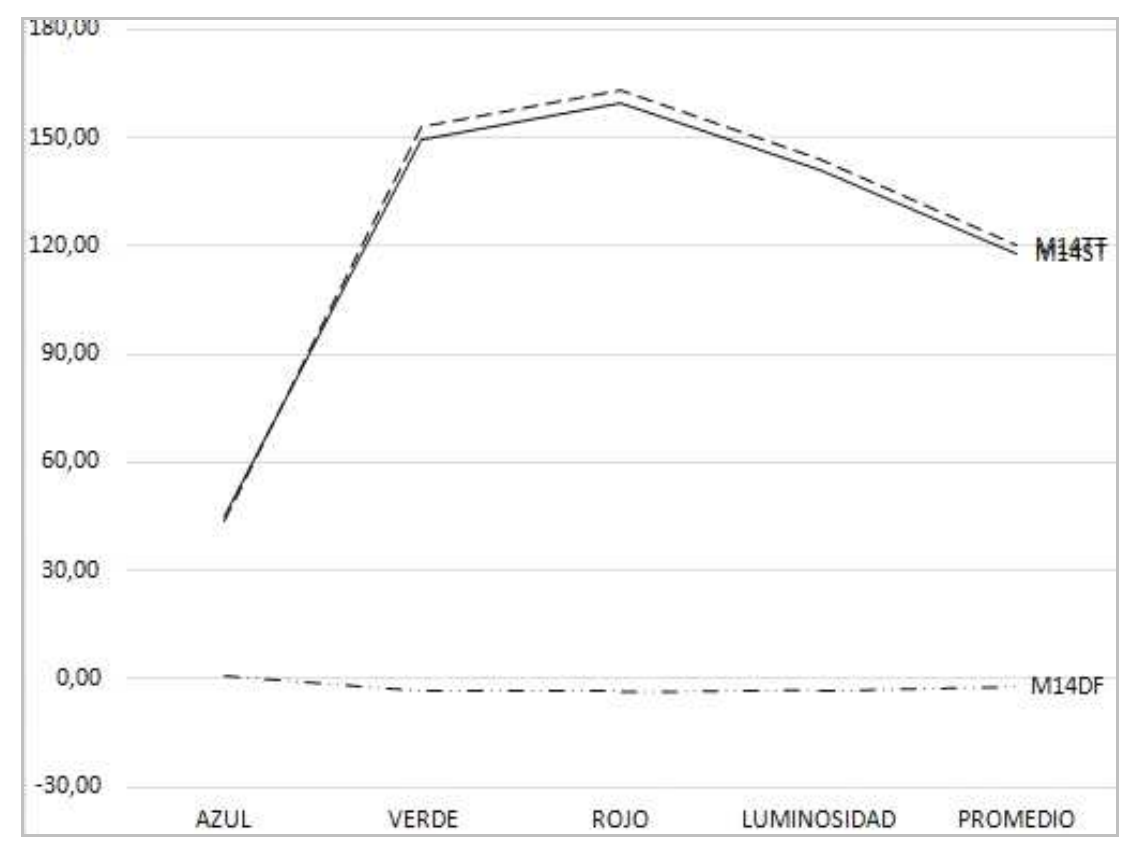

Universidad Politécnica de Madrid - Escuela Técnica Superior de Arquitectura - Departamento de Construcción y Tecnología Arquitectónica Directores: Dr. Alfonso García Santos y Dr. Antonio Rodríguez Rodríguez. Doctorando: D. Francisco Lora Toro 


\section{FICHA DE ENSAYOS DE MADERA Y ACIDOS}

\section{ACIDO A02/CR/ACIDO ACRILICO}
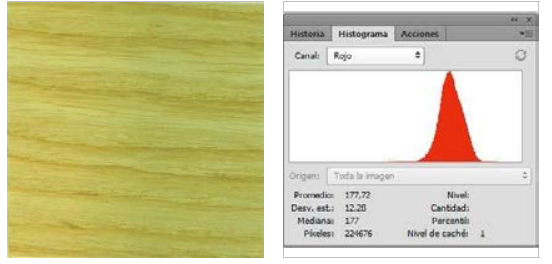

SIN TRATAR (ST): Grafica R (ST)

Valor R(ST):

177,72

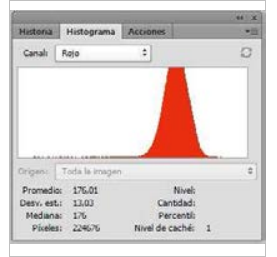

TRATADA (TT): Grafica R (TT)

Valor $\mathrm{R}(\mathrm{TT})$ :

176,01

DIFERENCIA (DF) Grafica R (DF): Valor DF-R:

1,71

GRAFICA:

\section{LEYENDA}

ST MADERA SIN TRATAR

Grafica R Histograma color Rojo

Grafica G Histograma color Verde

Grafica B Histograma color Azul

Grafica L Histograma Luminosidad

Grafica C Histograma RGB

\section{TT MADERA TRATADA}

Valor R Número pixeles color Rojo

Valor $\mathrm{G}$ Número pixeles color Verde

Valor B Número pixeles color Azul

Valor $L$ Número pixeles Luminosidad

Valor C Número pixeles RG

DF DIFERENCIA DE VALORES R;G; $\mathrm{DF}=$ Valor $\mathrm{ST}(\mathrm{R} ; \mathrm{G} ; \mathrm{B})$ - Valor TT $(\mathrm{R} ; \mathrm{G} ; \mathrm{B}$

\section{MADERA M15/FBA/FRESNO BLANCO AMERICAN}

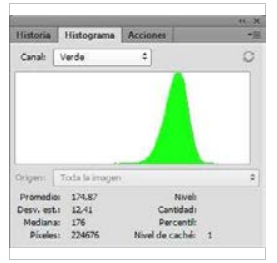

Grafica G (ST)

Valor $\mathrm{G}(\mathrm{ST})$ :

174,87

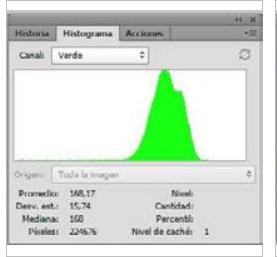

Grafica G (TT)

Valor G(TT):

168,17

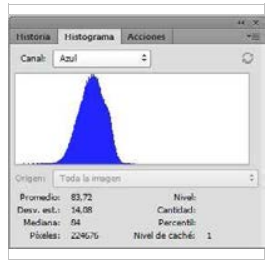

Grafica B (ST)

Valor B(ST):

83,72

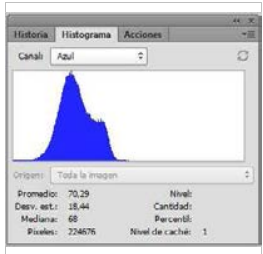

Grafica B (TT)

Valor $\mathrm{B}(\mathrm{TT})$ :

70,29

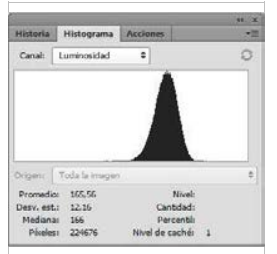

Grafica L (ST)

Valor L(ST):

165,56

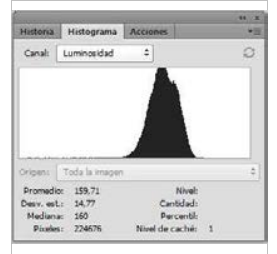

Grafica L (TT)

Valor L(TT):

159,71

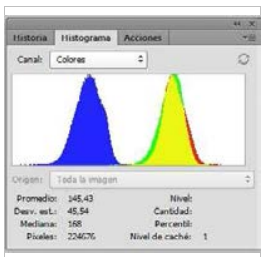

Grafica C (ST)

Valor C(ST):

145,43

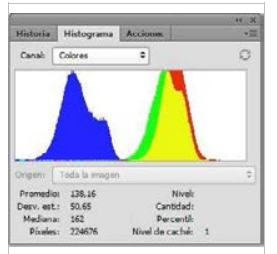

Grafica C (TT)

Valor C(TT):

138,16

Grafica G (DF): Grafica B (DF): Grafica L (DF): Grafica C (DF):

Valor DF-G: Valor DF-B:

Valor DF-L:

Valor DF-C:

$6,70 \quad 13,43 \quad 5,85 \quad 7,27$

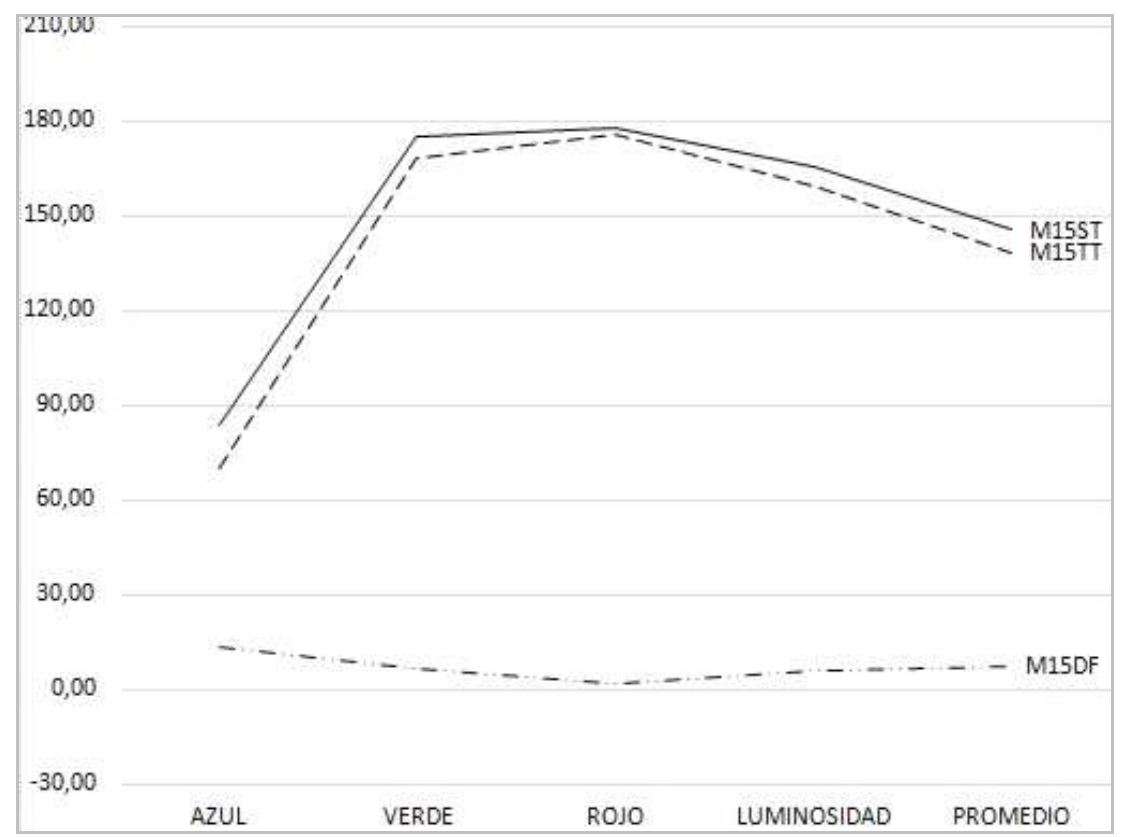

Universidad Politécnica de Madrid - Escuela Técnica Superior de Arquitectura - Departamento de Construcción y Tecnología Arquitectónica Directores: Dr. Alfonso García Santos y Dr. Antonio Rodríguez Rodríguez. Doctorando: D. Francisco Lora Toro 


\section{FICHA DE ENSAYOS DE MADERA Y ACIDOS}

\section{ACIDO A02/CR/ACIDO ACRILICO}
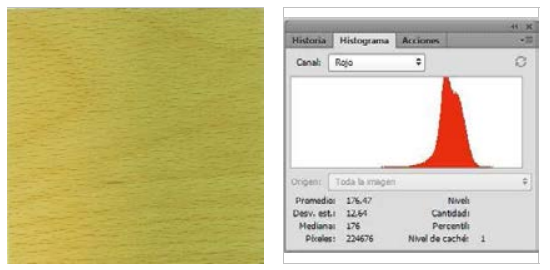

SIN TRATAR (ST): Grafica R (ST)

Valor R(ST):

176,47

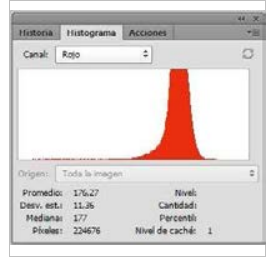

TRATADA (TT): Grafica $R(T T)$

Valor $\mathrm{R}(\mathrm{TT})$ :

176,27

DIFERENCIA (DF) Grafica R (DF): Valor DF-R:

0,20

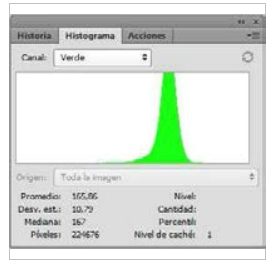

Grafica G (ST)

Valor G(ST):

165,86

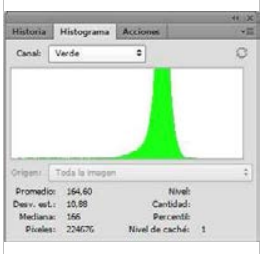

Grafica G (TT)

Valor G(TT):

164,60
MADERA M16/H/HAYA

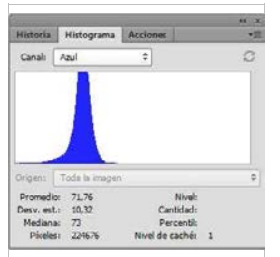

Grafica B (ST)

Valor B(ST):

71,76

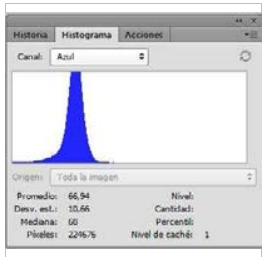

Grafica B (TT)

Valor $\mathrm{B}(\mathrm{TT})$ :

66,94

Grafica G (DF): Grafica B (DF):

Grafica L (DF):

Grafica C (DF):

Valor DF-G:

Valor DF-B:

Valor DF-L:

Valor DF-C:

1,26

4,82

1,26

2,09

\section{LEYENDA}

ST MADERA SIN TRATAR

Grafica R Histograma color Rojo

Grafica G Histograma color Verde

Grafica B Histograma color Azul

Grafica L Histograma Luminosidad

Grafica C Histograma RGB

TT MADERA TRATADA

Valor $R$ Número pixeles color Rojo

Valor G Número pixeles color Verde

Valor B Número pixeles color Azul

Valor $L$ Número pixeles Luminosidad

Valor C Número pixeles RG

DF DIFERENCIA DE VALORES R;G; $\mathrm{DF}=$ Valor $\mathrm{ST}(\mathrm{R} ; \mathrm{G} ; \mathrm{B})$ - Valor TT(R;G;B

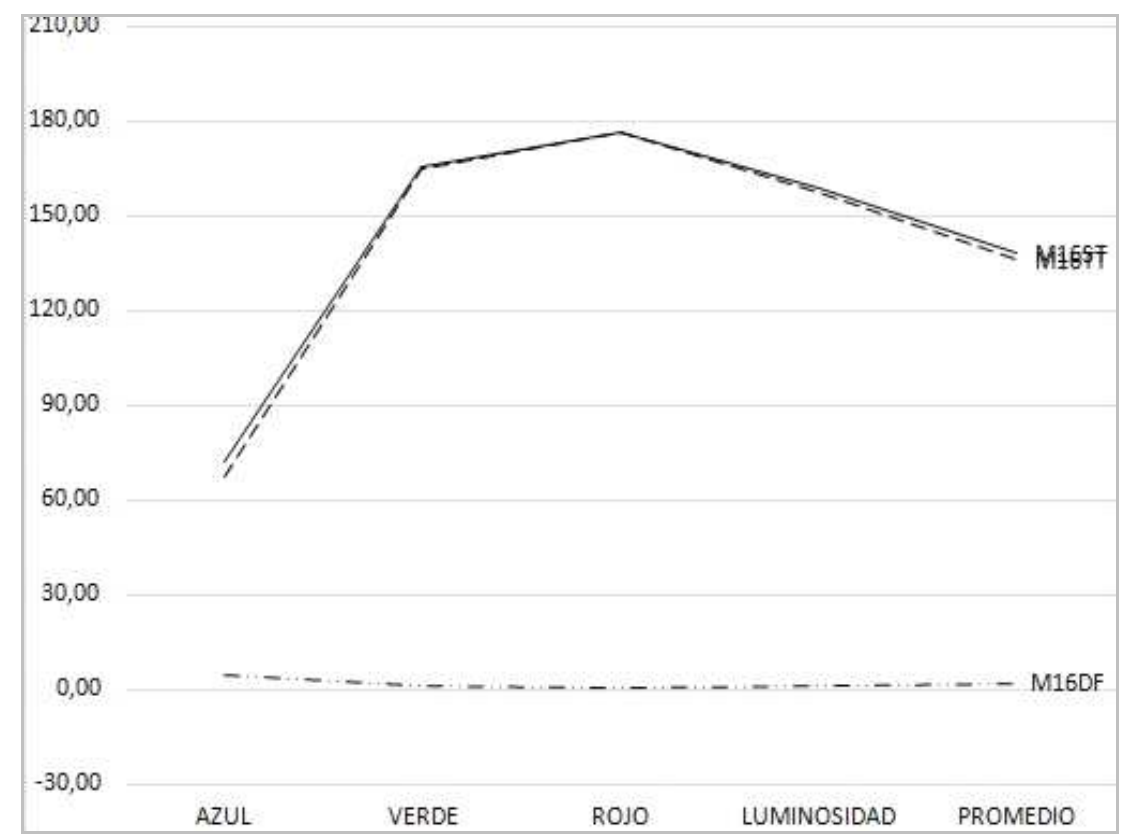

Universidad Politécnica de Madrid - Escuela Técnica Superior de Arquitectura - Departamento de Construcción y Tecnología Arquitectónica Directores: Dr. Alfonso García Santos y Dr. Antonio Rodríguez Rodríguez. Doctorando: D. Francisco Lora Toro 


\section{FICHA DE ENSAYOS DE MADERA Y ACIDOS}

\section{ACIDO A02/CR/ACIDO ACRILICO}
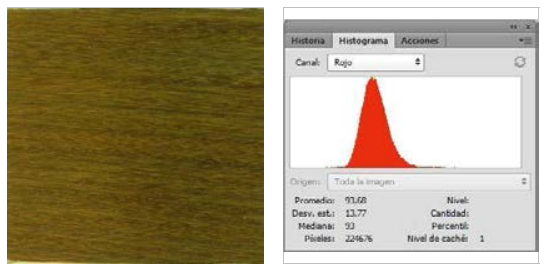

SIN TRATAR (ST): Grafica R (ST)

Valor R(ST):

93,68
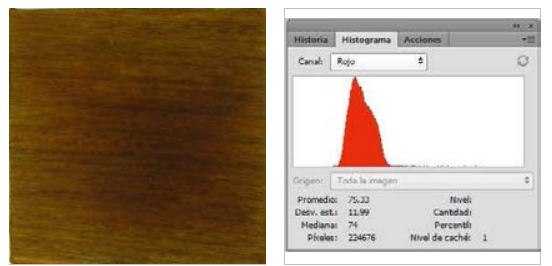

TRATADA (TT): Grafica $R(T T)$

Valor $\mathrm{R}(\mathrm{TT})$ :

75,33

DIFERENCIA (DF) Grafica R (DF): Valor DF-R: 18,35

GRAFICA:

\section{LEYENDA}

ST MADERA SIN TRATAR

Grafica R Histograma color Rojo Grafica G Histograma color Verde Grafica B Histograma color Azul Grafica L Histograma Luminosidad Grafica C Histograma RGB

\section{TT MADERA TRATADA}

Valor R Número pixeles color Rojo Valor $G$ Número pixeles color Verde Valor B Número pixeles color Azul Valor $\mathrm{L}$ Número pixeles Luminosidad Valor C Número pixeles RG DF DIFERENCIA DE VALORES R;G; $\mathrm{DF}=$ Valor $\mathrm{ST}(\mathrm{R} ; \mathrm{G} ; \mathrm{B})$ - Valor $\mathrm{TT}(\mathrm{R} ; \mathrm{G} ; \mathrm{B}$

$$
-30,0
$$

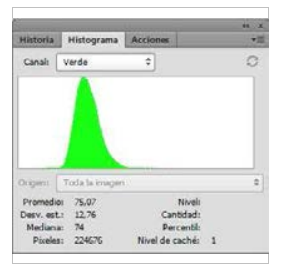

Grafica G (ST)

75,07

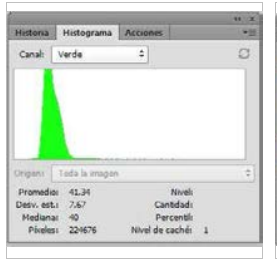

Grafica G (TT)

Valor $\mathrm{G}(\mathrm{TT})$ :

41,34
Valor $\mathrm{G}(\mathrm{ST})$ :

\section{MADERA M17/IP/IPÉ}

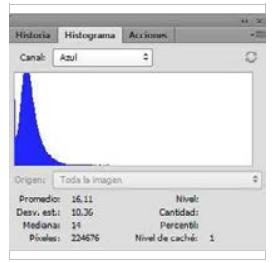

Grafica B (ST)

Valor B(ST):

16,11

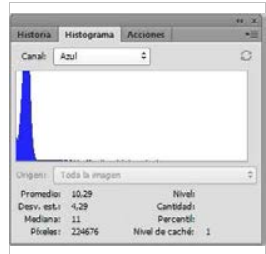

Grafica B (TT)

Valor $\mathrm{B}(\mathrm{TT})$ :

10,29

Grafica G (DF): Grafica B (DF):

Grafica L (DF):

Valor DF-L:

26,05

Valor DF-G:

5,82

33,73

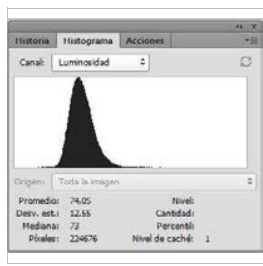

Grafica L (ST)

Valor L(ST):

74,05

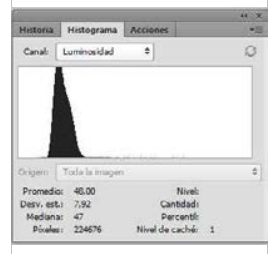

Grafica L (TT)

Valor L(TT):

48,00

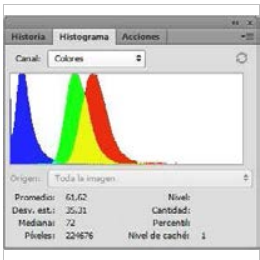

Grafica C (ST)

Valor C(ST):

61,62

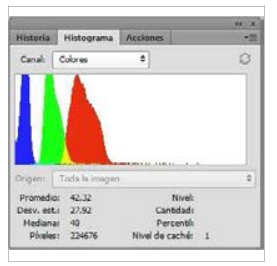

Grafica C (TT)

Valor C(TT):

42,32
Grafica C (DF):

5,82

Universidad Politécnica de Madrid - Escuela Técnica Superior de Arquitectura - Departamento de Construcción y Tecnología Arquitectónica Directores: Dr. Alfonso García Santos y Dr. Antonio Rodríguez Rodríguez. Doctorando: D. Francisco Lora Toro 


\section{FICHA DE ENSAYOS DE MADERA Y ACIDOS}

\section{ACIDO A02/CR/ACIDO ACRILICO}
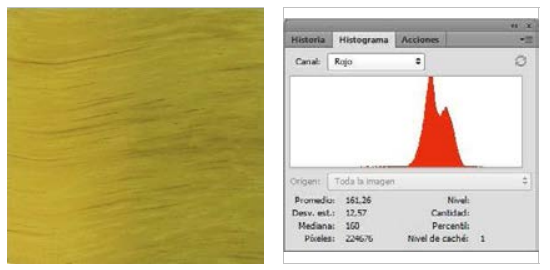

SIN TRATAR (ST): Grafica R (ST)

Valor R(ST):

161,26

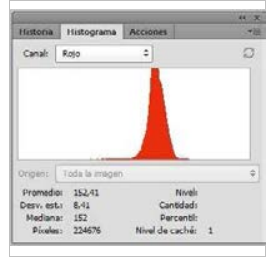

TRATADA (TT): Grafica $R(T T)$

Valor R(TT):

152,41

DIFERENCIA (DF) Grafica R (DF): Valor DF-R:

8,85

GRAFICA:

\section{LEYENDA}

ST MADERA SIN TRATAR

Grafica R Histograma color Rojo

Grafica G Histograma color Verde

Grafica B Histograma color Azul

Grafica L Histograma Luminosidad

Grafica C Histograma RGB

\section{TT MADERA TRATADA}

Valor R Número pixeles color Rojo

Valor $G$ Número pixeles color Verde

Valor B Número pixeles color Azul

Valor $L$ Número pixeles Luminosidad

Valor C Número pixeles RG

DF DIFERENCIA DE VALORES R;G; $\mathrm{DF}=$ Valor $\mathrm{ST}(\mathrm{R} ; \mathrm{G} ; \mathrm{B})$ - Valor $\mathrm{TT}(\mathrm{R} ; \mathrm{G} ; \mathrm{B}$

\section{MADERA M18/IK/IROKO}
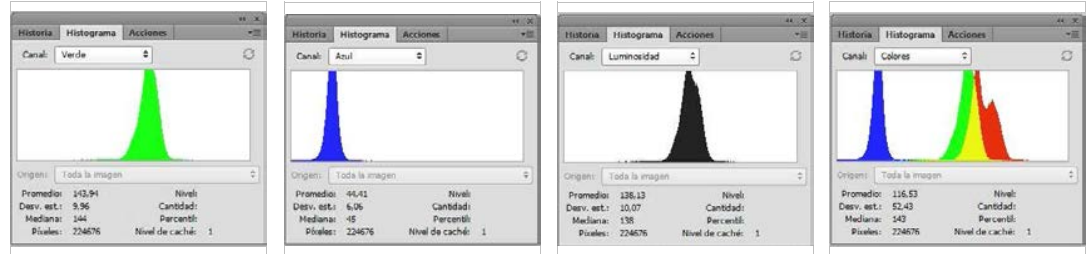

Grafica G (ST)

Grafica B (ST)

Grafica L (ST)

Grafica C (ST)

Valor $\mathrm{G}(\mathrm{ST})$ :

Valor B(ST):

Valor L(ST):

Valor C(ST):

143,94

44,41

138,13

116,53
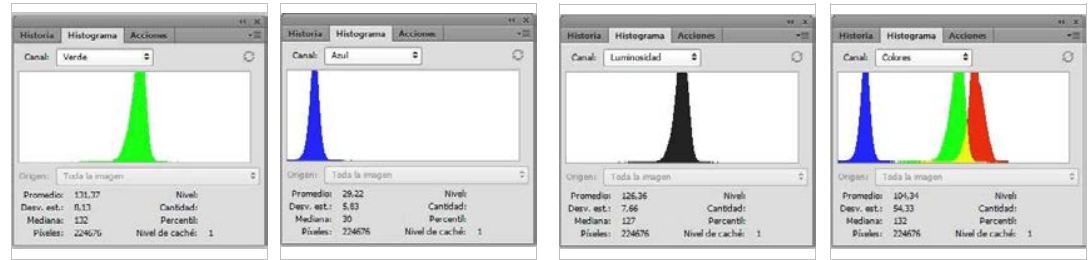

Grafica G (TT)

Grafica B (TT)

Grafica L (TT)

Grafica C (TT)

Valor $\mathrm{G}(\mathrm{TT})$ :

Valor $\mathrm{B}(\mathrm{TT})$ :

Valor L(TT):

Valor C(TT):

29,22

126,36

104,34 131,37

Grafica G (DF): Grafica B (DF):

Grafica L (DF):

Grafica C (DF): Valor DF-G: Valor DF-B: Valor DF-L: Valor DF-C:

$\begin{array}{llll}12,57 & 15,19 & 11,77 & 12,19\end{array}$

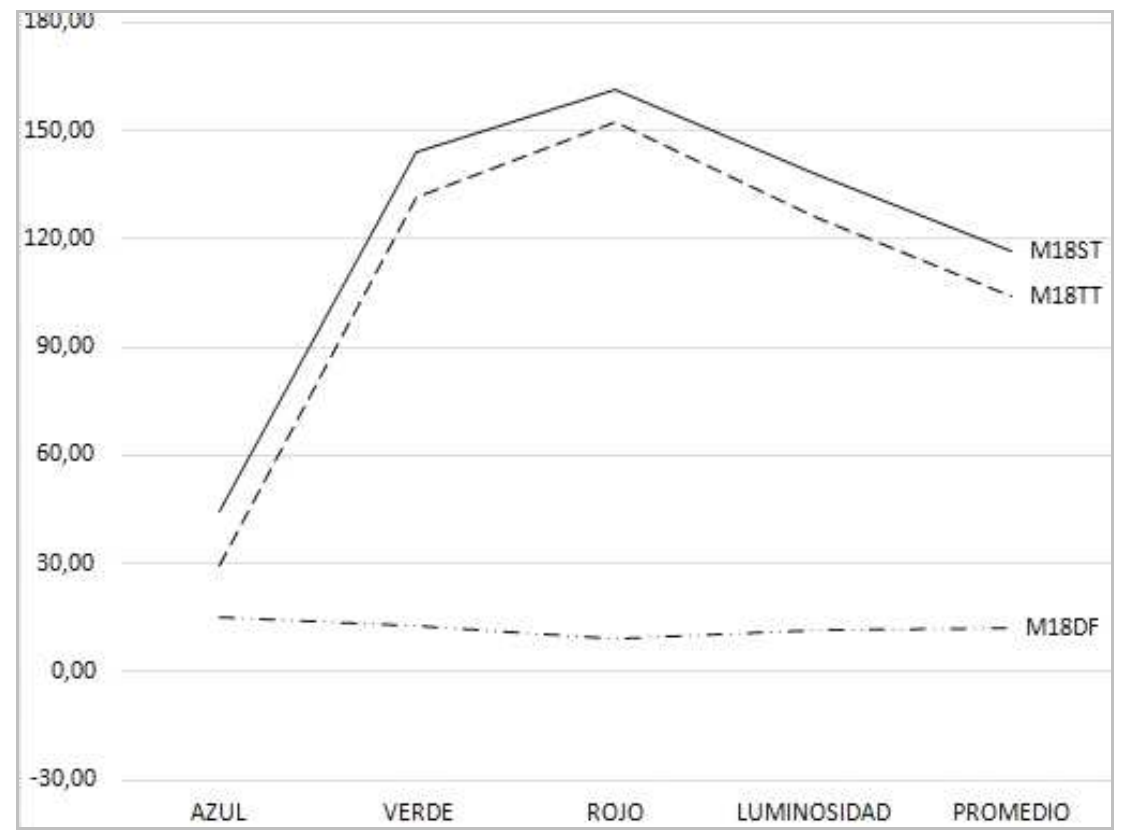

Universidad Politécnica de Madrid - Escuela Técnica Superior de Arquitectura - Departamento de Construcción y Tecnología Arquitectónica Directores: Dr. Alfonso García Santos y Dr. Antonio Rodríguez Rodríguez. Doctorando: D. Francisco Lora Toro 


\section{FICHA DE ENSAYOS DE MADERA Y ACIDOS}

\section{ACIDO A02/CR/ACIDO ACRILICO}
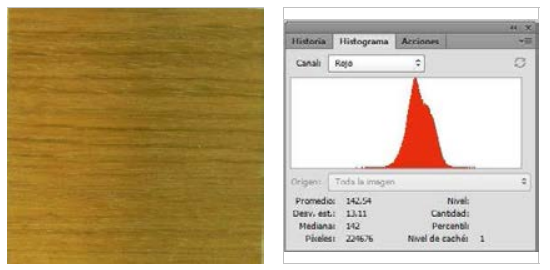

SIN TRATAR (ST): Grafica R (ST)

Valor R(ST):

142,54

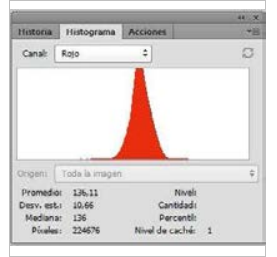

TRATADA (TT): Grafica $R(T T)$

Valor R(TT):

136,11

DIFERENCIA (DF) Grafica R (DF): Valor DF-R:

6,43

GRAFICA:

\section{LEYENDA}

ST MADERA SIN TRATAR

Grafica R Histograma color Rojo

Grafica G Histograma color Verde

Grafica B Histograma color Azul

Grafica L Histograma Luminosidad

Grafica C Histograma RGB

\section{TT MADERA TRATADA}

Valor R Número pixeles color Rojo

Valor $G$ Número pixeles color Verde

Valor B Número pixeles color Azul

Valor $L$ Número pixeles Luminosidad

Valor C Número pixeles RG

DF DIFERENCIA DE VALORES R;G; $\mathrm{DF}=$ Valor $\mathrm{ST}(\mathrm{R} ; \mathrm{G} ; \mathrm{B})$ - Valor $\mathrm{TT}(\mathrm{R} ; \mathrm{G} ; \mathrm{B}$

\section{MADERA M19/JT/JATOBA}
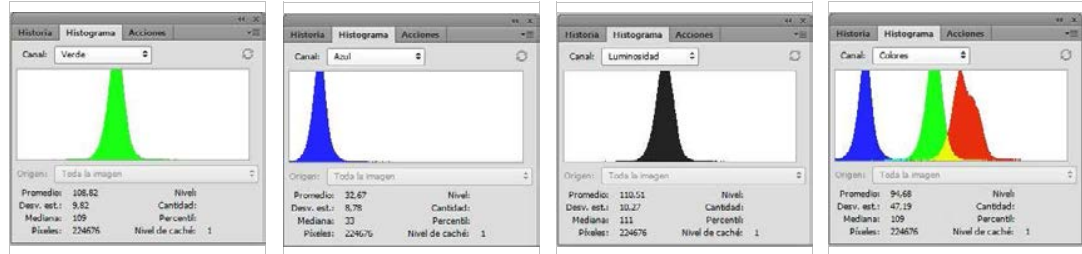

Grafica G (ST) Grafica B (ST)

Grafica L (ST)

Grafica C (ST)

Valor $\mathrm{G}(\mathrm{ST})$ :

Valor B(ST):

Valor L(ST):

Valor C(ST):

108,82

32,67

110,51

94,68
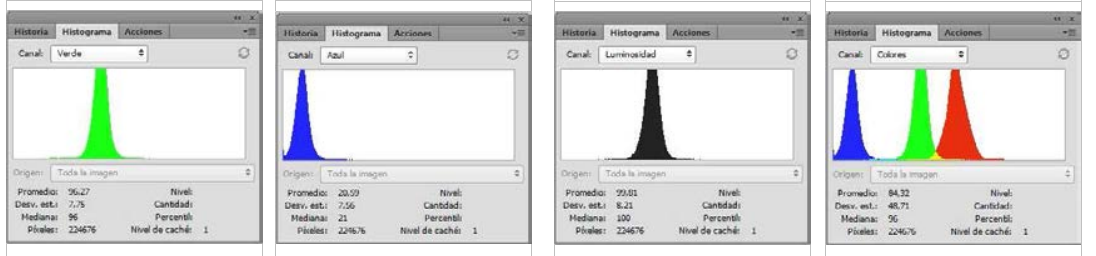

Grafica G (TT)

Grafica B (TT)

Grafica L (TT)

Grafica C (TT)

Valor $\mathrm{G}(\mathrm{TT})$ :

Valor $\mathrm{B}(\mathrm{TT})$ :

Valor L(TT):

Valor C(TT):

96,27

20,59

99,81

84,32

Grafica G (DF): Grafica B (DF): Grafica L (DF): Grafica C (DF): Valor DF-G: Valor DF-B: Valor DF-L: Valor DF-C:
12,55
12,08
10,70
10,36

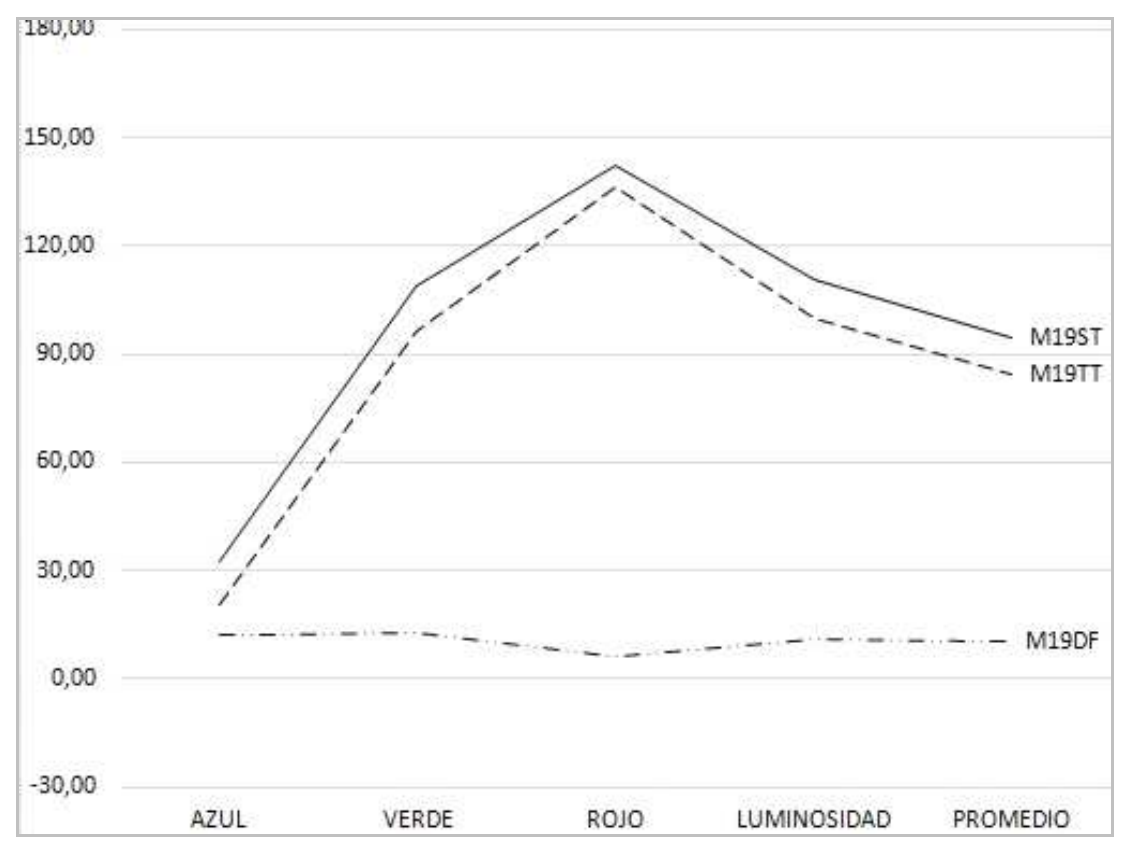

Universidad Politécnica de Madrid - Escuela Técnica Superior de Arquitectura - Departamento de Construcción y Tecnología Arquitectónica Directores: Dr. Alfonso García Santos y Dr. Antonio Rodríguez Rodríguez. Doctorando: D. Francisco Lora Toro 


\section{FICHA DE ENSAYOS DE MADERA Y ACIDOS}

\section{ACIDO A02/CR/ACIDO ACRILICO}
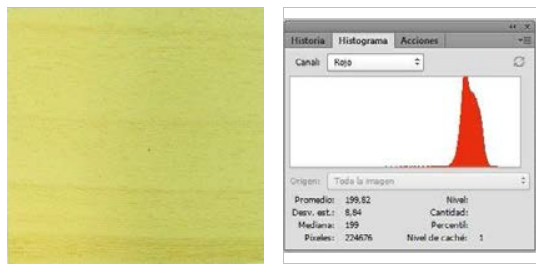

SIN TRATAR (ST): Grafica R (ST)

Valor R(ST):

199,82

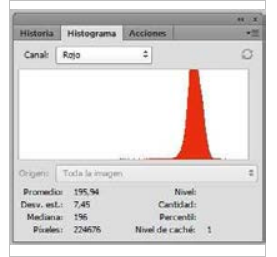

TRATADA (TT): Grafica $R(T T)$

Valor R(TT):

195,94

DIFERENCIA (DF) Grafica R (DF): Valor DF-R:

3,88

GRAFICA:

\section{LEYENDA}

ST MADERA SIN TRATAR

Grafica R Histograma color Rojo

Grafica G Histograma color Verde

Grafica B Histograma color Azul

Grafica L Histograma Luminosidad

Grafica C Histograma RGB

TT MADERA TRATADA

Valor $R$ Número pixeles color Rojo

Valor $G$ Número pixeles color Verde

Valor B Número pixeles color Azul

Valor $L$ Número pixeles Luminosidad

Valor C Número pixeles RG

DF DIFERENCIA DE VALORES R;G; $\mathrm{DF}=$ Valor $\mathrm{ST}(\mathrm{R} ; \mathrm{G} ; \mathrm{B})$ - Valor $\mathrm{TT}(\mathrm{R} ; \mathrm{G} ; \mathrm{B}$

\section{MADERA M20/KT/KOTO}

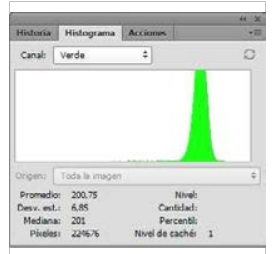

Grafica G (ST)

Valor G(ST):

200,75

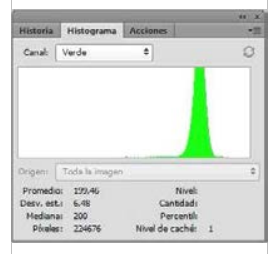

Grafica G (TT)

Valor G(TT):

199,46

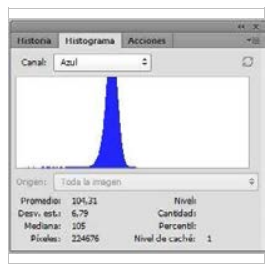

Grafica B (ST)

Valor B(ST):

104,31

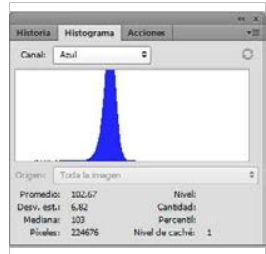

Grafica B (TT)

Valor $\mathrm{B}(\mathrm{TT})$ :

102,67

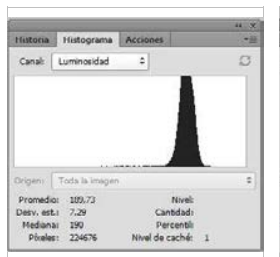

Grafica L (ST)

Valor L(ST):

189,73

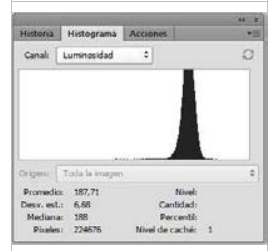

Grafica L (TT)

Valor L(TT):

187,71

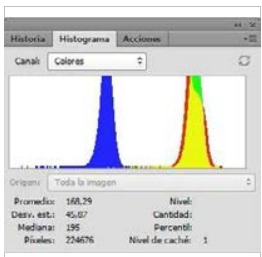

Grafica C (ST)

Valor C(ST):

168,29

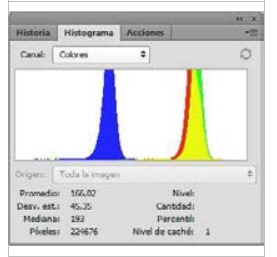

Grafica C (TT)

Valor C(TT):

166,02

Grafica G (DF): Grafica B (DF): Grafica L (DF): Grafica C (DF): Valor DF-G: $\quad$ Valor DF-B:

Valor DF-L:

Valor DF-C:

$\begin{array}{llll}1,29 & 2,64 & 2,02 & 27\end{array}$

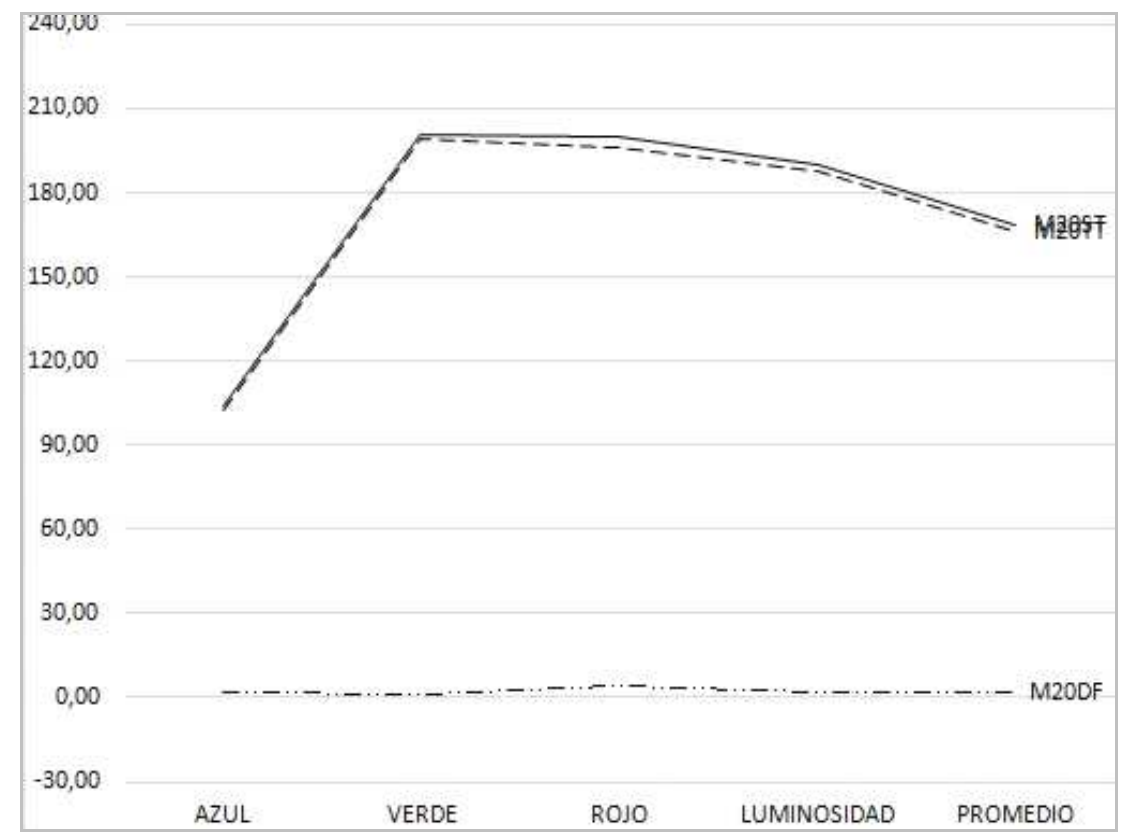

Universidad Politécnica de Madrid - Escuela Técnica Superior de Arquitectura - Departamento de Construcción y Tecnología Arquitectónica Directores: Dr. Alfonso García Santos y Dr. Antonio Rodríguez Rodríguez. Doctorando: D. Francisco Lora Toro 


\section{FICHA DE ENSAYOS DE MADERA Y ACIDOS}

\section{ACIDO A02/CR/ACIDO ACRILICO}
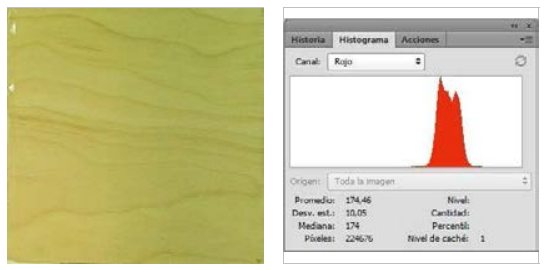

SIN TRATAR (ST): Grafica R (ST)

Valor R(ST):

174,46

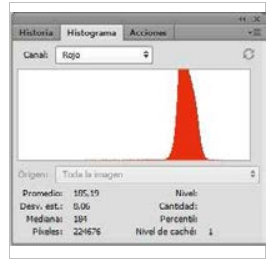

TRATADA (TT): Grafica R (TT) Valor R(TT): 185,19

DIFERENCIA (DF) Grafica R (DF): Valor DF-R: $-10,73$

GRAFICA:

\section{LEYENDA}

ST MADERA SIN TRATAR

Grafica R Histograma color Rojo Grafica G Histograma color Verde Grafica B Histograma color Azul Grafica L Histograma Luminosidad Grafica C Histograma RGB

\section{TT MADERA TRATADA}

Valor R Número pixeles color Rojo Valor $\mathrm{G}$ Número pixeles color Verde Valor B Número pixeles color Azul Valor $L$ Número pixeles Luminosidad Valor C Número pixeles RG DF DIFERENCIA DE VALORES R;G; $\mathrm{DF}=$ Valor $\mathrm{ST}(\mathrm{R} ; \mathrm{G} ; \mathrm{B})$ - Valor TT $(\mathrm{R} ; \mathrm{G} ; \mathrm{B}$

\section{MADERA M21/LG/LENGA}
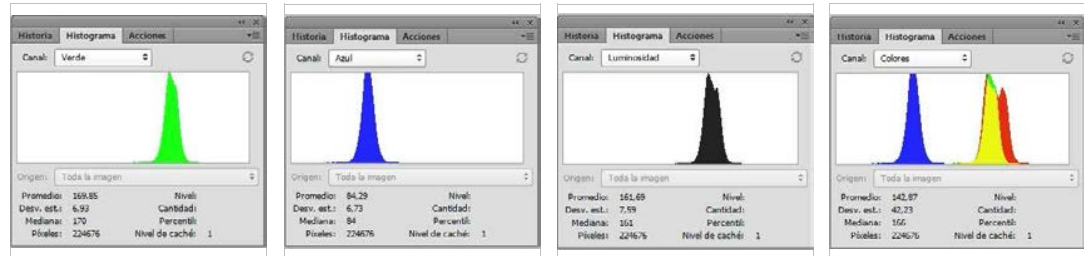

Grafica G (ST)

Grafica B (ST)

Grafica L (ST)

Grafica C (ST)

Valor G(ST):

Valor B(ST):

Valor L(ST):

Valor C(ST):

169,85

84,29

161,69

142,87
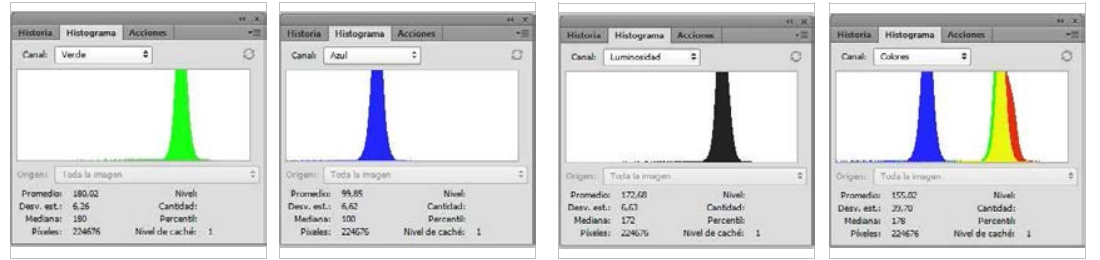

Grafica G (TT)

Grafica B (TT)

Grafica L (TT)

Grafica C (TT)

Valor G(TT):

Valor B(TT):

Valor L(TT):

Valor C(TT):

180,02

99,85

172,68

155,02

Grafica G (DF): Grafica B (DF): Grafica L (DF): Grafica C (DF): Valor DF-G: Valor DF-B: Valor DF-L: Valor DF-C:

$-10,17 \quad-15,56 \quad-10,99 \quad-12,15$

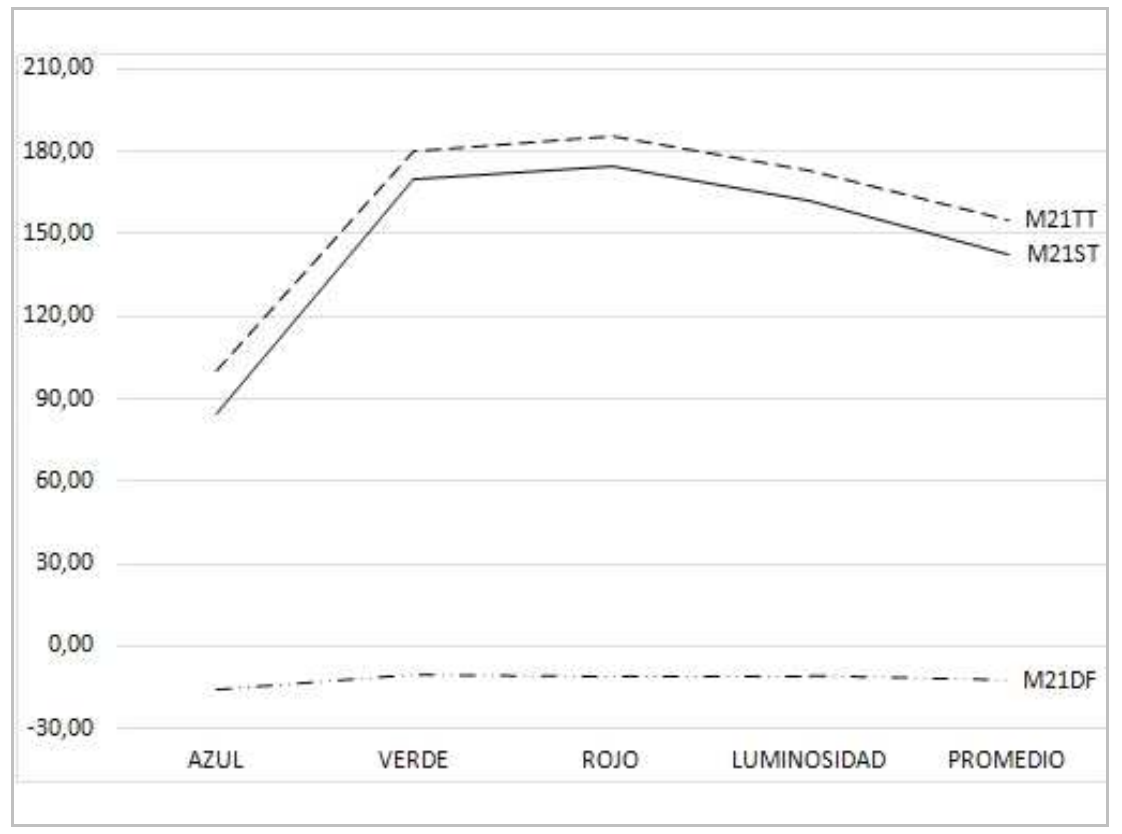

Universidad Politécnica de Madrid - Escuela Técnica Superior de Arquitectura - Departamento de Construcción y Tecnología Arquitectónica Directores: Dr. Alfonso García Santos y Dr. Antonio Rodríguez Rodríguez. Doctorando: D. Francisco Lora Toro 


\section{FICHA DE ENSAYOS DE MADERA Y ACIDOS}

\section{ACIDO A02/CR/ACIDO ACRILICO}
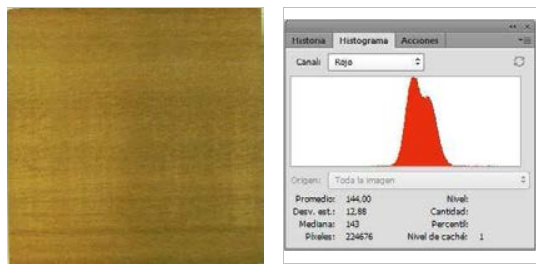

SIN TRATAR (ST): Grafica R (ST)

Valor R(ST):

144,00
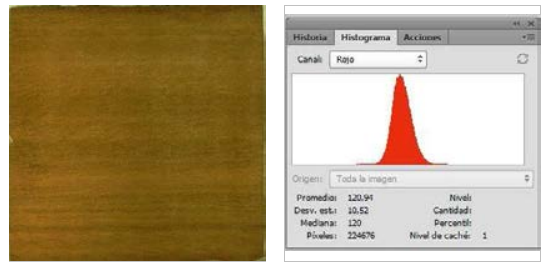

TRATADA (TT): Grafica $R(T T)$

Valor R(TT):

120,94

DIFERENCIA (DF) Grafica R (DF):

Valor DF-R:

23,06

GRAFICA:

\section{LEYENDA}

ST MADERA SIN TRATAR

Grafica R Histograma color Rojo

Grafica G Histograma color Verde

Grafica B Histograma color Azul

Grafica L Histograma Luminosidad

Grafica C Histograma RGB

\section{TT MADERA TRATADA}

Valor R Número pixeles color Rojo

Valor $G$ Número pixeles color Verde

Valor B Número pixeles color Azul

Valor $L$ Número pixeles Luminosidad

Valor C Número pixeles RG

DF DIFERENCIA DE VALORES R;G; $\mathrm{DF}=$ Valor $\mathrm{ST}(\mathrm{R} ; \mathrm{G} ; \mathrm{B})$ - Valor $\mathrm{TT}(\mathrm{R} ; \mathrm{G} ; \mathrm{B}$

\section{MADERA M22/MK/MAKORÉ}
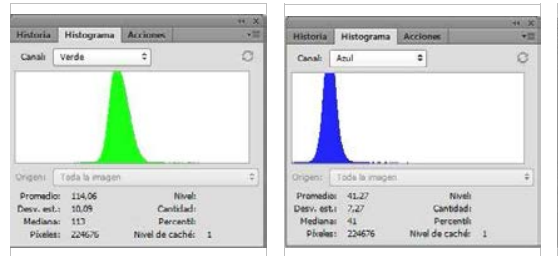

Grafica B (ST)

Valor $\mathrm{B}(\mathrm{ST})$ :

41,27
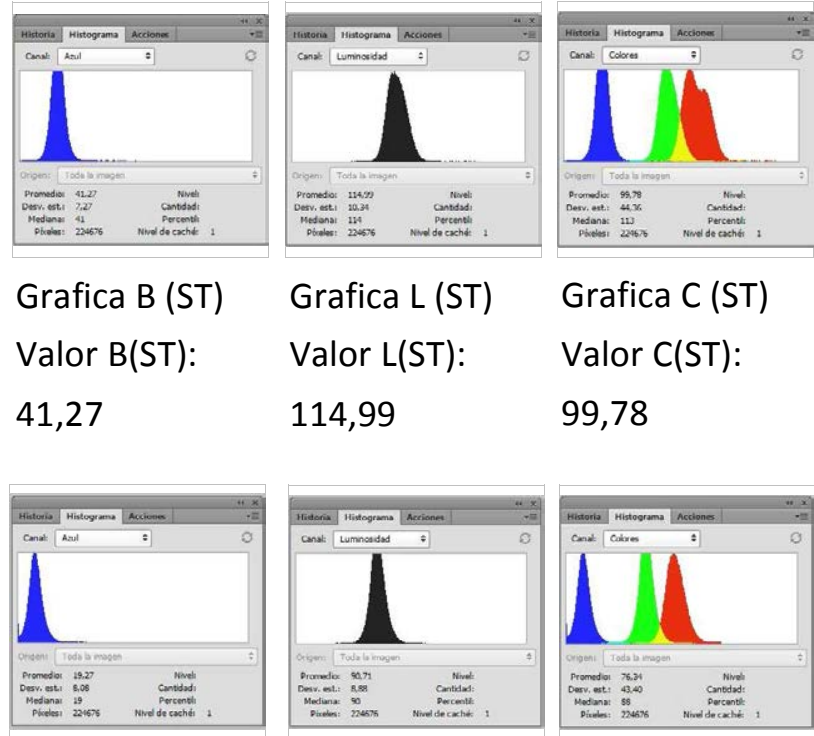

Grafica G (ST)

Grafica L (ST)

Grafica C (ST)

Valor G(ST):

114,06

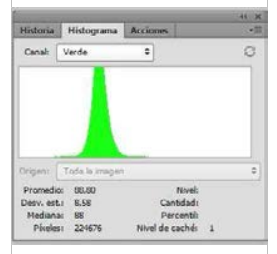

Grafica G (TT)

Grafica B (TT)

Valor L(ST):

Valor C(ST):

114,99

99,78
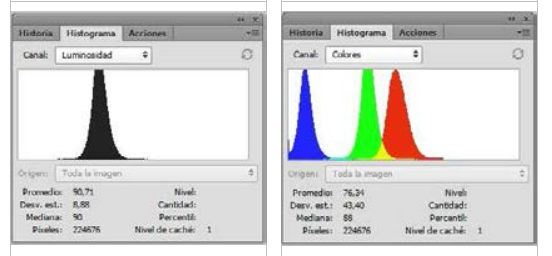

Grafica L (TT)

Grafica C (TT)

Valor $\mathrm{G}(\mathrm{TT})$ :

Valor $\mathrm{B}(\mathrm{TT})$ :

Valor L(TT):

Valor C(TT):

88,80

19,27

90,71

76,34

Grafica G (DF): Grafica B (DF): Grafica L (DF): Grafica C (DF): Valor DF-G: $\quad$ Valor DF-B: Valor DF-L: Valor DF-C:

$25,26 \quad 22,00 \quad 23,28 \quad 23$

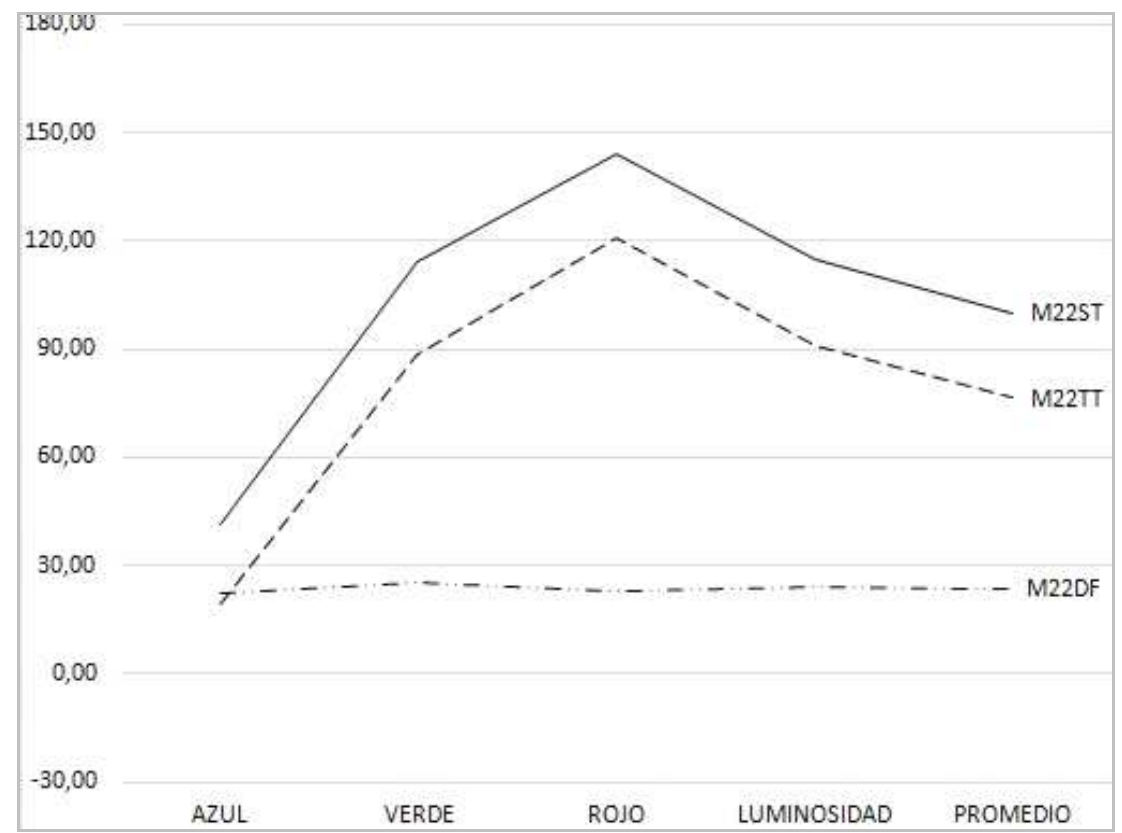

Universidad Politécnica de Madrid - Escuela Técnica Superior de Arquitectura - Departamento de Construcción y Tecnología Arquitectónica Directores: Dr. Alfonso García Santos y Dr. Antonio Rodríguez Rodríguez. Doctorando: D. Francisco Lora Toro 


\section{FICHA DE ENSAYOS DE MADERA y ACIDOS}

\section{ACIDO A02/CR/ACIDO ACRILICO}
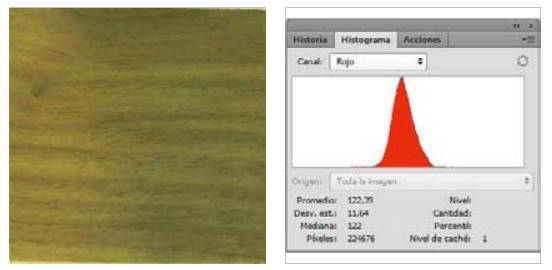

SIN TRATAR (ST): Grafica R (ST)

Valor R(ST):

122,39

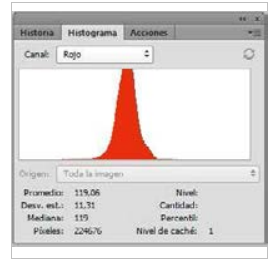

TRATADA (TT): Grafica $R(T T)$

Valor R(TT):

119,06

DIFERENCIA (DF) Grafica R (DF): Valor DF-R:

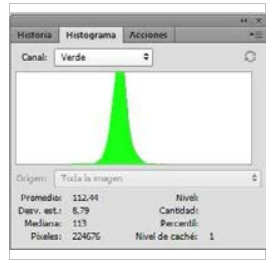

Grafica G (ST)

Valor G(ST):

112,44

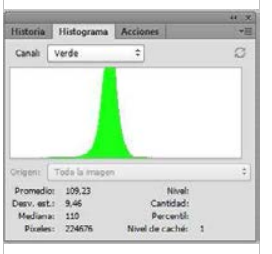

Grafica G (TT)

Valor $\mathrm{G}(\mathrm{TT})$ :

109,23
MADERA M23/NGA/NOGAL NEGRO AMERICANO

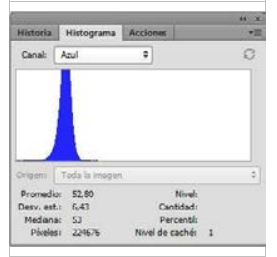

Grafica B (ST)

Valor B(ST):

52,80

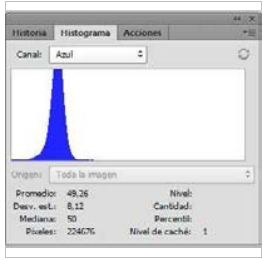

Grafica B (TT)

Valor $\mathrm{B}(\mathrm{TT})$ :

49,26

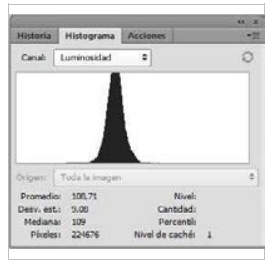

Grafica L (ST)

Valor L(ST):

108,71

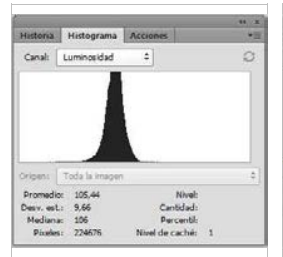

Grafica L (TT)

Valor L(TT):

105,44

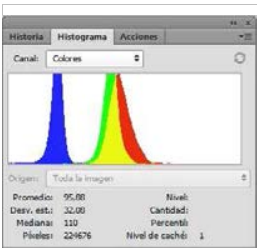

Grafica C (ST)

Valor C(ST):

95,88

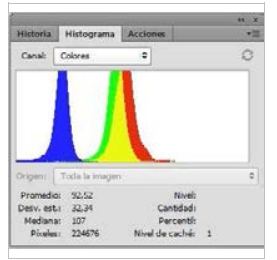

Grafica C (TT)

Valor C(TT):

92,52
Grafica G (DF): Grafica B (DF):

Valor DF-G:

3,21

Valor DF-B:

3,54

Grafica L (DF):

Grafica C (DF):

Valor DF-L:

Valor DF-C:

3,33

3,27

3,36

GRAFICA:

\section{LEYENDA}

ST MADERA SIN TRATAR

Grafica R Histograma color Rojo

Grafica G Histograma color Verde

Grafica B Histograma color Azul

Grafica L Histograma Luminosidad

Grafica C Histograma RGB

\section{TT MADERA TRATADA}

Valor R Número pixeles color Rojo

Valor G Número pixeles color Verde Valor B Número pixeles color Azul

Valor $\mathrm{L}$ Número pixeles Luminosidad Valor C Número pixeles RG

DF DIFERENCIA DE VALORES R;G; $\mathrm{DF}=$ Valor $\mathrm{ST}(\mathrm{R} ; \mathrm{G} ; \mathrm{B})$ - Valor $\mathrm{TT}(\mathrm{R} ; \mathrm{G} ; \mathrm{B}$

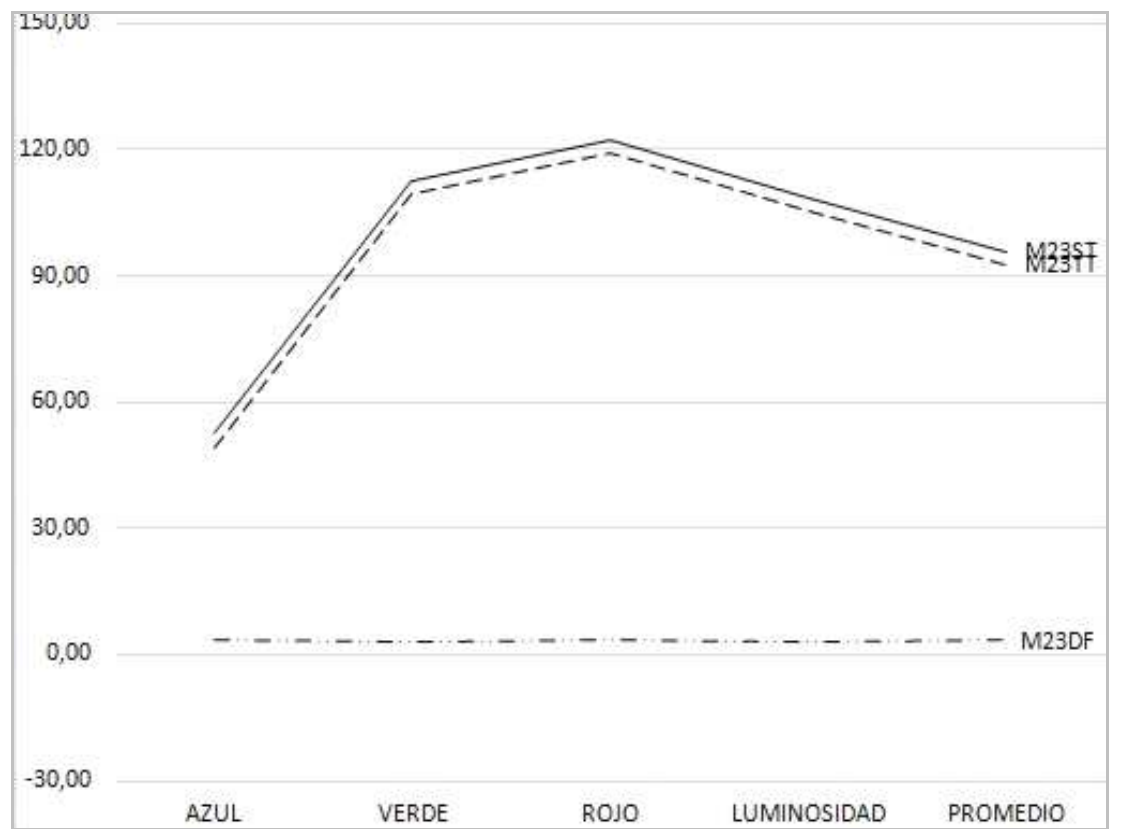

Universidad Politécnica de Madrid - Escuela Técnica Superior de Arquitectura - Departamento de Construcción y Tecnología Arquitectónica Directores: Dr. Alfonso García Santos y Dr. Antonio Rodríguez Rodríguez. Doctorando: D. Francisco Lora Toro 


\section{FICHA DE ENSAYOS DE MADERA Y ACIDOS}

\section{ACIDO A02/CR/ACIDO ACRILICO}
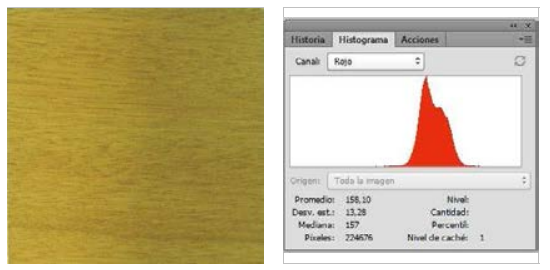

SIN TRATAR (ST): Grafica R (ST)

Valor R(ST):

158,10

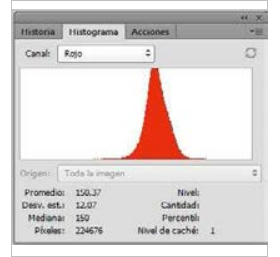

TRATADA (TT): Grafica R (TT)

Valor R(TT):

150,37

DIFERENCIA (DF) Grafica R (DF):

Valor DF-R:

7,73

GRAFICA:

\section{LEYENDA}

ST MADERA SIN TRATAR

Grafica R Histograma color Rojo

Grafica G Histograma color Verde

Grafica B Histograma color Azul

Grafica L Histograma Luminosidad

Grafica C Histograma RGB

\section{TT MADERA TRATADA}

Valor R Número pixeles color Rojo

Valor $\mathrm{G}$ Número pixeles color Verde

Valor B Número pixeles color Azul

Valor $\mathrm{L}$ Número pixeles Luminosidad

Valor C Número pixeles RG

DF DIFERENCIA DE VALORES R;G; $\mathrm{DF}=$ Valor $\mathrm{ST}(\mathrm{R} ; \mathrm{G} ; \mathrm{B})$ - Valor $\mathrm{TT}(\mathrm{R} ; \mathrm{G} ; \mathrm{B}$

\section{MADERA M24/OK/OKUMÉ}

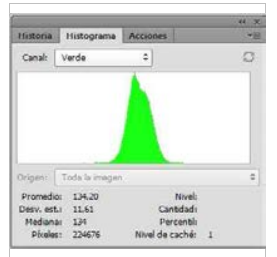

Grafica G (ST)

Valor G(ST):

134,20

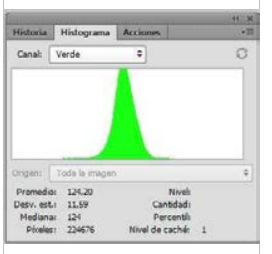

Grafica G (TT)

Valor G(TT):

124,20
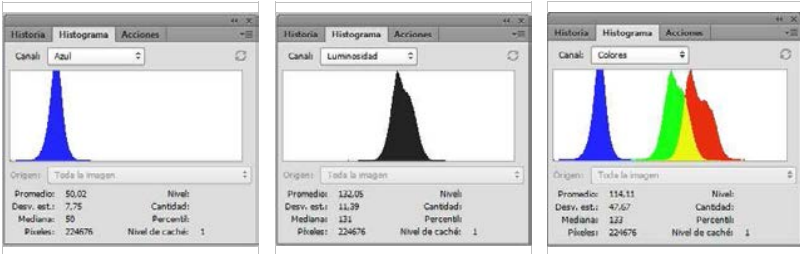

Grafica B (ST)

Grafica L (ST)

Grafica C (ST)

Valor $\mathrm{B}(\mathrm{ST})$ :

Valor L(ST):

Valor C(ST):

50,02

132,05

114,11
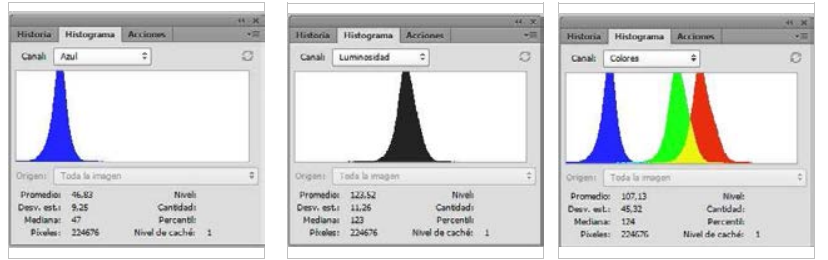

Grafica B (TT)

Grafica L (TT)

Grafica C (TT)

Valor $\mathrm{B}(\mathrm{TT})$ :

Valor L(TT):

Valor C(TT):

46,83

123,52

107,13

Grafica G (DF): Grafica B (DF): Grafica L (DF): Grafica C (DF): Valor DF-G: Valor DF-B: Valor DF-L: Valor DF-C: $\begin{array}{llll}10,00 & 3,19 & 8,53 & 6,98\end{array}$

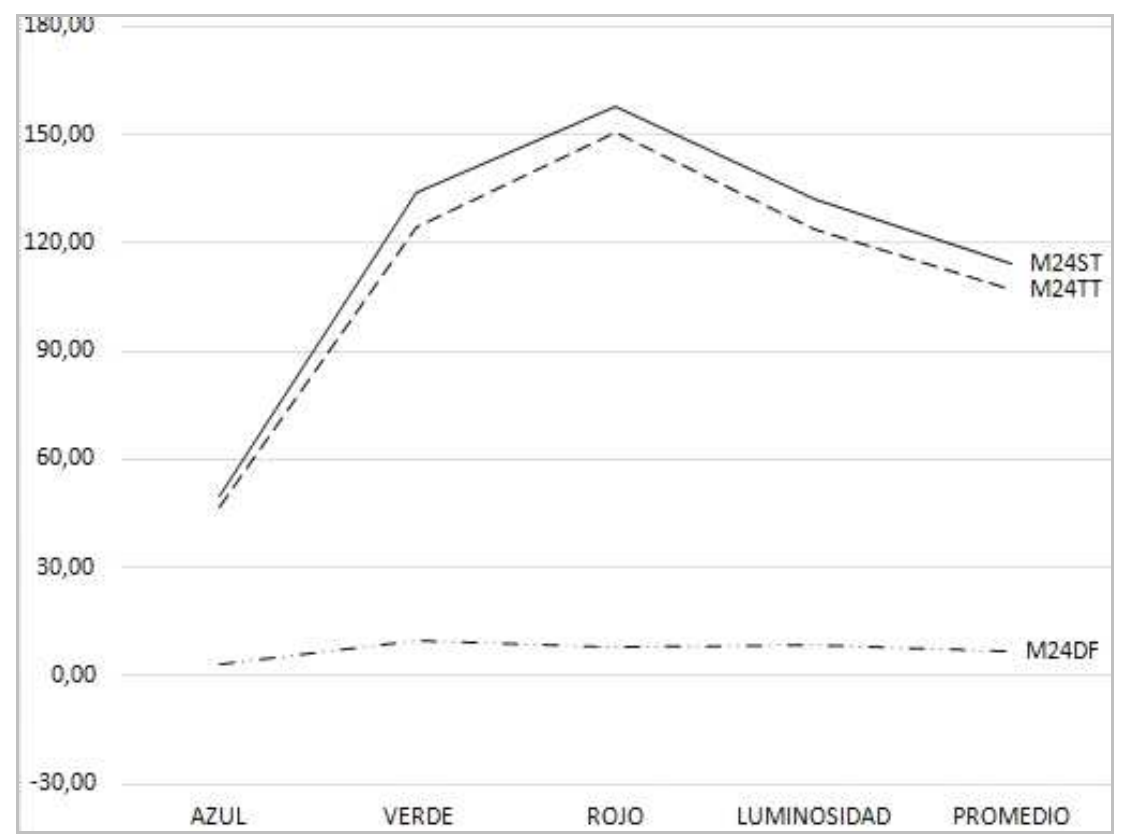

Universidad Politécnica de Madrid - Escuela Técnica Superior de Arquitectura - Departamento de Construcción y Tecnología Arquitectónica Directores: Dr. Alfonso García Santos y Dr. Antonio Rodríguez Rodríguez. Doctorando: D. Francisco Lora Toro 


\section{FICHA DE ENSAYOS DE MADERA Y ACIDOS}

\section{ACIDO A02/CR/ACIDO ACRILICO}
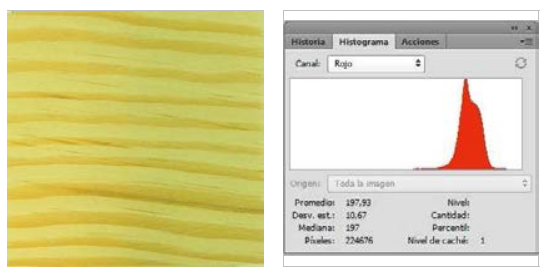

SIN TRATAR (ST): Grafica R (ST)

Valor R(ST):

197,93

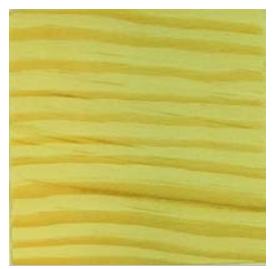

TRATADA (TT):

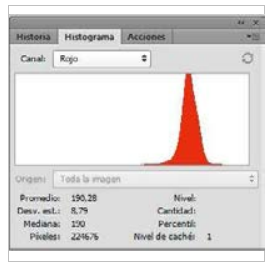

Grafica R (TT) Valor $\mathrm{R}(\mathrm{TT})$ : 190,28

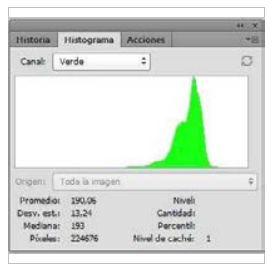

Grafica G (ST)

Valor G(ST):

190,06

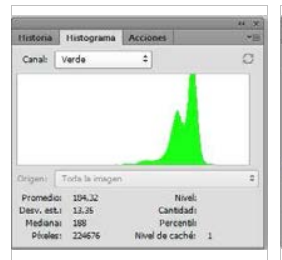

Grafica G (TT)

Valor $\mathrm{G}(\mathrm{TT})$ :

184,32
MADERA M25/PX/PINO AMARILLO DEL SUR

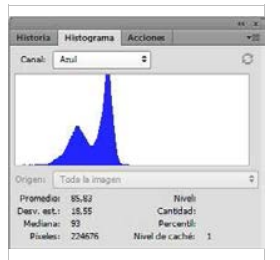

Grafica B (ST)

Valor B(ST):

85,83

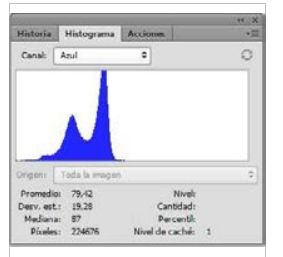

Grafica B (TT)

Valor $\mathrm{B}(\mathrm{TT})$ :

79,42

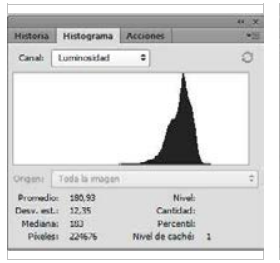

Grafica L (ST)

Valor L(ST):

180,93

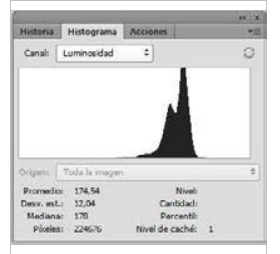

Grafica L (TT)

Valor L(TT):

174,54

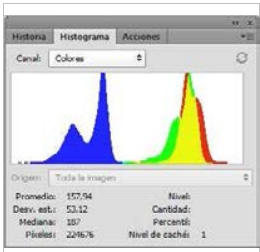

Grafica C (ST)

Valor C(ST):

157,94

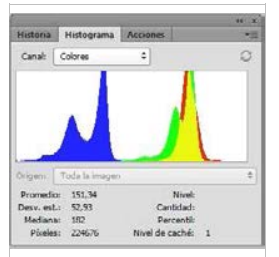

Grafica C (TT)

Valor $\mathrm{C}(\mathrm{TT})$ :

151,34

DIFERENCIA (DF) Grafica R (DF):

Grafica G (DF): Grafica B (DF):

Grafica L (DF):

Grafica C (DF): Valor DF-R:

Valor DF-G:

Valor DF-B:

Valor DF-L:

Valor DF-C: 7,65

5,74

6,41

6,39

6,60

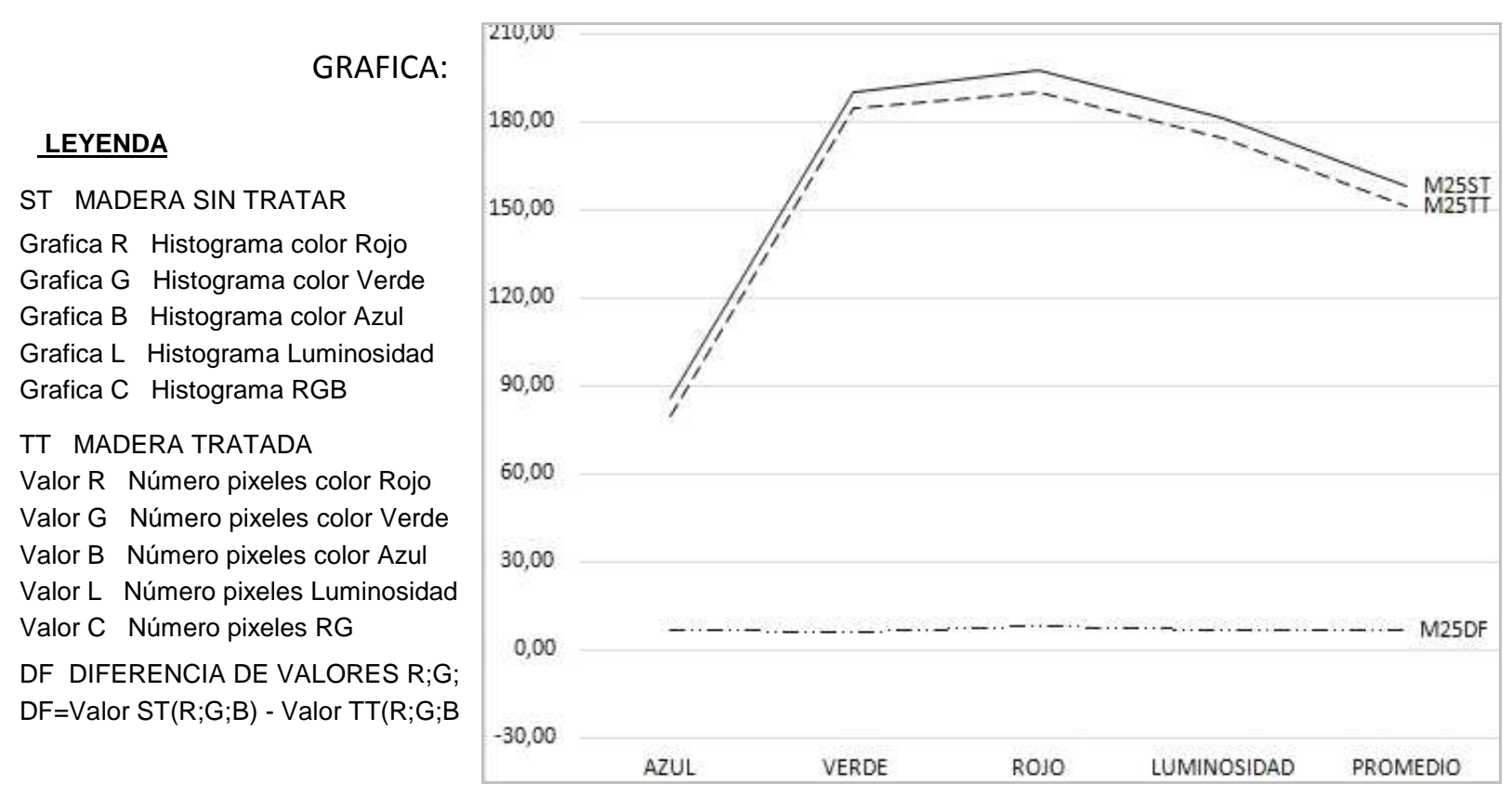

Universidad Politécnica de Madrid - Escuela Técnica Superior de Arquitectura - Departamento de Construcción y Tecnología Arquitectónica Directores: Dr. Alfonso García Santos y Dr. Antonio Rodríguez Rodríguez. Doctorando: D. Francisco Lora Toro 


\section{FICHA DE ENSAYOS DE MADERA Y ACIDOS}

\section{ACIDO A02/CR/ACIDO ACRILICO}
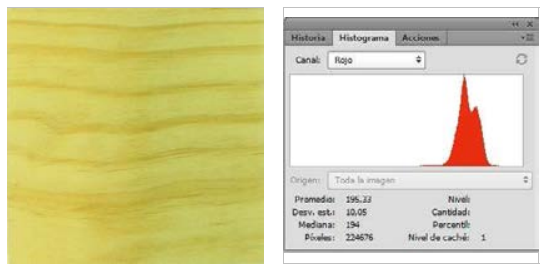

SIN TRATAR (ST): Grafica R (ST)

Valor R(ST):

195,33

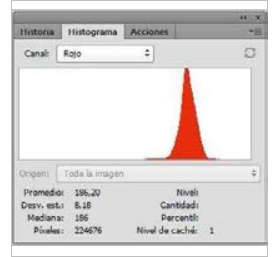

TRATADA (TT): Grafica R (TT)

Valor R(TT):

186,20

DIFERENCIA (DF) Grafica R (DF): Valor DF-R:

9,13

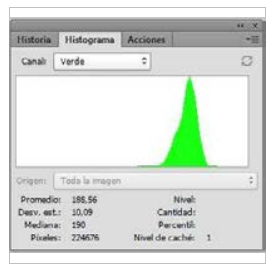

Grafica G (ST)

Valor G(ST):

186,56

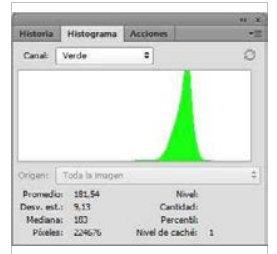

Grafica G (TT)

Valor G(TT):

181,54
MADERA M26/PR/PINO RADIATA

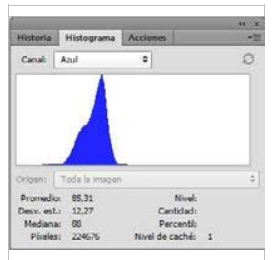

Grafica B (ST)

Valor B(ST):

85,31

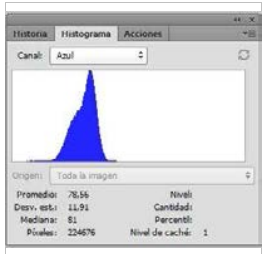

Grafica B (TT)

Valor $\mathrm{B}(\mathrm{TT})$ :

78,56

Grafica G (DF): Grafica B (DF):

Grafica L (DF):

Grafica C (DF):

Valor DF-G:

Valor DF-B:

Valor DF-L:

Valor DF-C:

5,02

6,75

7,64

7,63

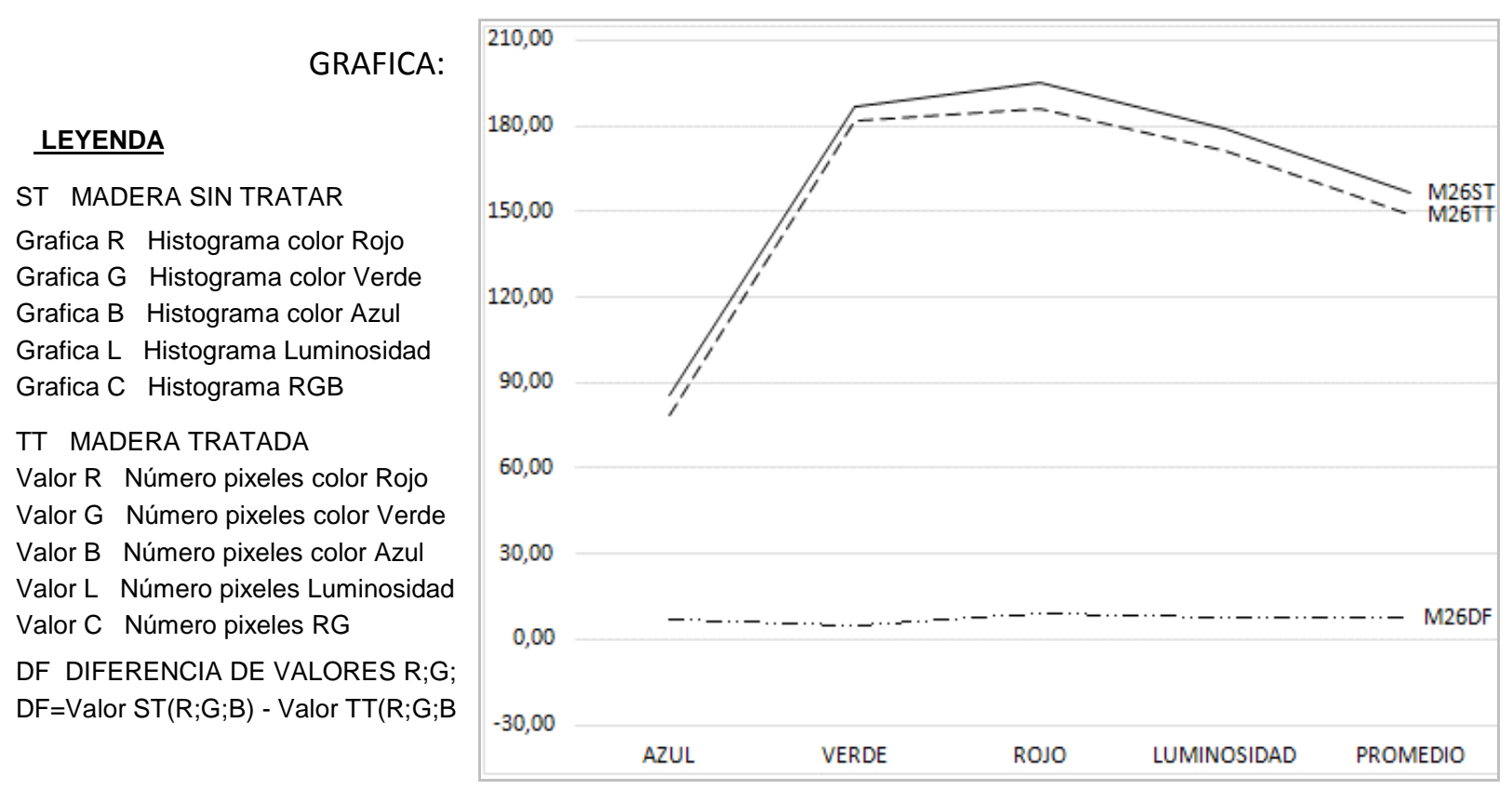

Universidad Politécnica de Madrid - Escuela Técnica Superior de Arquitectura - Departamento de Construcción y Tecnología Arquitectónica Directores: Dr. Alfonso García Santos y Dr. Antonio Rodríguez Rodríguez. Doctorando: D. Francisco Lora Toro 


\section{FICHA DE ENSAYOS DE MADERA Y ACIDOS}

\section{ACIDO A02/CR/ACIDO ACRILICO}

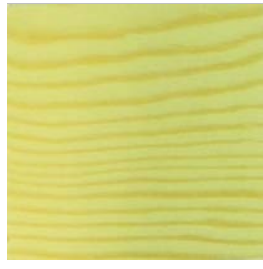

SIN TRATAR (ST): Grafica R (ST)

Valor R(ST):

200,16

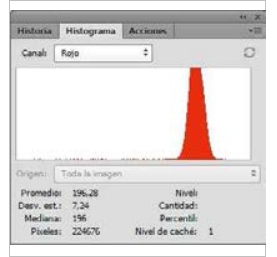

TRATADA (TT): Grafica $R(T T)$

Valor R(TT):

196,28

DIFERENCIA (DF) Grafica R (DF): Valor DF-R:

3,88

GRAFICA :

\section{LEYENDA}

ST MADERA SIN TRATAR

Grafica R Histograma color Rojo

Grafica G Histograma color Verde

Grafica B Histograma color Azul

Grafica L Histograma Luminosidad

Grafica C Histograma RGB

\section{TT MADERA TRATADA}

Valor R Número pixeles color Rojo

Valor $G$ Número pixeles color Verde

Valor B Número pixeles color Azul

Valor $L$ Número pixeles Luminosidad

Valor C Número pixeles RG

DF DIFERENCIA DE VALORES R;G; $\mathrm{DF}=$ Valor $\mathrm{ST}(\mathrm{R} ; \mathrm{G} ; \mathrm{B})$ - Valor $\mathrm{TT}(\mathrm{R} ; \mathrm{G} ; \mathrm{B}$

\section{MADERA M27/PS/PINO SILVESTRE}
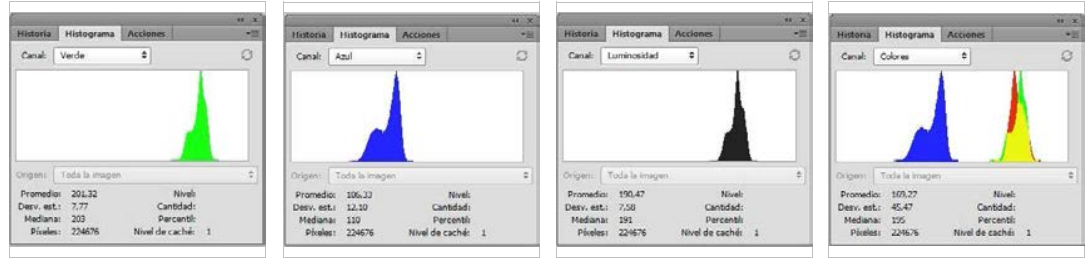

Grafica G (ST)

Grafica B (ST)

Grafica L (ST)

Grafica C (ST)

Valor $\mathrm{G}(\mathrm{ST})$ :

Valor B(ST):

Valor L(ST):

Valor C(ST):

201,32

106,33

190,47

169,27
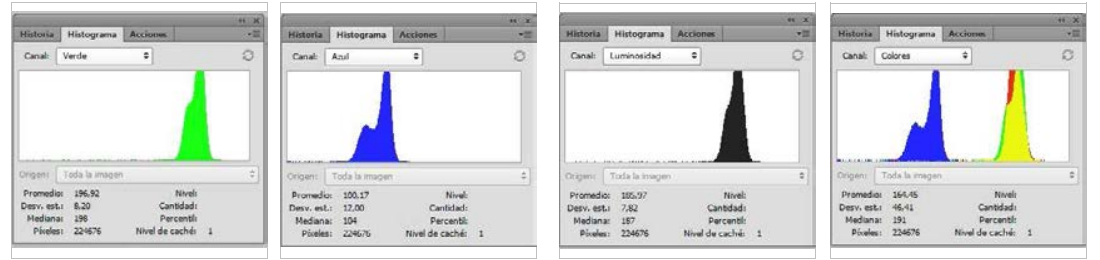

Grafica G (TT)

Grafica B (TT)

Grafica L (TT)

Grafica C (TT)

Valor G(TT):

Valor $\mathrm{B}(\mathrm{TT})$ :

Valor L(TT):

Valor C(TT):

100,17

185,97

164,45

\section{Grafica G (DF): Grafica B (DF): Grafica L (DF): Grafica C (DF):} Valor DF-G: Valor DF-B: Valor DF-L: Valor DF-C:

$\begin{array}{llll}4,40 & 6,16 & 4,50 & 4,82\end{array}$

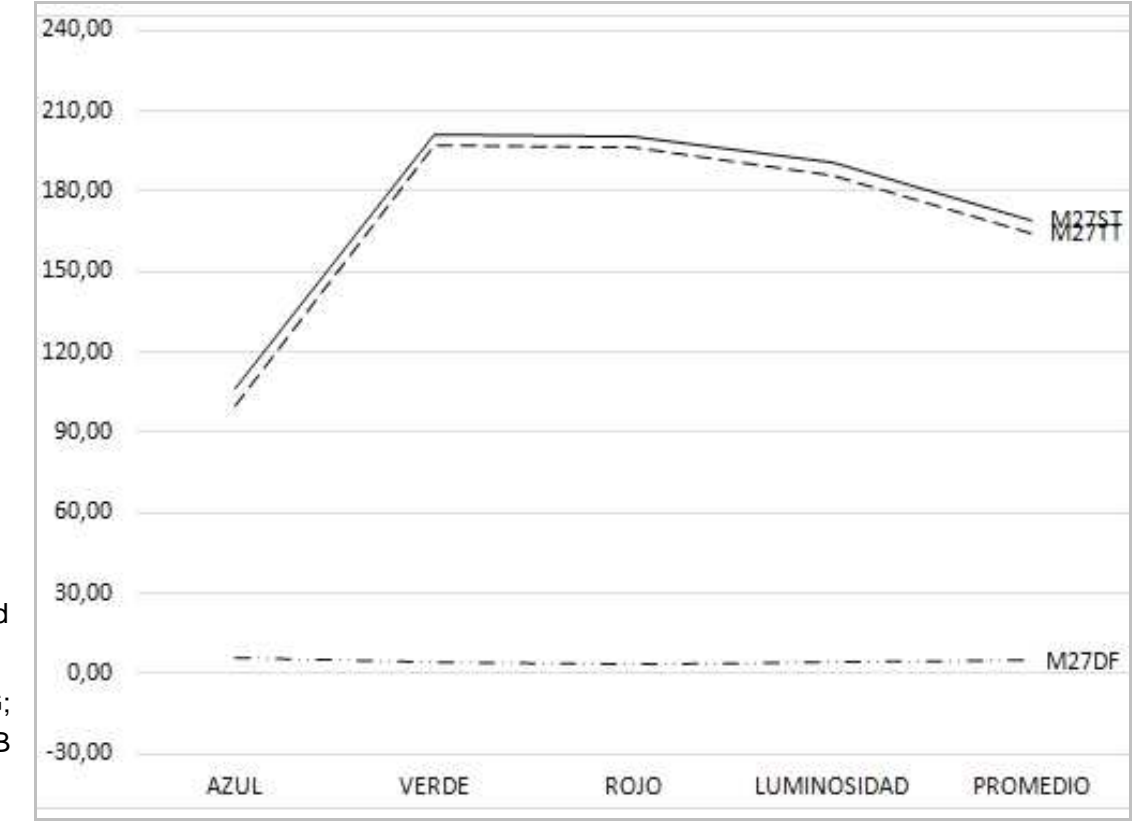

Universidad Politécnica de Madrid - Escuela Técnica Superior de Arquitectura - Departamento de Construcción y Tecnología Arquitectónica Directores: Dr. Alfonso García Santos y Dr. Antonio Rodríguez Rodríguez. Doctorando: D. Francisco Lora Toro 


\section{FICHA DE ENSAYOS DE MADERA y ACIDOS}

\section{ACIDO A02/CR/ACIDO ACRILICO}
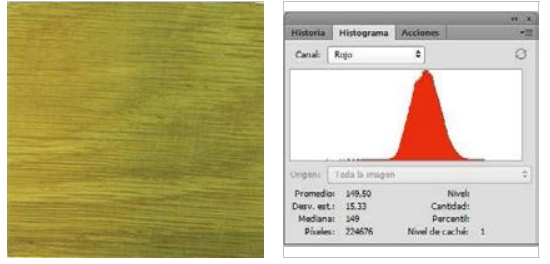

SIN TRATAR (ST): Grafica R (ST)

Valor R(ST):

149,50

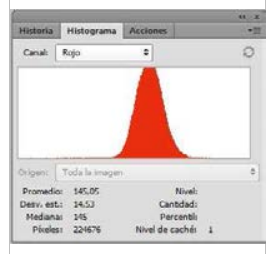

TRATADA (TT): Grafica $R(T T)$

Valor $\mathrm{R}(\mathrm{TT})$ :

145,05

DIFERENCIA (DF) Grafica R (DF): Valor DF-R:

\section{4,45}

GRAFICA

\section{LEYENDA}

ST MADERA SIN TRATAR

Grafica R Histograma color Rojo

Grafica G Histograma color Verde

Grafica B Histograma color Azul

Grafica L Histograma Luminosidad

Grafica C Histograma RGB

\section{TT MADERA TRATADA}

Valor R Número pixeles color Rojo

Valor G Número pixeles color Verde

Valor B Número pixeles color Azul

Valor $L$ Número pixeles Luminosidad

Valor C Número pixeles RG

DF DIFERENCIA DE VALORES R;G; $\mathrm{DF}=$ Valor $\mathrm{ST}(\mathrm{R} ; \mathrm{G} ; \mathrm{B})$ - Valor $\mathrm{TT}(\mathrm{R} ; \mathrm{G} ; \mathrm{B}$

MADERA M28/RBA/ROBLE BLANCO AMERICANO

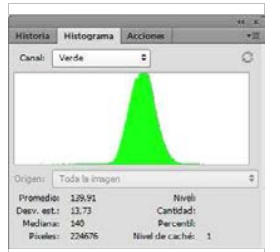

Grafica G (ST)

Valor G(ST):

139,91

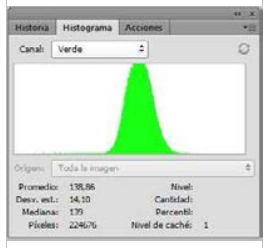

Grafica G (TT)

Valor G(TT):

138,86

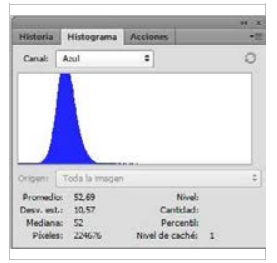

Grafica B (ST)

Valor B(ST):

52,69

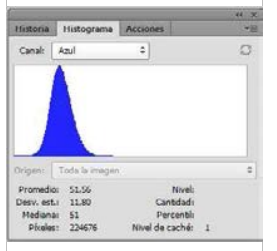

Grafica B (TT)

Valor $\mathrm{B}(\mathrm{TT})$ :

51,56

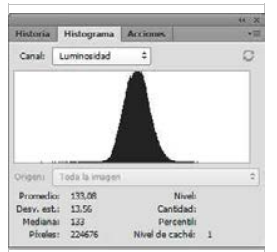

Grafica L (ST)

Valor L(ST):

133,08

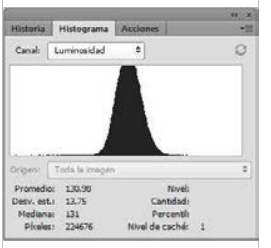

Grafica L (TT)

Valor L(TT):

130,98

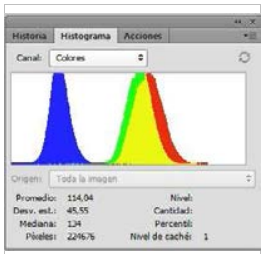

Grafica C (ST)

Valor C(ST):

114,04

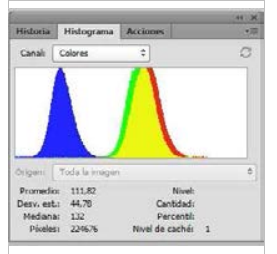

Grafica C (TT)

Valor C(TT):

111,82

\section{Grafica G (DF): Grafica B (DF): Grafica L (DF): Grafica C (DF):}

Valor DF-G: Valor DF-B:

Valor DF-L:

Valor DF-C:

$1,05 \quad 2,13 \quad 2,22$

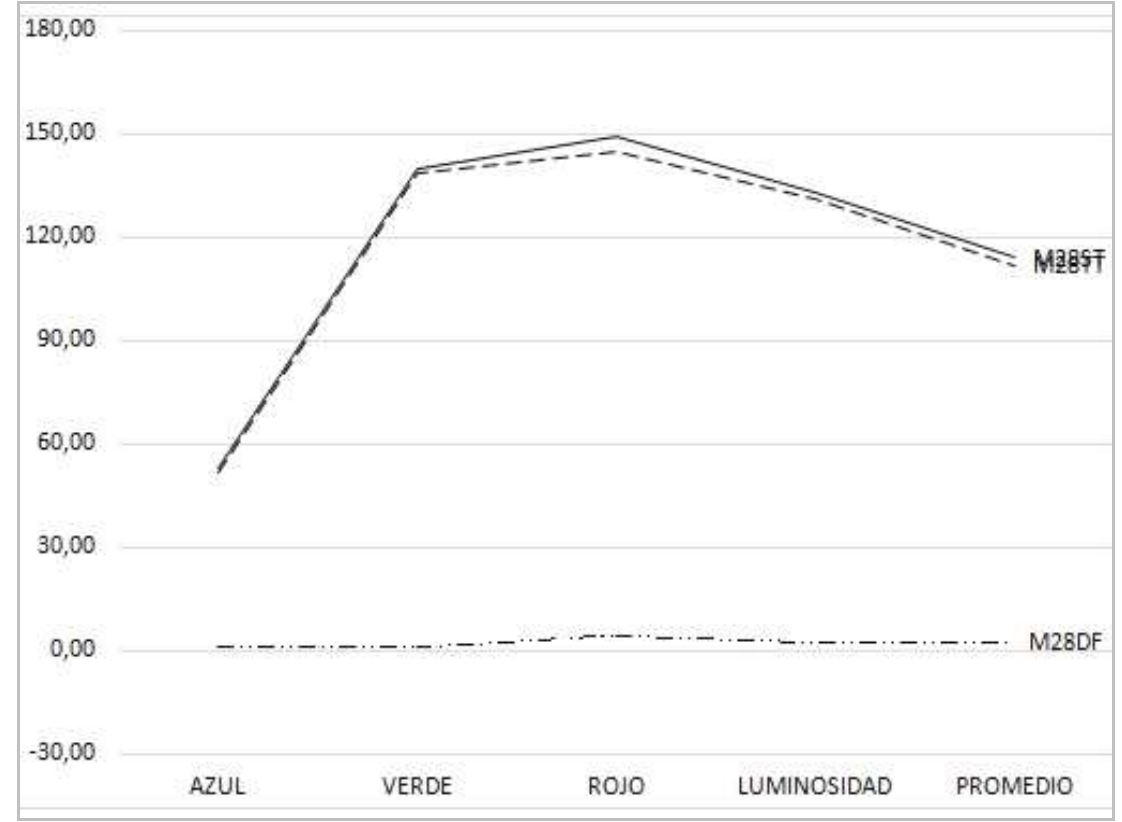

Universidad Politécnica de Madrid - Escuela Técnica Superior de Arquitectura - Departamento de Construcción y Tecnología Arquitectónica Directores: Dr. Alfonso García Santos y Dr. Antonio Rodríguez Rodríguez. Doctorando: D. Francisco Lora Toro 


\section{FICHA DE ENSAYOS DE MADERA y ACIDOS}

\section{ACIDO A02/CR/ACIDO ACRILICO}
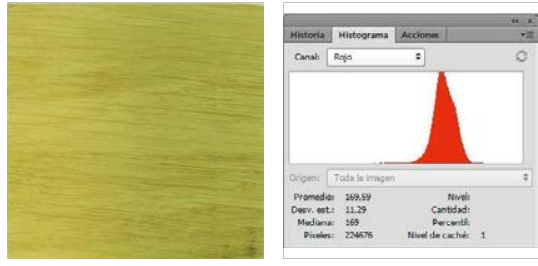

SIN TRATAR (ST): Grafica R (ST)

Valor R(ST)

169,59

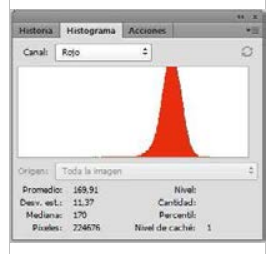

TRATADA (TT): Grafica $R(T T)$

Valor $\mathrm{R}(\mathrm{TT})$ :

169,91

DIFERENCIA (DF) Grafica R (DF): Valor DF-R: $-0,32$

GRAFICA

\section{LEYENDA}

ST MADERA SIN TRATAR

Grafica R Histograma color Rojo

Grafica G Histograma color Verde

Grafica B Histograma color Azul

Grafica L Histograma Luminosidad

Grafica C Histograma RGB

TT MADERA TRATADA

Valor R Número pixeles color Rojo

Valor $\mathrm{G}$ Número pixeles color Verde

Valor B Número pixeles color Azul

Valor L Número pixeles Luminosidad

Valor $C$ Número pixeles $R G$

DF DIFERENCIA DE VALORES R;G; $\mathrm{DF}=$ Valor $\mathrm{ST}(\mathrm{R} ; \mathrm{G} ; \mathrm{B})$ - Valor $\mathrm{TT}(\mathrm{R} ; \mathrm{G} ; \mathrm{B}$

MADERA M29/RBE/ROBLE BLANCO EUROPEO

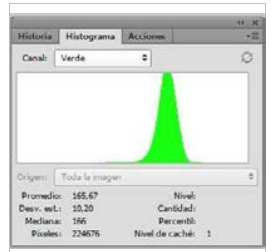

Grafica G (ST)

Valor G(ST):

165,67

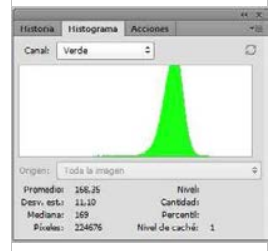

Grafica G (TT)

Valor G(TT):

168,35

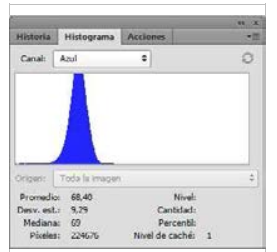

Grafica B (ST)

Valor $\mathrm{B}(\mathrm{ST})$ :

68,40

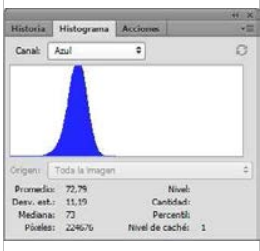

Grafica B (TT)

Valor $\mathrm{B}(\mathrm{TT})$ :

72,79

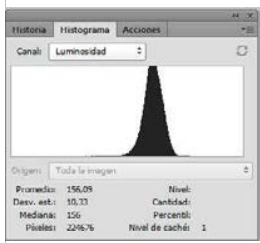

Grafica L (ST)

Valor L(ST):

156,09

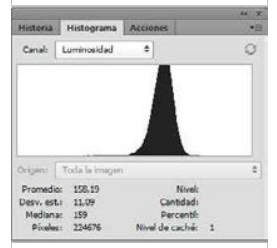

Grafica L (TT)

Valor L(TT):

158,19

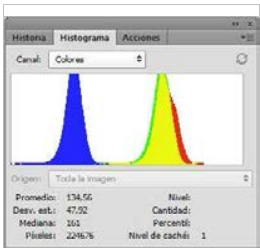

Grafica C (ST)

Valor C(ST):

134,56

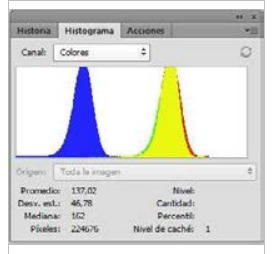

Grafica C (TT)

Valor $\mathrm{C}(\mathrm{TT})$ :

137,02

Grafica G (DF): Grafica B (DF): Grafica L (DF): Grafica C (DF): Valor DF-G: Valor DF-B: Valor DF-L: Valor DF-C:

$\begin{array}{llll}-2,68 & -4,39 & -2,10 & -2,46\end{array}$

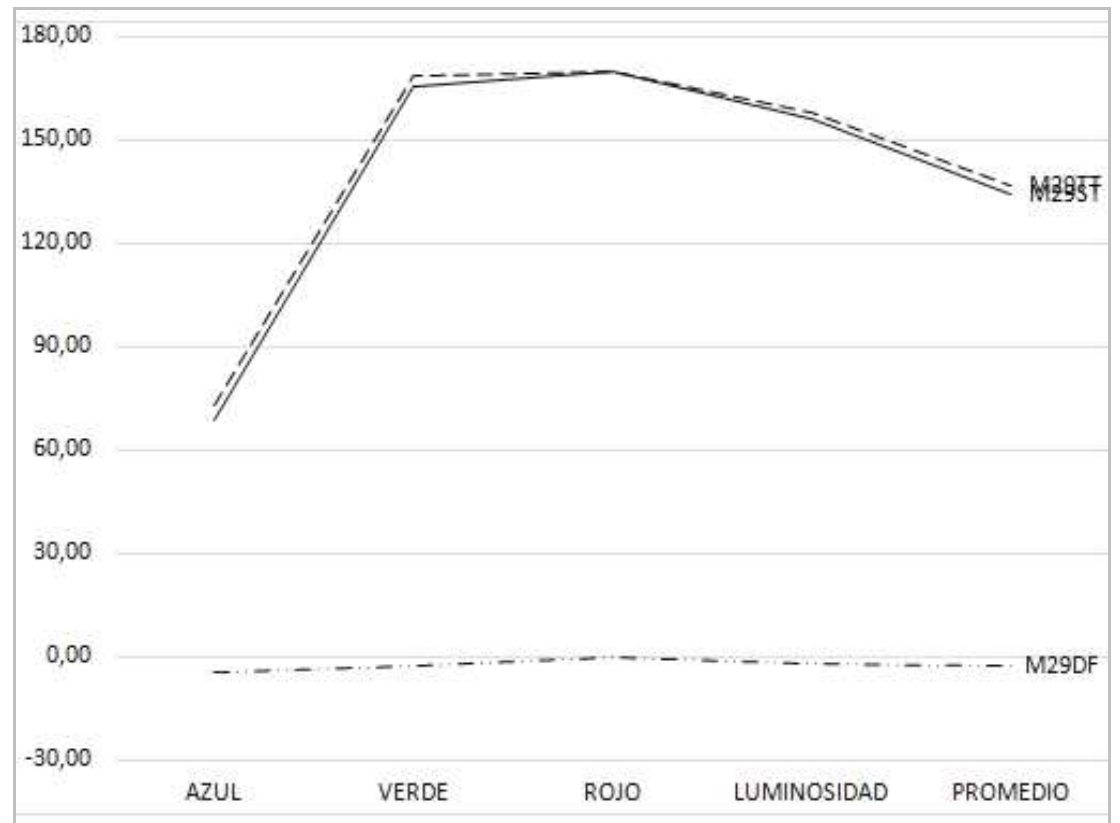

Universidad Politécnica de Madrid - Escuela Técnica Superior de Arquitectura - Departamento de Construcción y Tecnología Arquitectónica Directores: Dr. Alfonso García Santos y Dr. Antonio Rodríguez Rodríguez. Doctorando: D. Francisco Lora Toro 


\section{FICHA DE ENSAYOS DE MADERA Y ACIDOS}

\section{ACIDO A02/CR/ACIDO ACRILICO}
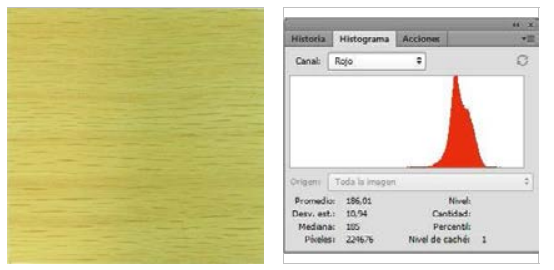

SIN TRATAR (ST): Grafica R (ST)

Valor R(ST):

186,01

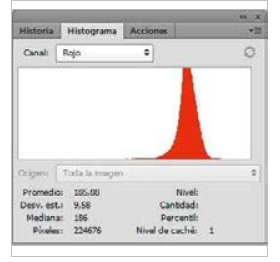

TRATADA (TT): Grafica R (TT) Valor $\mathrm{R}(\mathrm{TT})$ : 185,88

DIFERENCIA (DF) Grafica R (DF): Valor DF-R: 0,13

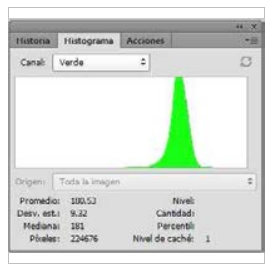

Grafica G (ST)

Valor G(ST):

180,53

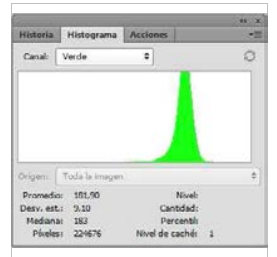

Grafica G (TT)

Valor $\mathrm{G}(\mathrm{TT})$ :

181,90
MADERA M30/RRA/ROBLE ROJO AMERICANO

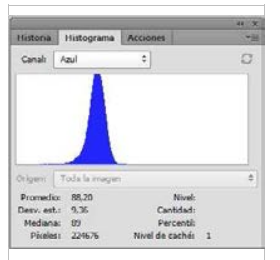

Grafica B (ST)

Valor B(ST):

88,20

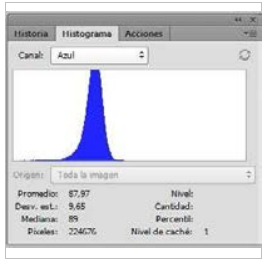

Grafica B (TT)

Valor $\mathrm{B}(\mathrm{TT})$ :

87,97

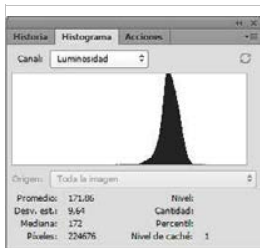

Grafica L (ST)

Valor L(ST):

171,86

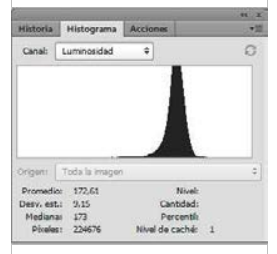

Grafica L (TT)

Valor L(TT):

172,61
Grafica C (TT)

Valor C(TT):

151,91

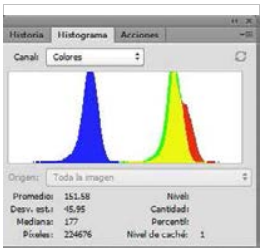

Grafica C (ST)

Valor C(ST):

151,58

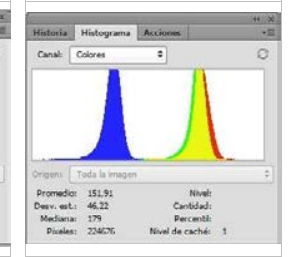

Grafica G (DF): Grafica B (DF): Grafica L (DF): Grafica C (DF): Valor DF-G: Valor DF-B: Valor DF-L: Valor DF-C:
$-1,37$
0,23
$-0,75$
$-0,33$

GRAFICA:

\section{LEYENDA}

ST MADERA SIN TRATAR

Grafica R Histograma color Rojo Grafica G Histograma color Verde Grafica B Histograma color Azul Grafica L Histograma Luminosidad Grafica C Histograma RGB

\section{TT MADERA TRATADA}

Valor $R$ Número pixeles color Rojo Valor $\mathrm{G}$ Número pixeles color Verde Valor B Número pixeles color Azul Valor L Número pixeles Luminosidad Valor C Número pixeles RG DF DIFERENCIA DE VALORES R;G; $\mathrm{DF}=$ Valor $\mathrm{ST}(\mathrm{R} ; \mathrm{G} ; \mathrm{B})$ - Valor $\mathrm{TT}(\mathrm{R} ; \mathrm{G} ; \mathrm{B}$

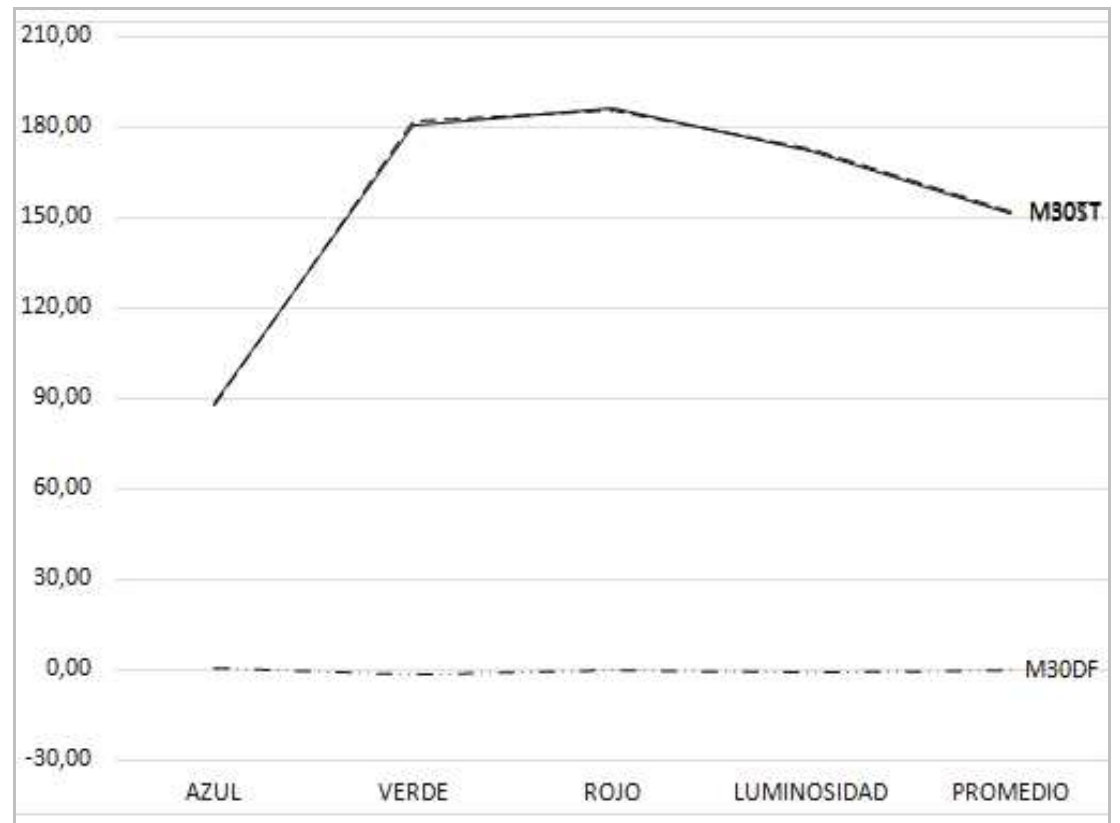

Universidad Politécnica de Madrid - Escuela Técnica Superior de Arquitectura - Departamento de Construcción y Tecnología Arquitectónica Directores: Dr. Alfonso García Santos y Dr. Antonio Rodríguez Rodríguez. Doctorando: D. Francisco Lora Toro 


\section{FICHA DE ENSAYOS DE MADERA Y ACIDOS}

\section{ACIDO A02/CR/ACIDO ACRILICO}
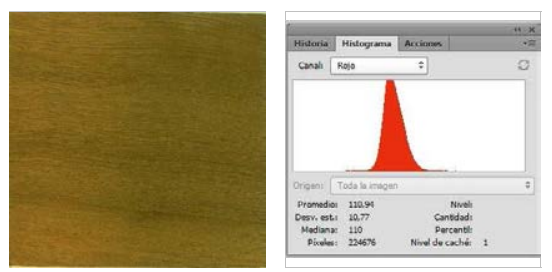

SIN TRATAR (ST): Grafica R (ST)

Valor R(ST):

110,94
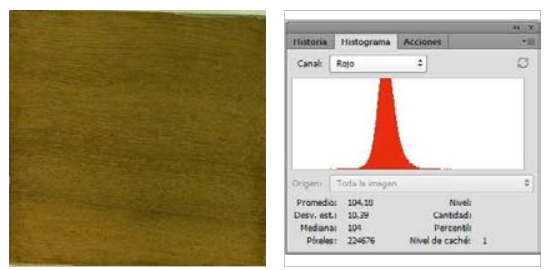

TRATADA (TT): Grafica $R(T T)$

Valor R(TT):

104,18

DIFERENCIA (DF) Grafica R (DF): Valor DF-R:

6,76

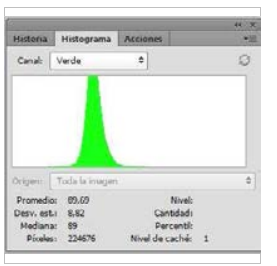

Grafica G (ST)

Valor G(ST):

89,69

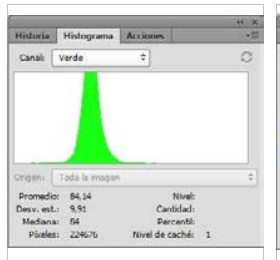

Grafica G (TT)

Valor $\mathrm{G}(\mathrm{TT})$ :

84,14
MADERA M31/SP/SAPELLI

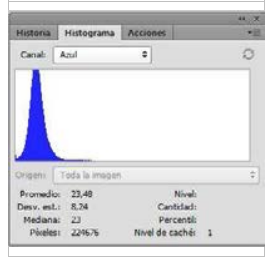

Grafica B (ST)

Valor $\mathrm{B}(\mathrm{ST})$ :

23,48

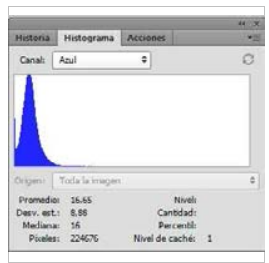

Grafica B (TT)

Valor $\mathrm{B}(\mathrm{TT})$ :

16,65

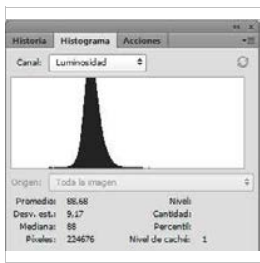

Grafica L (ST)

Valor L(ST):

88,68

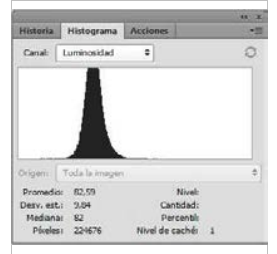

Grafica L (TT)

Valor L(TT):

82,59

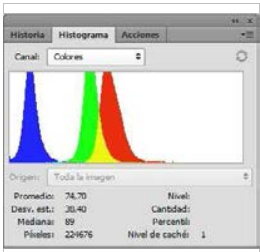

Grafica C (ST)

Valor C(ST):

74,70

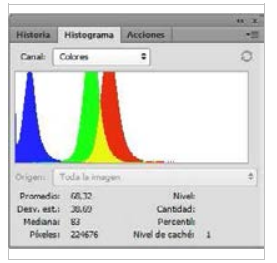

Grafica C (TT)

Valor C(TT):

68,32

Grafica G (DF): Grafica B (DF): Grafica L (DF): Grafica C (DF): Valor DF-G: Valor DF-B: Valor DF-L: Valor DF-C:

$\begin{array}{llll}5,55 & 6,83 & 6,09 & 6,38\end{array}$

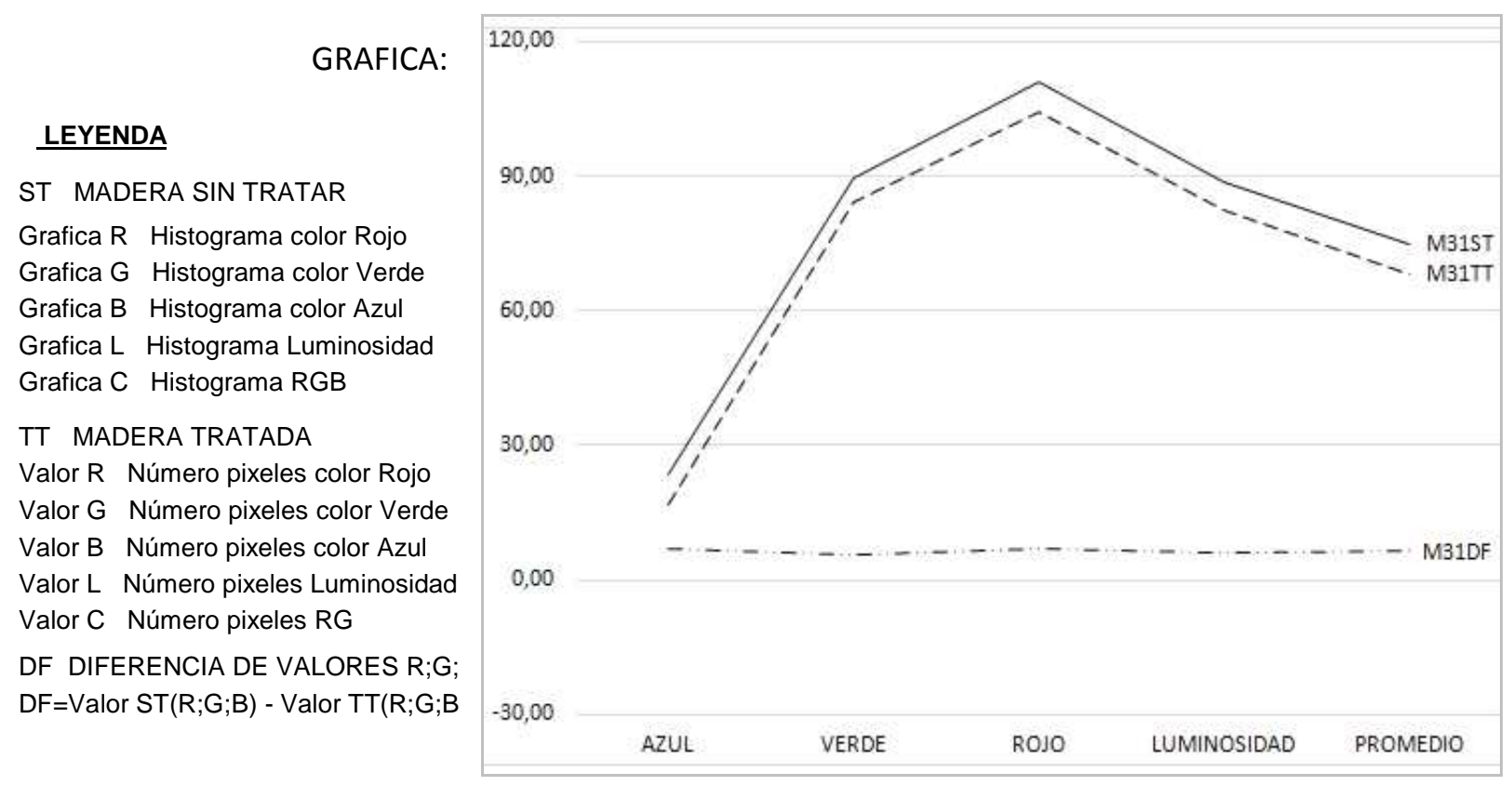

Universidad Politécnica de Madrid - Escuela Técnica Superior de Arquitectura - Departamento de Construcción y Tecnología Arquitectónica Directores: Dr. Alfonso García Santos y Dr. Antonio Rodríguez Rodríguez. Doctorando: D. Francisco Lora Toro 


\section{FICHA DE ENSAYOS DE MADERA Y ACIDOS}

\section{ACIDO A02/CR/ACIDO ACRILICO}
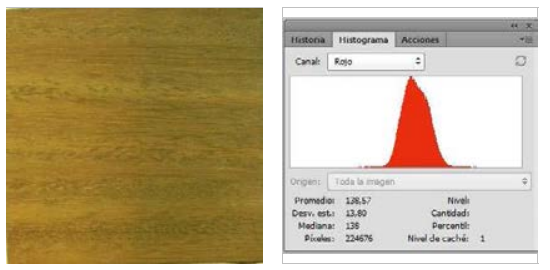

SIN TRATAR (ST): Grafica R (ST)

Valor R(ST):

138,57

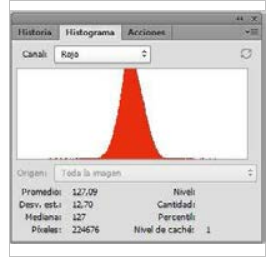

TRATADA (TT): Grafica R (TT)

Valor $\mathrm{R}(\mathrm{TT})$ :

127,09

DIFERENCIA (DF) Grafica R (DF): Valor DF-R: 11,48

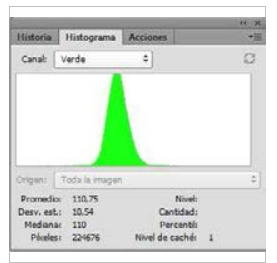

Grafica G (ST)

Valor G(ST):

110,75

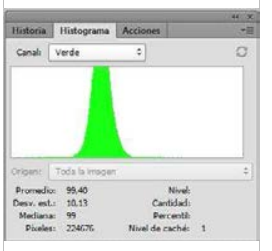

Grafica G (TT)

Valor $\mathrm{G}(\mathrm{TT})$ :

99,40
MADERA M32/TL/TALI

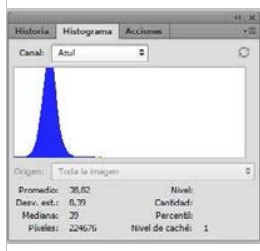

Grafica B (ST)

Valor $\mathrm{B}(\mathrm{ST})$ :

38,82

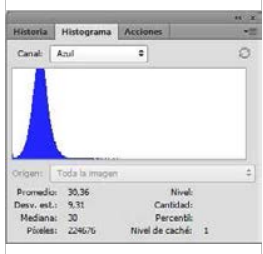

Grafica B (TT)

Valor $\mathrm{B}(\mathrm{TT})$ :

30,36

Grafica G (DF): Grafica B (DF):

Valor DF-B:

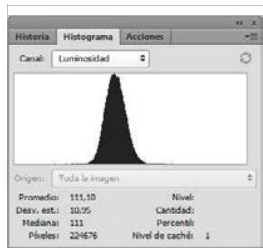

Grafica L (ST)

Valor L(ST):

111,10

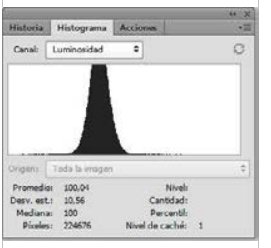

Grafica L (TT)

Valor L(TT):

100,44

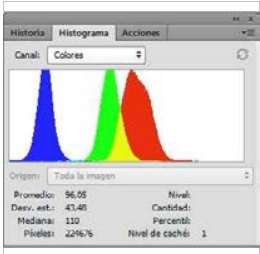

Grafica C (ST)

Valor C(ST):

96,05

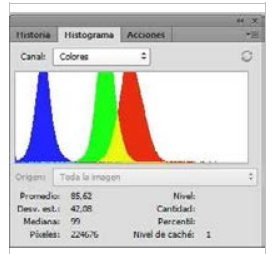

Grafica C (TT)

Valor $\mathrm{C}(\mathrm{TT})$ :

85,62

Grafica L (DF): Grafica C (DF): Valor DF-L: Valor DF-C:
8,46
11,35
10,66
10,43

GRAFICA :

\section{LEYENDA}

ST MADERA SIN TRATAR

Grafica R Histograma color Rojo

Grafica G Histograma color Verde

Grafica B Histograma color Azul

Grafica L Histograma Luminosidad

Grafica C Histograma RGB

TT MADERA TRATADA

Valor R Número pixeles color Rojo

Valor G Número pixeles color Verde

Valor B Número pixeles color Azul

Valor $L$ Número pixeles Luminosidad

Valor C Número pixeles RG

DF DIFERENCIA DE VALORES R;G; $\mathrm{DF}=$ Valor $\mathrm{ST}(\mathrm{R} ; \mathrm{G} ; \mathrm{B})$ - Valor $\mathrm{TT}(\mathrm{R} ; \mathrm{G} ; \mathrm{B}$

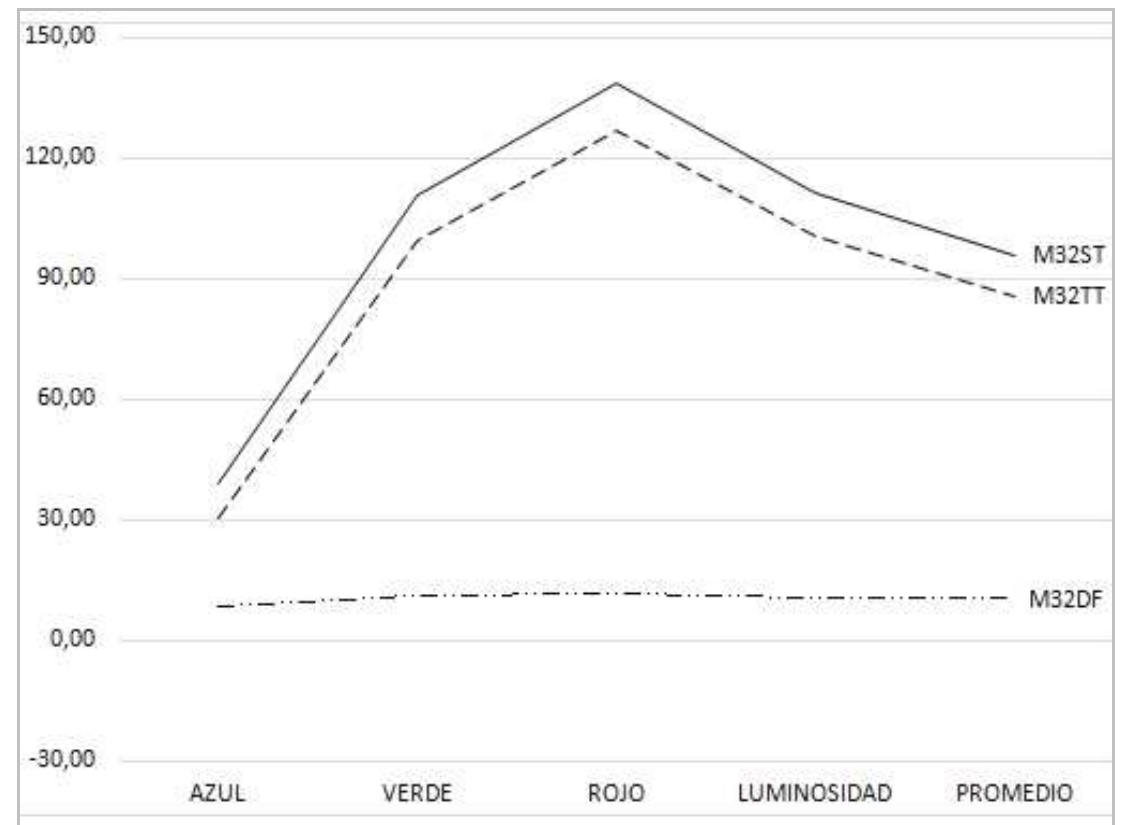

Universidad Politécnica de Madrid - Escuela Técnica Superior de Arquitectura - Departamento de Construcción y Tecnología Arquitectónica Directores: Dr. Alfonso García Santos y Dr. Antonio Rodríguez Rodríguez. Doctorando: D. Francisco Lora Toro 


\section{FICHA DE ENSAYOS DE MADERA Y ACIDOS}

\section{ACIDO A02/CR/ACIDO ACRILICO}
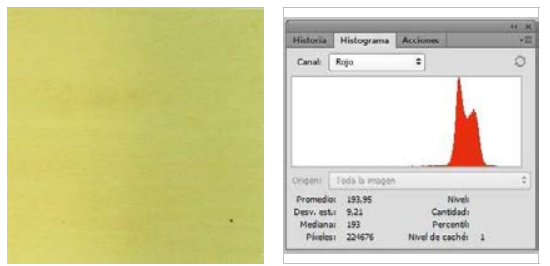

SIN TRATAR (ST): Grafica R (ST)

Valor R(ST):

193,95

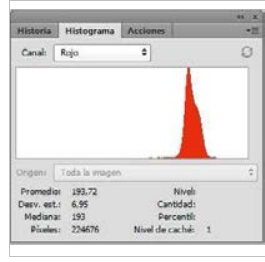

TRATADA (TT): Grafica R (TT) Valor R(TT): 193,72

DIFERENCIA (DF) Grafica R (DF): Valor DF-R: 0,23

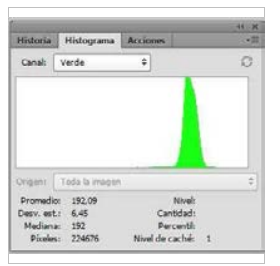

Grafica G (ST)

Valor G(ST):

192,09

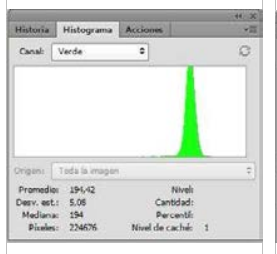

Grafica G (TT)

Valor $\mathrm{G}(\mathrm{TT})$ :

194,42
MADERA M33/TA/TILO AMERICANO

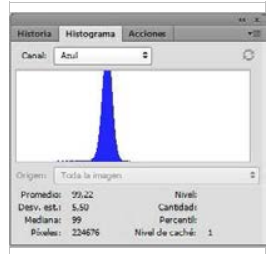

Grafica B (ST)

Valor B(ST):

92,22

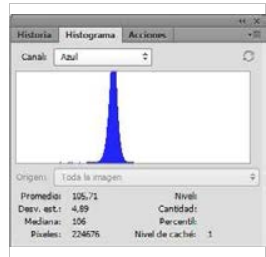

Grafica B (TT)

Valor $\mathrm{B}(\mathrm{TT})$ :

105,71

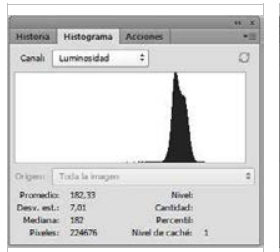

Grafica L (ST)

Valor L(ST):

182,33

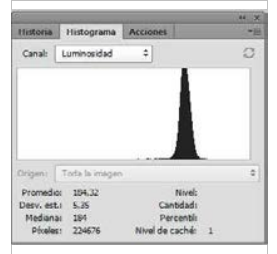

Grafica L (TT)

Valor L(TT):

184,32

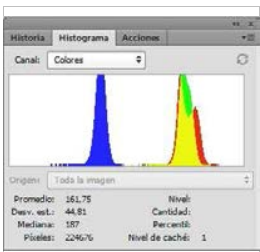

Grafica C (ST)

Valor C(ST):

161,75

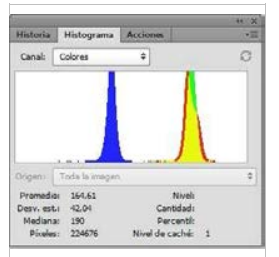

Grafica C (TT)

Valor C(TT):

164,61

Grafica G (DF): Grafica B (DF): Grafica L (DF): Grafica C (DF): Valor DF-G: Valor DF-B: Valor DF-L: Valor DF-C: $\begin{array}{llll}-2,33 & -13,49 & -1,99 & -2,86\end{array}$

\section{LEYENDA}

ST MADERA SIN TRATAR

Grafica R Histograma color Rojo Grafica G Histograma color Verde Grafica B Histograma color Azul Grafica L Histograma Luminosidad Grafica C Histograma RGB

\section{TT MADERA TRATADA}

Valor $R$ Número pixeles color Rojo Valor G Número pixeles color Verde Valor B Número pixeles color Azul Valor L Número pixeles Luminosidad Valor C Número pixeles RG DF DIFERENCIA DE VALORES R;G; $\mathrm{DF}=$ Valor $\mathrm{ST}(\mathrm{R} ; \mathrm{G} ; \mathrm{B})$ - Valor $\mathrm{TT}(\mathrm{R} ; \mathrm{G} ; \mathrm{B}$

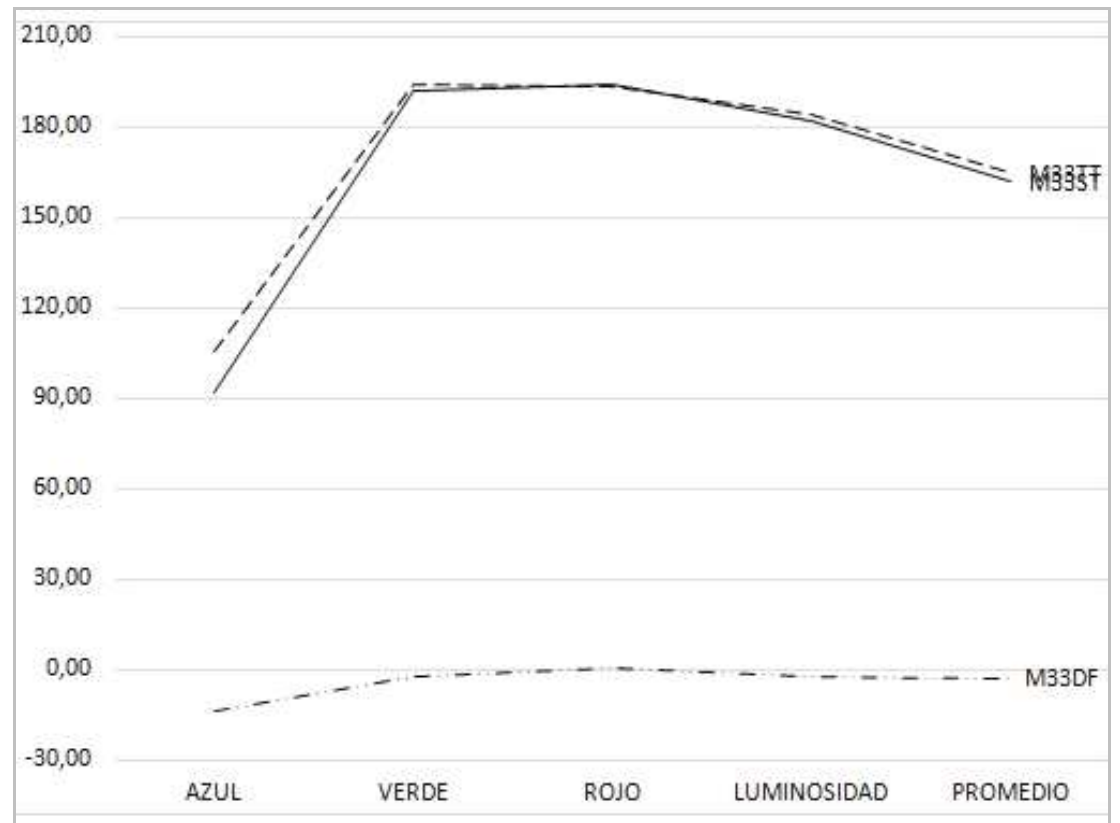

Universidad Politécnica de Madrid - Escuela Técnica Superior de Arquitectura - Departamento de Construcción y Tecnología Arquitectónica Directores: Dr. Alfonso García Santos y Dr. Antonio Rodríguez Rodríguez. Doctorando: D. Francisco Lora Toro 


\section{FICHA DE ENSAYOS DE MADERA Y ACIDOS}

\section{ACIDO A02/CR/ACIDO ACRILICO}
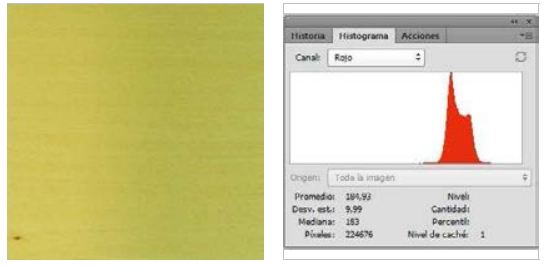

SIN TRATAR (ST): Grafica R (ST)

Valor R(ST):

184,93

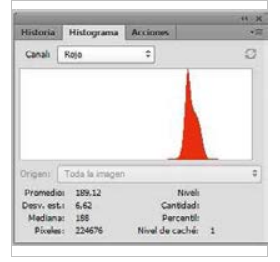

TRATADA (TT): Grafica R (TT) Valor $\mathrm{R}(\mathrm{TT})$ : 189,12

DIFERENCIA (DF) Grafica R (DF): Valor DF-R: $-4,19$

GRAFICA:

\section{LEYENDA}

ST MADERA SIN TRATAR

Grafica R Histograma color Rojo Grafica G Histograma color Verde Grafica B Histograma color Azul Grafica L Histograma Luminosidad Grafica C Histograma RGB

\section{TT MADERA TRATADA}

Valor R Número pixeles color Rojo Valor $\mathrm{G}$ Número pixeles color Verde Valor B Número pixeles color Azul Valor $L$ Número pixeles Luminosidad Valor C Número pixeles RG DF DIFERENCIA DE VALORES R;G; $\mathrm{DF}=$ Valor $\mathrm{ST}(\mathrm{R} ; \mathrm{G} ; \mathrm{B})$ - Valor $\mathrm{TT}(\mathrm{R} ; \mathrm{G} ; \mathrm{B}$

\section{MADERA M34/TE/TILO EUROPEO}
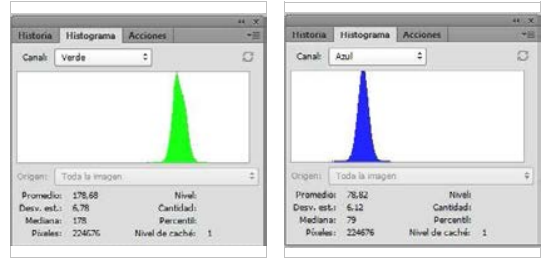

Grafica G (ST)

Grafica B (ST)
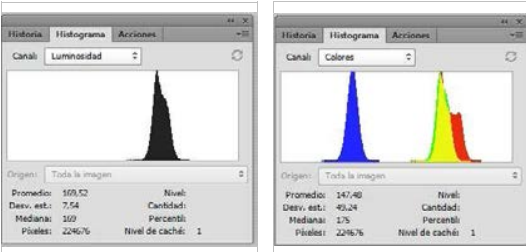

Grafica L (ST)

Grafica C (ST)

Valor $\mathrm{G}(\mathrm{ST})$ :

Valor B(ST):

Valor L(ST):

Valor C(ST):

178,68

78,82

169,52

147,48
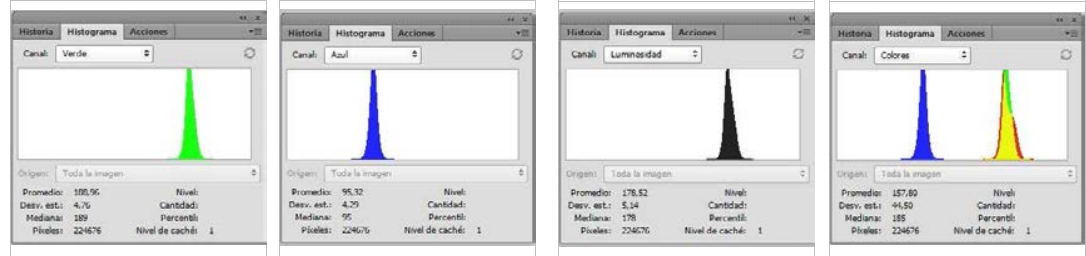

Grafica G (TT)

Grafica B (TT)

Grafica L (TT)

Grafica C (TT)

Valor $\mathrm{G}(\mathrm{TT})$ :

Valor $\mathrm{B}(\mathrm{TT})$ :

Valor L(TT):

Valor $\mathrm{C}(\mathrm{TT})$ :

188,96

95,32

178,52

157,80

Grafica G (DF): Grafica B (DF): Grafica L (DF): Grafica C (DF): Valor DF-G: Valor DF-B: Valor DF-L: Valor DF-C: $\begin{array}{llll}-10,28 & -16,50 & -9,00 & -10,32\end{array}$

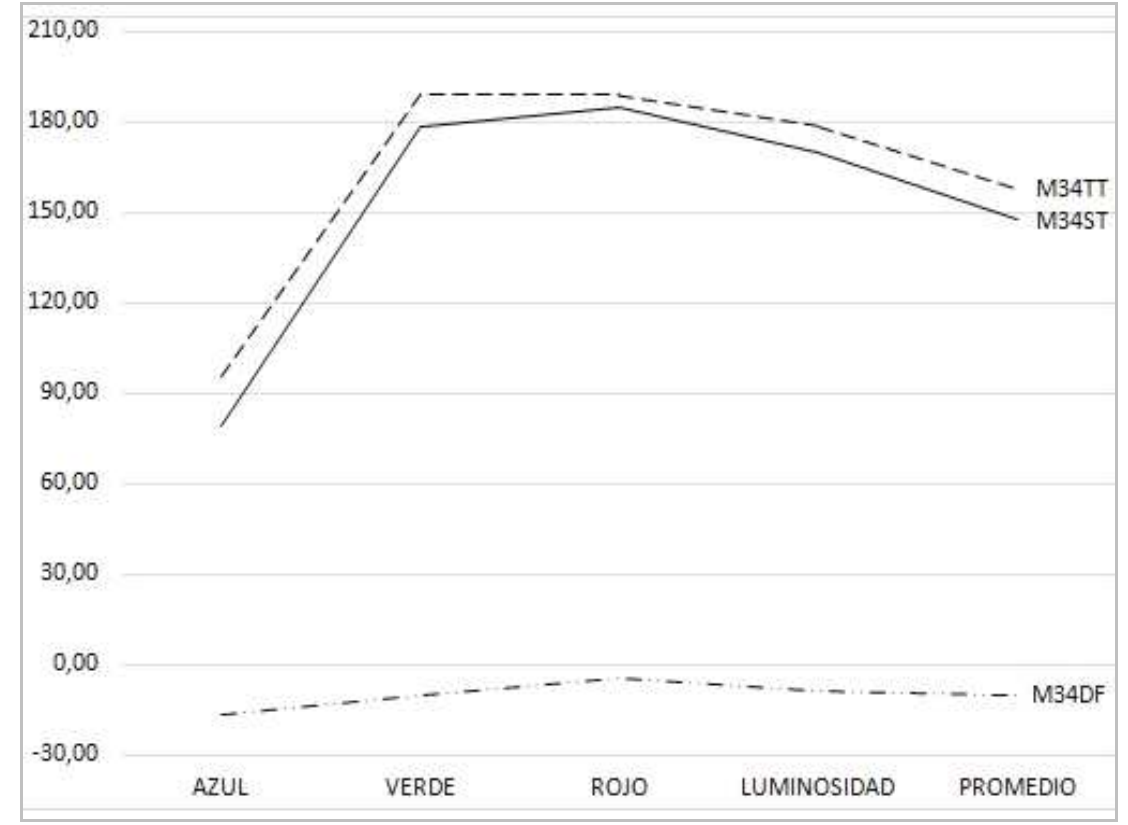

Universidad Politécnica de Madrid - Escuela Técnica Superior de Arquitectura - Departamento de Construcción y Tecnología Arquitectónica Directores: Dr. Alfonso García Santos y Dr. Antonio Rodríguez Rodríguez. Doctorando: D. Francisco Lora Toro 


\section{A03 / ÁCIDO CLORHÍDRICO}

\section{FICHA DE ENSAYOS DE MADERA Y ACIDOS}

\section{ACIDO A03/CL/ACIDO CLORHIDRICO}
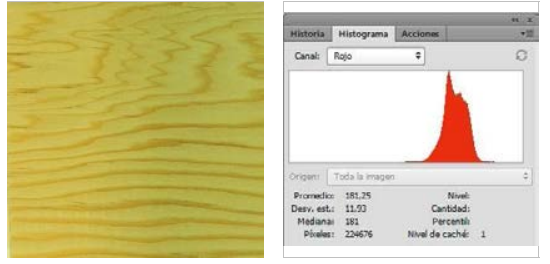

SIN TRATAR (ST): Grafica R (ST)

Valor R(ST):

181,25

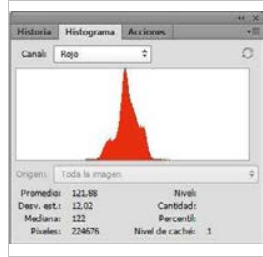

TRATADA (TT): Grafica R (TT)

Valor R(TT):

121,88

DIFERENCIA (DF) Grafica R (DF): Valor DF-R:

59,37

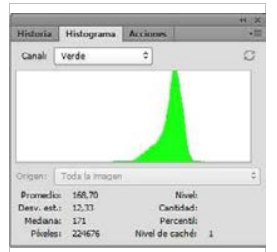

Grafica G (ST)

Valor G(ST):

168,70

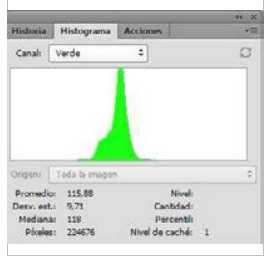

Grafica G (TT)

Valor $\mathrm{G}(\mathrm{TT})$ :

115,88

\section{MADERA M01/AD/ABETO DOUGLAS}

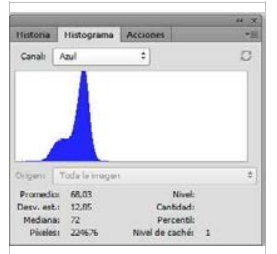

Grafica B (ST)

Valor B(ST):

68,03

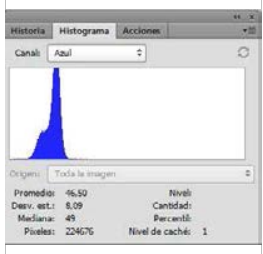

Grafica B (TT)

Valor $\mathrm{B}(\mathrm{TT})$ :

46,50

Grafica G (DF): Grafica B (DF):

Valor DF-G:

Valor DF-B:

21,53

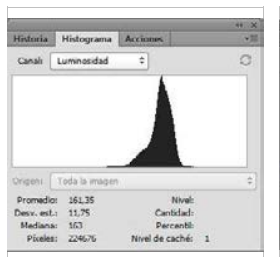

Grafica L (ST)

Valor L(ST):

161,35

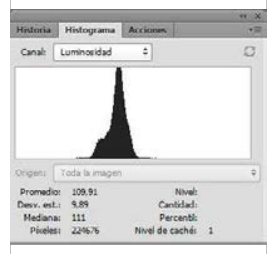

Grafica L (TT)

Valor L(TT):

109,91
Valor DF-L:

$52,82 \quad 21,53 \quad 51,44 \quad 44,57$

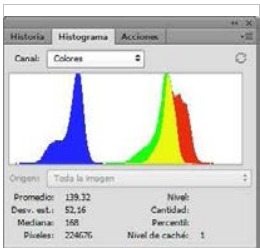

Grafica C (ST)

Valor C(ST):

139,32

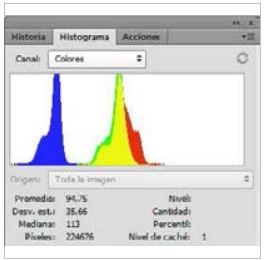

Grafica C (TT)

Valor C(TT):

94,75

Grafica L (DF): Grafica C (DF):

Valor DF-C:

GRAFICA:

\section{LEYENDA}

ST MADERA SIN TRATAR

Grafica R Histograma color Rojo

Grafica G Histograma color Verde

Grafica B Histograma color Azul

Grafica L Histograma Luminosidad

Grafica C Histograma RGB

TT MADERA TRATADA

Valor $\mathrm{R}$ Número pixeles color Rojo

Valor $\mathrm{G}$ Número pixeles color Verde

Valor B Número pixeles color Azul

Valor $\mathrm{L}$ Número pixeles Luminosidad

Valor C Número pixeles RG

DF DIFERENCIA DE VALORES R;G;

$\mathrm{DF}=$ Valor $\mathrm{ST}(\mathrm{R} ; \mathrm{G} ; \mathrm{B})$ - Valor TT(R;G;B

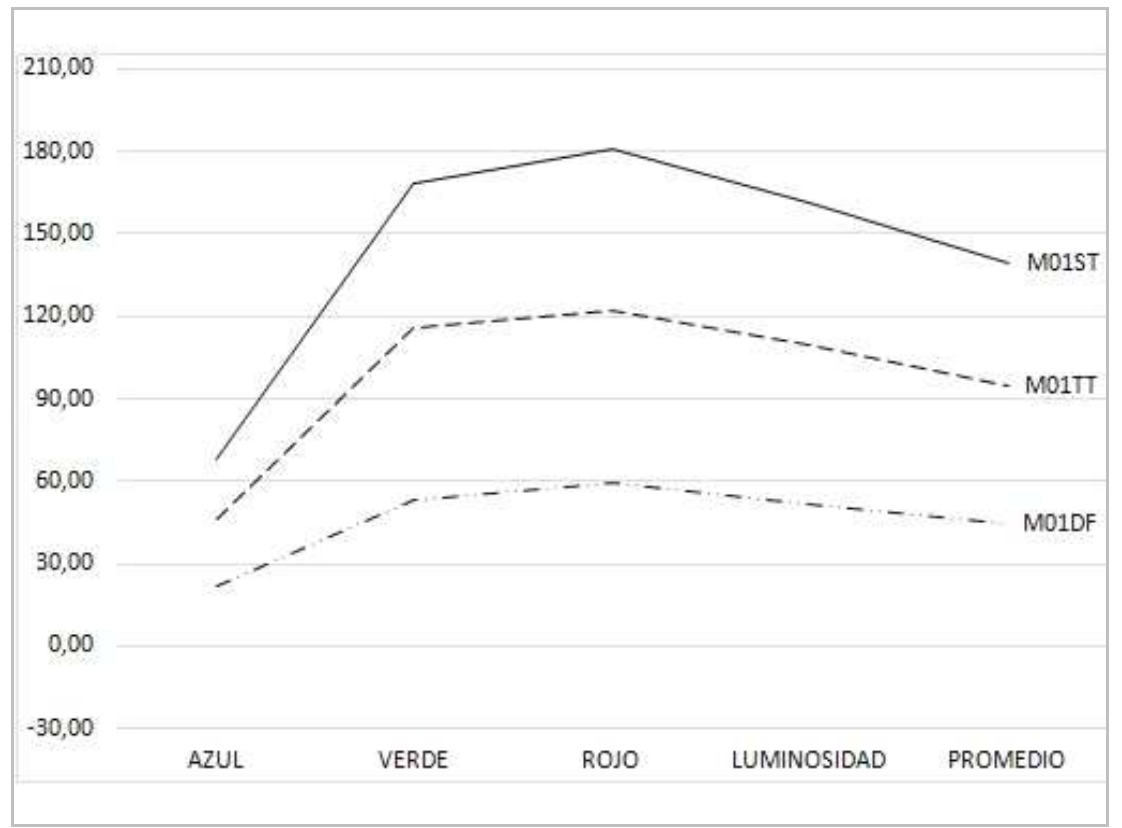

Universidad Politécnica de Madrid - Escuela Técnica Superior de Arquitectura - Departamento de Construcción y Tecnología Arquitectónica Directores: Dr. Alfonso García Santos y Dr. Antonio Rodríguez Rodríguez. Doctorando: D. Francisco Lora Toro 


\section{FICHA DE ENSAYOS DE MADERA Y ACIDOS}

\section{ACIDO A03/CL/ACIDO CLORHIDRICO}

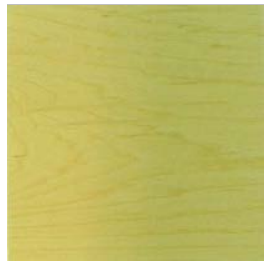

SIN TRATAR (ST): Grafica R (ST)

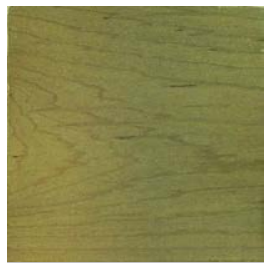

TRATADA (TT):
Valor R(ST):

181,38
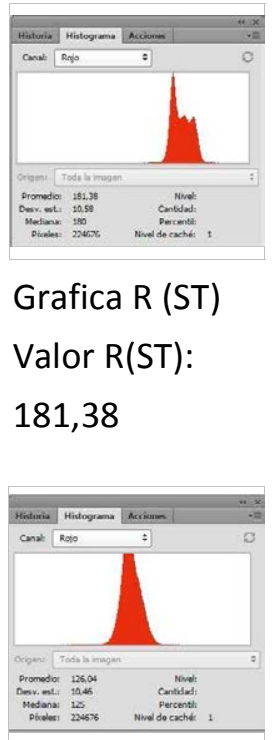

Grafica R (TT)

Valor R(TT):

126,04

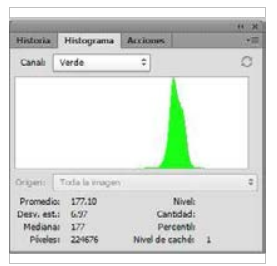

Grafica G (ST)

Valor G(ST):

177,10

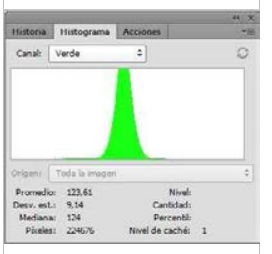

Grafica G (TT)

Valor $\mathrm{G}(\mathrm{TT})$ :

123,61

MADERA M02/ABA/ARCE BLANDO AMERICANO

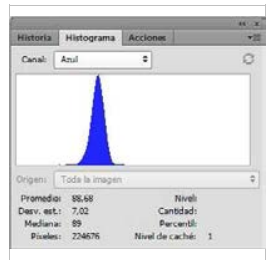

Grafica B (ST)

Valor B(ST):

88,68

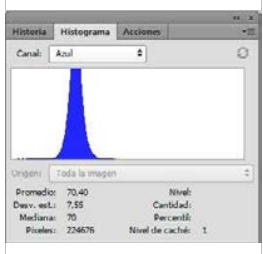

Grafica B (TT)

Valor $\mathrm{B}(\mathrm{TT})$ :

70,40

Grafica G (DF): Grafica B (DF):

Valor DF-B:

18,28

53,49

55,34

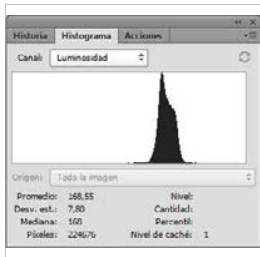

Grafica L (ST)

Valor L(ST):

168,55

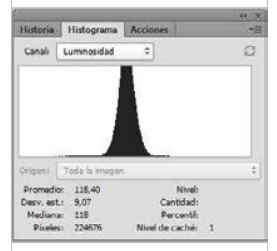

Grafica L (TT)

Valor L(TT):

118,40

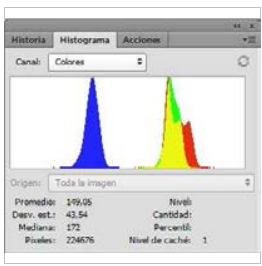

Grafica C (ST)

Valor C(ST):

149,05

DIFERENCIA (DF) Grafica R (DF)

Valor DF-G:

Grafica L (DF):

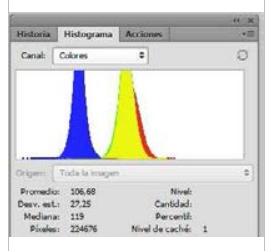

Grafica C (TT)

GRAFICA:

\section{LEYENDA}

ST MADERA SIN TRATAR

Grafica R Histograma color Rojo

Grafica G Histograma color Verde

Grafica B Histograma color Azul

Grafica L Histograma Luminosidad

Grafica C Histograma RGB

\section{TT MADERA TRATADA}

Valor R Número pixeles color Rojo

Valor $\mathrm{G}$ Número pixeles color Verde

Valor B Número pixeles color Azul

Valor $L$ Número pixeles Luminosidad

Valor $C$ Número pixeles $R G$

DF DIFERENCIA DE VALORES R;G; $\mathrm{DF}=$ Valor $\mathrm{ST}(\mathrm{R} ; \mathrm{G} ; \mathrm{B})$ - Valor TT(R;G;B

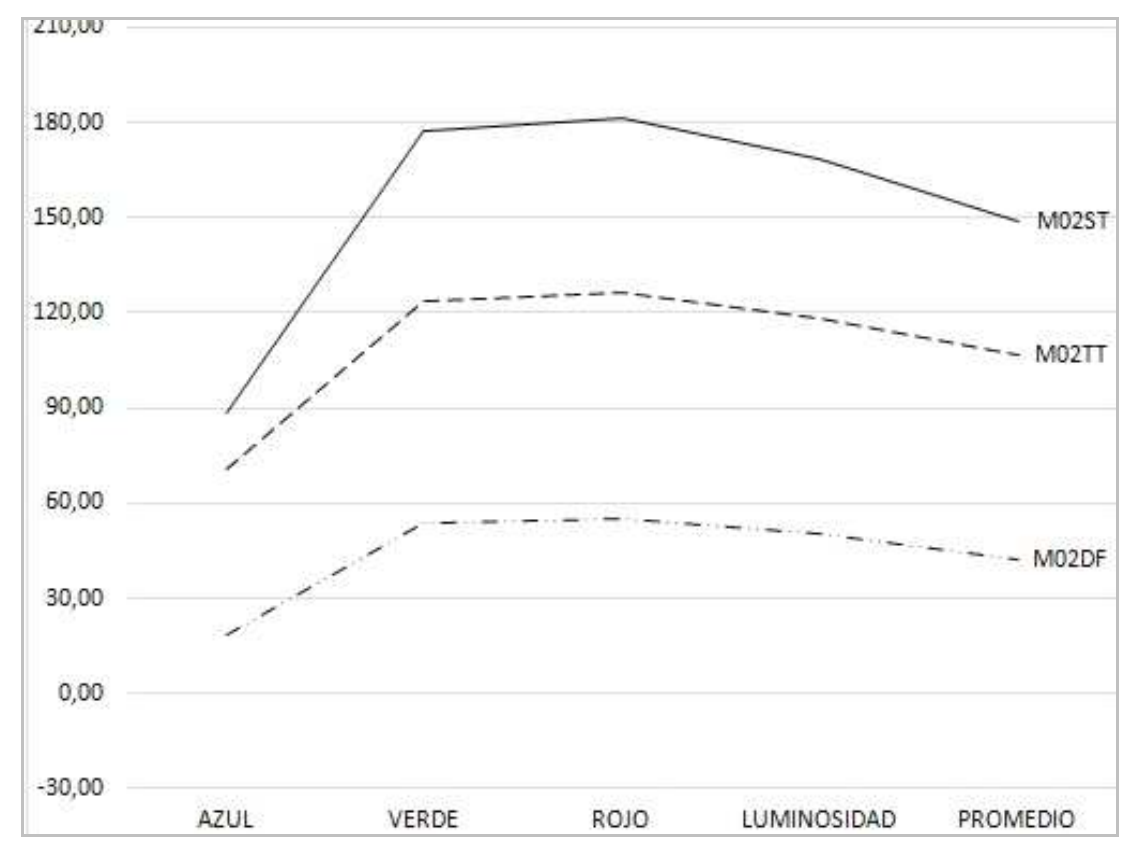

Universidad Politécnica de Madrid - Escuela Técnica Superior de Arquitectura - Departamento de Construcción y Tecnología Arquitectónica Directores: Dr. Alfonso García Santos y Dr. Antonio Rodríguez Rodríguez. Doctorando: D. Francisco Lora Toro 


\section{FICHA DE ENSAYOS DE MADERA Y ACIDOS}

ACIDO A03/CL/ACIDO CLORHIDRICO

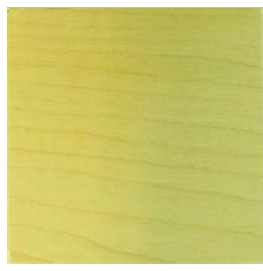

SIN TRATAR (ST): Grafica R (ST)

Valor R(ST):

192,52

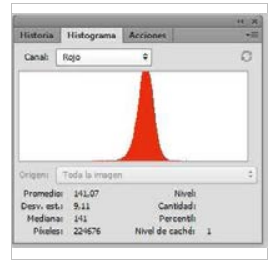

TRATADA (TT): Grafica R (TT)

Valor $\mathrm{R}(\mathrm{TT})$ :

141,07

DIFERENCIA (DF) Grafica R (DF):

Valor DF-R:

51,45

GRAFICA:

\section{LEYENDA}

ST MADERA SIN TRATAR

Grafica R Histograma color Rojo

Grafica G Histograma color Verde

Grafica B Histograma color Azul

Grafica L Histograma Luminosidad

Grafica C Histograma RGB

TT MADERA TRATADA

Valor R Número pixeles color Rojo

Valor $\mathrm{G}$ Número pixeles color Verde

Valor B Número pixeles color Azul

Valor $L$ Número pixeles Luminosidad

Valor C Número pixeles RG

DF DIFERENCIA DE VALORES R;G; $\mathrm{DF}=$ Valor $\mathrm{ST}(\mathrm{R} ; \mathrm{G} ; \mathrm{B})$ - Valor TT(R;G;B
MADERA MO3/ADA/ARCE DURO AMERICANO

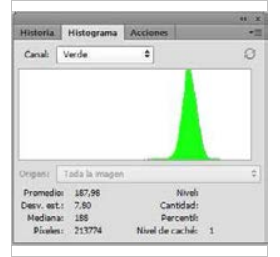

Grafica G (ST)

Valor $\mathrm{G}(\mathrm{ST})$ :

187,98

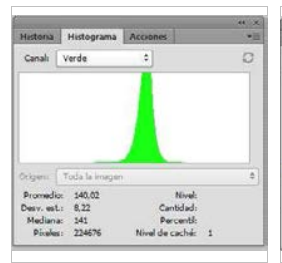

Grafica G (TT)

Valor G(TT):

140,02
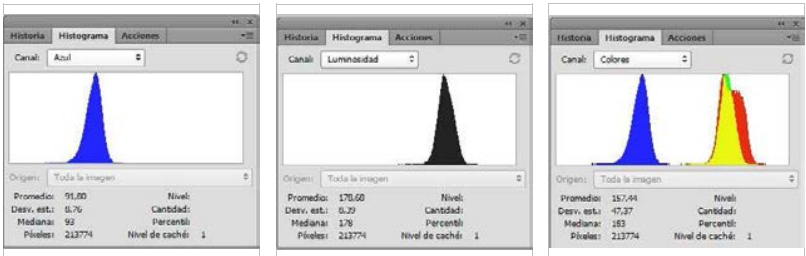

Grafica B (ST)

Grafica L (ST)

Grafica C (ST)

Valor $\mathrm{B}(\mathrm{ST})$ :

Valor L(ST):

Valor C(ST):

91,80

178,68

157,44
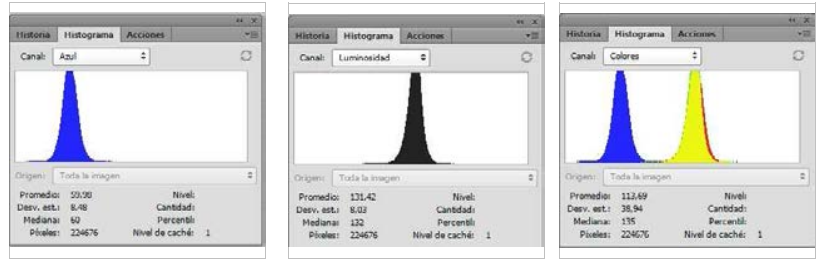

Grafica B (TT)

Grafica L (TT)

Grafica C (TT)

Valor $\mathrm{B}(\mathrm{TT})$ :

Valor L(TT):

Valor C(TT):

59,98

131,42

113,59

Grafica G (DF): Grafica B (DF): Grafica L (DF): Grafica C (DF): Valor DF-G: $\quad$ Valor DF-B: $\quad$ Valor DF-L: Valor DF-C:

$\begin{array}{llll}47,96 & 31,82 & 47,26 & 43,85\end{array}$

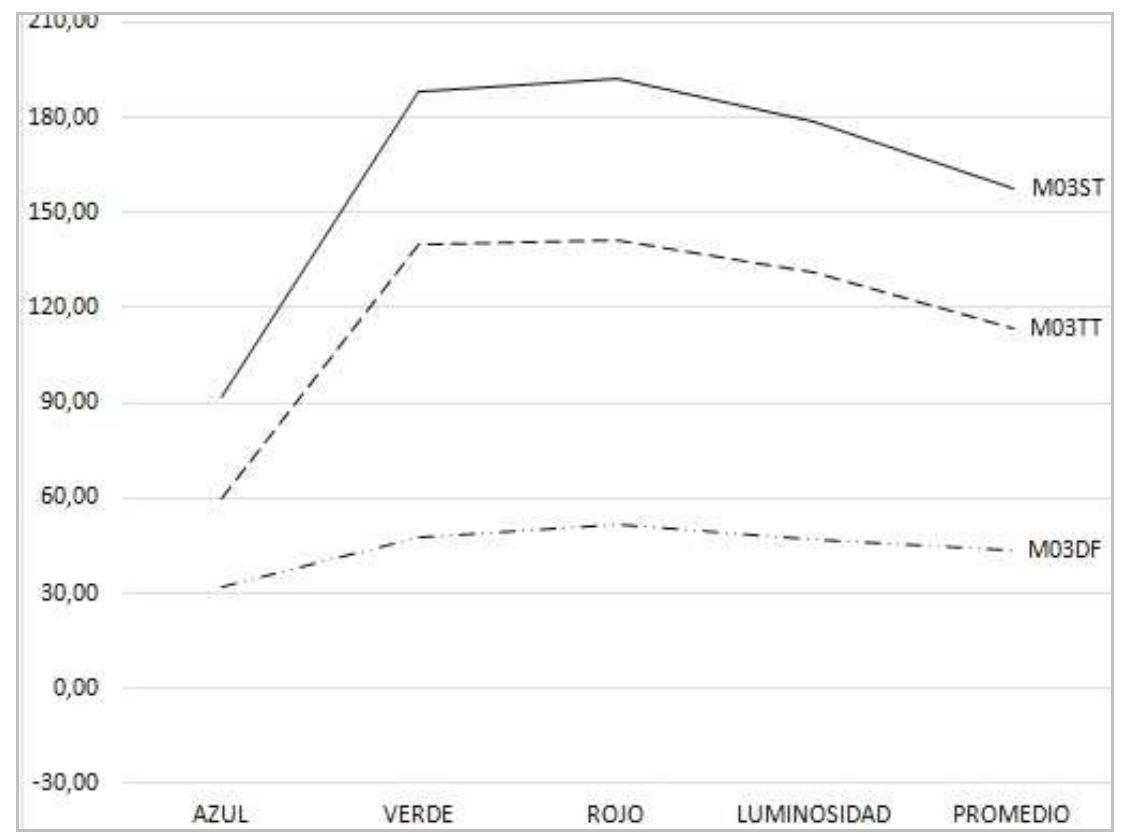

Universidad Politécnica de Madrid - Escuela Técnica Superior de Arquitectura - Departamento de Construcción y Tecnología Arquitectónica Directores: Dr. Alfonso García Santos y Dr. Antonio Rodríguez Rodríguez. Doctorando: D. Francisco Lora Toro 


\section{FICHA DE ENSAYOS DE MADERA Y ACIDOS}

\section{ACIDO A03/CL/ACIDO CLORHIDRICO}

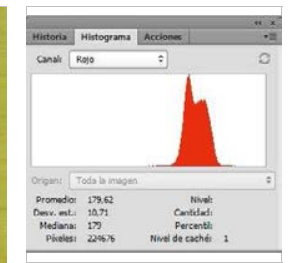

SIN TRATAR (ST): Grafica R (ST)

Valor R(ST):

179,62

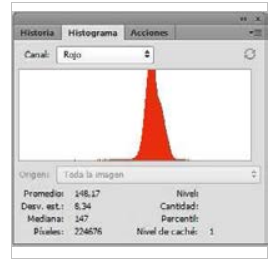

TRATADA (TT): Grafica R (TT)

Valor R(TT):

148,17

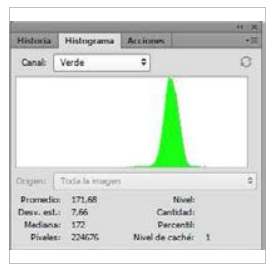

Grafica G (ST)

Valor $\mathrm{G}(\mathrm{ST})$ :

171,68

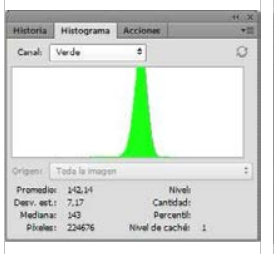

Grafica G (TT)

Valor $\mathrm{G}(\mathrm{TT})$ :

142,14

\section{MADERA M04/AS/AYOUS}

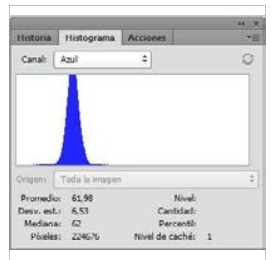

Grafica B (ST)

Valor B(ST):

61,98

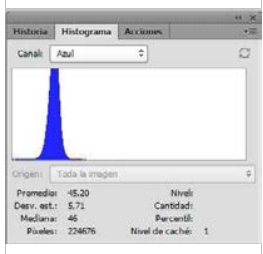

Grafica B (TT)

Valor $\mathrm{B}(\mathrm{TT})$ :

45,20

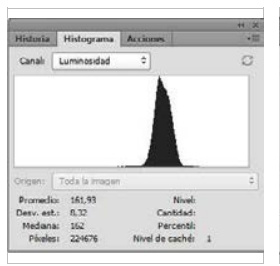

Grafica L (ST)

Valor L(ST):

161,93

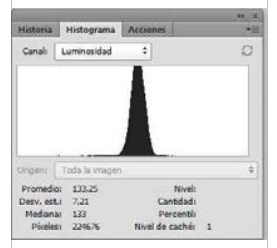

Grafica L (TT)

Valor L(TT):

133,25

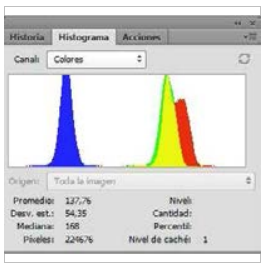

Grafica C (ST)

Valor C(ST):

137,76

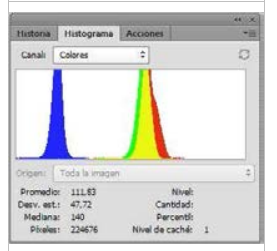

Grafica C (TT)

Valor C(TT):

111,83

DIFERENCIA (DF) Grafica R (DF):

Grafica G (DF): Grafica B (DF):

Grafica L (DF):

Grafica C (DF):

Valor DF-R:

Valor DF-G:

Valor DF-B:

Valor DF-L:

Valor DF-C: 31,45

29,54

16,78

28,68

25,93

\section{GRAFICA:}

\section{LEYENDA}

ST MADERA SIN TRATAR

Grafica R Histograma color Rojo

Grafica G Histograma color Verde

Grafica B Histograma color Azul

Grafica L Histograma Luminosidad

Grafica C Histograma RGB

\section{TT MADERA TRATADA}

Valor R Número pixeles color Rojo

Valor $\mathrm{G}$ Número pixeles color Verde

Valor B Número pixeles color Azul

Valor L Número pixeles Luminosidad

Valor C Número pixeles RG

DF DIFERENCIA DE VALORES R;G; $\mathrm{DF}=$ Valor $\mathrm{ST}(\mathrm{R} ; \mathrm{G} ; \mathrm{B})$ - Valor TT(R;G;B

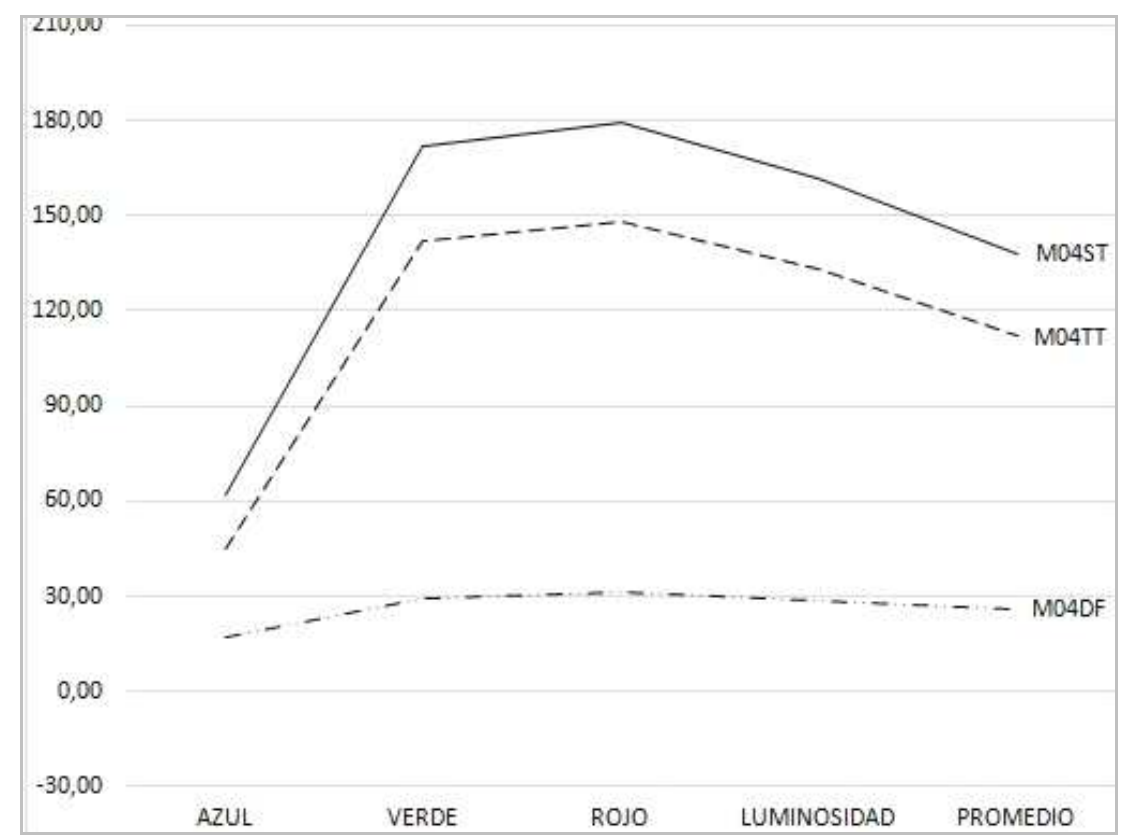

Universidad Politécnica de Madrid - Escuela Técnica Superior de Arquitectura - Departamento de Construcción y Tecnología Arquitectónica Directores: Dr. Alfonso García Santos y Dr. Antonio Rodríguez Rodríguez. Doctorando: D. Francisco Lora Toro 


\section{FICHA DE ENSAYOS DE MADERA Y ACIDOS}

\section{ACIDO A03/CL/ACIDO CLORHIDRICO}
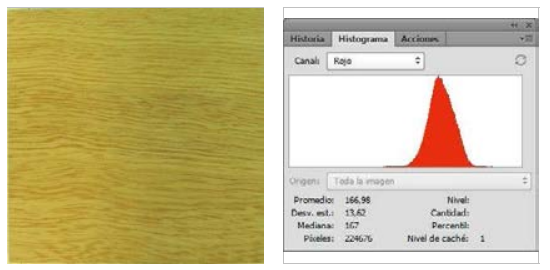

SIN TRATAR (ST): Grafica R (ST)

Valor R(ST):

$166,, 98$

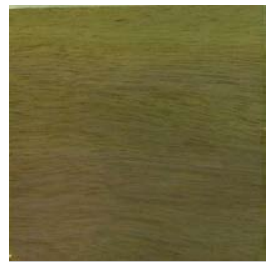

TRATADA (TT):

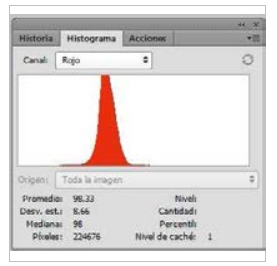

Grafica R (TT)

Valor $\mathrm{R}(\mathrm{TT})$ :

98,33

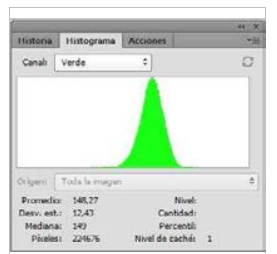

Grafica G (ST)

Valor G(ST):

148,27

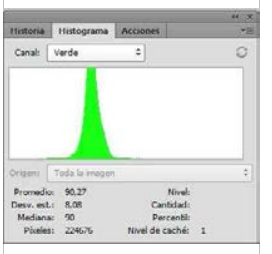

Grafica G (TT)

Valor $\mathrm{G}(\mathrm{TT})$ :

90,27
MADERA M05/BS/BOSSÉ

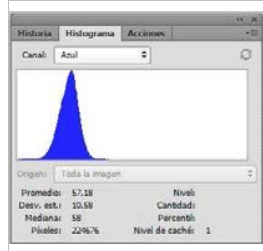

Grafica B (ST)

Valor B(ST):

57,18

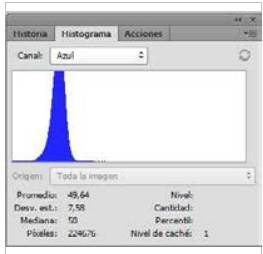

Grafica B (TT)

Valor $\mathrm{B}(\mathrm{TT})$ :

49.64

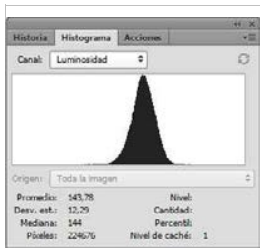

Grafica L (ST)

Valor L(ST):

143,78

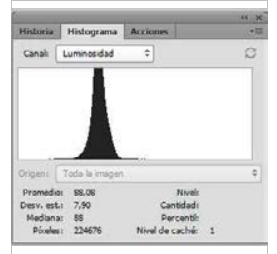

Grafica L (TT)

Valor L(TT):

88,08

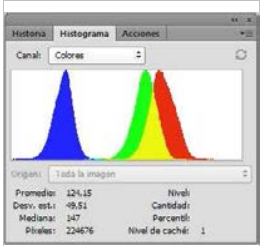

Grafica C (ST)

Valor C(ST):

124,15

DIFERENCIA (DF) Grafica R (DF):

Grafica G (DF): Grafica B (DF):

Grafica L (DF):

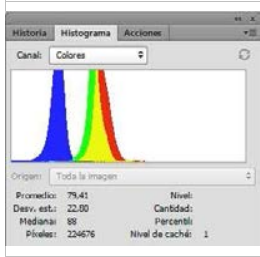

Valor DF-R:

Valor DF-G:

Valor DF-B:

Valor DF-L:

Grafica C (TT)

\#Error

58,00

$-4.906,82$

55,70

Valor C(TT):

79,41

Grafica C (DF):

Valor DF-C:

44,74

\section{LEYENDA}

ST MADERA SIN TRATAR

Grafica R Histograma color Rojo

Grafica G Histograma color Verde

Grafica B Histograma color Azul

Grafica L Histograma Luminosidad

Grafica C Histograma RGB

\section{TT MADERA TRATADA}

Valor R Número pixeles color Rojo

Valor $G$ Número pixeles color Verde

Valor B Número pixeles color Azul

Valor $L$ Número pixeles Luminosidad

Valor C Número pixeles RG

DF DIFERENCIA DE VALORES R;G; $\mathrm{DF}=$ Valor $\mathrm{ST}(\mathrm{R} ; \mathrm{G} ; \mathrm{B})$ - Valor $\mathrm{TT}(\mathrm{R} ; \mathrm{G} ; \mathrm{B}$

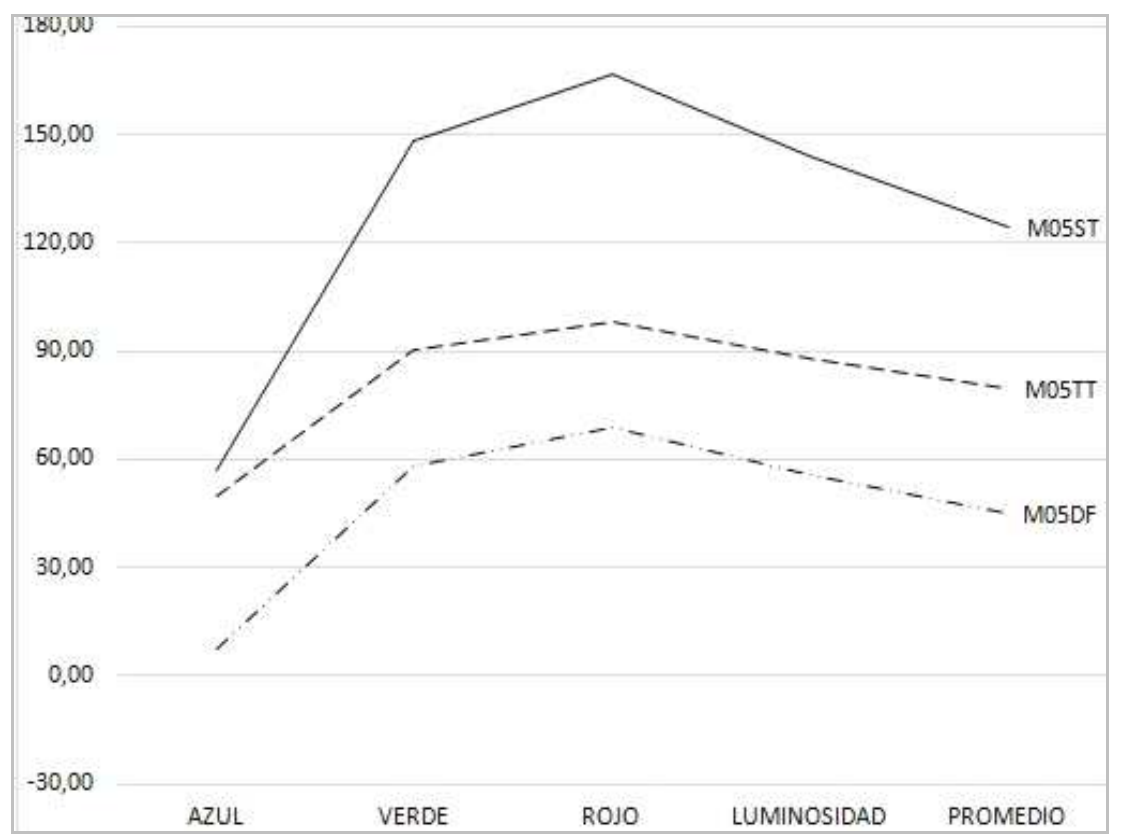

Universidad Politécnica de Madrid - Escuela Técnica Superior de Arquitectura - Departamento de Construcción y Tecnología Arquitectónica Directores: Dr. Alfonso García Santos y Dr. Antonio Rodríguez Rodríguez. Doctorando: D. Francisco Lora Toro 


\section{FICHA DE ENSAYOS DE MADERA Y ACIDOS}

\section{ACIDO A03/CL/ACIDO CLORHIDRICO}

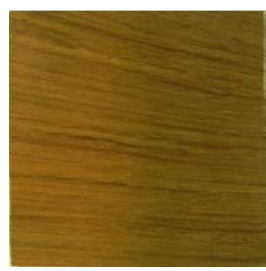

SIN TRATAR (ST): Grafica R (ST)

Valor R(ST):

115,55

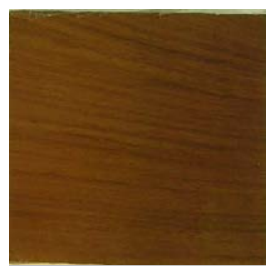

TRATADA (TT): Grafica R (TT)

Valor $\mathrm{R}(\mathrm{TT})$ :

93,47
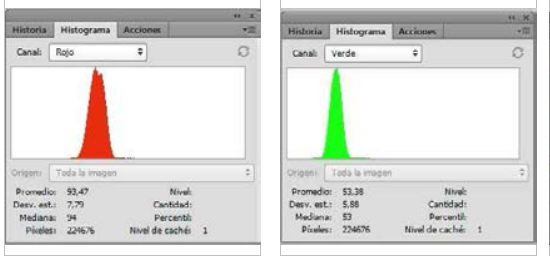

Grafica G (TT)

Valor $\mathrm{G}(\mathrm{TT})$ :

53,38

\section{MADERA M06/BG/BUBINGA}

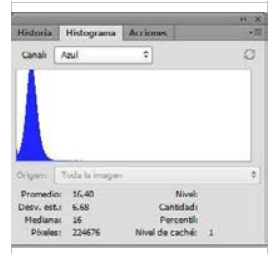

Grafica B (ST)

Valor $\mathrm{B}(\mathrm{ST})$ :

16,40

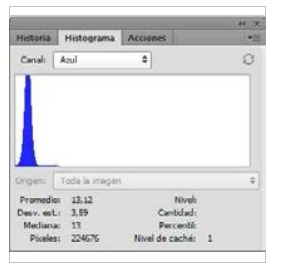

Grafica B (TT)

Valor $\mathrm{B}(\mathrm{TT})$ :

13,12

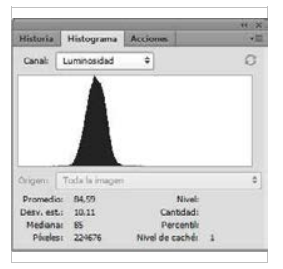

Grafica L (ST)

Valor L(ST):

84,59

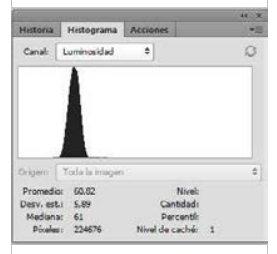

Grafica L (TT)

Valor L(TT):

60,82

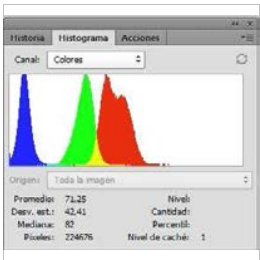

Grafica C (ST)

Valor C(ST):

71,25

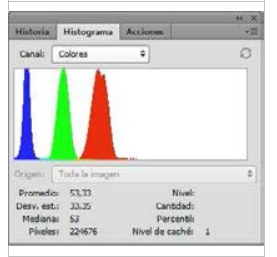

Grafica C (TT)

Valor C(TT):

53,33

DIFERENCIA (DF) Grafica R (DF): Grafica G (DF): Grafica B (DF): Grafica L (DF): Grafica C (DF): Valor DF-R: Valor DF-G: Valor DF-B: Valor DF-L: Valor DF-C: 22,08 28,41 3,28 23,77 17,92 GRAFICA:

\section{LEYENDA}

ST MADERA SIN TRATAR

Grafica R Histograma color Rojo Grafica G Histograma color Verde Grafica B Histograma color Azul Grafica L Histograma Luminosidad Grafica C Histograma RGB

\section{TT MADERA TRATADA}

Valor $\mathrm{R}$ Número pixeles color Rojo Valor G Número pixeles color Verde Valor B Número pixeles color Azul Valor L Número pixeles Luminosidad Valor $C$ Número pixeles $R G$ DF DIFERENCIA DE VALORES R;G; $\mathrm{DF}=$ Valor ST(R;G;B) - Valor TT(R;G;B

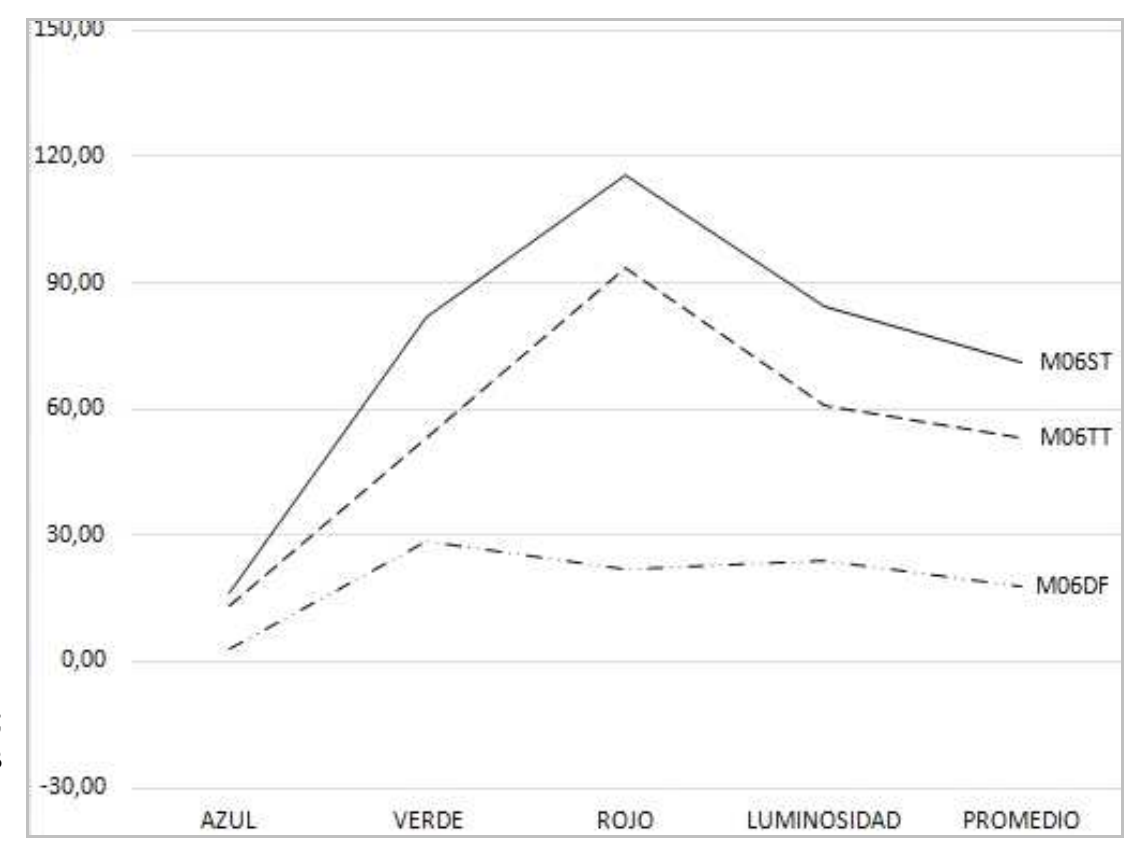

Universidad Politécnica de Madrid - Escuela Técnica Superior de Arquitectura - Departamento de Construcción y Tecnología Arquitectónica Directores: Dr. Alfonso García Santos y Dr. Antonio Rodríguez Rodríguez. Doctorando: D. Francisco Lora Toro 


\section{FICHA DE ENSAYOS DE MADERA Y ACIDOS}

ACIDO A03/CL/ACIDO CLORHIDRICO
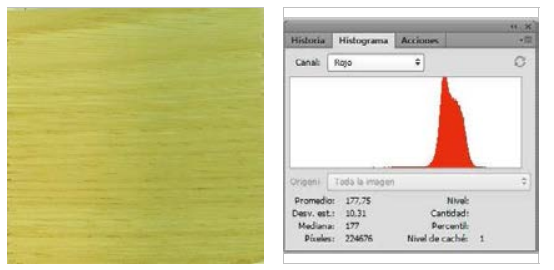

SIN TRATAR (ST): Grafica R (ST)

Valor R(ST):

177,75

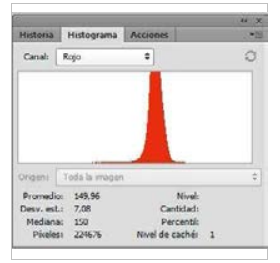

TRATADA (TT): Grafica R (TT)

Valor $\mathrm{R}(\mathrm{TT})$ :

149,96

DIFERENCIA (DF) Grafica R (DF):

Valor DF-R:

27,79

GRAFICA:

\section{LEYENDA}

ST MADERA SIN TRATAR

Grafica R Histograma color Rojo

Grafica G Histograma color Verde

Grafica B Histograma color Azul

Grafica L Histograma Luminosidad

Grafica C Histograma RGB

\section{TT MADERA TRATADA}

Valor R Número pixeles color Rojo

Valor $\mathrm{G}$ Número pixeles color Verde

Valor B Número pixeles color Azul

Valor $L$ Número pixeles Luminosidad

Valor $C$ Número pixeles $R G$

DF DIFERENCIA DE VALORES R;G; $\mathrm{DF}=$ Valor $\mathrm{ST}(\mathrm{R} ; \mathrm{G} ; \mathrm{B})$ - Valor TT(R;G;B
MADERA M07/CÑ/CASTAÑO EUROPEO

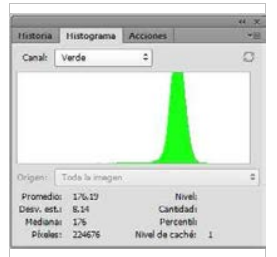

Grafica G (ST)

Valor $\mathrm{G}(\mathrm{ST})$ :

176,19

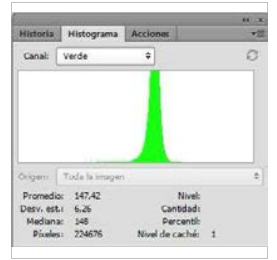

Grafica G (TT)
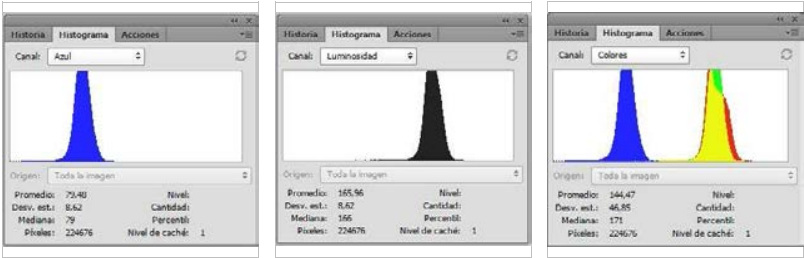

Grafica B (ST)

Grafica L (ST)

Grafica C (ST)

Valor $\mathrm{B}(\mathrm{ST})$ :

Valor L(ST):

Valor C(ST):

79,48

165,96

144,47
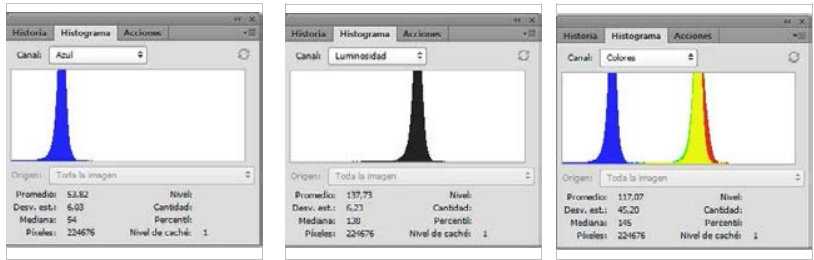

Grafica B (TT)

Grafica L (TT)

Grafica C (TT)

Valor $\mathrm{G}(\mathrm{TT})$ :

Valor $\mathrm{B}(\mathrm{TT})$ :

Valor L(TT):

Valor C(TT):

147,42

53,82

137,73

117,07

Grafica G (DF): Grafica B (DF): Grafica L (DF): Grafica C (DF): Valor DF-G: $\quad$ Valor DF-B: $\quad$ Valor DF-L: Valor DF-C:

$28,7725,66 \quad 28,23 \quad 27,40$

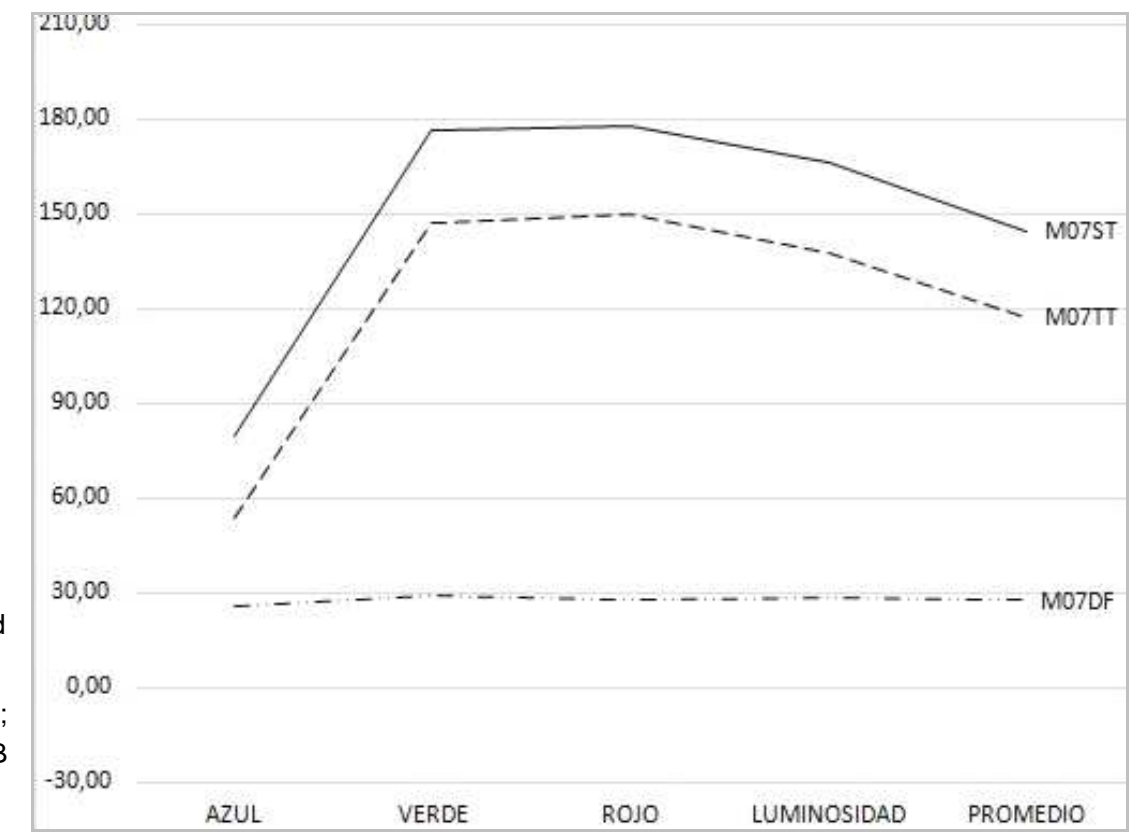

Universidad Politécnica de Madrid - Escuela Técnica Superior de Arquitectura - Departamento de Construcción y Tecnología Arquitectónica Directores: Dr. Alfonso García Santos y Dr. Antonio Rodríguez Rodríguez. Doctorando: D. Francisco Lora Toro 


\section{FICHA DE ENSAYOS DE MADERA Y ACIDOS}

\section{ACIDO A03/CL/ACIDO CLORHIDRICO}

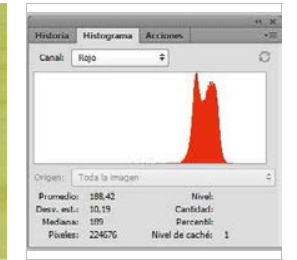

SIN TRATAR (ST): Grafica R (ST)

Valor R(ST):

188,42

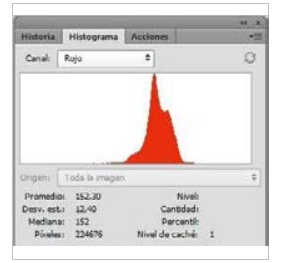

TRATADA (TT): Grafica R (TT)

Valor $\mathrm{R}(\mathrm{TT})$ :

152,30

DIFERENCIA (DF) Grafica R (DF):

Valor DF-R:

36,12

GRAFICA:

\section{LEYENDA}

ST MADERA SIN TRATAR

Grafica R Histograma color Rojo

Grafica G Histograma color Verde

Grafica B Histograma color Azul

Grafica L Histograma Luminosidad

Grafica C Histograma RGB

TT MADERA TRATADA

Valor R Número pixeles color Rojo

Valor $\mathrm{G}$ Número pixeles color Verde

Valor B Número pixeles color Azul

Valor $L$ Número pixeles Luminosidad

Valor C Número pixeles RG

DF DIFERENCIA DE VALORES R;G; $\mathrm{DF}=$ Valor $\mathrm{ST}(\mathrm{R} ; \mathrm{G} ; \mathrm{B})$ - Valor TT(R;G;B

\section{MADERA M08/CPE/CHOPO EUROPEO}

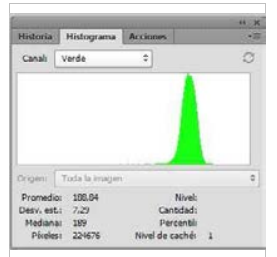

Grafica G (ST)

Valor $\mathrm{G}(\mathrm{ST})$ :

188,84
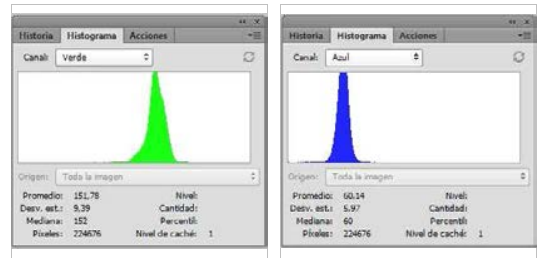

Grafica G (TT)

Grafica B (TT)

Valor $\mathrm{B}(\mathrm{TT})$ :

60,14

151,78

Grafica G (DF): Grafica B (DF):

Grafica L (DF):

Grafica C (DF):

Valor DF-G:

Valor DF-B:

Valor DF-L:

Valor DF-C:

37,06 34,21

36,48

35,79

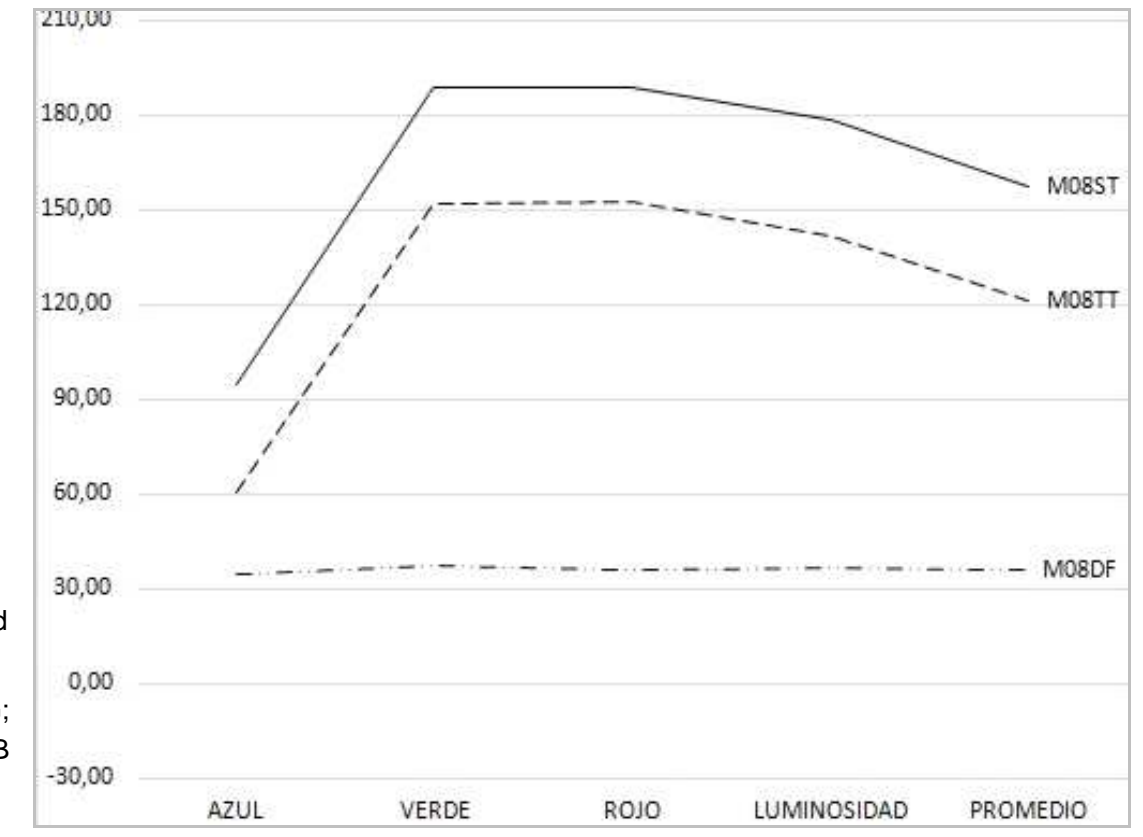

Universidad Politécnica de Madrid - Escuela Técnica Superior de Arquitectura - Departamento de Construcción y Tecnología Arquitectónica Directores: Dr. Alfonso García Santos y Dr. Antonio Rodríguez Rodríguez. Doctorando: D. Francisco Lora Toro 


\section{FICHA DE ENSAYOS DE MADERA Y ACIDOS}

\section{ACIDO A03/CL/ACIDO CLORHIDRICO}
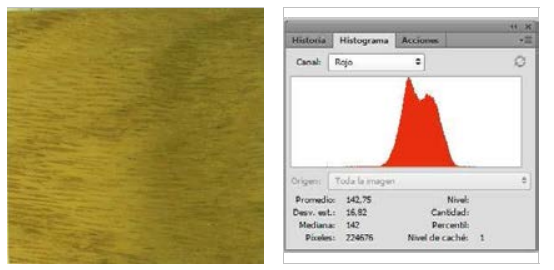

SIN TRATAR (ST): Grafica R (ST)

Valor R(ST):

142,75

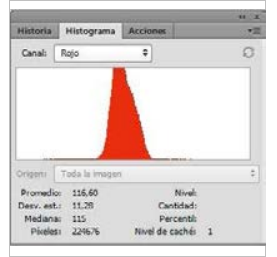

TRATADA (TT): Grafica $R(T T)$

Valor $\mathrm{R}(\mathrm{TT})$ :

116,60

DIFERENCIA (DF) Grafica R (DF): Valor DF-R: 26,15

GRAFICA:

\section{LEYENDA}

ST MADERA SIN TRATAR

Grafica R Histograma color Rojo

Grafica G Histograma color Verde

Grafica B Histograma color Azul

Grafica L Histograma Luminosidad

Grafica C Histograma RGB

\section{TT MADERA TRATADA}

Valor R Número pixeles color Rojo

Valor $G$ Número pixeles color Verde

Valor B Número pixeles color Azul

Valor $L$ Número pixeles Luminosidad

Valor C Número pixeles RG

DF DIFERENCIA DE VALORES R;G; $\mathrm{DF}=$ Valor $\mathrm{ST}(\mathrm{R} ; \mathrm{G} ; \mathrm{B})$ - Valor $\mathrm{TT}(\mathrm{R} ; \mathrm{G} ; \mathrm{B}$

\section{MADERA M09/CJ/CEREJEIRA}

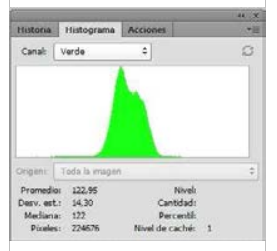

Grafica G (ST)

Valor $\mathrm{G}(\mathrm{ST})$ :

122,95
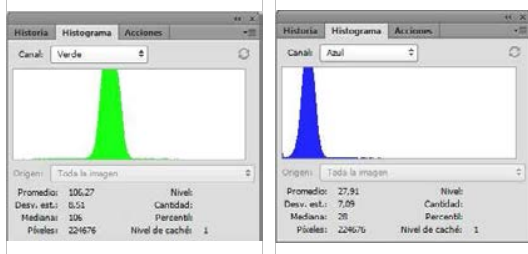

Grafica G (TT)

Grafica B (TT)

Valor $\mathrm{B}(\mathrm{TT})$ :

27,91

106,27

Grafica G (DF): Grafica B (DF):

Valor DF-G:

Valor DF-B:

7,96
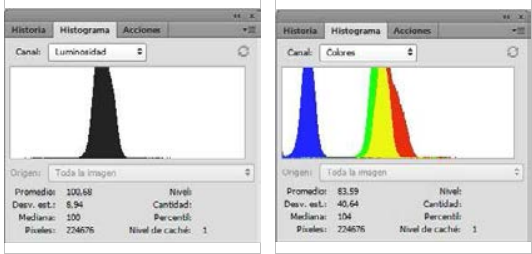

Grafica L (TT)

Grafica C (TT)

Valor L(TT):

Valor $\mathrm{C}(\mathrm{TT})$ :

100,68

83,59

Grafica L (DF): Grafica C (DF): Valor DF-L: Valor DF-C: 16,68 16,93

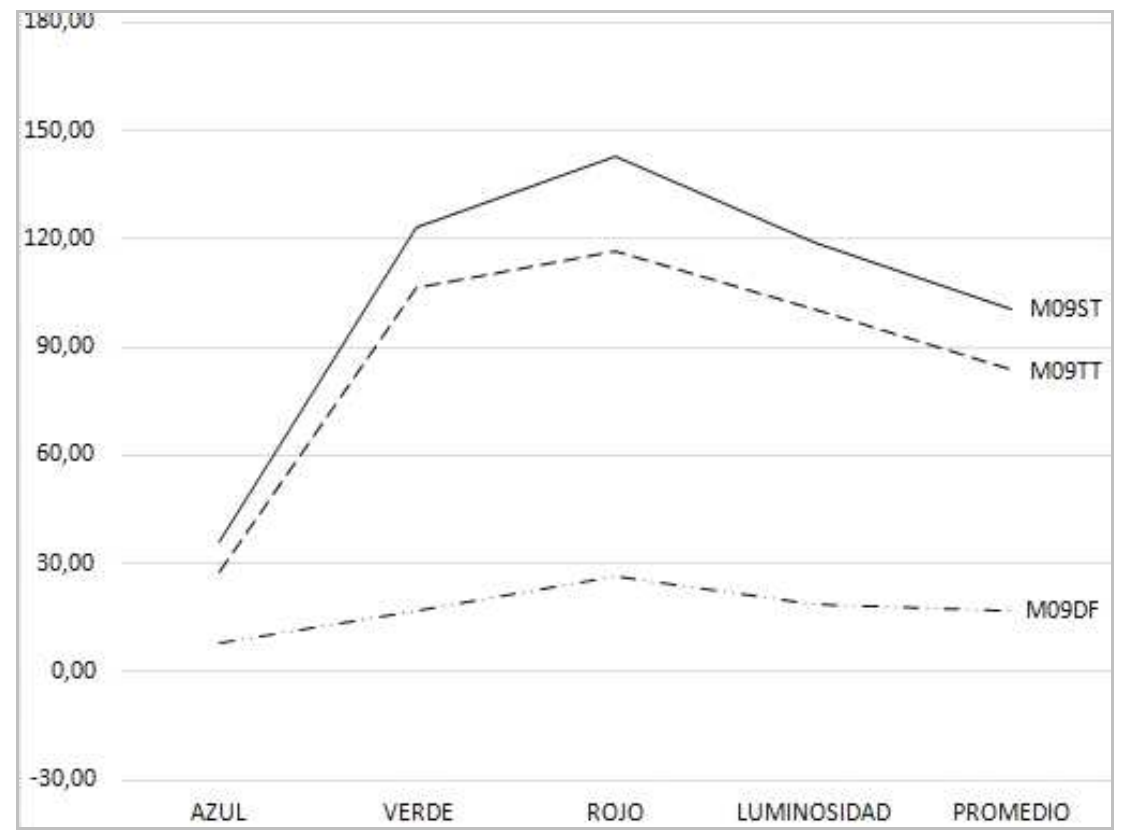

Universidad Politécnica de Madrid - Escuela Técnica Superior de Arquitectura - Departamento de Construcción y Tecnología Arquitectónica Directores: Dr. Alfonso García Santos y Dr. Antonio Rodríguez Rodríguez. Doctorando: D. Francisco Lora Toro 


\section{FICHA DE ENSAYOS DE MADERA Y ACIDOS}

\section{ACIDO A03/CL/ACIDO CLORHIDRICO}
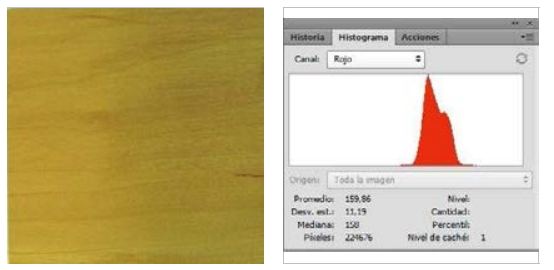

SIN TRATAR (ST): Grafica R (ST)

Valor R(ST):

159,86

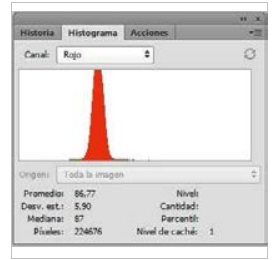

TRATADA (TT): Grafica R (TT)

Valor R(TT):

86,77

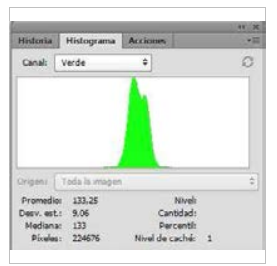

Grafica G (ST)

Valor G(ST):

133,25

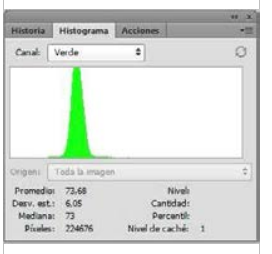

Grafica G (TT)

Valor $\mathrm{G}(\mathrm{TT})$ :

73,68

\section{MADERA M10/CZA/CEREZO AMERICANO}

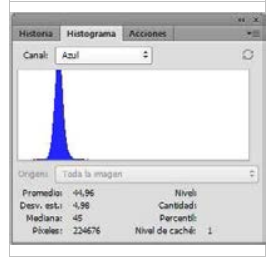

Grafica B (ST)

Valor B(ST):

44,96

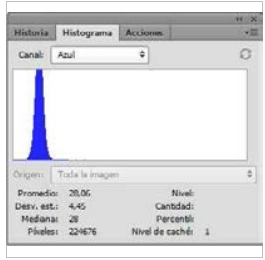

Grafica B (TT)

Valor $\mathrm{B}(\mathrm{TT})$ :

28,06

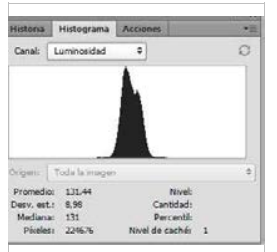

Grafica L (ST)

Valor L(ST):

131,44

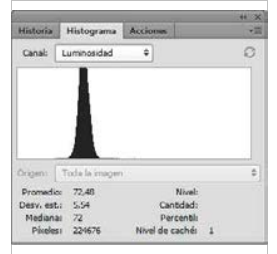

Grafica L (TT)

Valor L(TT):

72,48
62,94

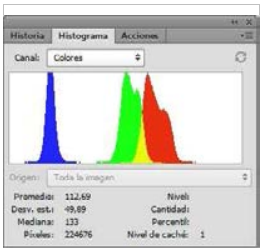

Grafica C (ST)

Valor C(ST):

112,69

DIFERENCIA (DF) Grafica R (DF):

Grafica G (DF): Grafica B (DF):

Grafica L (DF):

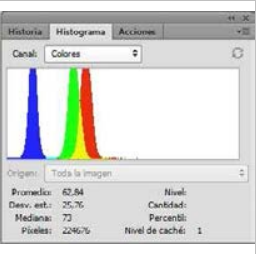

Valor DF-R:

Valor DF-G:

Valor DF-B:

Valor DF-L:

Grafica C (TT)

73,09

59,57

16,90

58,96

Valor C(TT):

\section{GRAFICA:}

\section{LEYENDA}

ST MADERA SIN TRATAR

Grafica R Histograma color Rojo

Grafica G Histograma color Verde

Grafica B Histograma color Azul

Grafica L Histograma Luminosidad

Grafica C Histograma RGB

\section{TT MADERA TRATADA}

Valor $\mathrm{R}$ Número pixeles color Rojo

Valor $\mathrm{G}$ Número pixeles color Verde

Valor B Número pixeles color Azul

Valor L Número pixeles Luminosidad

Valor $C$ Número pixeles $R G$

DF DIFERENCIA DE VALORES R;G; $\mathrm{DF}=$ Valor $\mathrm{ST}(\mathrm{R} ; \mathrm{G} ; \mathrm{B})$ - Valor TT(R;G;B

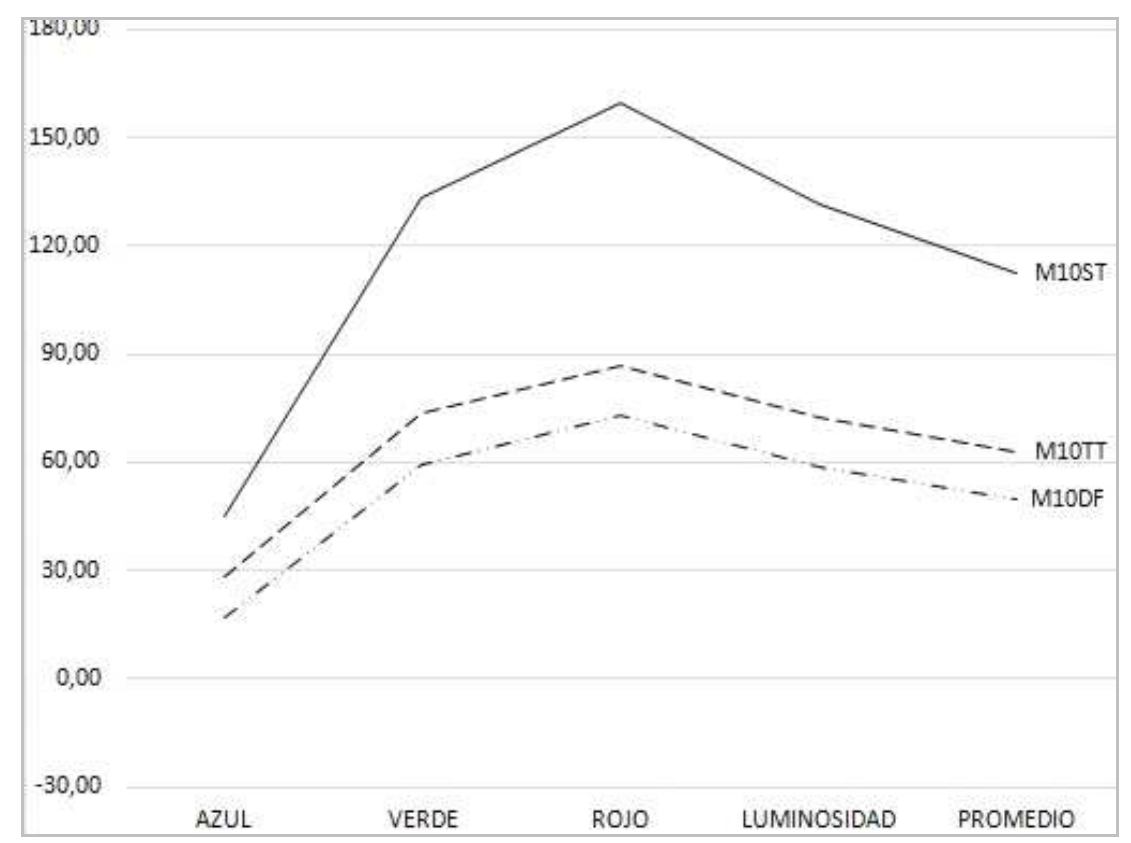

Universidad Politécnica de Madrid - Escuela Técnica Superior de Arquitectura - Departamento de Construcción y Tecnología Arquitectónica Directores: Dr. Alfonso García Santos y Dr. Antonio Rodríguez Rodríguez. Doctorando: D. Francisco Lora Toro 


\section{FICHA DE ENSAYOS DE MADERA Y ACIDOS}

\section{ACIDO A03/CL/ACIDO CLORHIDRICO}
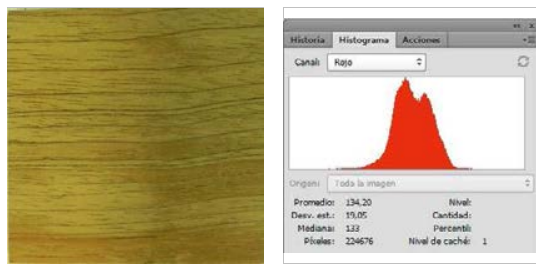

SIN TRATAR (ST): Grafica R (ST)

Valor R(ST):

134,20
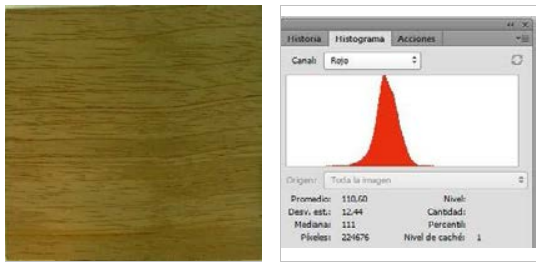

TRATADA (TT): Grafica R (TT)

Valor $\mathrm{R}(\mathrm{TT})$ :

110,60

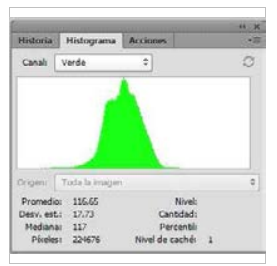

Grafica G (ST)

Valor $\mathrm{G}(\mathrm{ST})$ :

116,65

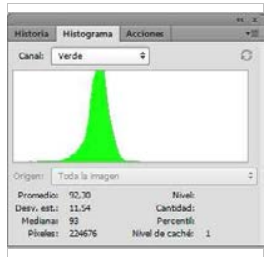

Grafica G (TT)

Valor $\mathrm{G}(\mathrm{TT})$ :

92,30

\section{MADERA M11/CB/COPAIBA}

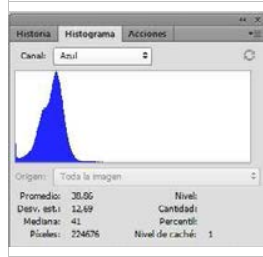

Grafica B (ST)

Valor B(ST):

38,86

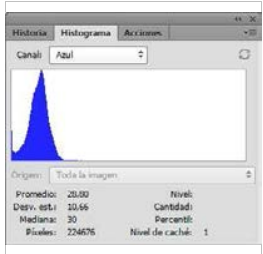

Grafica B (TT)

Valor $\mathrm{B}(\mathrm{TT})$ :

28,80

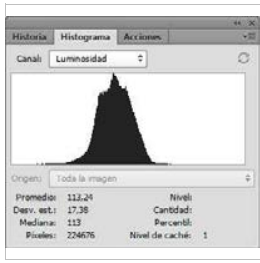

Grafica L (ST)

Valor L(ST):

113,24

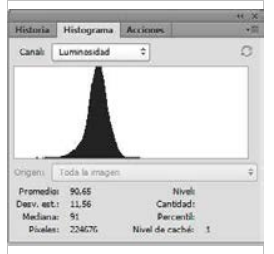

Grafica L (TT)

Valor L(TT):

90,65

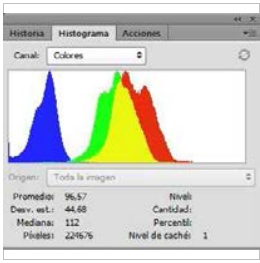

Grafica C (ST)

Valor C(ST):

96,57

DIFERENCIA (DF) Grafica R (DF): Grafica G (DF): Grafica B (DF): Grafica L (DF): Grafica C (DF): Valor DF-R: Valor DF-G: Valor DF-B: Valor DF-L:

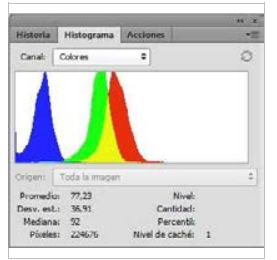
23,60 24,35 10,06 22,59 Valor DF-C: 19,34

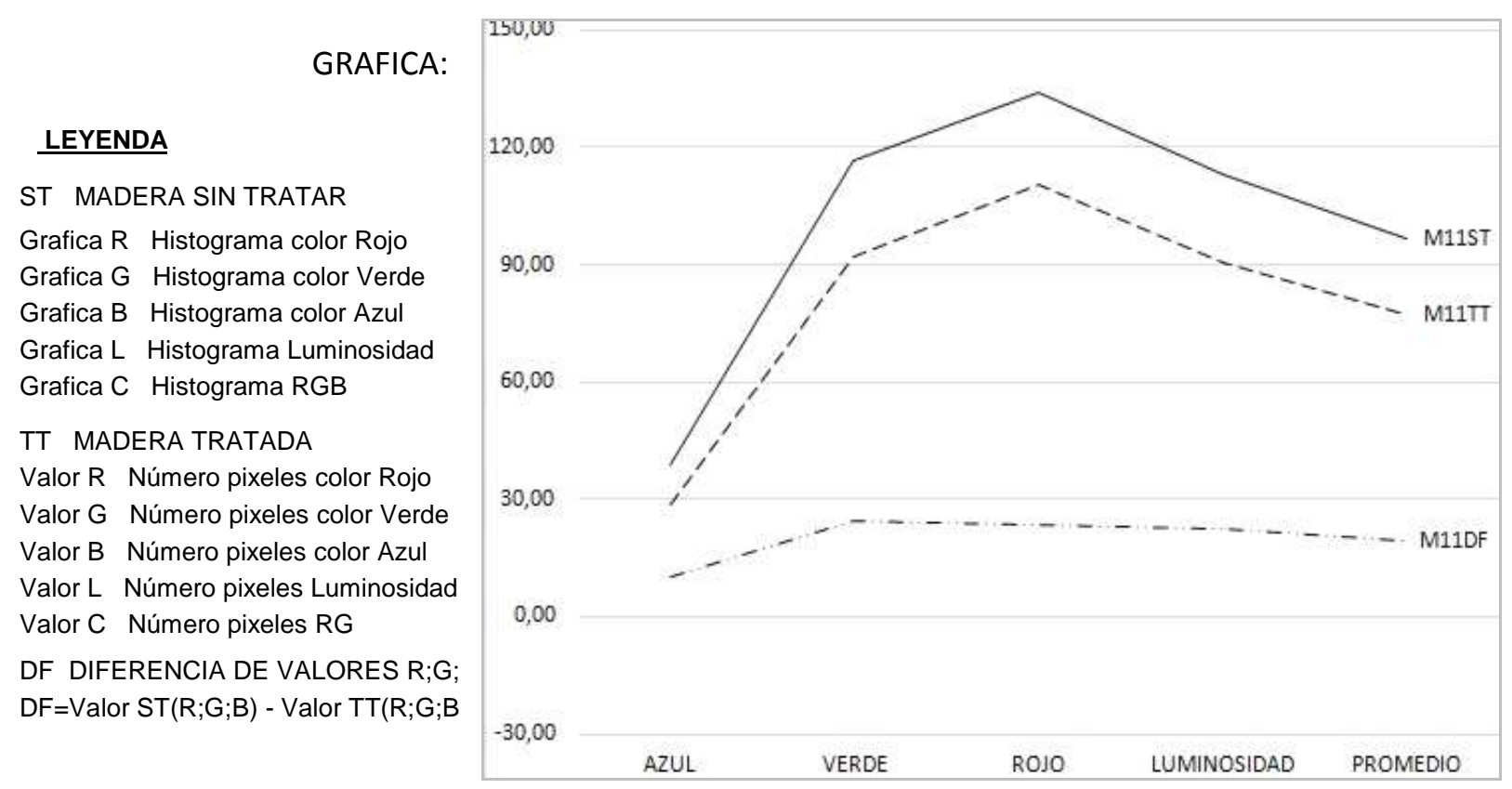

Universidad Politécnica de Madrid - Escuela Técnica Superior de Arquitectura - Departamento de Construcción y Tecnología Arquitectónica Directores: Dr. Alfonso García Santos y Dr. Antonio Rodríguez Rodríguez. Doctorando: D. Francisco Lora Toro 


\section{FICHA DE ENSAYOS DE MADERA Y ACIDOS}

\section{ACIDO A03/CL/ACIDO CLORHIDRICO}
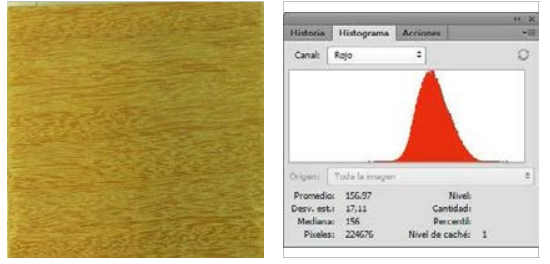

SIN TRATAR (ST): Grafica R (ST)

Valor R(ST):

156,97

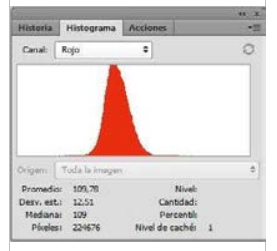

TRATADA (TT): Grafica $R(T T)$

Valor $\mathrm{R}(\mathrm{TT})$ :

109,78

DIFERENCIA (DF) Grafica R (DF):

Valor DF-R:

47,19

GRAFICA:

\section{LEYENDA}

ST MADERA SIN TRATAR

Grafica R Histograma color Rojo

Grafica G Histograma color Verde

Grafica B Histograma color Azul

Grafica L Histograma Luminosidad

Grafica C Histograma RGB

TT MADERA TRATADA

Valor R Número pixeles color Rojo

Valor $\mathrm{G}$ Número pixeles color Verde

Valor B Número pixeles color Azul

Valor $L$ Número pixeles Luminosidad

Valor $C$ Número pixeles $R G$

DF DIFERENCIA DE VALORES R;G; $\mathrm{DF}=$ Valor $\mathrm{ST}(\mathrm{R} ; \mathrm{G} ; \mathrm{B})$ - Valor TT $(\mathrm{R} ; \mathrm{G} ; \mathrm{B}$

\section{MADERA M12/CM/CUMARÚ}

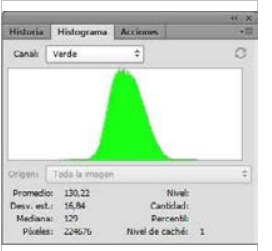

Grafica G (ST)

Valor $\mathrm{G}(\mathrm{ST})$ :

130,22

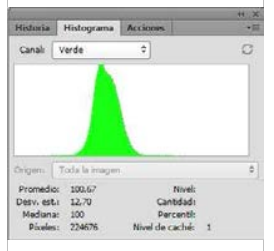

Grafica G (TT)
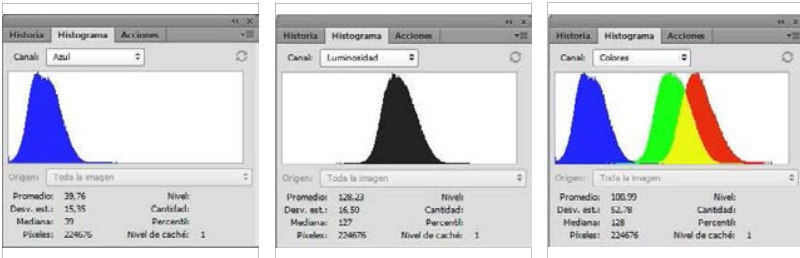

Grafica B (ST)

Grafica L (ST)

Grafica C (ST)

Valor B(ST):

Valor L(ST):

Valor C(ST):

39,76

128,23

108,99
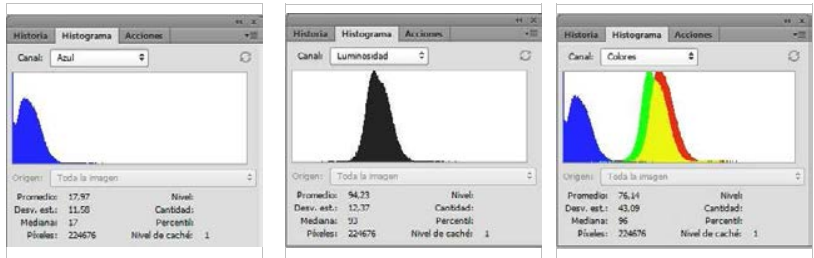

Grafica L (TT)

Grafica C (TT)

Valor $\mathrm{G}(\mathrm{TT})$ :

Valor $\mathrm{B}(\mathrm{TT})$ :

Valor L(TT):

Valor $\mathrm{C}(\mathrm{TT})$ :

100,67

17,97

94,23

76,14

Grafica G (DF): Grafica B (DF): Grafica L (DF): Grafica C (DF): Valor DF-G: Valor DF-B: Valor DF-L: Valor DF-C: 29,55 21,79 34,00 32,85

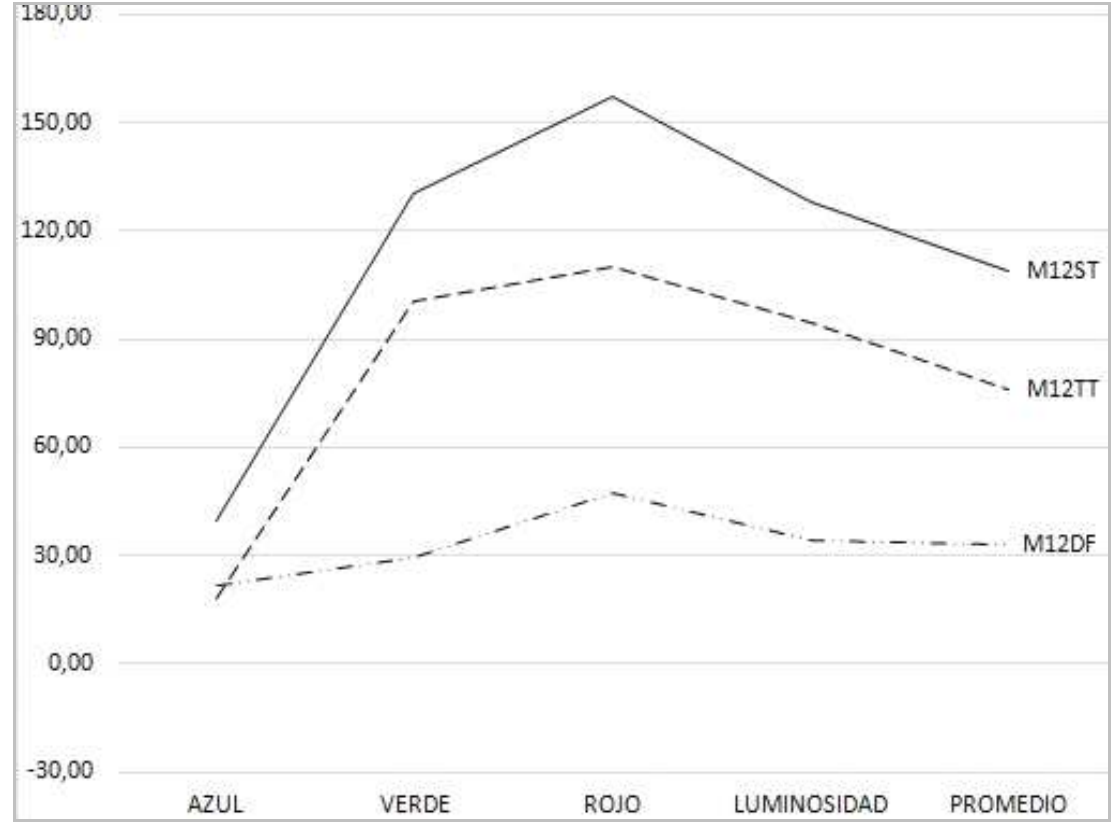

Universidad Politécnica de Madrid - Escuela Técnica Superior de Arquitectura - Departamento de Construcción y Tecnología Arquitectónica Directores: Dr. Alfonso García Santos y Dr. Antonio Rodríguez Rodríguez. Doctorando: D. Francisco Lora Toro 


\section{FICHA DE ENSAYOS DE MADERA Y ACIDOS}

\section{ACIDO A03/CL/ACIDO CLORHIDRICO}
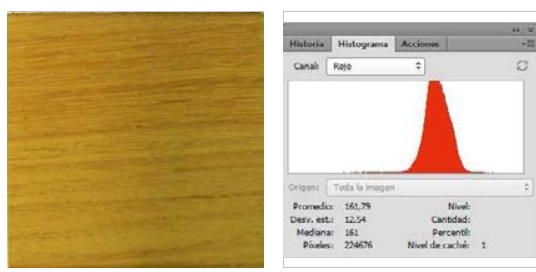

SIN TRATAR (ST): Grafica R (ST)

Valor R(ST):

161,79

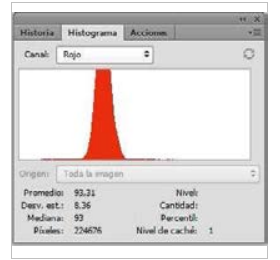

TRATADA (TT): Grafica R (TT)

Valor $\mathrm{R}(\mathrm{TT})$ :

93,31

DIFERENCIA (DF) Grafica R (DF): Valor DF-R: 68,48

GRAFICA:

\section{LEYENDA}

ST MADERA SIN TRATAR

Grafica R Histograma color Rojo

Grafica G Histograma color Verde

Grafica B Histograma color Azul

Grafica L Histograma Luminosidad

Grafica C Histograma RGB

TT MADERA TRATADA

Valor $R$ Número pixeles color Rojo

Valor $\mathrm{G}$ Número pixeles color Verde

Valor B Número pixeles color Azul

Valor $L$ Número pixeles Luminosidad

Valor C Número pixeles RG

DF DIFERENCIA DE VALORES R;G; $\mathrm{DF}=$ Valor $\mathrm{ST}(\mathrm{R} ; \mathrm{G} ; \mathrm{B})$ - Valor TT $(\mathrm{R} ; \mathrm{G} ; \mathrm{B}$
MADERA M13/DS/DOUSSIÉ

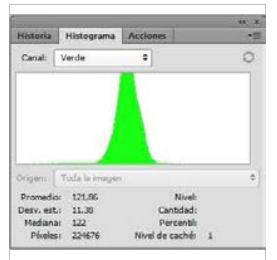

Grafica G (ST)

Valor $\mathrm{G}(\mathrm{ST})$ :

121,86

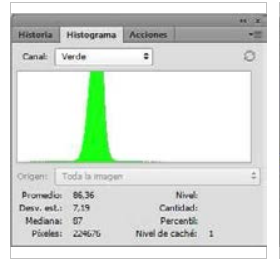

Grafica G (TT)

Valor $\mathrm{G}(\mathrm{TT})$ :

86,36

Grafica G (DF): Grafica B (DF): Valor DF-B:

8,41

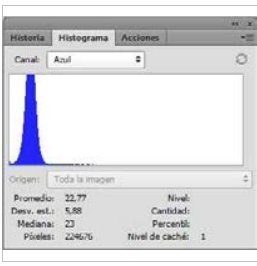

Grafica B (TT)

Valor $\mathrm{B}(\mathrm{TT})$ :

22,77
Valor DF-G:

Grafica L (DF):

35,50

42,50

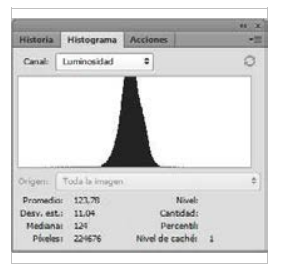

Grafica L (ST)

Valor L(ST):

123,78

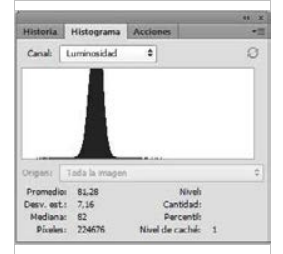

Grafica L (TT)

Valor L(TT):

81,28

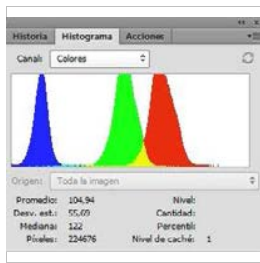

Grafica C (ST)

Valor C(ST):

104,94

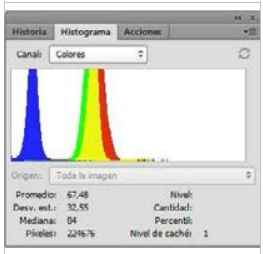

Grafica C (TT)

Valor C(TT):

67,48

Grafica C (DF):

Valor DF-C:

37,46

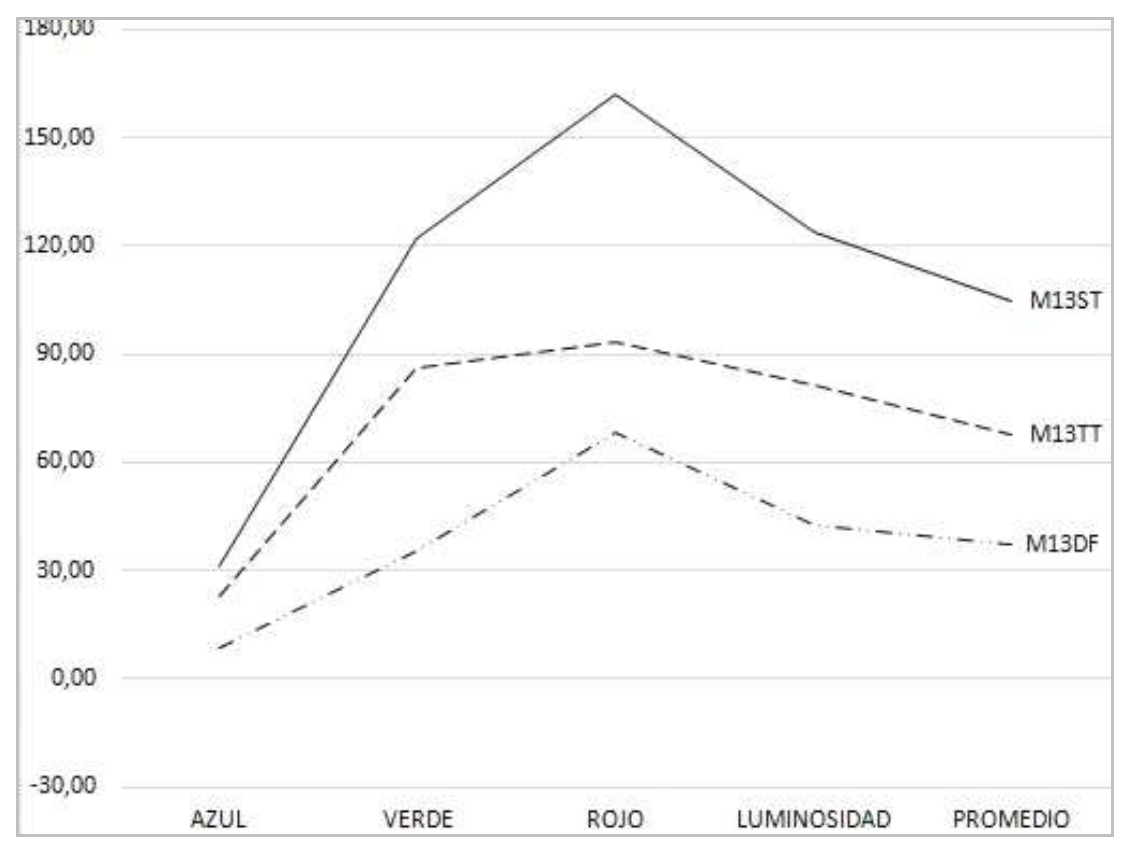

Universidad Politécnica de Madrid - Escuela Técnica Superior de Arquitectura - Departamento de Construcción y Tecnología Arquitectónica Directores: Dr. Alfonso García Santos y Dr. Antonio Rodríguez Rodríguez. Doctorando: D. Francisco Lora Toro 


\section{FICHA DE ENSAYOS DE MADERA Y ACIDOS}

\section{ACIDO A03/CL/ACIDO CLORHIDRICO}
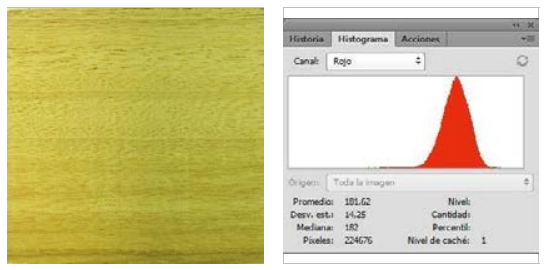

SIN TRATAR (ST): Grafica R (ST)

Valor R(ST):

181,62

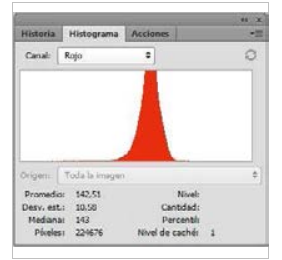

TRATADA (TT): Grafica R (TT)

Valor $\mathrm{R}(\mathrm{TT})$ :

142,51

DIFERENCIA (DF) Grafica R (DF): Valor DF-R: 39,11

GRAFICA:

\section{LEYENDA}

ST MADERA SIN TRATAR

Grafica R Histograma color Rojo Grafica G Histograma color Verde Grafica B Histograma color Azul Grafica L Histograma Luminosidad Grafica C Histograma RGB

\section{TT MADERA TRATADA}

Valor $R$ Número pixeles color Rojo Valor $\mathrm{G}$ Número pixeles color Verde Valor B Número pixeles color Azul Valor $L$ Número pixeles Luminosidad Valor C Número pixeles RG DF DIFERENCIA DE VALORES R;G; $\mathrm{DF}=$ Valor $\mathrm{ST}(\mathrm{R} ; \mathrm{G} ; \mathrm{B})$ - Valor TT $(\mathrm{R} ; \mathrm{G} ; \mathrm{B}$

\section{MADERA M14/FR/FRAMIRÉ}

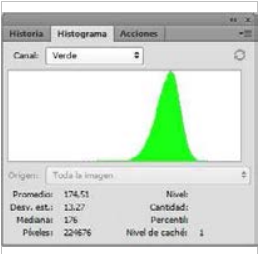

Grafica G (ST)

Valor $\mathrm{G}(\mathrm{ST})$ :

174,51

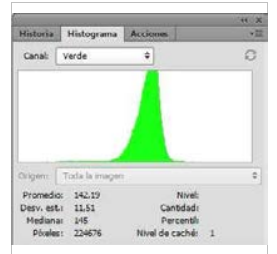

Grafica G (TT)

Valor $\mathrm{G}(\mathrm{TT})$ :

142,19

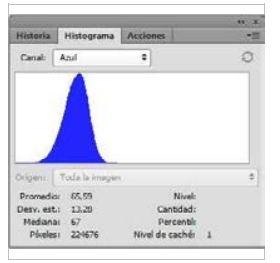

Grafica B (ST)

Valor B(ST):

65,59

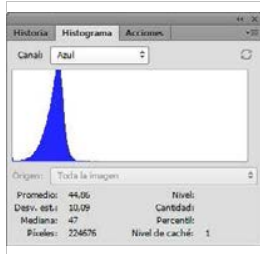

Grafica B (TT)

Valor $\mathrm{B}(\mathrm{TT})$ :

44,86

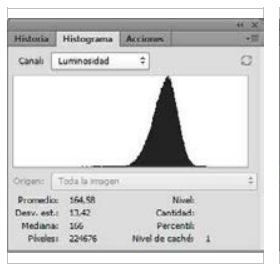

Grafica L (ST)

Valor L(ST):

164,58

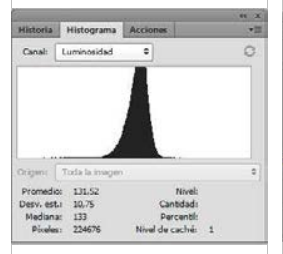

Grafica L (TT)

Valor L(TT):

131,52

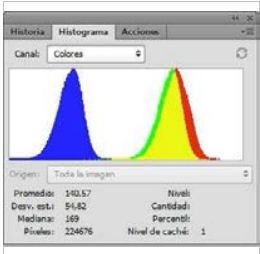

Grafica C (ST)

Valor C(ST):

140,57

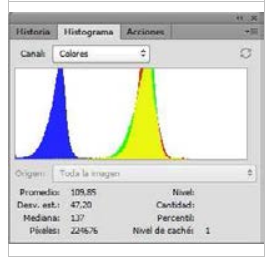

Grafica C (TT)

Valor C(TT):

109,85

Grafica G (DF): Grafica B (DF): Grafica L (DF): Grafica C (DF): Valor DF-G: $\quad$ Valor DF-B: $\quad$ Valor DF-L: Valor DF-C:

$32,32 \quad 30,73 \quad 33,06 \quad 30,72$

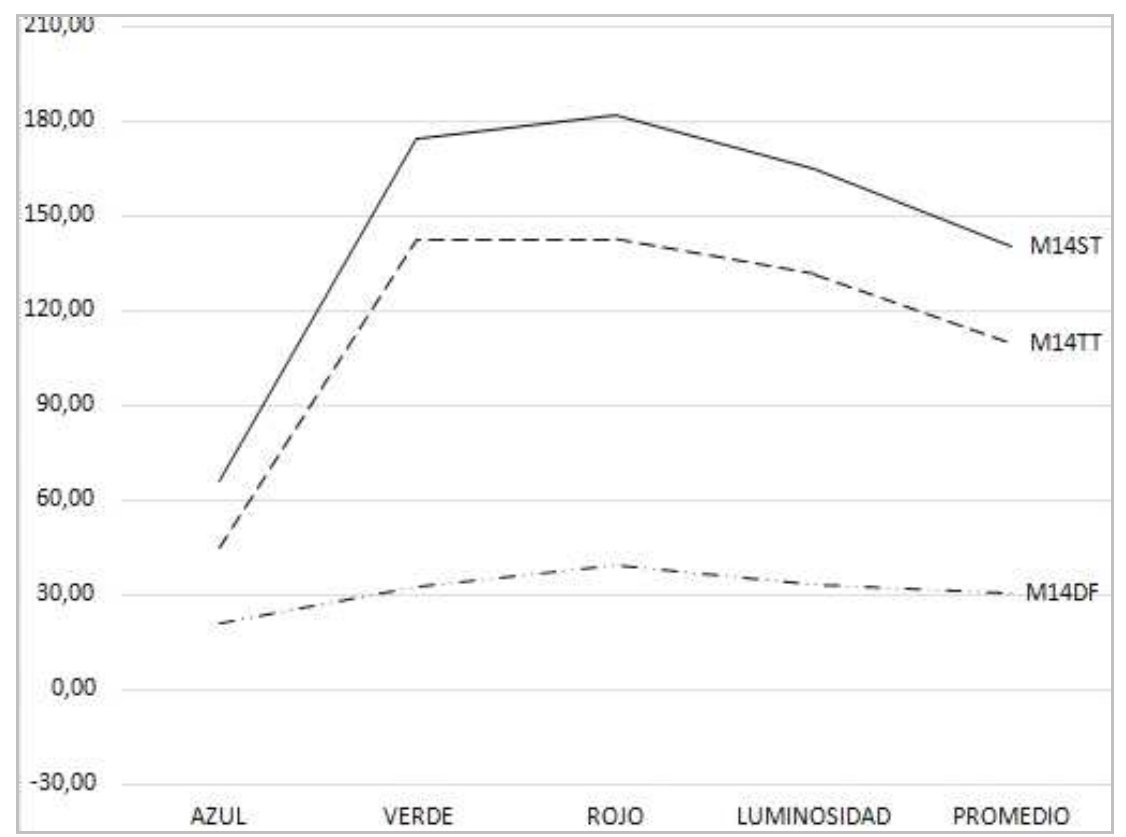

Universidad Politécnica de Madrid - Escuela Técnica Superior de Arquitectura - Departamento de Construcción y Tecnología Arquitectónica Directores: Dr. Alfonso García Santos y Dr. Antonio Rodríguez Rodríguez. Doctorando: D. Francisco Lora Toro 


\section{FICHA DE ENSAYOS DE MADERA Y ACIDOS}

\section{ACIDO A03/CL/ACIDO CLORHIDRICO}

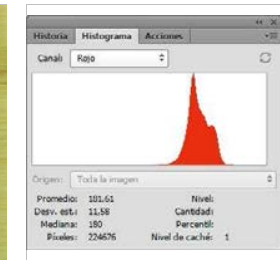

SIN TRATAR (ST): Grafica R (ST)

Valor R(ST):

181,61

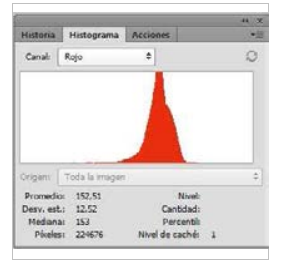

TRATADA (TT): Grafica R (TT)

Valor $\mathrm{R}(\mathrm{TT})$ :

152,51

DIFERENCIA (DF) Grafica R (DF): Valor DF-R: 29,10

GRAFICA:

\section{LEYENDA}

ST MADERA SIN TRATAR

Grafica R Histograma color Rojo Grafica G Histograma color Verde Grafica B Histograma color Azul Grafica L Histograma Luminosidad Grafica C Histograma RGB

\section{TT MADERA TRATADA}

Valor R Número pixeles color Rojo Valor $\mathrm{G}$ Número pixeles color Verde Valor B Número pixeles color Azul Valor $L$ Número pixeles Luminosidad Valor C Número pixeles RG DF DIFERENCIA DE VALORES R;G; $\mathrm{DF}=$ Valor $\mathrm{ST}(\mathrm{R} ; \mathrm{G} ; \mathrm{B})$ - Valor TT(R;G;B

\section{MADERA M15/FBA/FRESNO BLANCO AMERICAN}

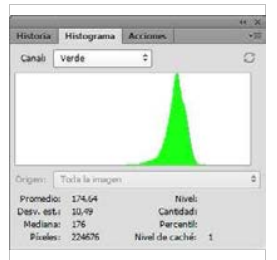

Grafica G (ST)

Valor $\mathrm{G}(\mathrm{ST})$ :

174,64
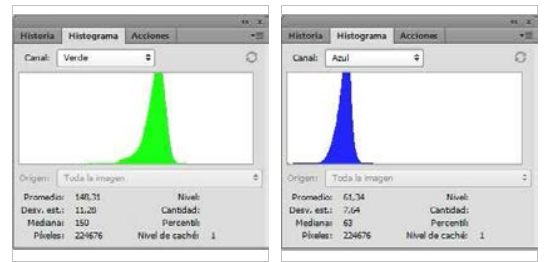

Grafica G (TT)

Grafica B (TT)

Valor $\mathrm{B}(\mathrm{TT})$ :

61,34

148,31

Grafica G (DF): Grafica B (DF):

Grafica L (DF):

Grafica C (DF):

Valor DF-G:

Valor DF-B:

Valor DF-L:

Valor DF-C:

26,33

21,52

26,63

25,65

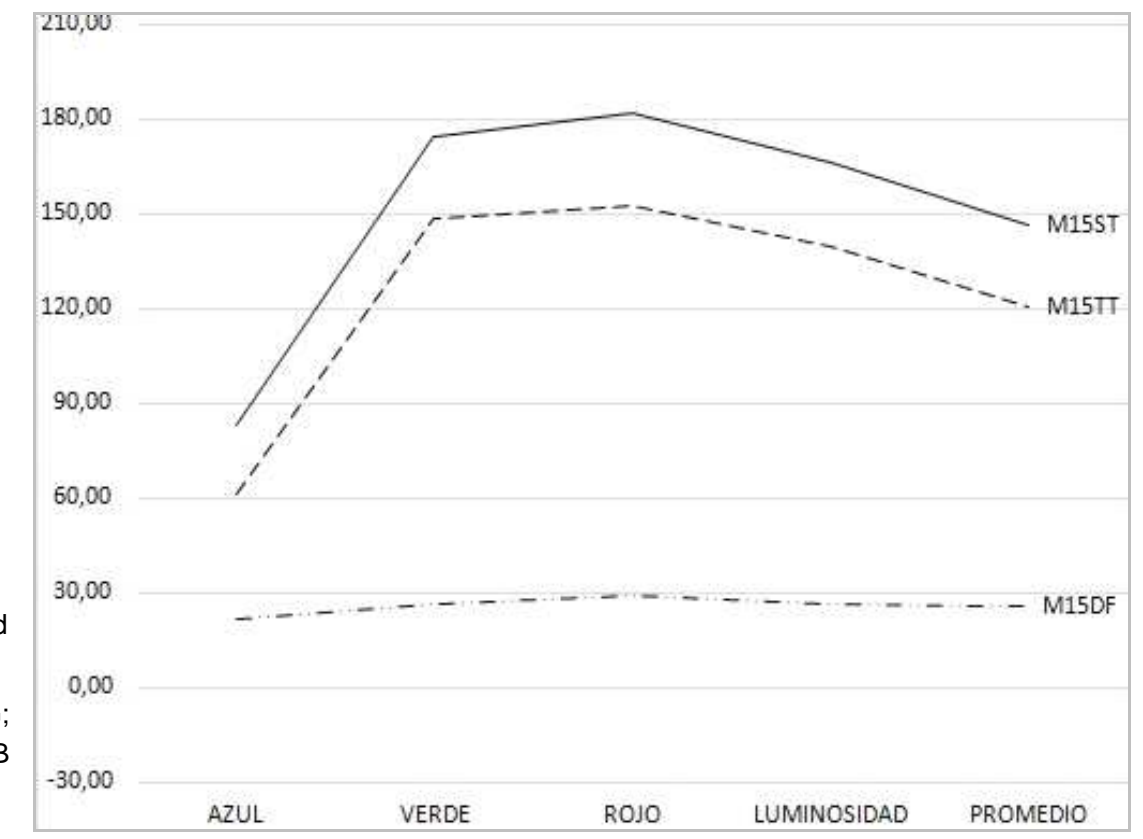

Universidad Politécnica de Madrid - Escuela Técnica Superior de Arquitectura - Departamento de Construcción y Tecnología Arquitectónica Directores: Dr. Alfonso García Santos y Dr. Antonio Rodríguez Rodríguez. Doctorando: D. Francisco Lora Toro 


\section{FICHA DE ENSAYOS DE MADERA Y ACIDOS}

\section{ACIDO A03/CL/ACIDO CLORHIDRICO}
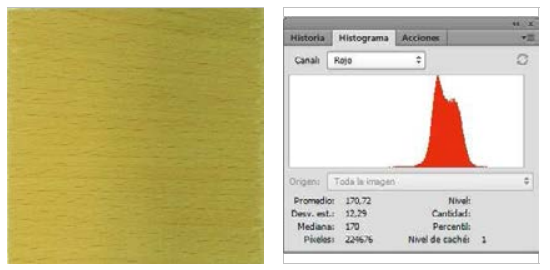

SIN TRATAR (ST): Grafica R (ST)

Valor R(ST):

170,72

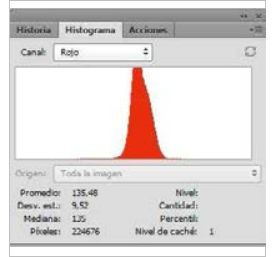

TRATADA (TT): Grafica R (TT)

Valor R(TT):

135,48

DIFERENCIA (DF) Grafica R (DF): Valor DF-R: 35,24

GRAFICA:

\section{LEYENDA}

ST MADERA SIN TRATAR

Grafica R Histograma color Rojo Grafica G Histograma color Verde Grafica B Histograma color Azul Grafica L Histograma Luminosidad Grafica C Histograma RGB

\section{TT MADERA TRATADA}

Valor R Número pixeles color Rojo Valor $G$ Número pixeles color Verde Valor B Número pixeles color Azul Valor $L$ Número pixeles Luminosidad Valor C Número pixeles RG DF DIFERENCIA DE VALORES R;G; $\mathrm{DF}=$ Valor $\mathrm{ST}(\mathrm{R} ; \mathrm{G} ; \mathrm{B})$ - Valor $\mathrm{TT}(\mathrm{R} ; \mathrm{G} ; \mathrm{B}$

\section{MADERA M16/H/HAYA}

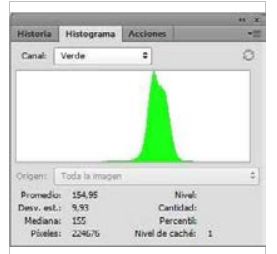

Grafica G (ST)

Valor G(ST):

154,95

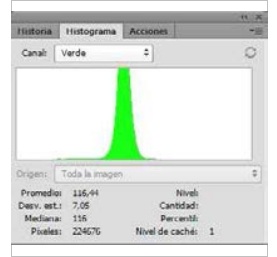

Grafica G (TT)

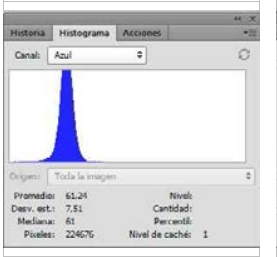

Grafica B (ST)

Valor B(ST):

61,24
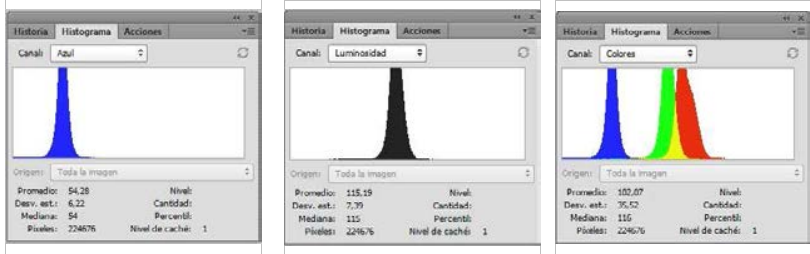

Grafica B (TT)

Grafica L (TT)

Grafica C (TT)

Valor G(TT):

Valor $\mathrm{B}(\mathrm{TT})$ :

Valor L(TT):

Valor C(TT):

116,44

54,28

115,19

102,07

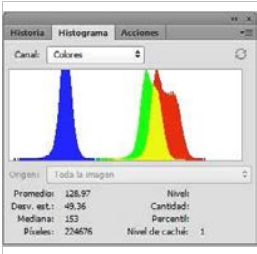

Grafica C (ST)

Valor C(ST):

128,97

Grafica G (DF): Grafica B (DF): Grafica L (DF): Grafica C (DF): Valor DF-G: Valor DF-B: Valor DF-L: Valor DF-C: 38,51 6,96 34,07 26,90

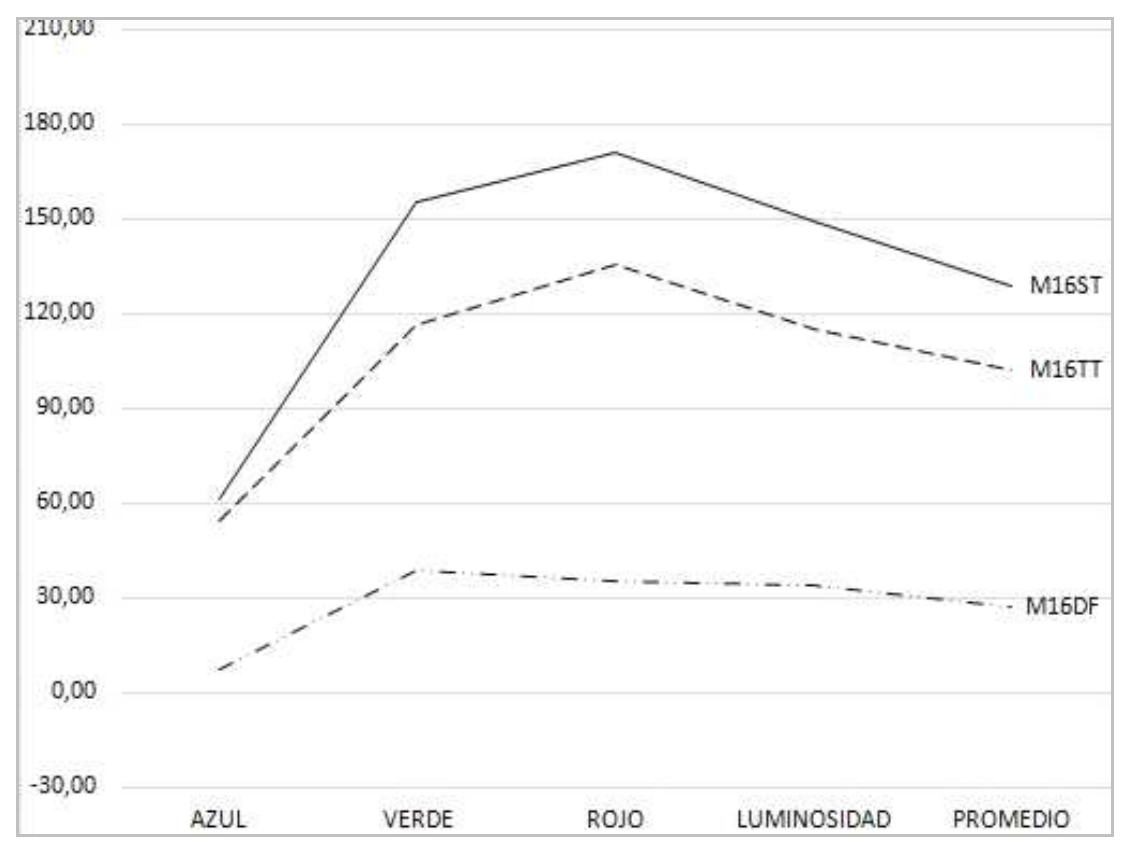

Universidad Politécnica de Madrid - Escuela Técnica Superior de Arquitectura - Departamento de Construcción y Tecnología Arquitectónica Directores: Dr. Alfonso García Santos y Dr. Antonio Rodríguez Rodríguez. Doctorando: D. Francisco Lora Toro 


\section{FICHA DE ENSAYOS DE MADERA Y ACIDOS}

\section{ACIDO A03/CL/ACIDO CLORHIDRICO}
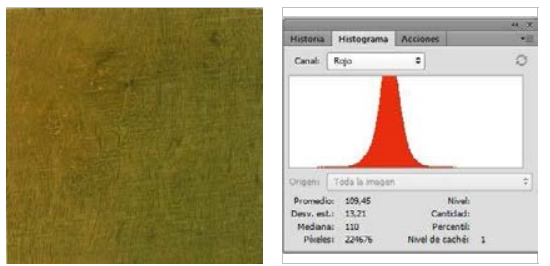

SIN TRATAR (ST): Grafica R (ST)

Valor R(ST):

109,45
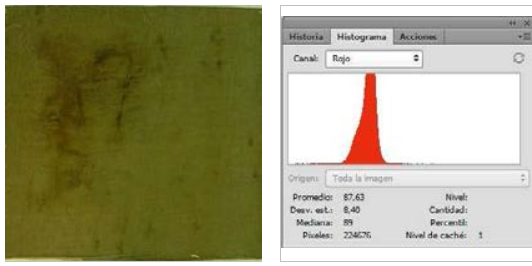

TRATADA (TT): Grafica R (TT)

Valor $\mathrm{R}(\mathrm{TT})$ :

87,63

DIFERENCIA (DF) Grafica R (DF): Valor DF-R: 21,82

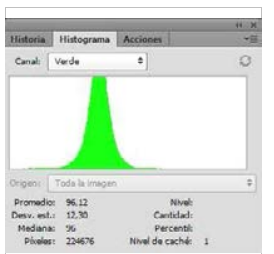

Grafica G (ST)

Valor G(ST):

96,12

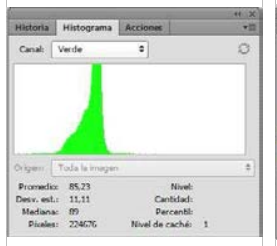

Grafica G (TT)

Valor $\mathrm{G}(\mathrm{TT})$ :

85,23
MADERA M17/IP/IPÉ

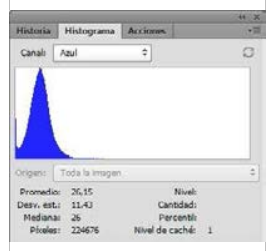

Grafica B (ST)

Valor $\mathrm{B}(\mathrm{ST})$ :

26,15

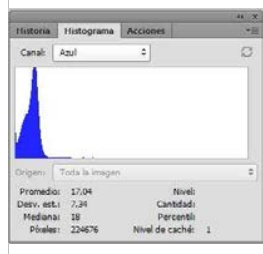

Grafica B (TT)

Valor $\mathrm{B}(\mathrm{TT})$ :

17,04

Grafica G (DF): Grafica B (DF): Valor DF-B:

9,11

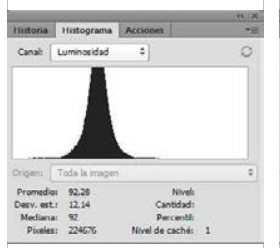

Grafica L (ST)

Valor L(ST):

92,28

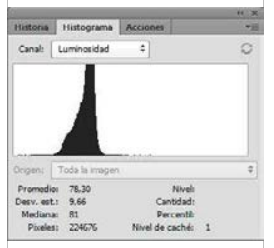

Grafica L (TT)

Valor L(TT):

78,30

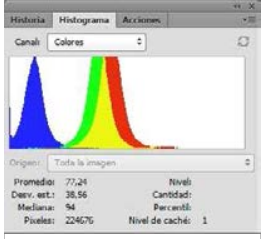

Grafica C (ST)

Valor C(ST):

77,24

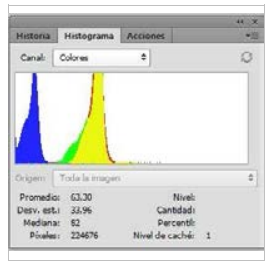

Grafica C (TT)

Valor $\mathrm{C}(\mathrm{TT})$ :

63,30

Grafica L (DF): Grafica C (DF): Valor DF-L: Valor DF-C:

$\begin{array}{llll}10,89 & 9,11 & 13,98 & 13,94\end{array}$

GRAFICA

\section{LEYENDA}

ST MADERA SIN TRATAR

Grafica R Histograma color Rojo Grafica G Histograma color Verde Grafica B Histograma color Azul Grafica L Histograma Luminosidad Grafica C Histograma RGB

TT MADERA TRATADA

Valor $\mathrm{R}$ Número pixeles color Rojo Valor $\mathrm{G}$ Número pixeles color Verde Valor B Número pixeles color Azul Valor $L$ Número pixeles Luminosidad Valor $C$ Número pixeles RG DF DIFERENCIA DE VALORES R;G; $\mathrm{DF}=$ Valor $\mathrm{ST}(\mathrm{R} ; \mathrm{G} ; \mathrm{B})$ - Valor TT(R;G;B

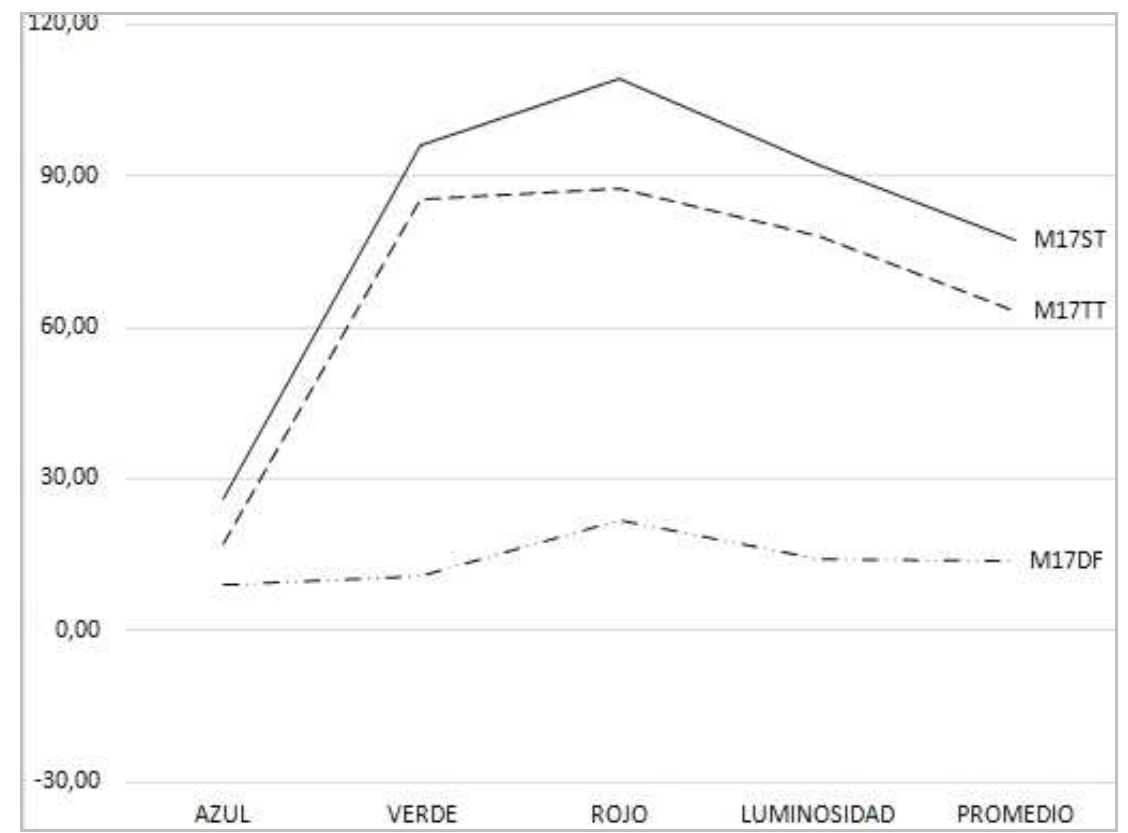

Universidad Politécnica de Madrid - Escuela Técnica Superior de Arquitectura - Departamento de Construcción y Tecnología Arquitectónica Directores: Dr. Alfonso García Santos y Dr. Antonio Rodríguez Rodríguez. Doctorando: D. Francisco Lora Toro 


\section{FICHA DE ENSAYOS DE MADERA Y ACIDOS}

\section{ACIDO A03/CL/ACIDO CLORHIDRICO}
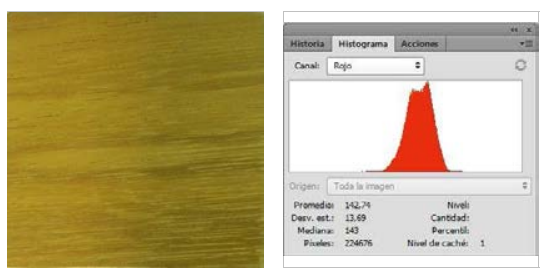

SIN TRATAR (ST): Grafica R (ST)

Valor R(ST):

142,74

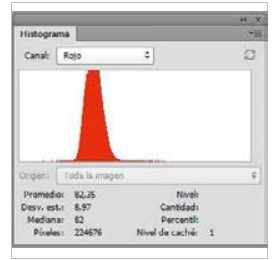

TRATADA (TT): Grafica R (TT)

Valor $\mathrm{R}(\mathrm{TT})$ :

82,35

DIFERENCIA (DF) Grafica R (DF): Valor DF-R:

60,39

GRAFICA:

\section{LEYENDA}

ST MADERA SIN TRATAR

Grafica R Histograma color Rojo

Grafica G Histograma color Verde

Grafica B Histograma color Azul

Grafica L Histograma Luminosidad

Grafica C Histograma RGB

TT MADERA TRATADA

Valor $R$ Número pixeles color Rojo

Valor $\mathrm{G}$ Número pixeles color Verde

Valor B Número pixeles color Azul

Valor $\mathrm{L}$ Número pixeles Luminosidad

Valor C Número pixeles RG

DF DIFERENCIA DE VALORES R;G; $\mathrm{DF}=$ Valor $\mathrm{ST}(\mathrm{R} ; \mathrm{G} ; \mathrm{B})$ - Valor TT $(\mathrm{R} ; \mathrm{G} ; \mathrm{B}$

\section{MADERA M18/IK/IROKO}

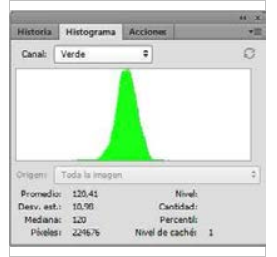

Grafica G (ST)

Valor $\mathrm{G}(\mathrm{ST})$ :

120,41

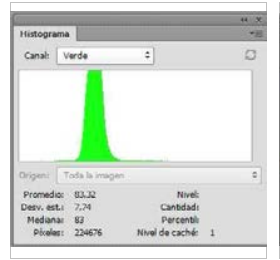

Grafica G (TT)

Valor $\mathrm{G}(\mathrm{TT})$ :

83,32

Grafica G (DF): Grafica B (DF):

Valor DF-B:

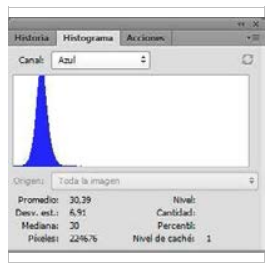

Grafica B (ST)

Valor B(ST):

30,39

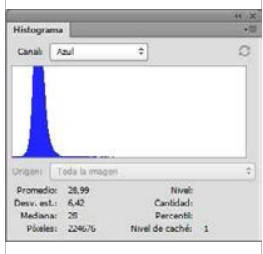

Grafica B (TT)

Valor B(TT):

28,99

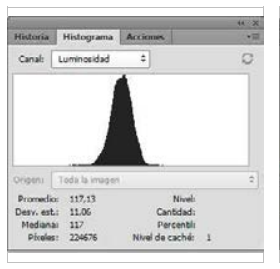

Grafica L (ST)

Valor L(ST):

117,13

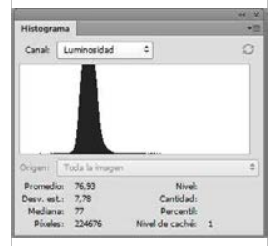

Grafica L (TT)

Valor L(TT):

76,93

Grafica L (DF):

Valor DF-L:

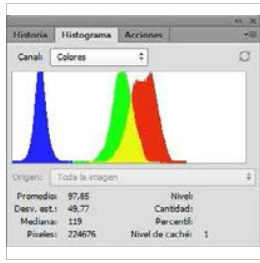

Grafica C (ST)

Valor C(ST):

97,85
1,40
40,20
37,09

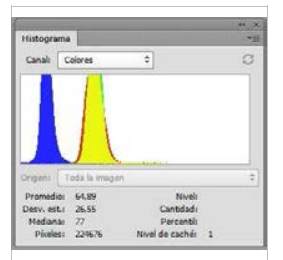

Grafica C (TT)

Valor C(TT):

64,89

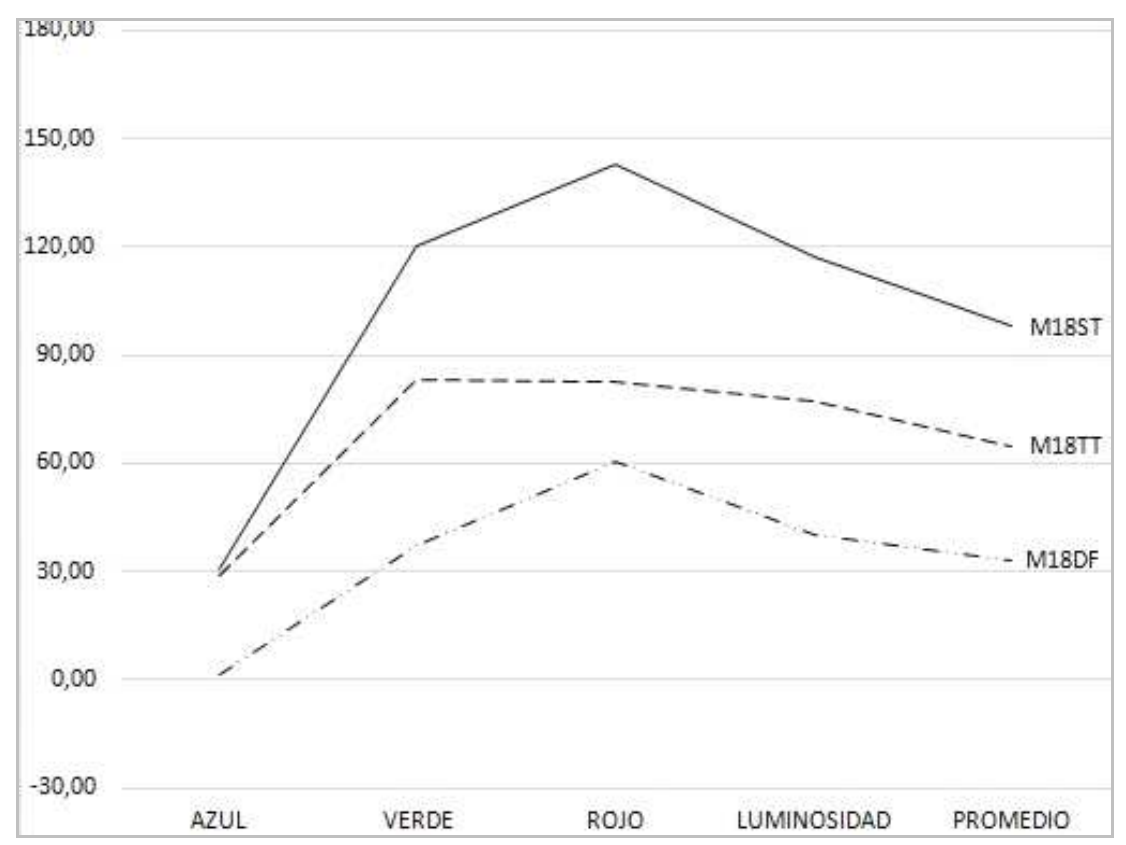

Universidad Politécnica de Madrid - Escuela Técnica Superior de Arquitectura - Departamento de Construcción y Tecnología Arquitectónica Directores: Dr. Alfonso García Santos y Dr. Antonio Rodríguez Rodríguez. Doctorando: D. Francisco Lora Toro 


\section{FICHA DE ENSAYOS DE MADERA Y ACIDOS}

\section{ACIDO A03/CL/ACIDO CLORHIDRICO}
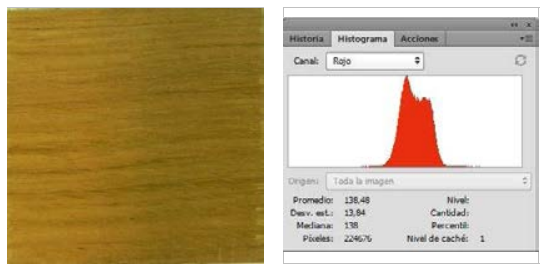

SIN TRATAR (ST): Grafica R (ST)

Valor R(ST):

138,48

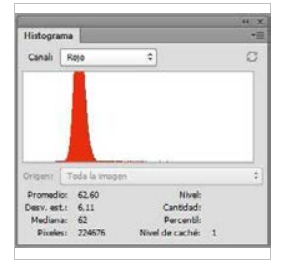

TRATADA (TT): Grafica R (TT)

Valor $R(T T)$ :

62,60

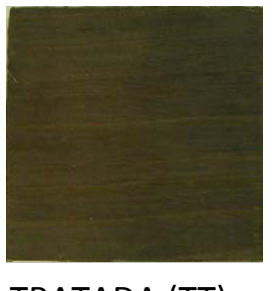

DIFERENCIA (DF) Grafica R (DF):

Valor DF-R:

75,88

GRAFICA:

\section{LEYENDA}

ST MADERA SIN TRATAR

Grafica R Histograma color Rojo

Grafica G Histograma color Verde

Grafica B Histograma color Azul

Grafica L Histograma Luminosidad

Grafica C Histograma RGB

\section{TT MADERA TRATADA}

Valor $\mathrm{R}$ Número pixeles color Rojo

Valor $\mathrm{G}$ Número pixeles color Verde

Valor B Número pixeles color Azul

Valor $\mathrm{L}$ Número pixeles Luminosidad

Valor C Número pixeles RG

DF DIFERENCIA DE VALORES R;G; $\mathrm{DF}=$ Valor $\mathrm{ST}(\mathrm{R} ; \mathrm{G} ; \mathrm{B})$ - Valor TT(R;G;B

\section{MADERA M19/JT/JATOBA}

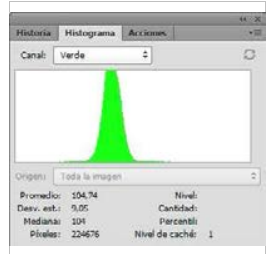

Grafica G (ST)

Valor G(ST):

104,74

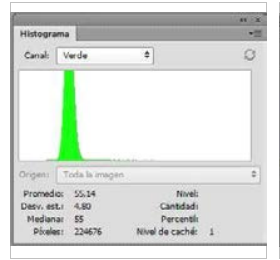

Grafica G (TT)

Valor G(TT):

55,14
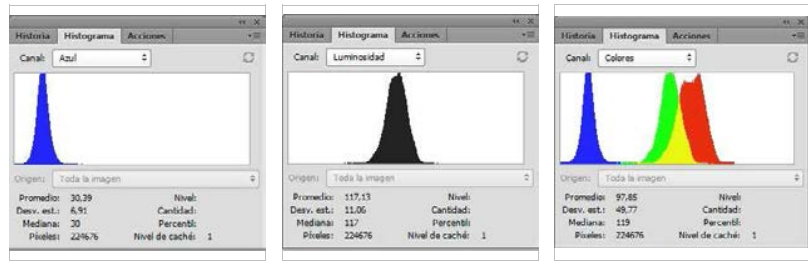

Grafica B (ST)

Grafica L (ST)

Grafica C (ST)

Valor $\mathrm{B}(\mathrm{ST})$ :

Valor L(ST):

Valor C(ST):

25,48

106,09

89,57
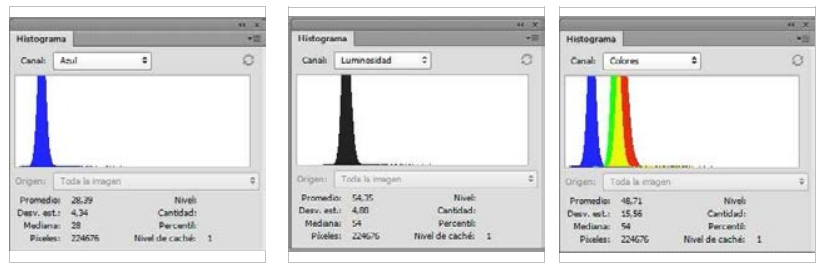

Grafica B (TT)

Grafica L (TT)

Grafica C (TT)

Valor $\mathrm{B}(\mathrm{TT})$ :

Valor L(TT):

Valor C(TT):

28,39

54,35

48,71

\section{Grafica G (DF): Grafica B (DF): Grafica L (DF):}

Grafica C (DF):

Valor DF-G:

Valor DF-B:

Valor DF-L:

Valor DF-C:

49,60

$-2,91$

51,74

40,86

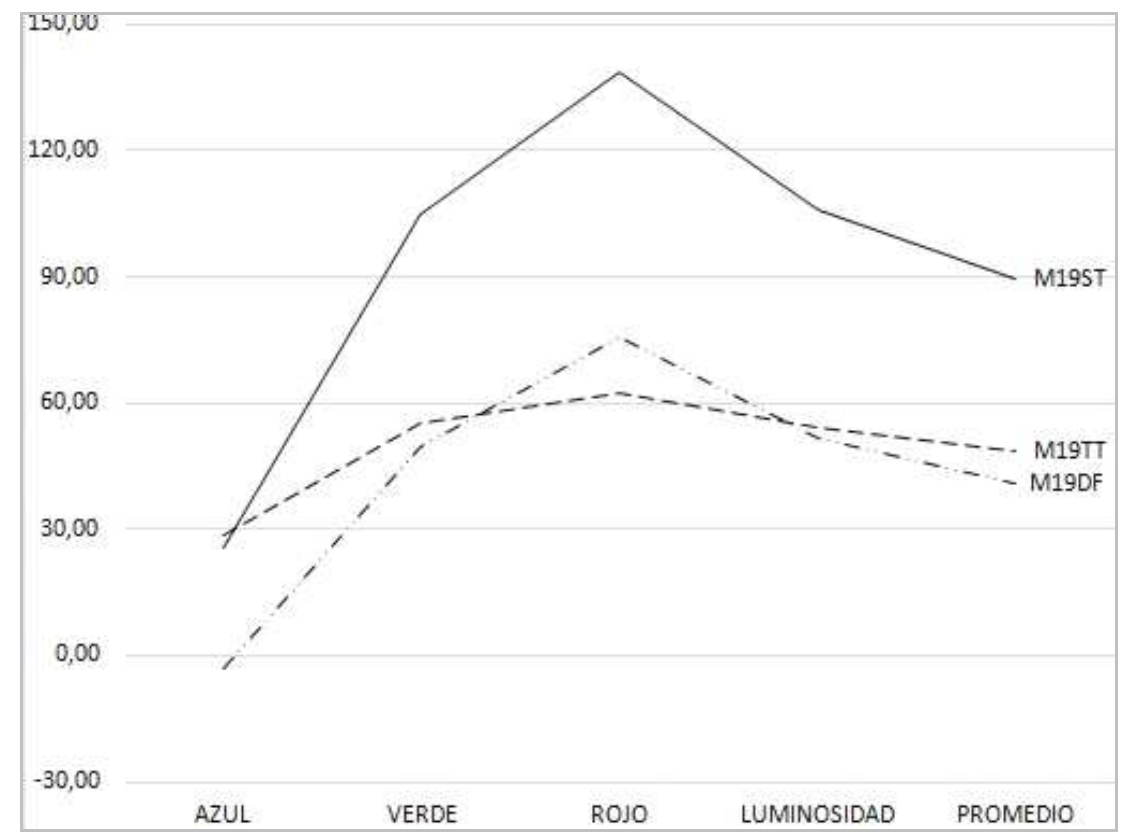

Universidad Politécnica de Madrid - Escuela Técnica Superior de Arquitectura - Departamento de Construcción y Tecnología Arquitectónica Directores: Dr. Alfonso García Santos y Dr. Antonio Rodríguez Rodríguez. Doctorando: D. Francisco Lora Toro 


\section{FICHA DE ENSAYOS DE MADERA Y ACIDOS}

\section{ACIDO A03/CL/ACIDO CLORHIDRICO}

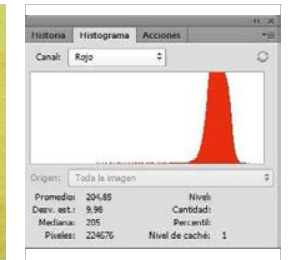

SIN TRATAR (ST): Grafica R (ST)

Valor R(ST):

204,85

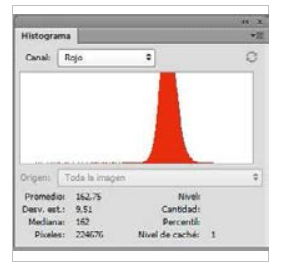

TRATADA (TT): Grafica R (TT)

Valor $\mathrm{R}(\mathrm{TT})$ :

162,75

DIFERENCIA (DF) Grafica R (DF):

Valor DF-R:

42,10

GRAFICA:

\section{LEYENDA}

ST MADERA SIN TRATAR

Grafica R Histograma color Rojo

Grafica G Histograma color Verde

Grafica B Histograma color Azul

Grafica L Histograma Luminosidad

Grafica C Histograma RGB

TT MADERA TRATADA

Valor $R$ Número pixeles color Rojo

Valor $\mathrm{G}$ Número pixeles color Verde

Valor B Número pixeles color Azul

Valor $L$ Número pixeles Luminosidad

Valor C Número pixeles RG

DF DIFERENCIA DE VALORES R;G;

$\mathrm{DF}=$ Valor $\mathrm{ST}(\mathrm{R} ; \mathrm{G} ; \mathrm{B})$ - Valor TT(R;G;B

\section{MADERA M20/KT/KOTO}

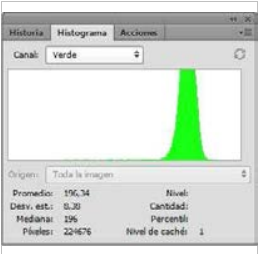

Grafica G (ST)

Valor $\mathrm{G}(\mathrm{ST})$ :

196,34

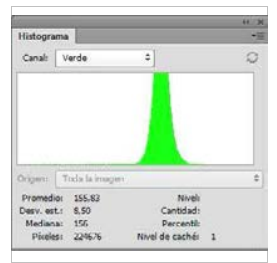

Grafica G (TT)

Valor $\mathrm{G}(\mathrm{TT})$ :

155,83

Grafica G (DF): Grafica B (DF):

Valor DF-G:

Valor DF-B:

33,27

40,51

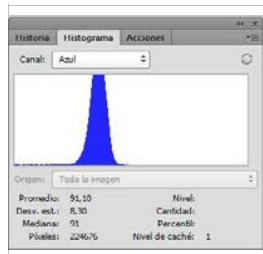

Grafica B (ST)

Valor B(ST):

91,10

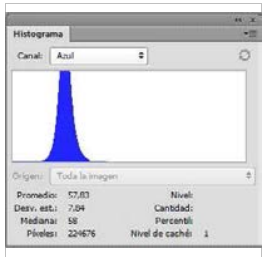

Grafica B (TT)

Valor $\mathrm{B}(\mathrm{TT})$ :

57,83

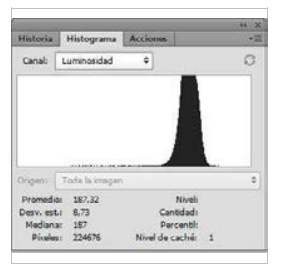

Grafica L (ST)

Valor L(ST):

187,32

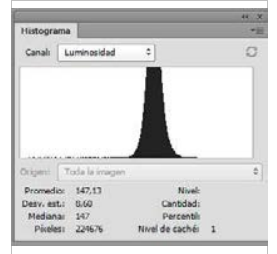

Grafica L (TT)

Valor L(TT):

147,13

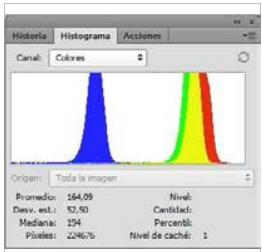

Grafica C (ST)

Valor C(ST):

164,09

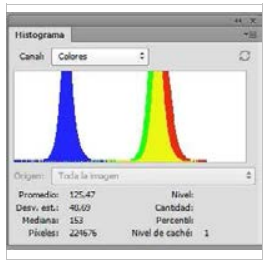

Grafica C (TT)

Valor C(TT):

125,47

Grafica L (DF): Grafica C (DF): Valor DF-L: Valor DF-C: 40,19 38,62

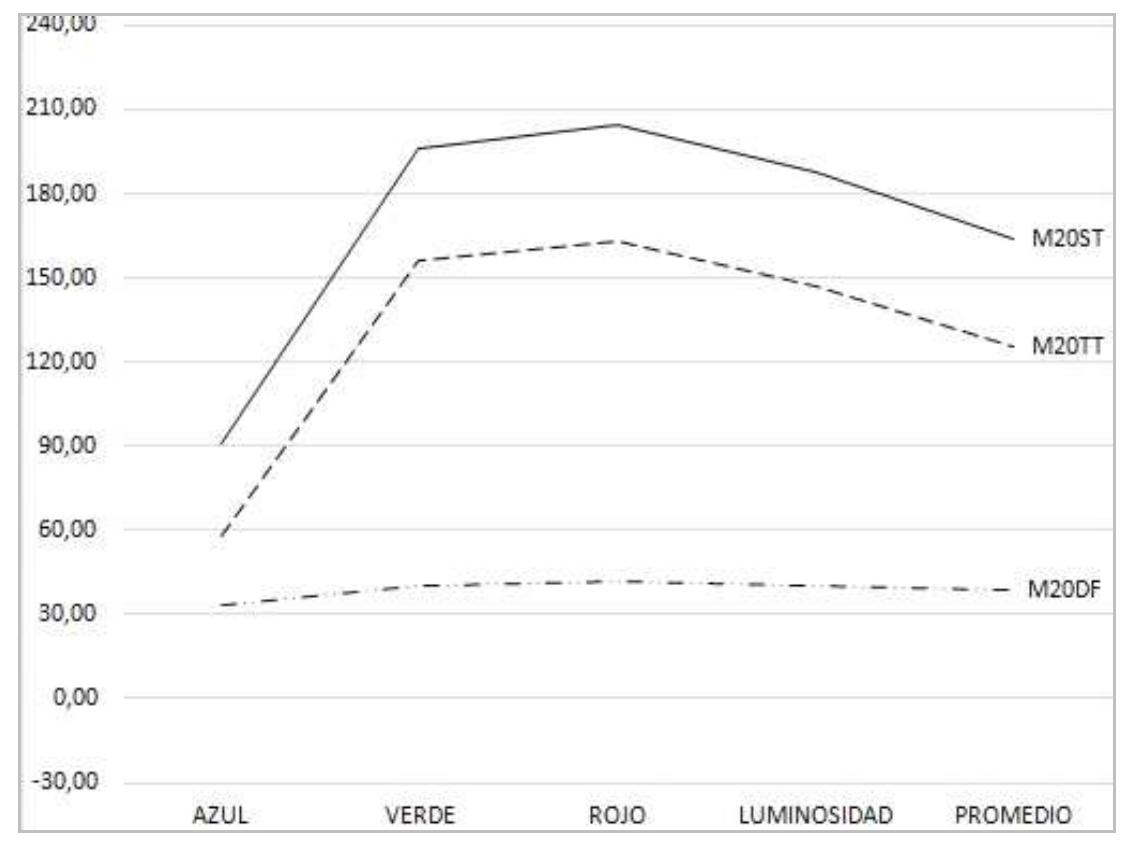

Universidad Politécnica de Madrid - Escuela Técnica Superior de Arquitectura - Departamento de Construcción y Tecnología Arquitectónica Directores: Dr. Alfonso García Santos y Dr. Antonio Rodríguez Rodríguez. Doctorando: D. Francisco Lora Toro 


\section{FICHA DE ENSAYOS DE MADERA Y ACIDOS}

\section{ACIDO A03/CL/ACIDO CLORHIDRICO}

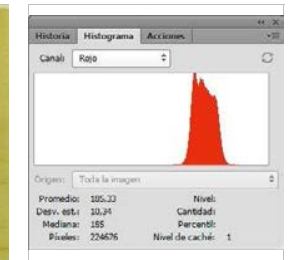

SIN TRATAR (ST): Grafica R (ST)

Valor R(ST):

185,33

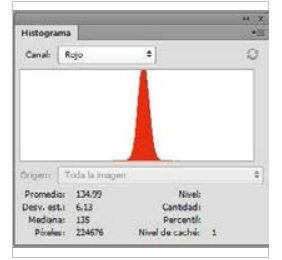

TRATADA (TT): Grafica R (TT)

Valor $\mathrm{R}(\mathrm{TT})$ :

134,99

DIFERENCIA (DF) Grafica R (DF):

Valor DF-R:

50,34

GRAFICA:

\section{LEYENDA}

ST MADERA SIN TRATAR

Grafica R Histograma color Rojo

Grafica G Histograma color Verde

Grafica B Histograma color Azul

Grafica L Histograma Luminosidad

Grafica C Histograma RGB

TT MADERA TRATADA

Valor $R$ Número pixeles color Rojo

Valor $\mathrm{G}$ Número pixeles color Verde

Valor B Número pixeles color Azul

Valor $L$ Número pixeles Luminosidad

Valor C Número pixeles RG

DF DIFERENCIA DE VALORES R;G;

$\mathrm{DF}=$ Valor $\mathrm{ST}(\mathrm{R} ; \mathrm{G} ; \mathrm{B})$ - Valor TT(R;G;B

\section{MADERA M21/LG/LENGA}

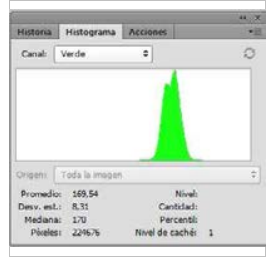

Grafica G (ST)

Valor $\mathrm{G}(\mathrm{ST})$ :

169,54

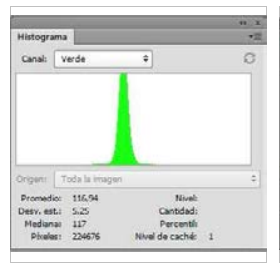

Grafica G (TT)

Valor G(TT):

116,94
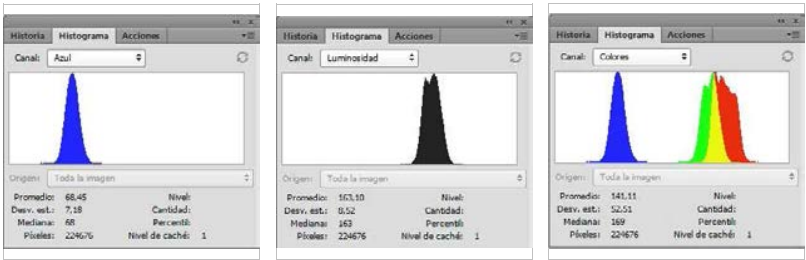

Grafica B (ST)

Grafica L (ST)

Grafica C (ST)

Valor B(ST):

Valor L(ST):

Valor C(ST):

68,45

163,10

141,11
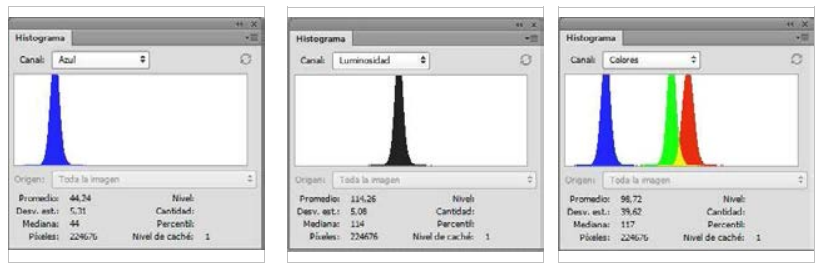

Grafica B (TT)

Grafica L (TT)

Grafica C (TT)

Valor $\mathrm{B}(\mathrm{TT})$ :

Valor L(TT):

Valor C(TT):

44,24

114,26

98,72

Grafica G (DF): Grafica B (DF): Grafica L (DF): Grafica C (DF): Valor DF-G: Valor DF-B: Valor DF-L: Valor DF-C:

$52,60 \quad 24,21 \quad 48,84 \quad 42,39$

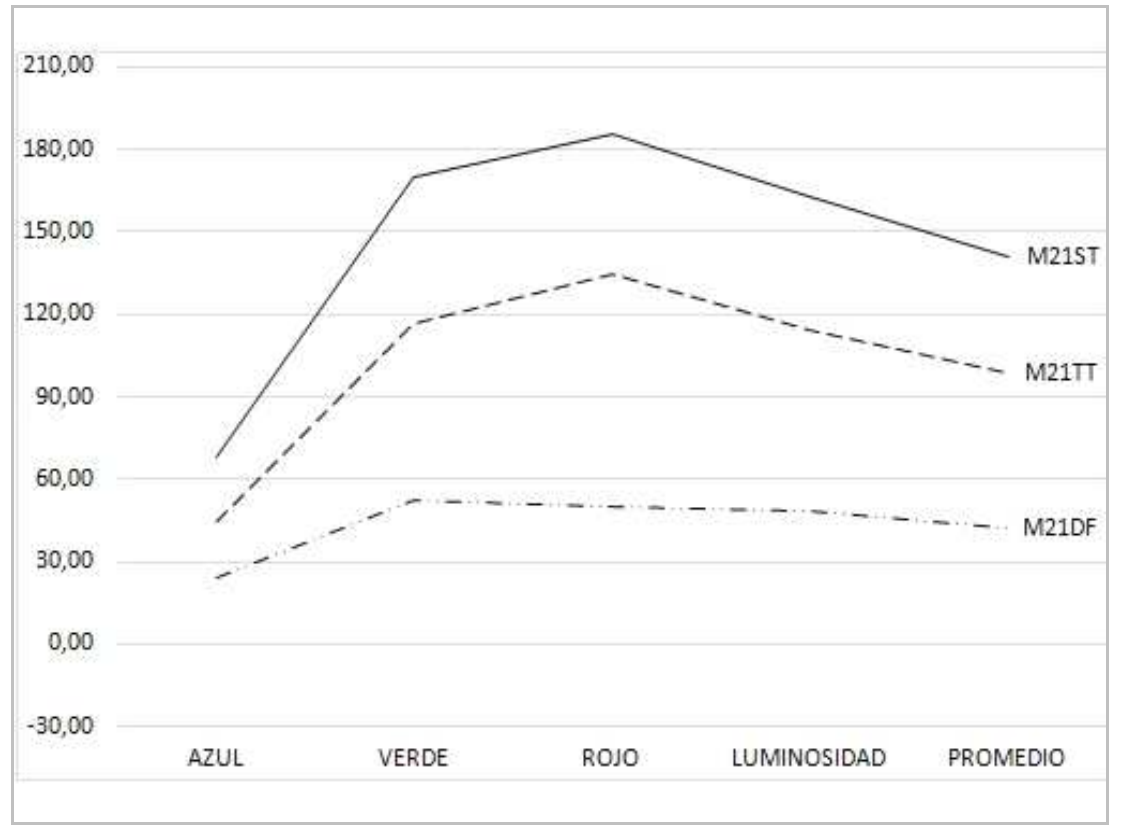

Universidad Politécnica de Madrid - Escuela Técnica Superior de Arquitectura - Departamento de Construcción y Tecnología Arquitectónica Directores: Dr. Alfonso García Santos y Dr. Antonio Rodríguez Rodríguez. Doctorando: D. Francisco Lora Toro 


\section{FICHA DE ENSAYOS DE MADERA Y ACIDOS}

\section{ACIDO A03/CL/ACIDO CLORHIDRICO}
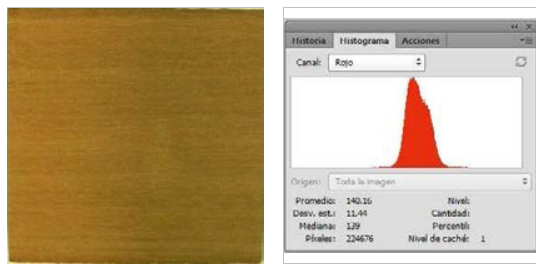

SIN TRATAR (ST): Grafica R (ST)

Valor R(ST):

140,16

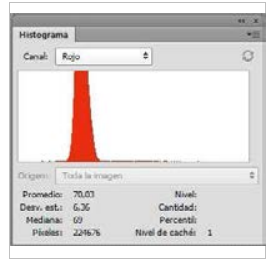

TRATADA (TT): Grafica $R(T T)$

Valor $\mathrm{R}(\mathrm{TT})$ :

70,03

DIFERENCIA (DF) Grafica R (DF): Valor DF-R: 70,13

GRAFICA:

\section{LEYENDA}

ST MADERA SIN TRATAR

Grafica R Histograma color Rojo

Grafica G Histograma color Verde

Grafica B Histograma color Azul

Grafica L Histograma Luminosidad

Grafica C Histograma RGB

\section{TT MADERA TRATADA}

Valor R Número pixeles color Rojo

Valor $G$ Número pixeles color Verde Valor B Número pixeles color Azul Valor $L$ Número pixeles Luminosidad Valor C Número pixeles RG DF DIFERENCIA DE VALORES R;G; $\mathrm{DF}=$ Valor $\mathrm{ST}(\mathrm{R} ; \mathrm{G} ; \mathrm{B})$ - Valor $\mathrm{TT}(\mathrm{R} ; \mathrm{G} ; \mathrm{B}$

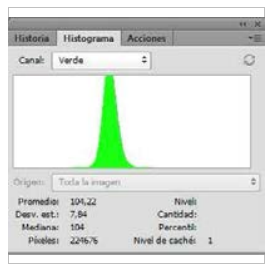

Grafica G (ST) Valor $\mathrm{G}(\mathrm{ST})$ : 104,22

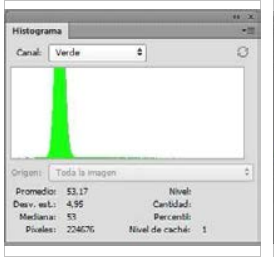

Grafica G (TT)

Valor G(TT):

53,17

\section{MADERA M22/MK/MAKORÉ}

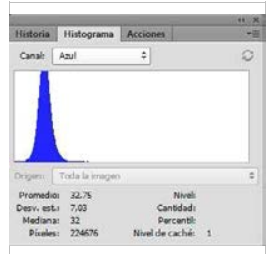

Grafica B (ST)

Valor B(ST):

32,75

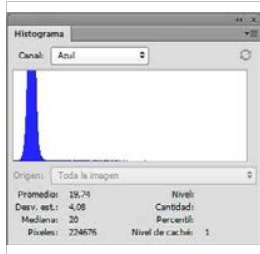

Grafica B (TT)

Valor $\mathrm{B}(\mathrm{TT})$ :

19,74

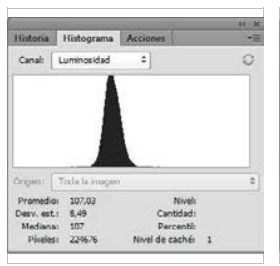

Grafica L (ST)

Valor L(ST):

107,03

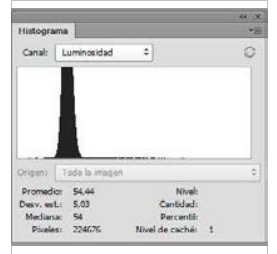

Grafica L (TT)

Valor L(TT):

54,44

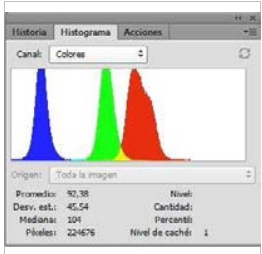

Grafica C (ST)

Valor C(ST):

92,38

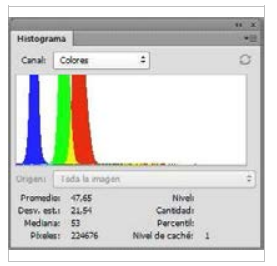

Grafica C (TT)

Valor C(TT):

47,65

Grafica G (DF): Grafica B (DF): Grafica L (DF): Grafica C (DF): Valor DF-G: Valor DF-B: Valor DF-L: Valor DF-C:

$\begin{array}{llll}51,05 & 13,01 & 52,59 & 44,73\end{array}$

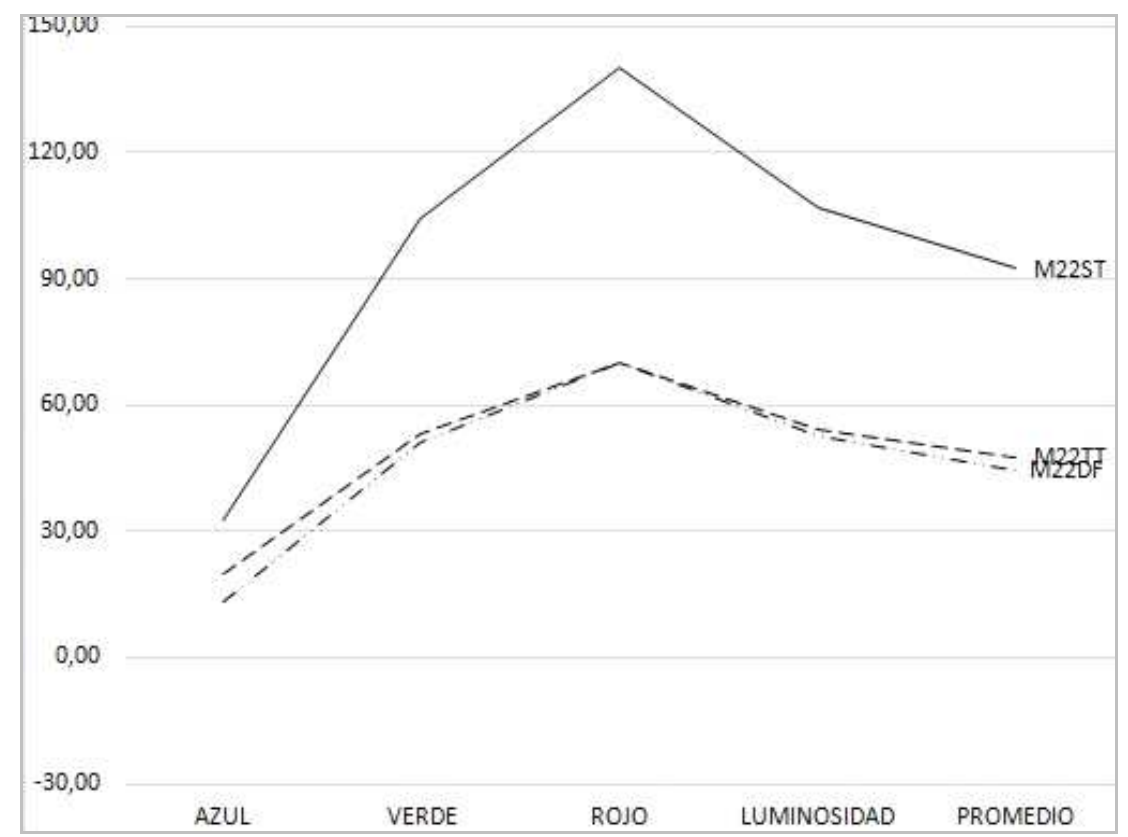

Universidad Politécnica de Madrid - Escuela Técnica Superior de Arquitectura - Departamento de Construcción y Tecnología Arquitectónica Directores: Dr. Alfonso García Santos y Dr. Antonio Rodríguez Rodríguez. Doctorando: D. Francisco Lora Toro 


\section{FICHA DE ENSAYOS DE MADERA Y ACIDOS}

\section{ACIDO A03/CL/ACIDO CLORHIDRICO}
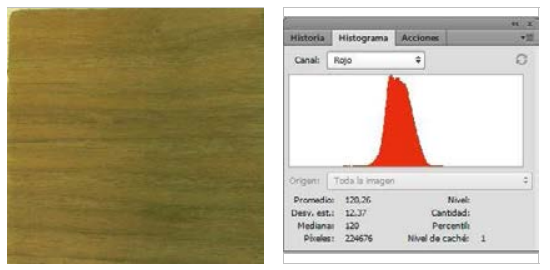

SIN TRATAR (ST): Grafica R (ST)

Valor R(ST):

120,26

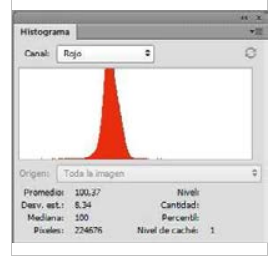

TRATADA (TT): Grafica R (TT)

Valor R(TT):

100,37

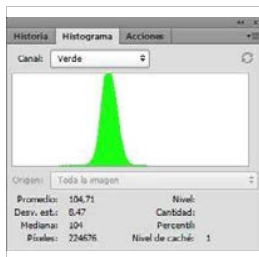

Grafica G (ST)

Valor G(ST):

104,71

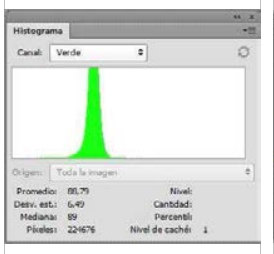

Grafica G (TT)

Valor G(TT):

88,79
MADERA M23/NGA/NOGAL NEGRO AMERICANO

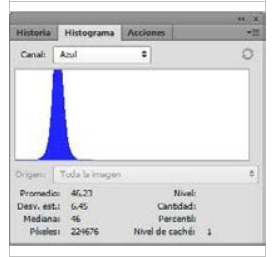

Grafica B (ST)

Valor B(ST):

46,23

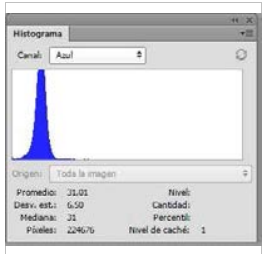

Grafica B (TT)

Valor $\mathrm{B}(\mathrm{TT})$ :

31,01

Grafica G (DF): Grafica B (DF):

Valor DF-B:

15,22

15,92
Grafica L (ST)

Valor L(ST):

102,85

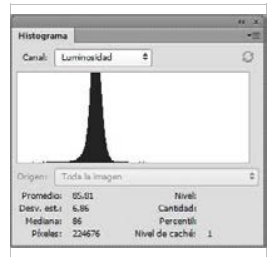

Grafica L (TT)

Valor L(TT):

85,81

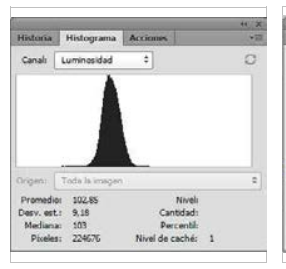

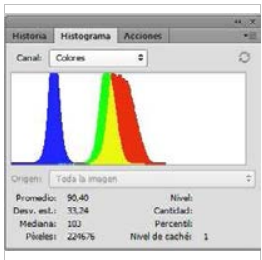

Grafica C (ST)

Valor C(ST):

90,40
Valor DF-G:

Grafica L (DF):

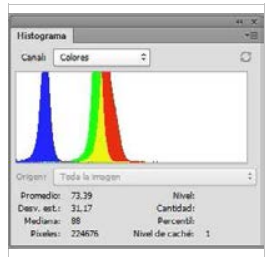
Valor DF-L:

Grafica C (TT)

Valor C(TT):

73,39

DIFERENCIA (DF) Grafica R (DF): Valor DF-R:

19,89

\section{GRAFICA:}

\section{LEYENDA}

ST MADERA SIN TRATAR

Grafica R Histograma color Rojo

Grafica G Histograma color Verde

Grafica B Histograma color Azul

Grafica L Histograma Luminosidad

Grafica C Histograma RGB

\section{TT MADERA TRATADA}

Valor $\mathrm{R}$ Número pixeles color Rojo

Valor $G$ Número pixeles color Verde

Valor B Número pixeles color Azul

Valor $L$ Número pixeles Luminosidad

Valor C Número pixeles RG

DF DIFERENCIA DE VALORES R;G; $\mathrm{DF}=\operatorname{Valor} \mathrm{ST}(\mathrm{R} ; \mathrm{G} ; \mathrm{B})$ - Valor TT(R;G;B

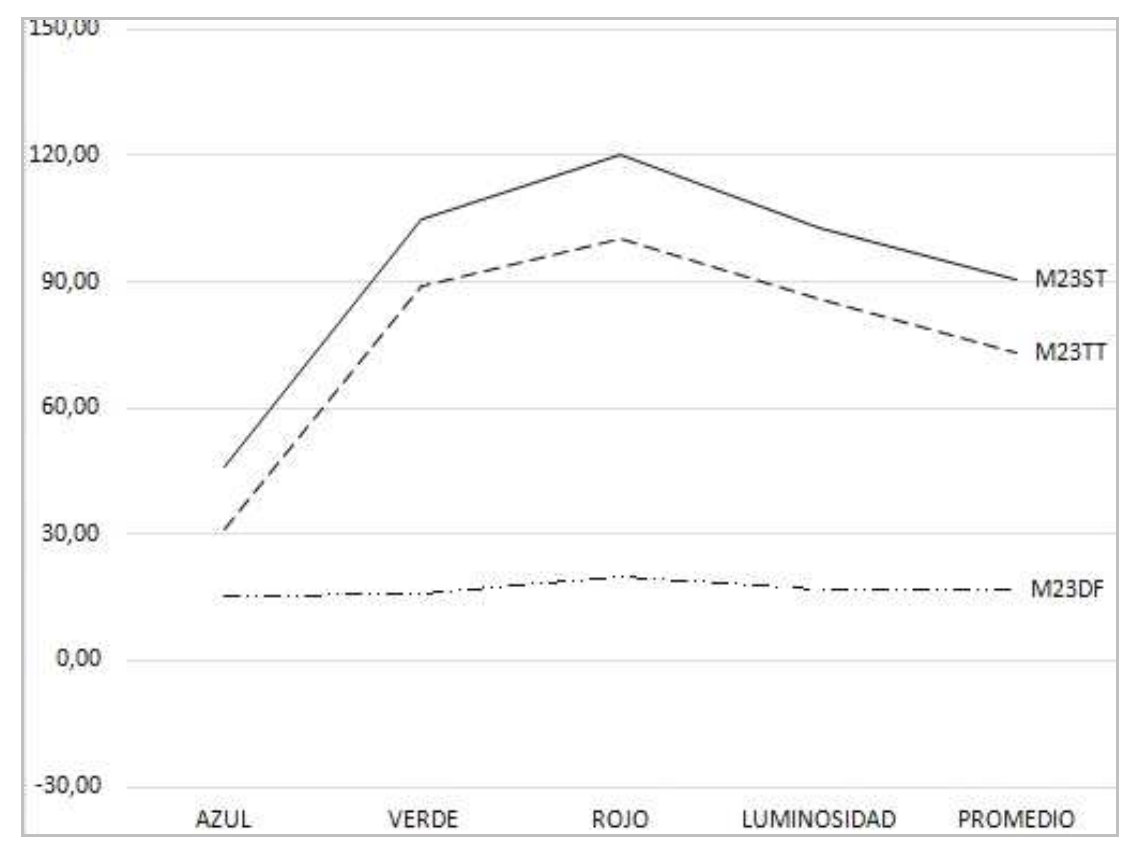

Universidad Politécnica de Madrid - Escuela Técnica Superior de Arquitectura - Departamento de Construcción y Tecnología Arquitectónica Directores: Dr. Alfonso García Santos y Dr. Antonio Rodríguez Rodríguez. Doctorando: D. Francisco Lora Toro 


\section{FICHA DE ENSAYOS DE MADERA Y ACIDOS}

\section{ACIDO A03/CL/ACIDO CLORHIDRICO}
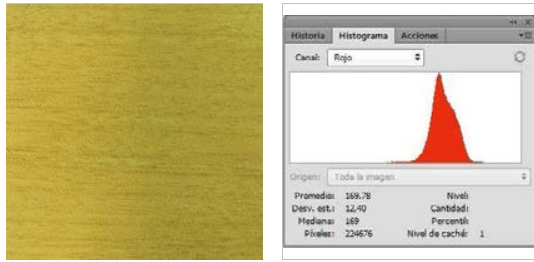

SIN TRATAR (ST): Grafica R (ST)

Valor R(ST):

169,78

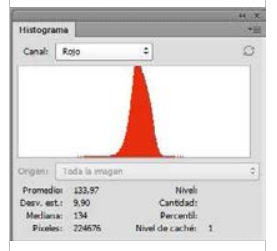

TRATADA (TT): Grafica R (TT)

Valor $\mathrm{R}(\mathrm{TT})$ :

133,97

DIFERENCIA (DF) Grafica R (DF): Valor DF-R: 35,81

GRAFICA:

\section{LEYENDA}

ST MADERA SIN TRATAR

Grafica R Histograma color Rojo Grafica G Histograma color Verde Grafica B Histograma color Azul Grafica L Histograma Luminosidad Grafica C Histograma RGB

TT MADERA TRATADA

Valor $\mathrm{R}$ Número pixeles color Rojo Valor $\mathrm{G}$ Número pixeles color Verde Valor B Número pixeles color Azul Valor $L$ Número pixeles Luminosidad Valor $C$ Número pixeles $R G$ DF DIFERENCIA DE VALORES R;G; $\mathrm{DF}=$ Valor $\mathrm{ST}(\mathrm{R} ; \mathrm{G} ; \mathrm{B})$ - Valor TT $(\mathrm{R} ; \mathrm{G} ; \mathrm{B}$

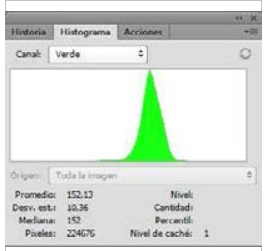

Grafica G (ST)

Valor G(ST):

152,13

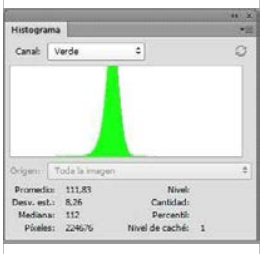

Grafica G (TT)

Valor G(TT):

111,83

Grafica G (DF): Grafica B (DF):

11,79

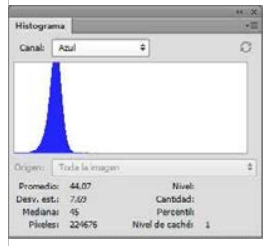

Grafica B (TT)

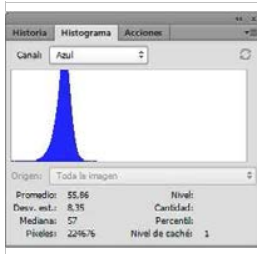

Grafica B (ST)

Valor B(ST):

55,86

Valor $\mathrm{B}(\mathrm{TT})$ :

44,07 Valor DF-G: Valor DF-B: Valor DF-L:

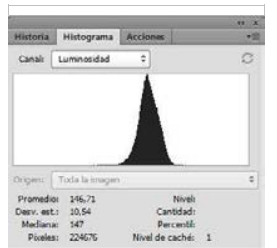

Grafica L (ST)

Valor L(ST):

146,71

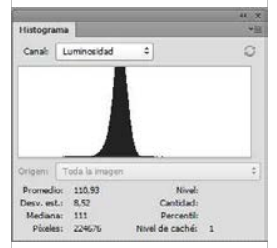

Grafica L (TT)

Valor L(TT):

110,93

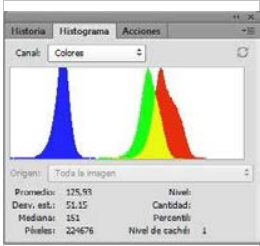

Grafica C (ST)

Valor C(ST):

125,93

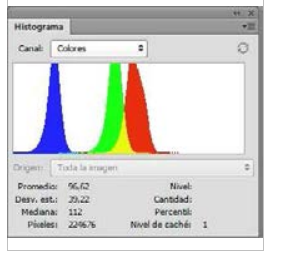

Grafica C (TT)

Valor $\mathrm{C}(\mathrm{TT})$ :

96,62

Grafica L (DF): Grafica C (DF): Valor DF-C:

$\begin{array}{llll}40,30 & 11,79 & 35,78 & 29,31\end{array}$

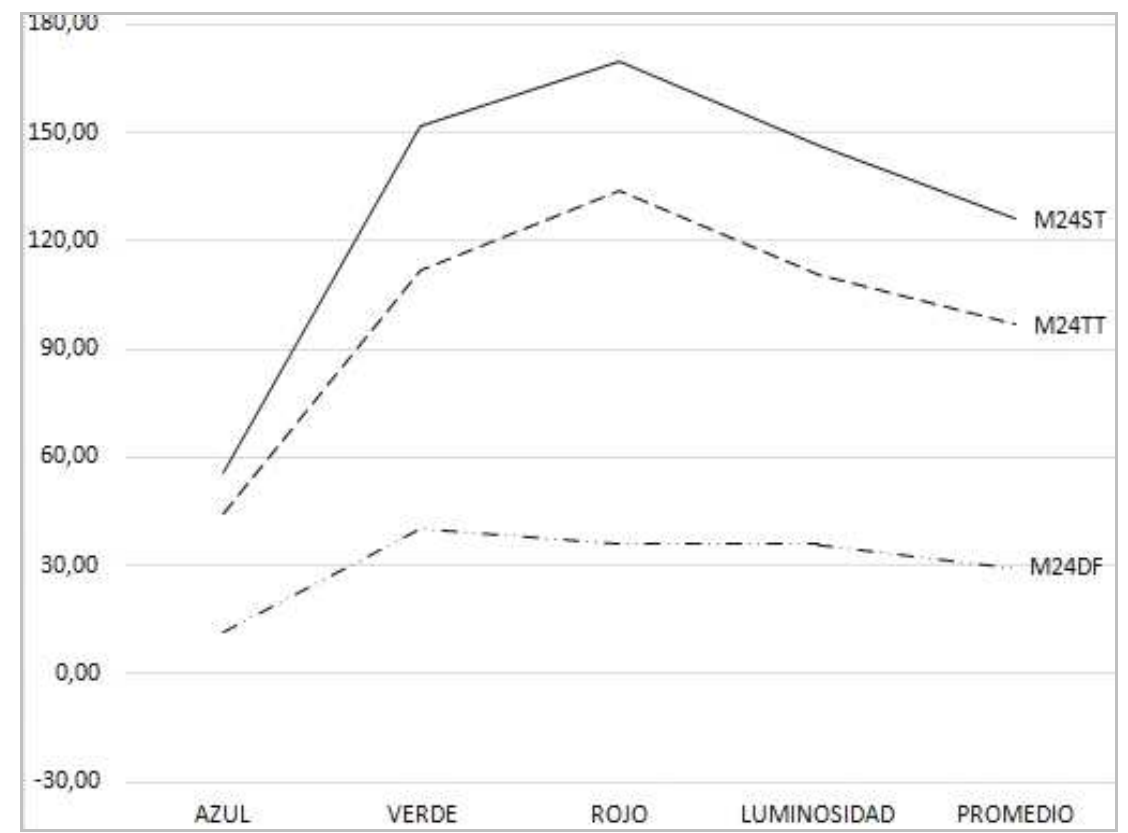

Universidad Politécnica de Madrid - Escuela Técnica Superior de Arquitectura - Departamento de Construcción y Tecnología Arquitectónica Directores: Dr. Alfonso García Santos y Dr. Antonio Rodríguez Rodríguez. Doctorando: D. Francisco Lora Toro 


\section{FICHA DE ENSAYOS DE MADERA Y ACIDOS}

\section{ACIDO A03/CL/ACIDO CLORHIDRICO}
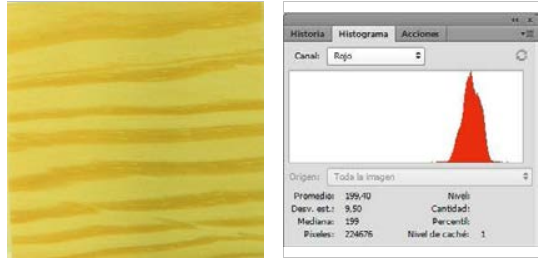

SIN TRATAR (ST): Grafica R (ST)

Valor R(ST):

199,40

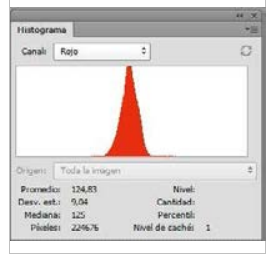

TRATADA (TT): Grafica R (TT)

Valor $\mathrm{R}(\mathrm{TT})$ :

124,83

DIFERENCIA (DF) Grafica R (DF):

Valor DF-R:

74,57

GRAFICA:

\section{LEYENDA}

ST MADERA SIN TRATAR

Grafica R Histograma color Rojo

Grafica G Histograma color Verde

Grafica B Histograma color Azul

Grafica L Histograma Luminosidad

Grafica C Histograma RGB

\section{TT MADERA TRATADA}

Valor R Número pixeles color Rojo

Valor $G$ Número pixeles color Verde

Valor B Número pixeles color Azul

Valor $L$ Número pixeles Luminosidad

Valor C Número pixeles RG

DF DIFERENCIA DE VALORES R;G;

$\mathrm{DF}=$ Valor $\mathrm{ST}(\mathrm{R} ; \mathrm{G} ; \mathrm{B})$ - Valor $\mathrm{TT}(\mathrm{R} ; \mathrm{G} ; \mathrm{B}$
MADERA M25/PX/PINO AMARILLO DEL SUR
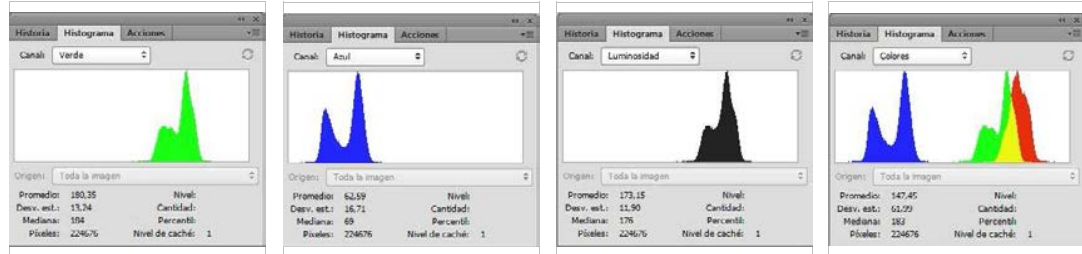

Grafica G (ST)

Grafica B (ST)

Grafica L (ST)

Grafica C (ST)

Valor $\mathrm{G}(\mathrm{ST})$ :

Valor B(ST):

Valor L(ST):

Valor C(ST):

180,35

62,59

173,15

147,45
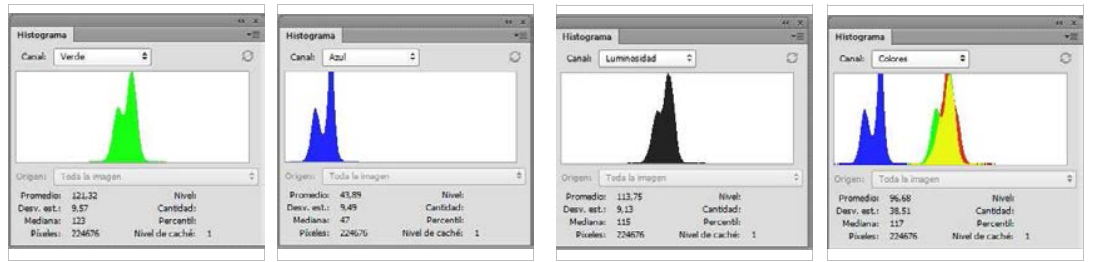

Grafica G (TT)

Grafica B (TT)

Grafica L (TT)

Grafica C (TT)

Valor $\mathrm{G}(\mathrm{TT})$ :

Valor $\mathrm{B}(\mathrm{TT})$ :

Valor L(TT):

Valor C(TT):

121,32

43,89

113,75

96,68

Grafica G (DF): Grafica B (DF): Grafica L (DF): Grafica C (DF): Valor DF-G: Valor DF-B: Valor DF-L: Valor DF-C: 59,03 18,70 59,40 50,77

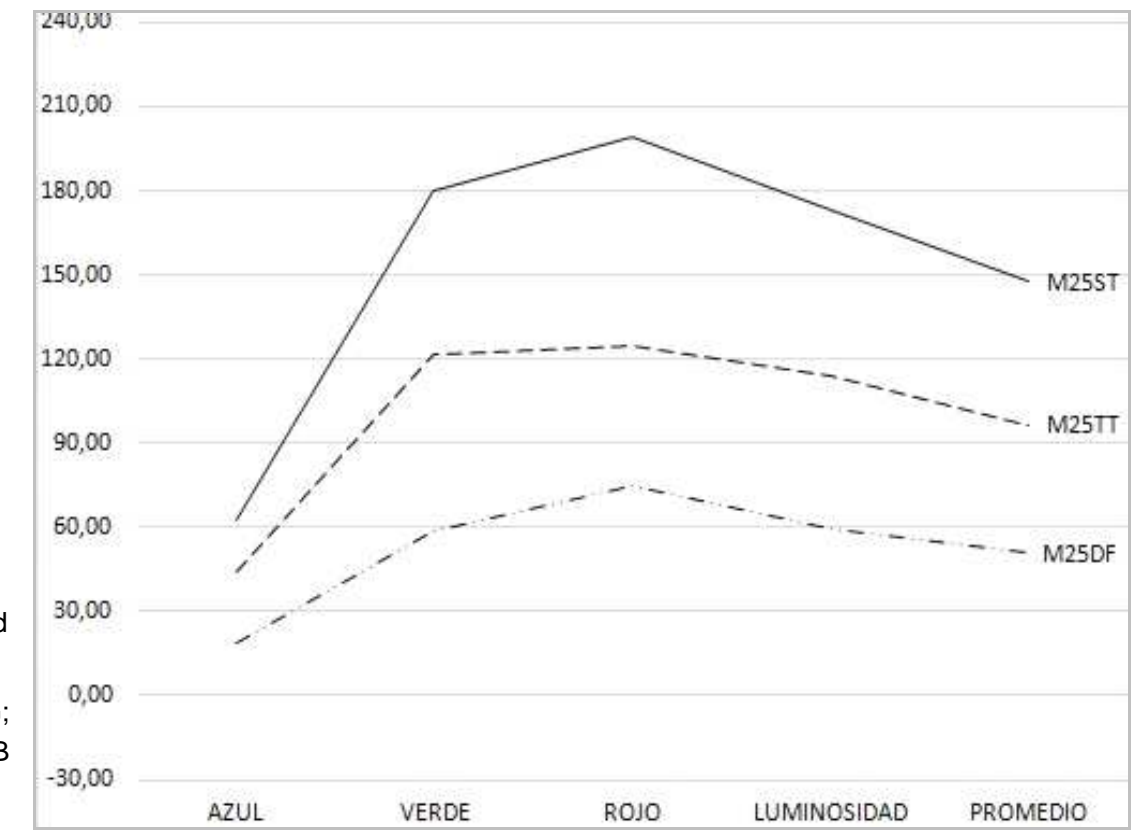

Universidad Politécnica de Madrid - Escuela Técnica Superior de Arquitectura - Departamento de Construcción y Tecnología Arquitectónica Directores: Dr. Alfonso García Santos y Dr. Antonio Rodríguez Rodríguez. Doctorando: D. Francisco Lora Toro 


\section{FICHA DE ENSAYOS DE MADERA Y ACIDOS}

\section{ACIDO A03/CL/ACIDO CLORHIDRICO}

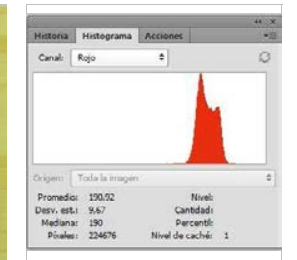

SIN TRATAR (ST): Grafica R (ST)

Valor R(ST):

190,92

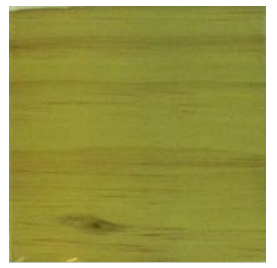

TRATADA (TT): Grafica R (TT)

Grafica $\mathrm{R}(\mathrm{TT})$
Valor $\mathrm{R}(\mathrm{TT})$ : 137,88

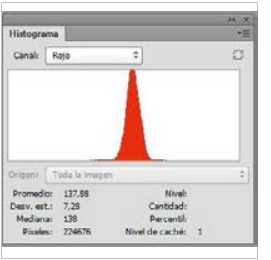

DIFERENCIA (DF) Grafica R (DF): Valor DF-R: 53,04

GRAFICA:

\section{LEYENDA}

ST MADERA SIN TRATAR

Grafica R Histograma color Rojo Grafica G Histograma color Verde Grafica B Histograma color Azul Grafica L Histograma Luminosidad Grafica C Histograma RGB

\section{TT MADERA TRATADA}

Valor $R$ Número pixeles color Rojo Valor $\mathrm{G}$ Número pixeles color Verde Valor B Número pixeles color Azul Valor $L$ Número pixeles Luminosidad Valor C Número pixeles RG DF DIFERENCIA DE VALORES R;G; $\mathrm{DF}=$ Valor $\mathrm{ST}(\mathrm{R} ; \mathrm{G} ; \mathrm{B})$ - Valor $\mathrm{TT}(\mathrm{R} ; \mathrm{G} ; \mathrm{B}$

\section{MADERA M26/PR/PINO RADIATA}

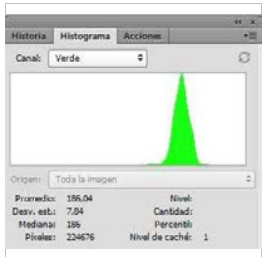

Grafica G (ST)

Valor $\mathrm{G}(\mathrm{ST})$ :

186,04
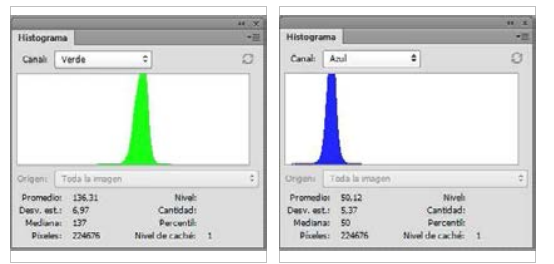

Grafica G (TT)

Grafica B (TT)

Valor $\mathrm{B}(\mathrm{TT})$ :

50,12

136,31

Grafica G (DF): Grafica B (DF):

Grafica L (DF):

Grafica C (DF):

Valor DF-G: Valor DF-B:

Valor DF-L:

Valor DF-C:

49,73

38,65

49,53

47,14

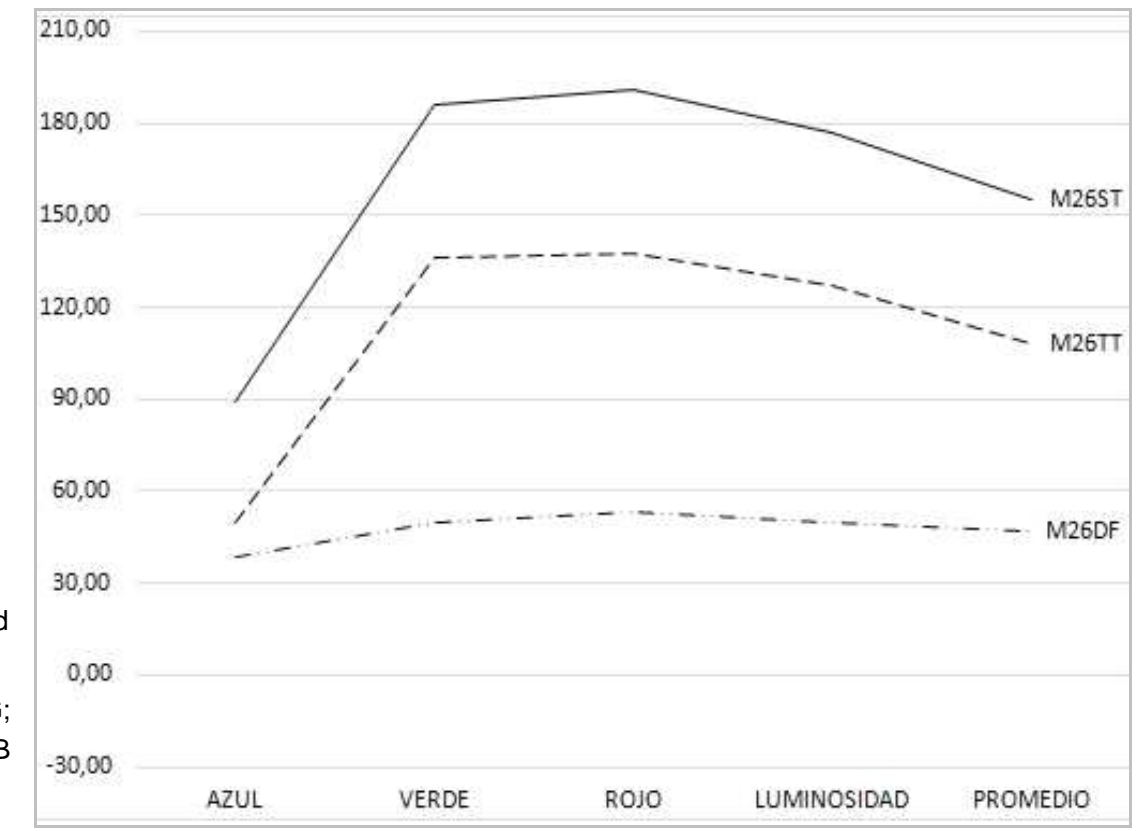

Universidad Politécnica de Madrid - Escuela Técnica Superior de Arquitectura - Departamento de Construcción y Tecnología Arquitectónica Directores: Dr. Alfonso García Santos y Dr. Antonio Rodríguez Rodríguez. Doctorando: D. Francisco Lora Toro 


\section{FICHA DE ENSAYOS DE MADERA Y ACIDOS}

\section{ACIDO A03/CL/ACIDO CLORHIDRICO}
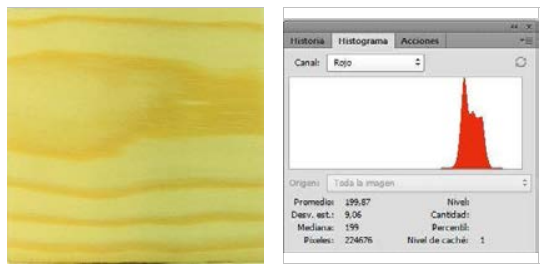

SIN TRATAR (ST): Grafica R (ST)

Valor R(ST):

199,87
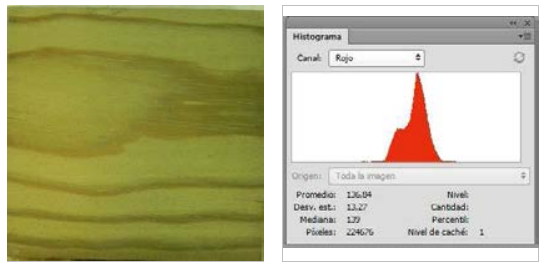

TRATADA (TT): Grafica R (TT)

Valor R(TT):

136,84

DIFERENCIA (DF) Grafica R (DF): Valor DF-R: 63,03

GRAFICA:

\section{LEYENDA}

ST MADERA SIN TRATAR

Grafica R Histograma color Rojo

Grafica G Histograma color Verde

Grafica B Histograma color Azul

Grafica L Histograma Luminosidad

Grafica C Histograma RGB

TT MADERA TRATADA

Valor R Número pixeles color Rojo

Valor $\mathrm{G}$ Número pixeles color Verde

Valor B Número pixeles color Azul

Valor $L$ Número pixeles Luminosidad

Valor $C$ Número pixeles $R G$

DF DIFERENCIA DE VALORES R;G; $\mathrm{DF}=$ Valor $\mathrm{ST}(\mathrm{R} ; \mathrm{G} ; \mathrm{B})$ - Valor TT(R;G;B

\section{MADERA M27/PS/PINO SILVESTRE}

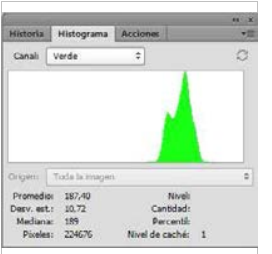

Grafica G (ST)

Valor G(ST):

187,40
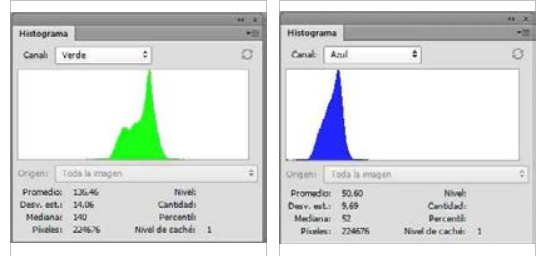

Grafica G (TT)

Grafica B (TT)

Valor $\mathrm{B}(\mathrm{TT})$ :

50,60

136,46

Grafica G (DF): Grafica B (DF):

Grafica L (DF):

Grafica C (DF):

Valor DF-G: Valor DF-B:

Valor DF-L:

Valor DF-C:

50,94

30,32

52,35

48,10

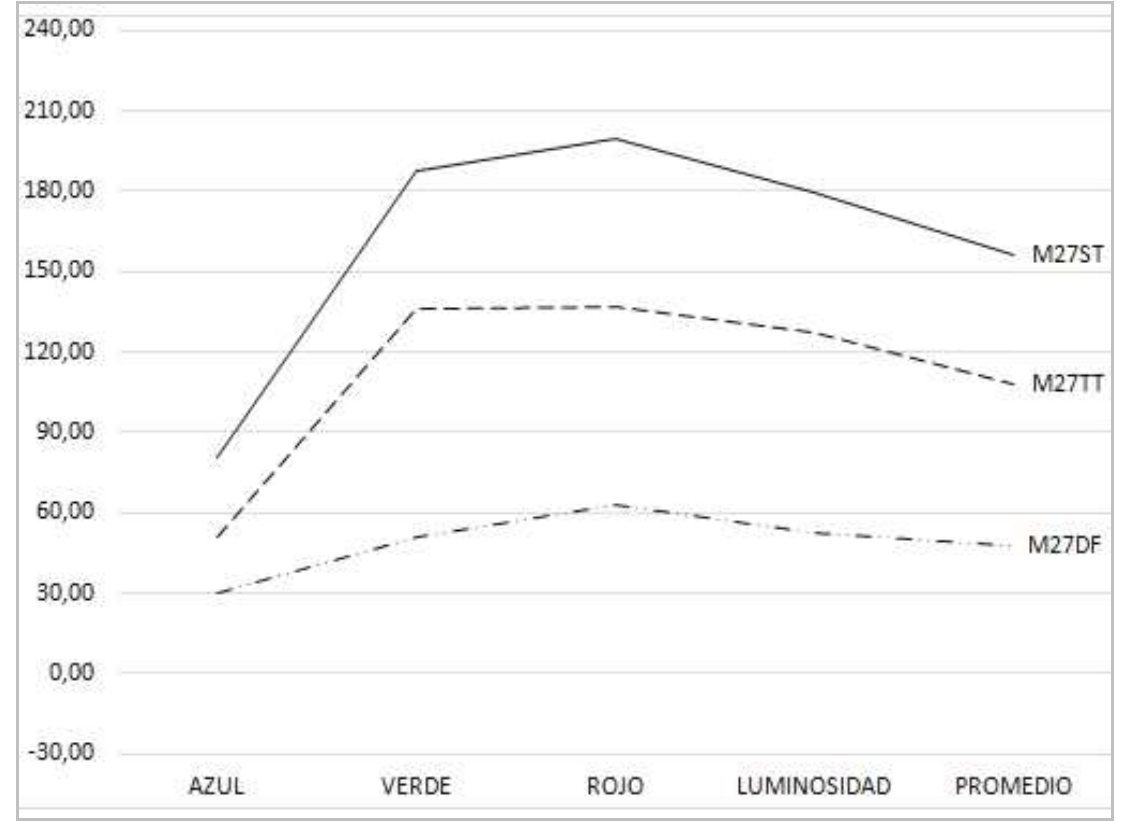

Universidad Politécnica de Madrid - Escuela Técnica Superior de Arquitectura - Departamento de Construcción y Tecnología Arquitectónica Directores: Dr. Alfonso García Santos y Dr. Antonio Rodríguez Rodríguez. Doctorando: D. Francisco Lora Toro 


\section{FICHA DE ENSAYOS DE MADERA Y ACIDOS}

\section{ACIDO A03/CL/ACIDO CLORHIDRICO}
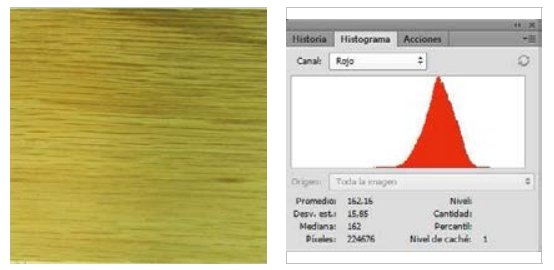

SIN TRATAR (ST): Grafica R (ST)

Valor R(ST):

162,16

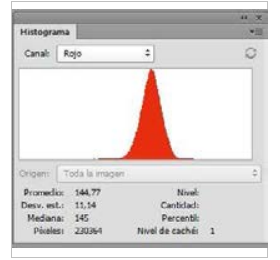

TRATADA (TT): Grafica $R(T T)$

Valor R(TT):

144,77

DIFERENCIA (DF) Grafica R (DF): Valor DF-R:

17,39

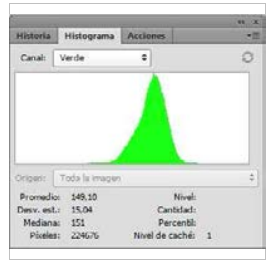

Grafica G (ST)

Valor G(ST):

149,10

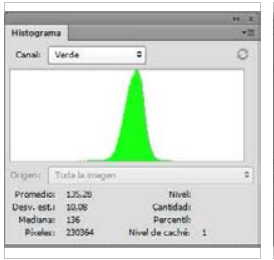

Grafica G (TT)

Valor $\mathrm{G}(\mathrm{TT})$ :

135,28
MADERA M28/RBA/ROBLE BLANCO AMERICANO

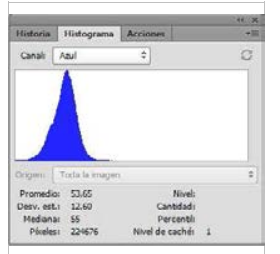

Grafica B (ST)

Valor B(ST):

53,65

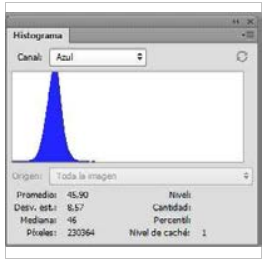

Grafica B (TT)

Valor $\mathrm{B}(\mathrm{TT})$ :

45,90

Grafica G (DF): Grafica B (DF):

Valor DF-G:

Valor DF-B:

7,75

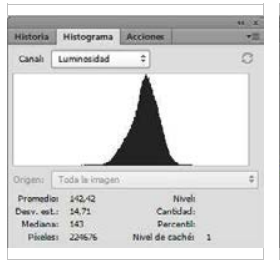

Grafica L (ST)

Valor L(ST):

142,42

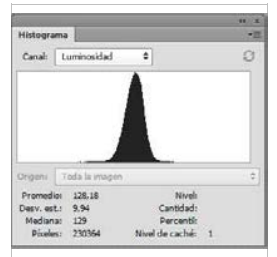

Grafica L (TT)

Valor L(TT):

128,18

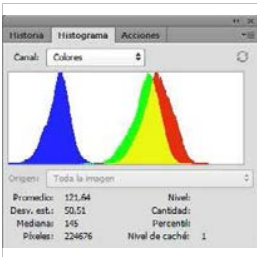

Grafica C (ST)

Valor C(ST):

121,64
13,82

Grafica L (DF):

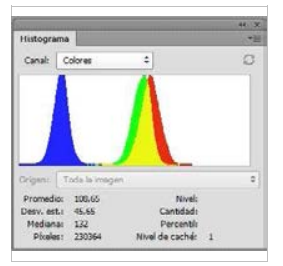

Grafica C (TT)

Valor C(TT):

108,65

Valor DF-L:

Grafica C (DF):

Valor DF-C:

14,24

12,99

GRAFICA:

\section{LEYENDA}

ST MADERA SIN TRATAR

Grafica R Histograma color Rojo

Grafica G Histograma color Verde

Grafica B Histograma color Azul

Grafica L Histograma Luminosidad

Grafica C Histograma RGB

TT MADERA TRATADA

Valor $\mathrm{R}$ Número pixeles color Rojo

Valor $\mathrm{G}$ Número pixeles color Verde

Valor B Número pixeles color Azul

Valor L Número pixeles Luminosidad

Valor C Número pixeles RG

DF DIFERENCIA DE VALORES R;G;

$\mathrm{DF}=$ Valor $\mathrm{ST}(\mathrm{R} ; \mathrm{G} ; \mathrm{B})$ - Valor TT(R;G;B

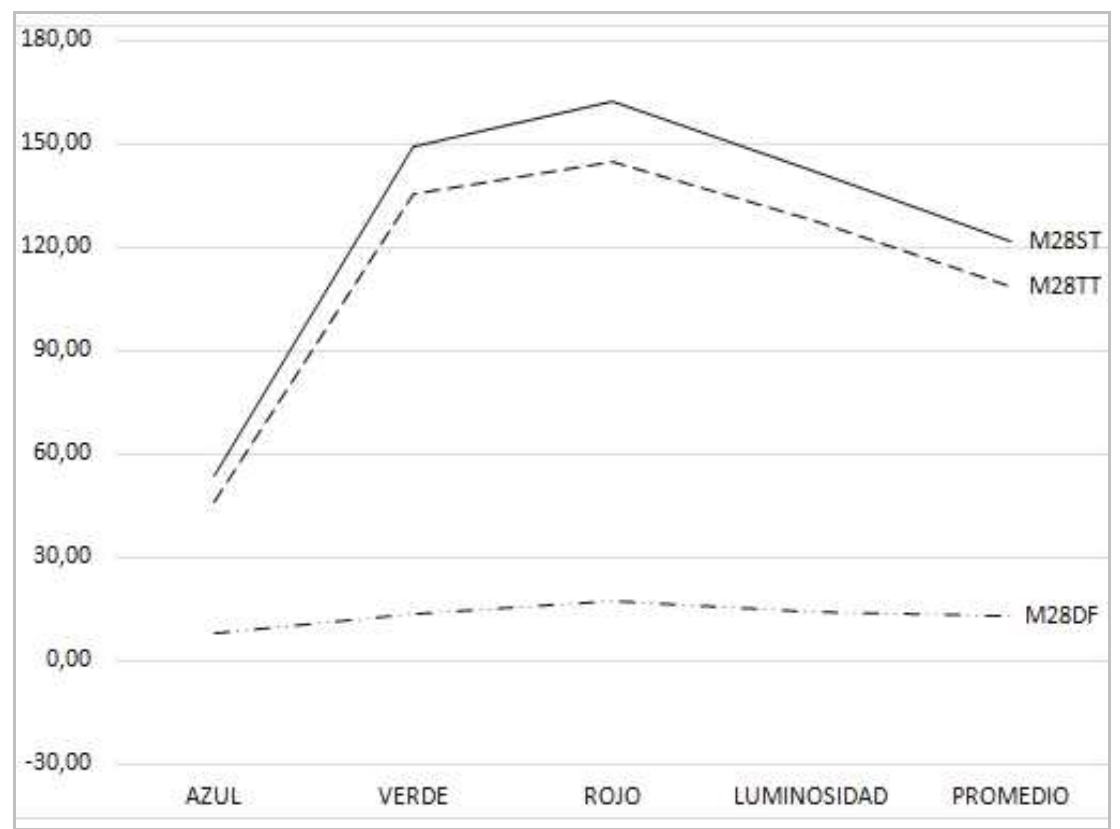

Universidad Politécnica de Madrid - Escuela Técnica Superior de Arquitectura - Departamento de Construcción y Tecnología Arquitectónica Directores: Dr. Alfonso García Santos y Dr. Antonio Rodríguez Rodríguez. Doctorando: D. Francisco Lora Toro 


\section{FICHA DE ENSAYOS DE MADERA Y ACIDOS}

\section{ACIDO A03/CL/ACIDO CLORHIDRICO}
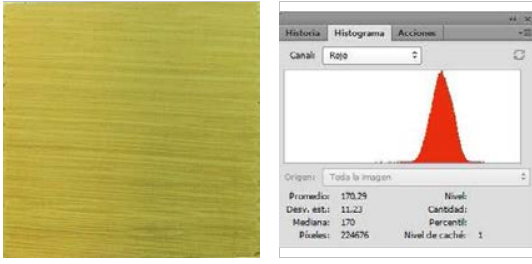

SIN TRATAR (ST): Grafica R (ST)

Valor R(ST):

170,29

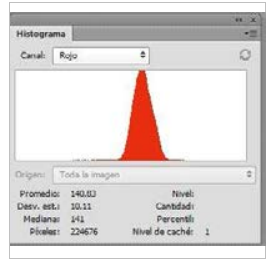

TRATADA (TT): Grafica R (TT)

Valor R(TT):

140,83

DIFERENCIA (DF) Grafica R (DF):

Valor DF-R:

29,46

GRAFICA:

\section{LEYENDA}

ST MADERA SIN TRATAR

Grafica R Histograma color Rojo

Grafica G Histograma color Verde

Grafica B Histograma color Azul

Grafica L Histograma Luminosidad

Grafica C Histograma RGB

\section{TT MADERA TRATADA}

Valor R Número pixeles color Rojo

Valor $\mathrm{G}$ Número pixeles color Verde

Valor B Número pixeles color Azul

Valor $L$ Número pixeles Luminosidad

Valor C Número pixeles RG

DF DIFERENCIA DE VALORES R;G; $\mathrm{DF}=$ Valor $\mathrm{ST}(\mathrm{R} ; \mathrm{G} ; \mathrm{B})$ - Valor $\mathrm{TT}(\mathrm{R} ; \mathrm{G} ; \mathrm{B}$
MADERA M29/RBE/ROBLE BLANCO EUROPEO

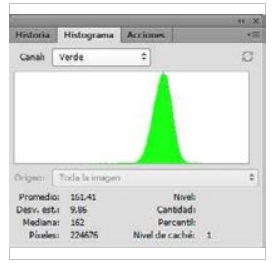

Grafica G (ST)

Valor $\mathrm{G}(\mathrm{ST})$ :

161,41

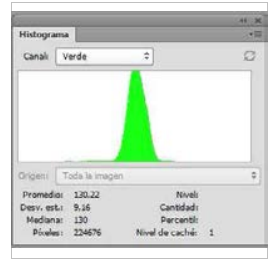

Grafica G (TT)

Valor $\mathrm{G}(\mathrm{TT})$ :

130,22

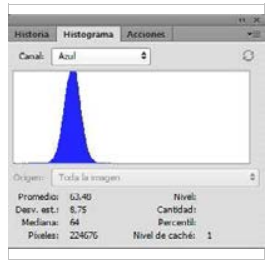

Grafica B (ST)

Valor B(ST):

63,48

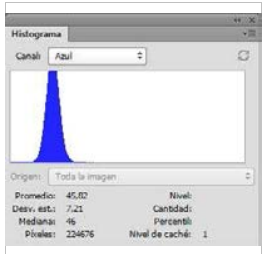

Grafica B (TT)

Valor $\mathrm{B}(\mathrm{TT})$ :

45,82

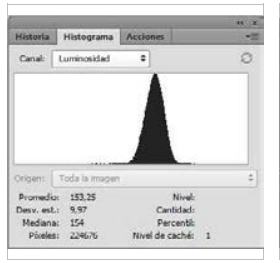

Grafica L (ST)

Valor L(ST):

153,25

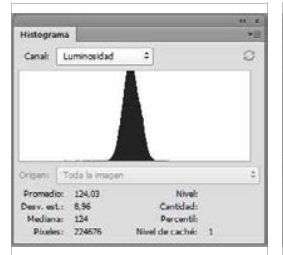

Grafica L (TT)

Valor L(TT):

124,03

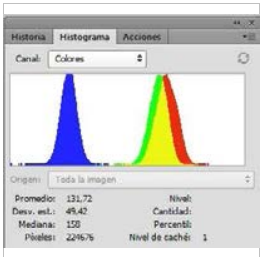

Grafica C (ST)

Valor C(ST):

131,72

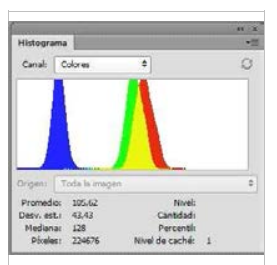

Grafica C (TT)

Valor C(TT):

105,62

Grafica G (DF): Grafica B (DF): Grafica L (DF): Grafica C (DF): Valor DF-G: Valor DF-B: Valor DF-L: Valor DF-C: $\begin{array}{llll}31,19 & 17,66 & 29,22 & 26,10\end{array}$

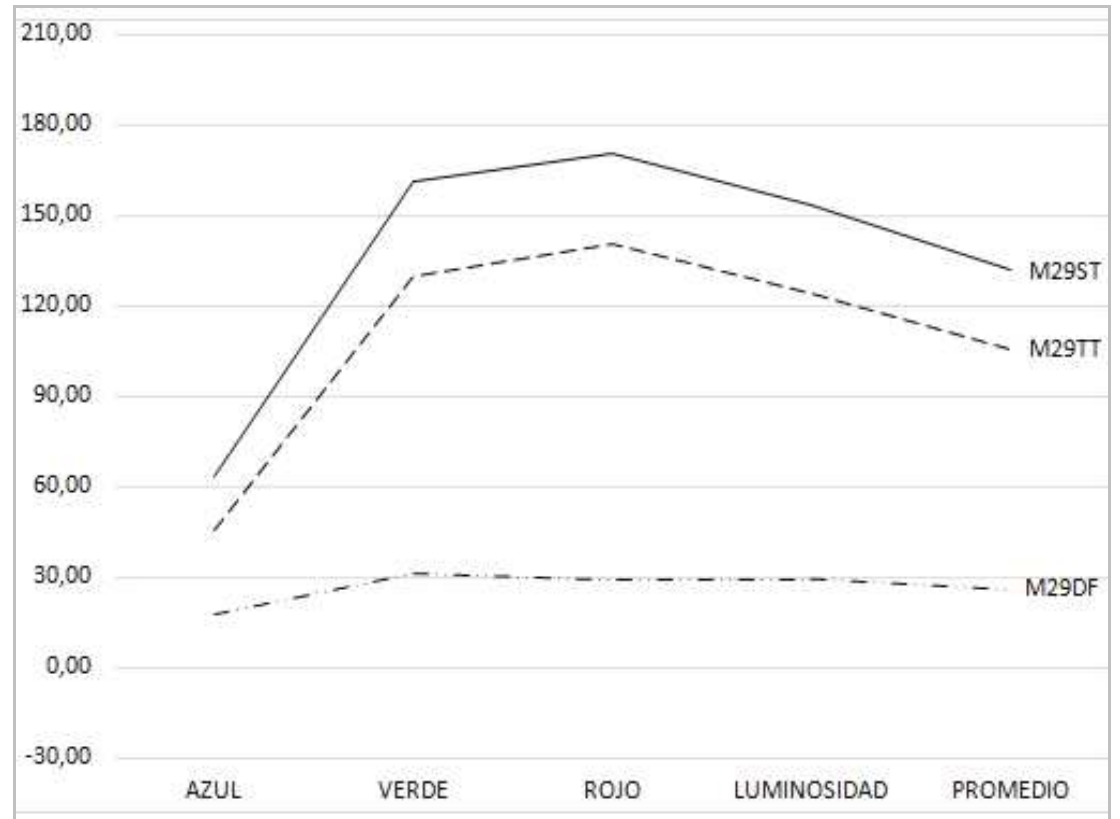

Universidad Politécnica de Madrid - Escuela Técnica Superior de Arquitectura - Departamento de Construcción y Tecnología Arquitectónica Directores: Dr. Alfonso García Santos y Dr. Antonio Rodríguez Rodríguez. Doctorando: D. Francisco Lora Toro 


\section{FICHA DE ENSAYOS DE MADERA Y ACIDOS}

ACIDO A03/CL/ACIDO CLORHIDRICO

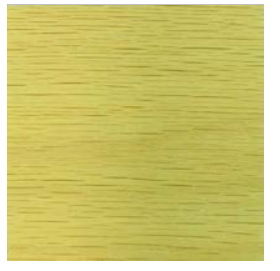

SIN TRATAR (ST): Grafica R (ST)

Valor R(ST):

189,62

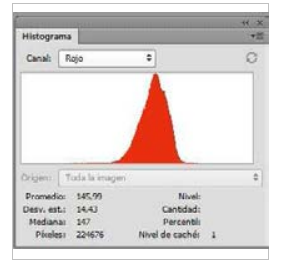

TRATADA (TT): Grafica R (TT)

Valor $\mathrm{R}(\mathrm{TT})$ :

145,99

DIFERENCIA (DF) Grafica R (DF):

Valor DF-R:

43,63

GRAFICA:

\section{LEYENDA}

ST MADERA SIN TRATAR

Grafica R Histograma color Rojo

Grafica G Histograma color Verde

Grafica B Histograma color Azul

Grafica L Histograma Luminosidad

Grafica C Histograma RGB

TT MADERA TRATADA

Valor R Número pixeles color Rojo

Valor $\mathrm{G}$ Número pixeles color Verde

Valor B Número pixeles color Azul

Valor $L$ Número pixeles Luminosidad

Valor C Número pixeles RG

DF DIFERENCIA DE VALORES R;G;

$\mathrm{DF}=$ Valor $\mathrm{ST}(\mathrm{R} ; \mathrm{G} ; \mathrm{B})$ - Valor TT(R;G;B
MADERA M30/RRA/ROBLE ROJO AMERICANO

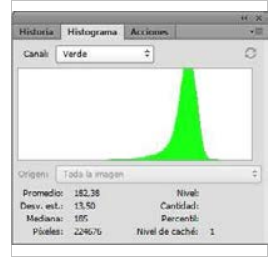

Grafica G (ST)

Valor G(ST):

182,38
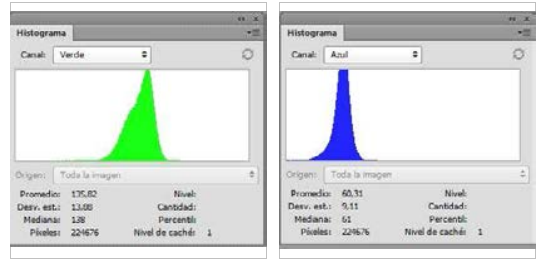

Grafica G (TT)

Grafica B (TT)

Valor $\mathrm{B}(\mathrm{TT})$ :

60,31

135,82

Grafica G (DF): Grafica B (DF):

Valor DF-G:

Valor DF-B:

26,16

46,56

43,49
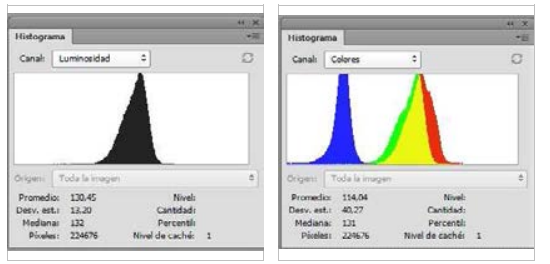

Grafica L (TT)

Grafica C (TT)

Valor L(TT):

Valor C(TT):

130,45

114,04

Grafica L (DF): Grafica C (DF):

Valor DF-L:

Valor DF-C:

38,78

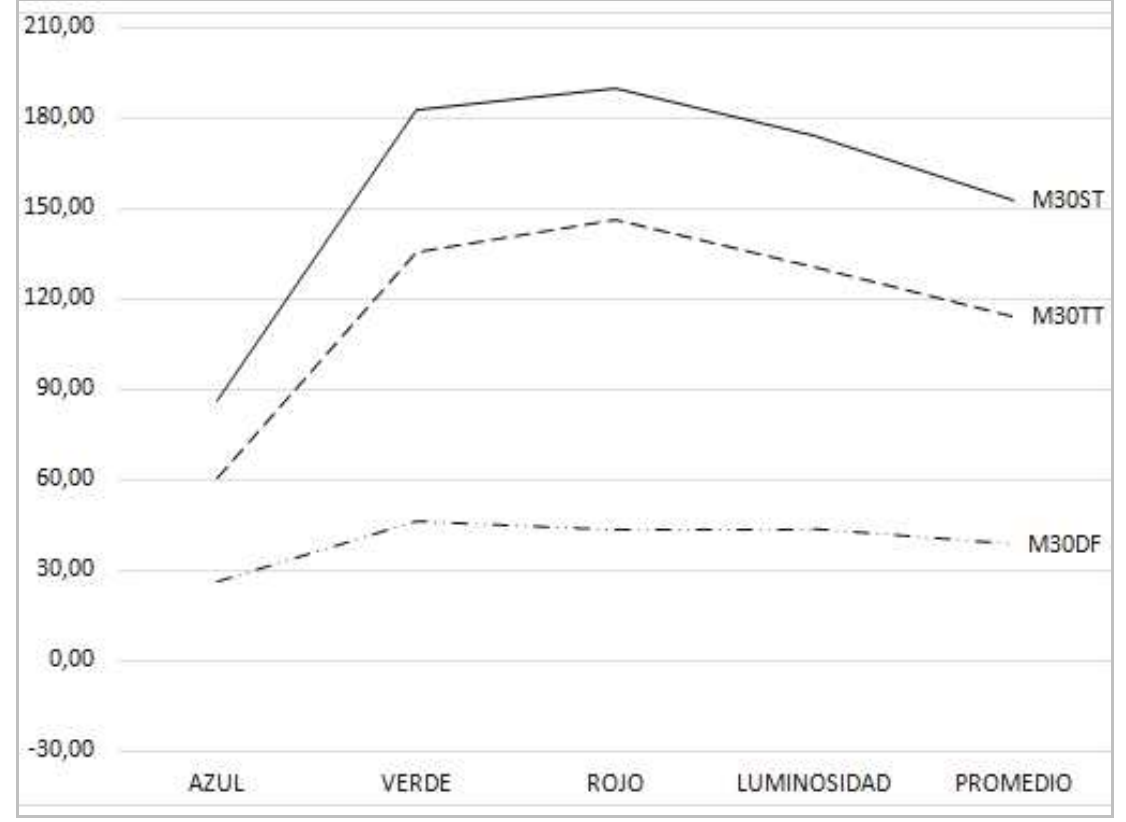

Universidad Politécnica de Madrid - Escuela Técnica Superior de Arquitectura - Departamento de Construcción y Tecnología Arquitectónica Directores: Dr. Alfonso García Santos y Dr. Antonio Rodríguez Rodríguez. Doctorando: D. Francisco Lora Toro 


\section{FICHA DE ENSAYOS DE MADERA Y ACIDOS}

\section{ACIDO A03/CL/ACIDO CLORHIDRICO}
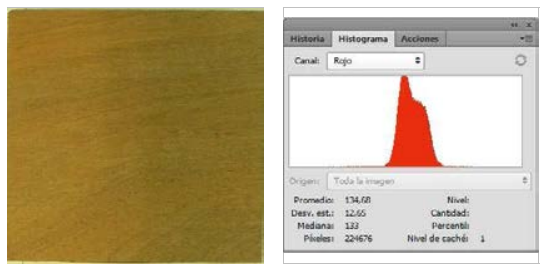

SIN TRATAR (ST): Grafica R (ST)

Valor R(ST):

134,68

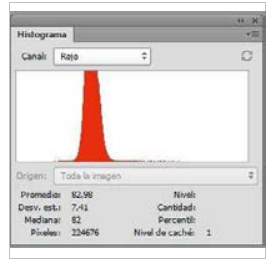

TRATADA (TT): Grafica $R(T T)$

Valor $\mathrm{R}(\mathrm{TT})$ :

82,98

DIFERENCIA (DF) Grafica R (DF): Valor DF-R: 51,70

GRAFICA

\section{LEYENDA}

ST MADERA SIN TRATAR

Grafica R Histograma color Rojo

Grafica G Histograma color Verde

Grafica B Histograma color Azul

Grafica L Histograma Luminosidad

Grafica C Histograma RGB

\section{TT MADERA TRATADA}

Valor R Número pixeles color Rojo

Valor G Número pixeles color Verde Valor B Número pixeles color Azul

Valor $L$ Número pixeles Luminosidad

Valor C Número pixeles RG

DF DIFERENCIA DE VALORES R;G; $\mathrm{DF}=$ Valor $\mathrm{ST}(\mathrm{R} ; \mathrm{G} ; \mathrm{B})$ - Valor $\mathrm{TT}(\mathrm{R} ; \mathrm{G} ; \mathrm{B}$

\section{MADERA M31/SP/SAPELLI}

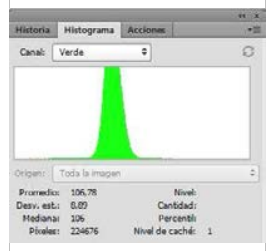

Grafica G (ST)

Valor $\mathrm{G}(\mathrm{ST})$ :

106,78

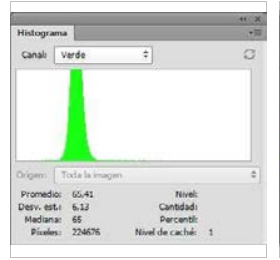

Grafica G (TT)
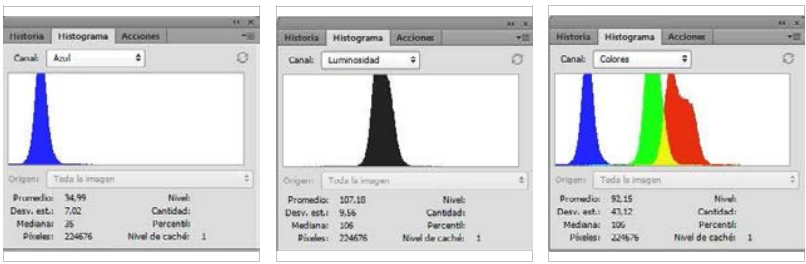

Grafica B (ST)

Grafica L (ST)

Grafica C (ST)

Valor $\mathrm{B}(\mathrm{ST})$ :

Valor L(ST):

Valor C(ST):

34,99

107,18

92,15
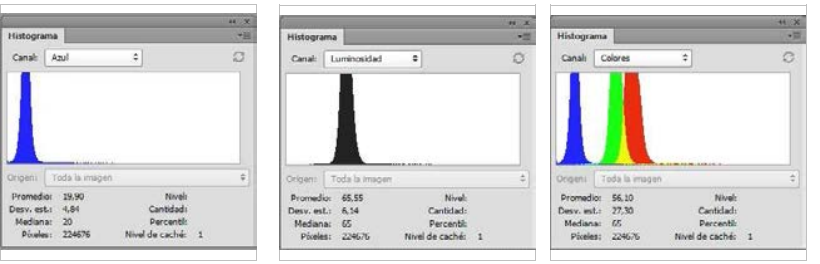

Grafica B (TT)

Grafica L (TT)

Grafica C (TT)

Valor $\mathrm{G}(\mathrm{TT})$ :

Valor $\mathrm{B}(\mathrm{TT})$ :

Valor L(TT):

Valor C(TT):

65,41

19,90

65,55

56,10

Grafica G (DF): Grafica B (DF): Grafica L (DF): Grafica C (DF): Valor DF-G: Valor DF-B: Valor DF-L: Valor DF-C:

$\begin{array}{llll}41,37 & 15,09 & 41,63 & 36,05\end{array}$

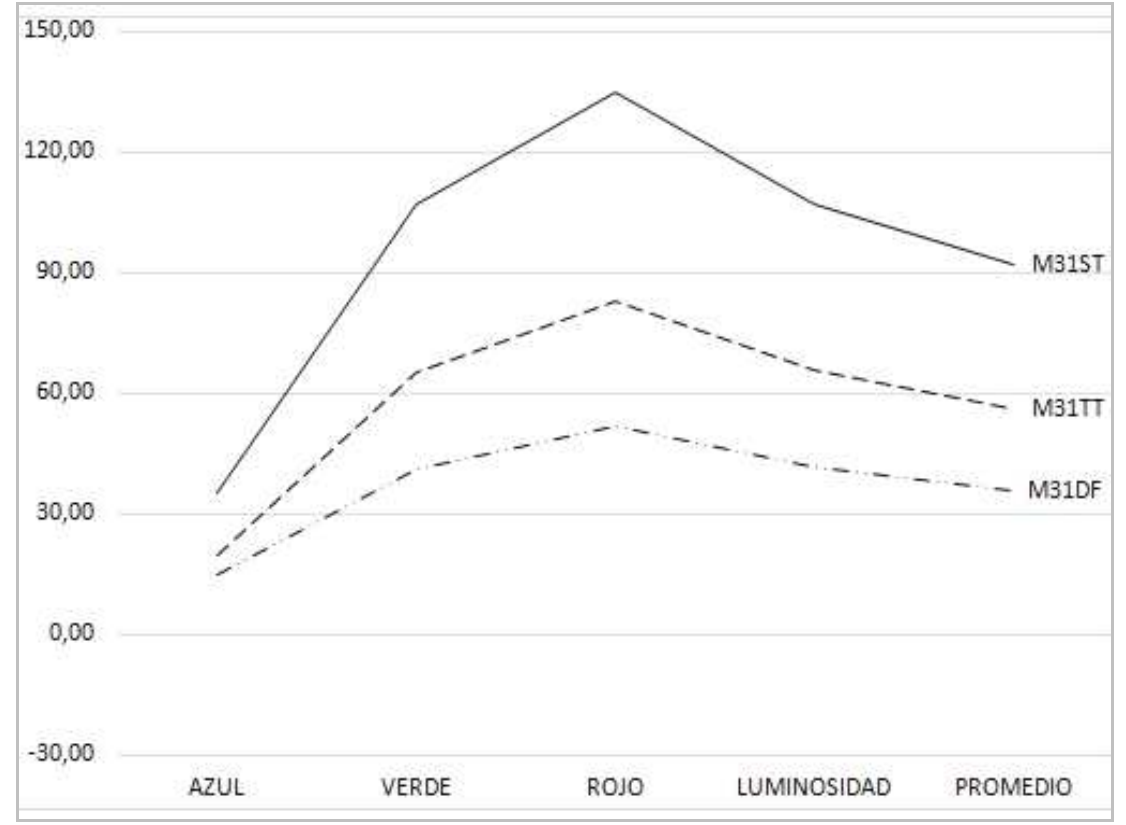

Universidad Politécnica de Madrid - Escuela Técnica Superior de Arquitectura - Departamento de Construcción y Tecnología Arquitectónica Directores: Dr. Alfonso García Santos y Dr. Antonio Rodríguez Rodríguez. Doctorando: D. Francisco Lora Toro 


\section{FICHA DE ENSAYOS DE MADERA Y ACIDOS}

\section{ACIDO A03/CL/ACIDO CLORHIDRICO}
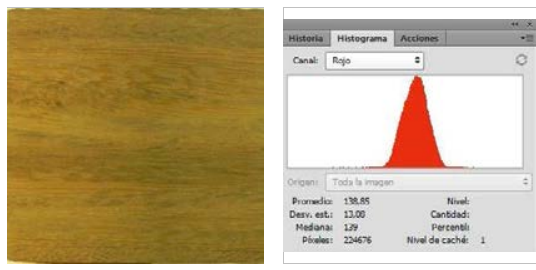

SIN TRATAR (ST): Grafica R (ST)

Valor R(ST):

138,85
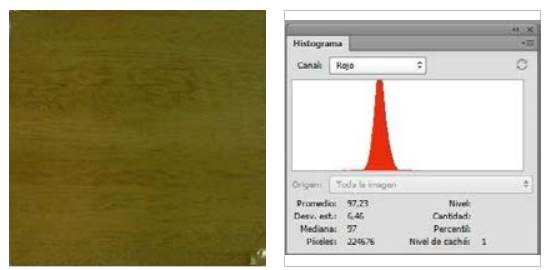

TRATADA (TT): Grafica R (TT)

Valor $\mathrm{R}(\mathrm{TT})$ :

97,23

DIFERENCIA (DF) Grafica R (DF): Valor DF-R: 41,62

GRAFICA:

\section{LEYENDA}

ST MADERA SIN TRATAR

Grafica R Histograma color Rojo Grafica G Histograma color Verde Grafica B Histograma color Azul Grafica L Histograma Luminosidad Grafica C Histograma RGB

\section{TT MADERA TRATADA}

Valor R Número pixeles color Rojo Valor $\mathrm{G}$ Número pixeles color Verde Valor B Número pixeles color Azul Valor $L$ Número pixeles Luminosidad Valor C Número pixeles RG DF DIFERENCIA DE VALORES R;G; $\mathrm{DF}=$ Valor $\mathrm{ST}(\mathrm{R} ; \mathrm{G} ; \mathrm{B})$ - Valor $\mathrm{TT}(\mathrm{R} ; \mathrm{G} ; \mathrm{B}$

\section{MADERA M32/TL/TALI}

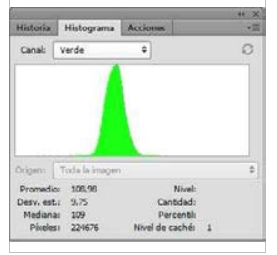

Grafica G (ST)

Valor $\mathrm{G}(\mathrm{ST})$ :

108,98
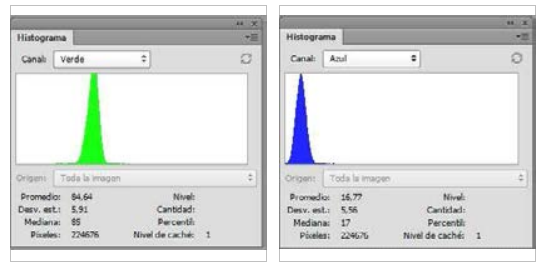

Grafica G (TT)

Grafica B (TT)

Valor $\mathrm{B}(\mathrm{TT})$ :

16,77

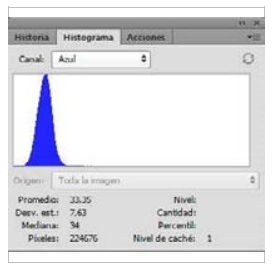

Grafica B (ST)

Valor $\mathrm{B}(\mathrm{ST})$ :

33,35

Valor G(TT):

84,64

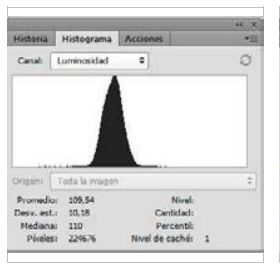

Grafica L (ST)

Valor L(ST):

109,54

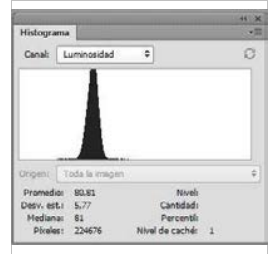

Grafica L (TT)

Valor L(TT):

80,81

Valor DF-L:

28,73

Grafica G (DF): Grafica B (DF): Grafica L (DF): Grafica C (DF):

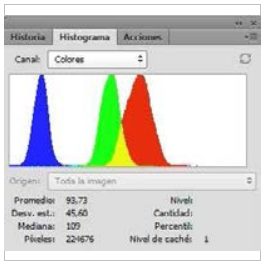

Grafica C (ST)

Valor C(ST):

93,73

Valor DF-G: Valor DF-B:

Valor DF-C:

24,34

16,58

27,52

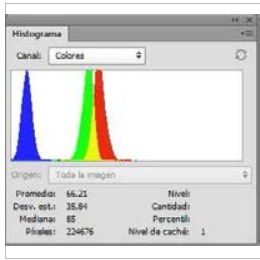

Grafica C (TT)

Valor C(TT):

66,21

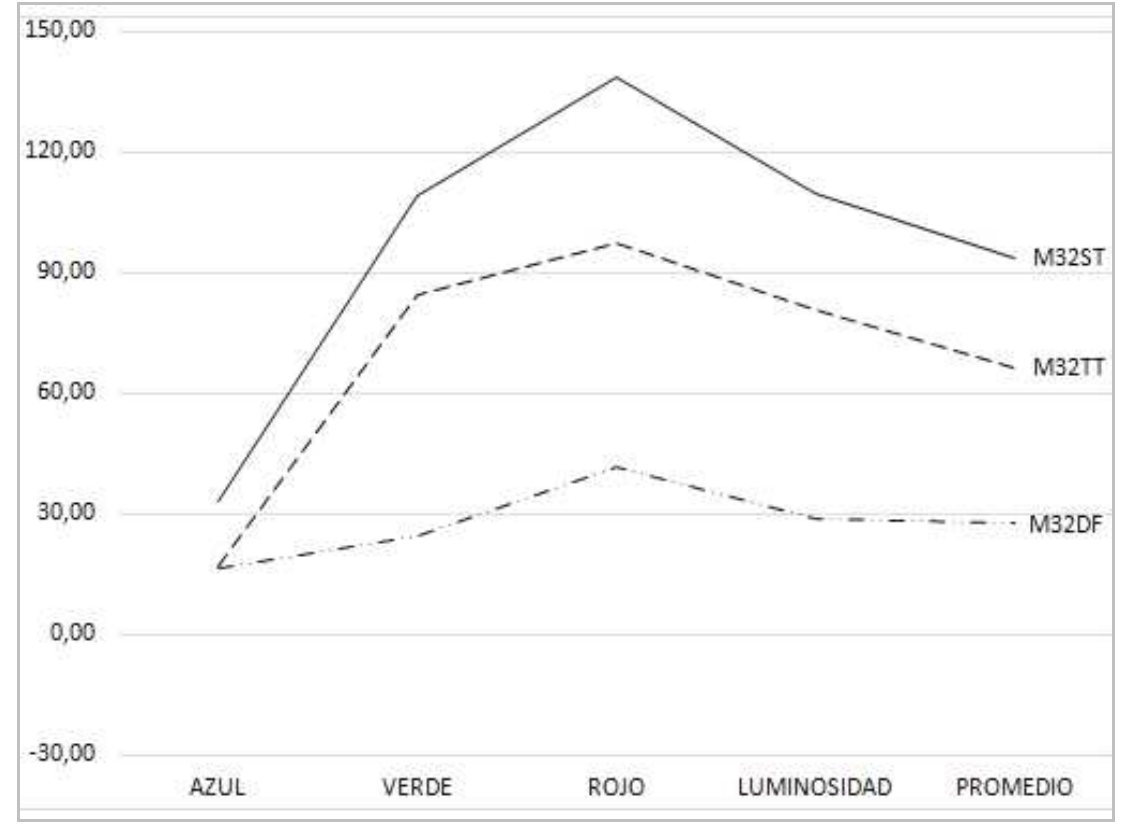

Universidad Politécnica de Madrid - Escuela Técnica Superior de Arquitectura - Departamento de Construcción y Tecnología Arquitectónica Directores: Dr. Alfonso García Santos y Dr. Antonio Rodríguez Rodríguez. Doctorando: D. Francisco Lora Toro 


\section{FICHA DE ENSAYOS DE MADERA Y ACIDOS}

\section{ACIDO A03/CL/ACIDO CLORHIDRICO}

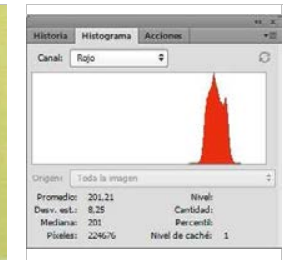

SIN TRATAR (ST): Grafica R (ST)

Valor R(ST):

201,21

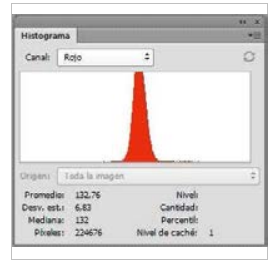

TRATADA (TT): Grafica R (TT)

Valor $\mathrm{R}(\mathrm{TT})$ :

132,76

DIFERENCIA (DF) Grafica R (DF):

Valor DF-R:

68,45

GRAFICA:

\section{LEYENDA}

ST MADERA SIN TRATAR

Grafica R Histograma color Rojo

Grafica G Histograma color Verde

Grafica B Histograma color Azul

Grafica L Histograma Luminosidad

Grafica C Histograma RGB

TT MADERA TRATADA

Valor $\mathrm{R}$ Número pixeles color Rojo

Valor $\mathrm{G}$ Número pixeles color Verde

Valor B Número pixeles color Azul

Valor $L$ Número pixeles Luminosidad

Valor $C$ Número pixeles $R G$

DF DIFERENCIA DE VALORES R;G;

$\mathrm{DF}=$ Valor $\mathrm{ST}(\mathrm{R} ; \mathrm{G} ; \mathrm{B})$ - Valor TT(R;G;B

\section{MADERA M33/TA/TILO AMERICANO}

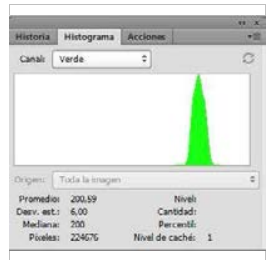

Grafica G (ST)

Valor $\mathrm{G}(\mathrm{ST})$ :

200,59
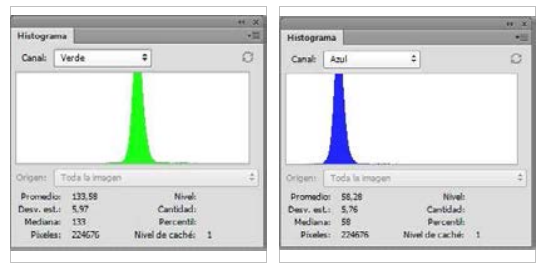

Grafica G (TT)

Grafica B (TT)
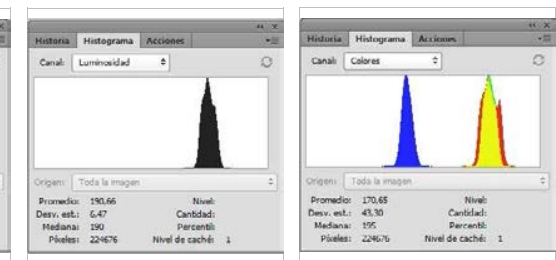

Grafica B (ST)

Grafica L (ST)

Grafica C (ST)

Valor $\mathrm{B}(\mathrm{ST})$ :

Valor L(ST):

190,66

Valor C(ST):

170,65
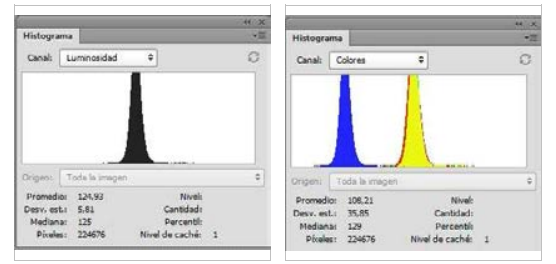

Grafica L (TT)

Grafica C (TT)

Valor G(TT):

Valor $\mathrm{B}(\mathrm{TT})$ :

Valor L(TT):

Valor C(TT):

133,58

58,28

124,93

108,21

Grafica G (DF): Grafica B (DF): Grafica L (DF): Grafica C (DF): Valor DF-G: Valor DF-B: Valor DF-L: Valor DF-C: 67,01 51,87 65,73 62,44

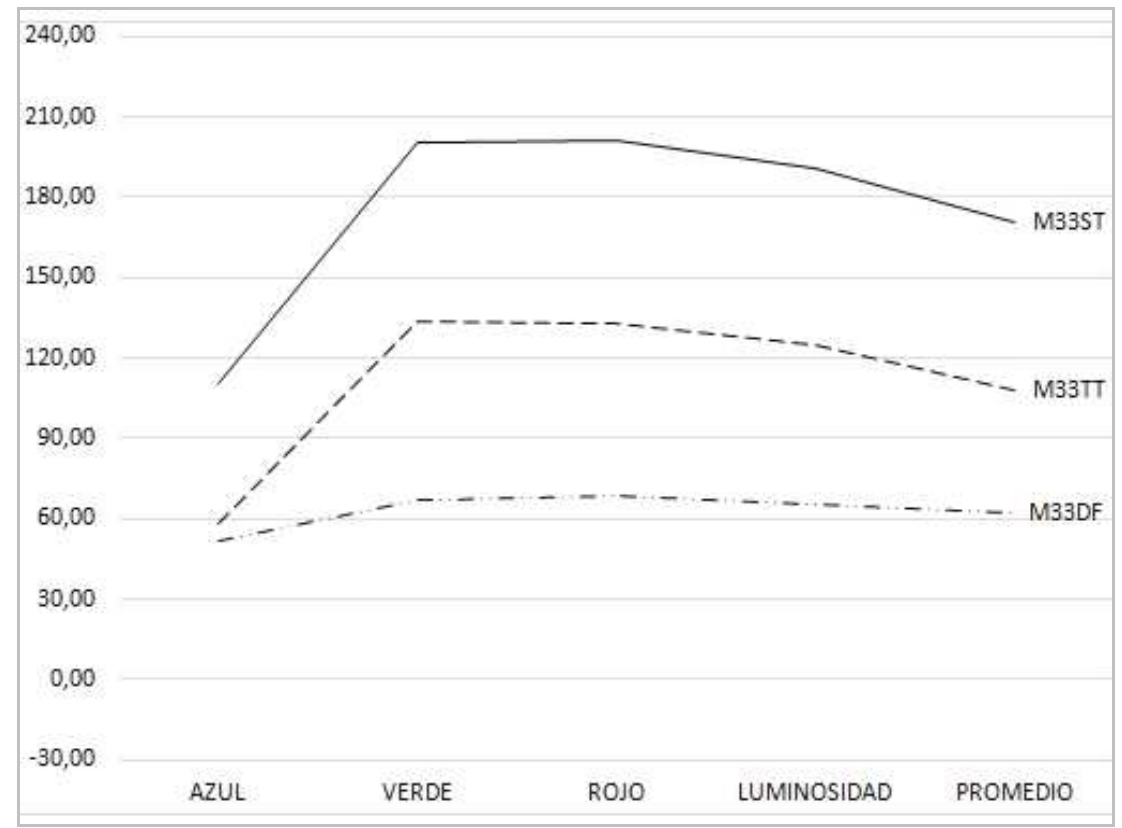

Universidad Politécnica de Madrid - Escuela Técnica Superior de Arquitectura - Departamento de Construcción y Tecnología Arquitectónica Directores: Dr. Alfonso García Santos y Dr. Antonio Rodríguez Rodríguez. Doctorando: D. Francisco Lora Toro 


\section{FICHA DE ENSAYOS DE MADERA Y ACIDOS}

\section{ACIDO A03/CL/ACIDO CLORHIDRICO}

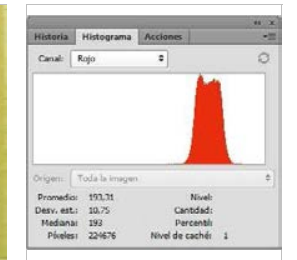

SIN TRATAR (ST): Grafica R (ST)

Valor R(ST):

193,31

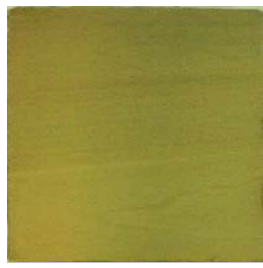

TRATADA (TT): $\quad$ Grafica $R(T T)$ Valor $\mathrm{R}(\mathrm{TT})$ : 139,51

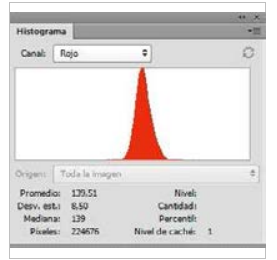

DIFERENCIA (DF) Grafica R (DF): Valor DF-R: 53,80

GRAFICA :

\section{LEYENDA}

ST MADERA SIN TRATAR

Grafica R Histograma color Rojo Grafica G Histograma color Verde Grafica B Histograma color Azul Grafica L Histograma Luminosidad Grafica C Histograma RGB

\section{TT MADERA TRATADA}

Valor $R$ Número pixeles color Rojo Valor $\mathrm{G}$ Número pixeles color Verde Valor B Número pixeles color Azul Valor $L$ Número pixeles Luminosidad Valor C Número pixeles RG DF DIFERENCIA DE VALORES R;G; $\mathrm{DF}=$ Valor $\mathrm{ST}(\mathrm{R} ; \mathrm{G} ; \mathrm{B})$ - Valor $\mathrm{TT}(\mathrm{R} ; \mathrm{G} ; \mathrm{B}$

\section{MADERA M34/TE/TILO EUROPEO}

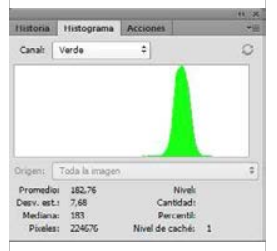

Grafica G (ST)

Valor G(ST):

182,76
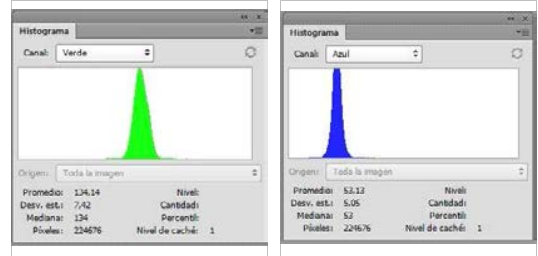

Grafica G (TT)

Grafica B (TT)

Valor $\mathrm{B}(\mathrm{TT})$ :

53,13

134,14

Grafica G (DF): Grafica B (DF):

Grafica L (DF):

Grafica C (DF):

Valor DF-G:

Valor DF-B:

Valor DF-L:

Valor DF-C:

48,62

28,25

48,06

43,55

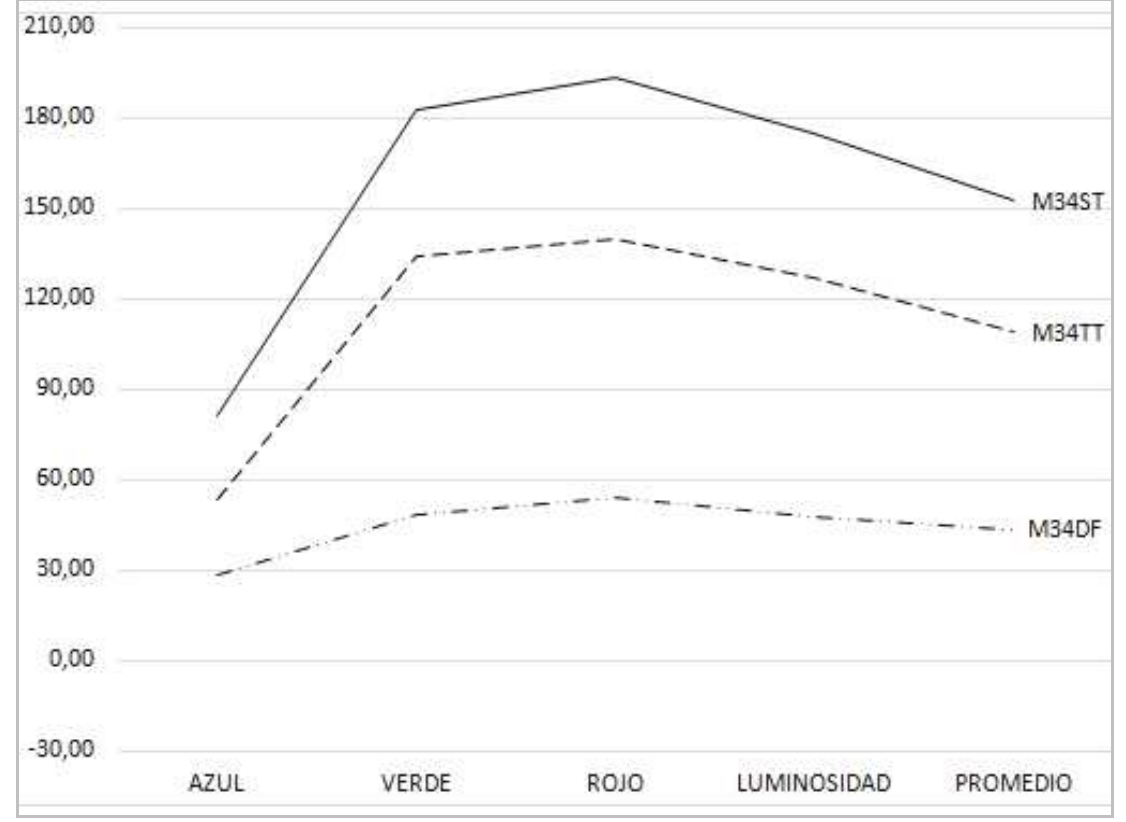

Universidad Politécnica de Madrid - Escuela Técnica Superior de Arquitectura - Departamento de Construcción y Tecnología Arquitectónica Directores: Dr. Alfonso García Santos y Dr. Antonio Rodríguez Rodríguez. Doctorando: D. Francisco Lora Toro 


\section{A04 / ÁCIDO FLUORHÍDRICO}

\section{FICHA DE ENSAYOS DE MADERA Y ACIDOS}

\section{ACIDO A04/FL/ACIDO FLUORHÍDRICO}

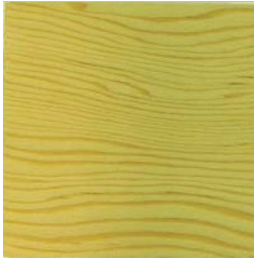

SIN TRATAR (ST): Grafica R (ST)

Valor R(ST):

183,41

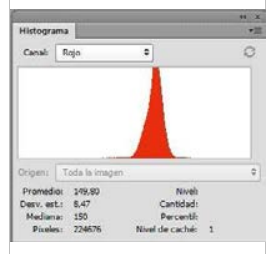

TRATADA (TT): Grafica $R(T T)$

Valor $\mathrm{R}(\mathrm{TT})$ :

149,80

DIFERENCIA (DF) Grafica R (DF):

Valor DF-R:

33,61

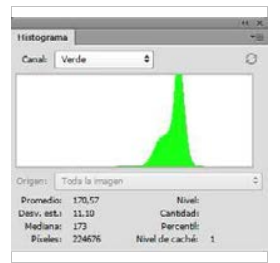

Grafica G (ST)

Valor G(ST):

170,57

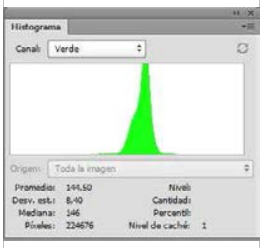

Grafica G (TT)

Valor $\mathrm{G}(\mathrm{TT})$ :

144,50
MADERA M01/AD/ABETO DOUGLAS

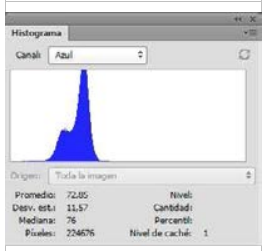

Grafica B (ST)

Valor B(ST):

72,85

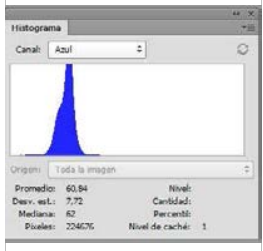

Grafica B (TT)

Valor $\mathrm{B}(\mathrm{TT})$ :

60,84

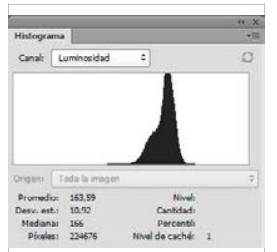

Grafica L (ST)

Valor L(ST):

163,59

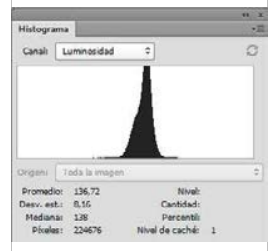

Grafica L (TT)

Valor L(TT):

136,72

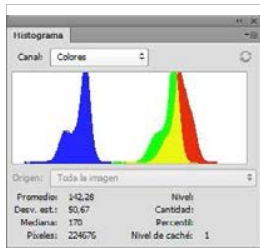

Grafica C (ST)

Valor C(ST):

142,28

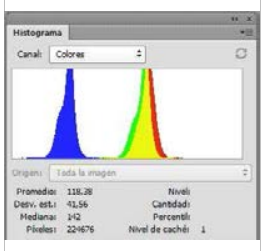

Grafica C (TT)

Valor $\mathrm{C}(\mathrm{TT})$ :

118.38

GRAFICA:

\section{LEYENDA}

ST MADERA SIN TRATAR

Grafica R Histograma color Rojo

Grafica G Histograma color Verde

Grafica B Histograma color Azul

Grafica L Histograma Luminosidad

Grafica C Histograma RGB

TT MADERA TRATADA

Valor $R$ Número pixeles color Rojo

Valor $\mathrm{G}$ Número pixeles color Verde

Valor B Número pixeles color Azul

Valor $L$ Número pixeles Luminosidad

Valor $C$ Número pixeles $R G$

DF DIFERENCIA DE VALORES R;G;

$\mathrm{DF}=$ Valor $\mathrm{ST}(\mathrm{R} ; \mathrm{G} ; \mathrm{B})$ - Valor TT(R;G;B
Grafica G (DF): Grafica B (DF): Grafica L (DF):

Valor DF-G:

Valor DF-B:

12,01
Valor DF-L:

26,87
Grafica C (DF):

Valor DF-C:

$-11.695,72$

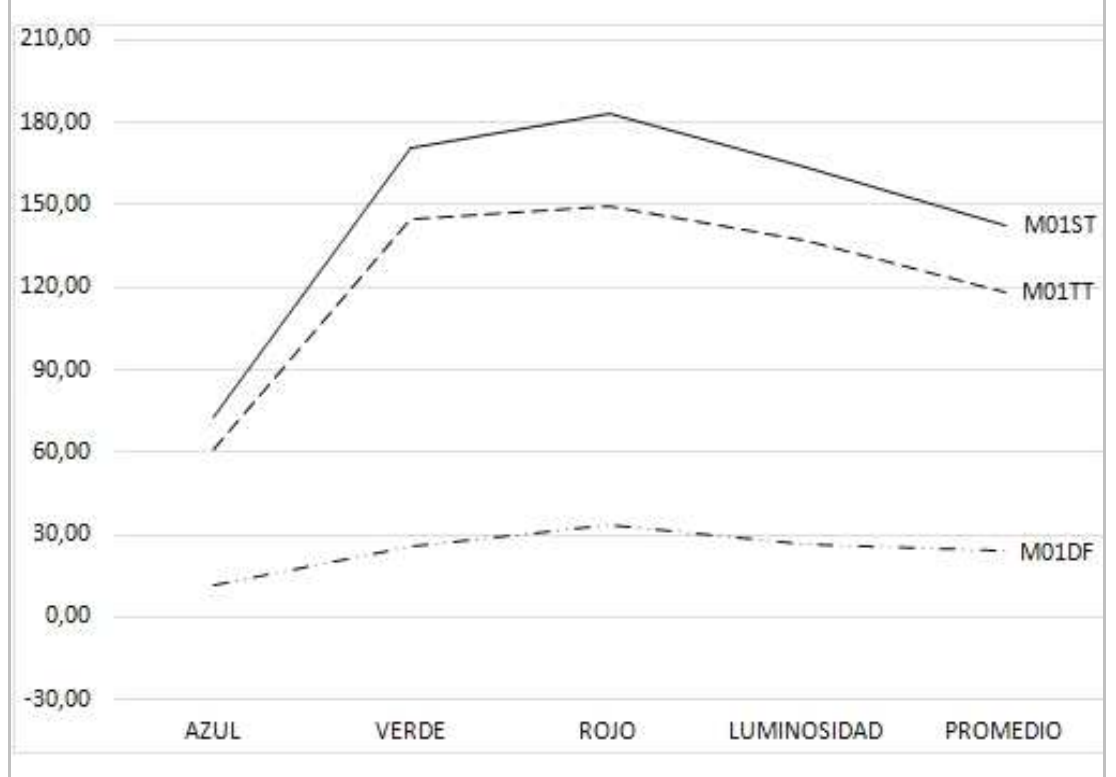

Universidad Politécnica de Madrid - Escuela Técnica Superior de Arquitectura - Departamento de Construcción y Tecnología Arquitectónica Directores: Dr. Alfonso García Santos y Dr. Antonio Rodríguez Rodríguez. Doctorando: D. Francisco Lora Toro 


\section{FICHA DE ENSAYOS DE MADERA Y ACIDOS}

ACIDO A04/FL/ACIDO FLUORHÍDRICO

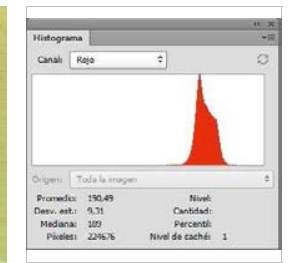

SIN TRATAR (ST): Grafica R (ST)

Valor R(ST):

190,49

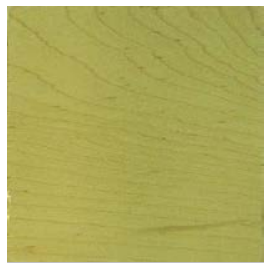

TRATADA (TT):

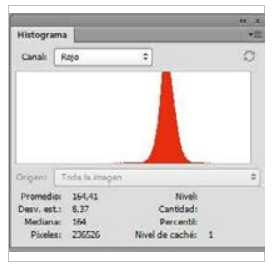

Grafica R (TT)

Valor $\mathrm{R}(\mathrm{TT})$ :

164,41

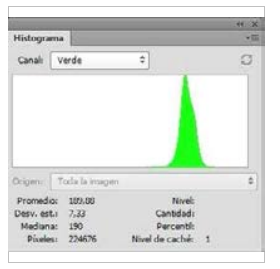

Grafica G (ST)

Valor $\mathrm{G}(\mathrm{ST})$ :

189.88

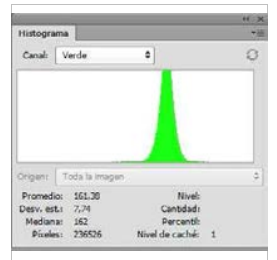

Grafica G (TT)

Valor $\mathrm{G}(\mathrm{TT})$ :

161,38
MADERA M02/ABA/ARCE BLANDO AMERICANO

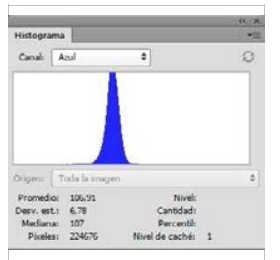

Grafica B (ST)

Valor B(ST):

106,91

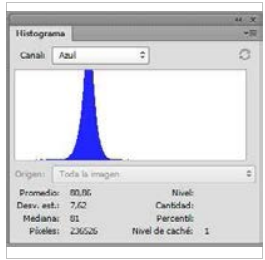

Grafica B (TT)

Valor $\mathrm{B}(\mathrm{TT})$ :

80,86

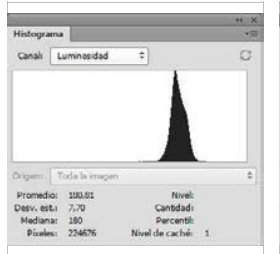

Grafica L (ST)

Valor L(ST):

180.81

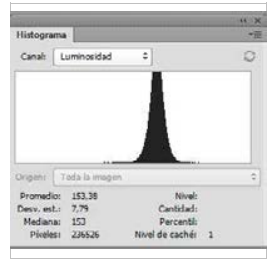

Grafica L (TT)

Valor L(TT):

153,38

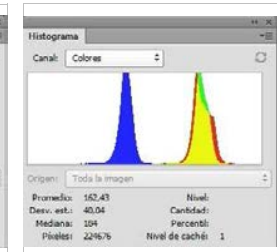

Grafica C (ST)

Valor C(ST):

162,43

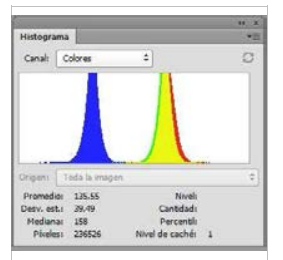

Grafica C (TT)

Valor C(TT):

135,55

DIFERENCIA (DF) Grafica R (DF): Valor DF-R:

Grafica G (DF): Grafica B (DF):

Grafica L (DF):

26,08

Valor DF-G: Valor DF-B:

Valor DF-L:

Grafica C (DF):

Valor DF-C:

26,88

\section{GRAFICA :}

\section{LEYENDA}

\section{ST MADERA SIN TRATAR}

Grafica R Histograma color Rojo

Grafica G Histograma color Verde

Grafica B Histograma color Azul

Grafica L Histograma Luminosidad

Grafica C Histograma RGB

\section{TT MADERA TRATADA}

Valor $R$ Número pixeles color Rojo

Valor $G$ Número pixeles color Verde

Valor B Número pixeles color Azul

Valor L Número pixeles Luminosidad

Valor C Número pixeles RG

DF DIFERENCIA DE VALORES R;G; $\mathrm{DF}=$ Valor $\mathrm{ST}(\mathrm{R} ; \mathrm{G} ; \mathrm{B})$ - Valor TT(R;G;B

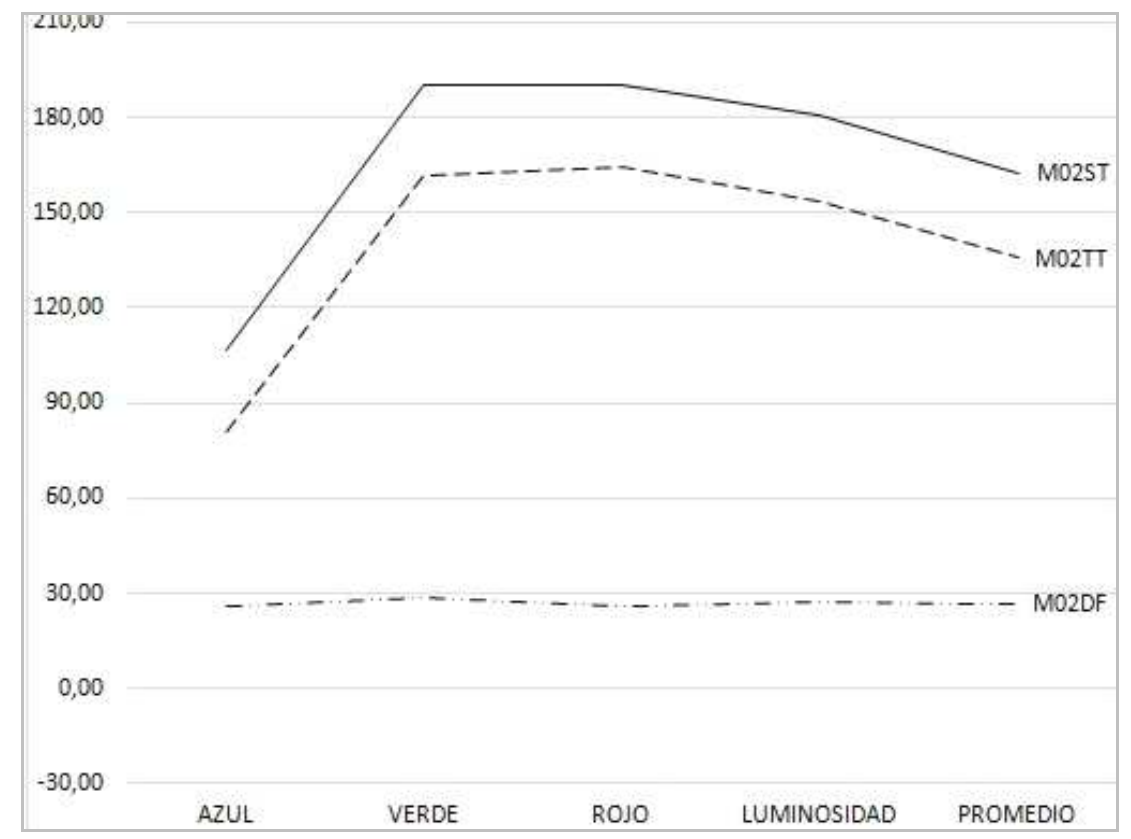

Universidad Politécnica de Madrid - Escuela Técnica Superior de Arquitectura - Departamento de Construcción y Tecnología Arquitectónica Directores: Dr. Alfonso García Santos y Dr. Antonio Rodríguez Rodríguez. Doctorando: D. Francisco Lora Toro 


\section{FICHA DE ENSAYOS DE MADERA Y ACIDOS}

ACIDO A04/FL/ACIDO FLUORHÍDRICO

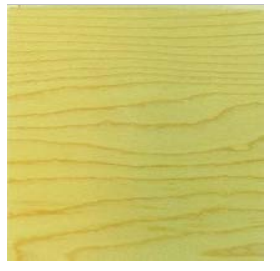

SIN TRATAR (ST): Grafica R (ST)

Valor R(ST):

192,95

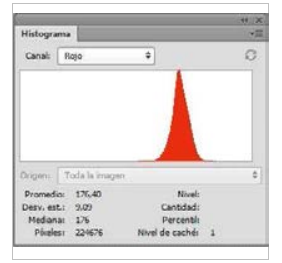

TRATADA (TT): Grafica R (TT)

Valor $\mathrm{R}(\mathrm{TT})$ :

176,40

DIFERENCIA (DF) Grafica R (DF): Valor DF-R: 16,55

GRAFICA:

\section{LEYENDA}

ST MADERA SIN TRATAR

Grafica R Histograma color Rojo Grafica G Histograma color Verde Grafica B Histograma color Azul Grafica L Histograma Luminosidad Grafica C Histograma RGB

\section{TT MADERA TRATADA}

Valor R Número pixeles color Rojo Valor $\mathrm{G}$ Número pixeles color Verde Valor B Número pixeles color Azul Valor $\mathrm{L}$ Número pixeles Luminosidad Valor C Número pixeles RG DF DIFERENCIA DE VALORES R;G; $\mathrm{DF}=$ Valor $\mathrm{ST}(\mathrm{R} ; \mathrm{G} ; \mathrm{B})$ - Valor TT(R;G;B
MADERA MO3/ADA/ARCE DURO AMERICANO
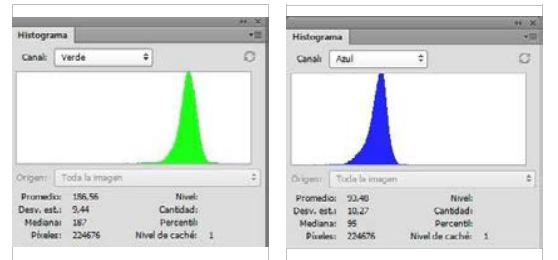

Grafica B (ST)

Valor B(ST):

93,48
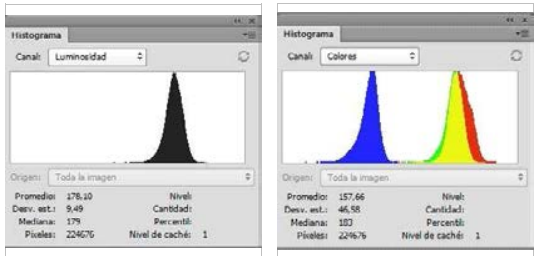

Grafica G (ST)

Valor G(ST):

186,56
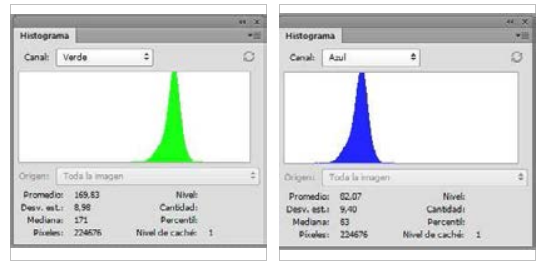

Grafica L (ST)

Grafica C (ST)

Valor L(ST):

Valor C(ST):

178,10

157,66
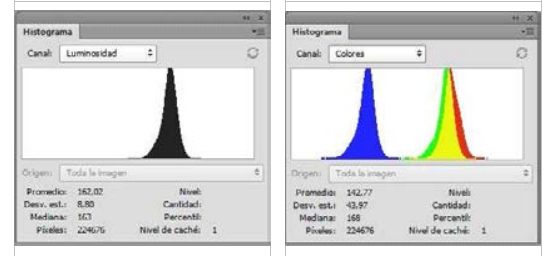

Grafica G (TT)

Grafica B (TT)

Grafica L (TT)

Grafica C (TT)

Valor $\mathrm{G}(\mathrm{TT})$ :

Valor $\mathrm{B}(\mathrm{TT})$ :

Valor L(TT):

Valor C(TT):

169,83

82,07

162,02

142,77

Grafica G (DF): Grafica B (DF): Grafica L (DF): Grafica C (DF): Valor DF-G: Valor DF-B: Valor DF-L: Valor DF-C:

$\begin{array}{llll}16,73 & 11,41 & 16,08 & 14,89\end{array}$

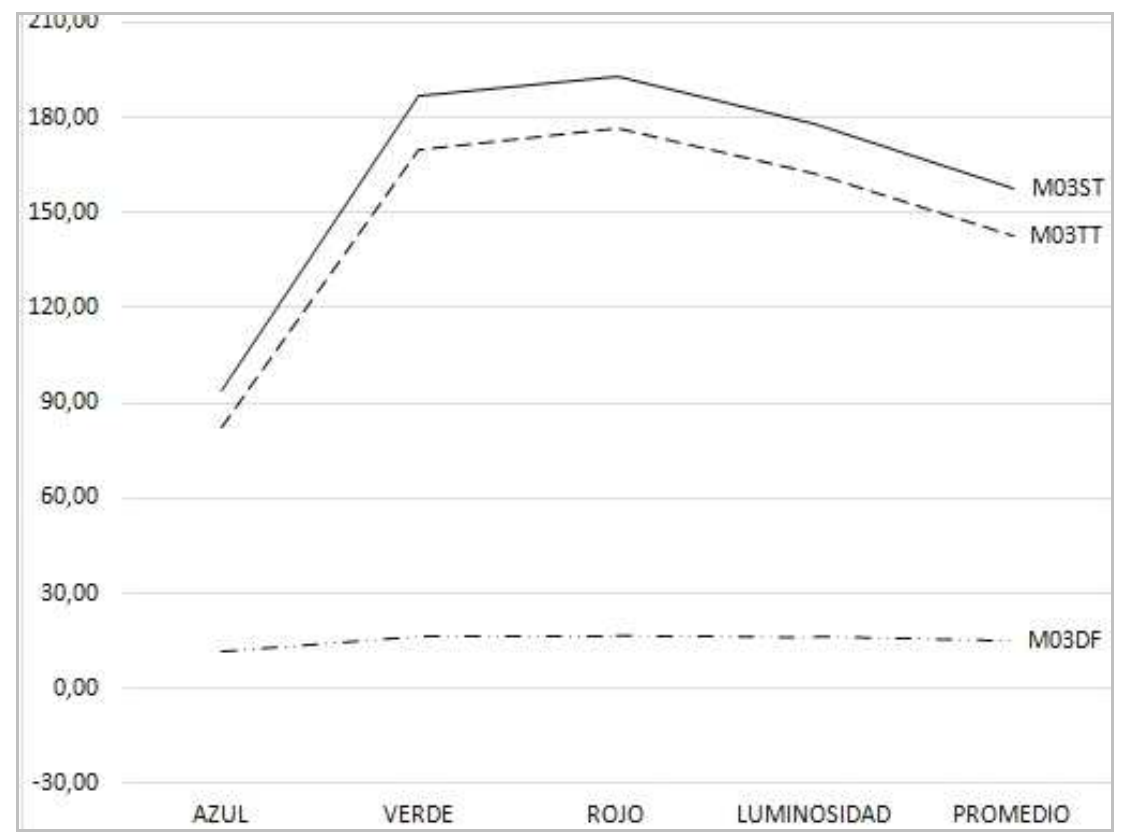

Universidad Politécnica de Madrid - Escuela Técnica Superior de Arquitectura - Departamento de Construcción y Tecnología Arquitectónica Directores: Dr. Alfonso García Santos y Dr. Antonio Rodríguez Rodríguez. Doctorando: D. Francisco Lora Toro 


\section{FICHA DE ENSAYOS DE MADERA Y ACIDOS}

ACIDO A04/FL/ACIDO FLUORHÍDRICO

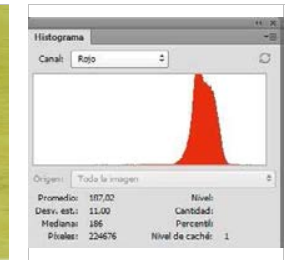

SIN TRATAR (ST): Grafica R (ST)

Valor R(ST):

187,02

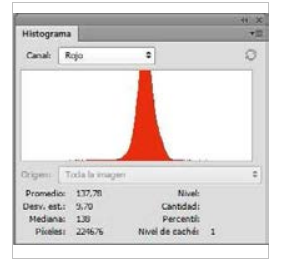

TRATADA (TT): Grafica R (TT)

Valor $\mathrm{R}(\mathrm{TT})$ :

137,78

DIFERENCIA (DF) Grafica R (DF):

Valor DF-R:

49,24

GRAFICA:

\section{LEYENDA}

ST MADERA SIN TRATAR

Grafica R Histograma color Rojo

Grafica G Histograma color Verde

Grafica B Histograma color Azul

Grafica L Histograma Luminosidad

Grafica C Histograma RGB

TT MADERA TRATADA

Valor R Número pixeles color Rojo

Valor $\mathrm{G}$ Número pixeles color Verde

Valor B Número pixeles color Azul

Valor $L$ Número pixeles Luminosidad

Valor C Número pixeles RG

DF DIFERENCIA DE VALORES R;G; $\mathrm{DF}=$ Valor $\mathrm{ST}(\mathrm{R} ; \mathrm{G} ; \mathrm{B})$ - Valor TT(R;G;B

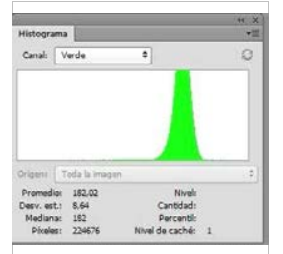

Grafica G (ST)

Valor $\mathrm{G}(\mathrm{ST})$ :

182,02

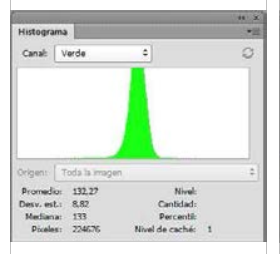

Grafica G (TT)

Valor $\mathrm{G}(\mathrm{TT})$ :

132,27

Grafica G (DF): Grafica B (DF):

Valor DF-G:

49,75

Valor DF-B:

24,99

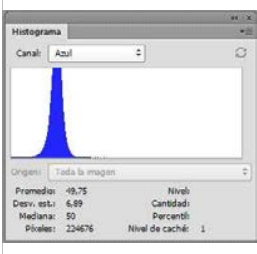

Grafica B (TT)

Valor $\mathrm{B}(\mathrm{TT})$ :

49,75

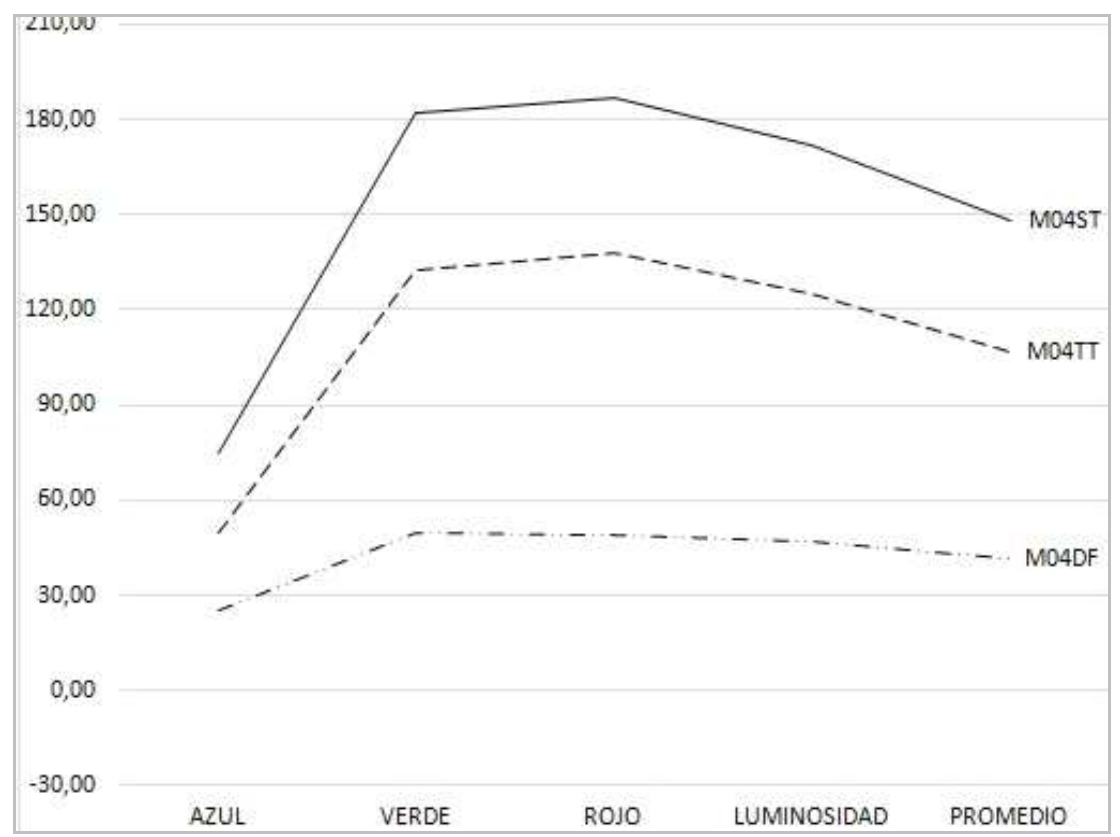

Universidad Politécnica de Madrid - Escuela Técnica Superior de Arquitectura - Departamento de Construcción y Tecnología Arquitectónica Directores: Dr. Alfonso García Santos y Dr. Antonio Rodríguez Rodríguez. Doctorando: D. Francisco Lora Toro
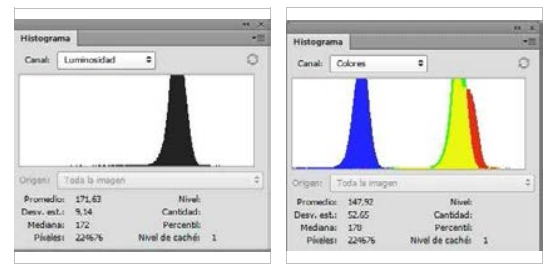

Grafica L (ST) Grafica C (ST)

Valor L(ST): $\quad$ Valor C(ST):

171,63

147,92
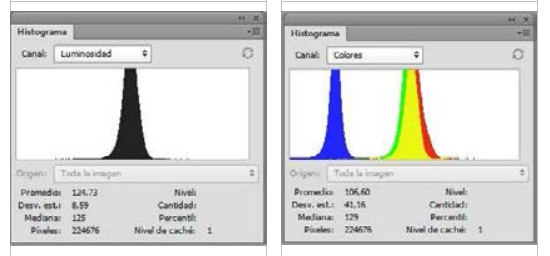

Grafica L (TT)

Grafica C (TT)

Valor L(TT):

Valor C(TT):

124,73

106,60

Grafica L (DF): Grafica C (DF): Valor DF-L: $\quad$ Valor DF-C: 46,90

41,32 


\section{FICHA DE ENSAYOS DE MADERA Y ACIDOS}

\section{ACIDO A04/FL/ACIDO FLUORHÍDRICO}
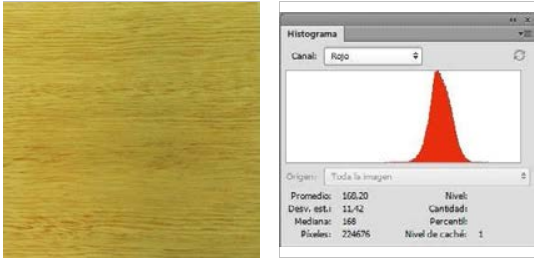

SIN TRATAR (ST): Grafica R (ST)

Valor R(ST):

168,20

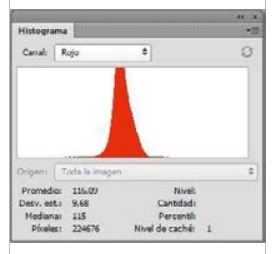

TRATADA (TT): Grafica R (TT)

Valor $\mathrm{R}(\mathrm{TT})$ :

116,09

DIFERENCIA (DF) Grafica R (DF): Valor DF-R: 52,11

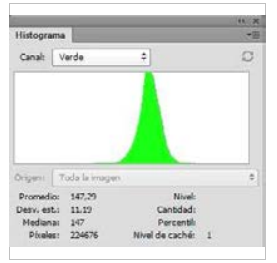

Grafica G (ST)

Valor G(ST):

147,29

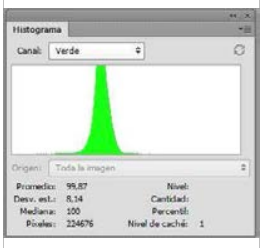

Grafica G (TT)

Valor $\mathrm{G}(\mathrm{TT})$ :

99,87
MADERA M05/BS/BOSSÉ

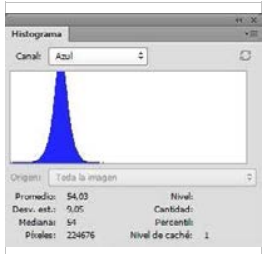

Grafica B (ST)

Valor B(ST):

54,03

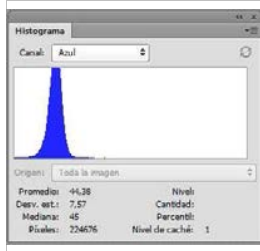

Grafica B (TT)

Valor $\mathrm{B}(\mathrm{TT})$ :

44,38

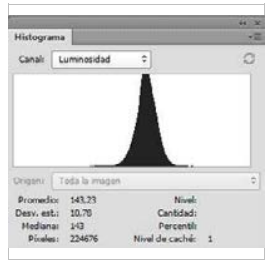

Grafica L (ST)

Valor L(ST):

143,23

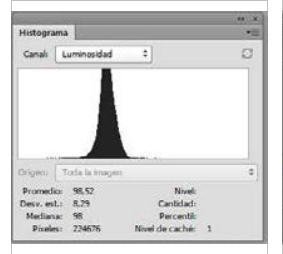

Grafica L (TT)

Valor L(TT):

98,52

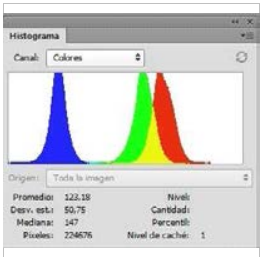

Grafica C (ST)

Valor C(ST):

123,18

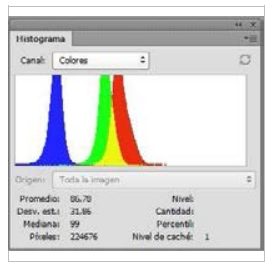

Grafica C (TT)

Valor $\mathrm{C}(\mathrm{TT})$ :

86,78

Grafica G (DF): Grafica B (DF): Grafica L (DF): Grafica C (DF): Valor DF-G: Valor DF-B: Valor DF-L: Valor DF-C: $\begin{array}{llll}47,42 & 9,65 & 44,71 & 36,40\end{array}$

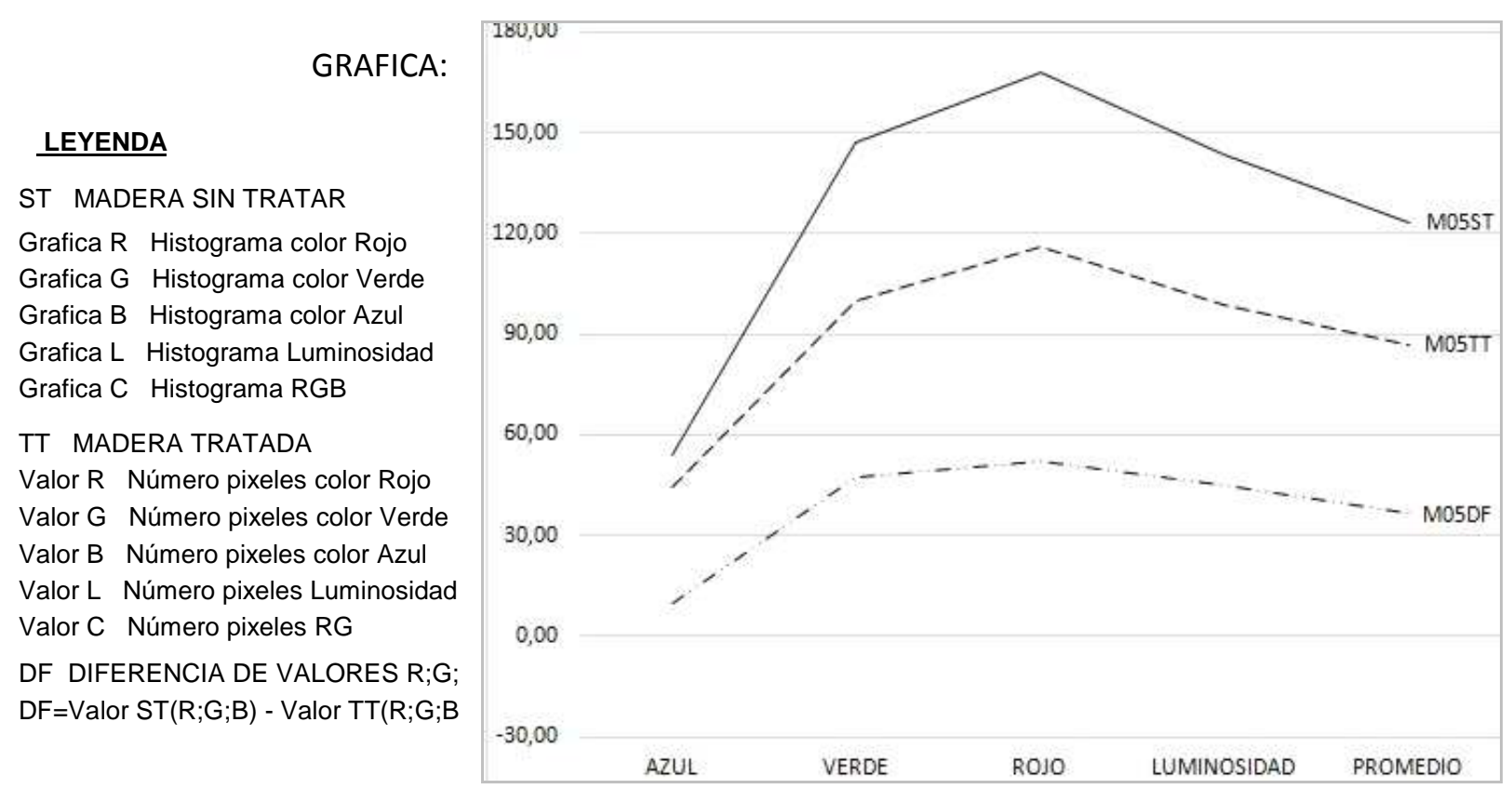

Universidad Politécnica de Madrid - Escuela Técnica Superior de Arquitectura - Departamento de Construcción y Tecnología Arquitectónica Directores: Dr. Alfonso García Santos y Dr. Antonio Rodríguez Rodríguez. Doctorando: D. Francisco Lora Toro 


\section{FICHA DE ENSAYOS DE MADERA Y ACIDOS}

\section{ACIDO A04/FL/ACIDO FLUORHÍDRICO}
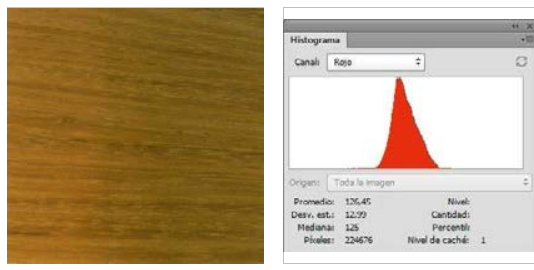

SIN TRATAR (ST): Grafica R (ST)

Valor R(ST):

126,45

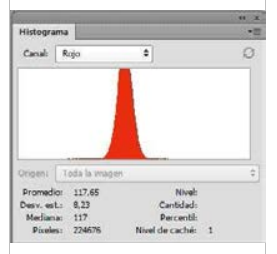

TRATADA (TT): Grafica R (TT)

Valor $\mathrm{R}(\mathrm{TT})$ :

117,65

DIFERENCIA (DF) Grafica R (DF): Valor DF-R: 8,80

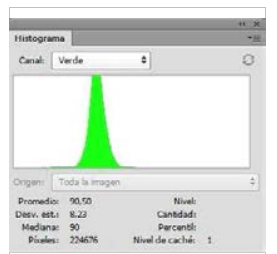

Grafica G (ST)

Valor G(ST):

90,50

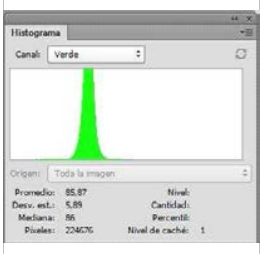

Grafica G (TT)

Valor $\mathrm{G}(\mathrm{TT})$ :

85,87
MADERA M06/BG/BUBINGA

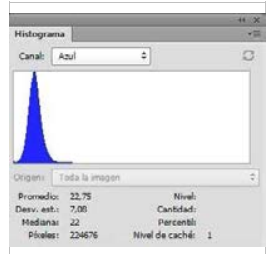

Grafica B (ST)

Valor $\mathrm{B}(\mathrm{ST})$ :

22,75

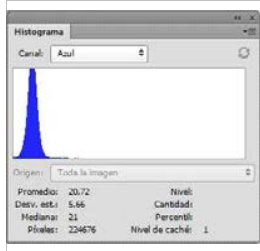

Grafica B (TT)

Valor $\mathrm{B}(\mathrm{TT})$ :

20,72

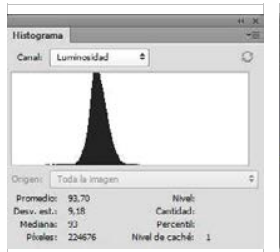

Grafica L (ST)

Valor L(ST):

93,70

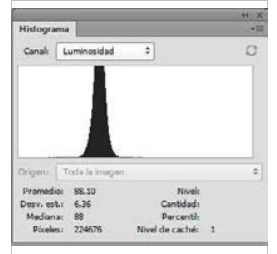

Grafica L (TT)

Valor L(TT):

88,10

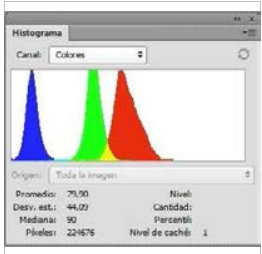

Grafica C (ST)

Valor C(ST):

79,90

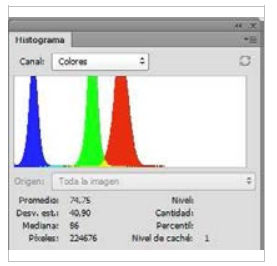

Grafica C (TT)

Valor $\mathrm{C}(\mathrm{TT})$ :

74,75

Grafica G (DF): Grafica B (DF): Grafica L (DF): Grafica C (DF): Valor DF-G: Valor DF-B: Valor DF-L: Valor DF-C:

$\begin{array}{llll}4,63 & 2,03 & 5,60 & 5,15\end{array}$

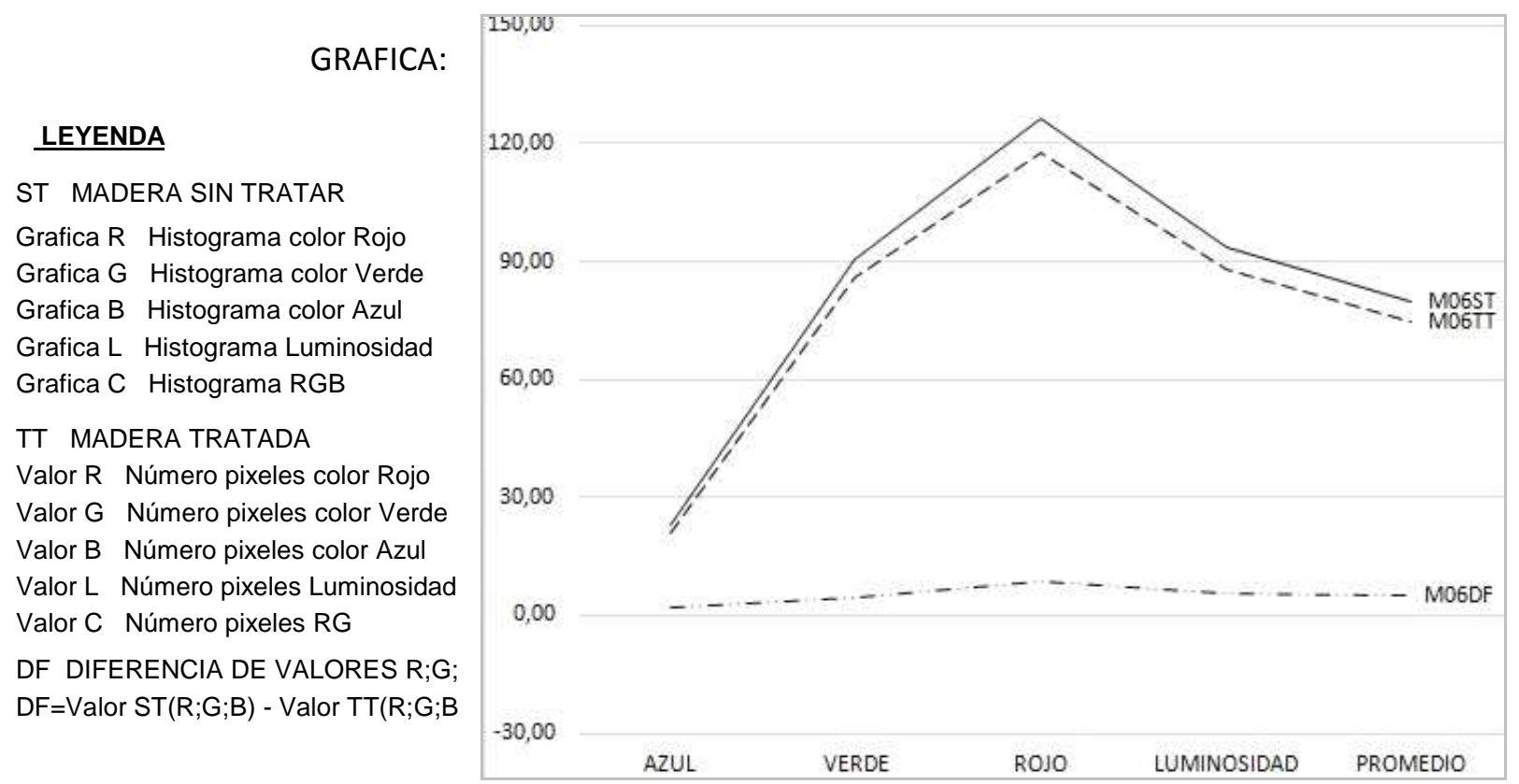

Universidad Politécnica de Madrid - Escuela Técnica Superior de Arquitectura - Departamento de Construcción y Tecnología Arquitectónica Directores: Dr. Alfonso García Santos y Dr. Antonio Rodríguez Rodríguez. Doctorando: D. Francisco Lora Toro 


\section{FICHA DE ENSAYOS DE MADERA Y ACIDOS}

ACIDO A04/FL/ACIDO FLUORHÍDRICO

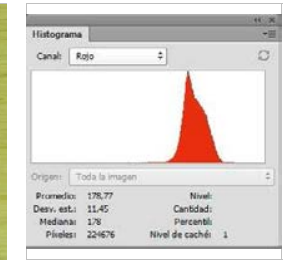

SIN TRATAR (ST): Grafica R (ST)

Valor R(ST):

178,77

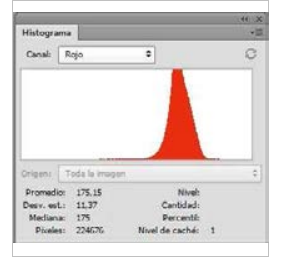

TRATADA (TT): Grafica R (TT)

Valor R(TT):

175,15

DIFERENCIA (DF) Grafica R (DF): Valor DF-R:

3,62

GRAFICA:

\section{LEYENDA}

ST MADERA SIN TRATAR

Grafica R Histograma color Rojo

Grafica G Histograma color Verde

Grafica B Histograma color Azul

Grafica L Histograma Luminosidad

Grafica C Histograma RGB

TT MADERA TRATADA

Valor $R$ Número pixeles color Rojo

Valor $\mathrm{G}$ Número pixeles color Verde

Valor B Número pixeles color Azul

Valor $L$ Número pixeles Luminosidad

Valor C Número pixeles RG

DF DIFERENCIA DE VALORES R;G; $\mathrm{DF}=$ Valor $\mathrm{ST}(\mathrm{R} ; \mathrm{G} ; \mathrm{B})$ - Valor TT $(\mathrm{R} ; \mathrm{G} ; \mathrm{B}$
MADERA MO7/CÑ/CASTAÑO EUROPEO
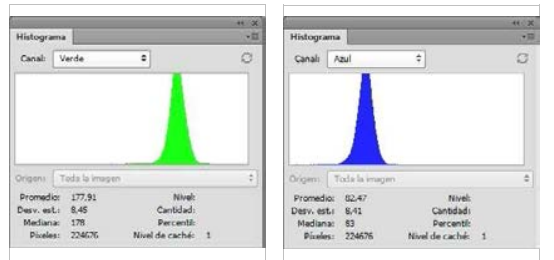

Grafica G (ST) Grafica B (ST)

Valor B(ST):

82,47
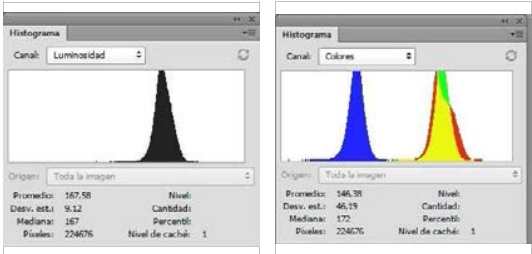

Grafica L (ST)

Grafica C (ST)

Valor G(ST):

177,91

Valor L(ST):

Valor C(ST):

167,58

146,38
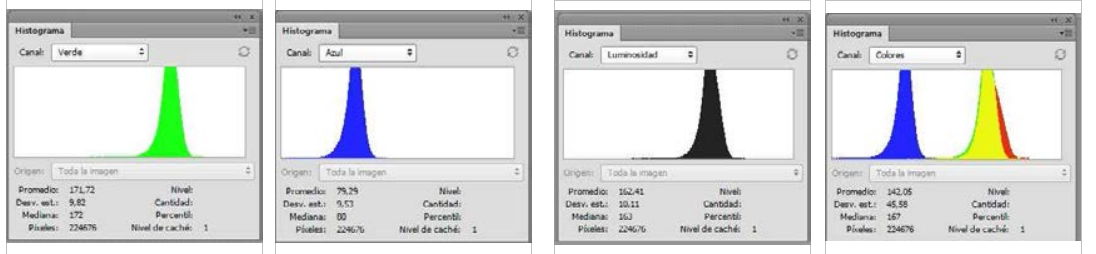

Grafica G (TT)

Grafica B (TT)

Grafica L (TT)

Grafica C (TT)

Valor $\mathrm{G}(\mathrm{TT})$ :

Valor $\mathrm{B}(\mathrm{TT})$ :

Valor L(TT):

Valor C(TT):

79,29

162,41

142,05

162,41

$\begin{array}{llll}\text { Grafica G (DF): } & \text { Grafica B (DF): } & \text { Grafica L (DF): } & \text { Grafica C (DF): } \\ \text { Valor DF-G: } & \text { Valor DF-B: } & \text { Valor DF-L: } & \text { Valor DF-C: }\end{array}$

$\begin{array}{llll}6,19 & 3,18 & 5,17 & 4,33\end{array}$

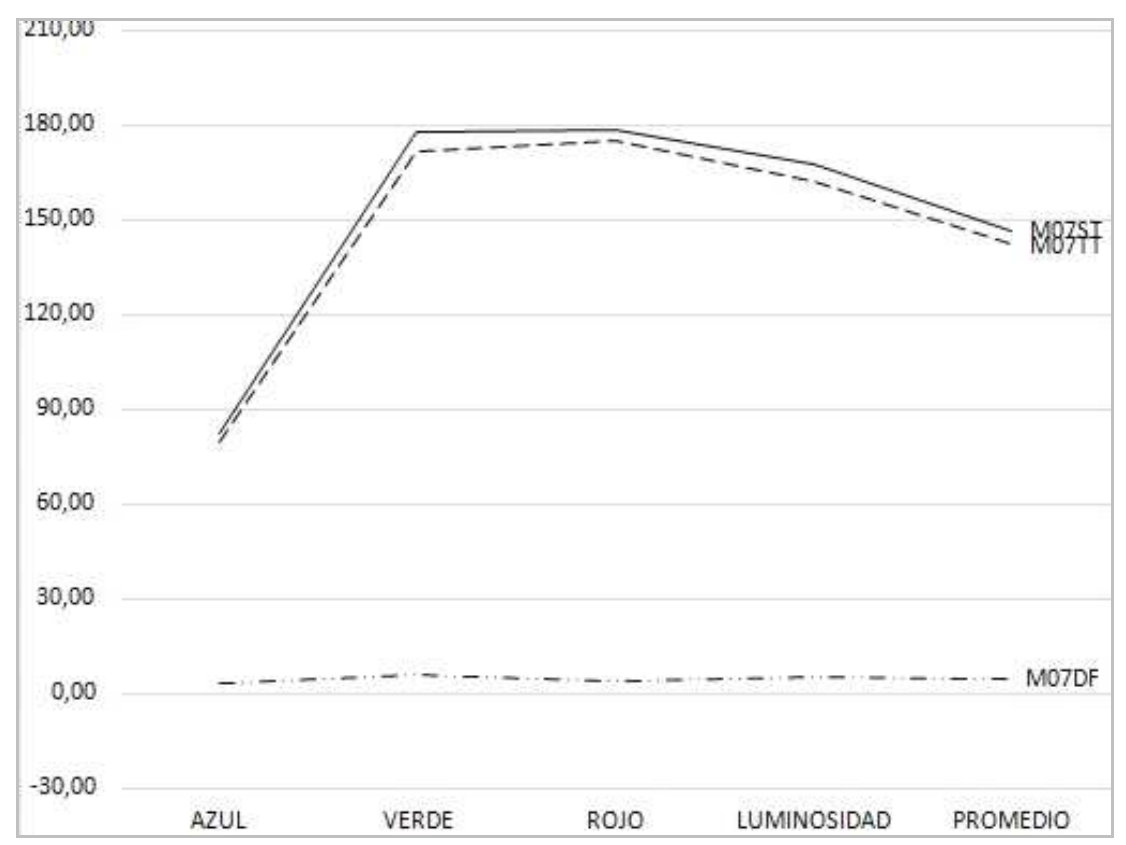

Universidad Politécnica de Madrid - Escuela Técnica Superior de Arquitectura - Departamento de Construcción y Tecnología Arquitectónica Directores: Dr. Alfonso García Santos y Dr. Antonio Rodríguez Rodríguez. Doctorando: D. Francisco Lora Toro 


\section{FICHA DE ENSAYOS DE MADERA Y ACIDOS}

ACIDO A04/FL/ACIDO FLUORHÍDRICO

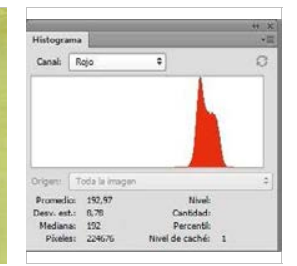

SIN TRATAR (ST): Grafica R (ST)

Valor R(ST):

192,97

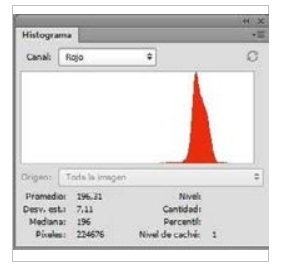

TRATADA (TT): $\quad$ Grafica $R$ (TT) Valor R(TT): 196,31

DIFERENCIA (DF) Grafica R (DF): Valor DF-R: $-3,34$ GRAFICA:

\section{LEYENDA}

ST MADERA SIN TRATAR

Grafica R Histograma color Rojo Grafica G Histograma color Verde Grafica B Histograma color Azul Grafica L Histograma Luminosidad Grafica C Histograma RGB

TT MADERA TRATADA

Valor R Número pixeles color Rojo Valor $\mathrm{G}$ Número pixeles color Verde Valor B Número pixeles color Azul Valor $L$ Número pixeles Luminosidad Valor $C$ Número pixeles $R G$ DF DIFERENCIA DE VALORES R;G; $\mathrm{DF}=$ Valor $\mathrm{ST}(\mathrm{R} ; \mathrm{G} ; \mathrm{B})$ - Valor TT $(\mathrm{R} ; \mathrm{G} ; \mathrm{B}$

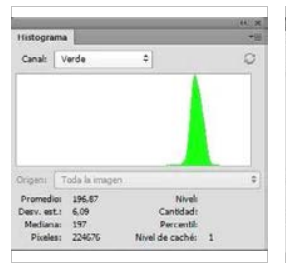

Grafica G (ST)

Valor $\mathrm{G}(\mathrm{ST})$ :

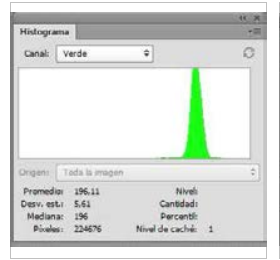

0,76
196,87

Grafica G (TT)

Valor G(TT):

196,11

MADERA M08/CPE/CHOPO EUROPEO

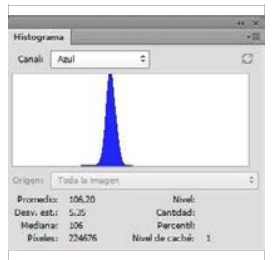

Grafica B (ST)

Valor B(ST):

106,20

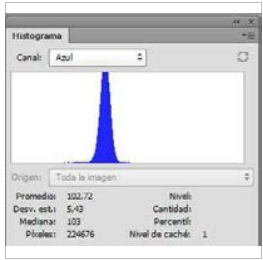

Grafica B (TT)

Valor $\mathrm{B}(\mathrm{TT})$ :

102,72

Grafica G (DF): Grafica B (DF):

Valor DF-B:

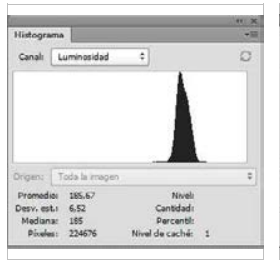

Grafica L (ST)

Valor L(ST):

185,67

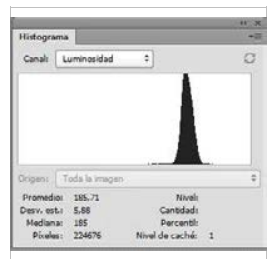

Grafica L (TT)

Valor L(TT):

185,71

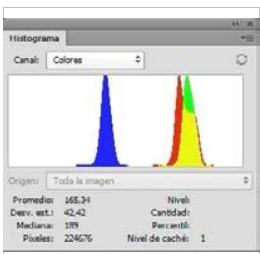

Grafica C (ST)

Valor C(ST):

165,34

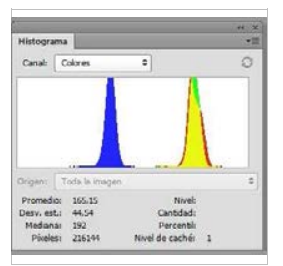

Grafica C (TT)

Valor C(TT):

165,15

Valor DF-G:

Grafica L (DF):

Grafica C (DF):

Valor DF-L:

Valor DF-C:

3,48

$-0,04$

0,19

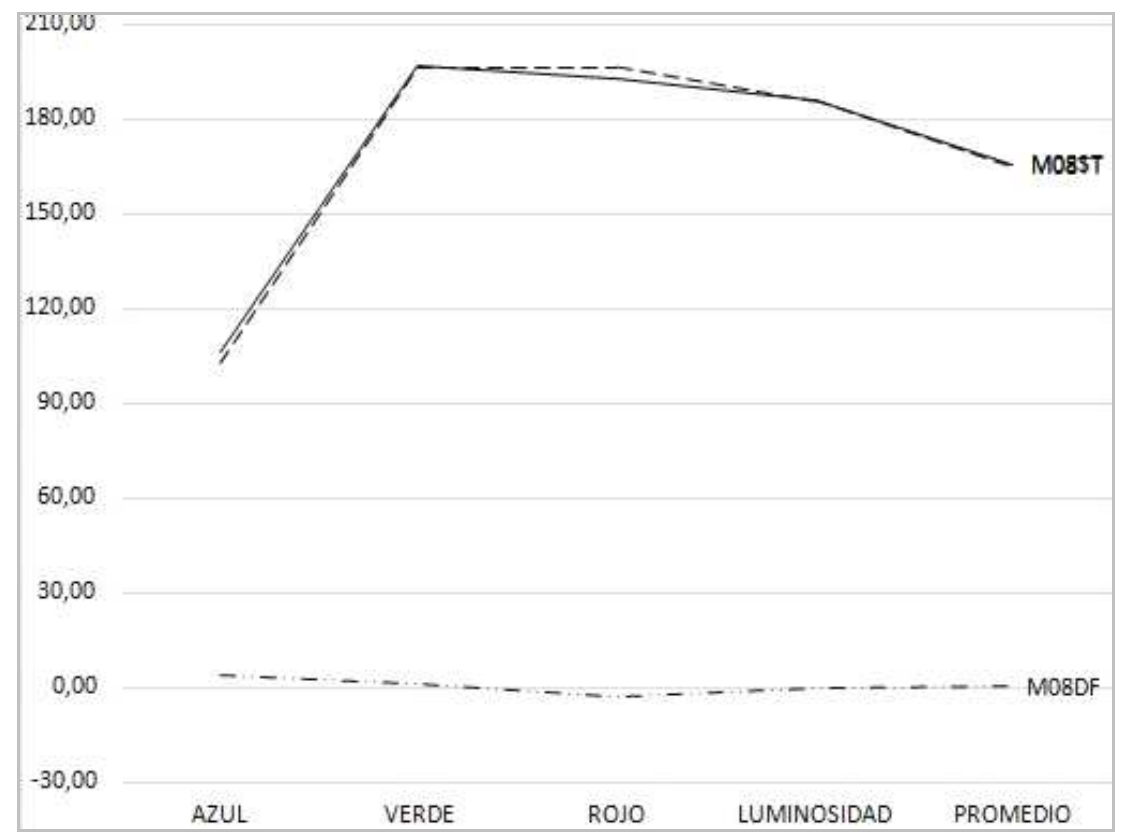

Universidad Politécnica de Madrid - Escuela Técnica Superior de Arquitectura - Departamento de Construcción y Tecnología Arquitectónica Directores: Dr. Alfonso García Santos y Dr. Antonio Rodríguez Rodríguez. Doctorando: D. Francisco Lora Toro 


\section{FICHA DE ENSAYOS DE MADERA Y ACIDOS}

ACIDO A04/FL/ACIDO FLUORHÍDRICO
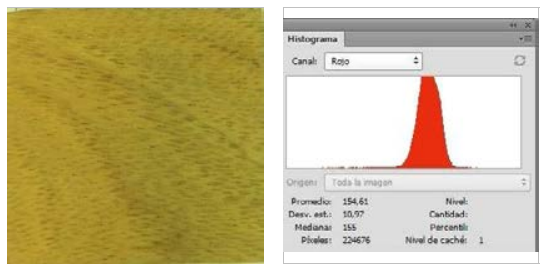

SIN TRATAR (ST): Grafica R (ST)

Valor R(ST):

154,61

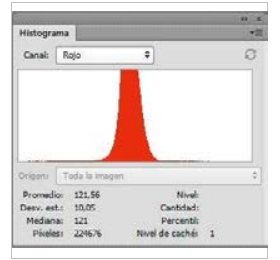

TRATADA (TT): Grafica R (TT)

Valor R(TT):

121,56

DIFERENCIA (DF) Grafica R (DF):

Valor DF-R:

33,05

GRAFICA:

\section{LEYENDA}

ST MADERA SIN TRATAR

Grafica R Histograma color Rojo

Grafica G Histograma color Verde

Grafica B Histograma color Azul

Grafica L Histograma Luminosidad

Grafica C Histograma RGB

TT MADERA TRATADA

Valor R Número pixeles color Rojo

Valor $\mathrm{G}$ Número pixeles color Verde

Valor B Número pixeles color Azul

Valor $\mathrm{L}$ Número pixeles Luminosidad

Valor $C$ Número pixeles $R G$

DF DIFERENCIA DE VALORES R;G; $\mathrm{DF}=$ Valor $\mathrm{ST}(\mathrm{R} ; \mathrm{G} ; \mathrm{B})$ - Valor TT(R;G;B

\section{MADERA M09/CJ/CEREJEIRA}
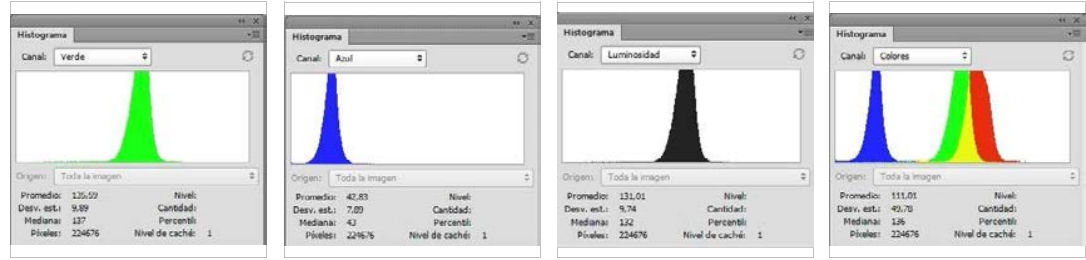

Grafica G (ST) Grafica B (ST)

Grafica L (ST)

Grafica C (ST)

Valor $\mathrm{G}(\mathrm{ST})$ :

Valor B(ST):

Valor L(ST):

Valor C(ST):

135,59

42,83

131,01

111,01
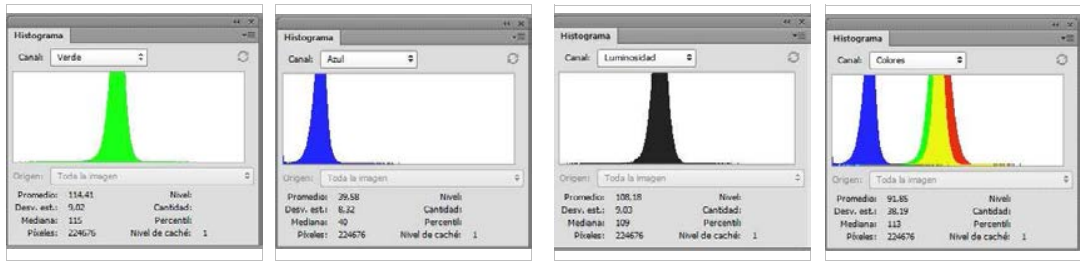

Grafica G (TT)

Grafica B (TT)

Grafica L (TT)

Grafica C (TT)

Valor G(TT):

Valor $\mathrm{B}(\mathrm{TT})$ :

Valor L(TT):

Valor C(TT):

114,41

39,58

108,18

91,58

Grafica G (DF): Grafica B (DF): Grafica L (DF): Grafica C (DF): Valor DF-G: Valor DF-B: Valor DF-L: Valor DF-C:
21,18
3,25
22,83
19,43

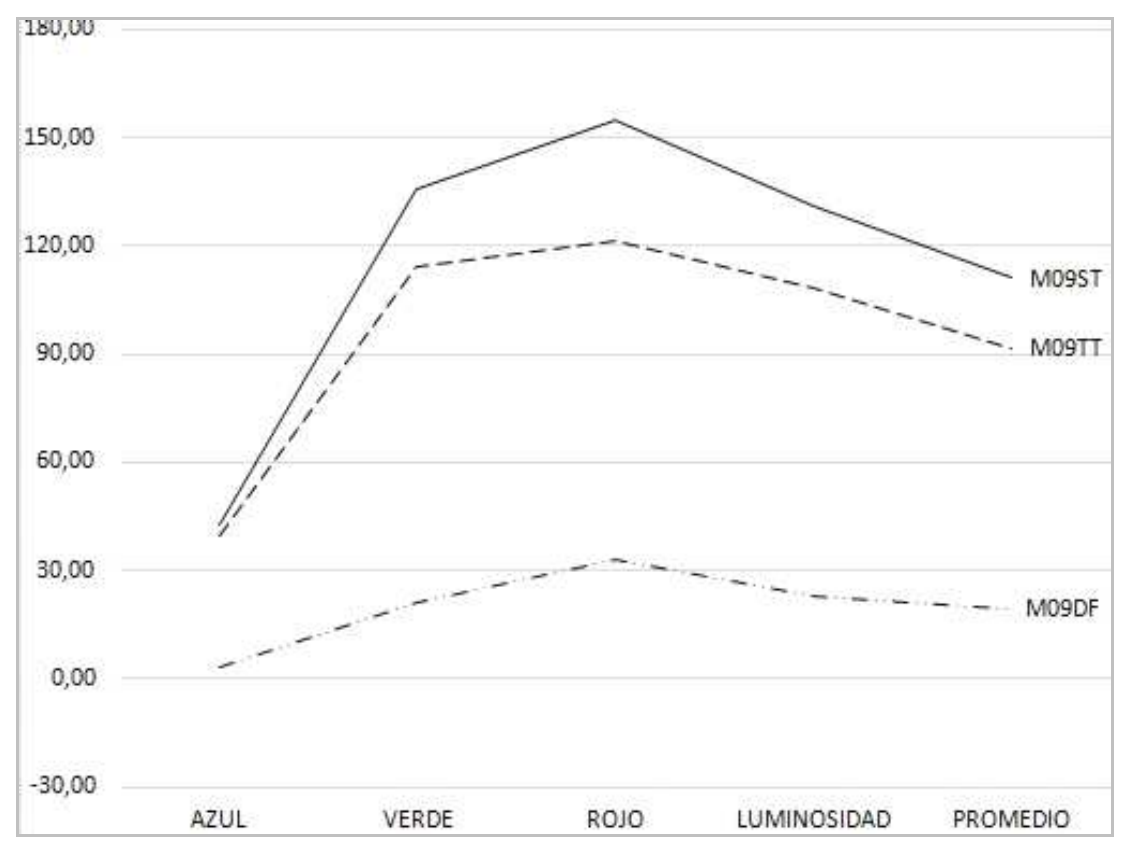

Universidad Politécnica de Madrid - Escuela Técnica Superior de Arquitectura - Departamento de Construcción y Tecnología Arquitectónica Directores: Dr. Alfonso García Santos y Dr. Antonio Rodríguez Rodríguez. Doctorando: D. Francisco Lora Toro 


\section{FICHA DE ENSAYOS DE MADERA y ACIDOS}

\section{ACIDO A04/FL/ACIDO FLUORHÍDRICO}
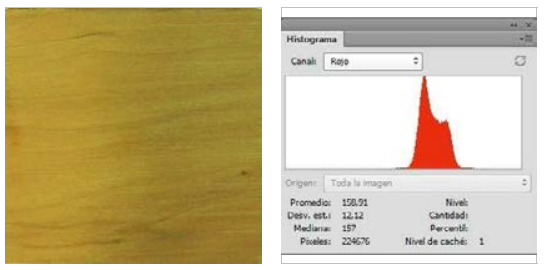

SIN TRATAR (ST): Grafica R (ST)

Valor R(ST):

158,91

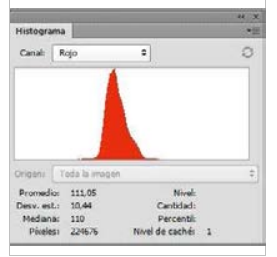

TRATADA (TT): Grafica $R(T T)$

Valor $\mathrm{R}(\mathrm{TT})$ :

111,05

DIFERENCIA (DF) Grafica R (DF): Valor DF-R:

47,86

GRAFICA:

\section{LEYENDA}

ST MADERA SIN TRATAR

Grafica R Histograma color Rojo

Grafica G Histograma color Verde

Grafica B Histograma color Azul

Grafica L Histograma Luminosidad

Grafica C Histograma RGB

TT MADERA TRATADA

Valor R Número pixeles color Rojo

Valor $\mathrm{G}$ Número pixeles color Verde

Valor B Número pixeles color Azul

Valor $L$ Número pixeles Luminosidad

Valor $C$ Número pixeles $R G$

DF DIFERENCIA DE VALORES R;G; $\mathrm{DF}=$ Valor $\mathrm{ST}(\mathrm{R} ; \mathrm{G} ; \mathrm{B})$ - Valor TT $(\mathrm{R} ; \mathrm{G} ; \mathrm{B}$

\section{MADERA M10/CZA/CEREZO AMERICANO}
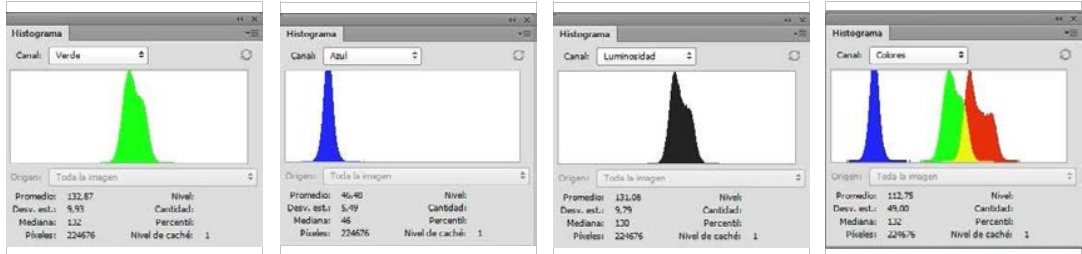

\section{Grafica G (ST)}

Grafica B (ST)

Grafica L (ST)

Grafica C (ST)

Valor $\mathrm{G}(\mathrm{ST})$ :

Valor B(ST):

Valor L(ST):

Valor C(ST):

132,87

46,48

131,08

112,75
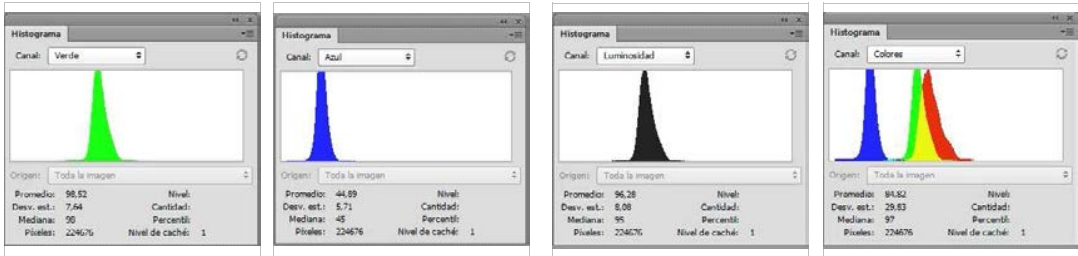

Grafica G (TT)

Grafica B (TT)

Grafica L (TT)

Grafica C (TT)

Valor $\mathrm{G}(\mathrm{TT})$ :

Valor $\mathrm{B}(\mathrm{TT})$ :

Valor L(TT):

Valor $\mathrm{C}(\mathrm{TT})$ :

98,52

44,89

96,28

84,82

Grafica G (DF): Grafica B (DF): Grafica L (DF): Grafica C (DF): Valor DF-G: Valor DF-B: Valor DF-L: Valor DF-C:

$\begin{array}{llll}34,35 & 1,59 & 34,80 & 27,93\end{array}$

1,59
27,93

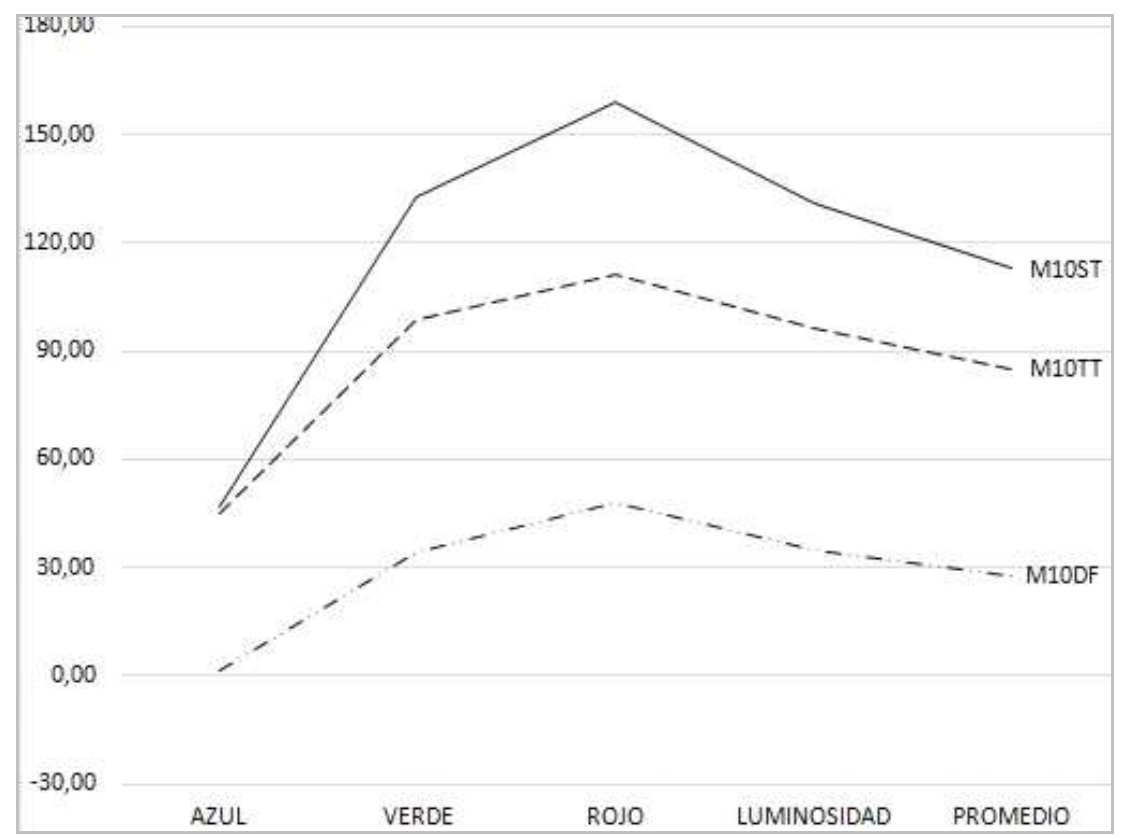

Universidad Politécnica de Madrid - Escuela Técnica Superior de Arquitectura - Departamento de Construcción y Tecnología Arquitectónica Directores: Dr. Alfonso García Santos y Dr. Antonio Rodríguez Rodríguez. Doctorando: D. Francisco Lora Toro 


\section{FICHA DE ENSAYOS DE MADERA Y ACIDOS}

\section{ACIDO A04/FL/ACIDO FLUORHÍDRICO}
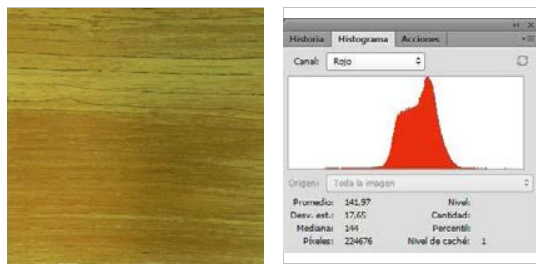

SIN TRATAR (ST): Grafica R (ST)

Valor R(ST):

141,97

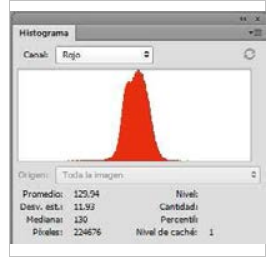

TRATADA (TT): Grafica R (TT)

Valor $\mathrm{R}(\mathrm{TT})$ :

129,94

DIFERENCIA (DF) Grafica R (DF): Valor DF-R: 12,03

GRAFICA:

\section{LEYENDA}

ST MADERA SIN TRATAR

Grafica R Histograma color Rojo Grafica G Histograma color Verde Grafica B Histograma color Azul Grafica L Histograma Luminosidad Grafica C Histograma RGB

\section{TT MADERA TRATADA}

Valor R Número pixeles color Rojo Valor $\mathrm{G}$ Número pixeles color Verde Valor B Número pixeles color Azul Valor $L$ Número pixeles Luminosidad Valor C Número pixeles RG DF DIFERENCIA DE VALORES R;G; $\mathrm{DF}=$ Valor $\mathrm{ST}(\mathrm{R} ; \mathrm{G} ; \mathrm{B})$ - Valor TT $(\mathrm{R} ; \mathrm{G} ; \mathrm{B}$

\section{MADERA M11/CB/COPAIBA}

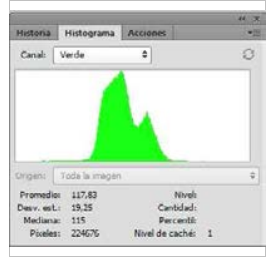

Grafica G (ST)

Valor G(ST):

117,83
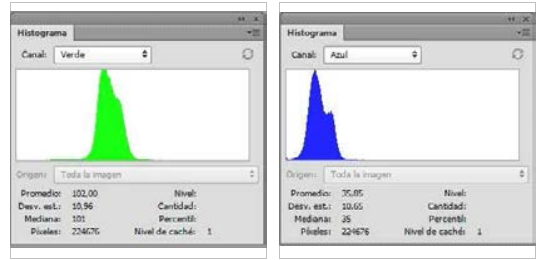

Grafica G (TT)

Grafica B (TT)

Valor $\mathrm{B}(\mathrm{TT})$ :

35,85

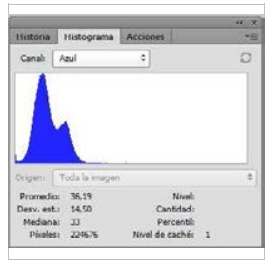

Grafica B (ST)

Valor B(ST):

36,19

Valor G(TT):

102,00

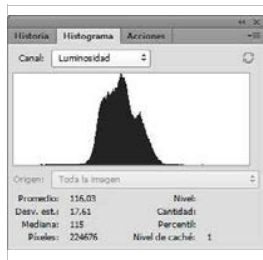

Grafica L (ST)

Valor L(ST):

116,03

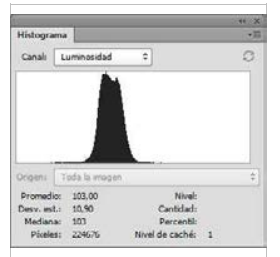

Grafica L (TT)

Valor L(TT):

103,00

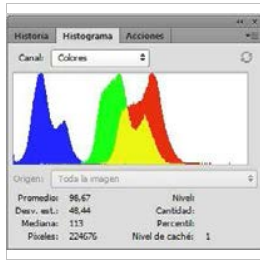

Grafica C (ST)

Valor C(ST):

98,67

\section{Grafica G (DF): Grafica B (DF): Grafica L (DF): Grafica C (DF):} Valor DF-G: Valor DF-B: Valor DF-L: Valor DF-C:

$\begin{array}{llll}15,83 & 0,34 & 13,03 & 9,41\end{array}$

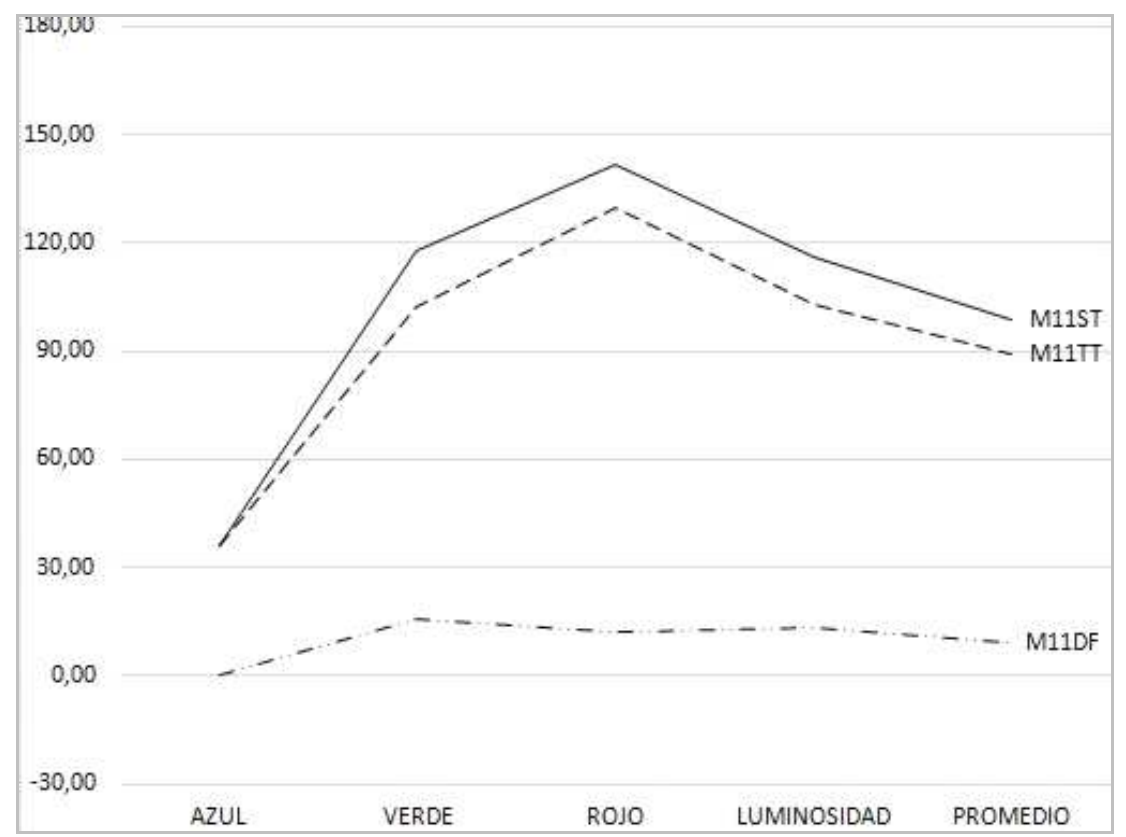

Universidad Politécnica de Madrid - Escuela Técnica Superior de Arquitectura - Departamento de Construcción y Tecnología Arquitectónica Directores: Dr. Alfonso García Santos y Dr. Antonio Rodríguez Rodríguez. Doctorando: D. Francisco Lora Toro 


\section{FICHA DE ENSAYOS DE MADERA y ACIDOS}

\section{ACIDO A04/FL/ACIDO FLUORHÍDRICO}
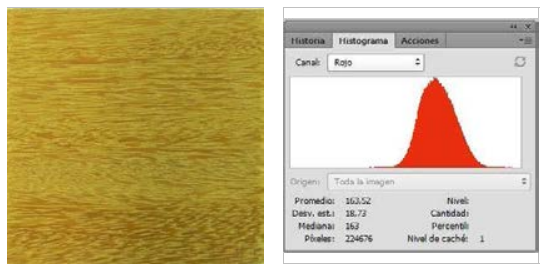

SIN TRATAR (ST): Grafica R (ST)

Valor R(ST):

163,52
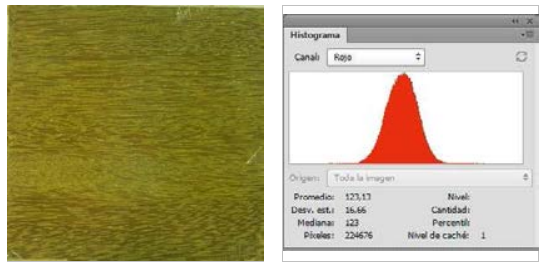

TRATADA (TT): Grafica $R(T T)$

Valor $\mathrm{R}(\mathrm{TT})$ :

123,13

DIFERENCIA (DF) Grafica R (DF):

Valor DF-R:

40,39

GRAFICA:

\section{LEYENDA}

ST MADERA SIN TRATAR

Grafica R Histograma color Rojo

Grafica G Histograma color Verde

Grafica B Histograma color Azul

Grafica L Histograma Luminosidad

Grafica C Histograma RGB

\section{TT MADERA TRATADA}

Valor R Número pixeles color Rojo

Valor G Número pixeles color Verde

Valor B Número pixeles color Azul

Valor L Número pixeles Luminosidad

Valor C Número pixeles RG

DF DIFERENCIA DE VALORES R;G; $\mathrm{DF}=$ Valor $\mathrm{ST}(\mathrm{R} ; \mathrm{G} ; \mathrm{B})$ - Valor TT(R;G;B

\section{MADERA M12/CM/CUMARÚ}
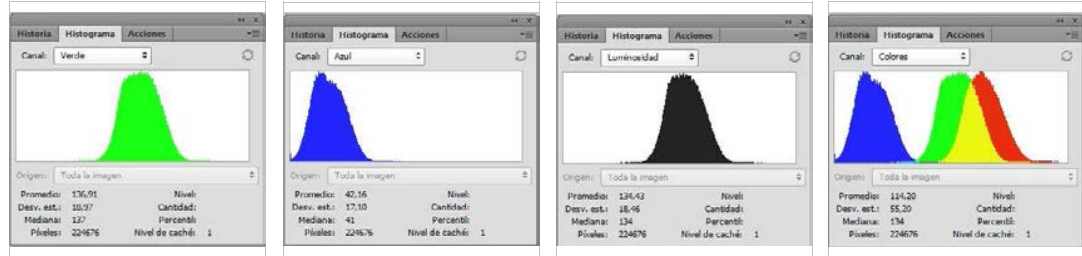

Grafica G (ST)

Grafica B (ST)

Grafica L (ST)

Grafica C (ST)

Valor $\mathrm{G}(\mathrm{ST})$ :

Valor B(ST):

Valor L(ST):

Valor C(ST):

136,91

42,16

134,43

114,20
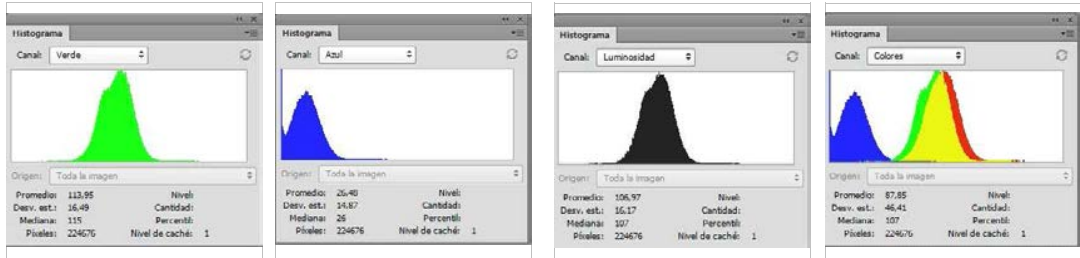

Grafica G (TT)

Grafica B (TT)

Grafica L (TT)

Grafica C (TT)

Valor $\mathrm{G}(\mathrm{TT})$ :

Valor $\mathrm{B}(\mathrm{TT})$ :

Valor L(TT):

Valor C(TT):

113,95

26,48

106,97

87,85

Grafica G (DF): Grafica B (DF): Grafica L (DF):

Grafica C (DF):

Valor DF-G:

Valor DF-B:

Valor DF-L:

Valor DF-C:

22,96

15,68

27,46

26,35

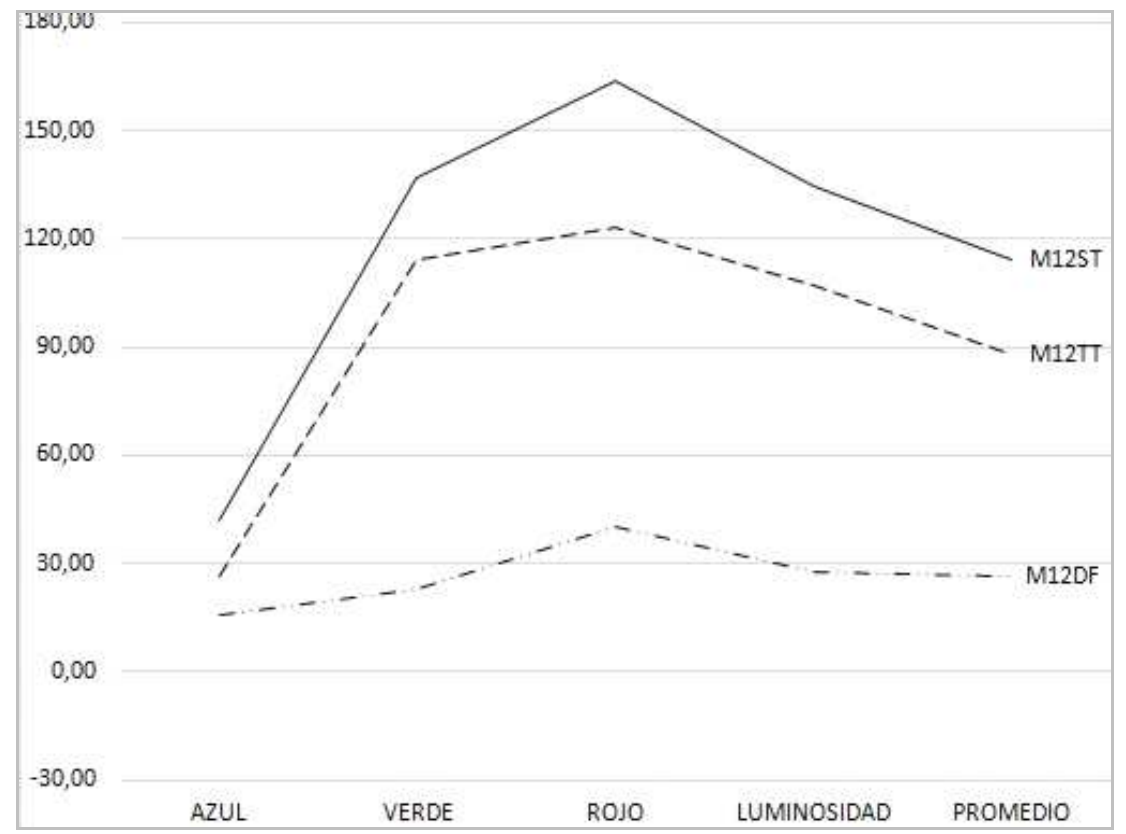

Universidad Politécnica de Madrid - Escuela Técnica Superior de Arquitectura - Departamento de Construcción y Tecnología Arquitectónica Directores: Dr. Alfonso García Santos y Dr. Antonio Rodríguez Rodríguez. Doctorando: D. Francisco Lora Toro 


\section{FICHA DE ENSAYOS DE MADERA Y ACIDOS}

\section{ACIDO A04/FL/ACIDO FLUORHÍDRICO}
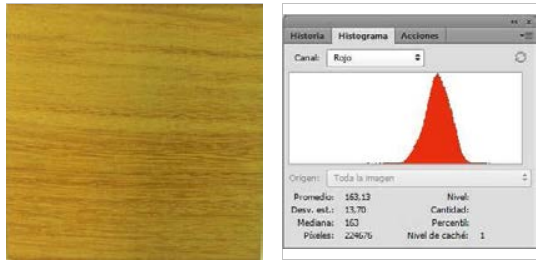

SIN TRATAR (ST): Grafica R (ST)

Valor R(ST):

163,13

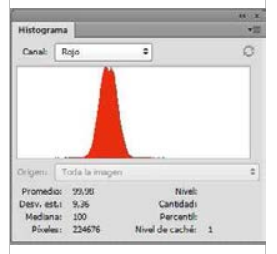

TRATADA (TT): Grafica R (TT)

Valor $\mathrm{R}(\mathrm{TT})$ :

99,98

DIFERENCIA (DF) Grafica R (DF): Valor DF-R: 63,15

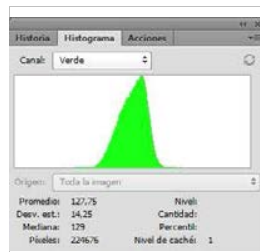

Grafica G (ST)

Valor G(ST):

127,75

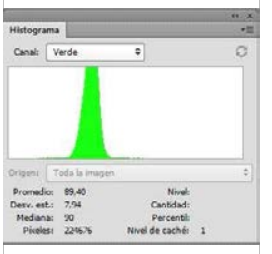

Grafica G (TT)

Valor G(TT):

89,40
MADERA M13/DS/DOUSSIÉ

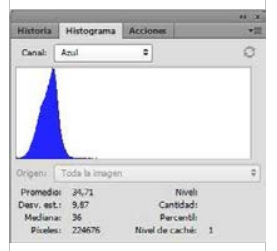

Grafica B (ST)

Valor B(ST):

34,71

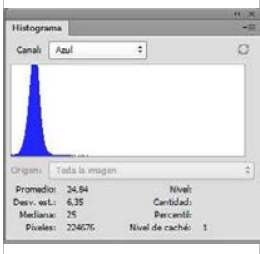

Grafica B (TT)

Valor $\mathrm{B}(\mathrm{TT})$ :

24,84

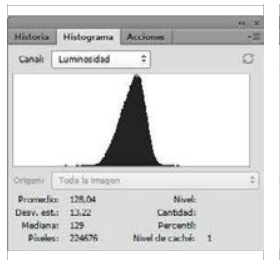

Grafica L (ST)

Valor L(ST):

128,04

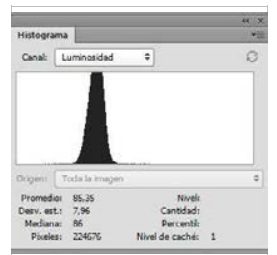

Grafica L (TT)

Valor L(TT):

85,35

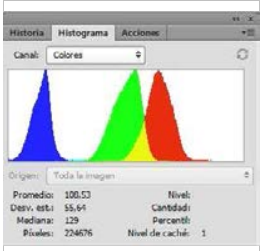

Grafica C (ST)

Valor C(ST):

108,53

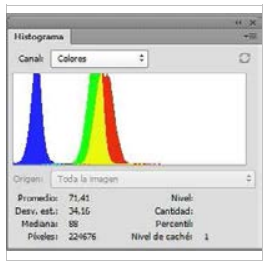

Grafica C (TT)

Valor $\mathrm{C}(\mathrm{TT})$ :

71,41

Grafica G (DF): Grafica B (DF): Grafica L (DF): Grafica C (DF): Valor DF-G: Valor DF-B: Valor DF-L: Valor DF-C:

$\begin{array}{llll}38,35 & 9,87 & 42,69 & 37,12\end{array}$

\section{LEYENDA}

ST MADERA SIN TRATAR

Grafica R Histograma color Rojo

Grafica G Histograma color Verde

Grafica B Histograma color Azul

Grafica L Histograma Luminosidad

Grafica C Histograma RGB

TT MADERA TRATADA

Valor $\mathrm{R}$ Número pixeles color Rojo

Valor $\mathrm{G}$ Número pixeles color Verde

Valor B Número pixeles color Azul

Valor $\mathrm{L}$ Número pixeles Luminosidad

Valor $C$ Número pixeles $R G$

DF DIFERENCIA DE VALORES R;G; $\mathrm{DF}=$ Valor $\mathrm{ST}(\mathrm{R} ; \mathrm{G} ; \mathrm{B})$ - Valor $\mathrm{TT}(\mathrm{R} ; \mathrm{G} ; \mathrm{B}$

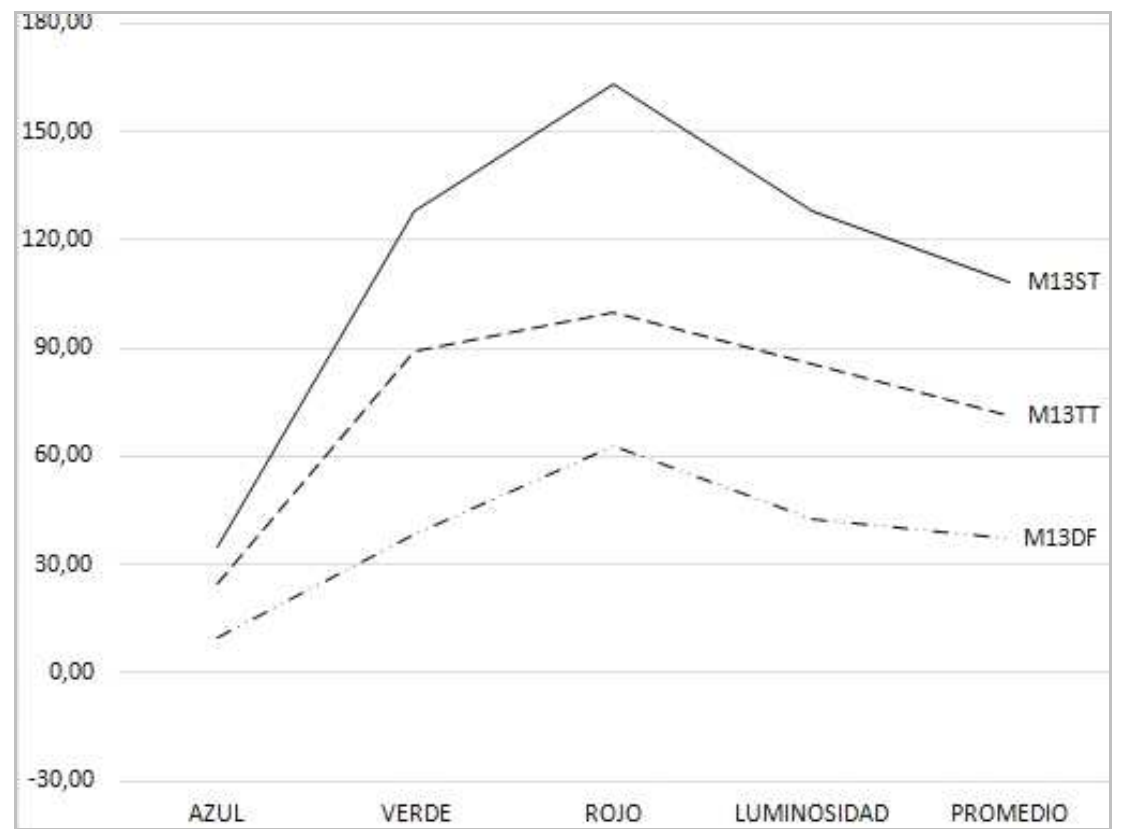

Universidad Politécnica de Madrid - Escuela Técnica Superior de Arquitectura - Departamento de Construcción y Tecnología Arquitectónica Directores: Dr. Alfonso García Santos y Dr. Antonio Rodríguez Rodríguez. Doctorando: D. Francisco Lora Toro 


\section{FICHA DE ENSAYOS DE MADERA Y ACIDOS}

ACIDO A04/FL/ACIDO FLUORHÍDRICO

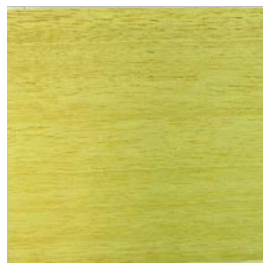

SIN TRATAR (ST): Grafica R (ST)

Valor R(ST):

188,95

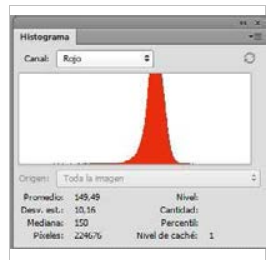

TRATADA (TT): Grafica R (TT)

Valor R(TT):

149,49

DIFERENCIA (DF) Grafica R (DF):

Valor DF-R:

39,46

GRAFICA:

\section{LEYENDA}

ST MADERA SIN TRATAR

Grafica R Histograma color Rojo

Grafica G Histograma color Verde

Grafica B Histograma color Azul

Grafica L Histograma Luminosidad

Grafica C Histograma RGB

\section{TT MADERA TRATADA}

Valor R Número pixeles color Rojo

Valor $\mathrm{G}$ Número pixeles color Verde

Valor B Número pixeles color Azul

Valor $L$ Número pixeles Luminosidad

Valor C Número pixeles RG

DF DIFERENCIA DE VALORES R;G; $\mathrm{DF}=$ Valor $\mathrm{ST}(\mathrm{R} ; \mathrm{G} ; \mathrm{B})$ - Valor TT $(\mathrm{R} ; \mathrm{G} ; \mathrm{B}$

\section{MADERA M14/FR/FRAMIRÉ}

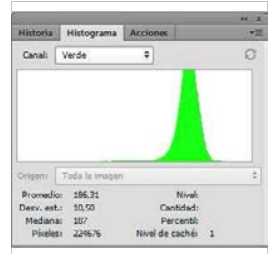

Grafica G (ST)

Valor G(ST):

186,31

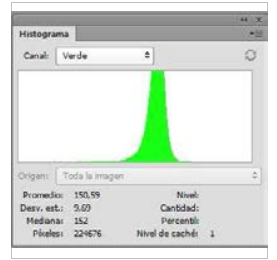

Grafica G (TT)

Valor G(TT):

150,59
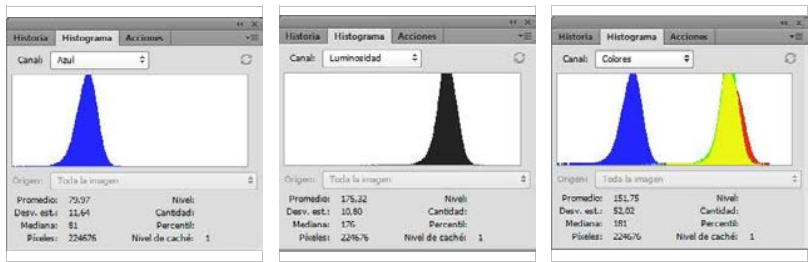

Grafica B (ST)

Grafica L (ST)

Grafica C (ST)

Valor B(ST):

Valor L(ST):

Valor C(ST):

79,97

175,32

151,75
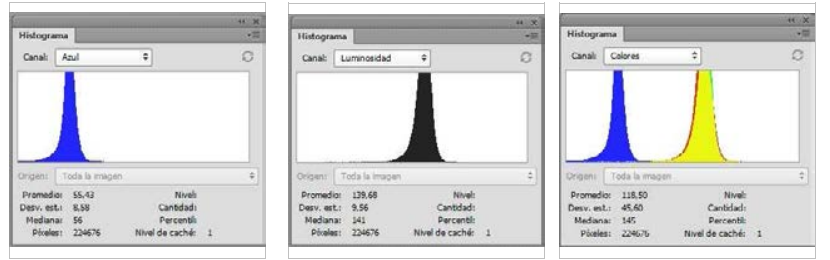

\section{Grafica B (TT)}

Grafica L (TT)

Grafica C (TT)

Valor $\mathrm{B}(\mathrm{TT})$ :

Valor L(TT):

Valor C(TT):

55,43

139,68

118,50

Grafica G (DF): Grafica B (DF): Grafica L (DF): Grafica C (DF): Valor DF-G: Valor DF-B: Valor DF-L: Valor DF-C:

$35,72 \quad 34,54 \quad 35,64 \quad 33,25$

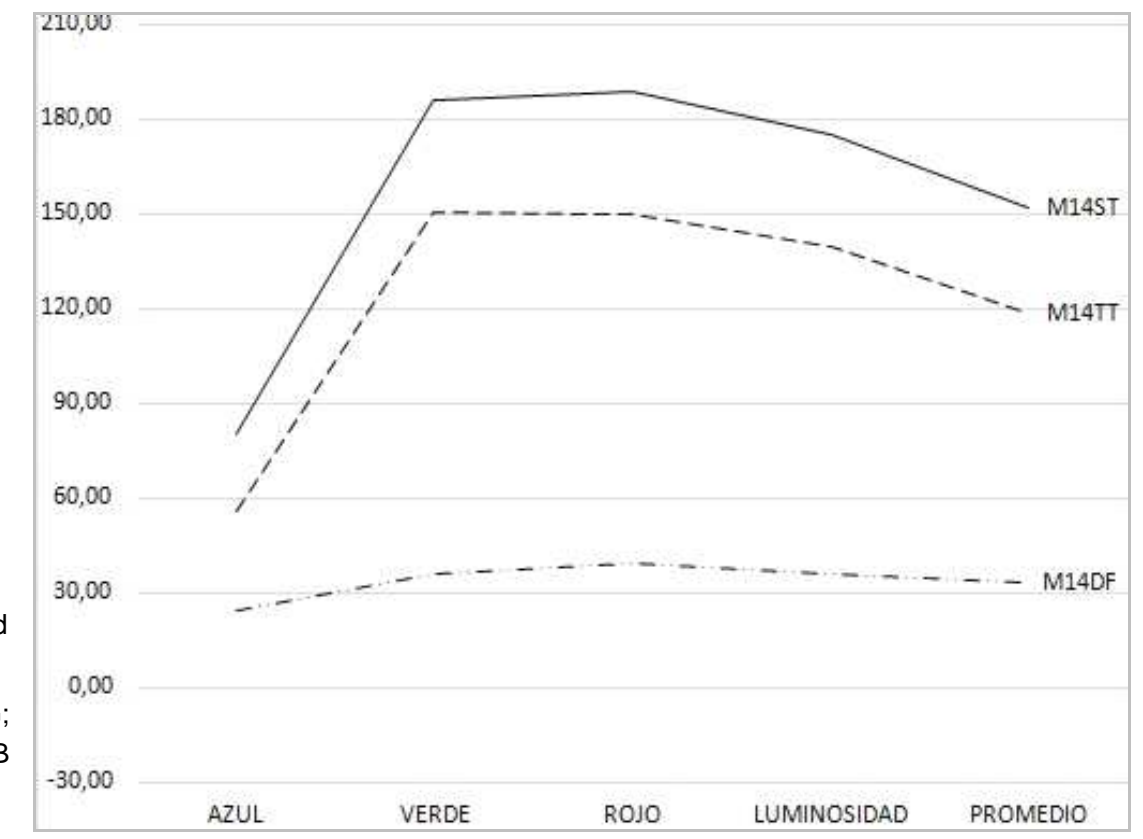

Universidad Politécnica de Madrid - Escuela Técnica Superior de Arquitectura - Departamento de Construcción y Tecnología Arquitectónica Directores: Dr. Alfonso García Santos y Dr. Antonio Rodríguez Rodríguez. Doctorando: D. Francisco Lora Toro 


\section{FICHA DE ENSAYOS DE MADERA Y ACIDOS}

ACIDO A04/FL/ACIDO FLUORHÍDRICO

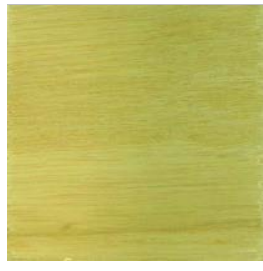

SIN TRATAR (ST): Grafica R (ST)

Valor R(ST):

178,64

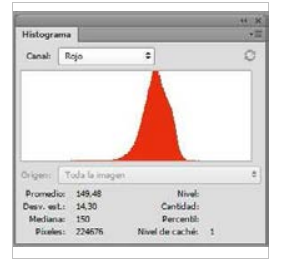

TRATADA (TT): Grafica R (TT)

Valor $\mathrm{R}(\mathrm{TT})$ :

149,48

DIFERENCIA (DF) Grafica R (DF): Valor DF-R: 29,16

GRAFICA:

\section{LEYENDA}

ST MADERA SIN TRATAR

Grafica R Histograma color Rojo Grafica G Histograma color Verde Grafica B Histograma color Azul Grafica L Histograma Luminosidad Grafica C Histograma RGB

\section{TT MADERA TRATADA}

Valor R Número pixeles color Rojo Valor $\mathrm{G}$ Número pixeles color Verde Valor B Número pixeles color Azul Valor $L$ Número pixeles Luminosidad Valor C Número pixeles RG DF DIFERENCIA DE VALORES R;G; $\mathrm{DF}=$ Valor $\mathrm{ST}(\mathrm{R} ; \mathrm{G} ; \mathrm{B})$ - Valor TT(R;G;B

\section{MADERA M15/FBA/FRESNO BLANCO AMERICAN}

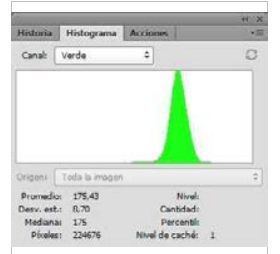

Grafica G (ST)

Valor $\mathrm{G}(\mathrm{ST})$ :

175,43

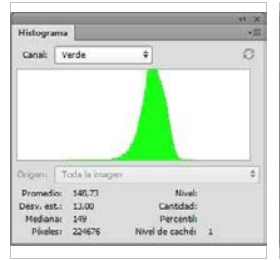

Grafica G (TT)
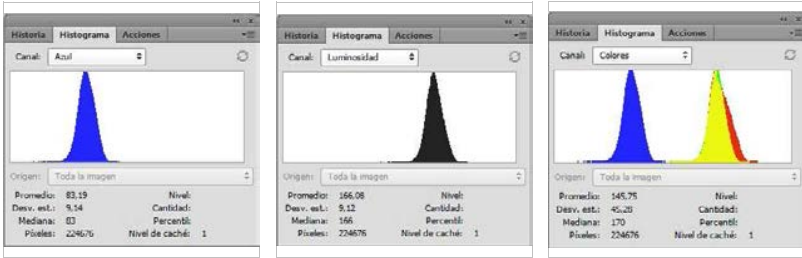

Grafica B (ST)

Grafica L (ST)

Grafica C (ST)

Valor B(ST):

Valor L(ST):

Valor C(ST):

83,19

166,08

145,75
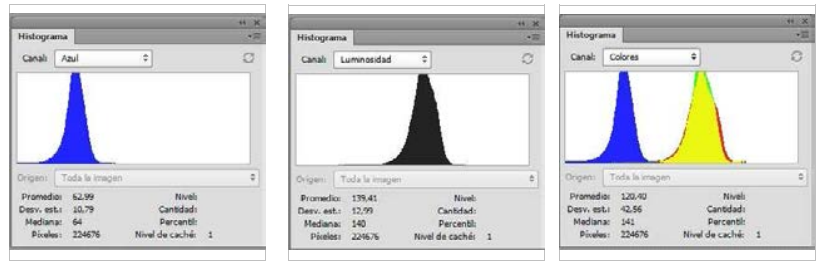

Grafica B (TT)

Grafica L (TT)

Grafica C (TT)

Valor $\mathrm{G}(\mathrm{TT})$ :

Valor $\mathrm{B}(\mathrm{TT})$ :

Valor L(TT):

Valor C(TT):

148,73

62,99

139,41

120,40

Grafica G (DF): Grafica B (DF): Grafica L (DF): Grafica C (DF): Valor DF-G: Valor DF-B: Valor DF-L: Valor DF-C:

$26,70 \quad 26,20 \quad 26,67 \quad 25,35$

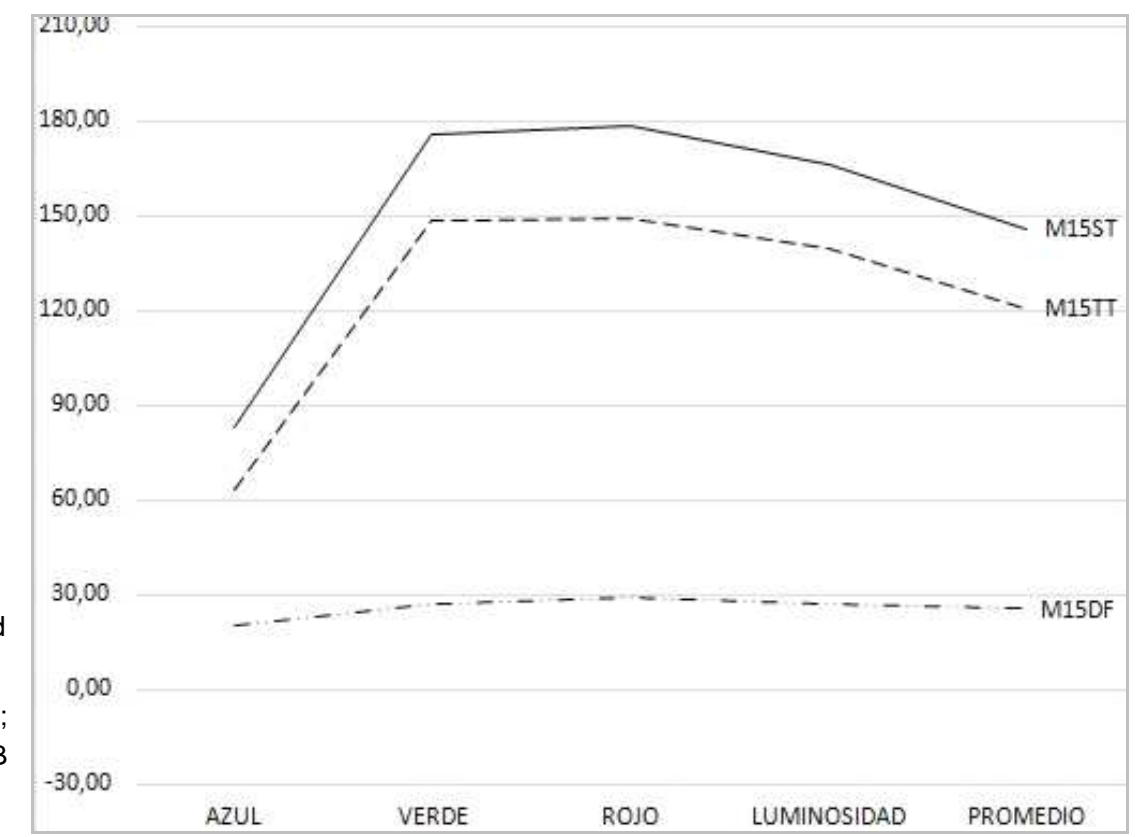

Universidad Politécnica de Madrid - Escuela Técnica Superior de Arquitectura - Departamento de Construcción y Tecnología Arquitectónica Directores: Dr. Alfonso García Santos y Dr. Antonio Rodríguez Rodríguez. Doctorando: D. Francisco Lora Toro 


\section{FICHA DE ENSAYOS DE MADERA Y ACIDOS}

\section{ACIDO A04/FL/ACIDO FLUORHÍDRICO}

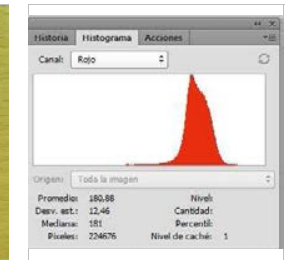

SIN TRATAR (ST): Grafica R (ST)

Valor R(ST):

180,88

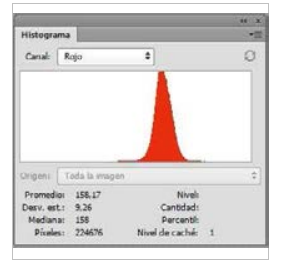

TRATADA (TT): Grafica R (TT)

Valor R(TT):

158,17

DIFERENCIA (DF) Grafica R (DF): Valor DF-R: 22,71

GRAFICA:

\section{LEYENDA}

ST MADERA SIN TRATAR

Grafica R Histograma color Rojo Grafica G Histograma color Verde Grafica B Histograma color Azul Grafica L Histograma Luminosidad Grafica C Histograma RGB

\section{TT MADERA TRATADA}

Valor R Número pixeles color Rojo Valor $\mathrm{G}$ Número pixeles color Verde Valor B Número pixeles color Azul Valor $L$ Número pixeles Luminosidad Valor C Número pixeles RG DF DIFERENCIA DE VALORES R;G; $\mathrm{DF}=$ Valor $\mathrm{ST}(\mathrm{R} ; \mathrm{G} ; \mathrm{B})$ - Valor TT $(\mathrm{R} ; \mathrm{G} ; \mathrm{B}$

\section{MADERA M16/H/HAYA}

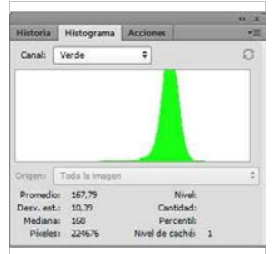

Grafica G (ST)

Valor $\mathrm{G}(\mathrm{ST})$ :

167,79

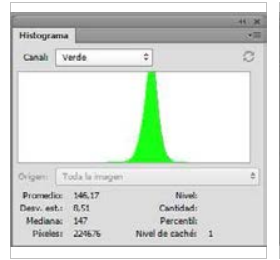

Grafica G (TT)

Valor $\mathrm{G}(\mathrm{TT})$ :

146,17

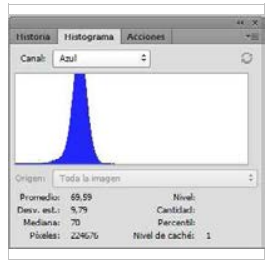

Grafica B (ST)

Valor B(ST):

69,59

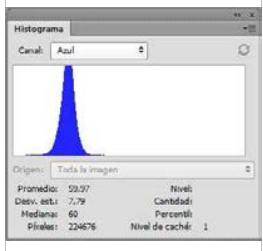

Grafica B (TT)

Valor $\mathrm{B}(\mathrm{TT})$ :

59,97

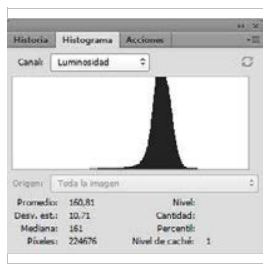

Grafica L (ST)

Valor L(ST):

160,81

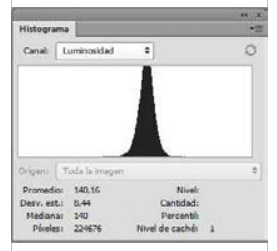

Grafica L (TT)

Valor L(TT):

140,16

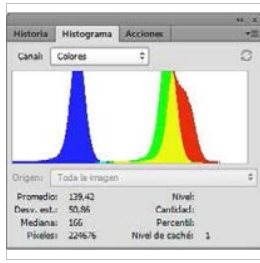

Grafica C (ST)

Valor C(ST):

139,42

Grafica G (DF): Grafica B (DF): Grafica L (DF): Grafica C (DF): Valor DF-G: Valor DF-B: Valor DF-L:

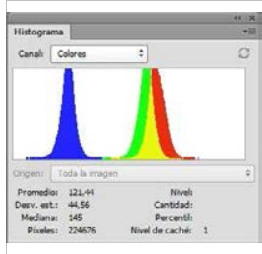

Grafica C (TT)

Valor C(TT):

121,44

Valor DF-C:

$\begin{array}{llll}21,62 & 9,62 & 20,65 & 17,98\end{array}$

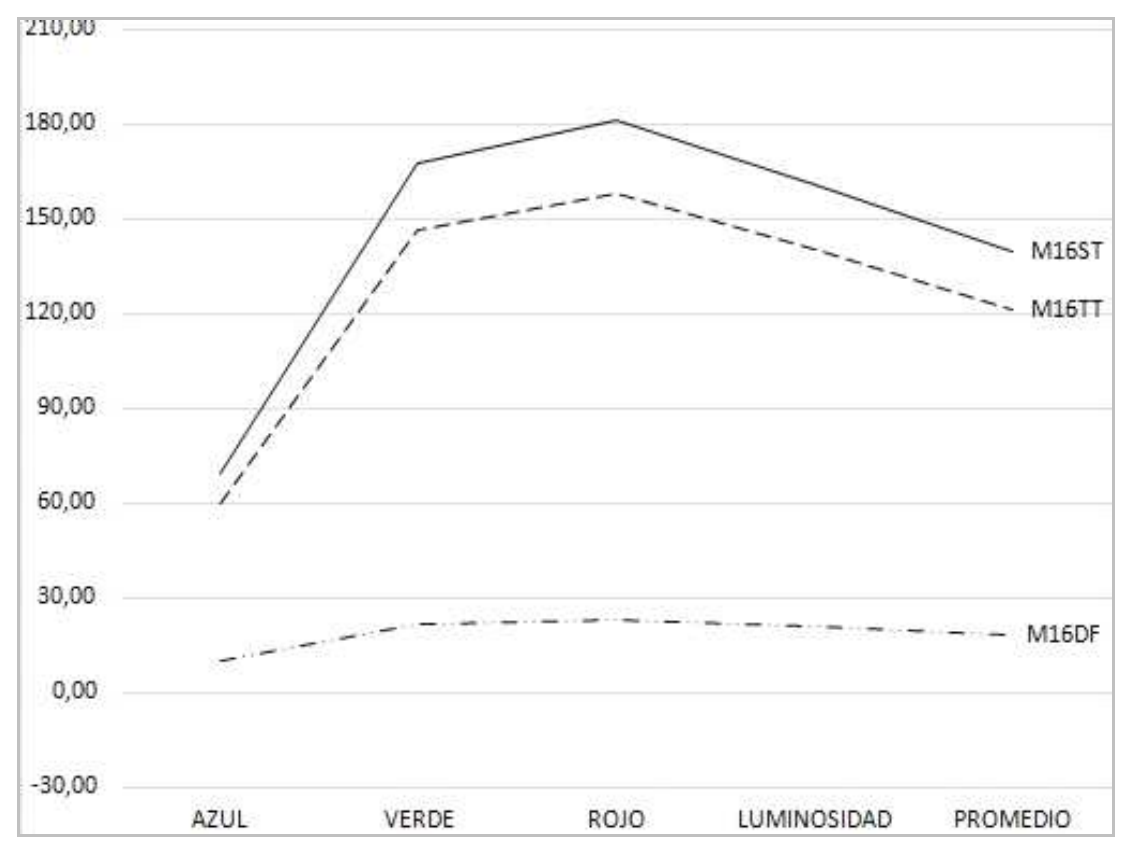

Universidad Politécnica de Madrid - Escuela Técnica Superior de Arquitectura - Departamento de Construcción y Tecnología Arquitectónica Directores: Dr. Alfonso García Santos y Dr. Antonio Rodríguez Rodríguez. Doctorando: D. Francisco Lora Toro 


\section{FICHA DE ENSAYOS DE MADERA Y ACIDOS}

\section{ACIDO A04/FL/ACIDO FLUORHÍDRICO}
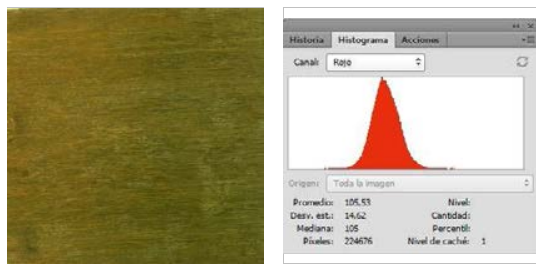

SIN TRATAR (ST): Grafica R (ST)

Valor R(ST):

105,53

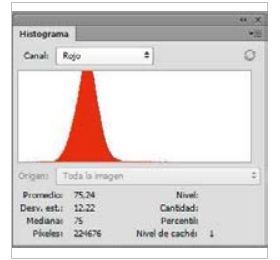

TRATADA (TT): Grafica R (TT)

Valor $\mathrm{R}(\mathrm{TT})$ :

75,24

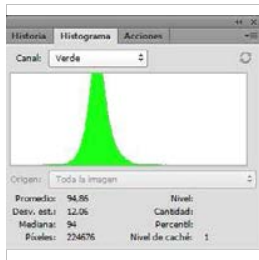

Grafica G (ST)

Valor $\mathrm{G}(\mathrm{ST})$ :

94,86

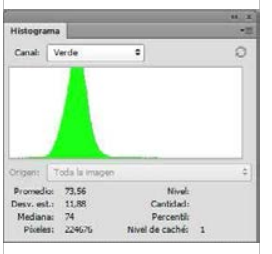

Grafica G (TT)

Valor G(TT):

73,56

\section{MADERA M17/IP/IPÉ}

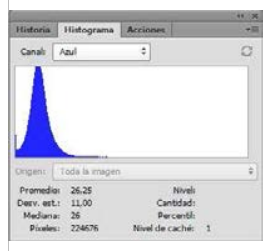

Grafica B (ST)

Valor $\mathrm{B}(\mathrm{ST})$ :

26,25

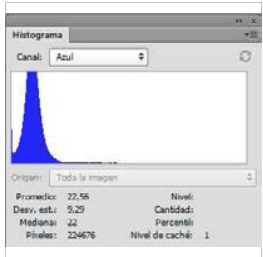

Grafica B (TT)

Valor $\mathrm{B}(\mathrm{TT})$ :

22,56

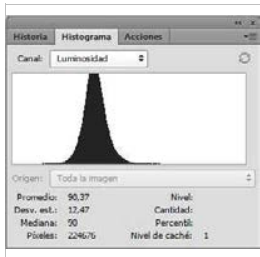

Grafica L (ST)

Valor L(ST):

90,37

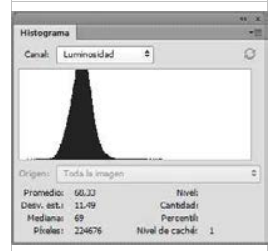

Grafica L (TT)

Valor L(TT):

68,33

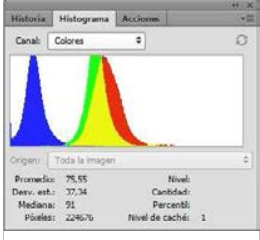

Grafica C (ST)

Valor C(ST):

75,55

DIFERENCIA (DF) Grafica R (DF): Grafica G (DF): Grafica B (DF): Grafica L (DF): Grafica C (DF): Valor DF-R: Valor DF-G: Valor DF-B: Valor DF-L:

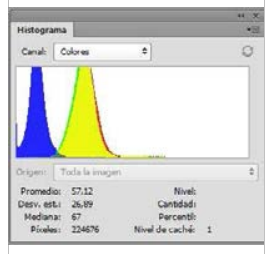
30,29 21,30 3,69 22,04 Valor DF-C: 18,43

GRAFICA:

\section{LEYENDA}

\section{ST MADERA SIN TRATAR}

Grafica R Histograma color Rojo Grafica G Histograma color Verde Grafica B Histograma color Azul Grafica L Histograma Luminosidad Grafica C Histograma RGB

\section{TT MADERA TRATADA}

Valor R Número pixeles color Rojo Valor $G$ Número pixeles color Verde Valor B Número pixeles color Azul Valor L Número pixeles Luminosidad Valor $\mathrm{C}$ Número pixeles RG DF DIFERENCIA DE VALORES R;G; $\mathrm{DF}=$ Valor $\mathrm{ST}(\mathrm{R} ; \mathrm{G} ; \mathrm{B})$ - Valor TT(R;G;B

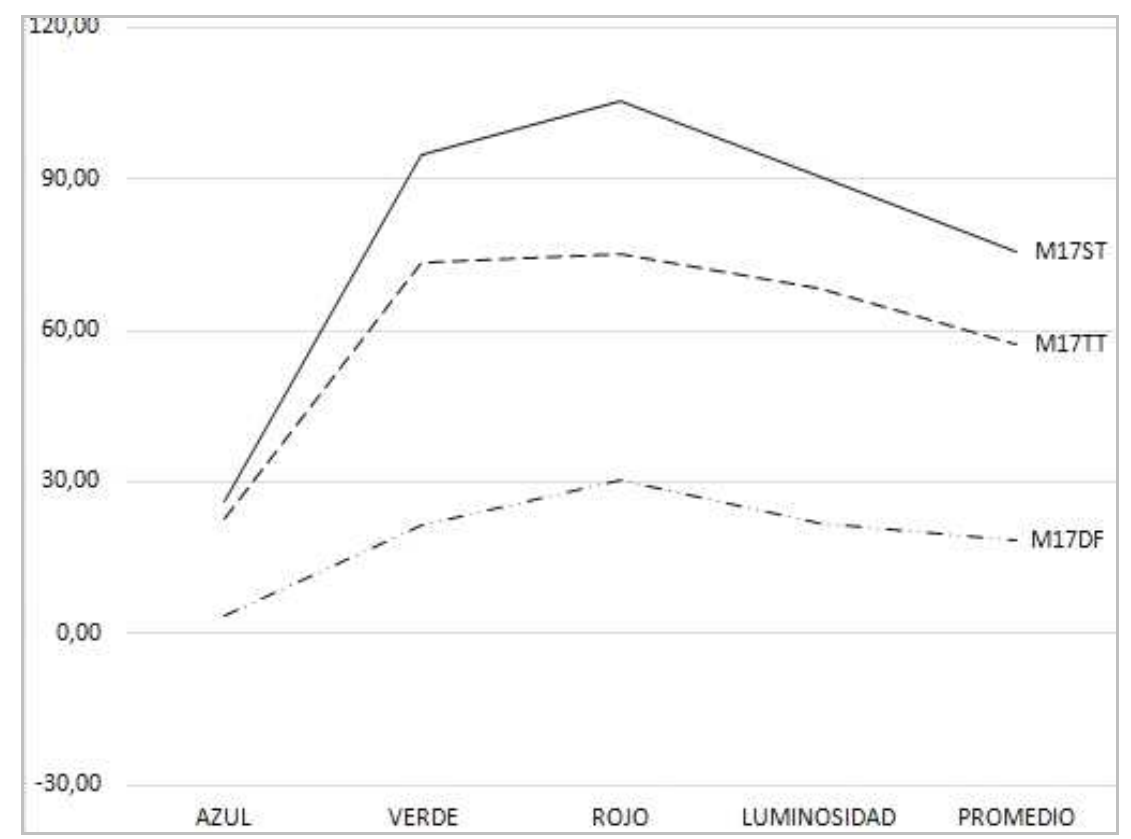

Universidad Politécnica de Madrid - Escuela Técnica Superior de Arquitectura - Departamento de Construcción y Tecnología Arquitectónica Directores: Dr. Alfonso García Santos y Dr. Antonio Rodríguez Rodríguez. Doctorando: D. Francisco Lora Toro 


\section{FICHA DE ENSAYOS DE MADERA Y ACIDOS}

\section{ACIDO A04/FL/ACIDO FLUORHÍDRICO}
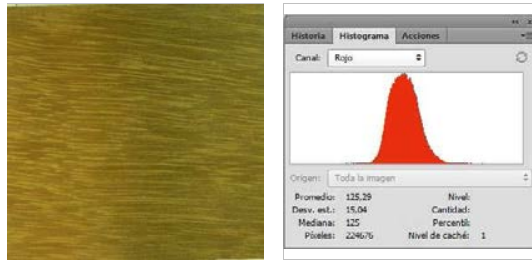

SIN TRATAR (ST): Grafica R (ST)

Valor R(ST):

125,29

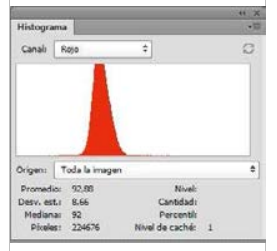

TRATADA (TT): Grafica R (TT)

Valor $\mathrm{R}(\mathrm{TT})$ :

92,88

DIFERENCIA (DF) Grafica R (DF): Valor DF-R: 32,41

GRAFICA:

\section{LEYENDA}

ST MADERA SIN TRATAR

Grafica R Histograma color Rojo Grafica G Histograma color Verde Grafica B Histograma color Azul Grafica L Histograma Luminosidad Grafica C Histograma RGB

TT MADERA TRATADA

Valor R Número pixeles color Rojo Valor G Número pixeles color Verde Valor B Número pixeles color Azul Valor $L$ Número pixeles Luminosidad Valor C Número pixeles RG DF DIFERENCIA DE VALORES R;G; $\mathrm{DF}=$ Valor $\mathrm{ST}(\mathrm{R} ; \mathrm{G} ; \mathrm{B})$ - Valor $\mathrm{TT}(\mathrm{R} ; \mathrm{G} ; \mathrm{B}$

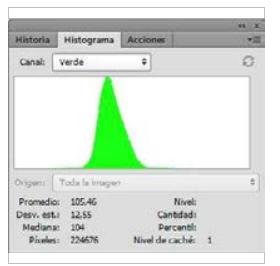

Grafica G (ST)

Valor G(ST):

105,46

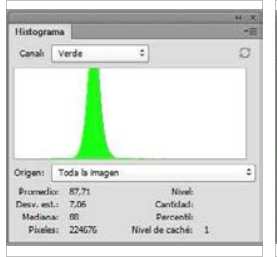

Grafica G (TT)

Valor G(TT):

87,71
MADERA M18/IK/IROKO

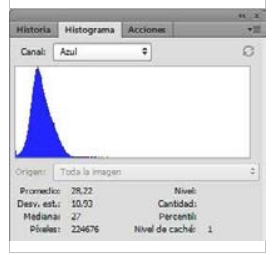

Grafica B (ST)

Valor B(ST):

28,22

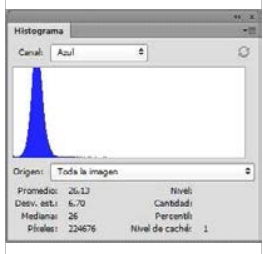

Grafica B (TT)

Valor $\mathrm{B}(\mathrm{TT})$ :

26,13

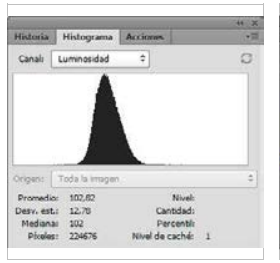

Grafica L (ST)

Valor L(ST):

102,82

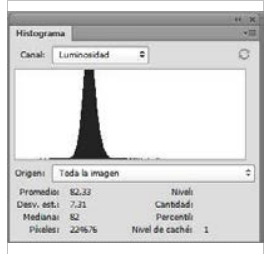

Grafica L (TT)

Valor L(TT):

82,33

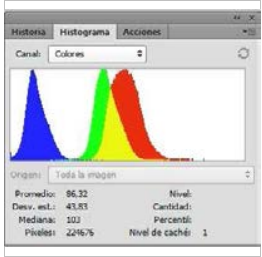

Grafica C (ST)

Valor C(ST):

86,32

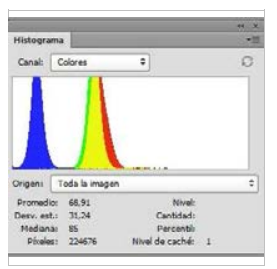

Grafica C (TT)

Valor $\mathrm{C}(\mathrm{TT})$ :

68,91

Grafica L (DF): Grafica C (DF): Valor DF-L: Valor DF-C: Valor DF-G: $\quad$ Valor DF-B: 20,49 17,41
17,75
2,09

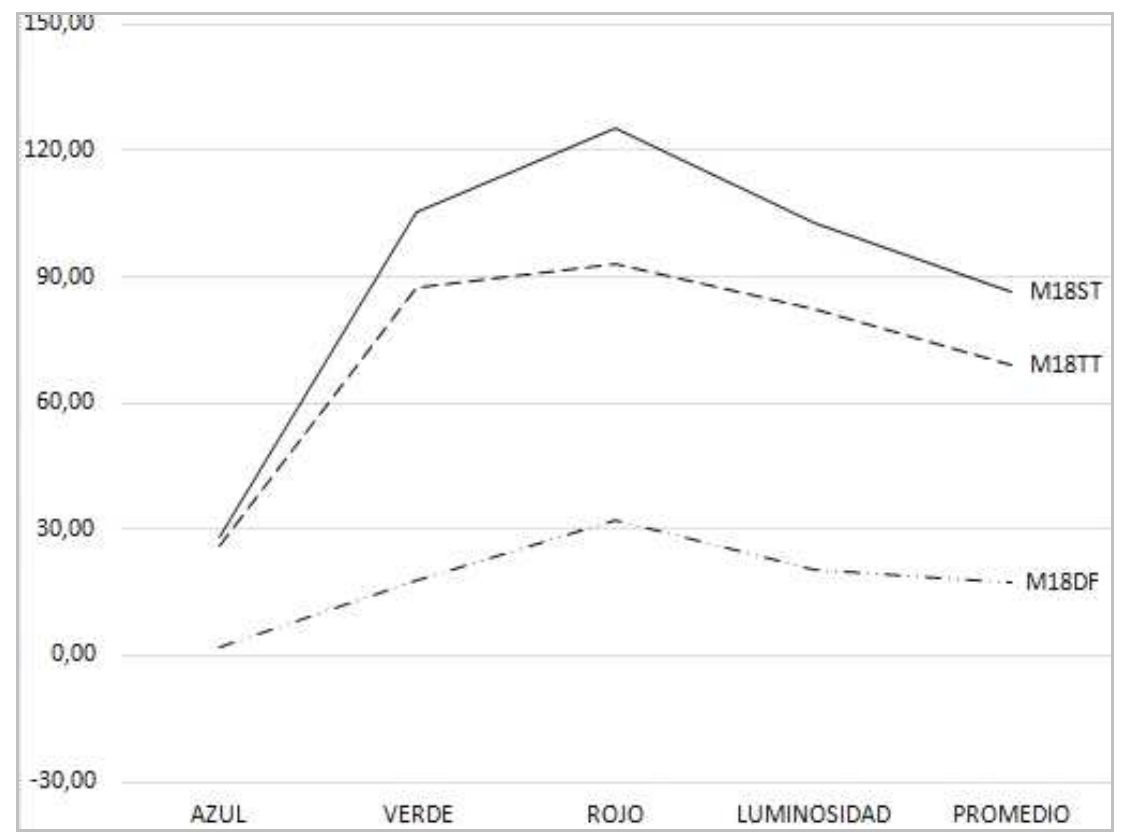

Universidad Politécnica de Madrid - Escuela Técnica Superior de Arquitectura - Departamento de Construcción y Tecnología Arquitectónica Directores: Dr. Alfonso García Santos y Dr. Antonio Rodríguez Rodríguez. Doctorando: D. Francisco Lora Toro 


\section{FICHA DE ENSAYOS DE MADERA Y ACIDOS}

\section{ACIDO A04/FL/ACIDO FLUORHÍDRICO}
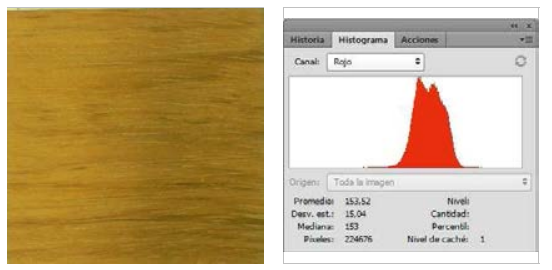

SIN TRATAR (ST): Grafica R (ST)

Valor R(ST):

153,52

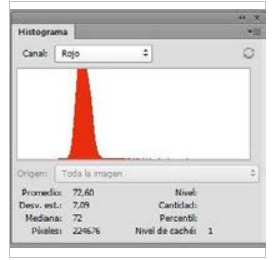

TRATADA (TT): Grafica R (TT)

Valor $\mathrm{R}(\mathrm{TT})$ :

72,60

DIFERENCIA (DF) Grafica R (DF): Valor DF-R: 80,92

GRAFICA:

\section{LEYENDA}

ST MADERA SIN TRATAR

Grafica R Histograma color Rojo

Grafica G Histograma color Verde

Grafica B Histograma color Azul

Grafica L Histograma Luminosidad

Grafica C Histograma RGB

\section{TT MADERA TRATADA}

Valor R Número pixeles color Rojo

Valor $\mathrm{G}$ Número pixeles color Verde

Valor B Número pixeles color Azul

Valor L Número pixeles Luminosidad

Valor C Número pixeles RG

DF DIFERENCIA DE VALORES R;G; $\mathrm{DF}=$ Valor $\mathrm{ST}(\mathrm{R} ; \mathrm{G} ; \mathrm{B})$ - Valor TT $(\mathrm{R} ; \mathrm{G} ; \mathrm{B}$

\section{MADERA M19/JT/JATOBA}

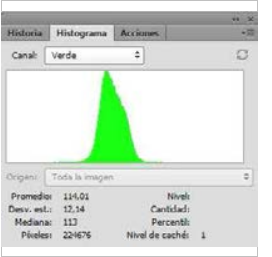

\section{Grafica G (ST)}

Valor G(ST):

114,01

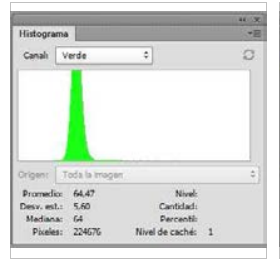

Grafica G (TT)
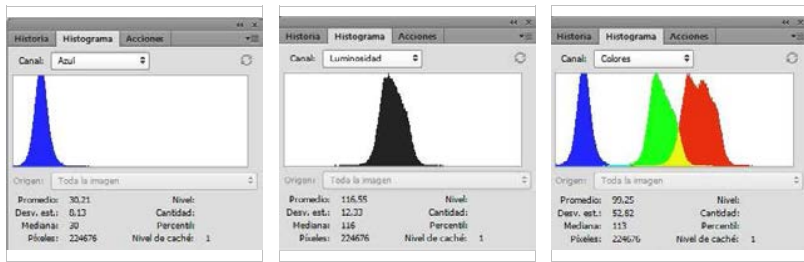

Grafica B (ST)

Grafica L (ST)

Grafica C (ST)

Valor $\mathrm{B}(\mathrm{ST})$ :

Valor L(ST):

Valor C(ST):

30,21

116,55

99,25
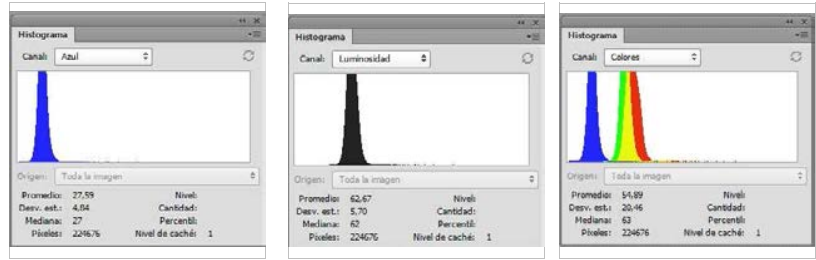

Grafica L (TT)

Grafica C (TT)

Valor G(TT):

Grafica B (TT)

Valor L(TT):

Valor $\mathrm{C}(\mathrm{TT})$ :

64,47

27,59

62,67

54,89

Grafica G (DF): Grafica B (DF): Grafica L (DF): Grafica C (DF): Valor DF-G: Valor DF-B: Valor DF-L: Valor DF-C: 49,54 2,62 53,88 44,36

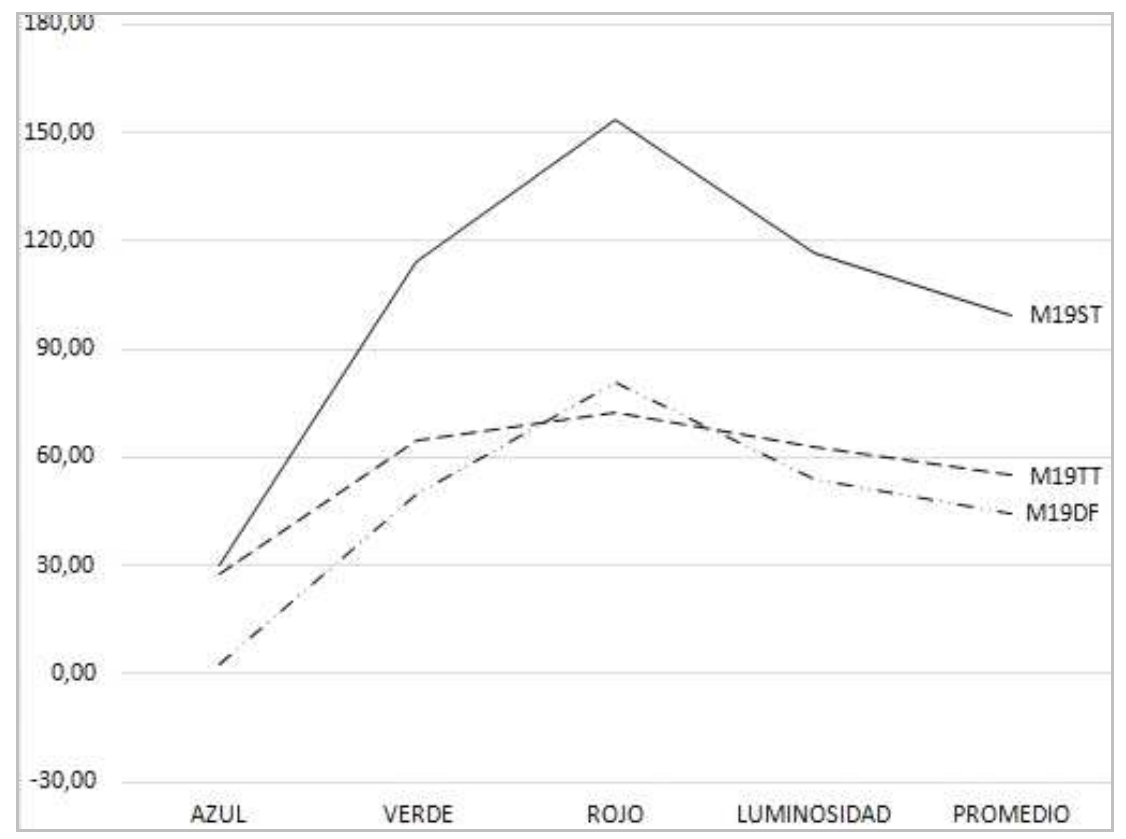

Universidad Politécnica de Madrid - Escuela Técnica Superior de Arquitectura - Departamento de Construcción y Tecnología Arquitectónica Directores: Dr. Alfonso García Santos y Dr. Antonio Rodríguez Rodríguez. Doctorando: D. Francisco Lora Toro 


\section{FICHA DE ENSAYOS DE MADERA Y ACIDOS}

ACIDO A04/FL/ACIDO FLUORHÍDRICO

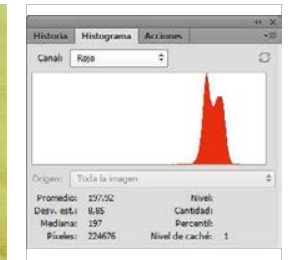

SIN TRATAR (ST): Grafica R (ST)

Valor R(ST):

197,92

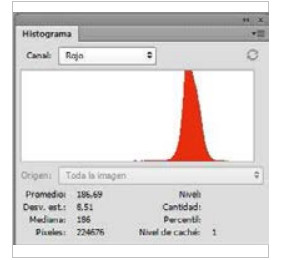

TRATADA (TT): Grafica R (TT)

Valor R(TT):

186,69

DIFERENCIA (DF) Grafica R (DF): Valor DF-R: 11,23

GRAFICA:

\section{LEYENDA}

ST MADERA SIN TRATAR

Grafica R Histograma color Rojo

Grafica G Histograma color Verde

Grafica B Histograma color Azul

Grafica L Histograma Luminosidad

Grafica C Histograma RGB

TT MADERA TRATADA

Valor R Número pixeles color Rojo

Valor $\mathrm{G}$ Número pixeles color Verde

Valor B Número pixeles color Azul

Valor $L$ Número pixeles Luminosidad

Valor $C$ Número pixeles $R G$

DF DIFERENCIA DE VALORES R;G; $\mathrm{DF}=$ Valor $\mathrm{ST}(\mathrm{R} ; \mathrm{G} ; \mathrm{B})$ - Valor TT $(\mathrm{R} ; \mathrm{G} ; \mathrm{B}$

\section{MADERA M2O/KT/KOTO}

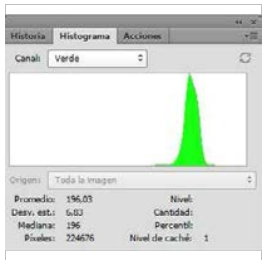

Grafica G (ST)

Valor $\mathrm{G}(\mathrm{ST})$ :

196,03

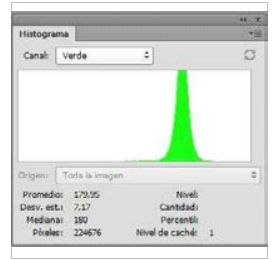

Grafica G (TT)

Valor G(TT):

179,95

Grafica G (DF): Grafica B (DF):

Valor DF-G:

Valor DF-B:

16,71
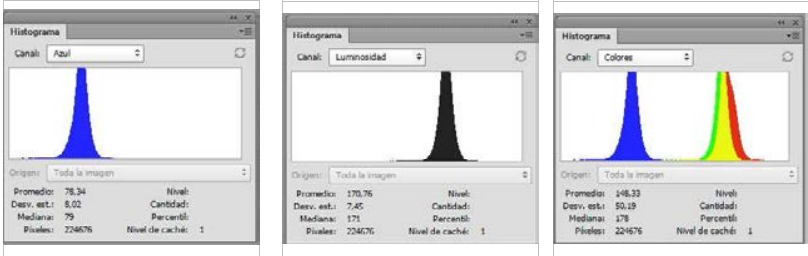

Grafica B (TT)

Grafica L (TT)

Grafica C (TT)

Valor $\mathrm{B}(\mathrm{TT})$ :

Valor L(TT):

Valor $\mathrm{C}(\mathrm{TT})$ :

148,33

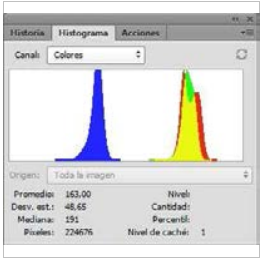

Grafica C (ST)

Valor C(ST):

163,00

$$
16,08
$$

Grafica L (DF):

Grafica C (DF):

Valor DF-L:

Valor DF-C:

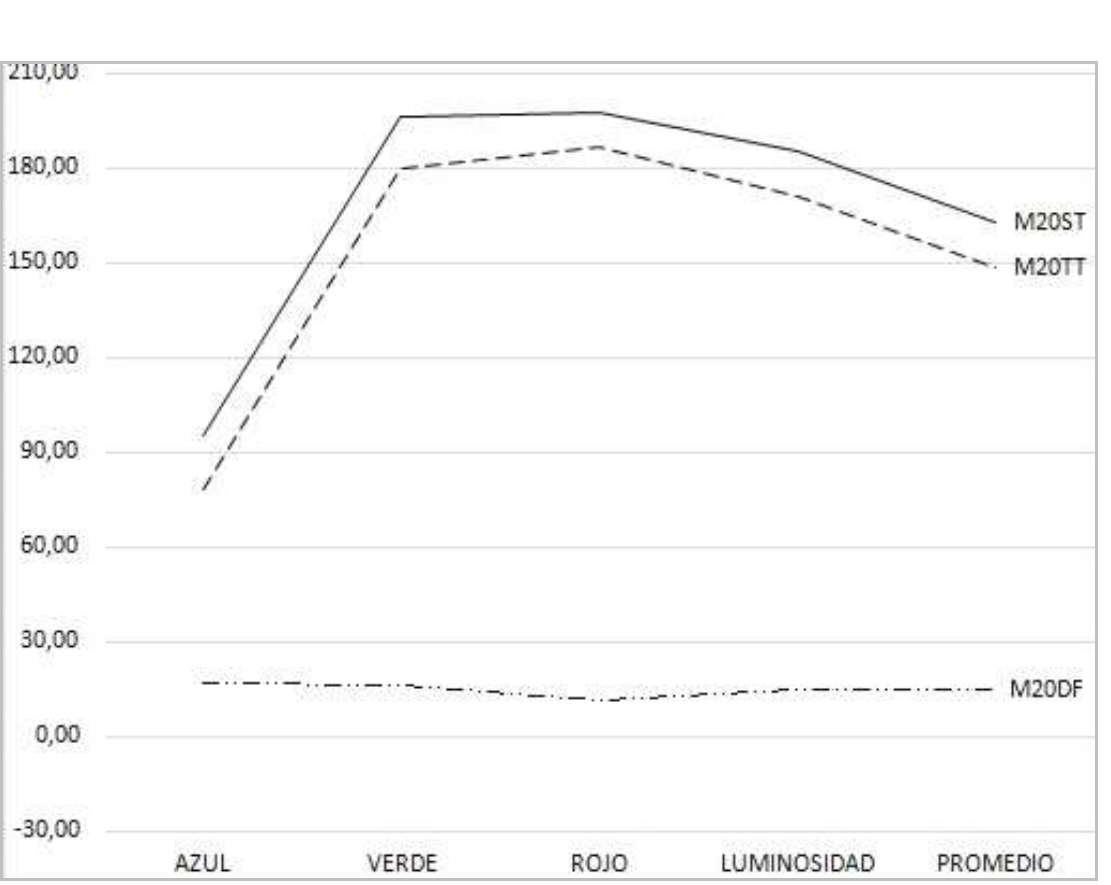

Universidad Politécnica de Madrid - Escuela Técnica Superior de Arquitectura - Departamento de Construcción y Tecnología Arquitectónica Directores: Dr. Alfonso García Santos y Dr. Antonio Rodríguez Rodríguez. Doctorando: D. Francisco Lora Toro 


\section{FICHA DE ENSAYOS DE MADERA Y ACIDOS}

ACIDO A04/FL/ACIDO FLUORHÍDRICO

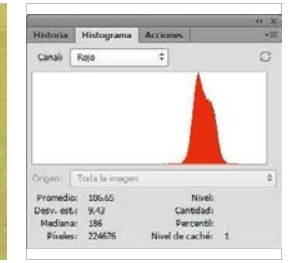

SIN TRATAR (ST): Grafica R (ST)

Valor R(ST):

186,65

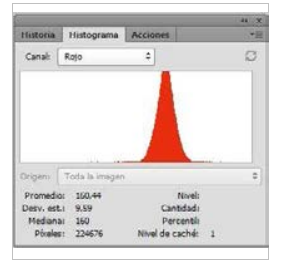

TRATADA (TT): Grafica R (TT)

Valor $\mathrm{R}(\mathrm{TT})$ :

160,44

DIFERENCIA (DF) Grafica R (DF): Valor DF-R:

26,21

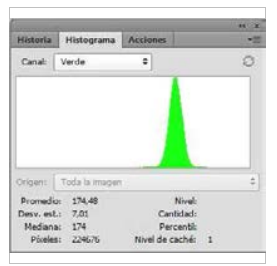

Grafica G (ST)

Valor G(ST):

174,48

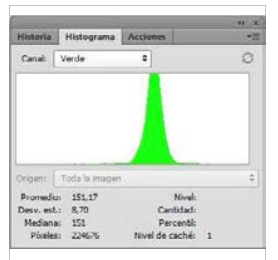

Grafica G (TT)

Valor $\mathrm{G}(\mathrm{TT})$ :

151,17

\section{MADERA M21/LG/LENGA}

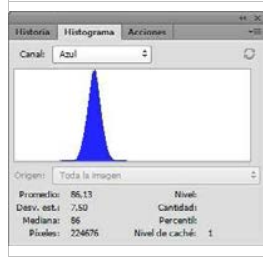

Grafica B (ST)

Valor B(ST):

86,13

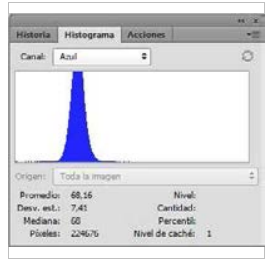

Grafica B (TT)

Valor $\mathrm{B}(\mathrm{TT})$ :

68,16

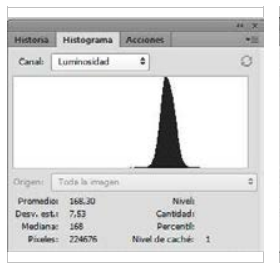

Grafica L (ST)

Valor L(ST):

168,30

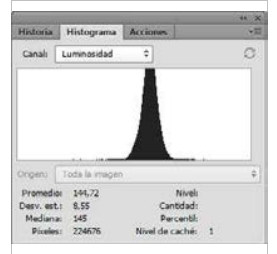

Grafica L (TT)

Valor L(TT):

144,72

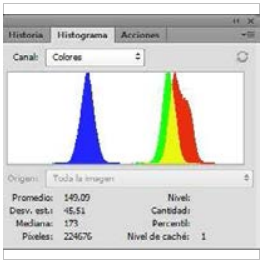

Grafica C (ST)

Valor C(ST):

149,09

Grafica G (DF): Grafica B (DF): Grafica L (DF): Grafica C (DF):

Valor DF-G: Valor DF-B:

Valor DF-L:

Valor DF-C:

$\begin{array}{llll}23,31 & 17,97 & 23,58 & 22,50\end{array}$

GRAFICA:

\section{LEYENDA}

ST MADERA SIN TRATAR

Grafica R Histograma color Rojo

Grafica G Histograma color Verde

Grafica B Histograma color Azul

Grafica L Histograma Luminosidad

Grafica C Histograma RGB

TT MADERA TRATADA

Valor $\mathrm{R}$ Número pixeles color Rojo

Valor $\mathrm{G}$ Número pixeles color Verde

Valor B Número pixeles color Azul

Valor L Número pixeles Luminosidad

Valor C Número pixeles RG

DF DIFERENCIA DE VALORES R;G;

$\mathrm{DF}=$ Valor $\mathrm{ST}(\mathrm{R} ; \mathrm{G} ; \mathrm{B})$ - Valor TT(R;G;B

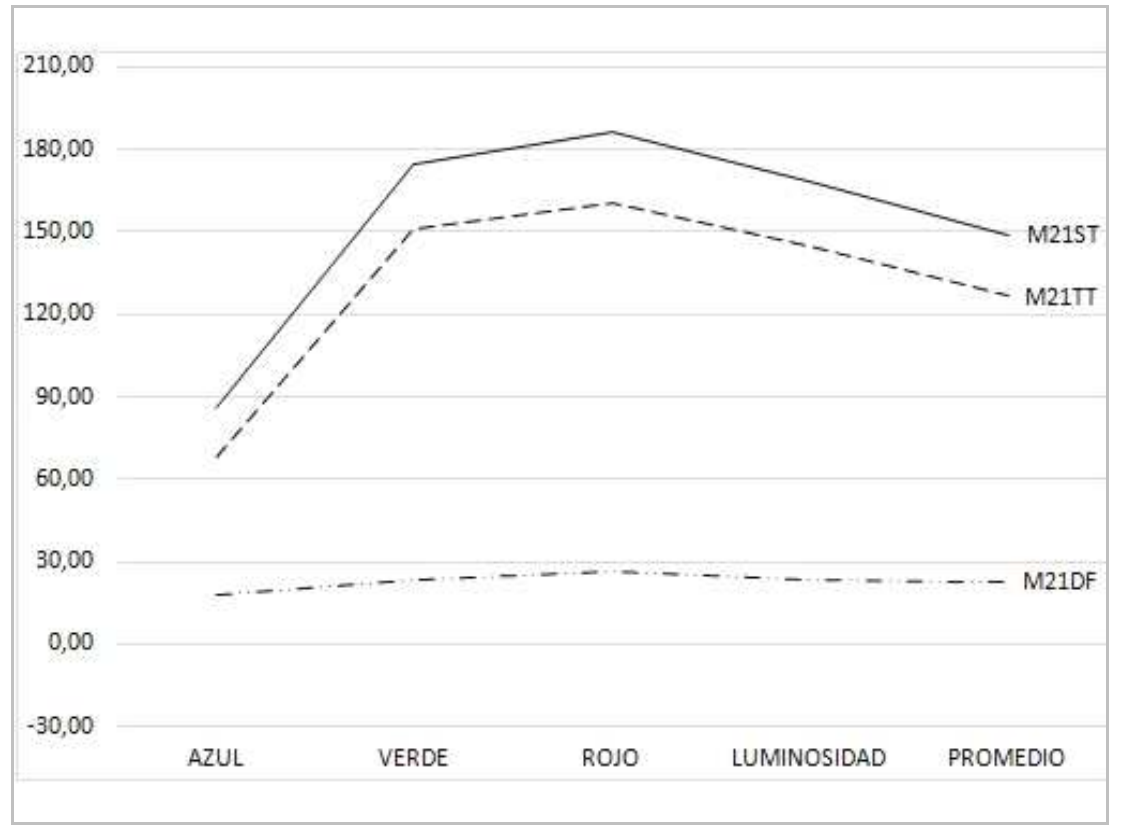

Universidad Politécnica de Madrid - Escuela Técnica Superior de Arquitectura - Departamento de Construcción y Tecnología Arquitectónica Directores: Dr. Alfonso García Santos y Dr. Antonio Rodríguez Rodríguez. Doctorando: D. Francisco Lora Toro 


\section{FICHA DE ENSAYOS DE MADERA Y ACIDOS}

\section{ACIDO A04/FL/ACIDO FLUORHÍDRICO}
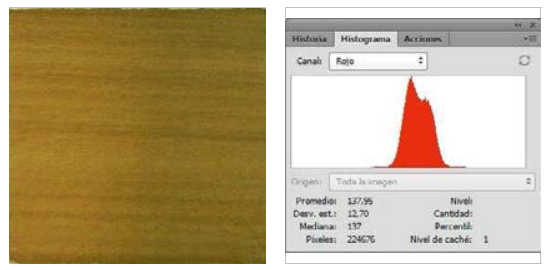

SIN TRATAR (ST): Grafica R (ST)

Valor R(ST):

137,95

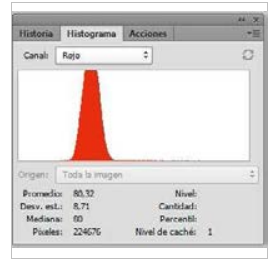

TRATADA (TT): Grafica $R(T T)$

Valor R(TT):

80,32

DIFERENCIA (DF) Grafica R (DF): Valor DF-R: 57,63

GRAFICA :

\section{LEYENDA}

ST MADERA SIN TRATAR

Grafica R Histograma color Rojo

Grafica G Histograma color Verde

Grafica B Histograma color Azul

Grafica L Histograma Luminosidad

Grafica C Histograma RGB

\section{TT MADERA TRATADA}

Valor R Número pixeles color Rojo

Valor $G$ Número pixeles color Verde Valor B Número pixeles color Azul Valor $L$ Número pixeles Luminosidad Valor C Número pixeles RG

DF DIFERENCIA DE VALORES R;G; $\mathrm{DF}=$ Valor $\mathrm{ST}(\mathrm{R} ; \mathrm{G} ; \mathrm{B})$ - Valor $\mathrm{TT}(\mathrm{R} ; \mathrm{G} ; \mathrm{B}$

\section{MADERA M22/MK/MAKORÉ}
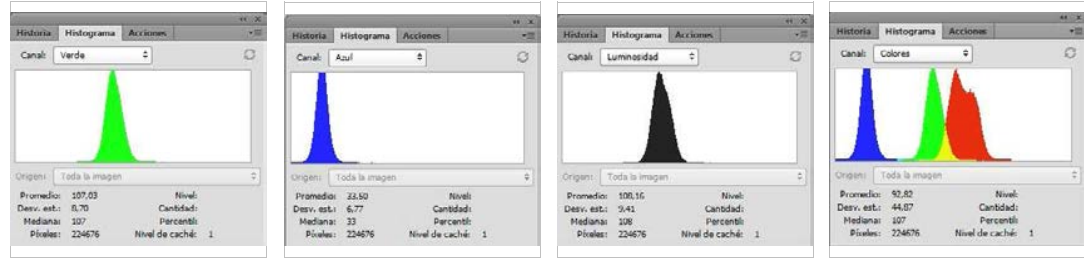

Grafica G (ST)

Grafica B (ST)

Grafica L (ST)

Grafica C (ST)

Valor $\mathrm{G}(\mathrm{ST})$ :

Valor B(ST):

Valor L(ST):

Valor C(ST):

33,50

108,16

92,82
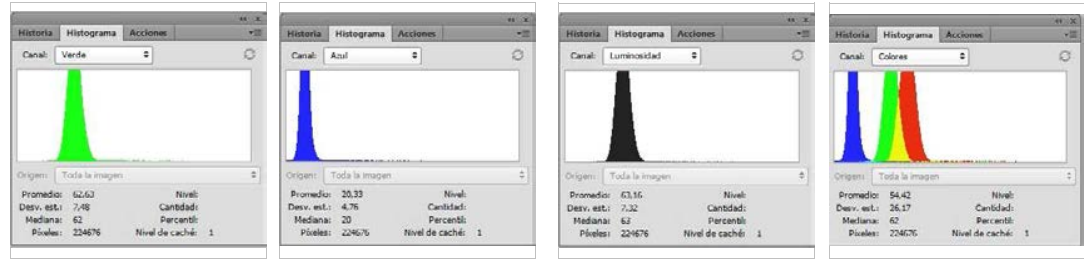

Grafica G (TT) Grafica B (TT)

Grafica L (TT)

Grafica C (TT)

Valor $\mathrm{G}(\mathrm{TT})$ :

Valor $\mathrm{B}(\mathrm{TT})$ :

Valor L(TT):

Valor $\mathrm{C}(\mathrm{TT})$ :

62,63

20,33

63,16

54,42

Grafica G (DF): Grafica B (DF): Grafica L (DF): Grafica C (DF): Valor DF-G: Valor DF-B: Valor DF-L: Valor DF-C:

$\begin{array}{llll}44,40 & 13,17 & 45,00 & 38,40\end{array}$

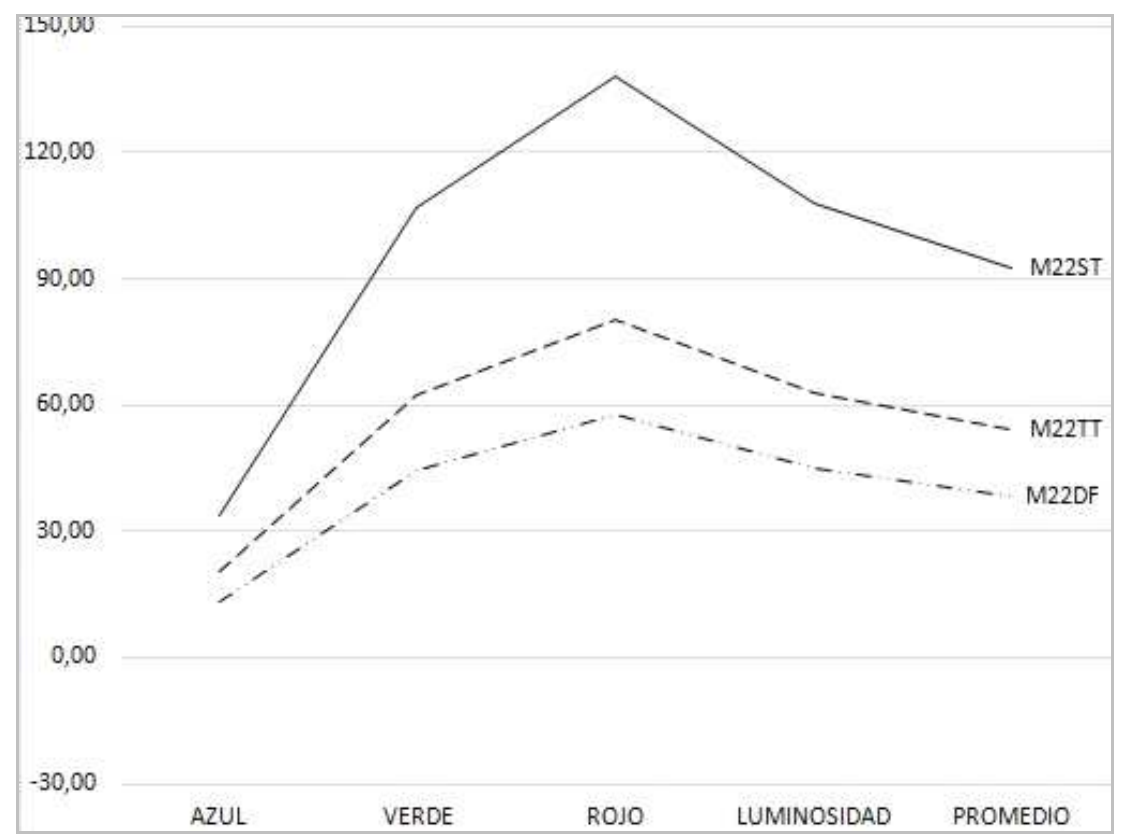

Universidad Politécnica de Madrid - Escuela Técnica Superior de Arquitectura - Departamento de Construcción y Tecnología Arquitectónica Directores: Dr. Alfonso García Santos y Dr. Antonio Rodríguez Rodríguez. Doctorando: D. Francisco Lora Toro 


\section{FICHA DE ENSAYOS DE MADERA Y ACIDOS}

ACIDO A04/FL/ACIDO FLUORHÍDRICO
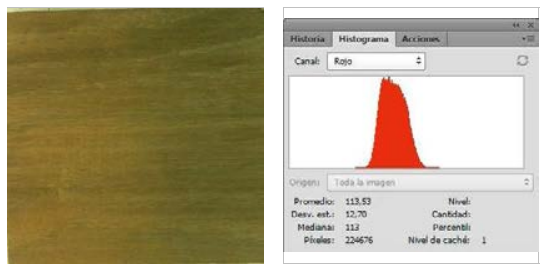

SIN TRATAR (ST): Grafica R (ST)

Valor R(ST):

113,53
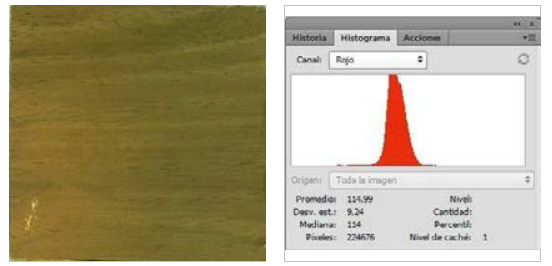

TRATADA (TT): Grafica R (TT)

Valor R(TT):

114,99

DIFERENCIA (DF) Grafica R (DF): Valor DF-R: $-1,46$

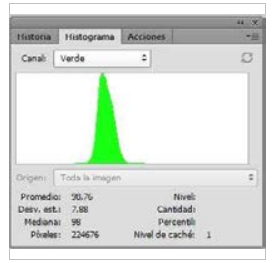

Grafica G (ST)

Valor G(ST):

98,76

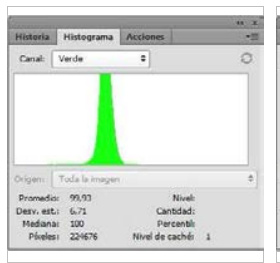

Grafica G (TT)

Valor G(TT):

99,93
MADERA M23/NGA/NOGAL NEGRO AMERICANO

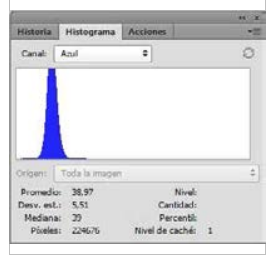

Grafica B (ST)

Valor B(ST):

38,97

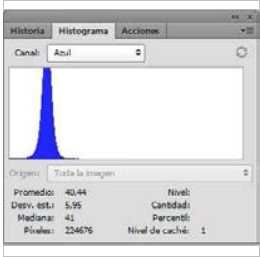

Grafica B (TT)

Valor $\mathrm{B}(\mathrm{TT})$ :

40,44

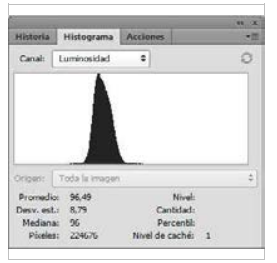

Grafica L (ST)

Valor L(ST):

96,49

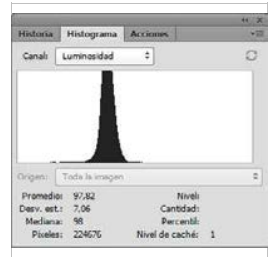

Grafica L (TT)

Valor L(TT):

97,82

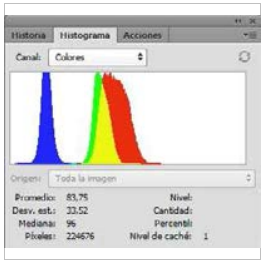

Grafica C (ST)

Valor C(ST):

83,75

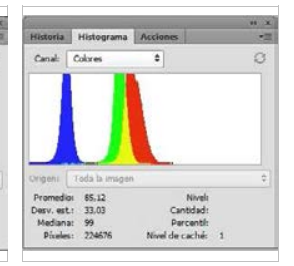

Grafica C (TT)

Valor $\mathrm{C}(\mathrm{TT})$ :

85,12

\section{Grafica G (DF): Grafica B (DF): Grafica L (DF): Grafica C (DF):} Valor DF-G: Valor DF-B: Valor DF-L: Valor DF-C:
$-1,17$
$-1,47$
$-1,33$
$-1,37$

\section{GRAFICA:}

\section{LEYENDA}

ST MADERA SIN TRATAR

Grafica R Histograma color Rojo

Grafica G Histograma color Verde

Grafica B Histograma color Azul

Grafica L Histograma Luminosidad

Grafica C Histograma RGB

TT MADERA TRATADA

Valor $\mathrm{R}$ Número pixeles color Rojo

Valor $\mathrm{G}$ Número pixeles color Verde

Valor B Número pixeles color Azul

Valor $L$ Número pixeles Luminosidad

Valor C Número pixeles RG

DF DIFERENCIA DE VALORES R;G; $\mathrm{DF}=$ Valor $\mathrm{ST}(\mathrm{R} ; \mathrm{G} ; \mathrm{B})$ - Valor TT $(\mathrm{R} ; \mathrm{G} ; \mathrm{B}$

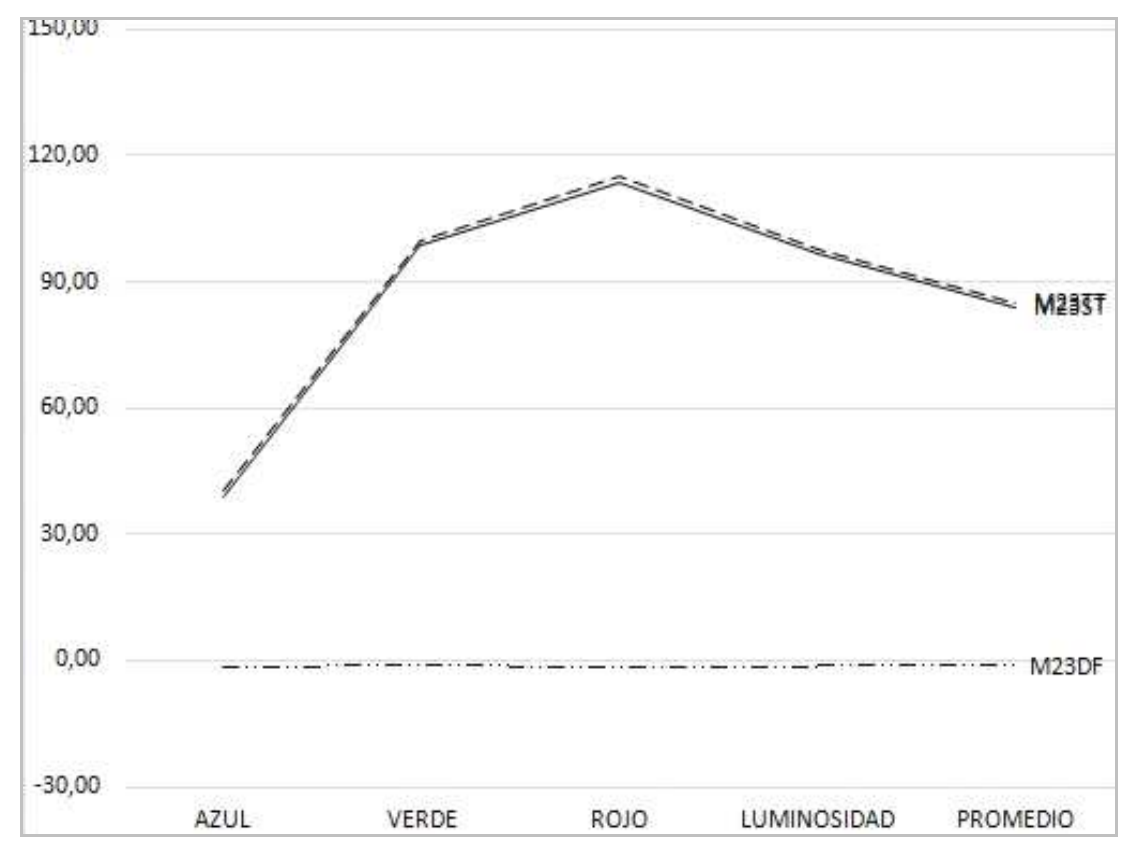

Universidad Politécnica de Madrid - Escuela Técnica Superior de Arquitectura - Departamento de Construcción y Tecnología Arquitectónica Directores: Dr. Alfonso García Santos y Dr. Antonio Rodríguez Rodríguez. Doctorando: D. Francisco Lora Toro 


\section{FICHA DE ENSAYOS DE MADERA Y ACIDOS}

\section{ACIDO A04/FL/ACIDO FLUORHÍDRICO}
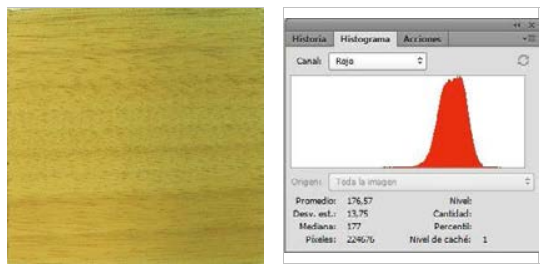

SIN TRATAR (ST): Grafica R (ST)

Valor R(ST):

176,57

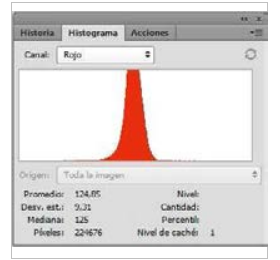

TRATADA (TT): Grafica R (TT)

Valor R(TT):

124,85

DIFERENCIA (DF) Grafica R (DF): Valor DF-R: 51,72

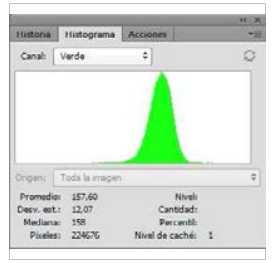

Grafica G (ST)

Valor $\mathrm{G}(\mathrm{ST})$ :

157,60

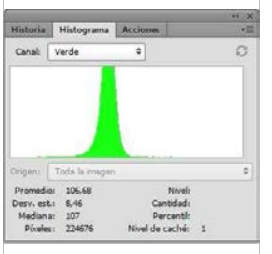

Grafica G (TT)

Valor $\mathrm{G}(\mathrm{TT})$ :

106,68
MADERA M24/OK/OKUMÉ

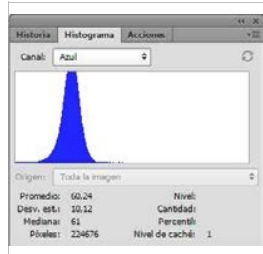

Grafica B (ST)

Valor B(ST):

60,24

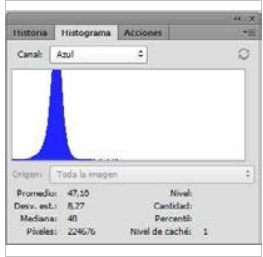

Grafica B (TT)

Valor $\mathrm{B}(\mathrm{TT})$ :

47,10

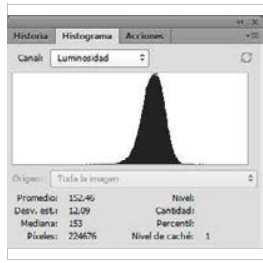

Grafica L (ST)

Valor L(ST):

152,46

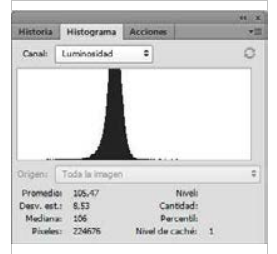

Grafica L (TT)

Valor L(TT):

105,47

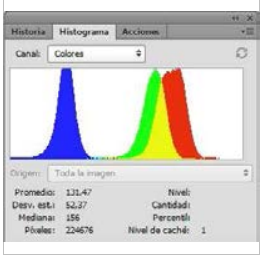

Grafica C (ST)

Valor C(ST):

131,47

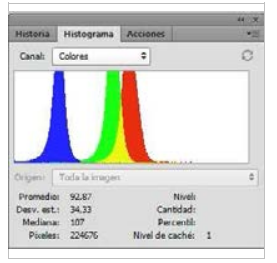

Grafica C (TT)

Valor C(TT):

92,87

Grafica G (DF): Grafica B (DF): Grafica L (DF): Grafica C (DF): Valor DF-G: Valor DF-B: Valor DF-L: Valor DF-C: $\begin{array}{llll}50,92 & 13,14 & 46,99 & 38,60\end{array}$

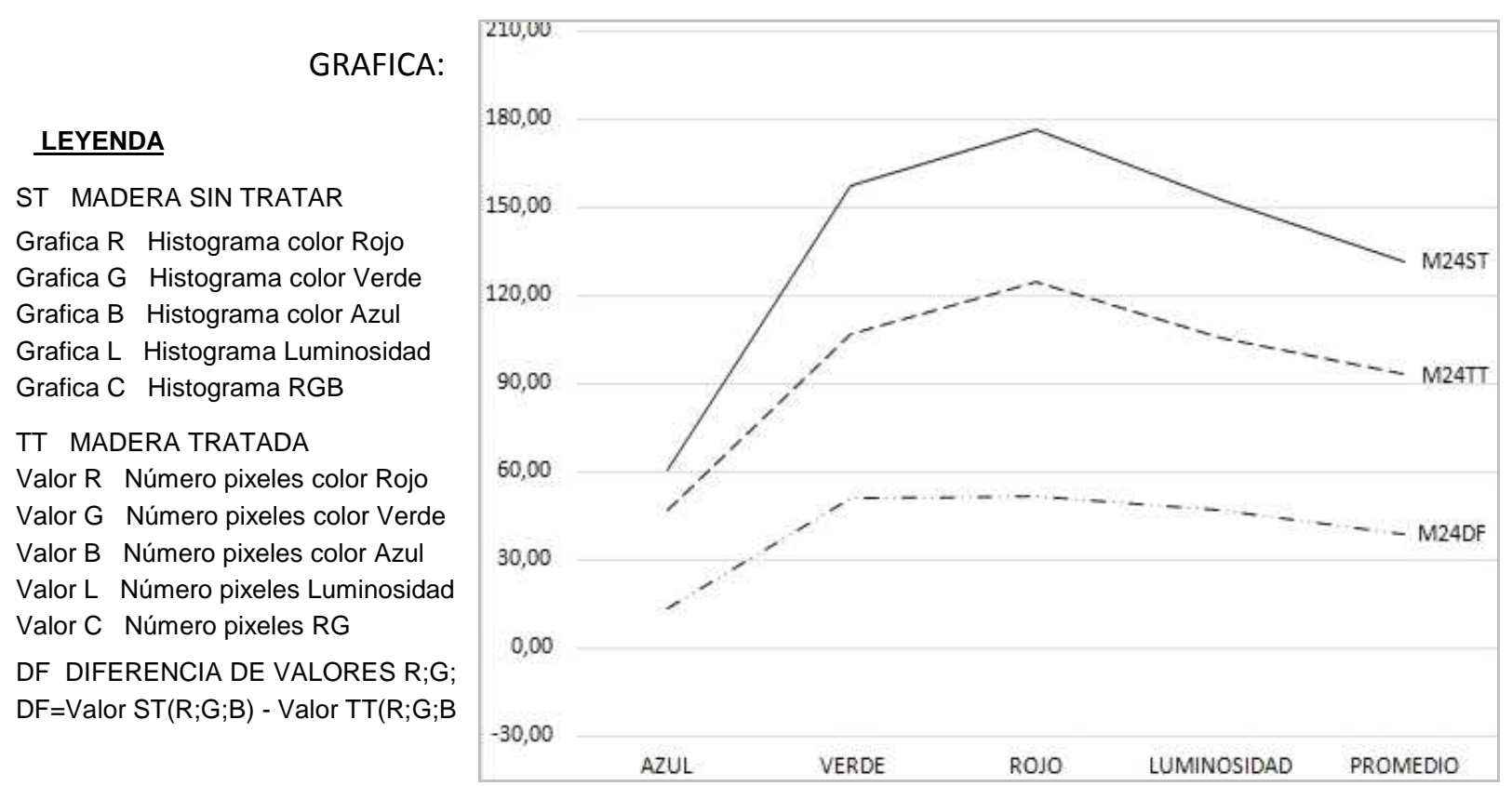

Universidad Politécnica de Madrid - Escuela Técnica Superior de Arquitectura - Departamento de Construcción y Tecnología Arquitectónica Directores: Dr. Alfonso García Santos y Dr. Antonio Rodríguez Rodríguez. Doctorando: D. Francisco Lora Toro 


\section{FICHA DE ENSAYOS DE MADERA Y ACIDOS}

ACIDO A04/FL/ACIDO FLUORHÍDRICO
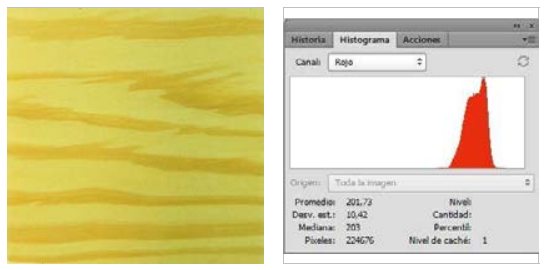

SIN TRATAR (ST): Grafica R (ST)

Valor R(ST):

201,73

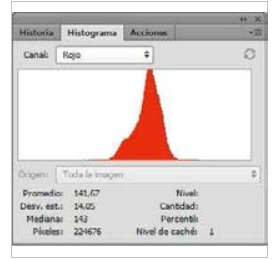

TRATADA (TT): Grafica R (TT)

Valor R(TT):

141,67

DIFERENCIA (DF) Grafica R (DF):

Valor DF-R:

60,06

GRAFICA:

\section{LEYENDA}

ST MADERA SIN TRATAR

Grafica R Histograma color Rojo

Grafica G Histograma color Verde

Grafica B Histograma color Azul

Grafica L Histograma Luminosidad

Grafica C Histograma RGB

TT MADERA TRATADA

Valor R Número pixeles color Rojo

Valor $\mathrm{G}$ Número pixeles color Verde

Valor B Número pixeles color Azul

Valor $L$ Número pixeles Luminosidad

Valor C Número pixeles RG

DF DIFERENCIA DE VALORES R;G;

$\mathrm{DF}=$ Valor $\mathrm{ST}(\mathrm{R} ; \mathrm{G} ; \mathrm{B})$ - Valor TT(R;G;B
MADERA M25/PX/PINO AMARILLO DEL SUR

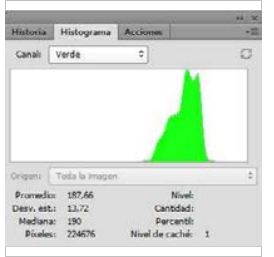

Grafica G (ST)

Valor G(ST):

187,66
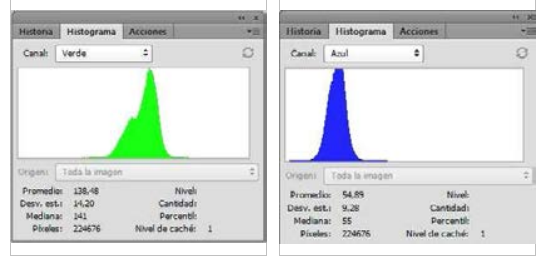

Grafica G (TT)

Grafica B (TT)

Valor $\mathrm{B}(\mathrm{TT})$ :

54,89

138,48

Grafica G (DF): Grafica B (DF):

Grafica L (DF):

Grafica C (DF):

Valor DF-G:

Valor DF-B:

Valor DF-L:

Valor DF-C:

49,18

17,23

49,06

42,16

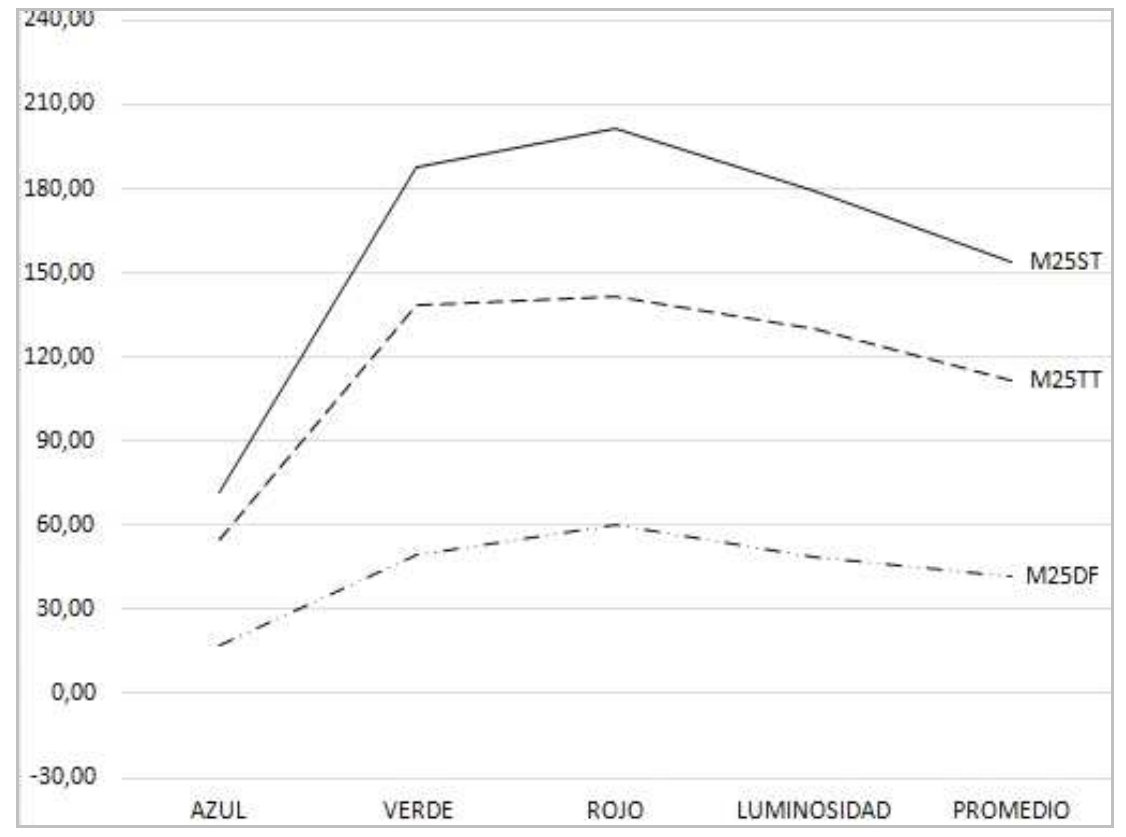

Universidad Politécnica de Madrid - Escuela Técnica Superior de Arquitectura - Departamento de Construcción y Tecnología Arquitectónica Directores: Dr. Alfonso García Santos y Dr. Antonio Rodríguez Rodríguez. Doctorando: D. Francisco Lora Toro 


\section{FICHA DE ENSAYOS DE MADERA Y ACIDOS}

\section{ACIDO A04/FL/ACIDO FLUORHÍDRICO}

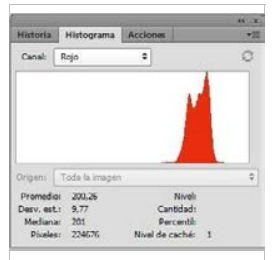

SIN TRATAR (ST): Grafica R (ST)

Valor R(ST):

200,26

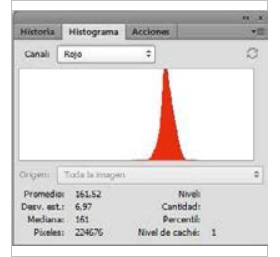

TRATADA (TT): Grafica R (TT)

Valor $\mathrm{R}(\mathrm{TT})$ :

161,52

DIFERENCIA (DF) Grafica R (DF): Valor DF-R: 38,74

\section{GRAFICA:}

\section{LEYENDA}

ST MADERA SIN TRATAR

Grafica R Histograma color Rojo

Grafica G Histograma color Verde

Grafica B Histograma color Azul

Grafica L Histograma Luminosidad

Grafica C Histograma RGB

TT MADERA TRATADA

Valor $\mathrm{R}$ Número pixeles color Rojo

Valor $\mathrm{G}$ Número pixeles color Verde

Valor B Número pixeles color Azul

Valor $L$ Número pixeles Luminosidad

Valor $C$ Número pixeles $R G$

DF DIFERENCIA DE VALORES R;G;

$\mathrm{DF}=$ Valor $\mathrm{ST}(\mathrm{R} ; \mathrm{G} ; \mathrm{B})$ - Valor TT $(\mathrm{R} ; \mathrm{G} ; \mathrm{B}$

\section{MADERA M26/PR/PINO RADIATA}
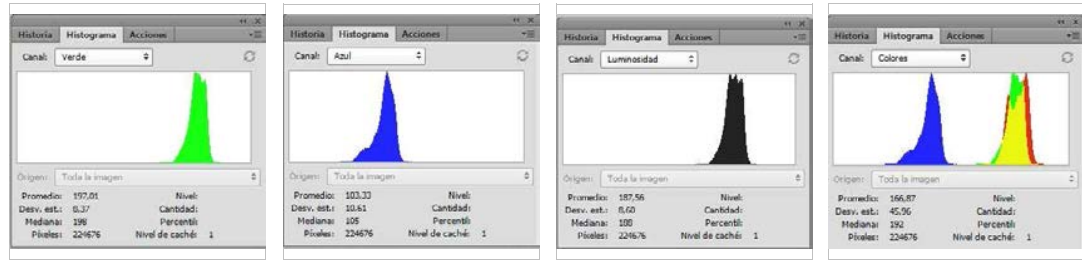

Grafica G (ST)

Grafica B (ST)

Grafica L (ST)

Grafica C (ST)

Valor $\mathrm{G}(\mathrm{ST})$ :

Valor B(ST):

Valor L(ST):

Valor C(ST):

197,01

103,33

187,56

166,87
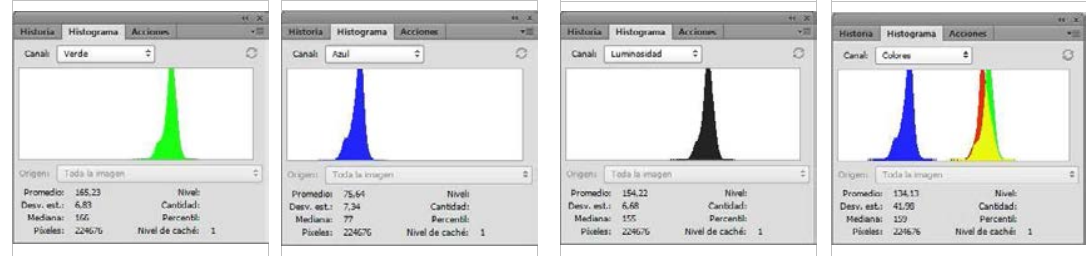

\section{Grafica G (TT)}

Grafica B (TT)

Grafica L (TT)

Grafica C (TT)

Valor $\mathrm{G}(\mathrm{TT})$ :

Valor $\mathrm{B}(\mathrm{TT})$ :

Valor L(TT):

Valor C(TT):

165,23

75,64

154,22

134,13

\section{Grafica G (DF): Grafica B (DF): Grafica L (DF):}

Grafica C (DF):

Valor DF-G:

Valor DF-B:

Valor DF-L:

Valor DF-C:

31,78

27,69

33,34

32,74

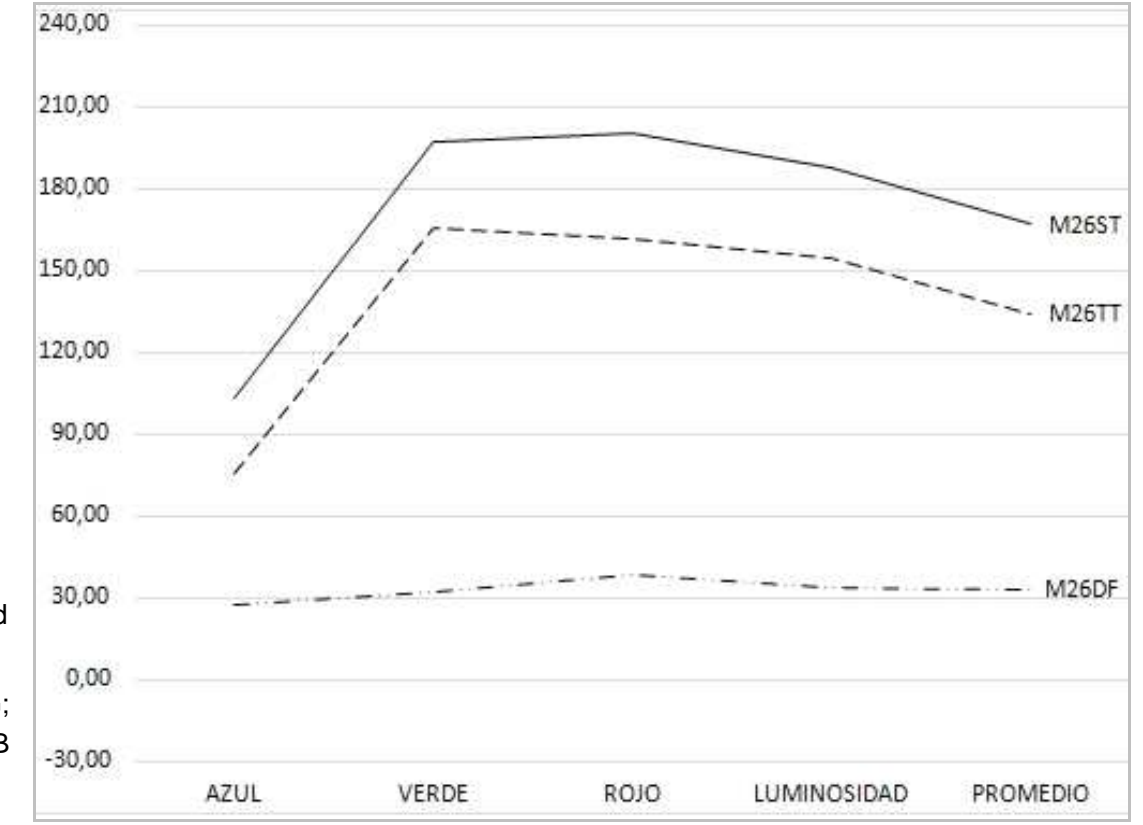

Universidad Politécnica de Madrid - Escuela Técnica Superior de Arquitectura - Departamento de Construcción y Tecnología Arquitectónica Directores: Dr. Alfonso García Santos y Dr. Antonio Rodríguez Rodríguez. Doctorando: D. Francisco Lora Toro 


\section{FICHA DE ENSAYOS DE MADERA Y ACIDOS}

ACIDO A04/FL/ACIDO FLUORHÍDRICO

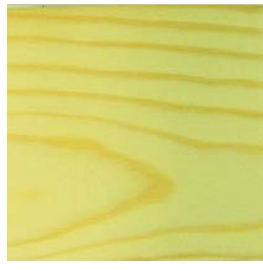

SIN TRATAR (ST): Grafica R (ST)

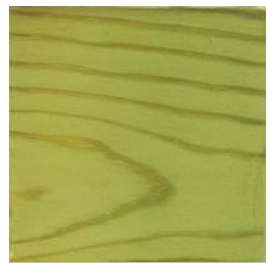

TRATADA (TT):
Valor R(ST):

205,20
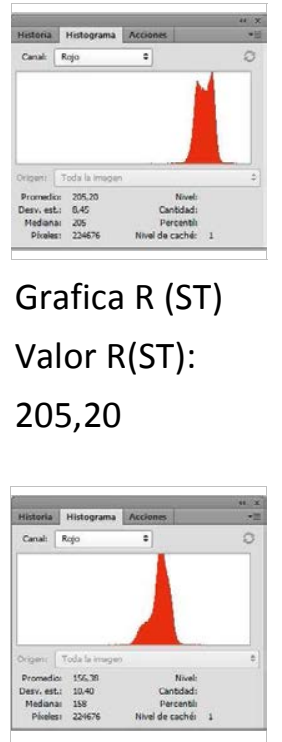

Grafica R (TT)

Valor $\mathrm{R}(\mathrm{TT})$ :

156,38

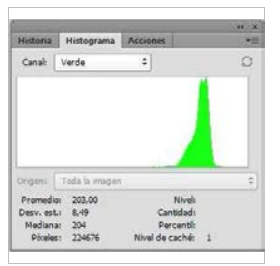

Grafica G (ST)

Valor G(ST):

203,00

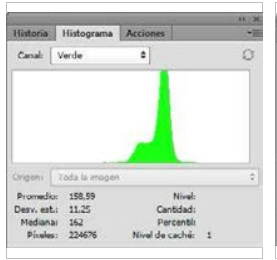

Grafica G (TT)

Valor G(TT):

158,59

MADERA M27/PS/PINO SILVESTRE

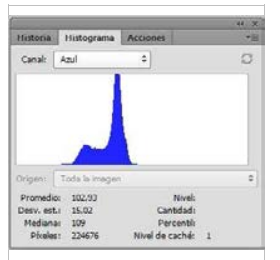

Grafica B (ST)

Valor B(ST):

102,93

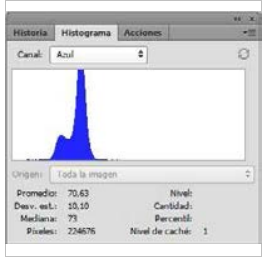

Grafica B (TT)

Valor $\mathrm{B}(\mathrm{TT})$ :

70,63

Grafica G (DF): Grafica B (DF):

Valor DF-B:

32,30

44,41

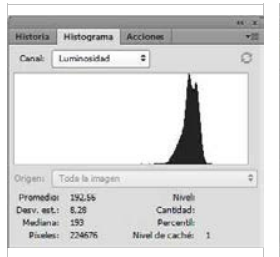

Grafica L (ST)

Valor L(ST):

192,56

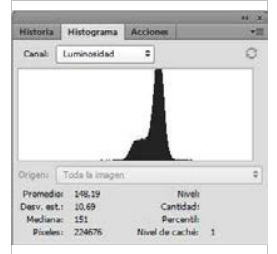

Grafica L (TT)

Valor L(TT):

148,19

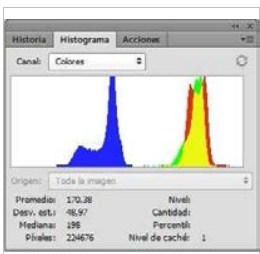

Grafica C (ST)

Valor C(ST):

170,38

DIFERENCIA (DF) Grafica R (DF): Valor DF-R:

Valor DF-G:

Grafica L (DF):

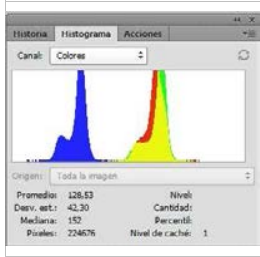

48,82

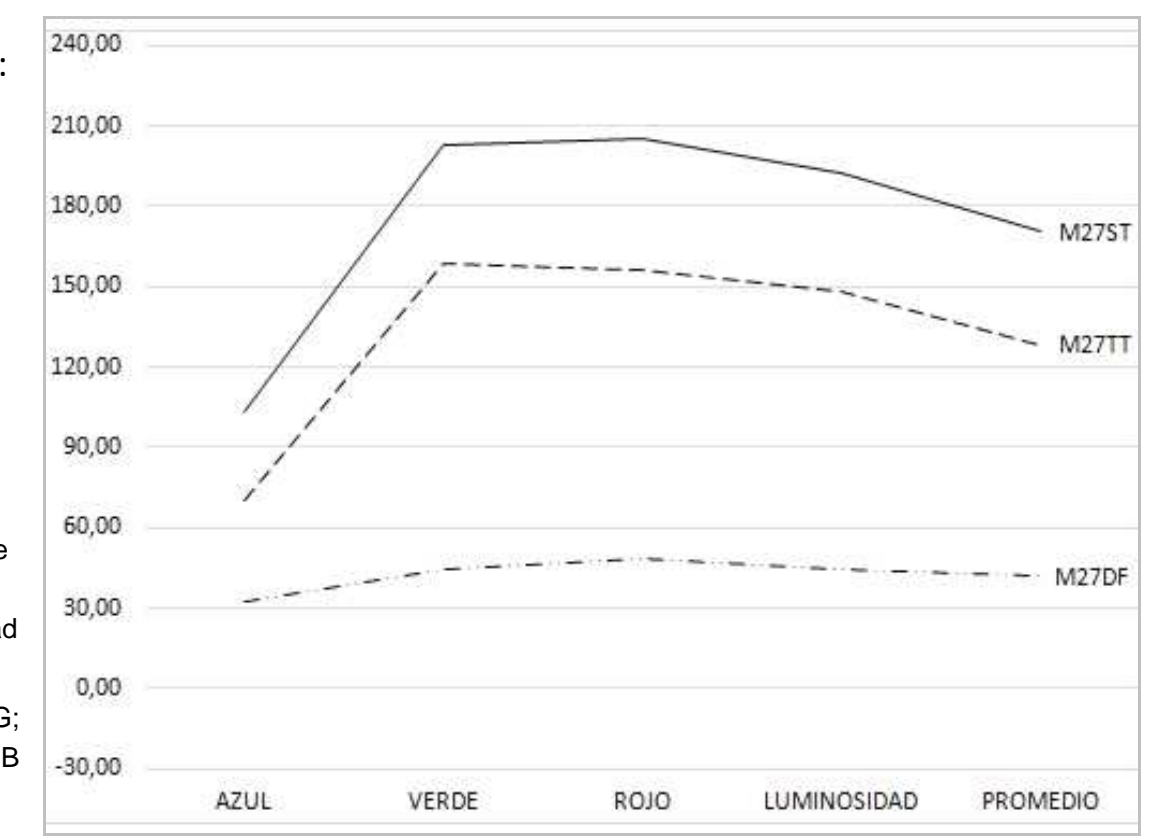

\section{LEYENDA}

ST MADERA SIN TRATAR

Grafica R Histograma color Rojo

Grafica G Histograma color Verde

Grafica B Histograma color Azul

Grafica L Histograma Luminosidad

Grafica C Histograma RGB

TT MADERA TRATADA

Valor $R$ Número pixeles color Rojo

Valor $\mathrm{G}$ Número pixeles color Verde

Valor B Número pixeles color Azul

Valor $L$ Número pixeles Luminosidad

Valor $C$ Número pixeles $R G$

DF DIFERENCIA DE VALORES R;G;

$\mathrm{DF}=$ Valor $\mathrm{ST}(\mathrm{R} ; \mathrm{G} ; \mathrm{B})$ - Valor $\mathrm{TT}(\mathrm{R} ; \mathrm{G} ; \mathrm{B}$

Universidad Politécnica de Madrid - Escuela Técnica Superior de Arquitectura - Departamento de Construcción y Tecnología Arquitectónica Directores: Dr. Alfonso García Santos y Dr. Antonio Rodríguez Rodríguez. Doctorando: D. Francisco Lora Toro 


\section{FICHA DE ENSAYOS DE MADERA Y ACIDOS}

ACIDO A04/FL/ACIDO FLUORHÍDRICO
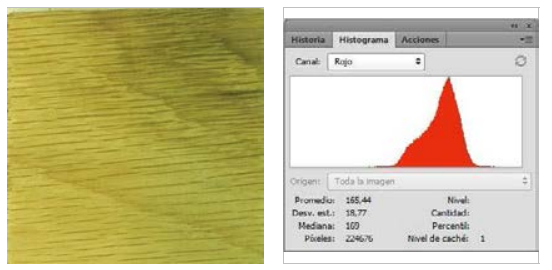

SIN TRATAR (ST): Grafica R (ST)

Valor R(ST):

165,44

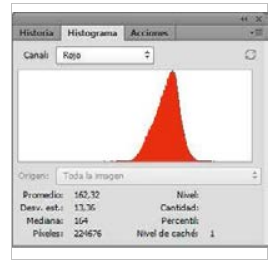

TRATADA (TT): Grafica R (TT)

Valor R(TT):

162,32

DIFERENCIA (DF) Grafica R (DF): Valor DF-R:

3,12

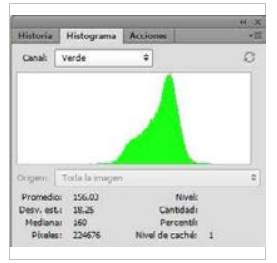

Grafica G (ST)

Valor G(ST):

156,03

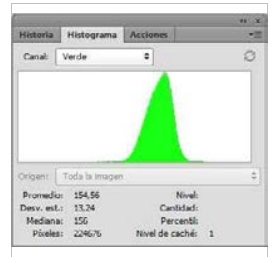

Grafica G (TT)

Valor $\mathrm{G}(\mathrm{TT})$ :

154,56
MADERA M28/RBA/ROBLE BLANCO AMERICANO

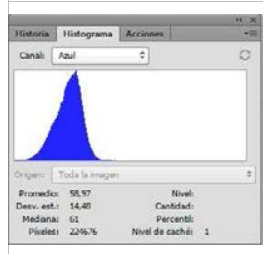

Grafica B (ST)

Valor B(ST):

58,97

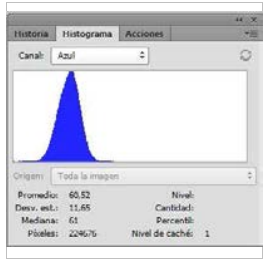

Grafica B (TT)

Valor $\mathrm{B}(\mathrm{TT})$ :

60,52

Grafica G (DF): Grafica B (DF):

Valor DF-G:

Valor DF-B:

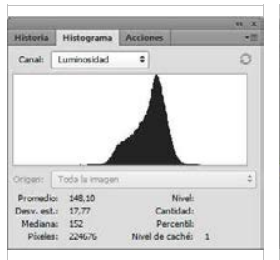

Grafica L (ST)

Valor L(ST):

148,10

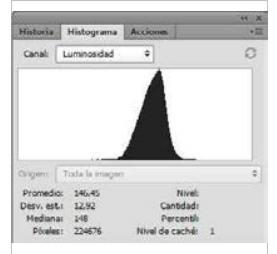

Grafica L (TT)

Valor L(TT):

146,45

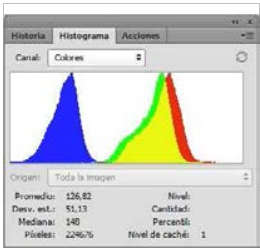

Grafica C (ST)

Valor C(ST):

126,82

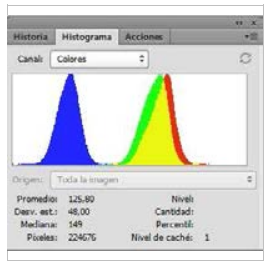

Grafica C (TT)

Valor C(TT):

125,80
$-1,55$
1,47

Grafica L (DF):

Grafica C (DF):

Valor DF-L:

Valor DF-C:

(1)

GRAFICA:

\section{LEYENDA}

ST MADERA SIN TRATAR

Grafica R Histograma color Rojo

Grafica G Histograma color Verde

Grafica B Histograma color Azul

Grafica L Histograma Luminosidad

Grafica C Histograma RGB

TT MADERA TRATADA

Valor $\mathrm{R}$ Número pixeles color Rojo

Valor $\mathrm{G}$ Número pixeles color Verde

Valor B Número pixeles color Azul

Valor $L$ Número pixeles Luminosidad

Valor $C$ Número pixeles $R G$

DF DIFERENCIA DE VALORES R;G;

$\mathrm{DF}=$ Valor $\mathrm{ST}(\mathrm{R} ; \mathrm{G} ; \mathrm{B})$ - Valor TT(R;G;B

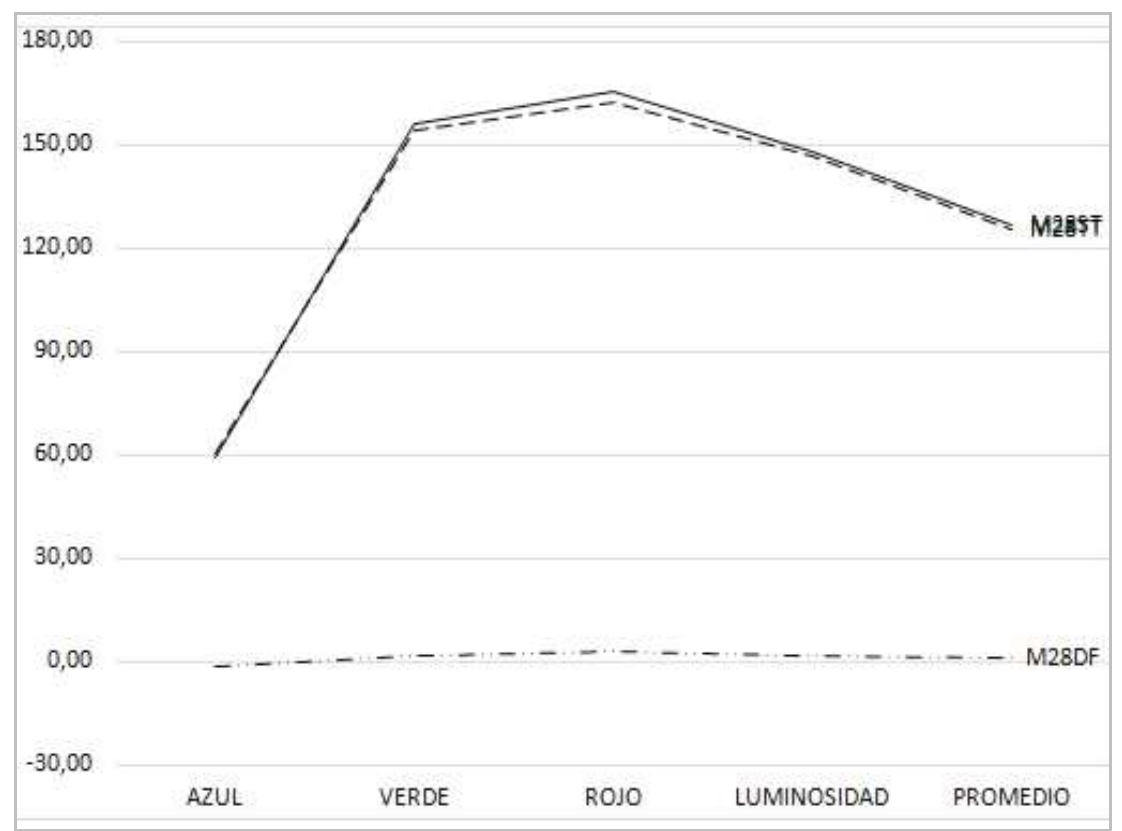

Universidad Politécnica de Madrid - Escuela Técnica Superior de Arquitectura - Departamento de Construcción y Tecnología Arquitectónica Directores: Dr. Alfonso García Santos y Dr. Antonio Rodríguez Rodríguez. Doctorando: D. Francisco Lora Toro 


\section{FICHA DE ENSAYOS DE MADERA Y ACIDOS}

ACIDO A04/FL/ACIDO FLUORHÍDRICO

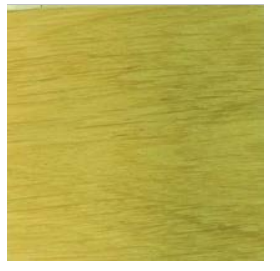

SIN TRATAR (ST): Grafica R (ST)

Valor R(ST):

172,62

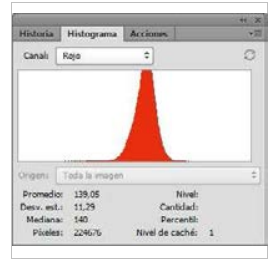

TRATADA (TT): Grafica R (TT)

Valor $\mathrm{R}(\mathrm{TT})$ :

139,05

DIFERENCIA (DF) Grafica R (DF): Valor DF-R: 33,57

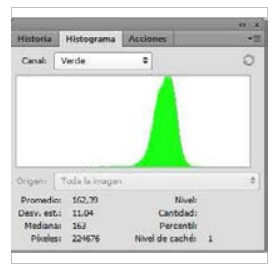

Grafica G (ST)

Valor G(ST):

162,39

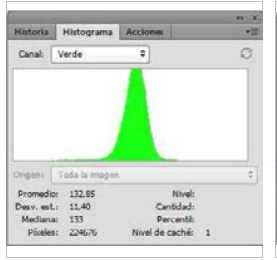

Grafica G (TT)

Valor $\mathrm{G}(\mathrm{TT})$ :

132,85
MADERA M29/RBE/ROBLE BLANCO EUROPEO

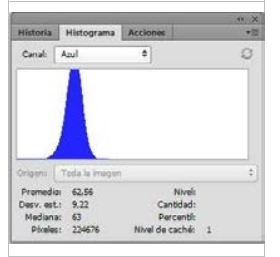

Grafica B (ST)

Valor B(ST):

62,56

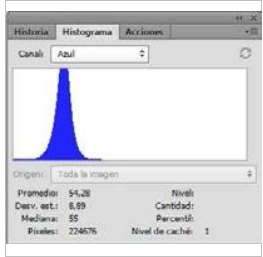

Grafica B (TT)

Valor $\mathrm{B}(\mathrm{TT})$ :

54,28

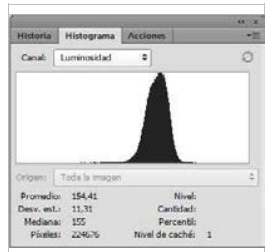

Grafica L (ST)

Valor L(ST):

154,41

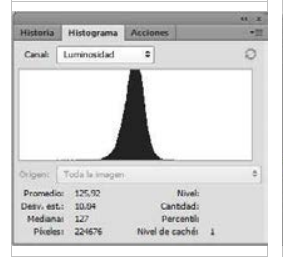

Grafica L (TT)

Valor L(TT):

125,92
Grafica C (TT)

Valor C(TT):

108,72

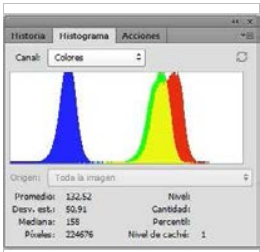

Grafica C (ST)

Valor C(ST):

132,52

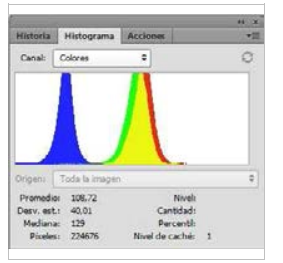

Grafica G (DF): Grafica B (DF): Grafica L (DF): Grafica C (DF): Valor DF-G: Valor DF-B: Valor DF-L: Valor DF-C:

$\begin{array}{llll}29,54 & 8,28 & 28,49 & 23,80\end{array}$

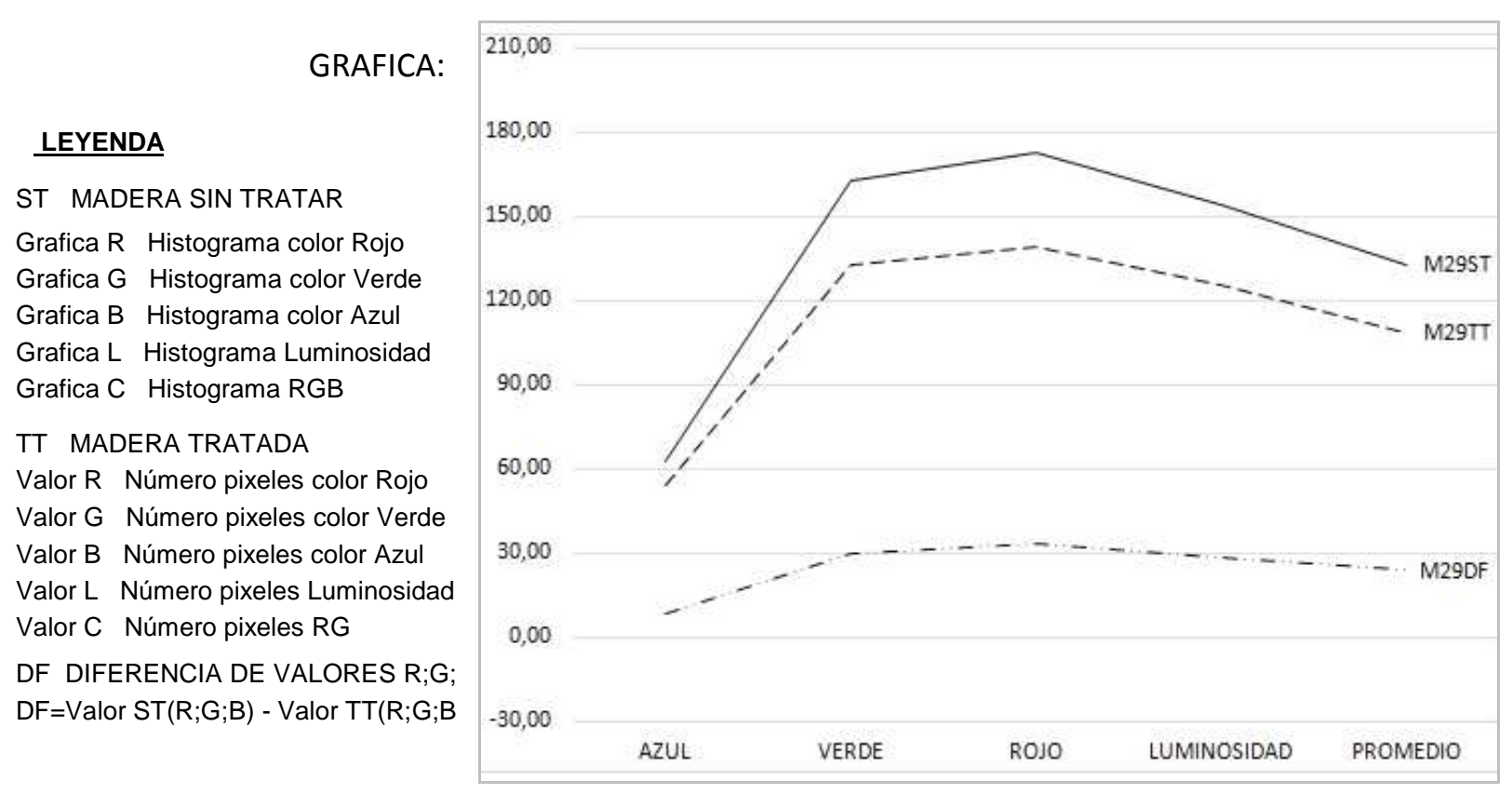

Universidad Politécnica de Madrid - Escuela Técnica Superior de Arquitectura - Departamento de Construcción y Tecnología Arquitectónica Directores: Dr. Alfonso García Santos y Dr. Antonio Rodríguez Rodríguez. Doctorando: D. Francisco Lora Toro 


\section{FICHA DE ENSAYOS DE MADERA Y ACIDOS}

\section{ACIDO A04/FL/ACIDO FLUORHÍDRICO}

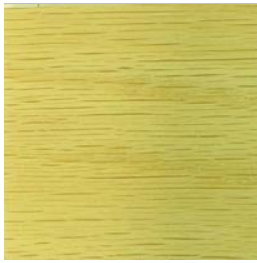

SIN TRATAR (ST): Grafica R (ST)

Valor R(ST):

195,25

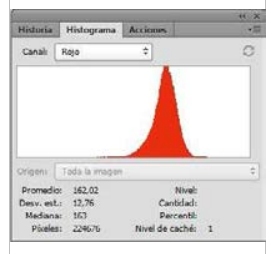

TRATADA (TT): Grafica $R(T T)$

Valor $\mathrm{R}(\mathrm{TT})$ :

162,02

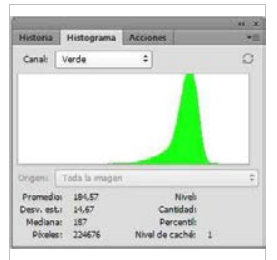

Grafica G (ST)

Valor G(ST):

184,57

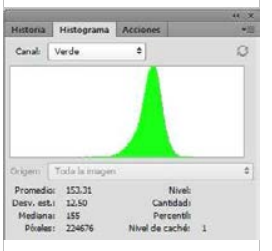

Grafica G (TT)

Valor $\mathrm{G}(\mathrm{TT})$ :

153,31
MADERA M30/RRA/ROBLE ROJO AMERICANO

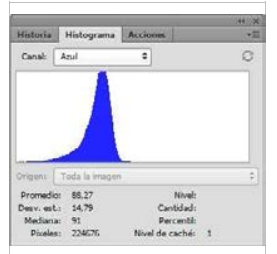

Grafica B (ST)

Valor B(ST):

88,27

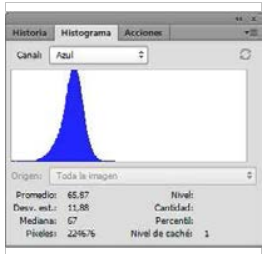

Grafica B (TT)

Valor B(TT):

65,87

Valor DF-B:

22,40 31,26

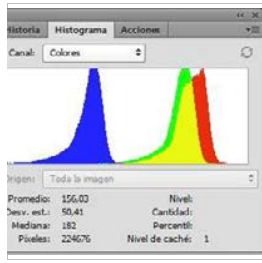

Grafica C (ST)

Valor C(ST):

156,03
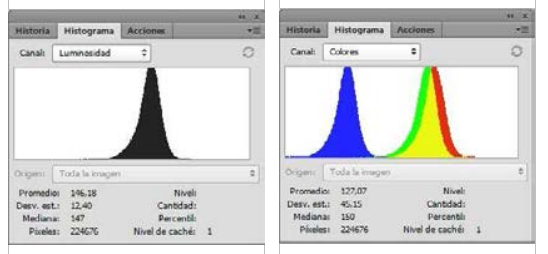

Grafica L (TT)

Grafica C (TT)

Valor L(TT):

Valor C(TT):

146,18

127,07 Valor DF-L: Valor DF-C:

DIFERENCIA (DF) Grafica R (DF): Grafica G (DF): Grafica B (DF): Grafica L (DF): Grafica C (DF): Valor DF-R: 33,23

GRAFICA:

\section{LEYENDA}

ST MADERA SIN TRATAR

Grafica R Histograma color Rojo Grafica G Histograma color Verde Grafica B Histograma color Azul Grafica L Histograma Luminosidad Grafica C Histograma RGB

TT MADERA TRATADA

Valor R Número pixeles color Rojo Valor G Número pixeles color Verde Valor B Número pixeles color Azul Valor $L$ Número pixeles Luminosidad Valor C Número pixeles RG DF DIFERENCIA DE VALORES R;G; $\mathrm{DF}=$ Valor $\mathrm{ST}(\mathrm{R} ; \mathrm{G} ; \mathrm{B})$ - Valor $\mathrm{TT}(\mathrm{R} ; \mathrm{G} ; \mathrm{B}$

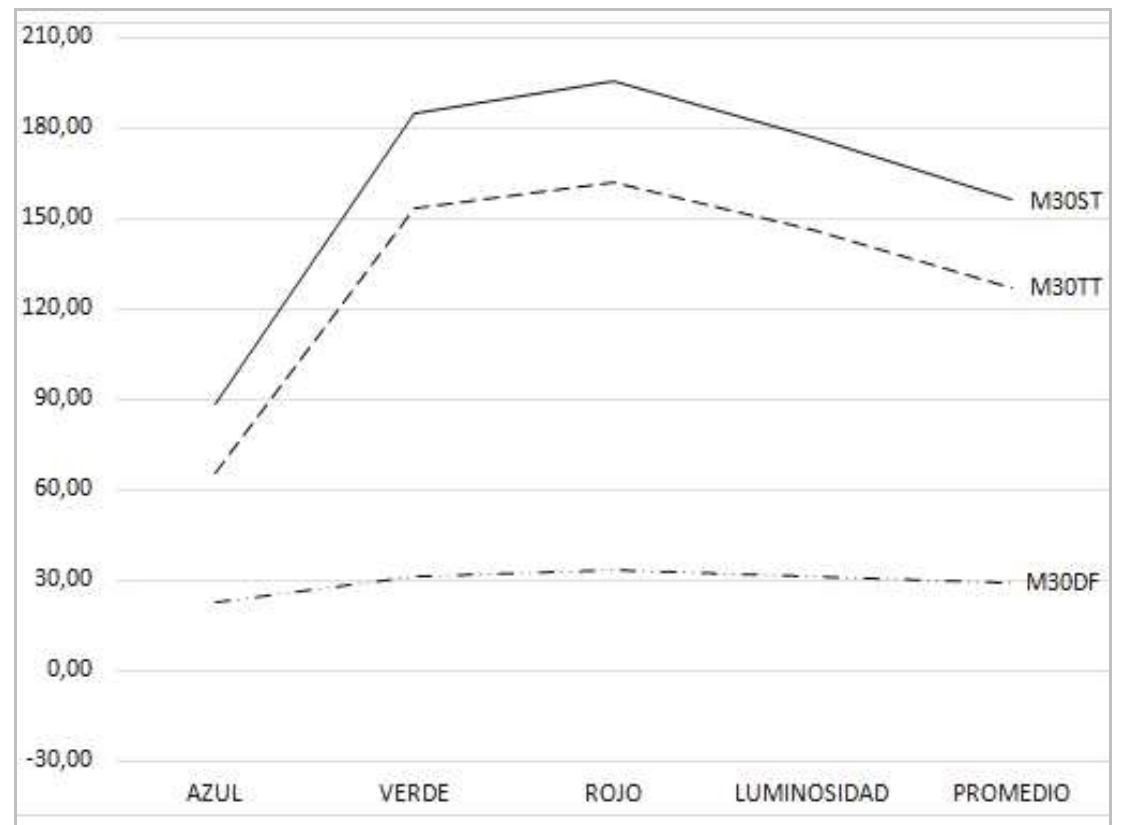

Universidad Politécnica de Madrid - Escuela Técnica Superior de Arquitectura - Departamento de Construcción y Tecnología Arquitectónica Directores: Dr. Alfonso García Santos y Dr. Antonio Rodríguez Rodríguez. Doctorando: D. Francisco Lora Toro 


\section{FICHA DE ENSAYOS DE MADERA Y ACIDOS}

\section{ACIDO A04/FL/ACIDO FLUORHÍDRICO}
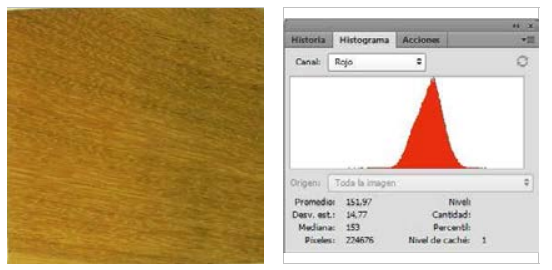

SIN TRATAR (ST): Grafica R (ST)

Valor R(ST):

151,97
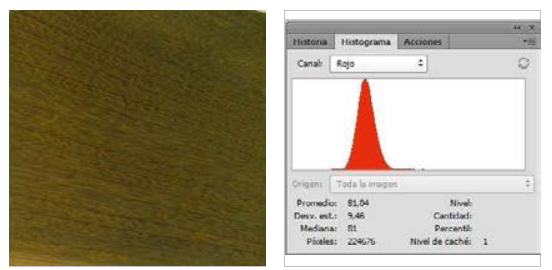

TRATADA (TT): Grafica R (TT)

Valor $\mathrm{R}(\mathrm{TT})$ :

81,04

DIFERENCIA (DF) Grafica R (DF): Valor DF-R: 70,93

GRAFICA:

\section{LEYENDA}

ST MADERA SIN TRATAR

Grafica R Histograma color Rojo

Grafica G Histograma color Verde

Grafica B Histograma color Azul

Grafica L Histograma Luminosidad

Grafica C Histograma RGB

\section{TT MADERA TRATADA}

Valor R Número pixeles color Rojo Valor G Número pixeles color Verde Valor B Número pixeles color Azul Valor L Número pixeles Luminosidad Valor C Número pixeles RG DF DIFERENCIA DE VALORES R;G; $\mathrm{DF}=$ Valor $\mathrm{ST}(\mathrm{R} ; \mathrm{G} ; \mathrm{B})$ - Valor $\mathrm{TT}(\mathrm{R} ; \mathrm{G} ; \mathrm{B}$

\section{MADERA M31/SP/SAPELLI}
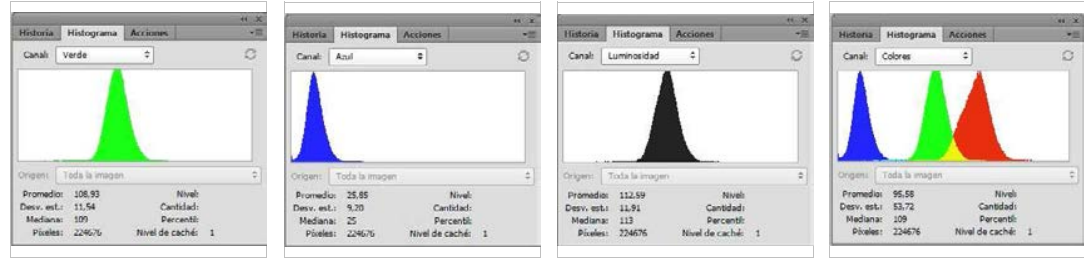

Grafica G (ST)

Grafica B (ST)

Grafica L (ST)

Grafica C (ST)

Valor $\mathrm{G}(\mathrm{ST})$ :

Valor B(ST):

Valor L(ST):

Valor C(ST):

108,93

25,85

112,59

95,58
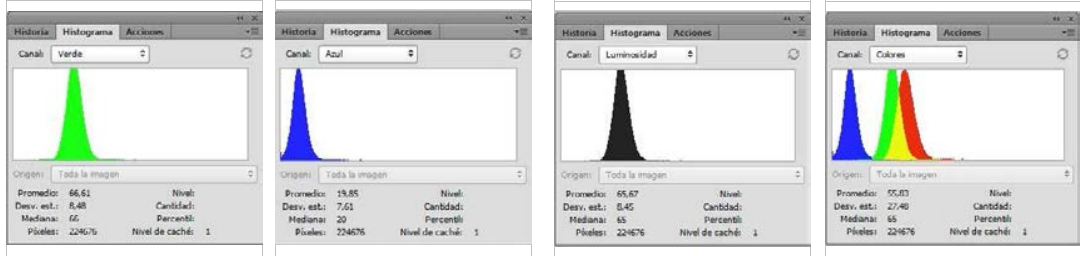

Grafica G (TT)

Grafica B (TT)

Grafica L (TT)

Grafica C (TT)

Valor $\mathrm{G}(\mathrm{TT})$ :

Valor $\mathrm{B}(\mathrm{TT})$ :

Valor L(TT):

Valor $\mathrm{C}(\mathrm{TT})$ :

66,61

19,85

65,67

55,83

Grafica G (DF): Grafica B (DF): Grafica L (DF): Grafica C (DF): Valor DF-G: Valor DF-B: Valor DF-L: Valor DF-C:

$\begin{array}{llll}42,32 & 6,00 & 46,92 & 39,75\end{array}$

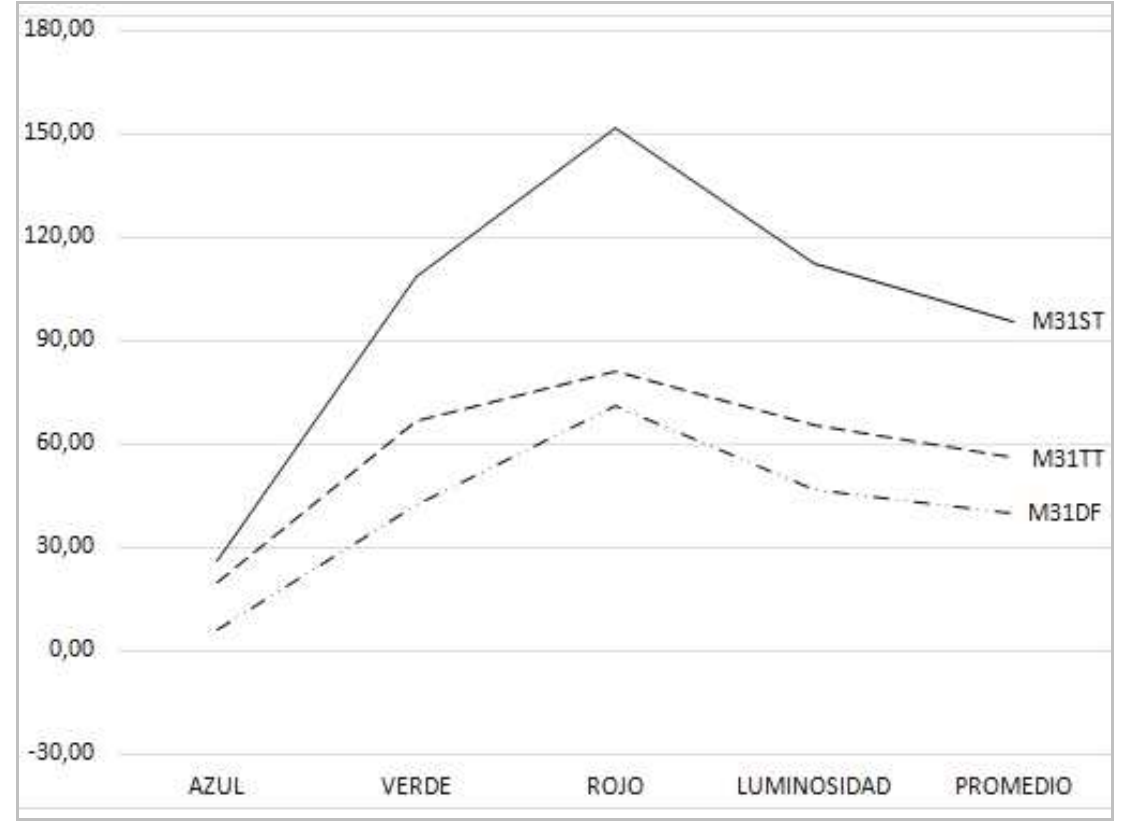

Universidad Politécnica de Madrid - Escuela Técnica Superior de Arquitectura - Departamento de Construcción y Tecnología Arquitectónica Directores: Dr. Alfonso García Santos y Dr. Antonio Rodríguez Rodríguez. Doctorando: D. Francisco Lora Toro 


\section{FICHA DE ENSAYOS DE MADERA Y ACIDOS}

\section{ACIDO A04/FL/ACIDO FLUORHÍDRICO}
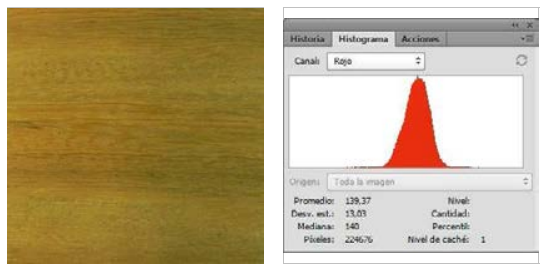

SIN TRATAR (ST): Grafica R (ST)

Valor R(ST):

139,37
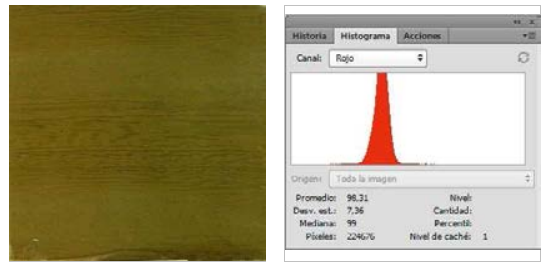

TRATADA (TT): Grafica R (TT)

Valor $\mathrm{R}(\mathrm{TT})$ :

98,31

DIFERENCIA (DF) Grafica R (DF): Valor DF-R: 41,06

GRAFICA

\section{LEYENDA}

ST MADERA SIN TRATAR

Grafica R Histograma color Rojo Grafica G Histograma color Verde Grafica B Histograma color Azul Grafica L Histograma Luminosidad Grafica C Histograma RGB

\section{TT MADERA TRATADA}

Valor R Número pixeles color Rojo Valor $G$ Número pixeles color Verde Valor B Número pixeles color Azul Valor $L$ Número pixeles Luminosidad Valor C Número pixeles RG DF DIFERENCIA DE VALORES R;G; $\mathrm{DF}=$ Valor $\mathrm{ST}(\mathrm{R} ; \mathrm{G} ; \mathrm{B})$ - Valor $\mathrm{TT}(\mathrm{R} ; \mathrm{G} ; \mathrm{B}$

\section{MADERA M32/TL/TALI}
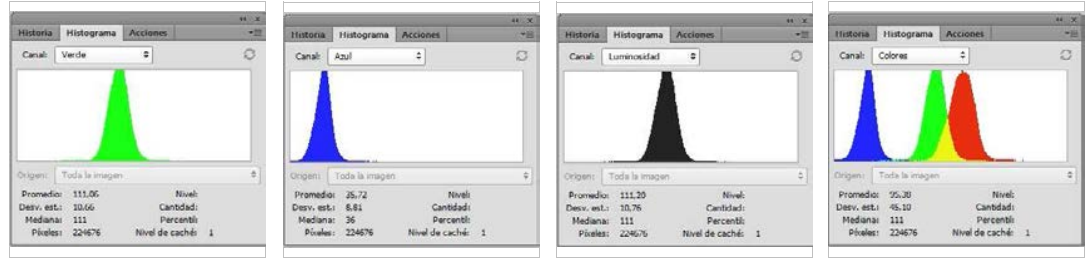

\section{Grafica G (ST)}

Grafica B (ST)

Grafica L (ST)

Grafica C (ST)

Valor $\mathrm{G}(\mathrm{ST})$ :

Valor B(ST):

Valor L(ST):

Valor C(ST):

35,72

111,20

95,38
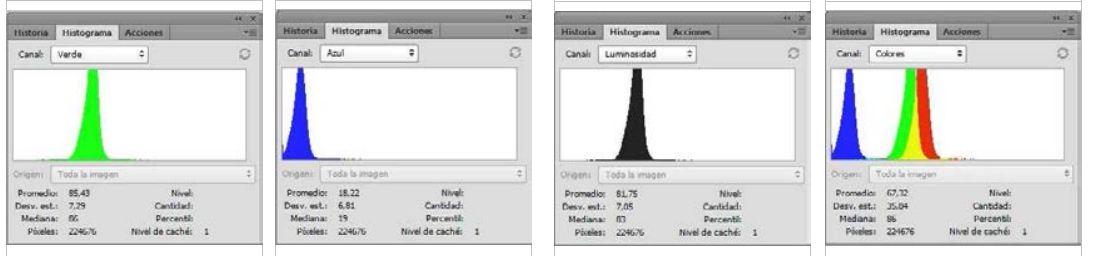

Grafica G (TT) Grafica B (TT)

Grafica L (TT)

Grafica C (TT)

Valor $\mathrm{G}(\mathrm{TT})$ :

Valor $\mathrm{B}(\mathrm{TT})$ :

Valor L(TT):

Valor C(TT):

85,43

18,22

81,75

67,32

Grafica G (DF): Grafica B (DF): Grafica L (DF): Grafica C (DF): Valor DF-G: Valor DF-B: Valor DF-L: Valor DF-C: 25,63 17,50 29,45 28,06

Universidad Politécnica de Madrid - Escuela Técnica Superior de Arquitectura - Departamento de Construcción y Tecnología Arquitectónica Directores: Dr. Alfonso García Santos y Dr. Antonio Rodríguez Rodríguez. Doctorando: D. Francisco Lora Toro 


\section{FICHA DE ENSAYOS DE MADERA Y ACIDOS}

ACIDO A04/FL/ACIDO FLUORHÍDRICO

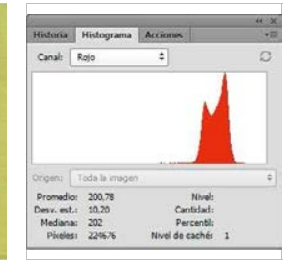

SIN TRATAR (ST): Grafica R (ST)

Valor R(ST):

200,78

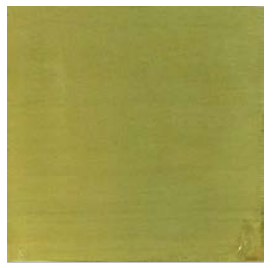

TRATADA (TT): Grafica R (TT)

Valor $\mathrm{R}(\mathrm{TT})$ :

145,87

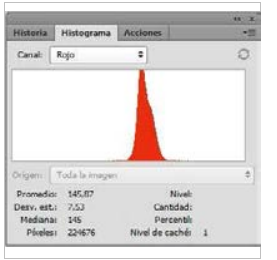

DIFERENCIA (DF) Grafica R (DF):

Valor DF-R:

54,91

GRAFICA:

\section{LEYENDA}

ST MADERA SIN TRATAR

Grafica R Histograma color Rojo

Grafica G Histograma color Verde

Grafica B Histograma color Azul

Grafica L Histograma Luminosidad

Grafica C Histograma RGB

TT MADERA TRATADA

Valor R Número pixeles color Rojo

Valor $\mathrm{G}$ Número pixeles color Verde

Valor B Número pixeles color Azul

Valor $L$ Número pixeles Luminosidad

Valor $C$ Número pixeles $R G$

DF DIFERENCIA DE VALORES R;G;

$\mathrm{DF}=$ Valor $\mathrm{ST}(\mathrm{R} ; \mathrm{G} ; \mathrm{B})$ - Valor TT(R;G;B
MADERA M33/TA/TILO AMERICANO

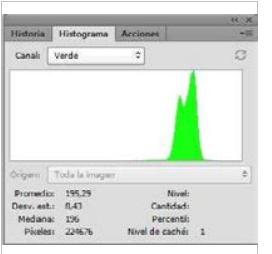

Grafica G (ST)

Valor $\mathrm{G}(\mathrm{ST})$ :

195,29
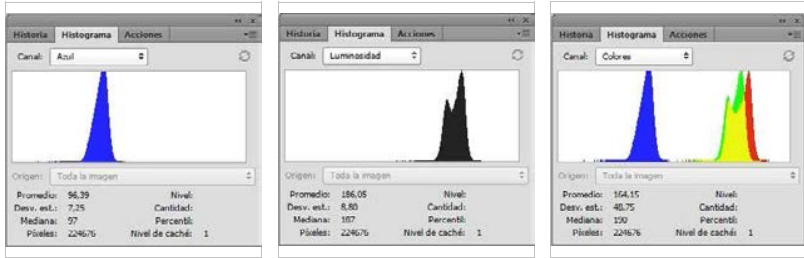

Grafica B (ST)

Grafica L (ST)

Grafica C (ST)

Valor $\mathrm{B}(\mathrm{ST})$ :

Valor L(ST):

Valor C(ST):

96,39

186,05

164,15
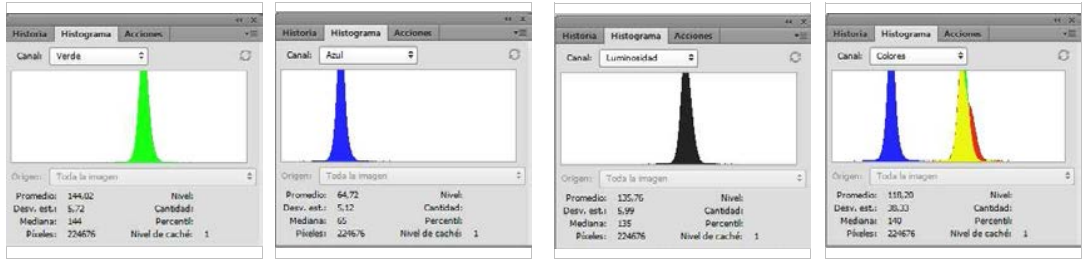

\section{Grafica G (TT)}

Grafica B (TT)

Grafica L (TT)

Grafica C (TT)

Valor $\mathrm{G}(\mathrm{TT})$ :

Valor $\mathrm{B}(\mathrm{TT})$ :

Valor L(TT):

Valor C(TT):

144,02

64,72

135,76

118,20

Grafica G (DF): Grafica B (DF): Grafica L (DF): Grafica C (DF): Valor DF-G: Valor DF-B: Valor DF-L: Valor DF-C:

$51,27 \quad 31,67 \quad 50,29 \quad 45,95$

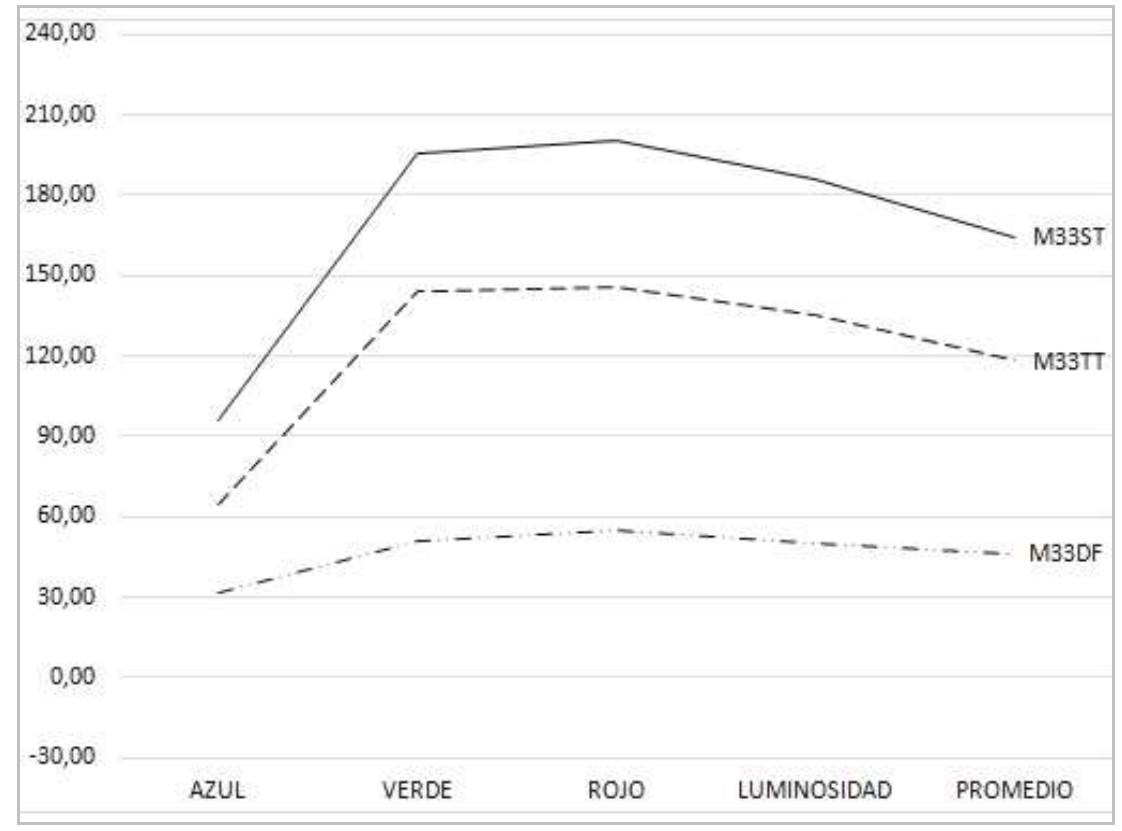

Universidad Politécnica de Madrid - Escuela Técnica Superior de Arquitectura - Departamento de Construcción y Tecnología Arquitectónica Directores: Dr. Alfonso García Santos y Dr. Antonio Rodríguez Rodríguez. Doctorando: D. Francisco Lora Toro 


\section{FICHA DE ENSAYOS DE MADERA Y ACIDOS}

ACIDO A04/FL/ACIDO FLUORHÍDRICO

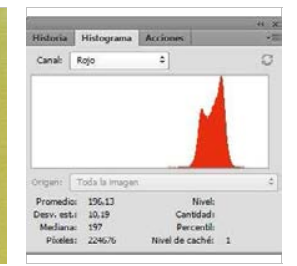

SIN TRATAR (ST): Grafica R (ST)

Valor R(ST):

196,13

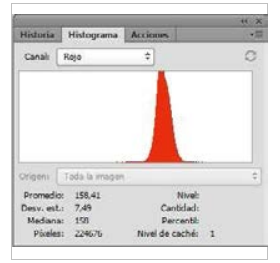

TRATADA (TT): Grafica R (TT)

Valor $\mathrm{R}(\mathrm{TT})$ :

158,41

DIFERENCIA (DF) Grafica R (DF):

Valor DF-R:

37,72

\section{GRAFICA:}

\section{LEYENDA}

ST MADERA SIN TRATAR

Grafica R Histograma color Rojo

Grafica G Histograma color Verde

Grafica B Histograma color Azul

Grafica L Histograma Luminosidad

Grafica C Histograma RGB

\section{TT MADERA TRATADA}

Valor R Número pixeles color Rojo

Valor $\mathrm{G}$ Número pixeles color Verde

Valor B Número pixeles color Azul

Valor $L$ Número pixeles Luminosidad

Valor $C$ Número pixeles $R G$

DF DIFERENCIA DE VALORES R;G; $\mathrm{DF}=$ Valor $\mathrm{ST}(\mathrm{R} ; \mathrm{G} ; \mathrm{B})$ - Valor TT(R;G;B

\section{MADERA M34/TE/TILO EUROPEO}
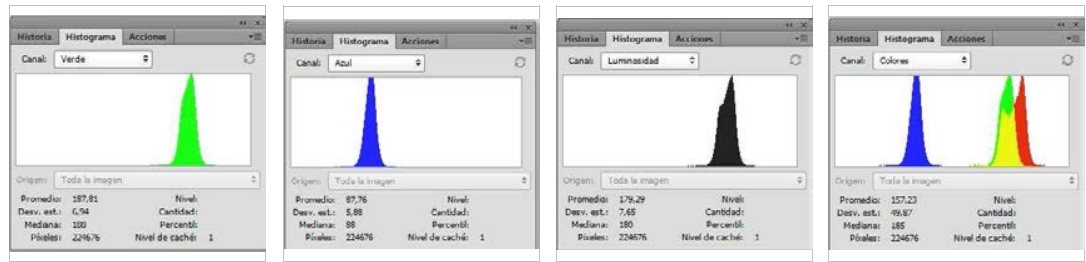

Grafica G (ST)

Grafica B (ST)

Grafica L (ST)

Grafica C (ST)

Valor $\mathrm{G}(\mathrm{ST})$ :

Valor B(ST):

Valor L(ST):

Valor C(ST):

187,81

87,76

179,29

157,23
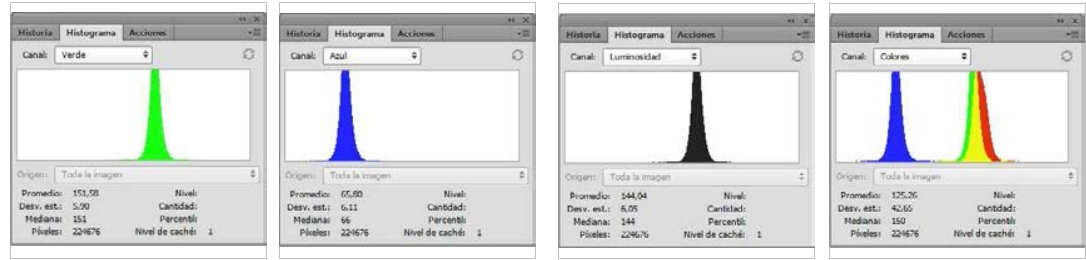

\section{Grafica G (TT)}

Grafica B (TT)

Grafica L (TT)

Grafica C (TT)

Valor G(TT):

Valor $\mathrm{B}(\mathrm{TT})$ :

Valor L(TT):

Valor C(TT):

151,58

65,80

144,04

125,26

Grafica G (DF): Grafica B (DF): Grafica L (DF):

Grafica C (DF):

Valor DF-G:

Valor DF-B:

Valor DF-L:

Valor DF-C:

36,23

21,96

35,25

31,97

Universidad Politécnica de Madrid - Escuela Técnica Superior de Arquitectura - Departamento de Construcción y Tecnología Arquitectónica Directores: Dr. Alfonso García Santos y Dr. Antonio Rodríguez Rodríguez. Doctorando: D. Francisco Lora Toro 


\section{A05 / ÁCIDO FÓRMICO}

\section{FICHA DE ENSAYOS DE MADERA Y ACIDOS}

\section{ACIDO A05/FM/ACIDO FÓRMICO}
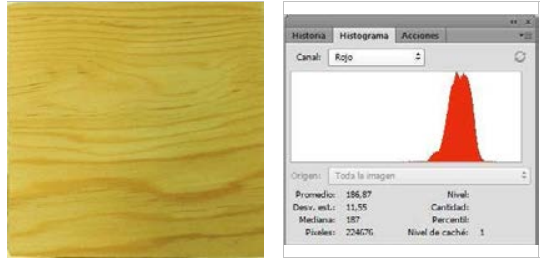

SIN TRATAR (ST): Grafica R (ST)

Valor R(ST):

186,87

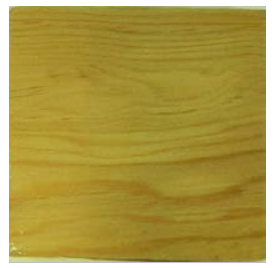

TRATADA (TT):

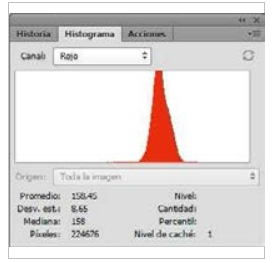

Grafica R (TT)

Valor $\mathrm{R}(\mathrm{TT})$ :

158,45

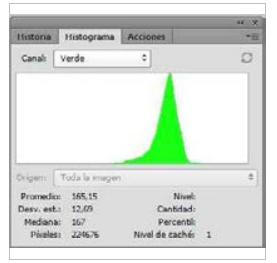

Grafica G (ST)

Valor $\mathrm{G}(\mathrm{ST})$ :

165,15

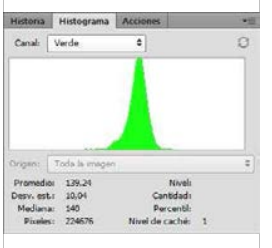

Grafica G (TT)

Valor $\mathrm{G}(\mathrm{TT})$ :

139,24

\section{MADERA M01/AD/ABETO DOUGLAS}

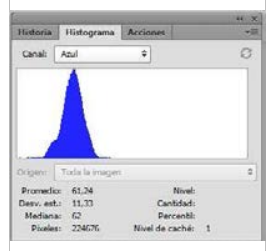

Grafica B (ST)

Valor B(ST):

61,24

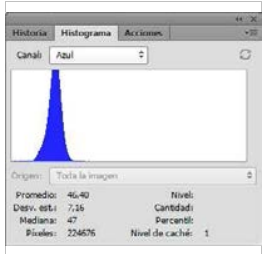

Grafica B (TT)

Valor $\mathrm{B}(\mathrm{TT})$ :

46,40

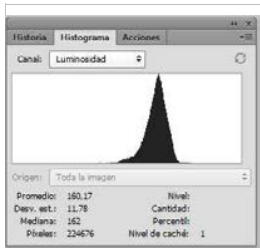

Grafica L (ST)

Valor L(ST):

160,17

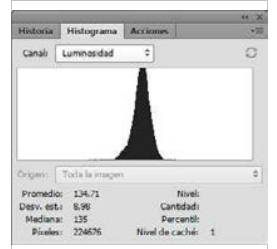

Grafica L (TT)

Valor L(TT):

134,71

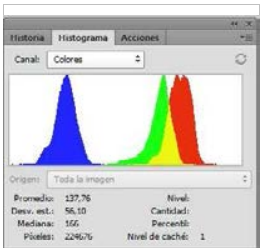

Grafica C (ST)

Valor C(ST):

137,76
DIFERENCIA (DF) Grafica R (DF): Valor DF-R: 28,42
Grafica G (DF): Grafica B (DF): Valor DF-G: 25,91
Valor DF-B:

14,84

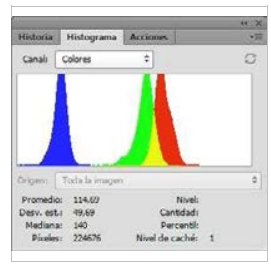

Grafica C (TT)

Valor C(TT):

114,69
GRAFICA:

\section{LEYENDA}

ST MADERA SIN TRATAR

Grafica R Histograma color Rojo

Grafica G Histograma color Verde

Grafica B Histograma color Azul

Grafica L Histograma Luminosidad

Grafica C Histograma RGB

\section{TT MADERA TRATADA}

Valor R Número pixeles color Rojo

Valor $\mathrm{G}$ Número pixeles color Verde Valor B Número pixeles color Azul Valor L Número pixeles Luminosidad Valor C Número pixeles RG

DF DIFERENCIA DE VALORES R;G; $\mathrm{DF}=$ Valor $\mathrm{ST}(\mathrm{R} ; \mathrm{G} ; \mathrm{B})$ - Valor TT(R;G;B

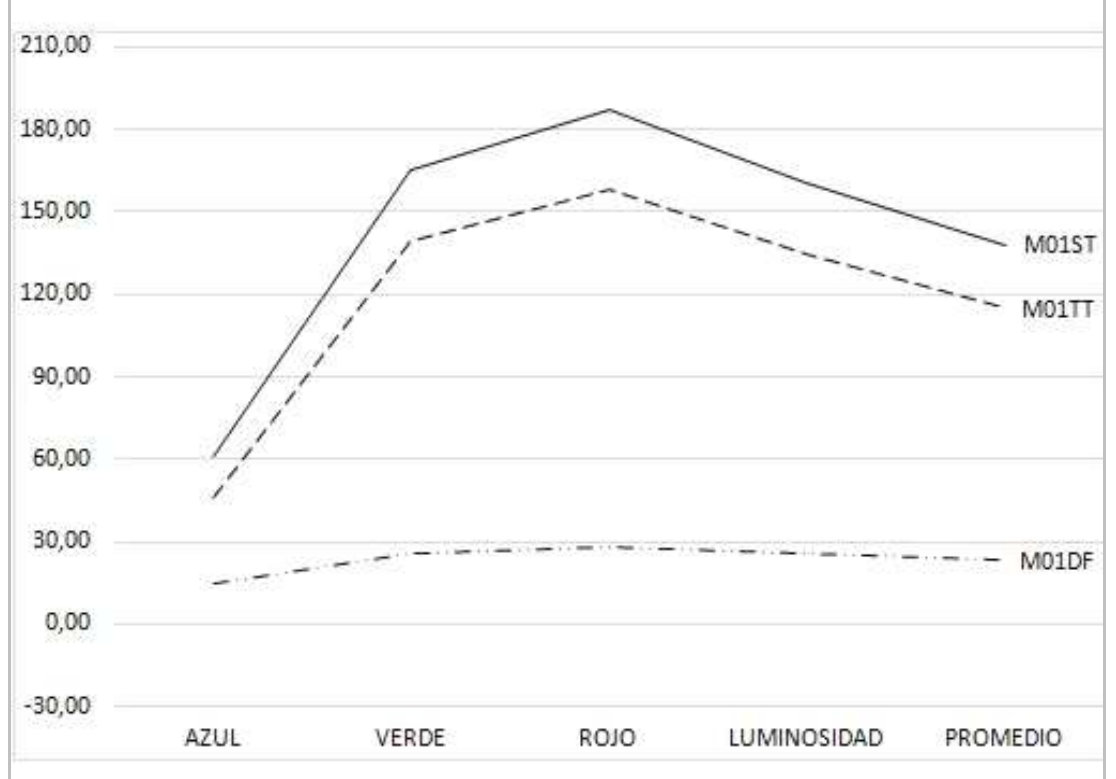

Universidad Politécnica de Madrid - Escuela Técnica Superior de Arquitectura - Departamento de Construcción y Tecnología Arquitectónica Directores: Dr. Alfonso García Santos y Dr. Antonio Rodríguez Rodríguez. Doctorando: D. Francisco Lora Toro 


\section{FICHA DE ENSAYOS DE MADERA Y ACIDOS}

\section{ACIDO A05/FM/ACIDO FÓRMICO}

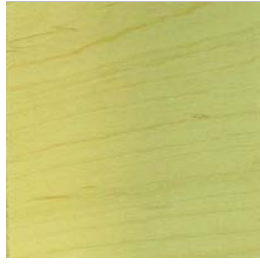

SIN TRATAR (ST): Grafica R (ST)

Valor R(ST):

186,73

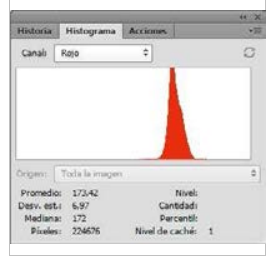

TRATADA (TT): Grafica $R(T T)$

Valor $\mathrm{R}(\mathrm{TT})$ :

173,42

DIFERENCIA (DF) Grafica R (DF): Valor DF-R: 13,31

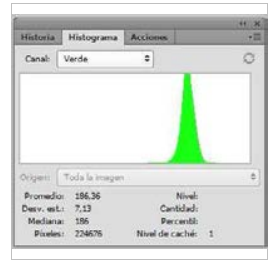

Grafica G (ST)

Valor G(ST):

186,36

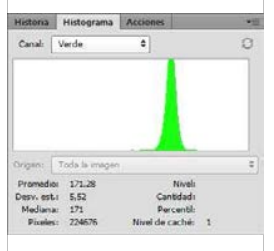

Grafica G (TT)

Valor $\mathrm{G}(\mathrm{TT})$ :

171,28
MADERA M02/ABA/ARCE BLANDO AMERICANO

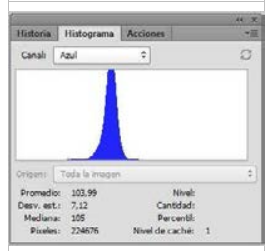

Grafica B (ST)

Valor B(ST):

103,99

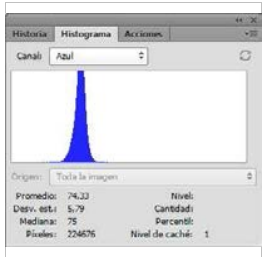

Grafica B (TT)

Valor $\mathrm{B}(\mathrm{TT})$ :

74,33

Grafica G (DF): Grafica B (DF):

Grafica L (DF):

Grafica C (DF):

Valor DF-G:

Valor DF-B:

Valor DF-L:

Valor DF-C:

15,08

29,66

16,10

19,35

GRAFICA:

\section{LEYENDA}

ST MADERA SIN TRATAR

Grafica R Histograma color Rojo

Grafica G Histograma color Verde

Grafica B Histograma color Azul

Grafica L Histograma Luminosidad

Grafica C Histograma RGB

\section{TT MADERA TRATADA}

Valor R Número pixeles color Rojo

Valor G Número pixeles color Verde

Valor B Número pixeles color Azul

Valor $L$ Número pixeles Luminosidad

Valor C Número pixeles RG

DF DIFERENCIA DE VALORES R;G; $\mathrm{DF}=$ Valor $\mathrm{ST}(\mathrm{R} ; \mathrm{G} ; \mathrm{B})$ - Valor $\mathrm{TT}(\mathrm{R} ; \mathrm{G} ; \mathrm{B}$

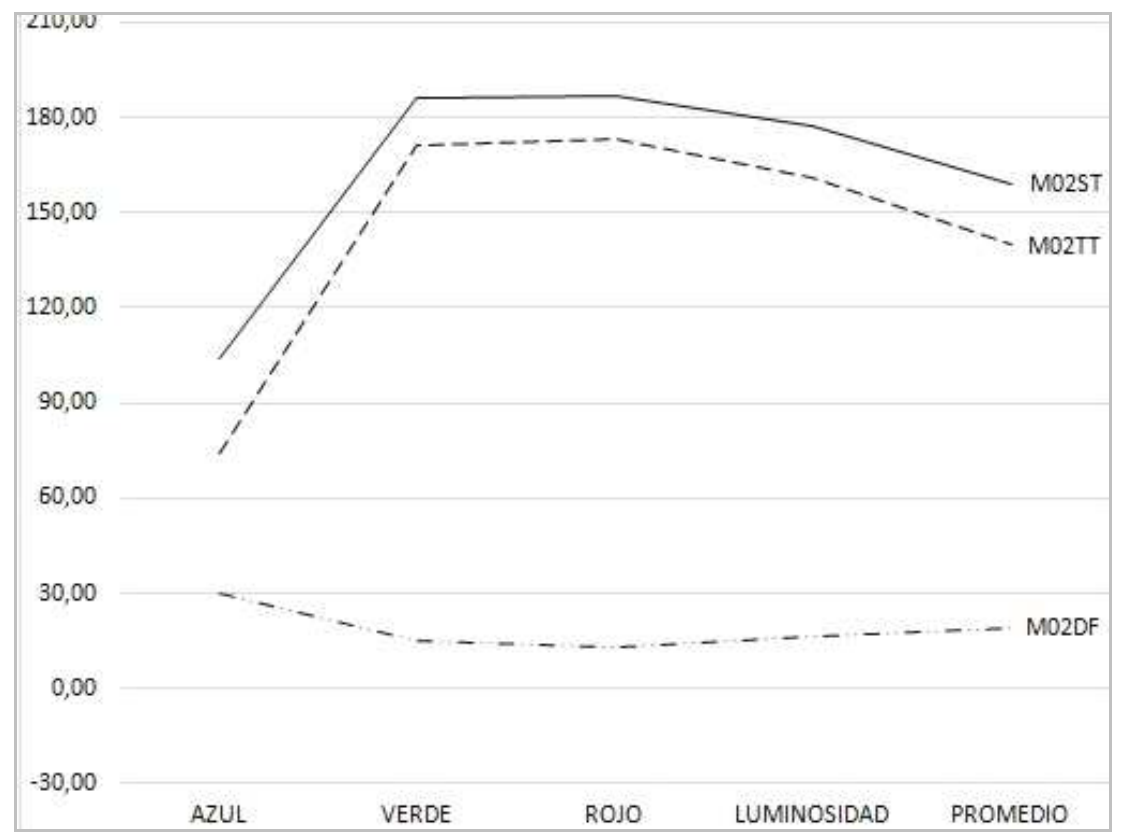

Universidad Politécnica de Madrid - Escuela Técnica Superior de Arquitectura - Departamento de Construcción y Tecnología Arquitectónica Directores: Dr. Alfonso García Santos y Dr. Antonio Rodríguez Rodríguez. Doctorando: D. Francisco Lora Toro 


\section{FICHA DE ENSAYOS DE MADERA Y ACIDOS}

\section{ACIDO A05/FM/ACIDO FÓRMICO}

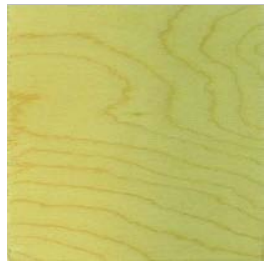

SIN TRATAR (ST): Grafica R (ST)

Valor R(ST):

185,63

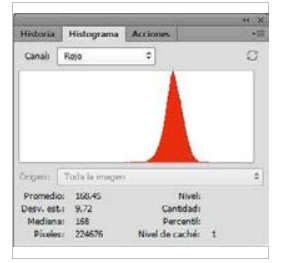

TRATADA (TT): Grafica R (TT)

Valor $\mathrm{R}(\mathrm{TT})$ :

168,45

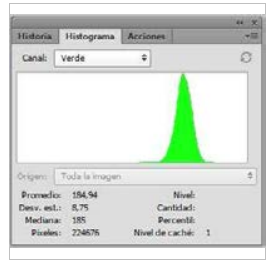

Grafica G (ST)

Valor G(ST):

184,94

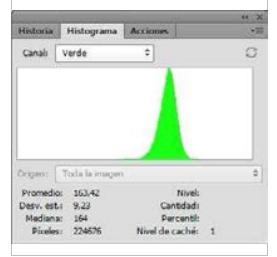

Grafica G (TT)

Valor $\mathrm{G}(\mathrm{TT})$ :

163,42
MADERA MO3/ADA/ARCE DURO AMERICANO

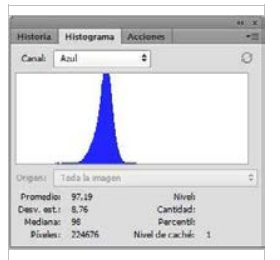

Grafica B (ST)

Valor B(ST):

97,19

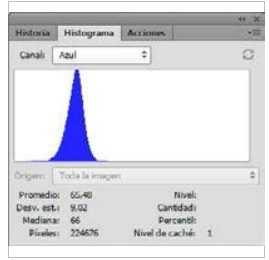

Grafica B (TT)

Valor $\mathrm{B}(\mathrm{TT})$ :

65,48

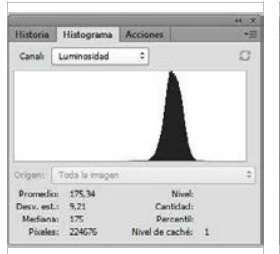

Grafica L (ST)

Valor L(ST):

175,34

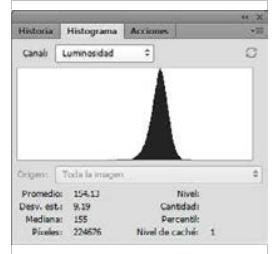

Grafica L (TT)

Valor L(TT):

154,13
Grafica C (TT)

Valor C(TT):

132,45

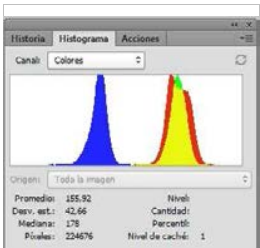

Grafica C (ST)

Valor C(ST):

155,92

DIFERENCIA (DF) Grafica R (DF): Valor DF-R:

Grafica G (DF): Grafica B (DF):

Grafica L (DF):

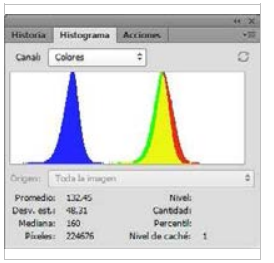

17,18

Valor DF-G:

Valor DF-B:

Valor DF-L:

21,52

31,71

21,21

Grafica C (DF):

Valor DF-C:

23,47

\section{LEYENDA}

ST MADERA SIN TRATAR

Grafica R Histograma color Rojo

Grafica G Histograma color Verde

Grafica B Histograma color Azul

Grafica L Histograma Luminosidad

Grafica C Histograma RGB

\section{TT MADERA TRATADA}

Valor $R$ Número pixeles color Rojo

Valor $\mathrm{G}$ Número pixeles color Verde

Valor B Número pixeles color Azul

Valor $L$ Número pixeles Luminosidad

Valor C Número pixeles RG

DF DIFERENCIA DE VALORES R;G; $\mathrm{DF}=$ Valor $\mathrm{ST}(\mathrm{R} ; \mathrm{G} ; \mathrm{B})$ - Valor $\mathrm{TT}(\mathrm{R} ; \mathrm{G} ; \mathrm{B}$

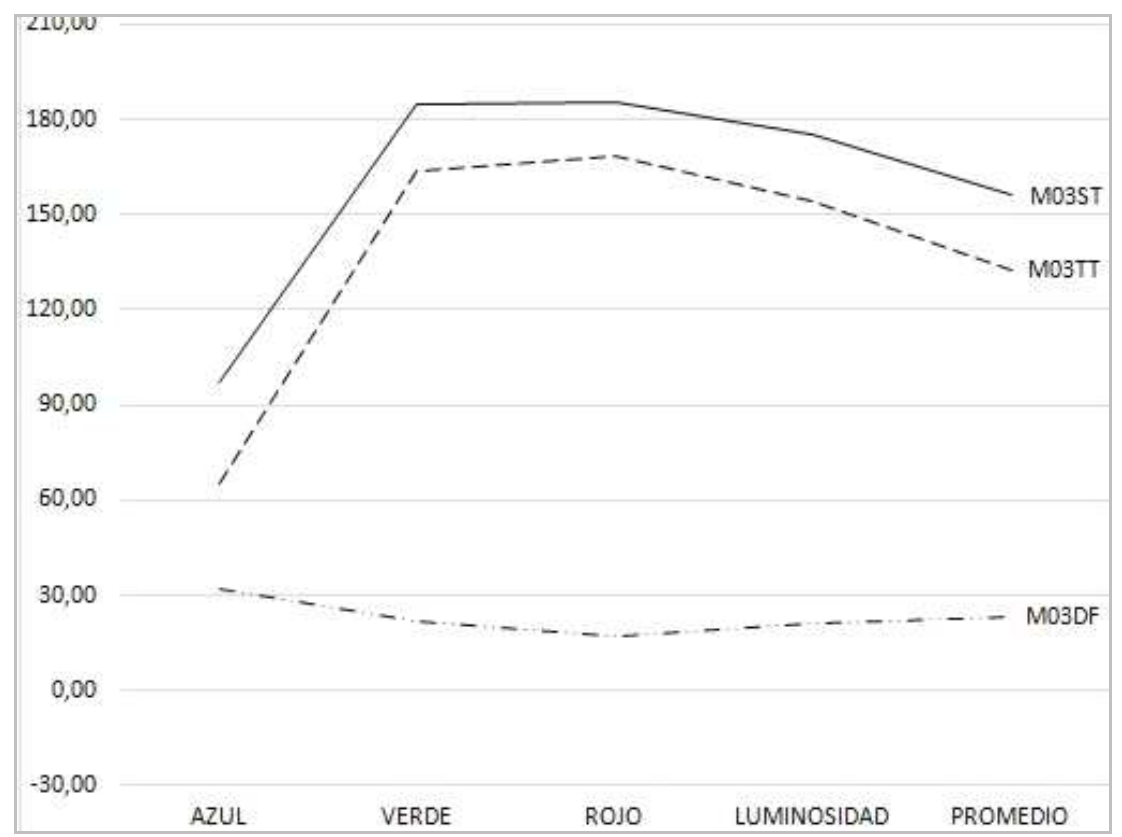

Universidad Politécnica de Madrid - Escuela Técnica Superior de Arquitectura - Departamento de Construcción y Tecnología Arquitectónica Directores: Dr. Alfonso García Santos y Dr. Antonio Rodríguez Rodríguez. Doctorando: D. Francisco Lora Toro 


\section{FICHA DE ENSAYOS DE MADERA Y ACIDOS}

\section{ACIDO A05/FM/ACIDO FÓRMICO}

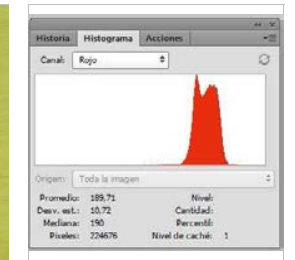

SIN TRATAR (ST): Grafica R (ST)

Valor R(ST):

189,71

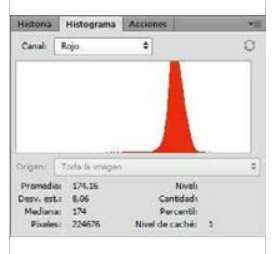

TRATADA (TT): Grafica R (TT)

Valor $\mathrm{R}(\mathrm{TT})$ :

174,16

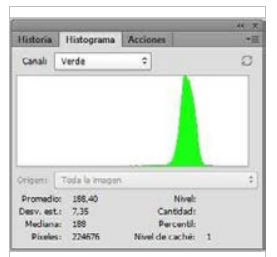

Grafica G (ST)

Valor $\mathrm{G}(\mathrm{ST})$ :

188,40

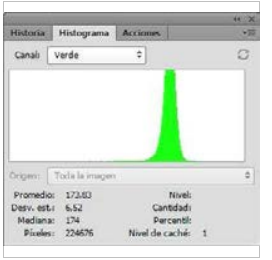

Grafica G (TT)

Valor $\mathrm{G}(\mathrm{TT})$ :

173,83

\section{MADERA M04/AS/AYOUS}

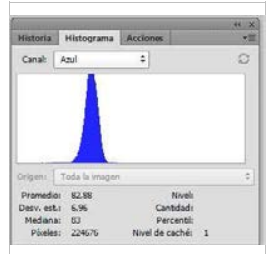

Grafica B (ST)

Valor B(ST):

82,88

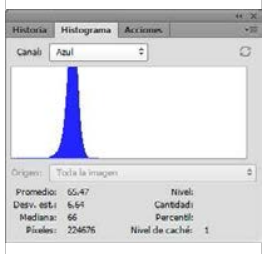

Grafica B (TT)

Valor $\mathrm{B}(\mathrm{TT})$ :

65,47

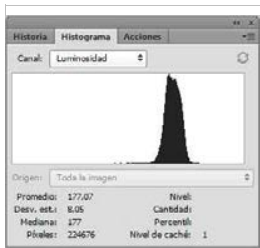

Grafica L (ST)

Valor L(ST):

177,07

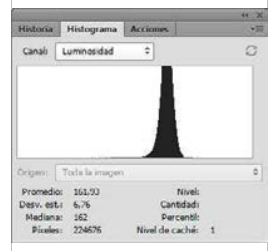

Grafica L (TT)

Valor L(TT):

161,93

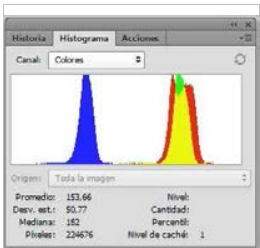

Grafica C (ST)

Valor C(ST):

153,66

DIFERENCIA (DF) Grafica R (DF): Valor DF-R:

Grafica G (DF): Grafica B (DF):

Grafica L (DF):

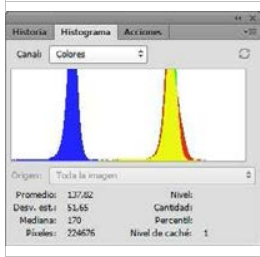

15,55

Valor DF-G:

Valor DF-B:

Valor DF-L:

Grafica C (TT)

Valor C(TT):

137,82

14,57

17,41

15,14

\section{ST MADERA SIN TRATAR}

Grafica R Histograma color Rojo Grafica G Histograma color Verde Grafica B Histograma color Azul Grafica L Histograma Luminosidad Grafica C Histograma RGB

\section{TT MADERA TRATADA}

Valor $R$ Número pixeles color Rojo Valor $\mathrm{G}$ Número pixeles color Verde Valor B Número pixeles color Azul Valor $L$ Número pixeles Luminosidad Valor C Número pixeles RG DF DIFERENCIA DE VALORES R;G; $\mathrm{DF}=$ Valor $\mathrm{ST}(\mathrm{R} ; \mathrm{G} ; \mathrm{B})$ - Valor TT(R;G;B

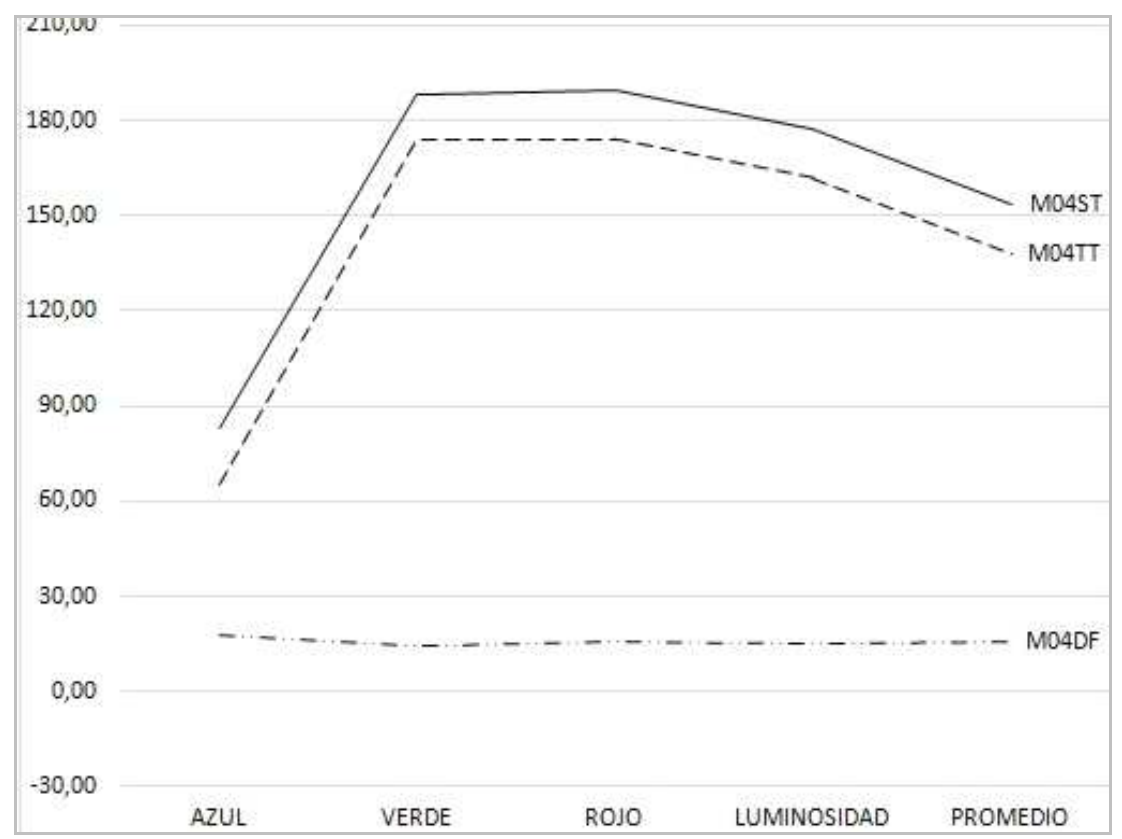

Universidad Politécnica de Madrid - Escuela Técnica Superior de Arquitectura - Departamento de Construcción y Tecnología Arquitectónica Directores: Dr. Alfonso García Santos y Dr. Antonio Rodríguez Rodríguez. Doctorando: D. Francisco Lora Toro 


\section{FICHA DE ENSAYOS DE MADERA Y ACIDOS}

\section{ACIDO A05/FM/ACIDO FÓRMICO}
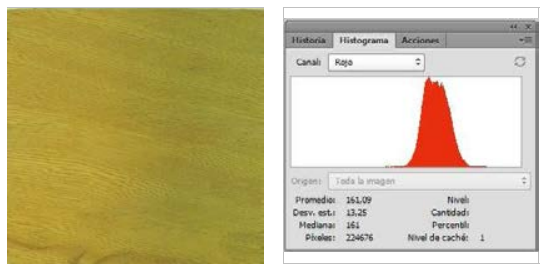

SIN TRATAR (ST): Grafica R (ST)

Valor R(ST):

161,09

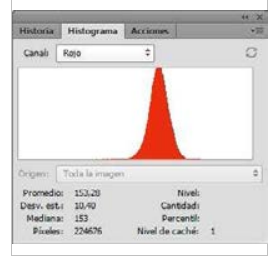

TRATADA (TT): Grafica R (TT)

Valor R(TT):

153,28

DIFERENCIA (DF) Grafica R (DF): Valor DF-R:

7,81

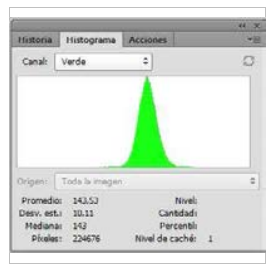

Grafica G (ST)

Valor $\mathrm{G}(\mathrm{ST})$ :

143,53

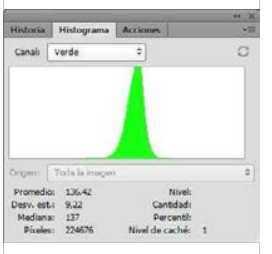

Grafica G (TT)

Valor $\mathrm{G}(\mathrm{TT})$ :

136,42

\section{MADERA M05/BS/BOSSÉ}

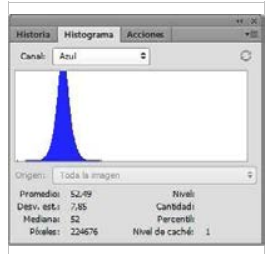

Grafica B (ST)

Valor B(ST):

52,49

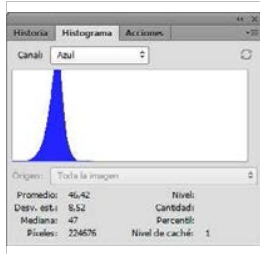

Grafica B (TT)

Valor $\mathrm{B}(\mathrm{TT})$ :

46,42

Grafica G (DF): Grafica B (DF):

Valor DF-G:

Valor DF-B:

6,07

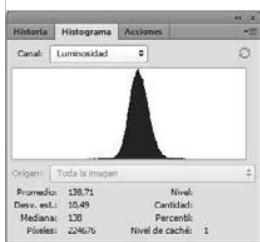

Grafica L (ST)

Valor L(ST):

138,71

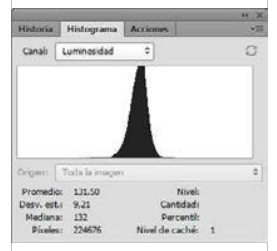

Grafica L (TT)

Valor L(TT):

131,50

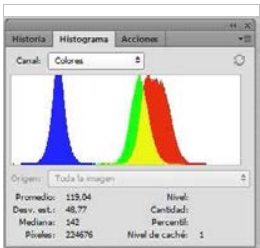

Grafica C (ST)

Valor C(ST):

119,04

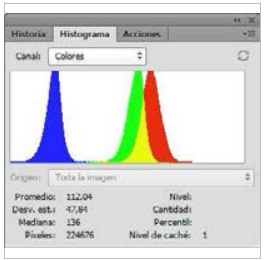

Grafica C (TT)

Valor C(TT):

112,04

$\begin{array}{llll}7,11 & 6,07 & 7,21 & 7,00\end{array}$

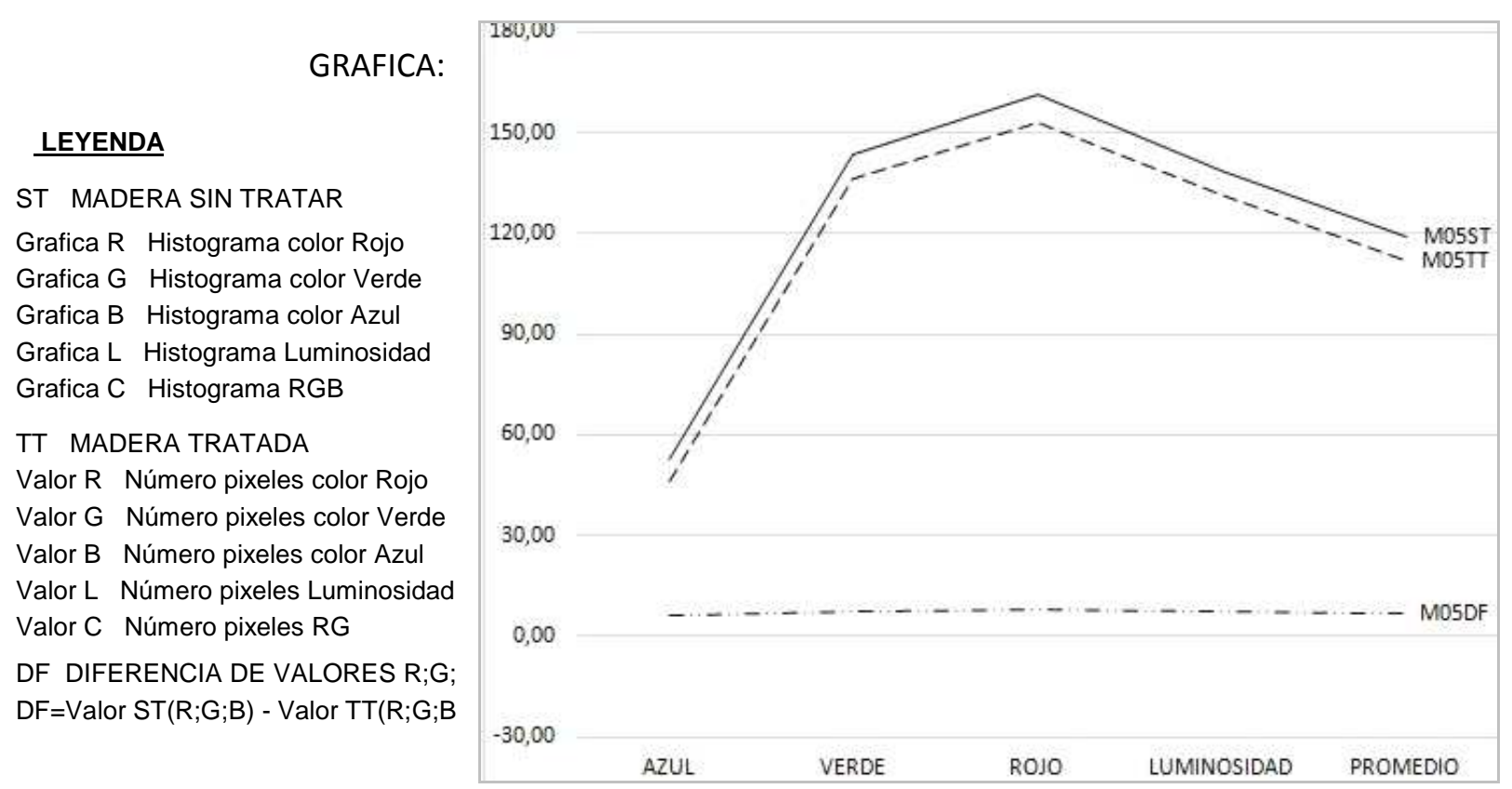

Universidad Politécnica de Madrid - Escuela Técnica Superior de Arquitectura - Departamento de Construcción y Tecnología Arquitectónica Directores: Dr. Alfonso García Santos y Dr. Antonio Rodríguez Rodríguez. Doctorando: D. Francisco Lora Toro 


\section{FICHA DE ENSAYOS DE MADERA Y ACIDOS}

\section{ACIDO A05/FM/ACIDO FÓRMICO}
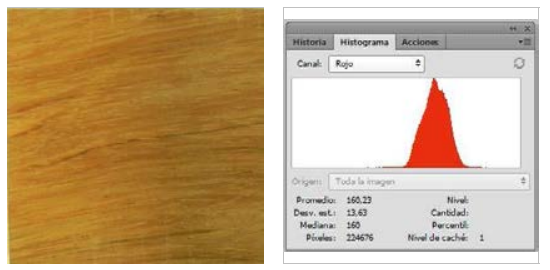

SIN TRATAR (ST): Grafica R (ST)

Valor R(ST):

160,23

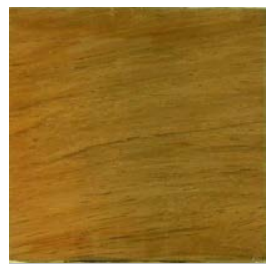

TRATADA (TT):

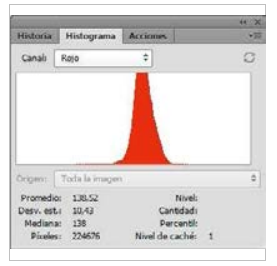

Grafica R (TT)

Valor $\mathrm{R}(\mathrm{TT})$ :

138,52

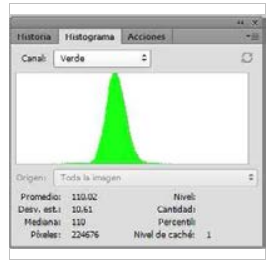

Grafica G (ST)

Valor $\mathrm{G}(\mathrm{ST})$ :

110,02

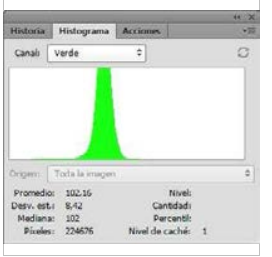

Grafica G (TT)

Valor $\mathrm{G}(\mathrm{TT})$ :

102,16

\section{MADERA M06/BG/BUBINGA}

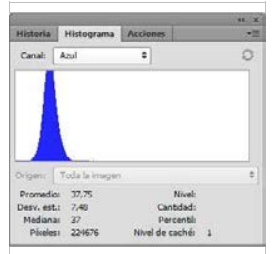

Grafica B (ST)

Valor $\mathrm{B}(\mathrm{ST})$ :

37,75

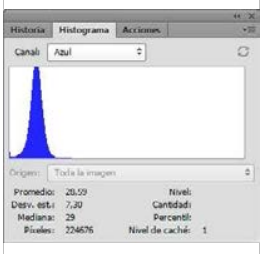

Grafica B (TT)

Valor $\mathrm{B}(\mathrm{TT})$ :

28,59

Grafica G (DF): Grafica B (DF):

Valor DF-G:

Valor DF-B:

9,16 7,86

Grafica L (DF): Valor DF-L: 12,15

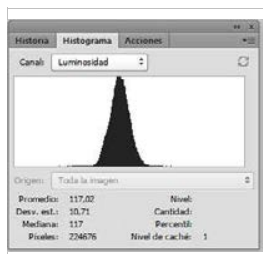

Grafica L (ST)

Valor L(ST):

117,02

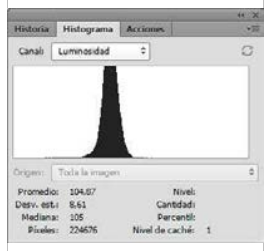

Grafica L (TT)

Valor L(TT):

104,87

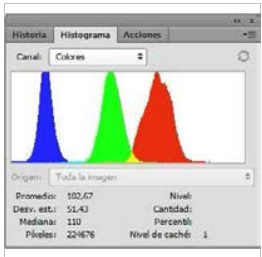

Grafica C (ST)

Valor C(ST):

102,67

DIFERENCIA (DF) Grafica R (DF): Valor DF-R:

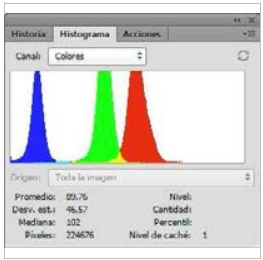
21,71

Grafica C (TT) Valor $\mathrm{C}(\mathrm{TT})$ : 89,76

Grafica C (DF): Valor DF-C: 12,91 GRAFICA:

\section{LEYENDA}

ST MADERA SIN TRATAR

Grafica R Histograma color Rojo Grafica G Histograma color Verde Grafica B Histograma color Azul Grafica L Histograma Luminosidad Grafica C Histograma RGB

\section{TT MADERA TRATADA}

Valor $\mathrm{R}$ Número pixeles color Rojo Valor $\mathrm{G}$ Número pixeles color Verde Valor B Número pixeles color Azul Valor $\mathrm{L}$ Número pixeles Luminosidad Valor C Número pixeles RG DF DIFERENCIA DE VALORES R;G; $\mathrm{DF}=$ Valor $\mathrm{ST}(\mathrm{R} ; \mathrm{G} ; \mathrm{B})$ - Valor TT(R;G;B

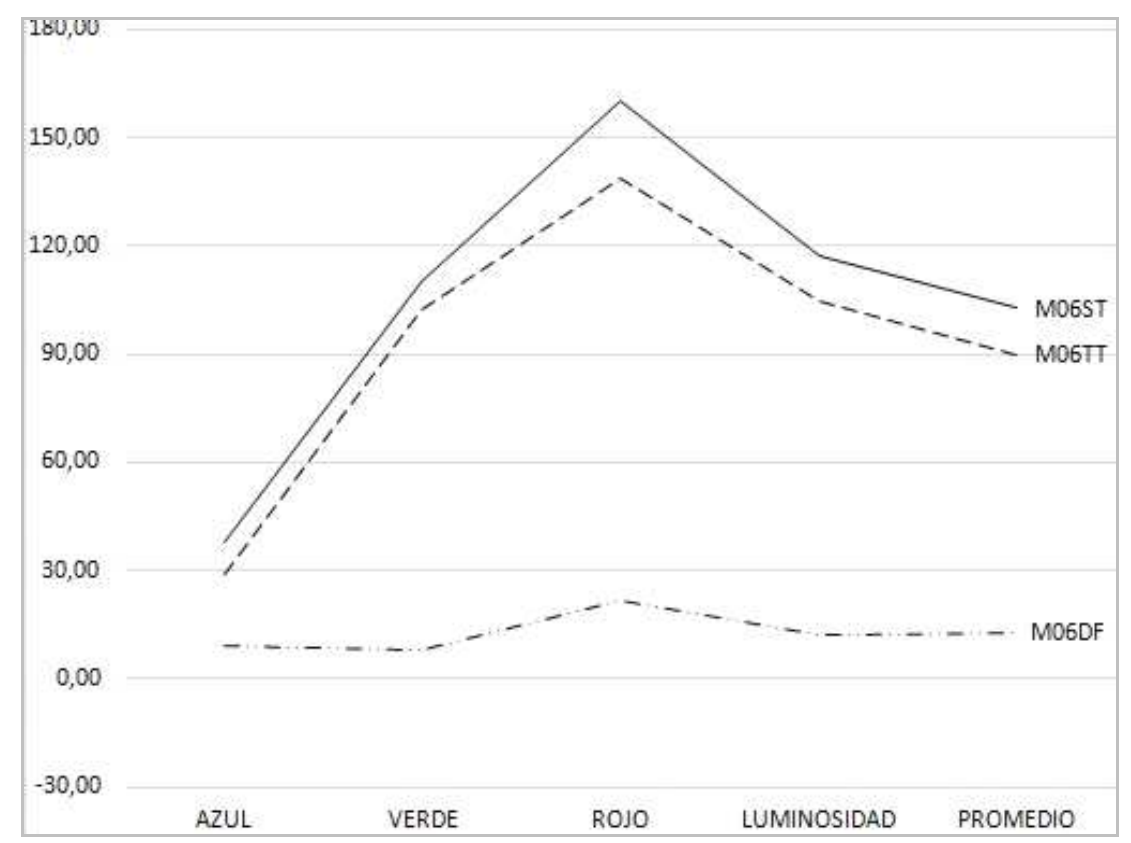

Universidad Politécnica de Madrid - Escuela Técnica Superior de Arquitectura - Departamento de Construcción y Tecnología Arquitectónica Directores: Dr. Alfonso García Santos y Dr. Antonio Rodríguez Rodríguez. Doctorando: D. Francisco Lora Toro 


\section{FICHA DE ENSAYOS DE MADERA y ACIDOS}

\section{ACIDO A05/FM/ACIDO FÓRMICO}
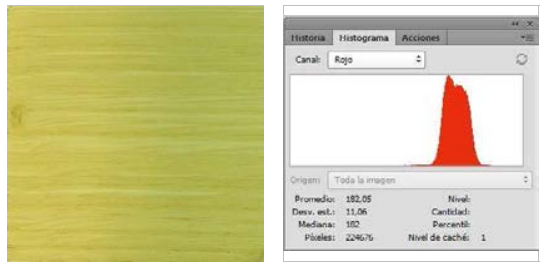

SIN TRATAR (ST): Grafica R (ST)

Valor R(ST):

182,05

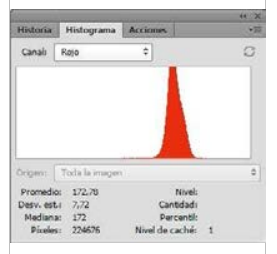

TRATADA (TT): Grafica $R(T T)$

Valor $\mathrm{R}(\mathrm{TT})$ :

172,78

DIFERENCIA (DF) Grafica R (DF): Valor DF-R:

9,27

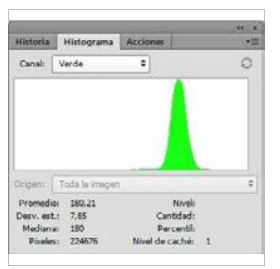

Grafica G (ST)

Valor G(ST):

180,21

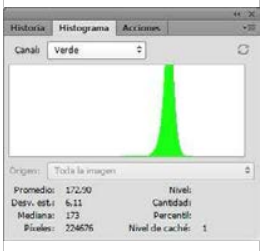

Grafica G (TT)

Valor $\mathrm{G}(\mathrm{TT})$ :

172,90
MADERA MOT/CÑ/CASTAÑO EUROPEO

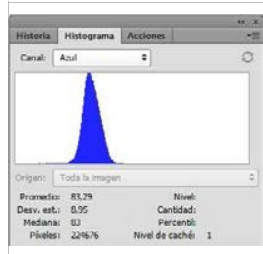

Grafica B (ST)

Valor B(ST):

83,29

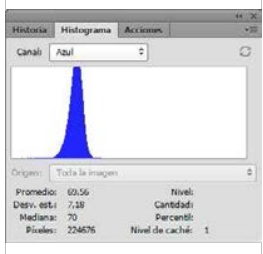

Grafica B (TT)

Valor B(TT):

69,56

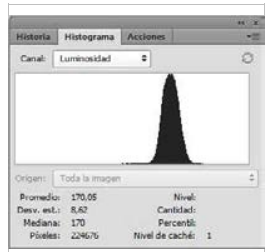

Grafica L (ST)

Valor L(ST):

170,05

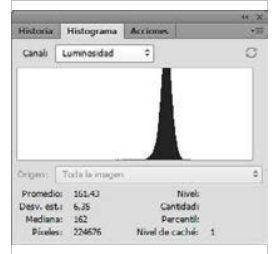

Grafica L (TT)

Valor L(TT):

161,43
138,41

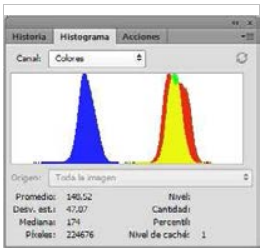

Grafica C (ST)

Valor C(ST):

148,52

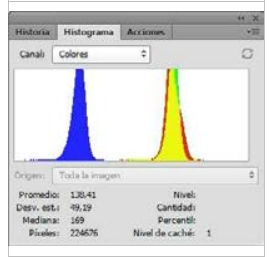

Grafica C (TT)

Valor C(TT):

\section{Grafica G (DF): Grafica B (DF): Grafica L (DF): Grafica C (DF):}

Valor DF-G: Valor DF-B:

Valor DF-L:

Valor DF-C:

$\begin{array}{llll}7,31 & 13,73 & 8,62 & 10,11\end{array}$

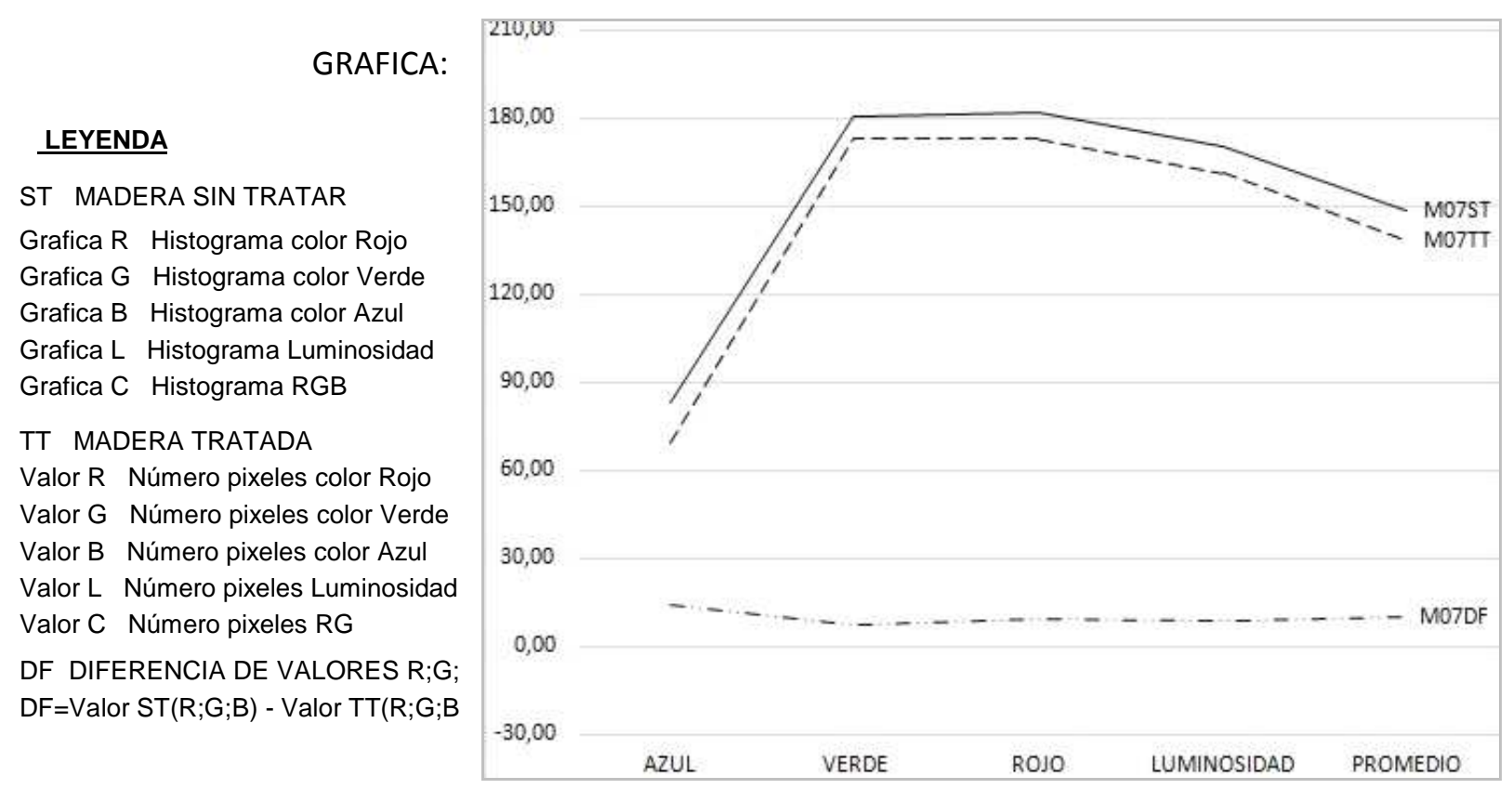

Universidad Politécnica de Madrid - Escuela Técnica Superior de Arquitectura - Departamento de Construcción y Tecnología Arquitectónica Directores: Dr. Alfonso García Santos y Dr. Antonio Rodríguez Rodríguez. Doctorando: D. Francisco Lora Toro 


\section{FICHA DE ENSAYOS DE MADERA Y ACIDOS}

\section{ACIDO A05/FM/ACIDO FÓRMICO}
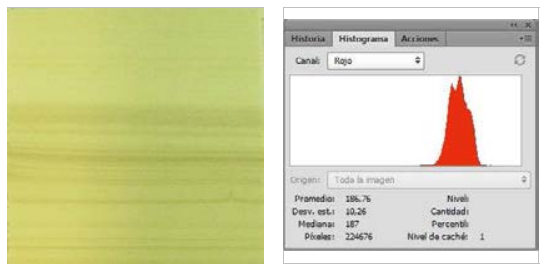

SIN TRATAR (ST): Grafica R (ST)

Valor R(ST):

186,76

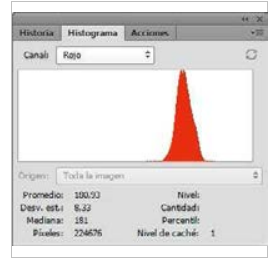

TRATADA (TT): Grafica R (TT)

Valor $\mathrm{R}(\mathrm{TT})$ :

180,93

DIFERENCIA (DF) Grafica R (DF): Valor DF-R:

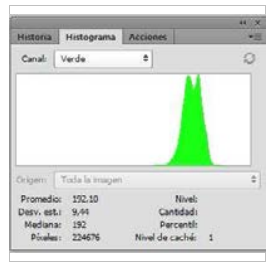

Grafica G (ST)

Valor G(ST):

192,10

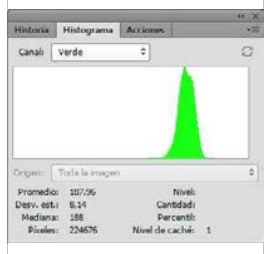

Grafica G (TT)

Valor $\mathrm{G}(\mathrm{TT})$ :

187,96
MADERA M08/CPE/CHOPO EUROPEO

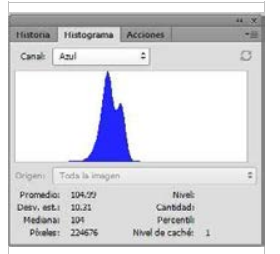

Grafica B (ST)

Valor B(ST):

104,99

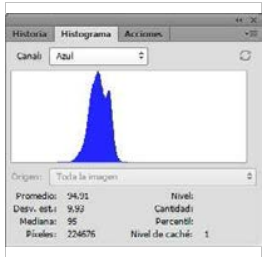

Grafica B (TT)

Valor $\mathrm{B}(\mathrm{TT})$ :

94,91

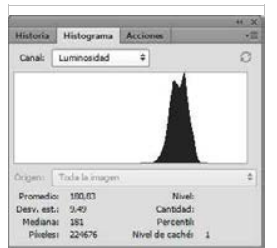

Grafica L (ST)

Valor L(ST):

180,83

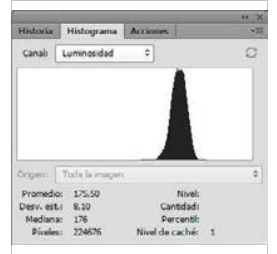

Grafica L (TT)

Valor L(TT):

175,50

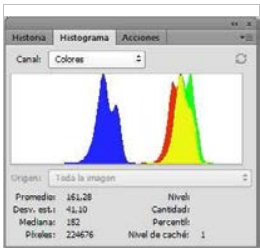

Grafica C (ST)

Valor C(ST):

161,28

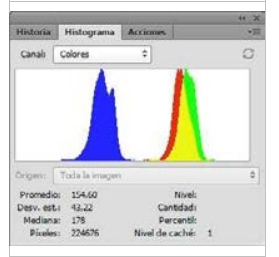

Grafica C (TT)

Valor C(TT):

154,60

5,83

Grafica G (DF): Grafica B (DF):

Grafica L (DF):

Grafica C (DF):

Valor DF-G: Valor DF-B:

Valor DF-L:

Valor DF-C:

$\begin{array}{llll}4,14 & 10,08 & 5,33 & 6,68\end{array}$

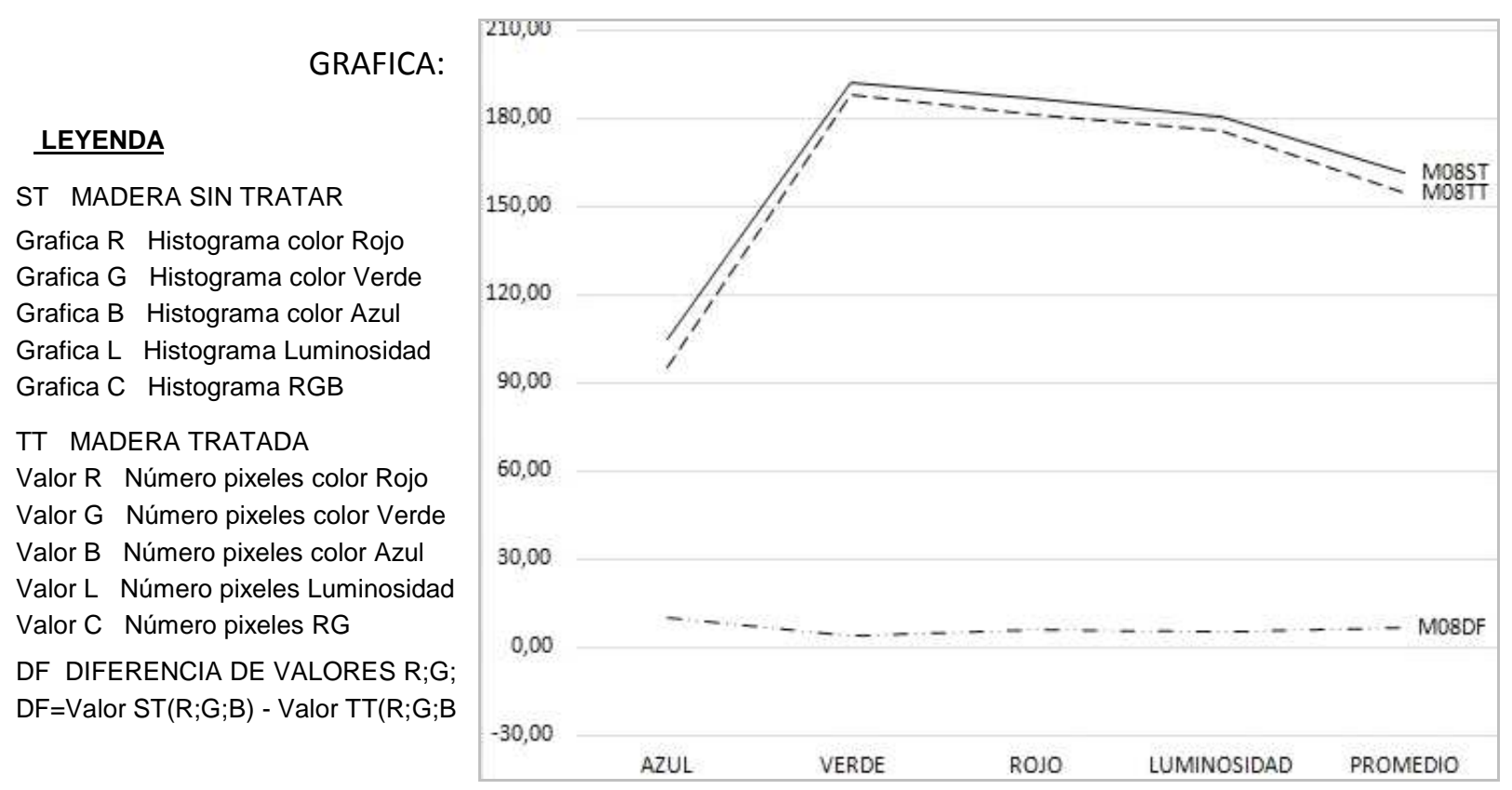

Universidad Politécnica de Madrid - Escuela Técnica Superior de Arquitectura - Departamento de Construcción y Tecnología Arquitectónica Directores: Dr. Alfonso García Santos y Dr. Antonio Rodríguez Rodríguez. Doctorando: D. Francisco Lora Toro 


\section{FICHA DE ENSAYOS DE MADERA Y ACIDOS}

\section{ACIDO A05/FM/ACIDO FÓRMICO}
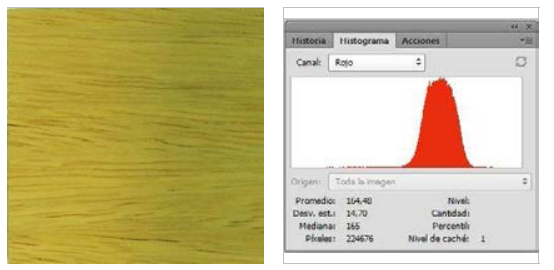

SIN TRATAR (ST): Grafica R (ST)

Valor R(ST):

164,48

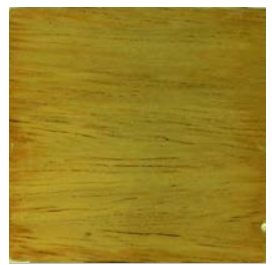

TRATADA (TT):

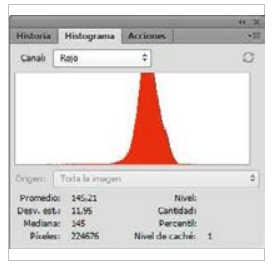

Grafica R (TT)

Valor $\mathrm{R}(\mathrm{TT})$ :

145,21

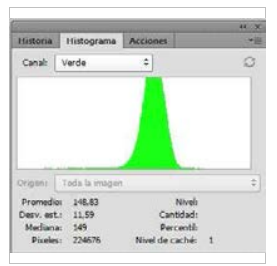

Grafica G (ST)

Valor $\mathrm{G}(\mathrm{ST})$ :

148,83

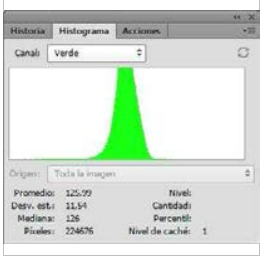

Grafica G (TT)

Valor $\mathrm{G}(\mathrm{TT})$ :

125,99

\section{MADERA M09/CJ/CEREJEIRA}

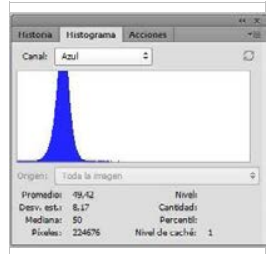

Grafica B (ST)

Valor B(ST):

49,42

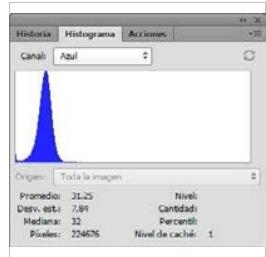

Grafica B (TT)

Valor $\mathrm{B}(\mathrm{TT})$ :

31,25

Valor DF-G:

Valor DF-B: 18,17
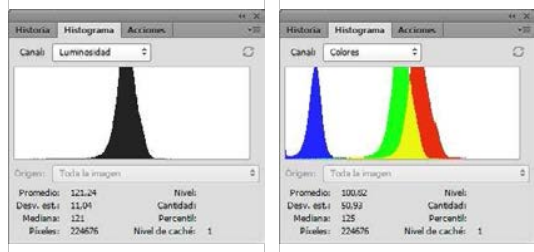

Grafica L (TT)

Grafica C (TT)

Valor L(TT):

Valor $\mathrm{C}(\mathrm{TT})$ :

121,24

100,82 22,84 Valor DF-L: Valor DF-C:

DIFERENCIA (DF) Grafica R (DF): Grafica G (DF): Grafica B (DF): Grafica L (DF): Grafica C (DF): Valor DF-R: 19,27

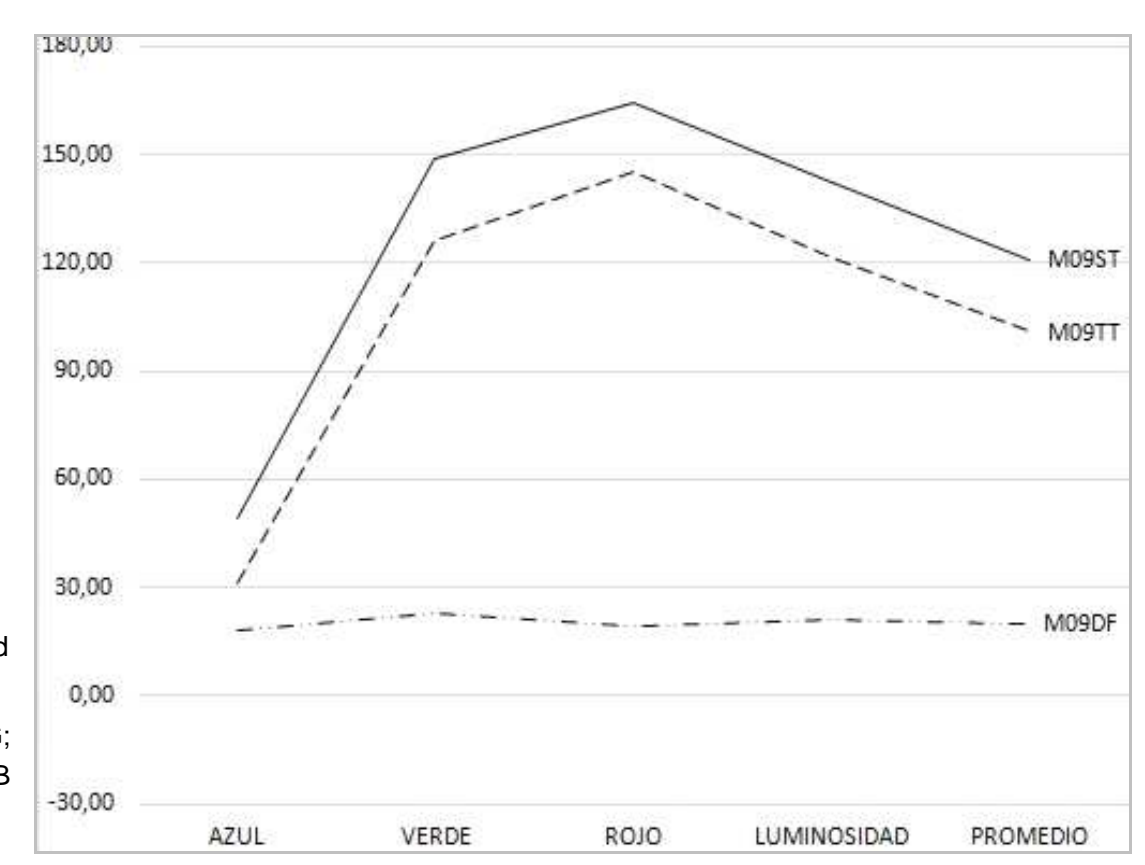

\section{LEYENDA}

ST MADERA SIN TRATAR

Grafica R Histograma color Rojo Grafica G Histograma color Verde Grafica B Histograma color Azul Grafica L Histograma Luminosidad Grafica C Histograma RGB

\section{TT MADERA TRATADA}

Valor $\mathrm{R}$ Número pixeles color Rojo Valor $G$ Número pixeles color Verde Valor B Número pixeles color Azul Valor $L$ Número pixeles Luminosidad Valor C Número pixeles RG DF DIFERENCIA DE VALORES R;G; $\mathrm{DF}=$ Valor $\mathrm{ST}(\mathrm{R} ; \mathrm{G} ; \mathrm{B})$ - Valor TT(R;G;B 


\section{FICHA DE ENSAYOS DE MADERA Y ACIDOS}

\section{ACIDO A05/FM/ACIDO FÓRMICO}
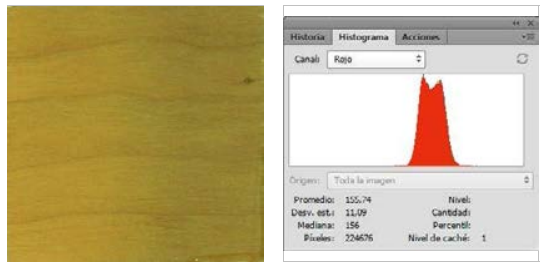

SIN TRATAR (ST): Grafica R (ST)

Valor R(ST):

155,74

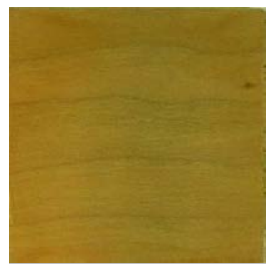

TRATADA (TT):

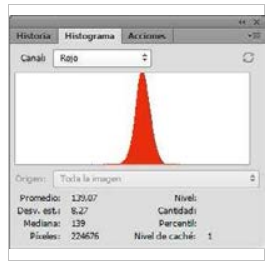

Grafica R (TT)

Valor R(TT):

139,07

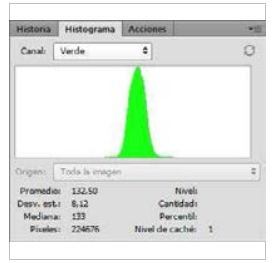

Grafica G (ST)

Valor $\mathrm{G}(\mathrm{ST})$ :

132,50

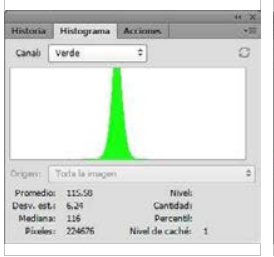

Grafica G (TT)

Valor $\mathrm{G}(\mathrm{TT})$ :

115,58

\section{MADERA M10/CZA/CEREZO AMERICANO}

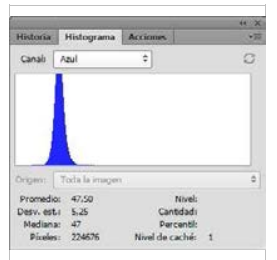

Grafica B (ST)

Valor B(ST):

47,50

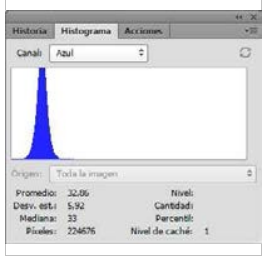

Grafica B (TT)

Valor $\mathrm{B}(\mathrm{TT})$ :

32,86

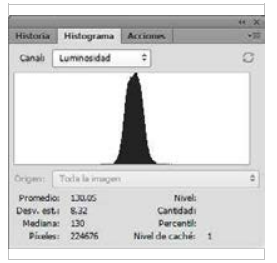

Grafica L (ST)

Valor L(ST):

130,05

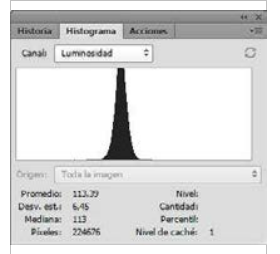

Grafica L (TT)

Valor L(TT):

113,39
95,84

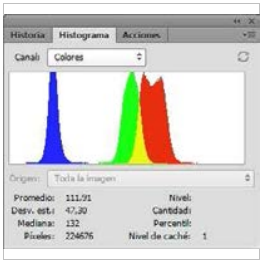

Grafica C (ST)

Valor C(ST):

111,91

DIFERENCIA (DF) Grafica R (DF):

Grafica G (DF): Grafica B (DF):

Grafica L (DF):

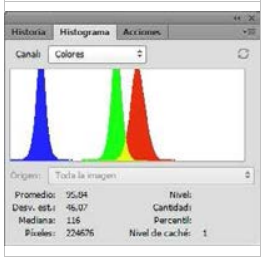

Valor DF-R:

Valor DF-G:

Valor DF-B:

Valor DF-L:

Grafica C (TT)

16,67

16,92

14,64

16,66

Valor C(TT):

Grafica C (DF):

Valor DF-C:

16,07

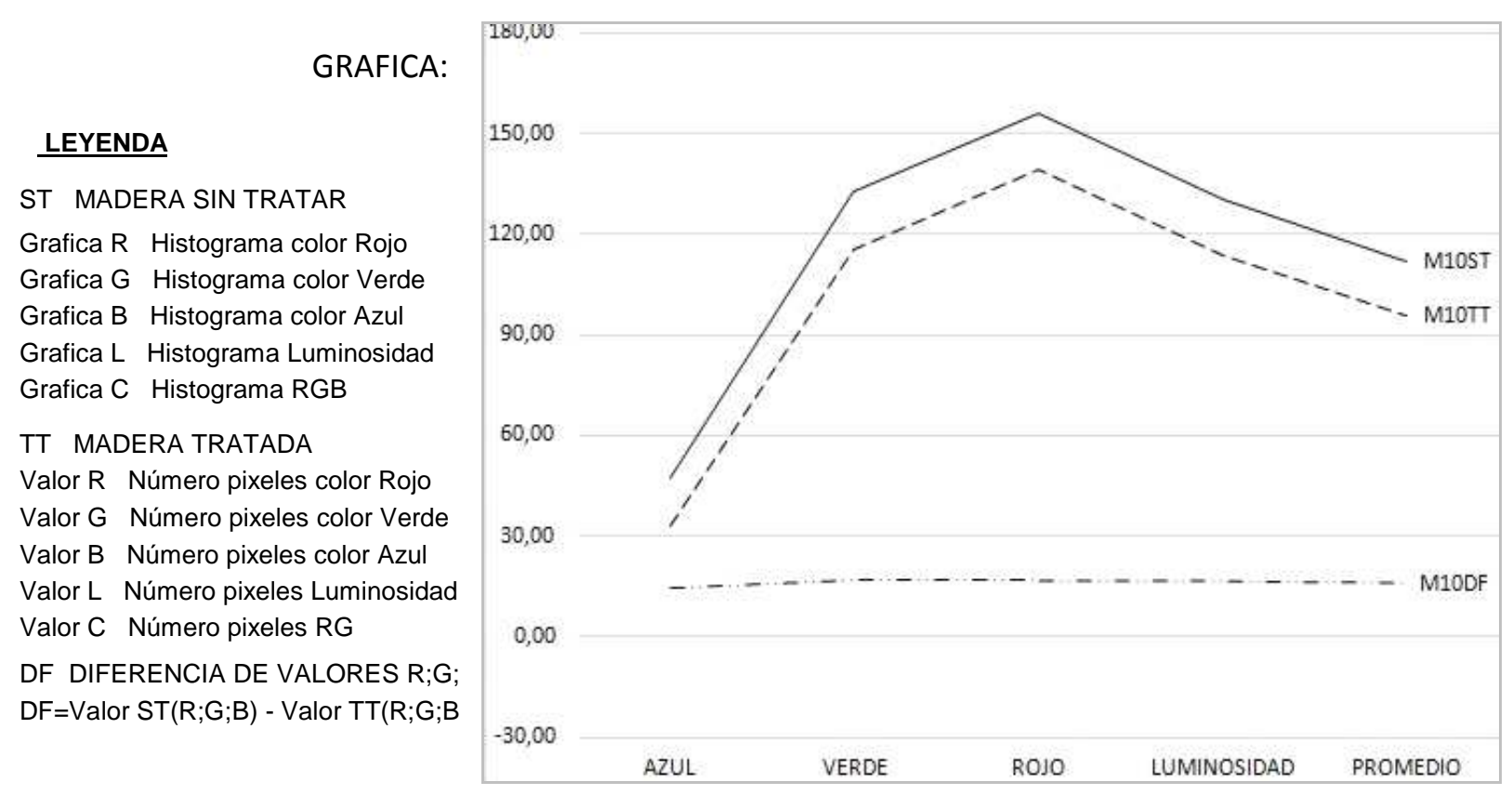

Universidad Politécnica de Madrid - Escuela Técnica Superior de Arquitectura - Departamento de Construcción y Tecnología Arquitectónica Directores: Dr. Alfonso García Santos y Dr. Antonio Rodríguez Rodríguez. Doctorando: D. Francisco Lora Toro 


\section{FICHA DE ENSAYOS DE MADERA Y ACIDOS}

\section{ACIDO A05/FM/ACIDO FÓRMICO}
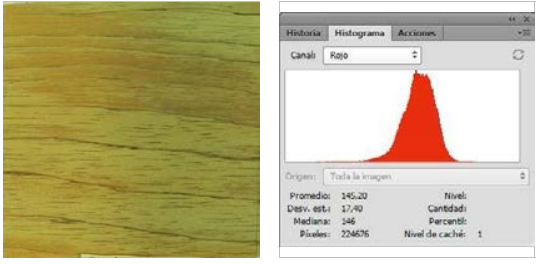

SIN TRATAR (ST): Grafica R (ST)

Valor R(ST):

145,20

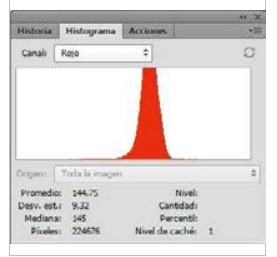

TRATADA (TT): Grafica $R(T T)$

Valor $\mathrm{R}(\mathrm{TT})$ :

144,75

DIFERENCIA (DF) Grafica R (DF):

Valor DF-R:

0,45

GRAFICA:

\section{LEYENDA}

ST MADERA SIN TRATAR

Grafica R Histograma color Rojo

Grafica G Histograma color Verde

Grafica B Histograma color Azul

Grafica L Histograma Luminosidad

Grafica C Histograma RGB

TT MADERA TRATADA

Valor R Número pixeles color Rojo

Valor G Número pixeles color Verde

Valor B Número pixeles color Azul

Valor $L$ Número pixeles Luminosidad

Valor C Número pixeles RG

DF DIFERENCIA DE VALORES R;G; $\mathrm{DF}=$ Valor $\mathrm{ST}(\mathrm{R} ; \mathrm{G} ; \mathrm{B})$ - Valor $\mathrm{TT}(\mathrm{R} ; \mathrm{G} ; \mathrm{B}$

\section{MADERA M11/CB/COPAIBA}
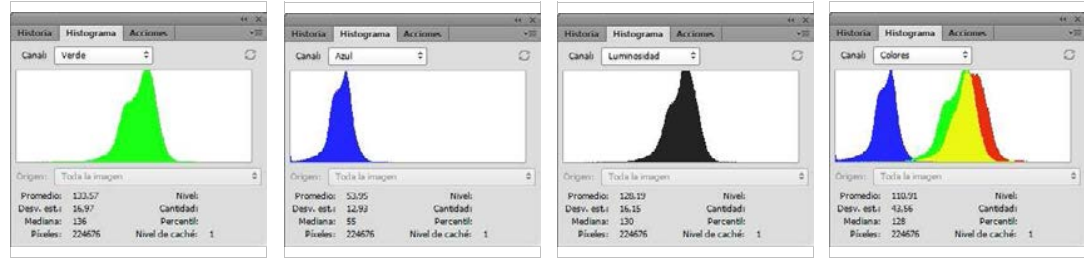

Grafica G (ST)

Grafica B (ST)

Grafica L (ST)

Grafica C (ST)

Valor $\mathrm{G}(\mathrm{ST})$ :

Valor B(ST):

Valor L(ST):

Valor C(ST):

133,57

53,95

128,19

110,91
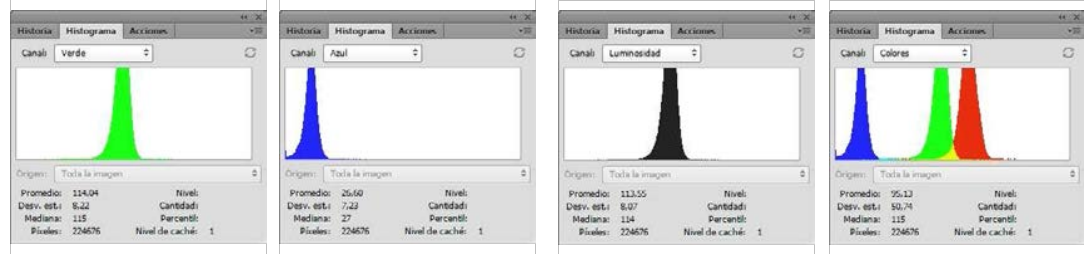

Grafica G (TT) Grafica B (TT)

Grafica L (TT)

Grafica C (TT)

Valor $\mathrm{G}(\mathrm{TT})$ :

Valor $\mathrm{B}(\mathrm{TT})$ :

Valor L(TT):

Valor C(TT):

114,04

26,60

113,55

95,13

Grafica G (DF): Grafica B (DF): Grafica L (DF): Grafica C (DF): Valor DF-G: Valor DF-B: Valor DF-L: Valor DF-C: 19,53 27,35 14,64 15,78

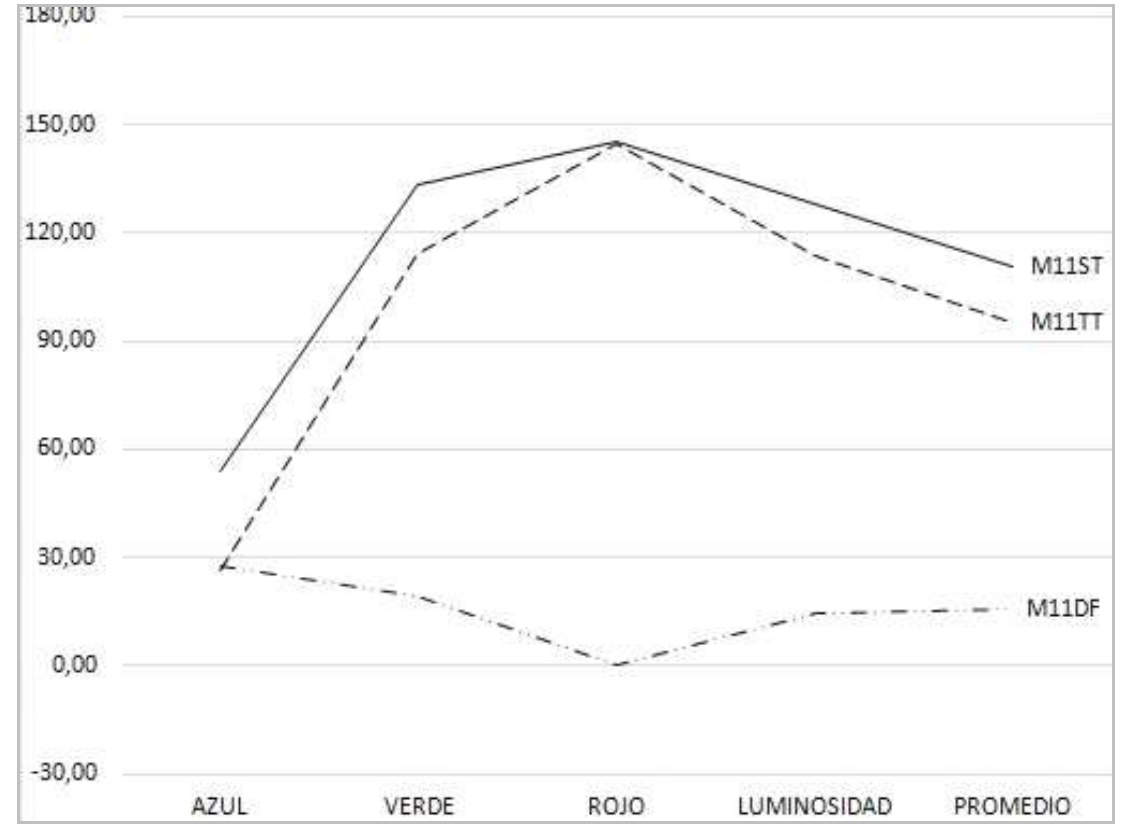

Universidad Politécnica de Madrid - Escuela Técnica Superior de Arquitectura - Departamento de Construcción y Tecnología Arquitectónica Directores: Dr. Alfonso García Santos y Dr. Antonio Rodríguez Rodríguez. Doctorando: D. Francisco Lora Toro 


\section{FICHA DE ENSAYOS DE MADERA Y ACIDOS}

\section{ACIDO A05/FM/ACIDO FÓRMICO}
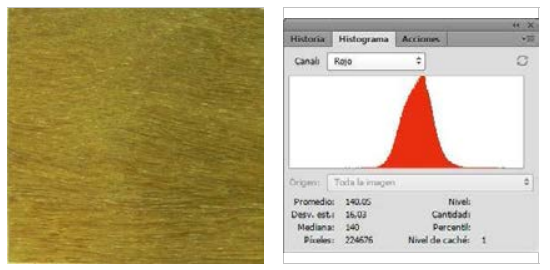

SIN TRATAR (ST): Grafica R (ST)

Valor R(ST):

140,05
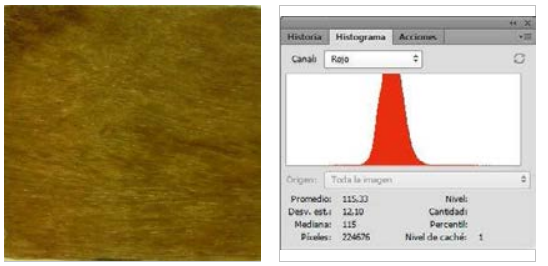

TRATADA (TT): Grafica $R(T T)$

Valor $\mathrm{R}(\mathrm{TT})$ :

115,33

DIFERENCIA (DF) Grafica R (DF): Valor DF-R: 24,72

GRAFICA:

\section{LEYENDA}

ST MADERA SIN TRATAR

Grafica R Histograma color Rojo Grafica G Histograma color Verde Grafica B Histograma color Azul Grafica L Histograma Luminosidad Grafica C Histograma RGB

TT MADERA TRATADA

Valor R Número pixeles color Rojo Valor G Número pixeles color Verde Valor B Número pixeles color Azul Valor $L$ Número pixeles Luminosidad Valor C Número pixeles RG DF DIFERENCIA DE VALORES R;G; $\mathrm{DF}=$ Valor $\mathrm{ST}(\mathrm{R} ; \mathrm{G} ; \mathrm{B})$ - Valor TT(R;G;B

$$
-30,00
$$

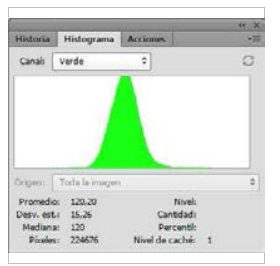

Grafica G (ST)

Valor $\mathrm{G}(\mathrm{ST})$ :

120,20

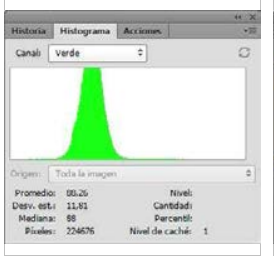

Grafica G (TT)

Valor $\mathrm{G}(\mathrm{TT})$ :

88,26

\section{MADERA M12/CM/CUMARÚ}
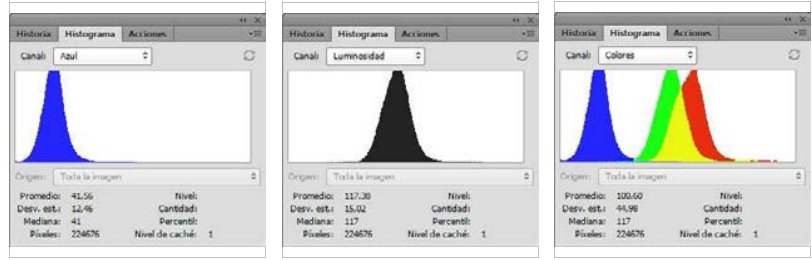

Grafica B (ST)

Grafica L (ST)

Grafica C (ST)

Valor B(ST):

Valor L(ST):

Valor C(ST):

41,56

117,38

100,60
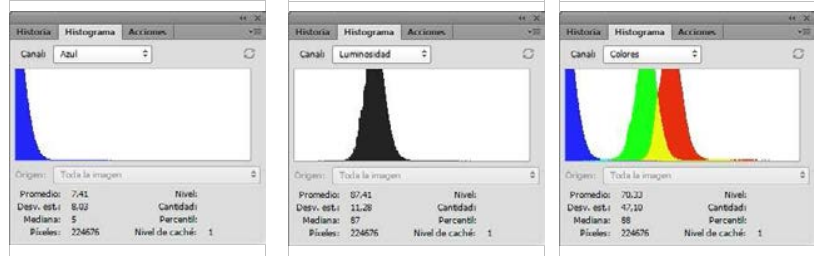

Grafica L (TT)

Grafica C (TT)

Valor L(TT):

Valor $\mathrm{C}(\mathrm{TT})$ :

Valor $\mathrm{B}(\mathrm{TT})$ :

87,41

70,33

Grafica G (DF): Grafica B (DF): Grafica L (DF): Grafica C (DF): Valor DF-G: Valor DF-B: Valor DF-L: Valor DF-C:

$\begin{array}{llll}31,94 & 34,15 & 29,97 & 30,27\end{array}$

Universidad Politécnica de Madrid - Escuela Técnica Superior de Arquitectura - Departamento de Construcción y Tecnología Arquitectónica Directores: Dr. Alfonso García Santos y Dr. Antonio Rodríguez Rodríguez. Doctorando: D. Francisco Lora Toro 


\section{FICHA DE ENSAYOS DE MADERA Y ACIDOS}

\section{ACIDO A05/FM/ACIDO FÓRMICO}
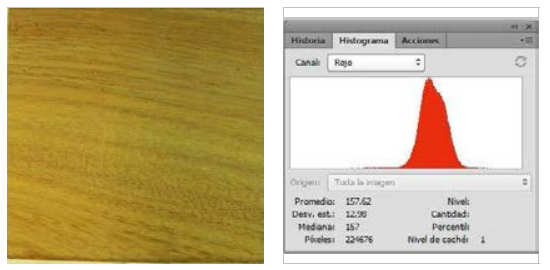

SIN TRATAR (ST): Grafica R (ST)

Valor R(ST):

157,62
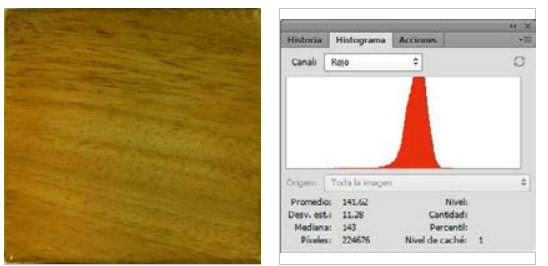

TRATADA (TT): Grafica $R(T T)$

Valor $\mathrm{R}(\mathrm{TT})$ :

141,62

DIFERENCIA (DF) Grafica R (DF):

Valor DF-R:

16,00

GRAFICA:

\section{LEYENDA}

ST MADERA SIN TRATAR

Grafica R Histograma color Rojo

Grafica G Histograma color Verde

Grafica B Histograma color Azul

Grafica L Histograma Luminosidad

Grafica C Histograma RGB

TT MADERA TRATADA

Valor R Número pixeles color Rojo

Valor $\mathrm{G}$ Número pixeles color Verde

Valor B Número pixeles color Azul

Valor $L$ Número pixeles Luminosidad

Valor $C$ Número pixeles $R G$

DF DIFERENCIA DE VALORES R;G; $\mathrm{DF}=$ Valor $\mathrm{ST}(\mathrm{R} ; \mathrm{G} ; \mathrm{B})$ - Valor TT $(\mathrm{R} ; \mathrm{G} ; \mathrm{B}$

\section{MADERA M13/DS/DOUSSIÉ}
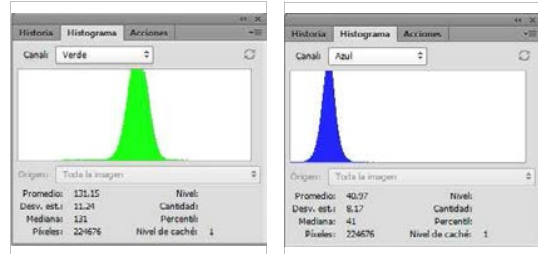

Grafica G (ST) Grafica B (ST)

Valor G(ST):

131,15

Valor $\mathrm{B}(\mathrm{ST})$ :

40,97
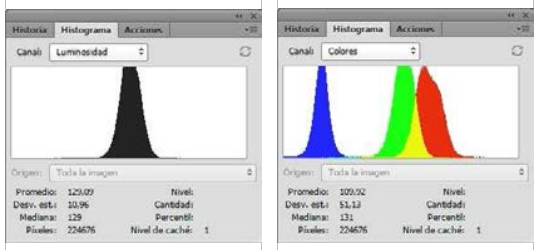

Grafica L (ST)

Grafica C (ST)

Valor L(ST):

Valor C(ST):

129,09

109,92
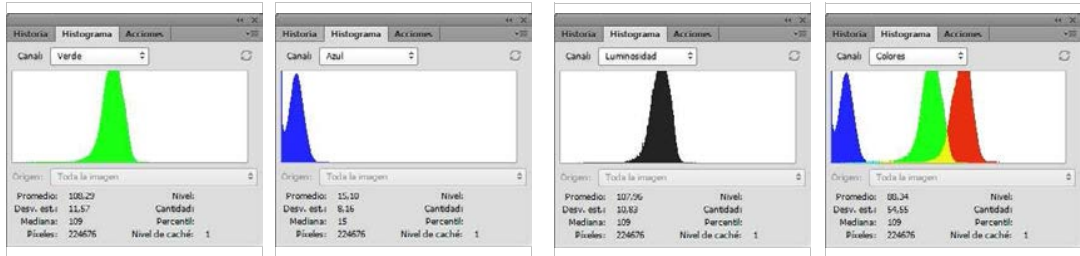

Grafica G (TT) Grafica B (TT)

Grafica L (TT)

Grafica C (TT)

Valor $\mathrm{G}(\mathrm{TT})$ :

Valor $\mathrm{B}(\mathrm{TT})$ :

Valor L(TT):

Valor $\mathrm{C}(\mathrm{TT})$ :

108,29

15,10

107,96

88,34

Grafica G (DF): Grafica B (DF): Grafica L (DF): Grafica C (DF): Valor DF-G: Valor DF-B: Valor DF-L: Valor DF-C: 22,86 25,87 21,13 21,58

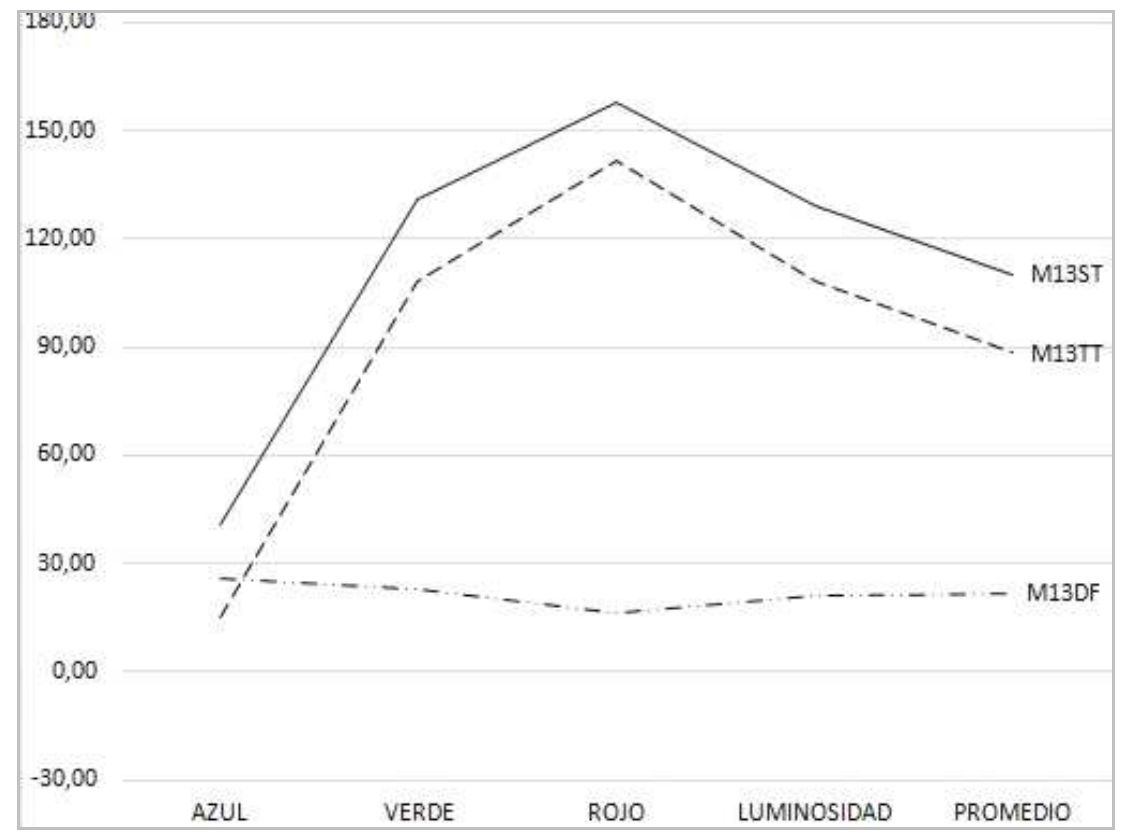

Universidad Politécnica de Madrid - Escuela Técnica Superior de Arquitectura - Departamento de Construcción y Tecnología Arquitectónica Directores: Dr. Alfonso García Santos y Dr. Antonio Rodríguez Rodríguez. Doctorando: D. Francisco Lora Toro 


\section{FICHA DE ENSAYOS DE MADERA Y ACIDOS}

\section{ACIDO A05/FM/ACIDO FÓRMICO}
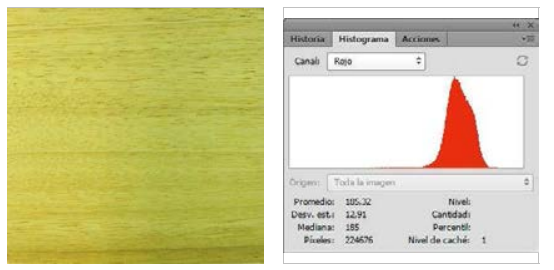

SIN TRATAR (ST): Grafica R (ST)

Valor R(ST):

185,32

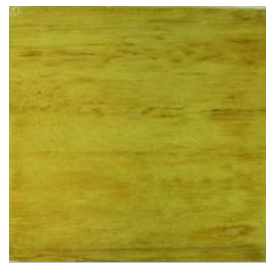

TRATADA (TT):

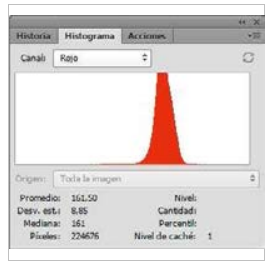

Grafica R (TT)

Valor R(TT):

161,50

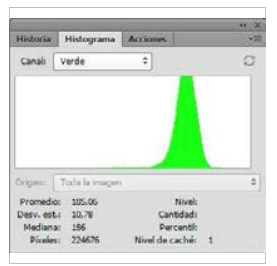

Grafica G (ST)

Valor $\mathrm{G}(\mathrm{ST})$ :

185,06

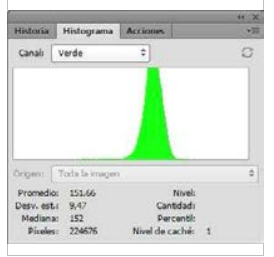

Grafica G (TT)

Valor $\mathrm{G}(\mathrm{TT})$ :

151,66
MADERA M14/FR/FRAMIRÉ

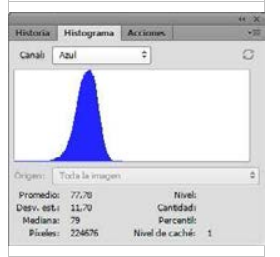

Grafica B (ST)

Valor B(ST):

77,78

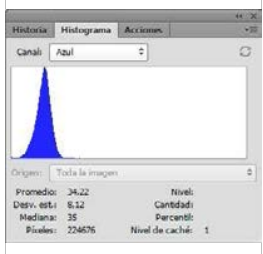

Grafica B (TT)

Valor $\mathrm{B}(\mathrm{TT})$ :

34,22

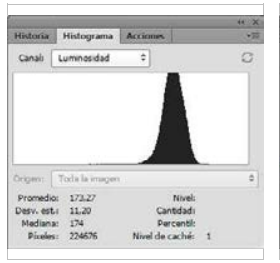

Grafica L (ST)

Valor L(ST):

173,27

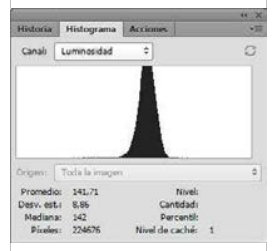

Grafica L (TT)

Valor L(TT):

141,71

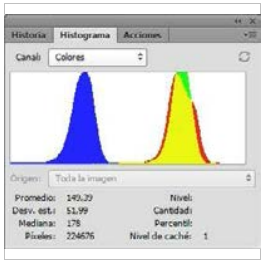

Grafica C (ST)

Valor C(ST):

149,39

DIFERENCIA (DF) Grafica R (DF):

Grafica G (DF): Grafica B (DF):

Grafica L (DF):

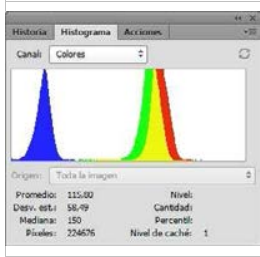

Valor DF-R:

Valor DF-G:

Valor DF-B:

Valor DF-L:

Grafica C (TT)

23,82

33,40

43,56

31,56

Valor C(TT):

115,80

Grafica C (DF):

Valor DF-C:

33,59

\section{LEYENDA}

ST MADERA SIN TRATAR

Grafica R Histograma color Rojo

Grafica G Histograma color Verde

Grafica B Histograma color Azul

Grafica L Histograma Luminosidad

Grafica C Histograma RGB

\section{TT MADERA TRATADA}

Valor R Número pixeles color Rojo

Valor G Número pixeles color Verde

Valor B Número pixeles color Azul

Valor $L$ Número pixeles Luminosidad

Valor C Número pixeles RG

DF DIFERENCIA DE VALORES R;G; $\mathrm{DF}=$ Valor $\mathrm{ST}(\mathrm{R} ; \mathrm{G} ; \mathrm{B})$ - Valor $\mathrm{TT}(\mathrm{R} ; \mathrm{G} ; \mathrm{B}$

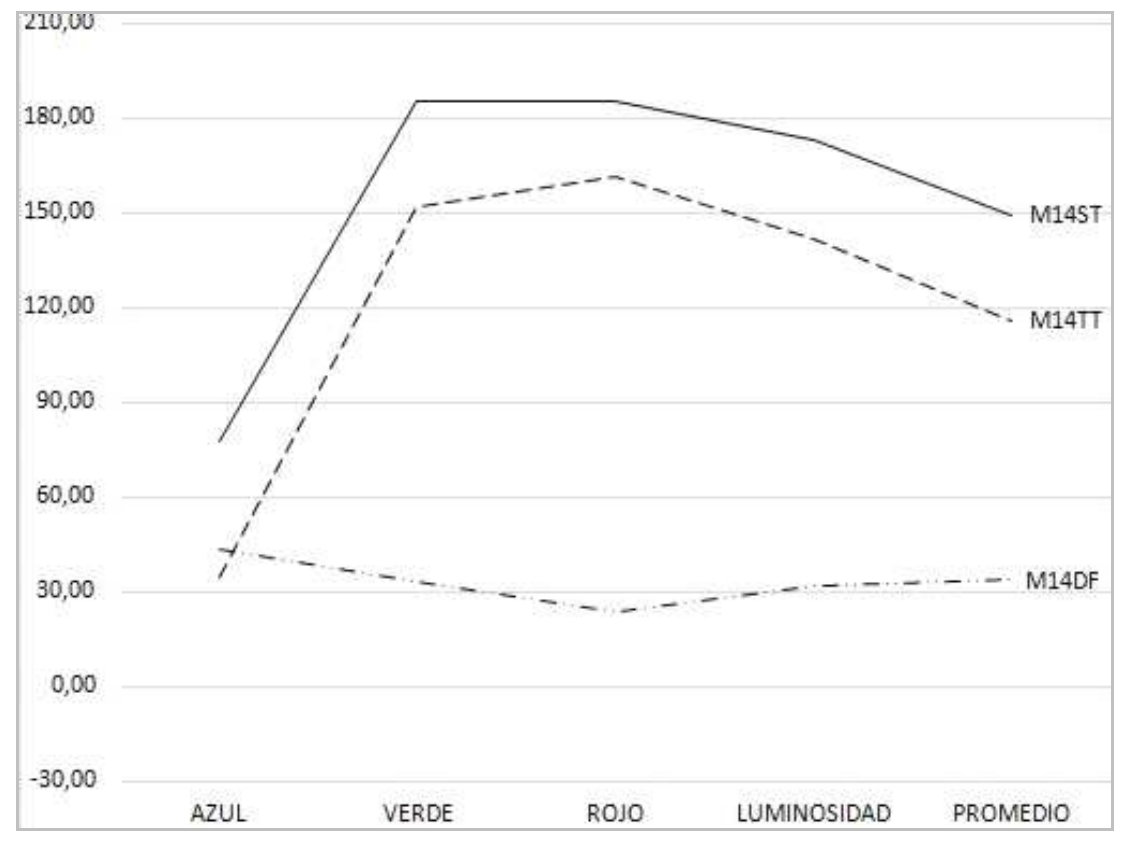

Universidad Politécnica de Madrid - Escuela Técnica Superior de Arquitectura - Departamento de Construcción y Tecnología Arquitectónica Directores: Dr. Alfonso García Santos y Dr. Antonio Rodríguez Rodríguez. Doctorando: D. Francisco Lora Toro 


\section{FICHA DE ENSAYOS DE MADERA Y ACIDOS}

\section{ACIDO A05/FM/ACIDO FÓRMICO}
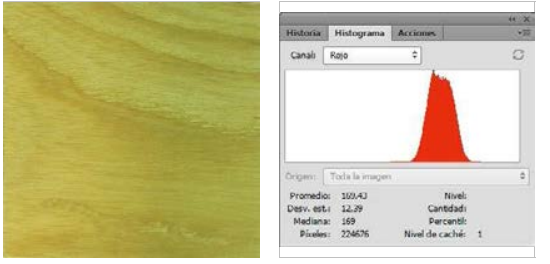

SIN TRATAR (ST): Grafica R (ST)

Valor R(ST):

169,43

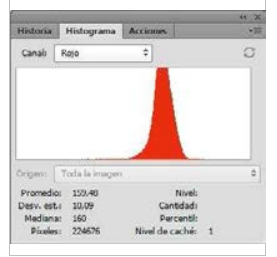

TRATADA (TT): Grafica R (TT)

Valor R(TT):

159,67

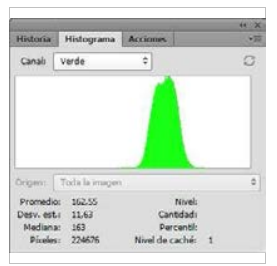

Grafica G (ST)

Valor $\mathrm{G}(\mathrm{ST})$ :

162,55

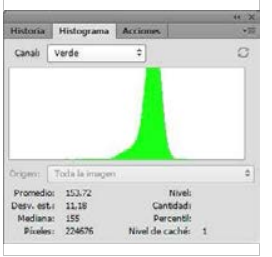

Grafica G (TT)

Valor $\mathrm{G}(\mathrm{TT})$ :

153,72
MADERA M15/FBA/FRESNO BLANCO AMERICAN

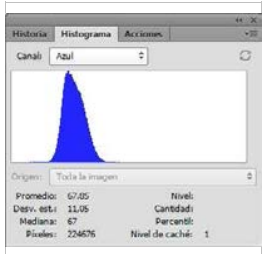

Grafica B (ST)

Valor B(ST):

67,85

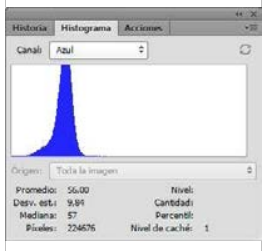

Grafica B (TT)

Valor $\mathrm{B}(\mathrm{TT})$ :

56,00

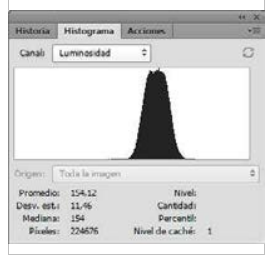

Grafica L (ST)

Valor L(ST):

154,12

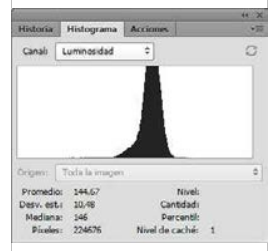

Grafica L (TT)

Valor L(TT):

144,67

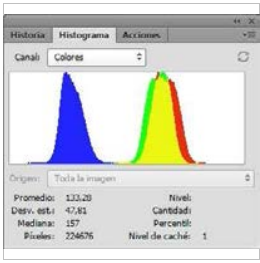

Grafica C (ST)

Valor C(ST):

133,28

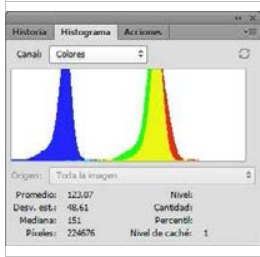

Grafica C (TT)

Valor C(TT):

123,07

DIFERENCIA (DF) Grafica R (DF):

Grafica G (DF): Grafica B (DF):

Grafica L (DF):

Valor DF-R:

Valor DF-G:

Valor DF-B:

Valor DF-L:

9,76

8,83

11,85

9,45

GRAFICA:

\section{LEYENDA}

ST MADERA SIN TRATAR

Grafica R Histograma color Rojo

Grafica G Histograma color Verde

Grafica B Histograma color Azul

Grafica L Histograma Luminosidad

Grafica C Histograma RGB

\section{TT MADERA TRATADA}

Valor R Número pixeles color Rojo

Valor G Número pixeles color Verde

Valor B Número pixeles color Azul

Valor $L$ Número pixeles Luminosidad

Valor C Número pixeles RG

DF DIFERENCIA DE VALORES R;G; $\mathrm{DF}=$ Valor $\mathrm{ST}(\mathrm{R} ; \mathrm{G} ; \mathrm{B})$ - Valor $\mathrm{TT}(\mathrm{R} ; \mathrm{G} ; \mathrm{B}$

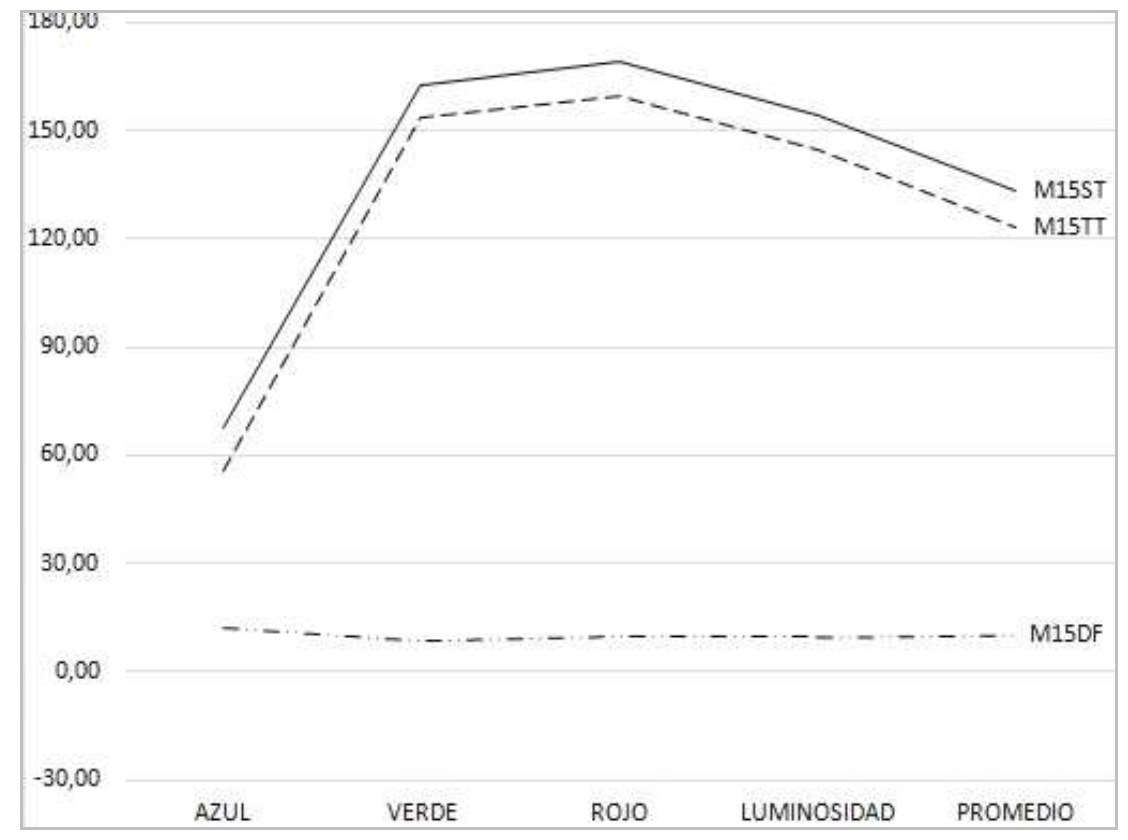

Universidad Politécnica de Madrid - Escuela Técnica Superior de Arquitectura - Departamento de Construcción y Tecnología Arquitectónica Directores: Dr. Alfonso García Santos y Dr. Antonio Rodríguez Rodríguez. Doctorando: D. Francisco Lora Toro 


\section{FICHA DE ENSAYOS DE MADERA Y ACIDOS}

\section{ACIDO A05/FM/ACIDO FÓRMICO}
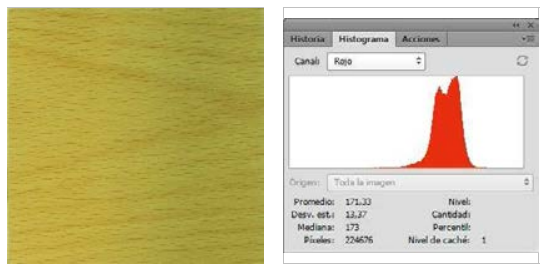

SIN TRATAR (ST): Grafica R (ST)

Valor R(ST):

171,33

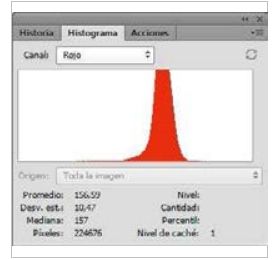

TRATADA (TT): Grafica R (TT)

Valor R(TT):

156,59

DIFERENCIA (DF) Grafica R (DF): Valor DF-R: 14,74

GRAFICA:

\section{LEYENDA}

ST MADERA SIN TRATAR

Grafica R Histograma color Rojo Grafica G Histograma color Verde Grafica B Histograma color Azul Grafica L Histograma Luminosidad Grafica C Histograma RGB

\section{TT MADERA TRATADA}

Valor $R$ Número pixeles color Rojo Valor $\mathrm{G}$ Número pixeles color Verde Valor B Número pixeles color Azul Valor $L$ Número pixeles Luminosidad Valor C Número pixeles RG DF DIFERENCIA DE VALORES R;G; $\mathrm{DF}=$ Valor $\mathrm{ST}(\mathrm{R} ; \mathrm{G} ; \mathrm{B})$ - Valor TT(R;G;B

\section{MADERA M16/H/HAYA}

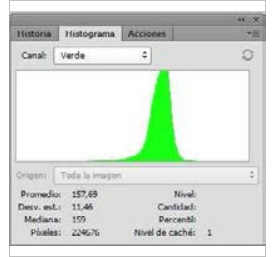

Grafica G (ST)

Valor G(ST):

157,69

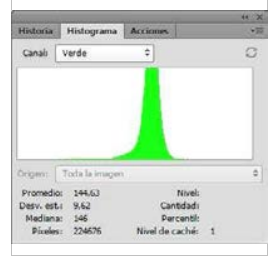

Grafica G (TT)

Valor $\mathrm{G}(\mathrm{TT})$ :

144,63

Grafica G (DF): Grafica B (DF): Valor DF-B:

9,39

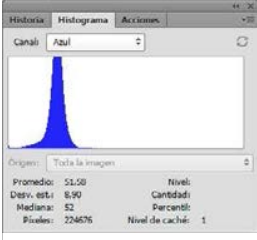

Grafica B (TT)

Valor $\mathrm{B}(\mathrm{TT})$ :

51,58

Valor DF-G:

13,06
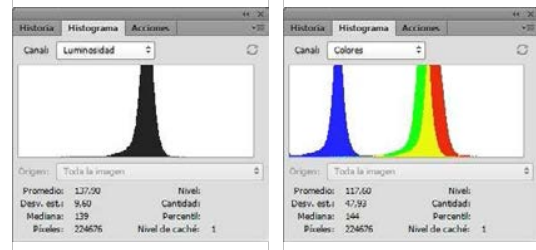

Grafica L (TT)

Grafica C (TT)

Valor L(TT):

Valor C(TT):

137,90

117,60

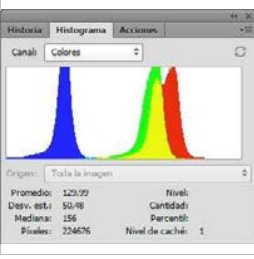

Grafica C (ST)

Valor C(ST):

129,99

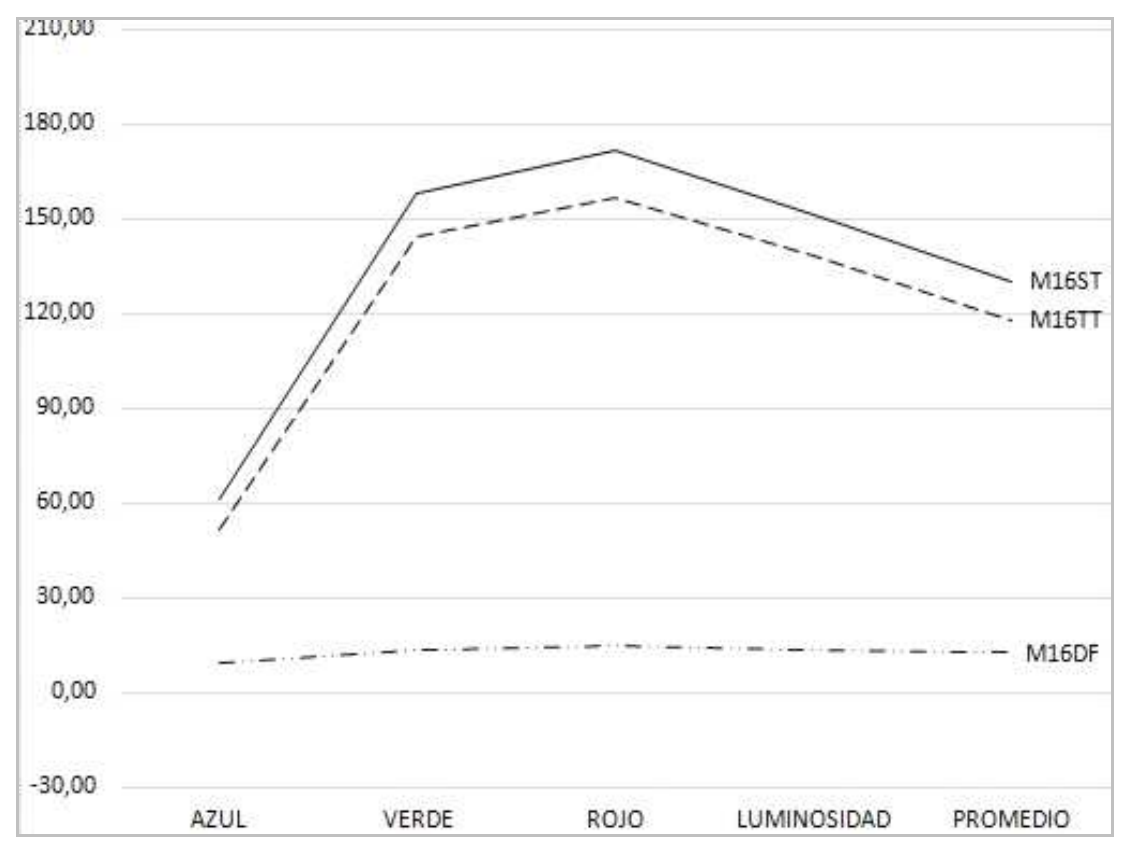

Universidad Politécnica de Madrid - Escuela Técnica Superior de Arquitectura - Departamento de Construcción y Tecnología Arquitectónica Directores: Dr. Alfonso García Santos y Dr. Antonio Rodríguez Rodríguez. Doctorando: D. Francisco Lora Toro 


\section{FICHA DE ENSAYOS DE MADERA Y ACIDOS}

\section{ACIDO A05/FM/ACIDO FÓRMICO}
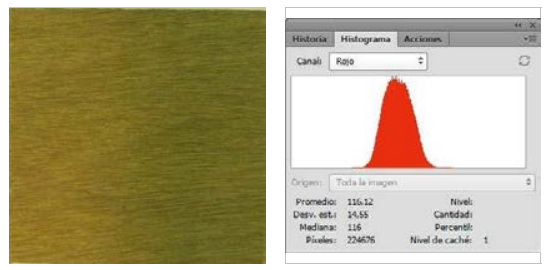

SIN TRATAR (ST): Grafica R (ST)

Valor R(ST):

116,12
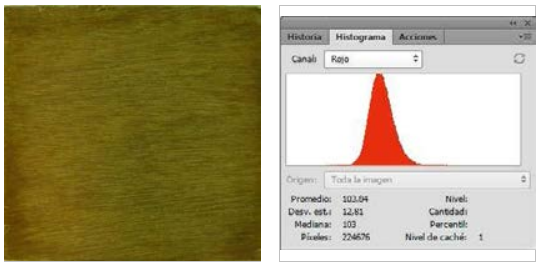

TRATADA (TT): Grafica R (TT)

Valor $\mathrm{R}(\mathrm{TT})$ :

103,84

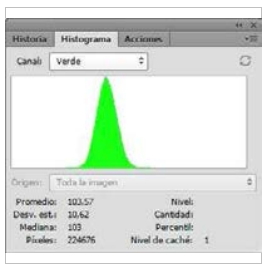

Grafica G (ST)

Valor $\mathrm{G}(\mathrm{ST})$ :

103,57

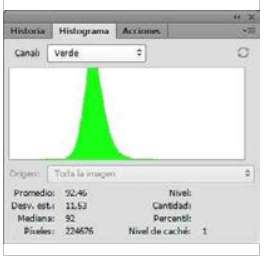

Grafica G (TT)

Valor $\mathrm{G}(\mathrm{TT})$ :

92,46

\section{MADERA M17/IP/IPÉ}

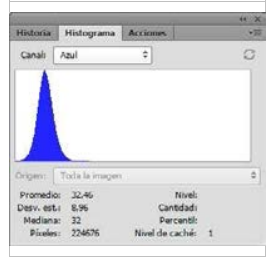

Grafica B (ST)

Valor B(ST):

32,46

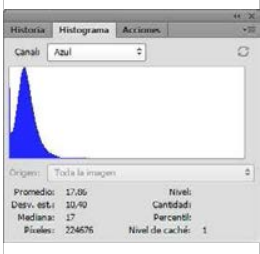

Grafica B (TT)

Valor $\mathrm{B}(\mathrm{TT})$ :

17,86

Grafica G (DF): Grafica B (DF):

Valor DF-B:

14,60

11,11

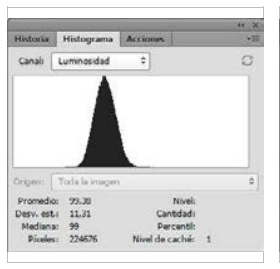

Grafica L (ST)

Valor L(ST):

99,38

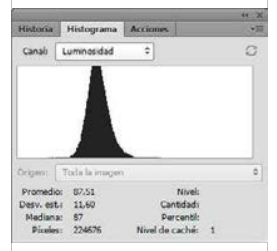

Grafica L (TT)

Valor L(TT):

87,51

Grafica L (DF):

Valor DF-L:

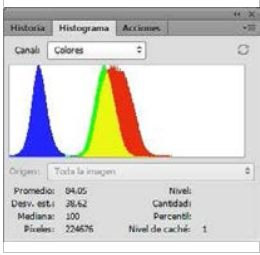

Grafica C (ST)

Valor C(ST):

84,05

Valor DF-R:

12,28

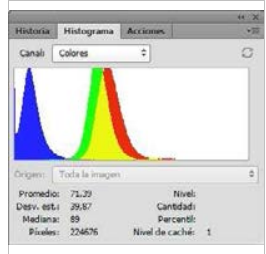

Grafica C (TT)

Valor C(TT):

71,39

Grafica C (DF):

Valor DF-C:

12,66

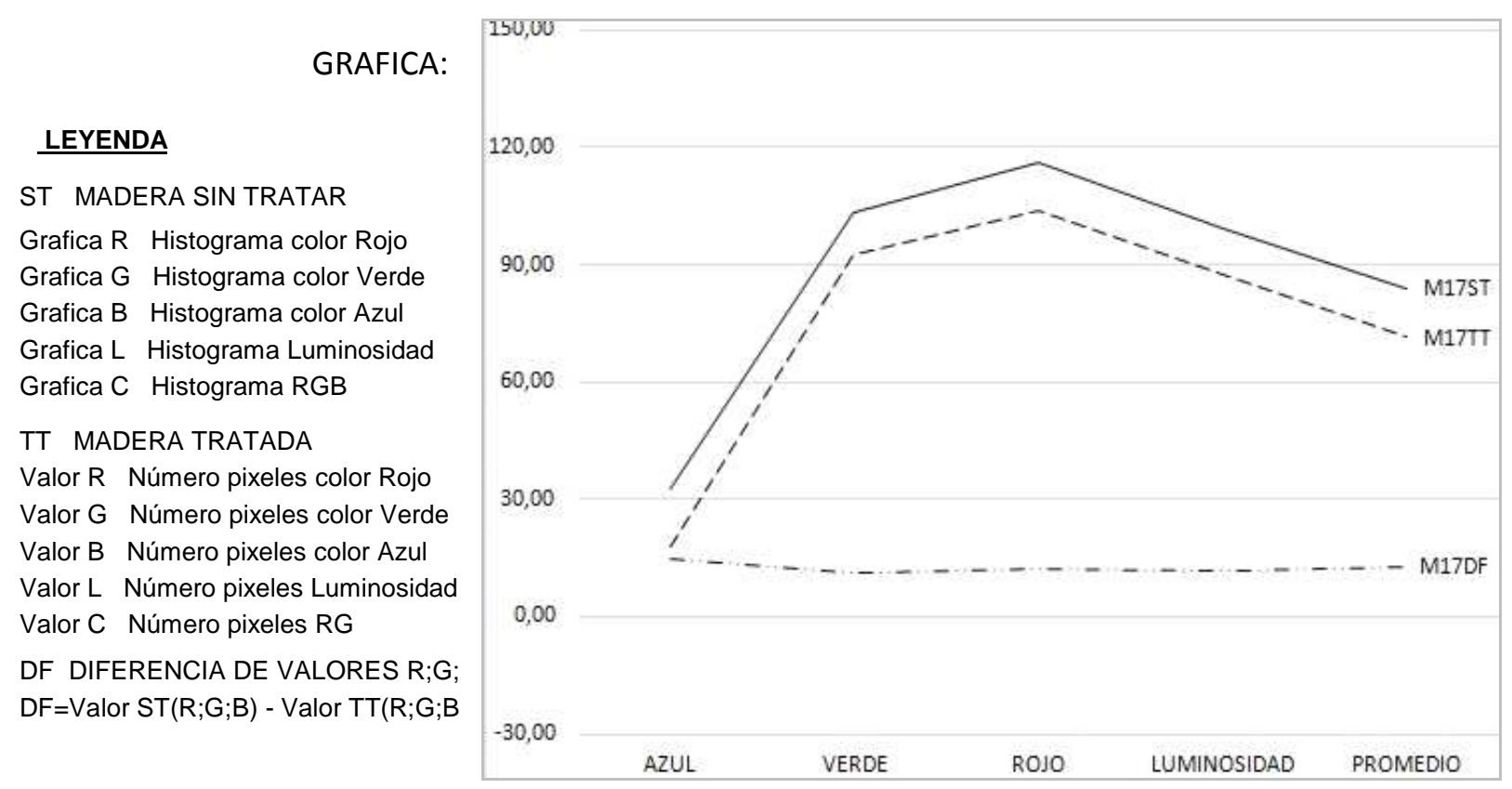

Universidad Politécnica de Madrid - Escuela Técnica Superior de Arquitectura - Departamento de Construcción y Tecnología Arquitectónica Directores: Dr. Alfonso García Santos y Dr. Antonio Rodríguez Rodríguez. Doctorando: D. Francisco Lora Toro 


\section{FICHA DE ENSAYOS DE MADERA Y ACIDOS}

\section{ACIDO A05/FM/ACIDO FÓRMICO}
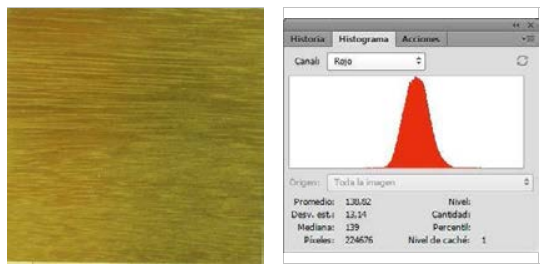

SIN TRATAR (ST): Grafica R (ST)

Valor R(ST):

138,82
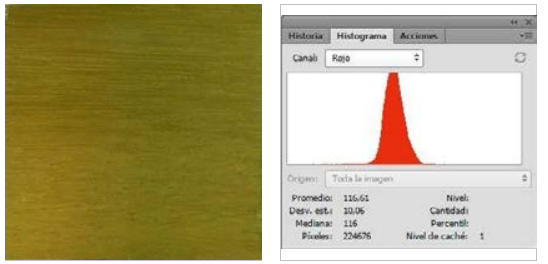

TRATADA (TT): Grafica $R(T T)$

Valor $\mathrm{R}(\mathrm{TT})$ :

116,61

DIFERENCIA (DF) Grafica R (DF): Valor DF-R: 22,21

GRAFICA:

\section{LEYENDA}

ST MADERA SIN TRATAR

Grafica R Histograma color Rojo Grafica G Histograma color Verde Grafica B Histograma color Azul Grafica L Histograma Luminosidad Grafica C Histograma RGB

TT MADERA TRATADA

Valor R Número pixeles color Rojo Valor G Número pixeles color Verde Valor B Número pixeles color Azul Valor $L$ Número pixeles Luminosidad Valor C Número pixeles RG DF DIFERENCIA DE VALORES R;G; $\mathrm{DF}=$ Valor $\mathrm{ST}(\mathrm{R} ; \mathrm{G} ; \mathrm{B})$ - Valor $\mathrm{TT}(\mathrm{R} ; \mathrm{G} ; \mathrm{B}$
MADERA M18/IK/IROKO
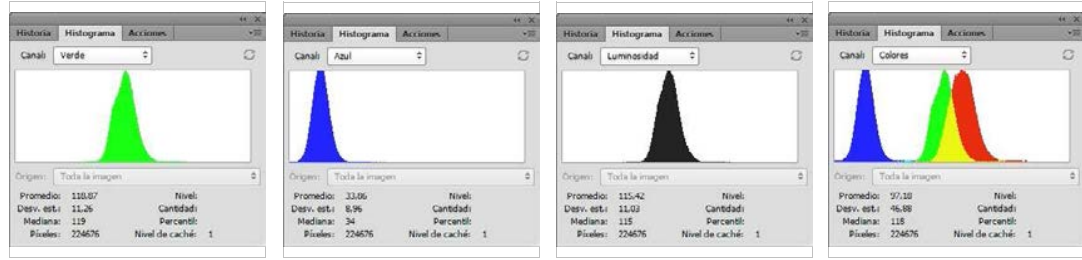

\section{Grafica G (ST)}

Grafica B (ST)

Grafica L (ST)

Grafica C (ST)

Valor $\mathrm{G}(\mathrm{ST})$ :

Valor B(ST):

Valor L(ST):

Valor C(ST):

118,87

33,86

115,42

97,18
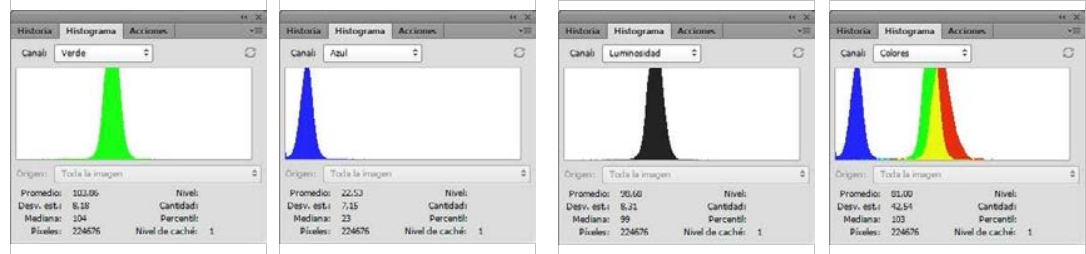

Grafica G (TT) Grafica B (TT)

Grafica L (TT)

Grafica C (TT)

Valor $\mathrm{G}(\mathrm{TT})$ :

Valor $\mathrm{B}(\mathrm{TT})$ :

Valor L(TT):

Valor C(TT):

103,86

22,53

98,68

81,00

Grafica G (DF): Grafica B (DF): Grafica L (DF): Grafica C (DF): Valor DF-G: Valor DF-B: Valor DF-L: Valor DF-C: 15,01 11,33 16,74 16,18 


\section{FICHA DE ENSAYOS DE MADERA Y ACIDOS}

\section{ACIDO A05/FM/ACIDO FÓRMICO}
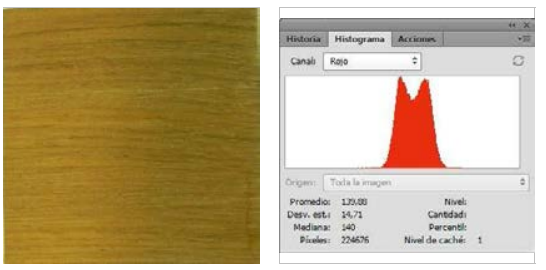

SIN TRATAR (ST): Grafica R (ST)

Valor R(ST):

139,88
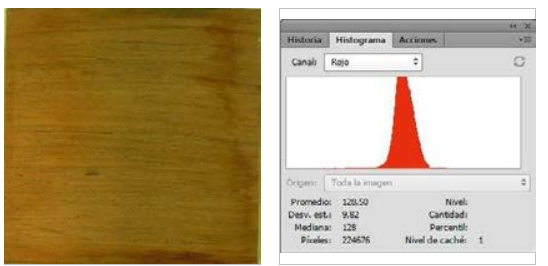

TRATADA (TT): Grafica $R(T T)$

Valor $\mathrm{R}(\mathrm{TT})$ :

128,50

DIFERENCIA (DF) Grafica R (DF): Valor DF-R: 11,38

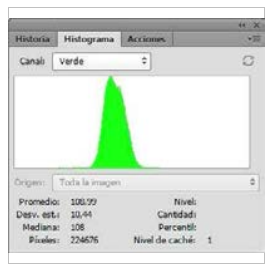

Grafica G (ST)

Valor G(ST):

108,99

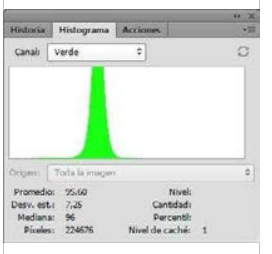

Grafica G (TT)

Valor $\mathrm{G}(\mathrm{TT})$ :

95,60

\section{MADERA M19/JT/JATOBA}

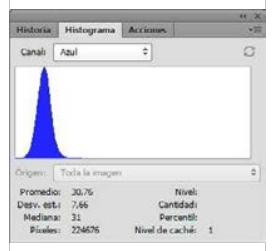

Grafica B (ST)

Valor B(ST):

30,76

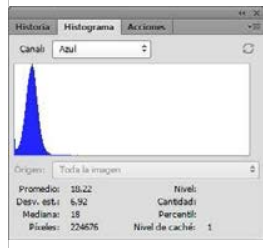

Grafica B (TT)

Valor $\mathrm{B}(\mathrm{TT})$ :

18,22

Grafica G (DF): Grafica B (DF): Valor DF-B: 12,54
13,39

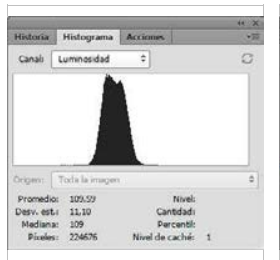

Grafica L (ST)

Valor L(ST):

109,59

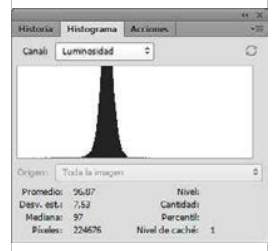

Grafica L (TT)

Valor L(TT):

96,87

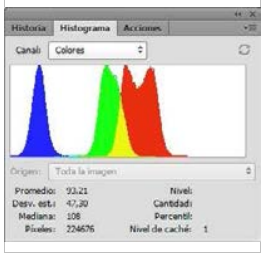

Grafica C (ST)

Valor C(ST):

93,21

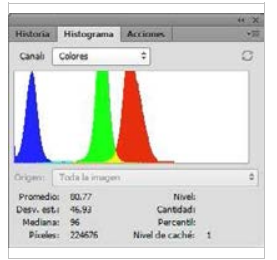

Grafica C (TT)

Valor C(TT):

80,77

\section{LEYENDA}

ST MADERA SIN TRATAR

Grafica R Histograma color Rojo

Grafica G Histograma color Verde

Grafica B Histograma color Azul

Grafica L Histograma Luminosidad

Grafica C Histograma RGB

\section{TT MADERA TRATADA}

Valor R Número pixeles color Rojo

Valor G Número pixeles color Verde

Valor B Número pixeles color Azul

Valor $L$ Número pixeles Luminosidad

Valor C Número pixeles RG

DF DIFERENCIA DE VALORES R;G; $\mathrm{DF}=$ Valor $\mathrm{ST}(\mathrm{R} ; \mathrm{G} ; \mathrm{B})$ - Valor TT(R;G;B
Grafica L (DF): Valor DF-L:
Grafica C (DF): Valor DF-C: 


\section{FICHA DE ENSAYOS DE MADERA Y ACIDOS}

\section{ACIDO A05/FM/ACIDO FÓRMICO}
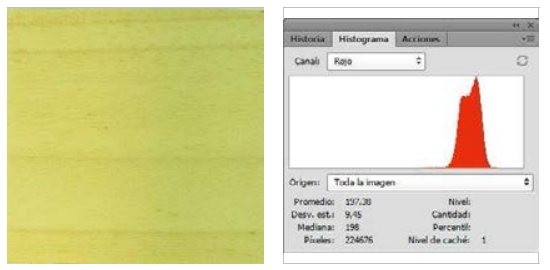

SIN TRATAR (ST): Grafica R (ST)

Valor R(ST):

197,38

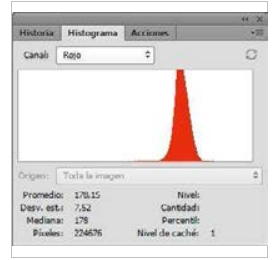

TRATADA (TT): Grafica R (TT)

Valor $\mathrm{R}(\mathrm{TT})$ :

178,15

DIFERENCIA (DF) Grafica R (DF): Valor DF-R: 19,23

GRAFICA:

\section{LEYENDA}

ST MADERA SIN TRATAR

Grafica R Histograma color Rojo Grafica G Histograma color Verde Grafica B Histograma color Azul Grafica L Histograma Luminosidad Grafica C Histograma RGB

\section{TT MADERA TRATADA}

Valor $R$ Número pixeles color Rojo Valor $\mathrm{G}$ Número pixeles color Verde Valor B Número pixeles color Azul Valor $L$ Número pixeles Luminosidad Valor C Número pixeles RG DF DIFERENCIA DE VALORES R;G; $\mathrm{DF}=$ Valor $\mathrm{ST}(\mathrm{R} ; \mathrm{G} ; \mathrm{B})$ - Valor $\mathrm{TT}(\mathrm{R} ; \mathrm{G} ; \mathrm{B}$

\section{MADERA M20/KT/KOTO}
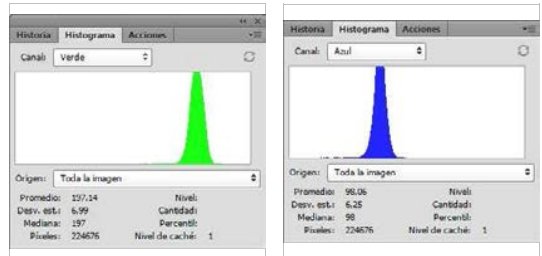

Grafica G (ST)

Grafica B (ST)

Valor B(ST):

98,06
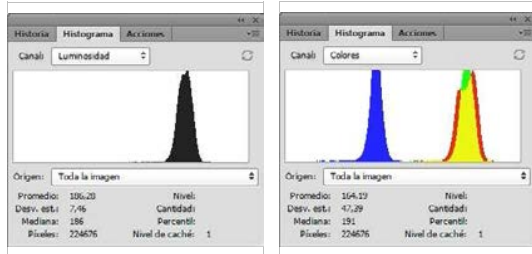

Grafica L (ST)

Grafica C (ST)

Valor G(ST):

197,14

Valor L(ST):

Valor C(ST):

186,28

164,19
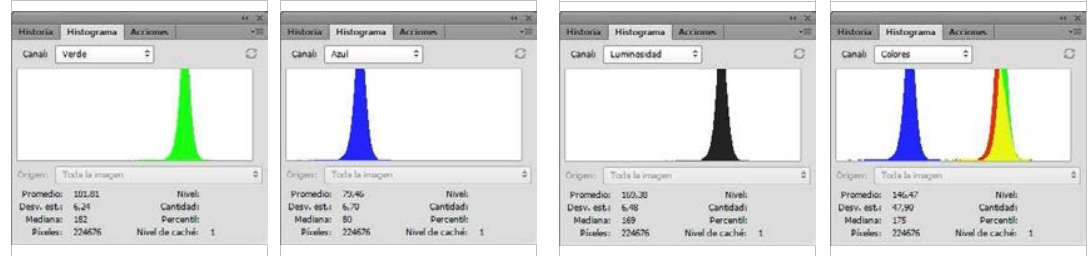

Grafica G (TT)

Grafica B (TT)

Grafica L (TT)

Grafica C (TT)

Valor $\mathrm{G}(\mathrm{TT})$ :

Valor $\mathrm{B}(\mathrm{TT})$ :

Valor L(TT):

Valor $\mathrm{C}(\mathrm{TT})$ :

79,46

169,38

146,47
181,81

Grafica G (DF): Grafica B (DF):

Grafica L (DF):

Grafica C (DF):

Valor DF-G:

Valor DF-B:

Valor DF-L:

Valor DF-C:

15,33

18,60

16,90

17,72

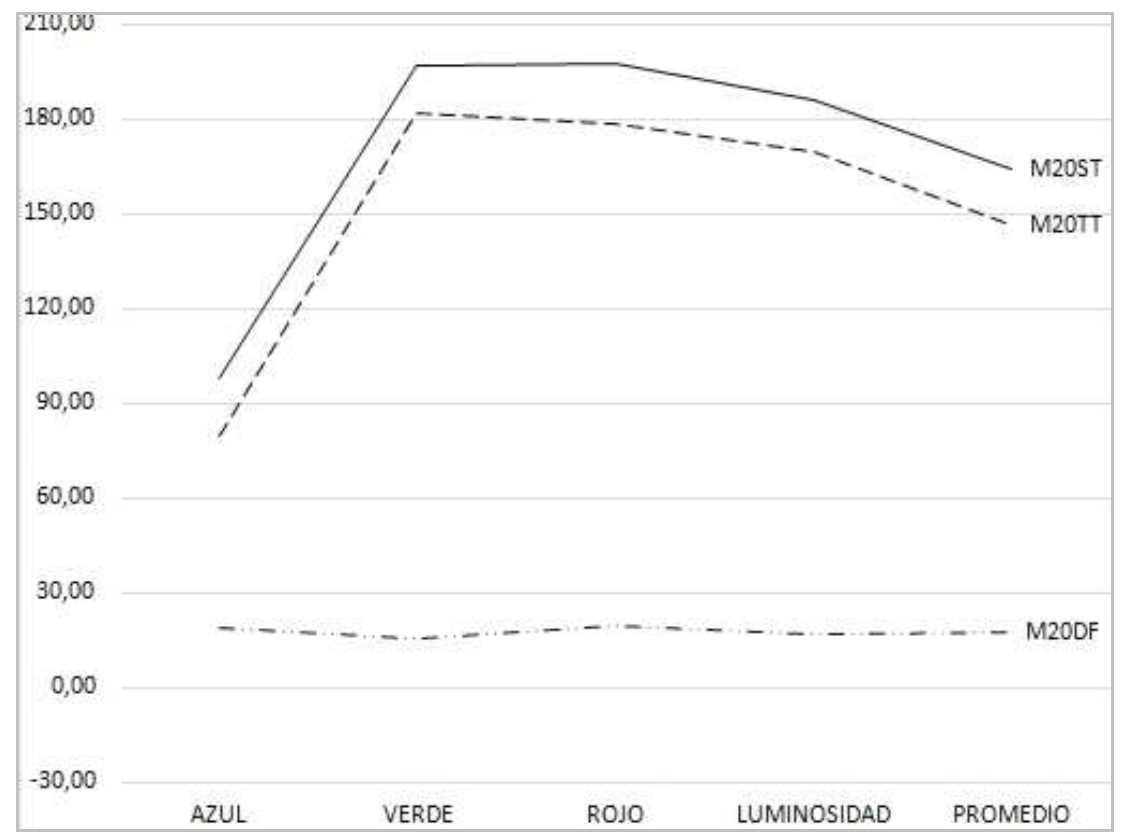

Universidad Politécnica de Madrid - Escuela Técnica Superior de Arquitectura - Departamento de Construcción y Tecnología Arquitectónica Directores: Dr. Alfonso García Santos y Dr. Antonio Rodríguez Rodríguez. Doctorando: D. Francisco Lora Toro 


\section{FICHA DE ENSAYOS DE MADERA Y ACIDOS}

\section{ACIDO A05/FM/ACIDO FÓRMICO}
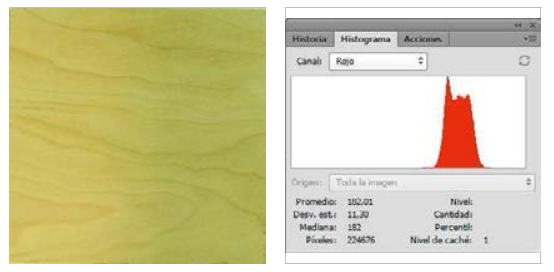

SIN TRATAR (ST): Grafica R (ST)

Valor R(ST):

182,01

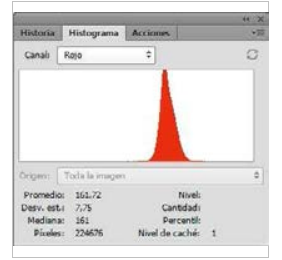

TRATADA (TT): Grafica R (TT)

Valor R(TT):

161,72

DIFERENCIA (DF) Grafica R (DF):

Valor DF-R:

20,29

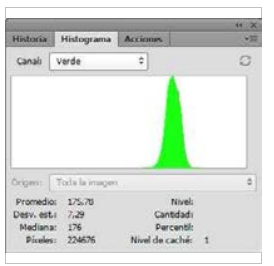

Grafica G (ST)

Valor G(ST):

175,78

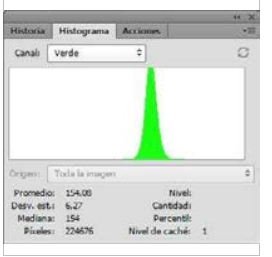

Grafica G (TT)

Valor $\mathrm{G}(\mathrm{TT})$ :

154,08

\section{MADERA M21/LG/LENGA}

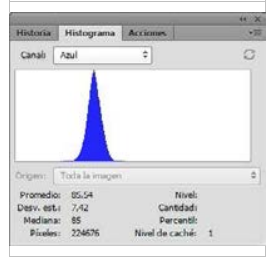

Grafica B (ST)

Valor B(ST):

85,54

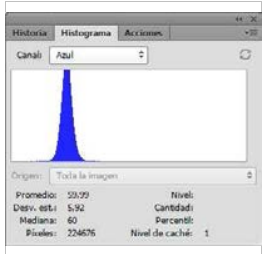

Grafica B (TT)

Valor $\mathrm{B}(\mathrm{TT})$ :

59,99

Grafica G (DF): Grafica B (DF):

Grafica L (DF):

Grafica C (DF):

Valor DF-G:

Valor DF-B:

Valor DF-L:

Valor DF-C:

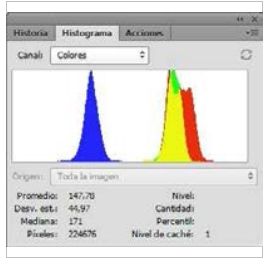

Grafica C (ST)

Valor C(ST):

147,78

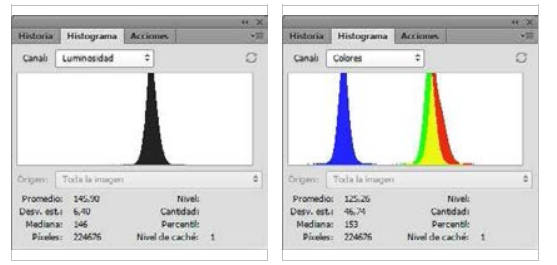

Grafica L (TT) Grafica C (TT)

Valor L(TT): $\quad$ Valor C(TT):

125,26
25,55

22,52

GRAFICA:

\section{LEYENDA}

ST MADERA SIN TRATAR

Grafica R Histograma color Rojo

Grafica G Histograma color Verde

Grafica B Histograma color Azul

Grafica L Histograma Luminosidad

Grafica C Histograma RGB

\section{TT MADERA TRATADA}

Valor $\mathrm{R}$ Número pixeles color Rojo

Valor $\mathrm{G}$ Número pixeles color Verde

Valor B Número pixeles color Azul

Valor L Número pixeles Luminosidad

Valor $C$ Número pixeles RG

DF DIFERENCIA DE VALORES R;G;

$\mathrm{DF}=$ Valor ST(R;G;B) - Valor TT(R;G;B

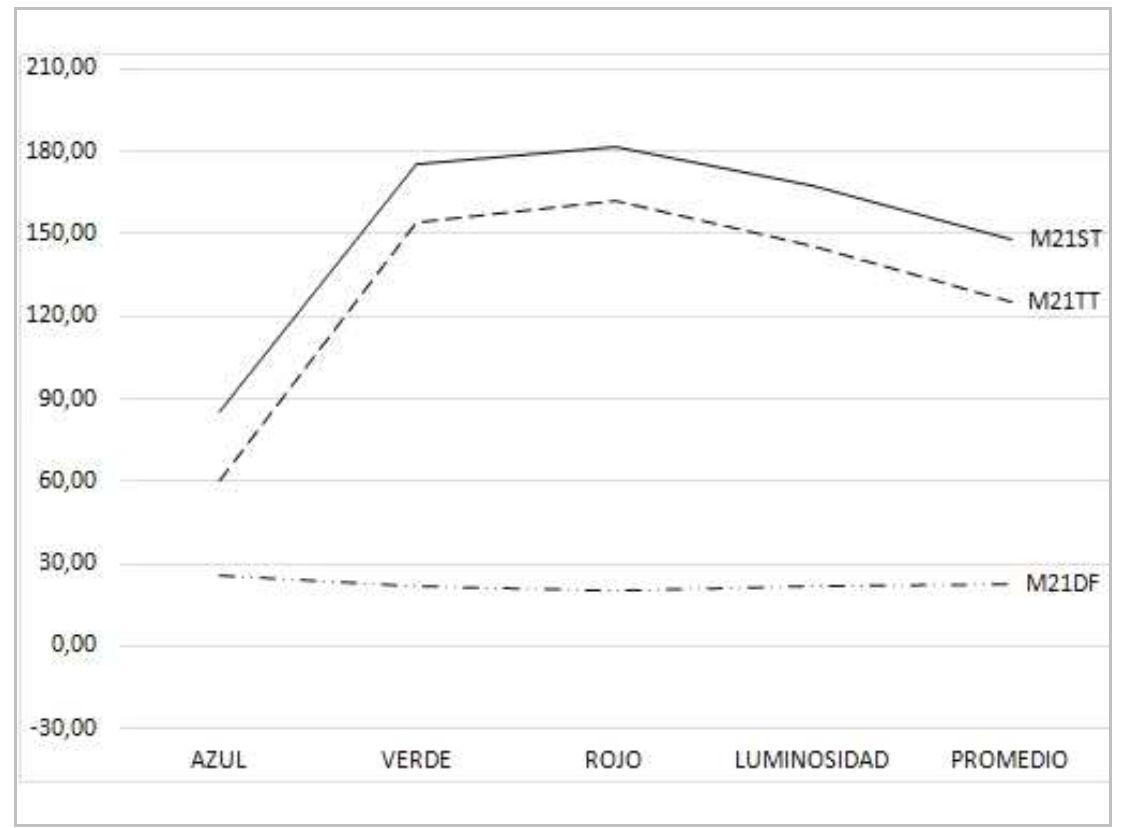

Universidad Politécnica de Madrid - Escuela Técnica Superior de Arquitectura - Departamento de Construcción y Tecnología Arquitectónica Directores: Dr. Alfonso García Santos y Dr. Antonio Rodríguez Rodríguez. Doctorando: D. Francisco Lora Toro 


\section{FICHA DE ENSAYOS DE MADERA Y ACIDOS}

\section{ACIDO A05/FM/ACIDO FÓRMICO}
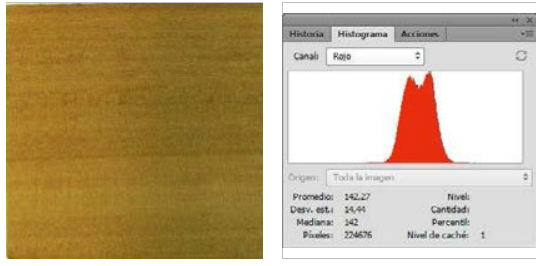

SIN TRATAR (ST): Grafica R (ST)

Valor R(ST):

142,27
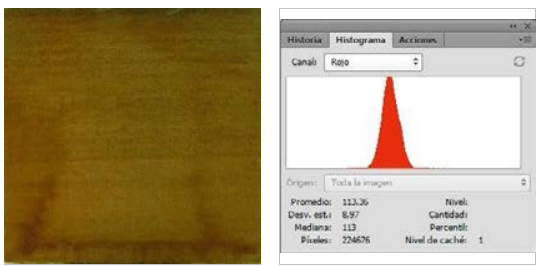

TRATADA (TT): Grafica $R(T T)$

Valor $\mathrm{R}(\mathrm{TT})$ :

113,36

DIFERENCIA (DF) Grafica R (DF): Valor DF-R: 28,91

GRAFICA:

\section{LEYENDA}

ST MADERA SIN TRATAR

Grafica R Histograma color Rojo

Grafica G Histograma color Verde

Grafica B Histograma color Azul

Grafica L Histograma Luminosidad

Grafica C Histograma RGB

\section{TT MADERA TRATADA}

Valor R Número pixeles color Rojo Valor G Número pixeles color Verde Valor B Número pixeles color Azul Valor L Número pixeles Luminosidad Valor C Número pixeles RG DF DIFERENCIA DE VALORES R;G; $\mathrm{DF}=$ Valor $\mathrm{ST}(\mathrm{R} ; \mathrm{G} ; \mathrm{B})$ - Valor TT(R;G;B

\section{MADERA M22/MK/MAKORÉ}

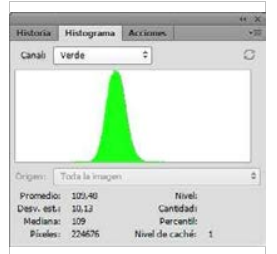

Grafica G (ST)

Valor G(ST):

109,48

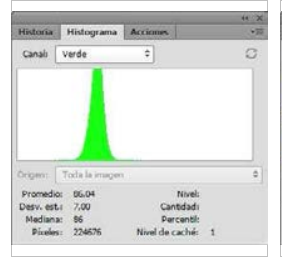

Grafica G (TT)

Valor G(TT):

86,04

Grafica G (DF): Grafica B (DF):

Valor DF-B:

25,71
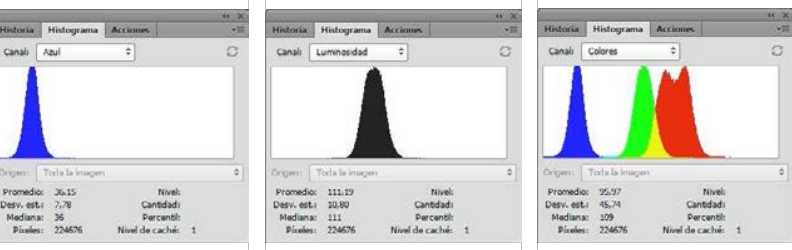

Grafica B (ST)

Grafica L (ST)

Grafica C (ST)

Valor $\mathrm{B}(\mathrm{ST})$ :

Valor L(ST):

Valor C(ST):

36,15

111,19

95,97
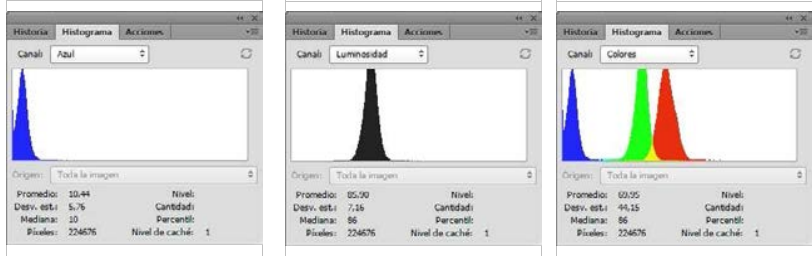

Grafica L (TT)

Grafica C (TT)

Valor $\mathrm{B}(\mathrm{TT})$ :

Valor L(TT):

Valor C(TT):

85,90

69,95

Grafica L (DF): Grafica C (DF): Valor DF-L: Valor DF-C:

$\begin{array}{llll}23,44 & 25,71 & 25,29 & 26,02\end{array}$

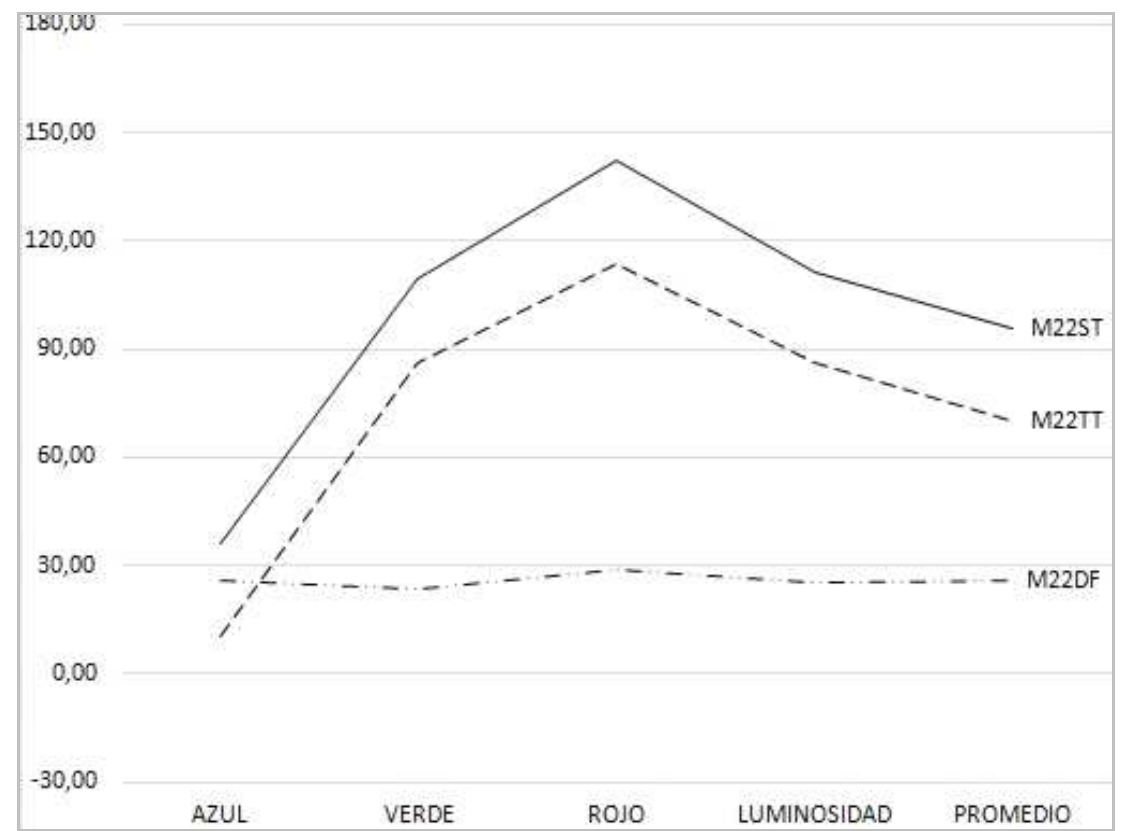

Universidad Politécnica de Madrid - Escuela Técnica Superior de Arquitectura - Departamento de Construcción y Tecnología Arquitectónica Directores: Dr. Alfonso García Santos y Dr. Antonio Rodríguez Rodríguez. Doctorando: D. Francisco Lora Toro 


\section{FICHA DE ENSAYOS DE MADERA Y ACIDOS}

\section{ACIDO A05/FM/ACIDO FÓRMICO}
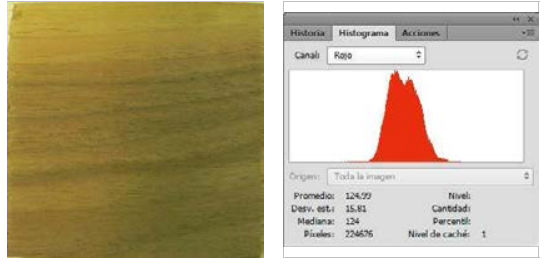

SIN TRATAR (ST): Grafica R (ST)

Valor R(ST):

124,99

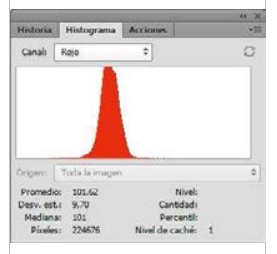

Grafica R (TT)

Valor $\mathrm{R}(\mathrm{TT})$ :

101,62

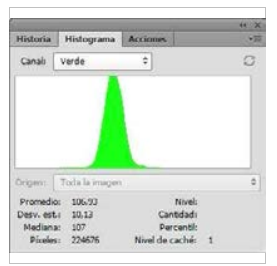

Grafica G (ST)

Valor $\mathrm{G}(\mathrm{ST})$ :

106,93

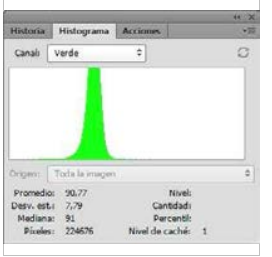

Grafica G (TT)

Valor $\mathrm{G}(\mathrm{TT})$ :

90,77
MADERA M23/NGA/NOGAL NEGRO AMERICANO

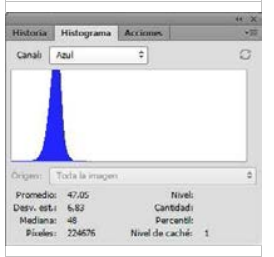

Grafica B (ST)

Valor B(ST):

47,05

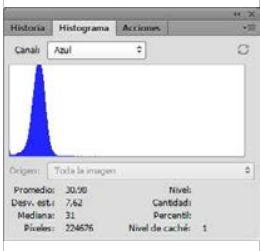

Grafica B (TT)

Valor $\mathrm{B}(\mathrm{TT})$ :

30,98

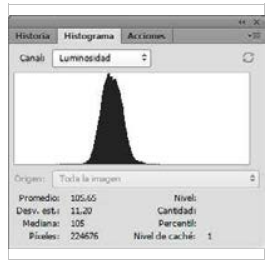

Grafica L (ST)

Valor L(ST):

105,65

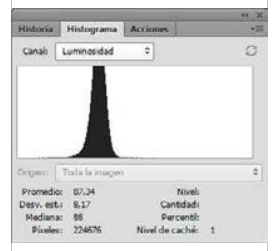

Grafica L (TT)

Valor L(TT):

87,34

Grafica L (DF):

Valor DF-L:

18,31

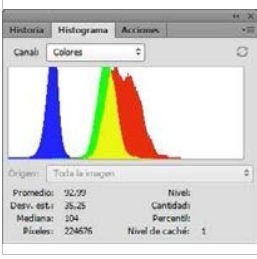

Grafica C (ST)

Valor C(ST):

92,99

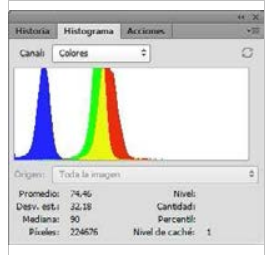

Grafica C (TT)

Valor C(TT):

74,46

DIFERENCIA (DF) Grafica R (DF):

Grafica G (DF): Grafica B (DF): Valor DF-B:

16,16 16,07

23,37

Valor DF-G:

18,31

18,53

Grafica C (DF):

Valor DF-C:

\section{GRAFICA:}

\section{LEYENDA}

ST MADERA SIN TRATAR

Grafica R Histograma color Rojo

Grafica G Histograma color Verde

Grafica B Histograma color Azul

Grafica L Histograma Luminosidad

Grafica C Histograma RGB

\section{TT MADERA TRATADA}

Valor R Número pixeles color Rojo

Valor G Número pixeles color Verde

Valor B Número pixeles color Azul

Valor $L$ Número pixeles Luminosidad

Valor $C$ Número pixeles $R G$

DF DIFERENCIA DE VALORES R;G; $\mathrm{DF}=$ Valor $\mathrm{ST}(\mathrm{R} ; \mathrm{G} ; \mathrm{B})$ - Valor TT $(\mathrm{R} ; \mathrm{G} ; \mathrm{B}$

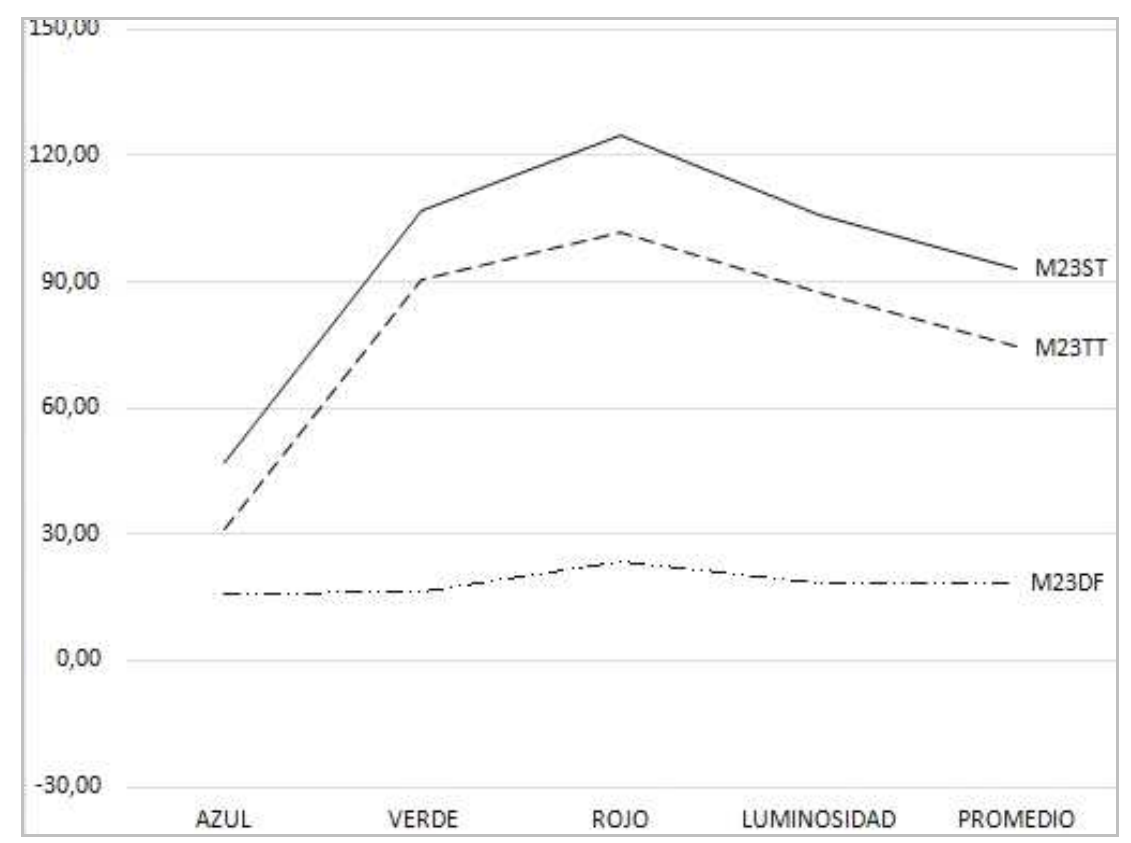

Universidad Politécnica de Madrid - Escuela Técnica Superior de Arquitectura - Departamento de Construcción y Tecnología Arquitectónica Directores: Dr. Alfonso García Santos y Dr. Antonio Rodríguez Rodríguez. Doctorando: D. Francisco Lora Toro 


\section{FICHA DE ENSAYOS DE MADERA Y ACIDOS}

\section{ACIDO A05/FM/ACIDO FÓRMICO}
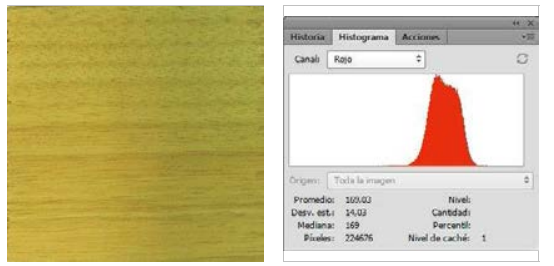

SIN TRATAR (ST): Grafica R (ST)

Valor R(ST):

169,03

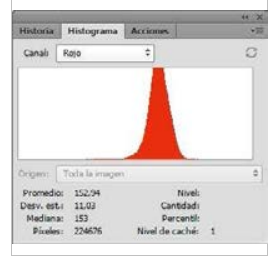

TRATADA (TT): Grafica R (TT)

Valor $\mathrm{R}(\mathrm{TT})$ :

152,94

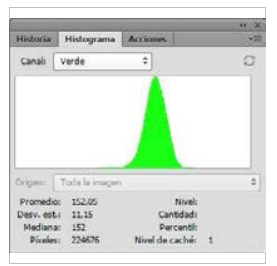

Grafica G (ST)

Valor G(ST):

152,05

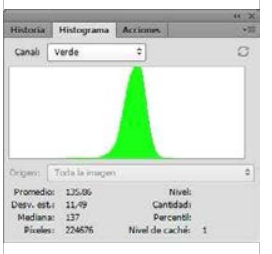

Grafica G (TT)

Valor $\mathrm{G}(\mathrm{TT})$ :

135,86
MADERA M24/OK/OKUMÉ

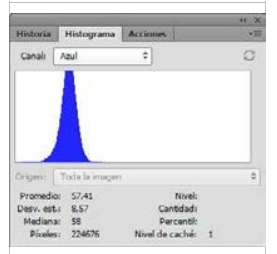

Grafica B (ST)

Valor B(ST):

57,41

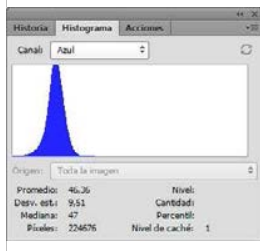

Grafica B (TT)

Valor $\mathrm{B}(\mathrm{TT})$ :

46,36

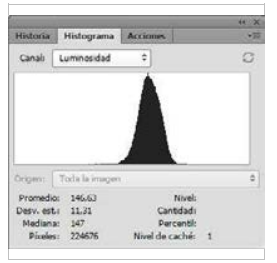

Grafica L (ST)

Valor L(ST):

146,63

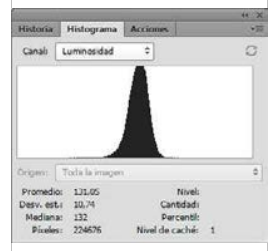

Grafica L (TT)

Valor L(TT):

131,05

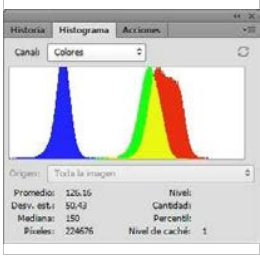

Grafica C (ST)

Valor C(ST):

126,16

DIFERENCIA (DF) Grafica R (DF):

Grafica G (DF): Grafica B (DF):

Grafica L (DF):

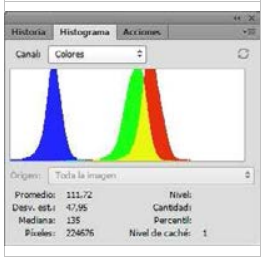

Valor DF-R:

Valor DF-G:

Valor DF-B:

Valor DF-L:

Grafica C (TT)

16,09

16,19

11,05

15,58

Valor C(TT):

111,72

Grafica C (DF):

Valor DF-C:

14,44

\section{LEYENDA}

ST MADERA SIN TRATAR

Grafica R Histograma color Rojo

Grafica G Histograma color Verde

Grafica B Histograma color Azul

Grafica L Histograma Luminosidad

Grafica C Histograma RGB

\section{TT MADERA TRATADA}

Valor R Número pixeles color Rojo

Valor $\mathrm{G}$ Número pixeles color Verde

Valor B Número pixeles color Azul

Valor L Número pixeles Luminosidad

Valor C Número pixeles RG

DF DIFERENCIA DE VALORES R;G; $\mathrm{DF}=$ Valor $\mathrm{ST}(\mathrm{R} ; \mathrm{G} ; \mathrm{B})$ - Valor $\mathrm{TT}(\mathrm{R} ; \mathrm{G} ; \mathrm{B}$

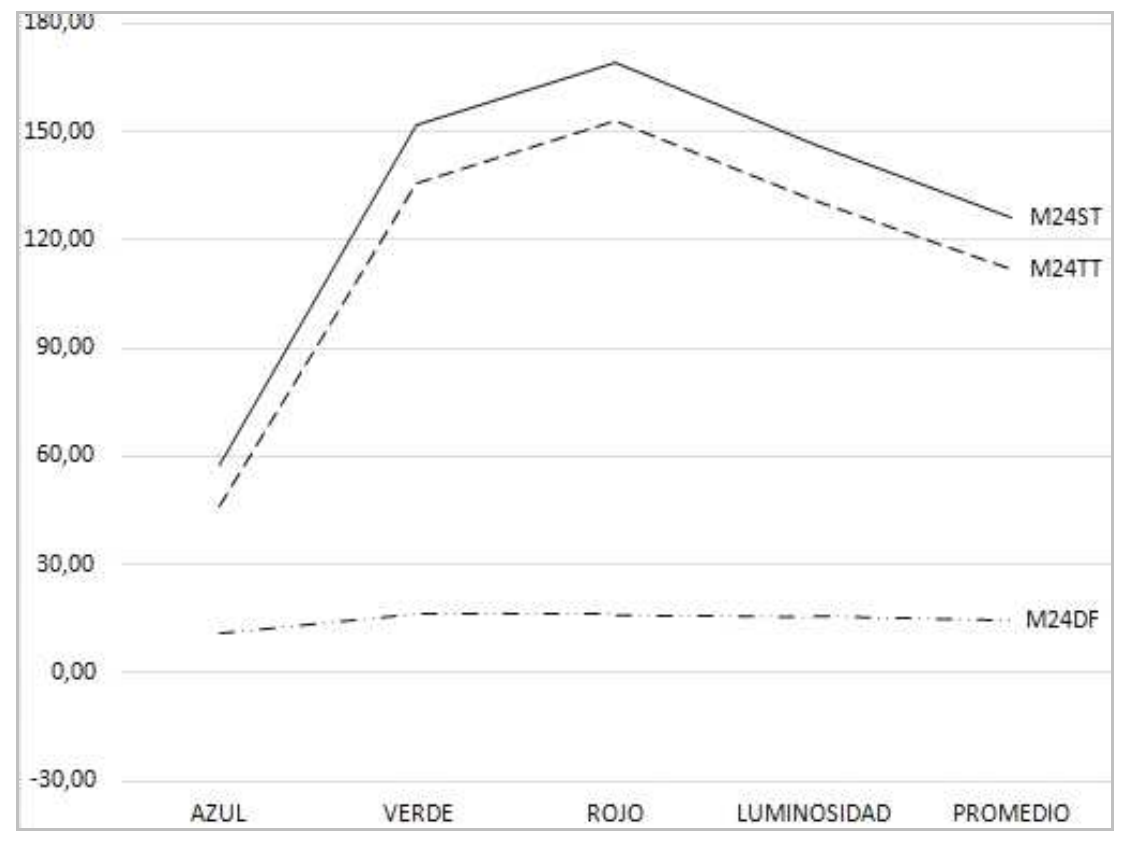

Universidad Politécnica de Madrid - Escuela Técnica Superior de Arquitectura - Departamento de Construcción y Tecnología Arquitectónica Directores: Dr. Alfonso García Santos y Dr. Antonio Rodríguez Rodríguez. Doctorando: D. Francisco Lora Toro 


\section{FICHA DE ENSAYOS DE MADERA Y ACIDOS}

\section{ACIDO A05/FM/ACIDO FÓRMICO}
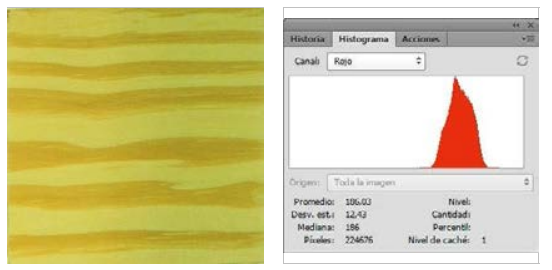

SIN TRATAR (ST): Grafica R (ST)

Valor R(ST):

186,03

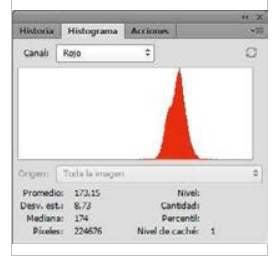

TRATADA (TT): Grafica $R(T T)$

Valor $\mathrm{R}(\mathrm{TT})$ :

173,15

DIFERENCIA (DF) Grafica R (DF): Valor DF-R: 12,88

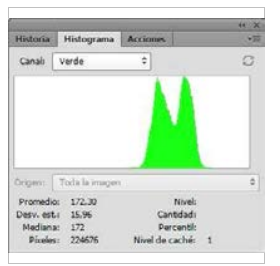

Grafica G (ST)

Valor $\mathrm{G}(\mathrm{ST})$ :

172,30

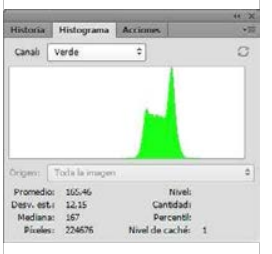

Grafica G (TT)

Valor G(TT):

165,46
MADERA M25/PX/PINO AMARILLO DEL SUR

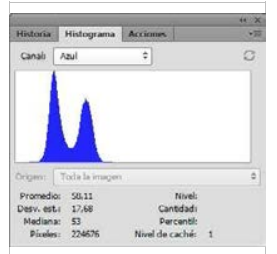

Grafica B (ST)

Valor B(ST):

58,11

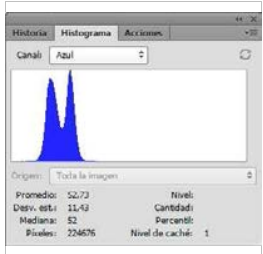

Grafica B (TT)

Valor B(TT):

52,73

Grafica G (DF): Grafica B (DF):

Valor DF-B:
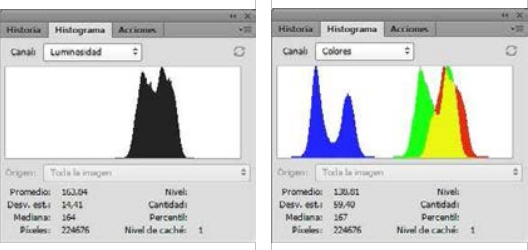

Grafica L (ST)

Grafica C (ST)

Valor L(ST):

Valor C(ST):

163,84

138,81
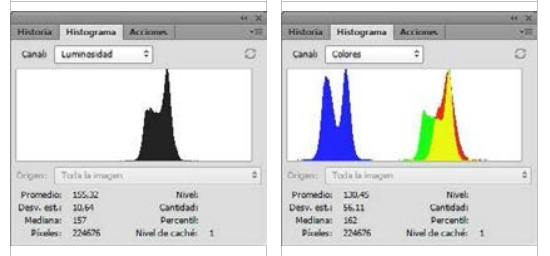

Grafica L (TT)

Grafica C (TT)

Valor L(TT):

Valor $\mathrm{C}(\mathrm{TT})$ :

155,32

130,45

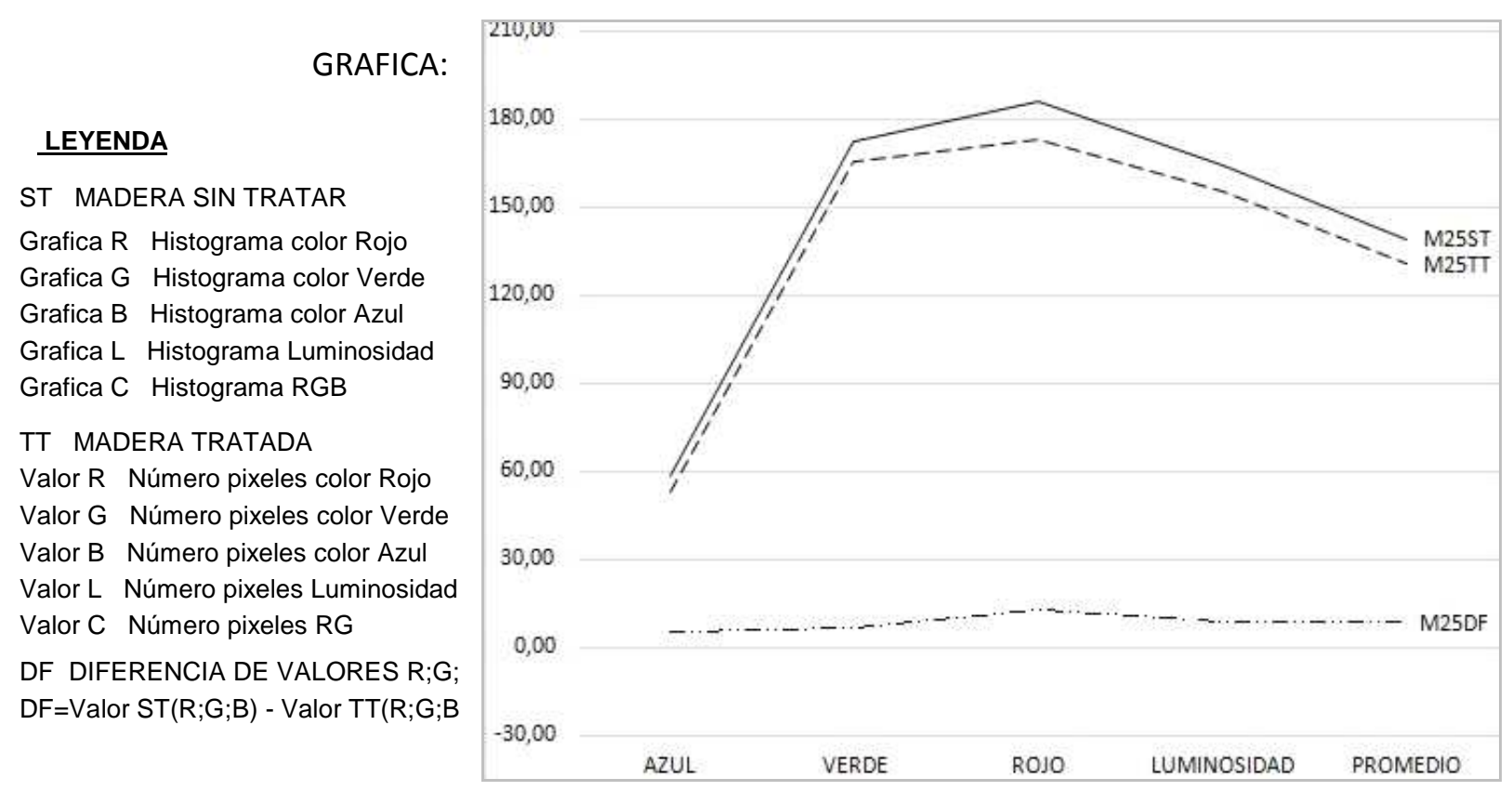

Universidad Politécnica de Madrid - Escuela Técnica Superior de Arquitectura - Departamento de Construcción y Tecnología Arquitectónica Directores: Dr. Alfonso García Santos y Dr. Antonio Rodríguez Rodríguez. Doctorando: D. Francisco Lora Toro 


\section{FICHA DE ENSAYOS DE MADERA Y ACIDOS}

\section{ACIDO A05/FM/ACIDO FÓRMICO}
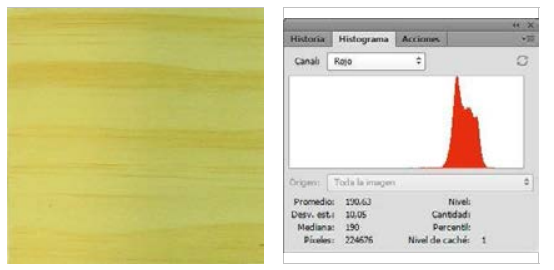

SIN TRATAR (ST): Grafica R (ST)

Valor R(ST):

190,63

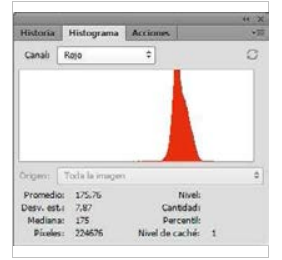

TRATADA (TT): Grafica R (TT)

Valor $\mathrm{R}(\mathrm{TT})$ :

175,76

DIFERENCIA (DF) Grafica R (DF): Valor DF-R:

14,87

GRAFICA:

\section{LEYENDA}

ST MADERA SIN TRATAR

Grafica R Histograma color Rojo

Grafica G Histograma color Verde

Grafica B Histograma color Azul

Grafica L Histograma Luminosidad

Grafica C Histograma RGB

\section{TT MADERA TRATADA}

Valor R Número pixeles color Rojo

Valor $\mathrm{G}$ Número pixeles color Verde

Valor B Número pixeles color Azul

Valor $L$ Número pixeles Luminosidad

Valor C Número pixeles RG

DF DIFERENCIA DE VALORES R;G; $\mathrm{DF}=$ Valor $\mathrm{ST}(\mathrm{R} ; \mathrm{G} ; \mathrm{B})$ - Valor TT $(\mathrm{R} ; \mathrm{G} ; \mathrm{B}$

\section{MADERA M26/PR/PINO RADIATA}
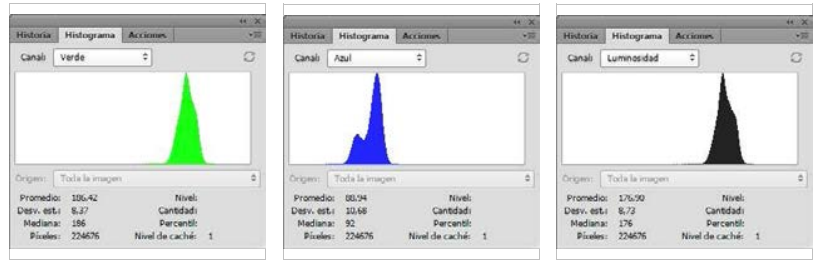

Grafica G (ST)

Grafica B (ST)

Grafica L (ST)

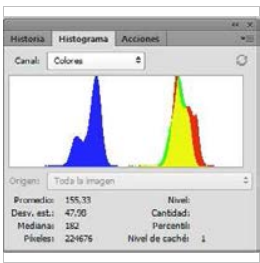

Valor $\mathrm{G}(\mathrm{ST})$ :

Valor B(ST):

Valor L(ST):

Grafica C (ST)

186,42

88,94

176,90

Valor C(ST):

155,33
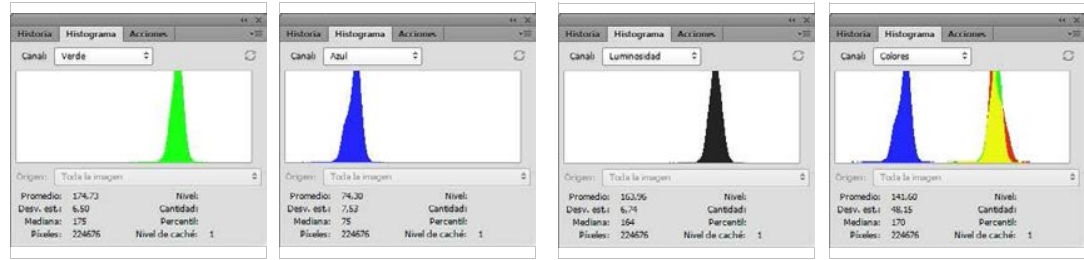

\section{Grafica G (TT)}

Grafica B (TT)

Grafica L (TT)

Grafica C (TT)

Valor $\mathrm{G}(\mathrm{TT})$ :

Valor $\mathrm{B}(\mathrm{TT})$ :

Valor L(TT):

Valor C(TT):

174,73

74,30

163,96

141,60

\section{Grafica G (DF): Grafica B (DF): Grafica L (DF):}

Grafica C (DF):

Valor DF-G: Valor DF-B:

Valor DF-L:

Valor DF-C:

11,69

14,64

12,94

13,73

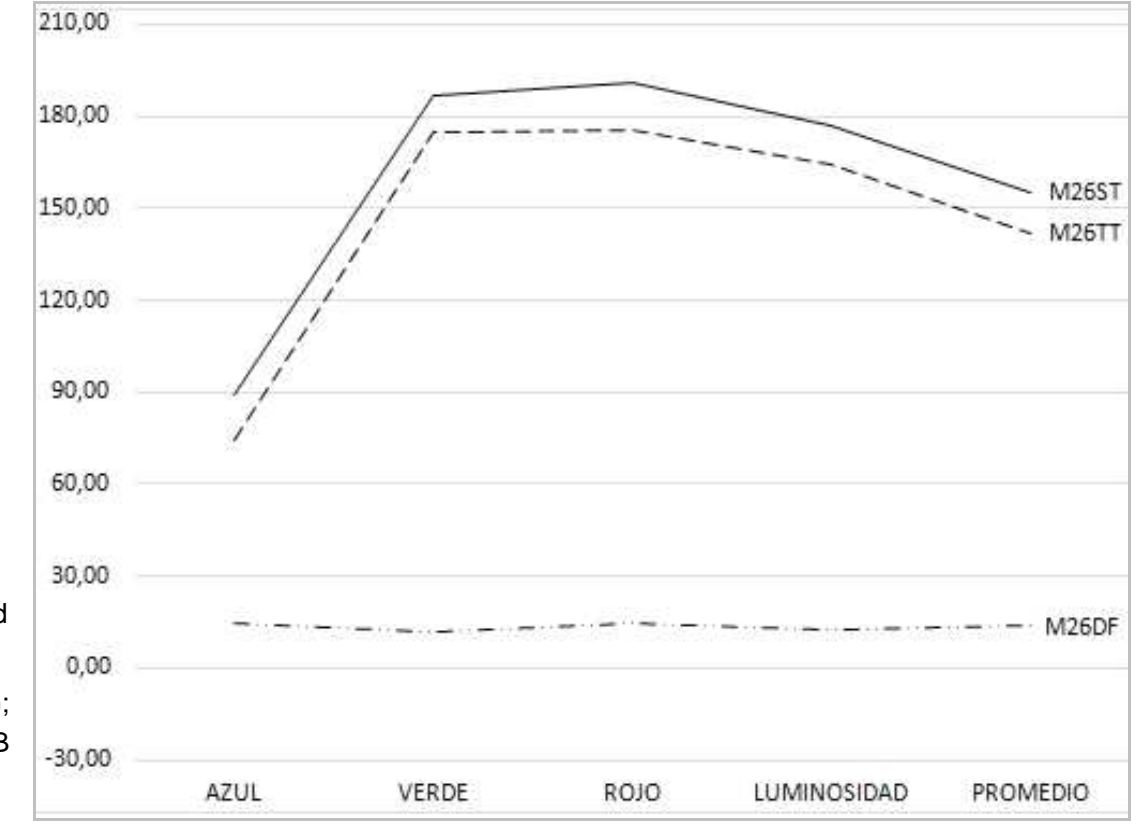

Universidad Politécnica de Madrid - Escuela Técnica Superior de Arquitectura - Departamento de Construcción y Tecnología Arquitectónica Directores: Dr. Alfonso García Santos y Dr. Antonio Rodríguez Rodríguez. Doctorando: D. Francisco Lora Toro 


\section{FICHA DE ENSAYOS DE MADERA Y ACIDOS}

\section{ACIDO A05/FM/ACIDO FÓRMICO}
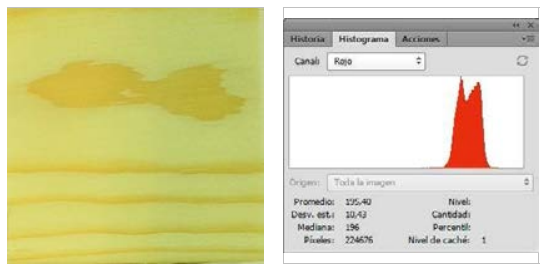

SIN TRATAR (ST): Grafica R (ST)

Valor R(ST):

195,40

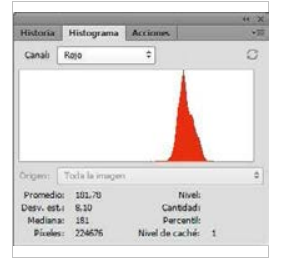

TRATADA (TT): Grafica R (TT)

Valor $\mathrm{R}(\mathrm{TT})$ :

181,78

DIFERENCIA (DF) Grafica R (DF): Valor DF-R:

13,62

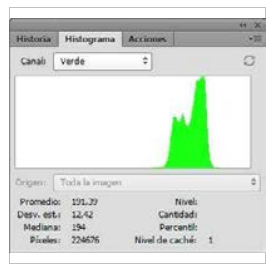

Grafica G (ST)

Valor G(ST):

191,39

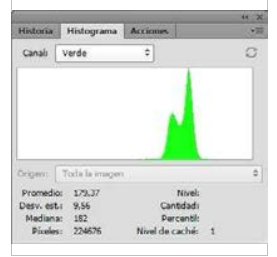

Grafica G (TT)

Valor G(TT):

179,37
MADERA M27/PS/PINO SILVESTRE

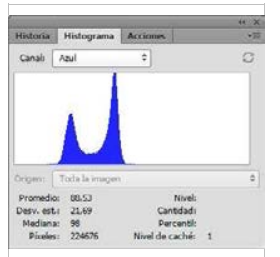

Grafica B (ST)

Valor B(ST):

88,53

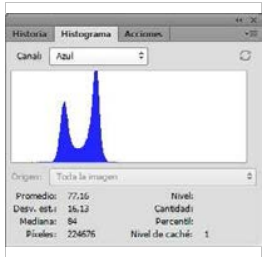

Grafica B (TT)

Valor $\mathrm{B}(\mathrm{TT})$ :

77,16

Grafica G (DF): Grafica B (DF):

Valor DF-B:

11,37

12,02

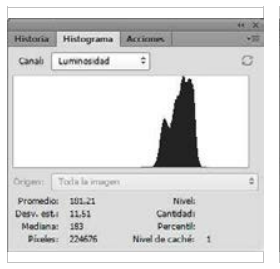

Grafica L (ST)

Valor L(ST):

181,21

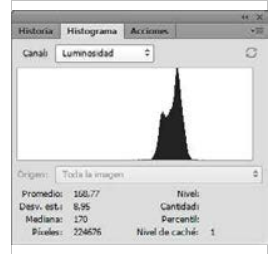

Grafica L (TT)

Valor L(TT):

168,77

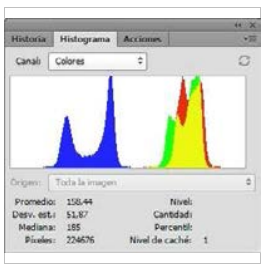

Grafica C (ST)

Valor C(ST):

158,44

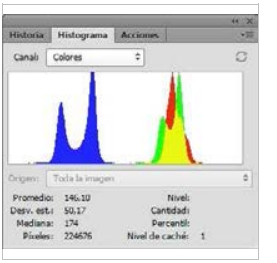

Grafica C (TT)

Valor C(TT):

146,10

Grafica L (DF): Grafica C (DF):

Valor DF-L:

Valor DF-C:

12,44

12,34

GRAFICA:

\section{LEYENDA}

ST MADERA SIN TRATAR

Grafica R Histograma color Rojo

Grafica G Histograma color Verde

Grafica B Histograma color Azul

Grafica L Histograma Luminosidad

Grafica C Histograma RGB

\section{TT MADERA TRATADA}

Valor $\mathrm{R}$ Número pixeles color Rojo

Valor $\mathrm{G}$ Número pixeles color Verde

Valor B Número pixeles color Azul

Valor $L$ Número pixeles Luminosidad

Valor $C$ Número pixeles $R G$

DF DIFERENCIA DE VALORES R;G;

$\mathrm{DF}=$ Valor $\mathrm{ST}(\mathrm{R} ; \mathrm{G} ; \mathrm{B})$ - Valor TT(R;G;B

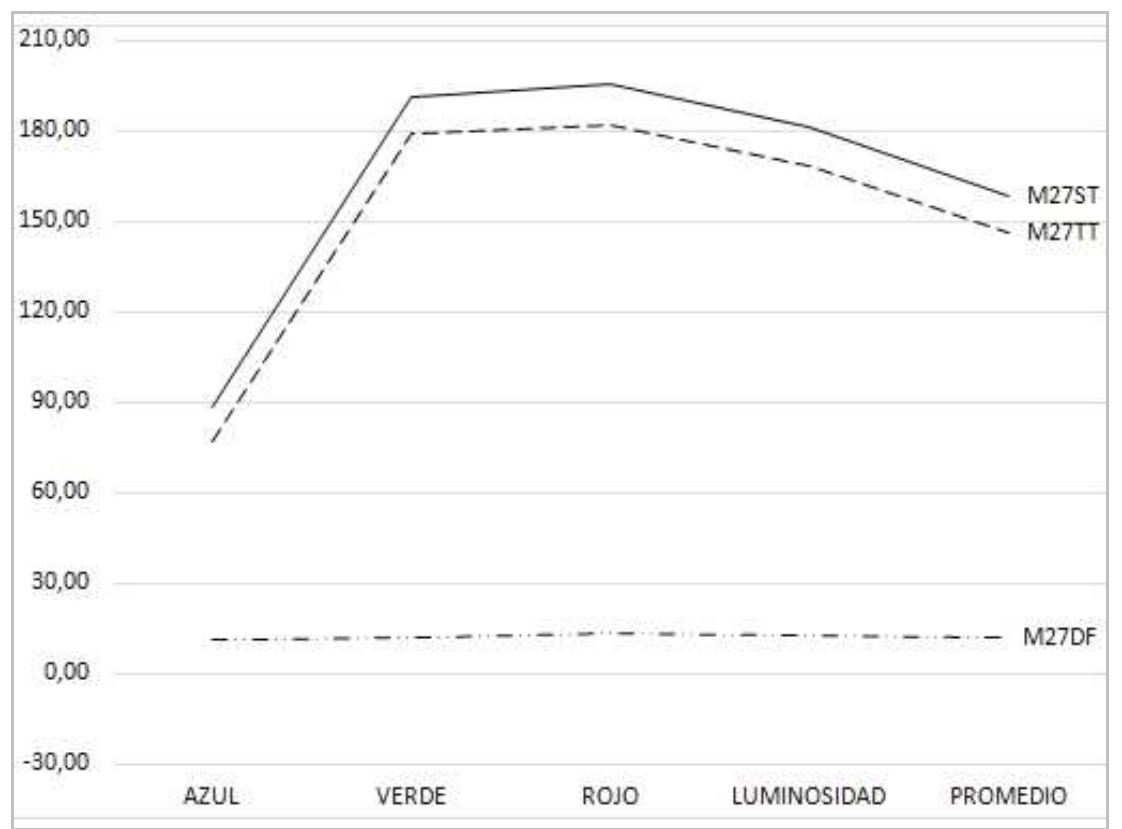

Universidad Politécnica de Madrid - Escuela Técnica Superior de Arquitectura - Departamento de Construcción y Tecnología Arquitectónica Directores: Dr. Alfonso García Santos y Dr. Antonio Rodríguez Rodríguez. Doctorando: D. Francisco Lora Toro 


\section{FICHA DE ENSAYOS DE MADERA y ACIDOS}

\section{ACIDO A05/FM/ACIDO FÓRMICO}
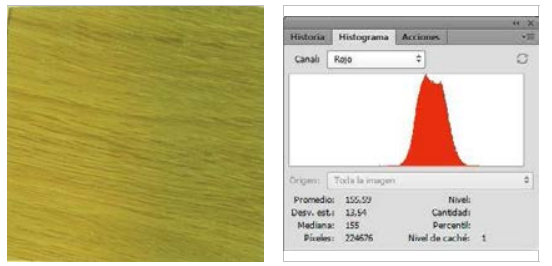

SIN TRATAR (ST): Grafica R (ST)

Valor R(ST):

155,59

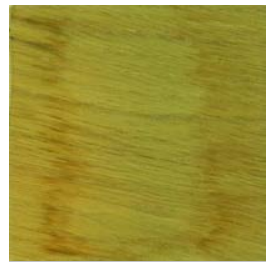

TRATADA (TT):

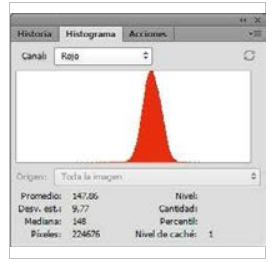

Grafica R (TT)

Valor $\mathrm{R}(\mathrm{TT})$ :

147,86

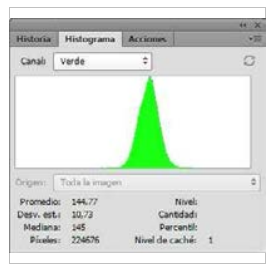

Grafica G (ST)

Valor G(ST):

144,77

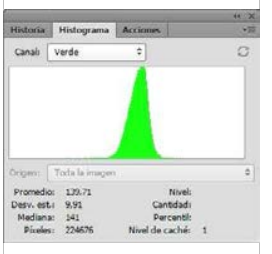

Grafica G (TT)

Valor $\mathrm{G}(\mathrm{TT})$ :

139,71
MADERA M28/RBA/ROBLE BLANCO AMERICANO

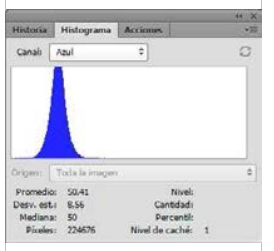

Grafica B (ST)

Valor B(ST):

50,41

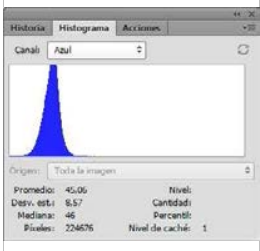

Grafica B (TT)

Valor $\mathrm{B}(\mathrm{TT})$ :

45,06

Grafica G (DF): Grafica B (DF):

Valor DF-B:

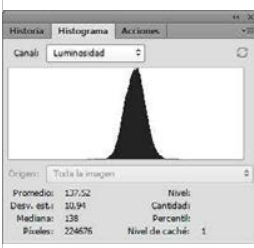

Grafica L (ST)

Valor L(ST):

137,52

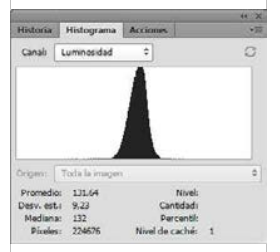

Grafica L (TT)

Valor L(TT):

131,64

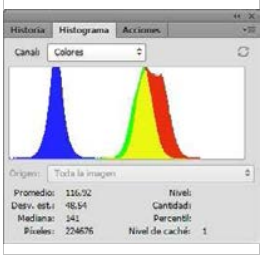

Grafica C (ST)

Valor C(ST):

116,92
DIFERENCIA (DF) Grafica R (DF): Valor DF-R:

Valor DF-G:

Grafica L (DF):

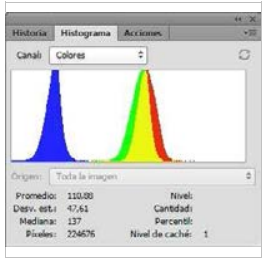

7,73

5,06

5,35

Valor DF-L:

Grafica C (TT)

Valor C(TT):

110,88

Grafica C (DF):

Valor DF-C:

6,04

\section{GRAFICA :}

\section{LEYENDA}

ST MADERA SIN TRATAR

Grafica R Histograma color Rojo

Grafica G Histograma color Verde

Grafica B Histograma color Azul

Grafica L Histograma Luminosidad

Grafica C Histograma RGB

\section{TT MADERA TRATADA}

Valor R Número pixeles color Rojo

Valor G Número pixeles color Verde

Valor B Número pixeles color Azul

Valor $L$ Número pixeles Luminosidad

Valor C Número pixeles RG

DF DIFERENCIA DE VALORES R;G; $\mathrm{DF}=$ Valor $\mathrm{ST}(\mathrm{R} ; \mathrm{G} ; \mathrm{B})$ - Valor $\mathrm{TT}(\mathrm{R} ; \mathrm{G} ; \mathrm{B}$

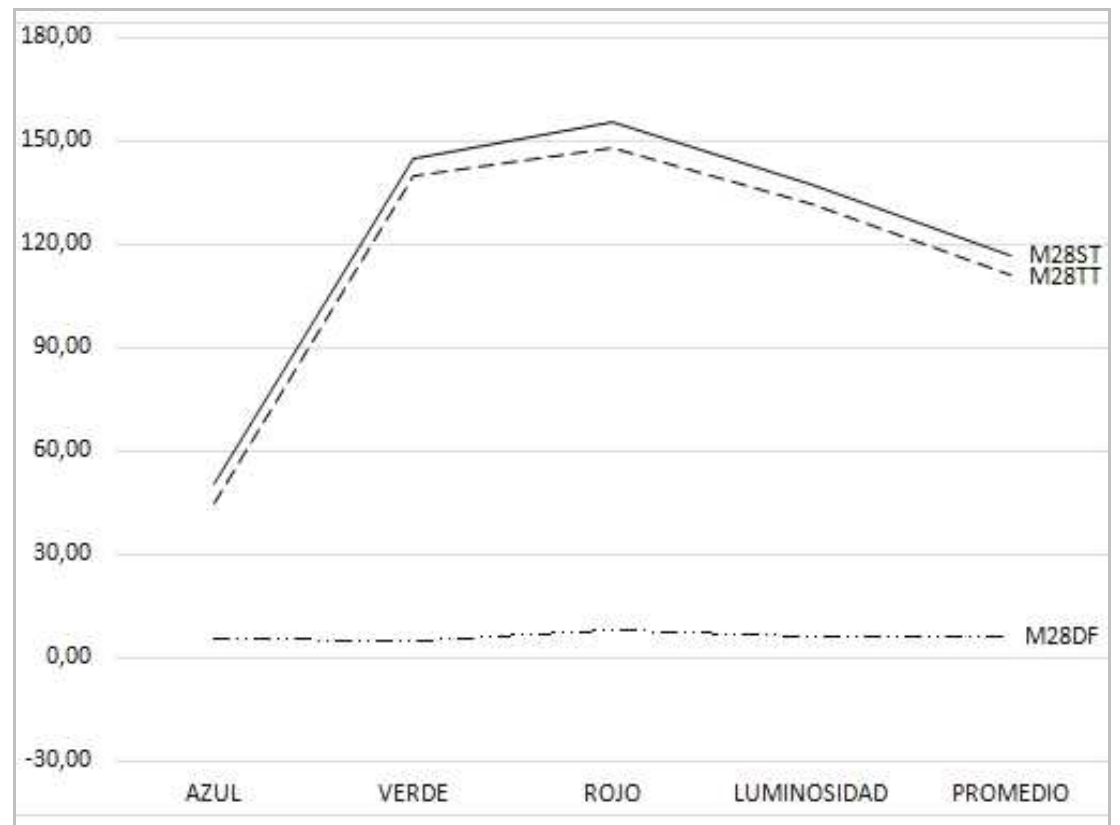

Universidad Politécnica de Madrid - Escuela Técnica Superior de Arquitectura - Departamento de Construcción y Tecnología Arquitectónica Directores: Dr. Alfonso García Santos y Dr. Antonio Rodríguez Rodríguez. Doctorando: D. Francisco Lora Toro 


\section{FICHA DE ENSAYOS DE MADERA y ACIDOS}

\section{ACIDO A05/FM/ACIDO FÓRMICO}
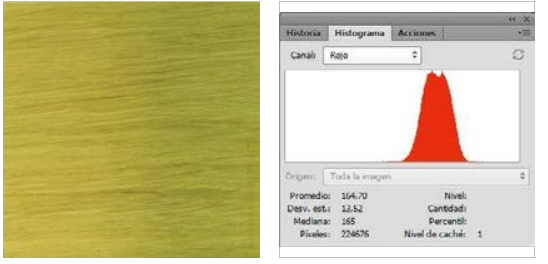

SIN TRATAR (ST): Grafica R (ST)

Valor R(ST):

164,70

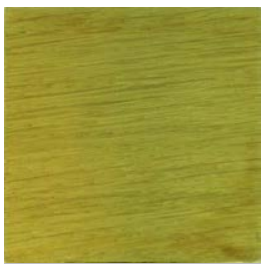

TRATADA (TT):

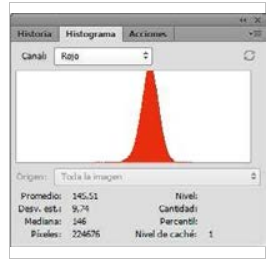

Grafica R (TT)

Valor $\mathrm{R}(\mathrm{TT})$ :

145,51

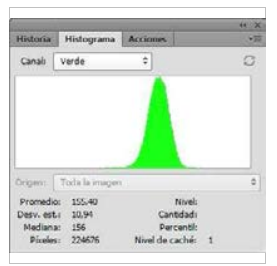

Grafica G (ST)

Valor G(ST):

155,40

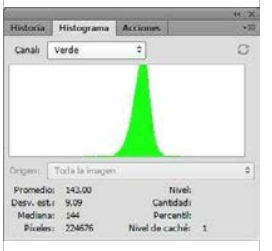

Grafica G (TT)

Valor $\mathrm{G}(\mathrm{TT})$ :

143,00
MADERA M29/RBE/ROBLE BLANCO EUROPEO

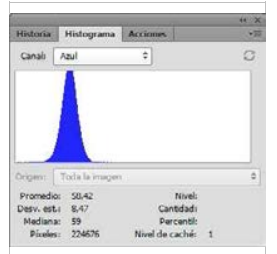

Grafica B (ST)

Valor B(ST):

58,42

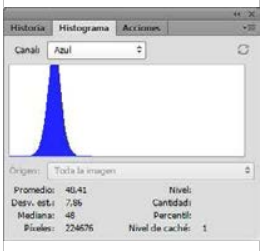

Grafica B (TT)

Valor $\mathrm{B}(\mathrm{TT})$ :

48,41

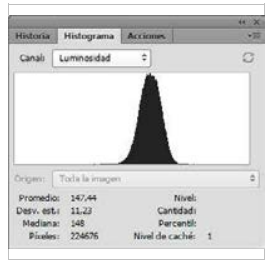

Grafica L (ST)

Valor L(ST):

147,44

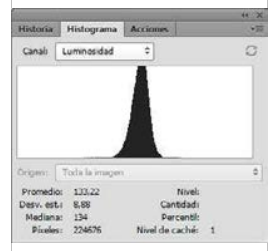

Grafica L (TT)

Valor L(TT):

133,22

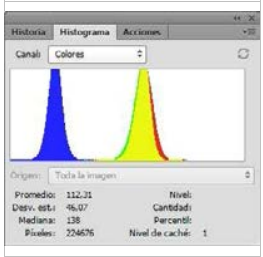

Grafica C (TT)

Valor C(TT):

112,31

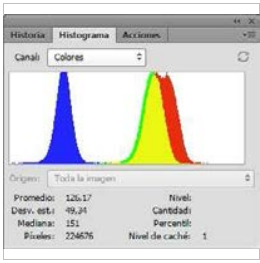

Grafica C (ST)

Valor C(ST):

126,17

DIFERENCIA (DF) Grafica R (DF):

Grafica G (DF): Grafica B (DF):

Grafica L (DF):

Valor DF-R:

Valor DF-G:

Valor DF-B:

Valor DF-L:

19,19

12,40

10,01

14,22

Grafica C (DF):

Valor DF-C:

13,86

\section{LEYENDA}

ST MADERA SIN TRATAR

Grafica R Histograma color Rojo

Grafica G Histograma color Verde

Grafica B Histograma color Azul

Grafica L Histograma Luminosidad

Grafica C Histograma RGB

\section{TT MADERA TRATADA}

Valor R Número pixeles color Rojo

Valor G Número pixeles color Verde

Valor B Número pixeles color Azul

Valor $L$ Número pixeles Luminosidad

Valor C Número pixeles RG

DF DIFERENCIA DE VALORES R;G; $\mathrm{DF}=$ Valor $\mathrm{ST}(\mathrm{R} ; \mathrm{G} ; \mathrm{B})$ - Valor TT(R;G;B

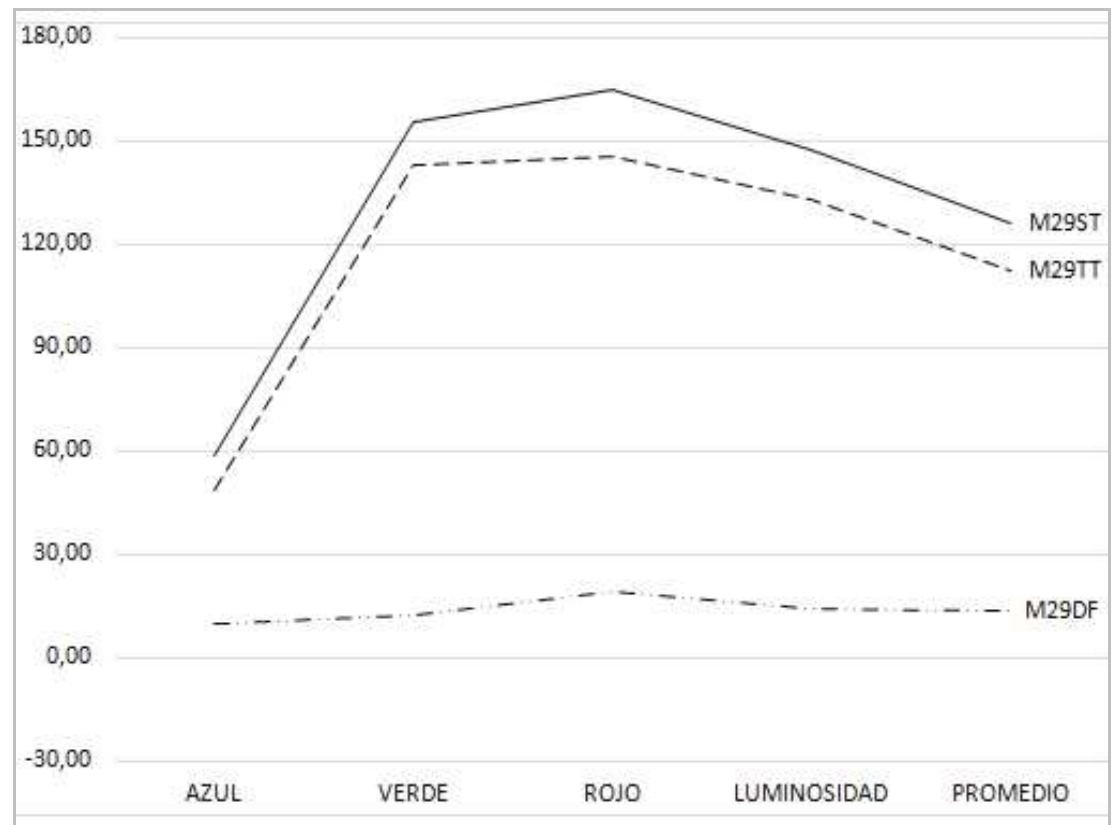

Universidad Politécnica de Madrid - Escuela Técnica Superior de Arquitectura - Departamento de Construcción y Tecnología Arquitectónica Directores: Dr. Alfonso García Santos y Dr. Antonio Rodríguez Rodríguez. Doctorando: D. Francisco Lora Toro 


\section{FICHA DE ENSAYOS DE MADERA Y ACIDOS}

\section{ACIDO A05/FM/ACIDO FÓRMICO}
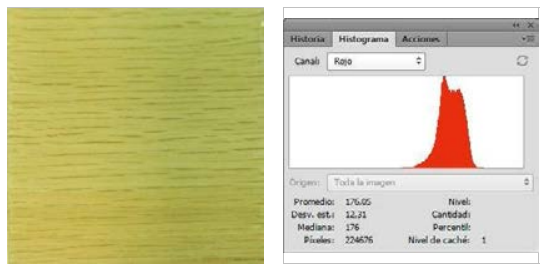

SIN TRATAR (ST): Grafica R (ST)

Valor R(ST):

176,05

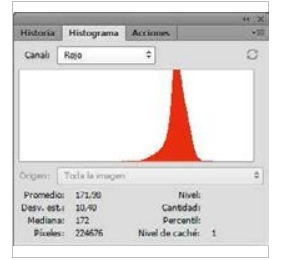

TRATADA (TT): Grafica R (TT)

Valor R(TT):

171,98

DIFERENCIA (DF) Grafica R (DF): Valor DF-R:

4,07

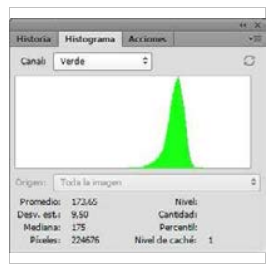

Grafica G (ST)

Valor G(ST):

173,65

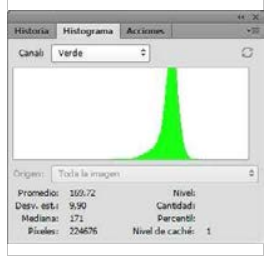

Grafica G (TT)

Valor $\mathrm{G}(\mathrm{TT})$ :

169,72

MADERA M30/RRA/ROBLE ROJO AMERICANO

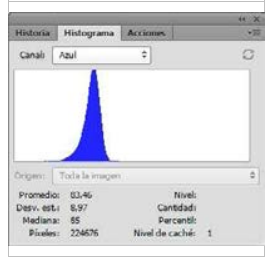

Grafica B (ST)

Valor B(ST):

83,46

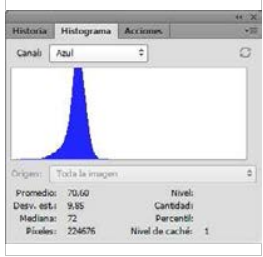

Grafica B (TT)

Valor $\mathrm{B}(\mathrm{TT})$ :

70,60

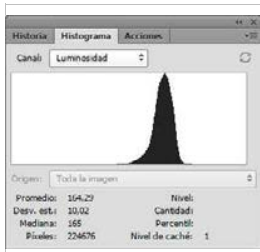

Grafica L (ST)

Valor L(ST):

164,29

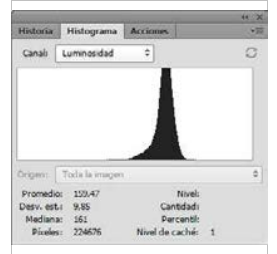

Grafica L (TT)

Valor L(TT):

159,47

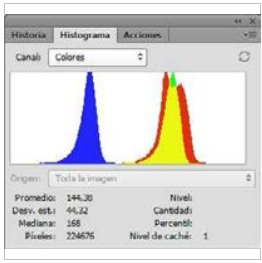

Grafica C (ST)

Valor C(ST):

144,38

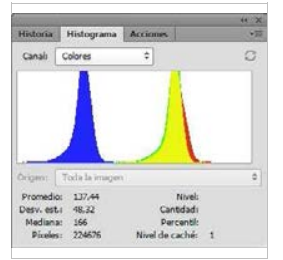

Grafica C (TT)

Valor C(TT):

137,44

Grafica G (DF): Grafica B (DF): Grafica L (DF): Grafica C (DF): Valor DF-G: Valor DF-B: Valor DF-L: Valor DF-C:

$\begin{array}{llll}3,93 & 12,86 & 4,82 & 6,94\end{array}$

GRAFICA:

\section{LEYENDA}

ST MADERA SIN TRATAR

Grafica R Histograma color Rojo Grafica G Histograma color Verde Grafica B Histograma color Azul Grafica L Histograma Luminosidad Grafica C Histograma RGB

\section{TT MADERA TRATADA}

Valor $\mathrm{R}$ Número pixeles color Rojo Valor $\mathrm{G}$ Número pixeles color Verde Valor B Número pixeles color Azul Valor $L$ Número pixeles Luminosidad Valor $C$ Número pixeles RG DF DIFERENCIA DE VALORES R;G; $\mathrm{DF}=$ Valor $\mathrm{ST}(\mathrm{R} ; \mathrm{G} ; \mathrm{B})$ - Valor TT(R;G;B

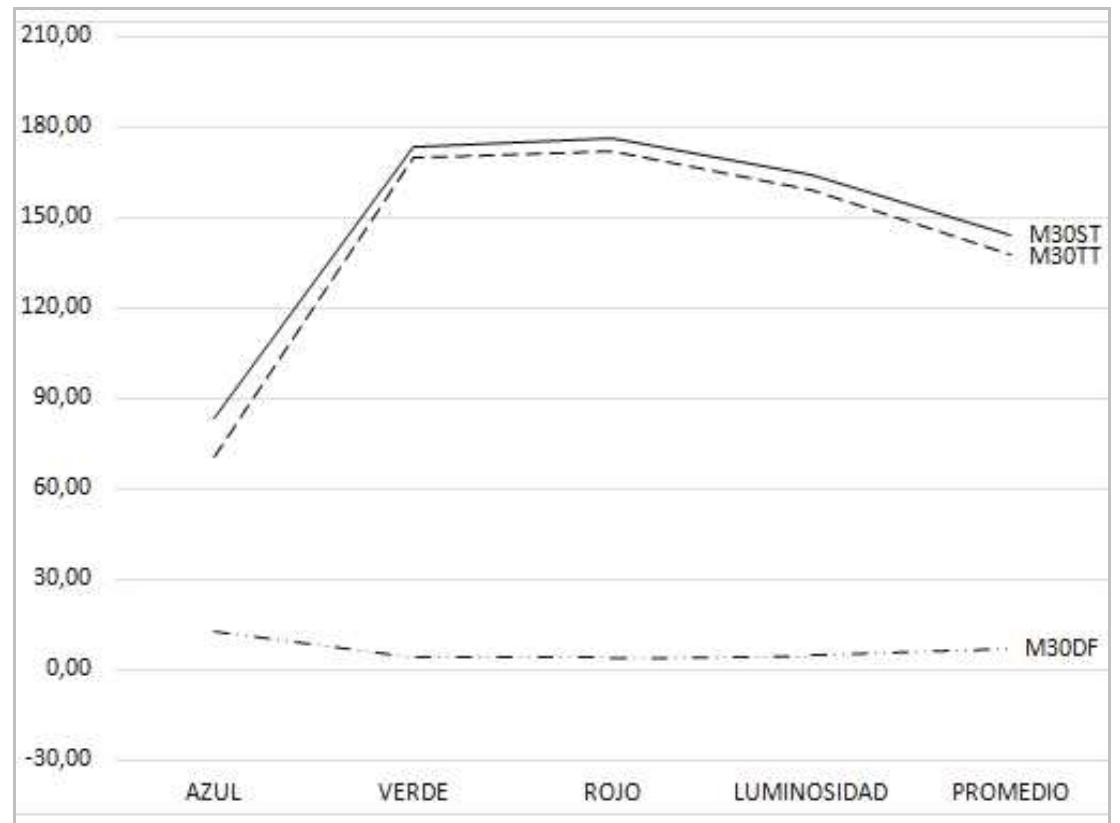

Universidad Politécnica de Madrid - Escuela Técnica Superior de Arquitectura - Departamento de Construcción y Tecnología Arquitectónica Directores: Dr. Alfonso García Santos y Dr. Antonio Rodríguez Rodríguez. Doctorando: D. Francisco Lora Toro 


\section{FICHA DE ENSAYOS DE MADERA Y ACIDOS}

\section{ACIDO A05/FM/ACIDO FÓRMICO}
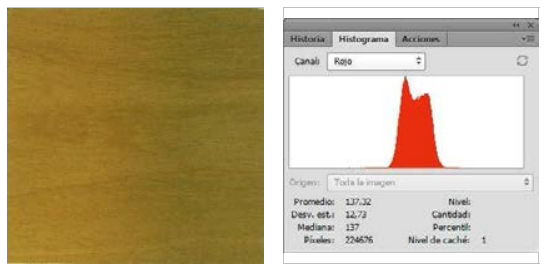

SIN TRATAR (ST): Grafica R (ST)

Valor R(ST):

137,32
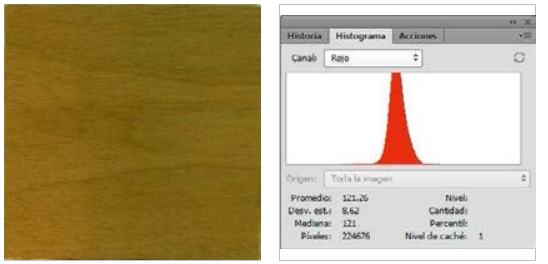

TRATADA (TT): Grafica $R(T T)$

Valor $\mathrm{R}(\mathrm{TT})$ :

121,26

DIFERENCIA (DF) Grafica R (DF): Valor DF-R: 16,06

GRAFICA

\section{LEYENDA}

ST MADERA SIN TRATAR

Grafica R Histograma color Rojo Grafica G Histograma color Verde Grafica B Histograma color Azul Grafica L Histograma Luminosidad Grafica C Histograma RGB

\section{TT MADERA TRATADA}

Valor R Número pixeles color Rojo Valor G Número pixeles color Verde Valor B Número pixeles color Azul Valor $L$ Número pixeles Luminosidad Valor C Número pixeles RG DF DIFERENCIA DE VALORES R;G; $\mathrm{DF}=$ Valor $\mathrm{ST}(\mathrm{R} ; \mathrm{G} ; \mathrm{B})$ - Valor $\mathrm{TT}(\mathrm{R} ; \mathrm{G} ; \mathrm{B}$

\section{MADERA M31/SP/SAPELLI}
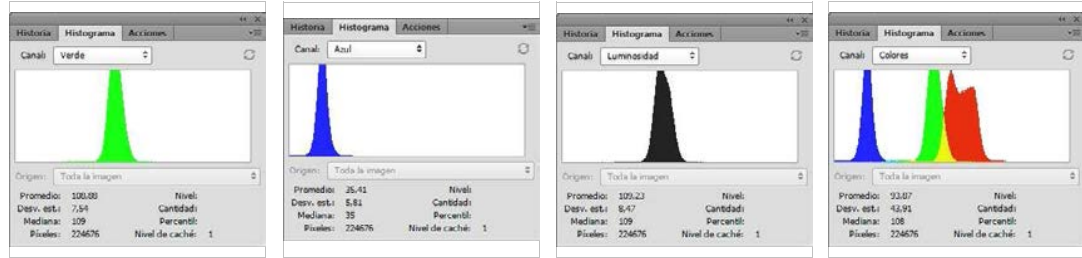

\section{Grafica G (ST)}

Grafica B (ST)

Grafica L (ST)

Grafica C (ST)

Valor $\mathrm{G}(\mathrm{ST})$ :

Valor B(ST):

Valor L(ST):

Valor C(ST):

108,88

35,41

109,23

93,87
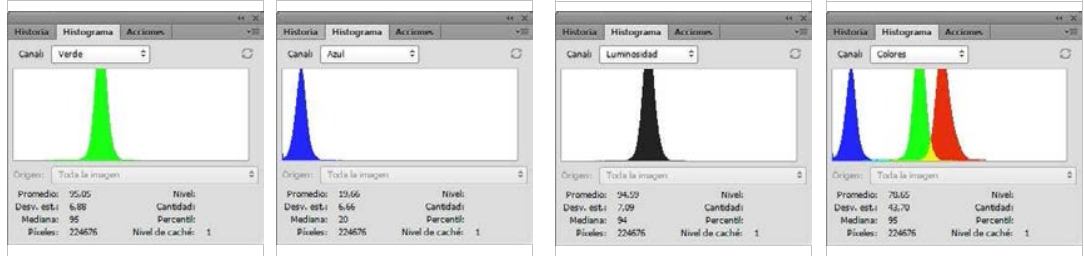

Grafica G (TT) Grafica B (TT)

Grafica L (TT)

Grafica C (TT)

Valor $\mathrm{G}(\mathrm{TT})$ :

Valor $\mathrm{B}(\mathrm{TT})$ :

Valor L(TT):

Valor $\mathrm{C}(\mathrm{TT})$ :

95,05

19,66

94,59

78,65

Grafica G (DF): Grafica B (DF): Grafica L (DF): Grafica C (DF): Valor DF-G: Valor DF-B: Valor DF-L: Valor DF-C: 13,83 15,75 14,64 15,22

Universidad Politécnica de Madrid - Escuela Técnica Superior de Arquitectura - Departamento de Construcción y Tecnología Arquitectónica Directores: Dr. Alfonso García Santos y Dr. Antonio Rodríguez Rodríguez. Doctorando: D. Francisco Lora Toro 


\section{FICHA DE ENSAYOS DE MADERA Y ACIDOS}

\section{ACIDO A05/FM/ACIDO FÓRMICO}
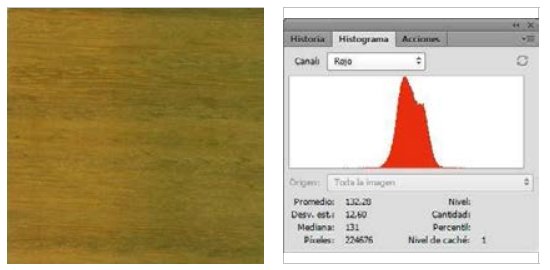

SIN TRATAR (ST): Grafica R (ST)

Valor R(ST):

132,28

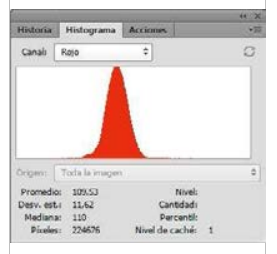

Grafica R (TT)

Valor R(TT):

109,53

DIFERENCIA (DF) Grafica R (DF): Valor DF-R: 22,75

GRAFICA

\section{LEYENDA}

ST MADERA SIN TRATAR

Grafica R Histograma color Rojo

Grafica G Histograma color Verde

Grafica B Histograma color Azul

Grafica L Histograma Luminosidad

Grafica C Histograma RGB

TT MADERA TRATADA

Valor R Número pixeles color Rojo

Valor G Número pixeles color Verde

Valor B Número pixeles color Azul

Valor $L$ Número pixeles Luminosidad

Valor C Número pixeles RG

DF DIFERENCIA DE VALORES R;G; $\mathrm{DF}=$ Valor $\mathrm{ST}(\mathrm{R} ; \mathrm{G} ; \mathrm{B})$ - Valor TT $(\mathrm{R} ; \mathrm{G} ; \mathrm{B}$

\section{MADERA M32/TL/TALI}
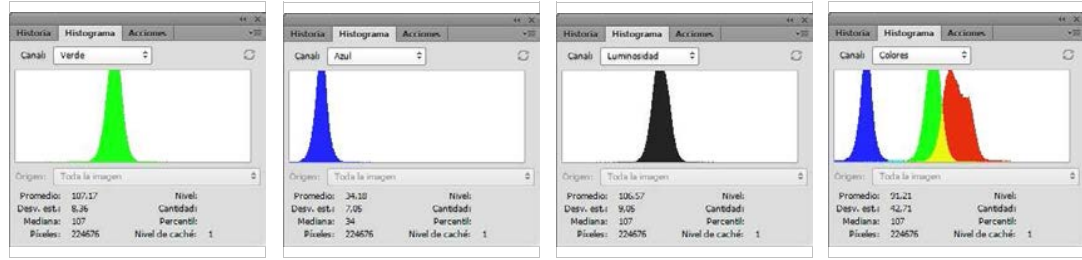

Grafica G (ST)

Grafica B (ST)

Grafica L (ST)

Grafica C (ST)

Valor $\mathrm{G}(\mathrm{ST})$ :

Valor B(ST):

Valor L(ST):

Valor C(ST):

107,17

34,18

106,57

91,21
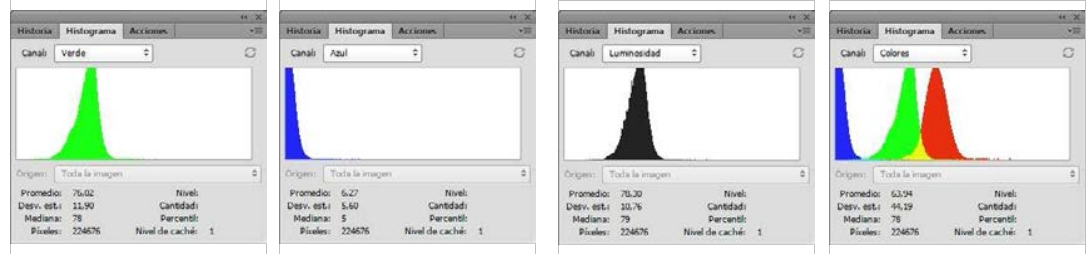

Grafica G (TT) Grafica B (TT)

Grafica L (TT)

Grafica C (TT)

Valor $\mathrm{G}(\mathrm{TT})$ :

Valor $\mathrm{B}(\mathrm{TT})$ :

Valor L(TT):

Valor $\mathrm{C}(\mathrm{TT})$ :

76,02

6,27

78,30

63,94

Grafica G (DF): Grafica B (DF): Grafica L (DF): Grafica C (DF): Valor DF-G: Valor DF-B: Valor DF-L: Valor DF-C: 31,15 27,91 28,27 27,27

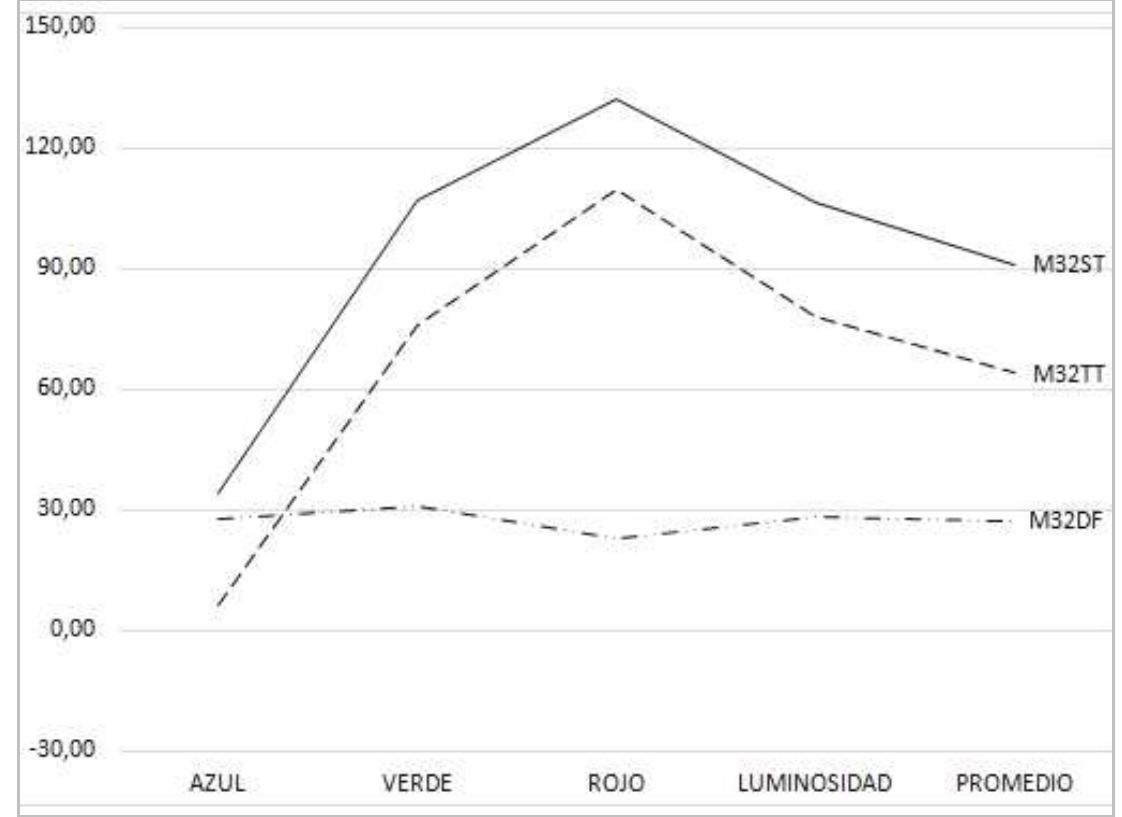

Universidad Politécnica de Madrid - Escuela Técnica Superior de Arquitectura - Departamento de Construcción y Tecnología Arquitectónica Directores: Dr. Alfonso García Santos y Dr. Antonio Rodríguez Rodríguez. Doctorando: D. Francisco Lora Toro 


\section{FICHA DE ENSAYOS DE MADERA Y ACIDOS}

\section{ACIDO A05/FM/ACIDO FÓRMICO}

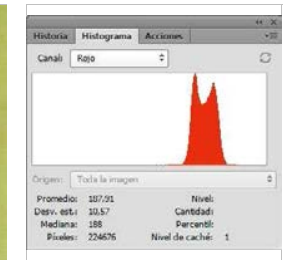

SIN TRATAR (ST): Grafica R (ST)

Valor R(ST):

187,91

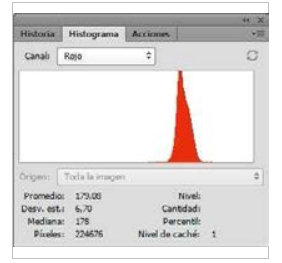

TRATADA (TT): Grafica R (TT)

Valor $\mathrm{R}(\mathrm{TT})$ :

179,08

DIFERENCIA (DF) Grafica R (DF): Valor DF-R:

8,83

GRAFICA:

\section{LEYENDA}

ST MADERA SIN TRATAR

Grafica R Histograma color Rojo

Grafica G Histograma color Verde

Grafica B Histograma color Azul

Grafica L Histograma Luminosidad

Grafica C Histograma RGB

TT MADERA TRATADA

Valor R Número pixeles color Rojo

Valor $\mathrm{G}$ Número pixeles color Verde

Valor B Número pixeles color Azul

Valor $\mathrm{L}$ Número pixeles Luminosidad

Valor C Número pixeles RG

DF DIFERENCIA DE VALORES R;G; $\mathrm{DF}=$ Valor $\mathrm{ST}(\mathrm{R} ; \mathrm{G} ; \mathrm{B})$ - Valor TT(R;G;B

\section{MADERA M33/TA/TILO AMERICANO}
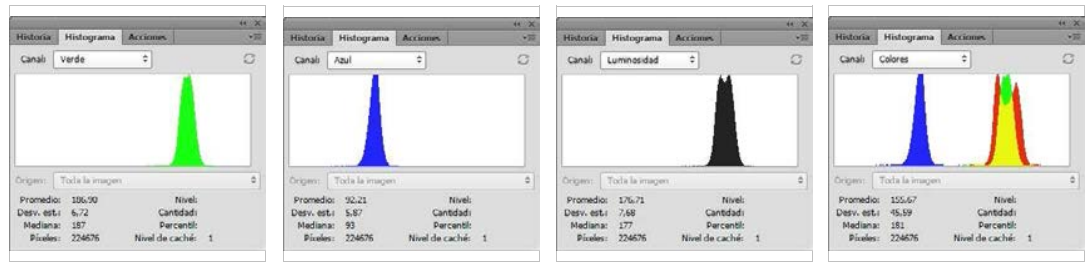

Grafica G (ST)

Grafica B (ST)

Grafica L (ST)

Grafica C (ST)

Valor $\mathrm{G}(\mathrm{ST})$ :

Valor B(ST):

Valor L(ST):

Valor C(ST):

186,90

92,21

176,71

155,67
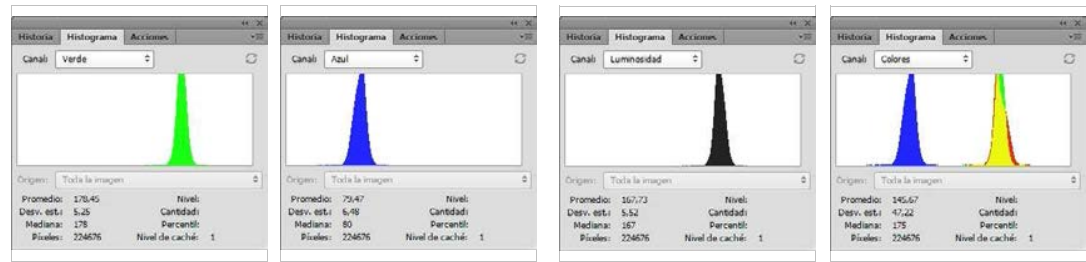

\section{Grafica G (TT)}

Grafica B (TT)

Grafica L (TT)

Grafica C (TT)

Valor $\mathrm{B}(\mathrm{TT})$ :

Valor L(TT):

Valor C(TT):

178,45

79,47

167,73

145,67

Grafica G (DF): Grafica B (DF): Grafica L (DF): Grafica C (DF): Valor DF-G: Valor DF-B: Valor DF-L: Valor DF-C:

$\begin{array}{llll}8,45 & 12,74 & 8,98 & 10,00\end{array}$

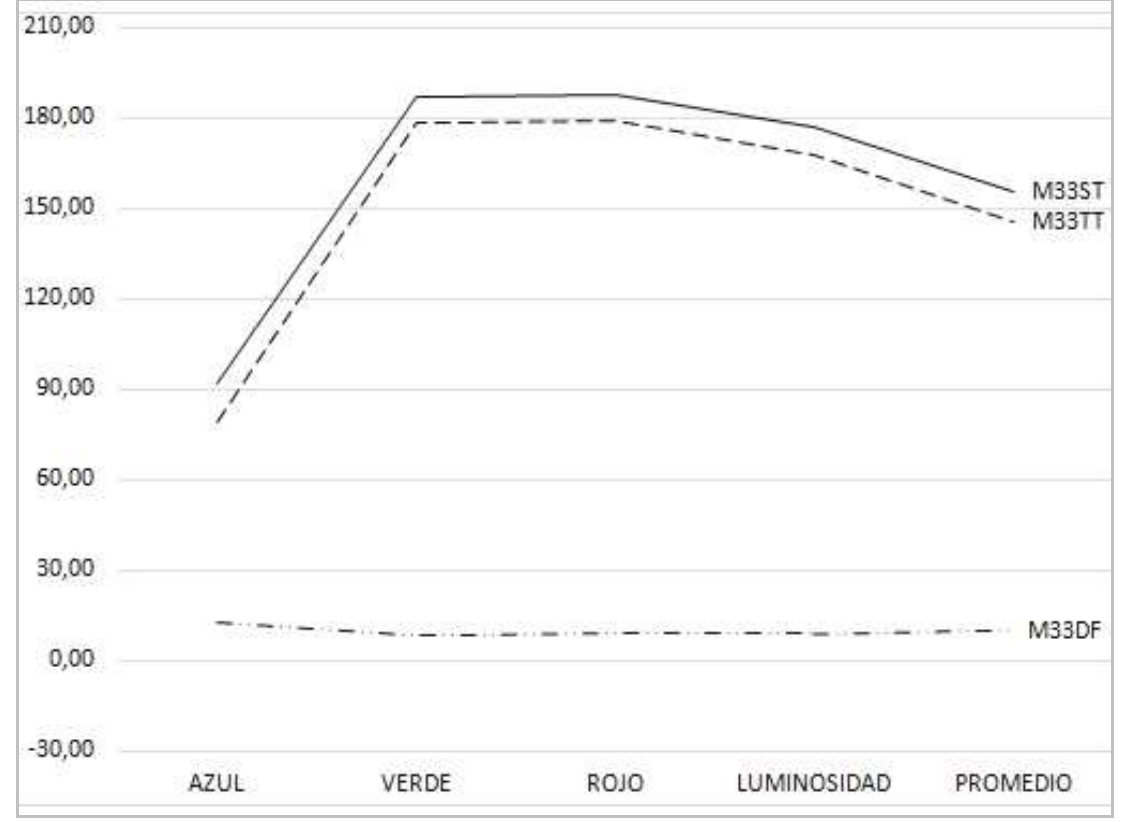

Universidad Politécnica de Madrid - Escuela Técnica Superior de Arquitectura - Departamento de Construcción y Tecnología Arquitectónica Directores: Dr. Alfonso García Santos y Dr. Antonio Rodríguez Rodríguez. Doctorando: D. Francisco Lora Toro 


\section{FICHA DE ENSAYOS DE MADERA Y ACIDOS}

\section{ACIDO A05/FM/ACIDO FÓRMICO}
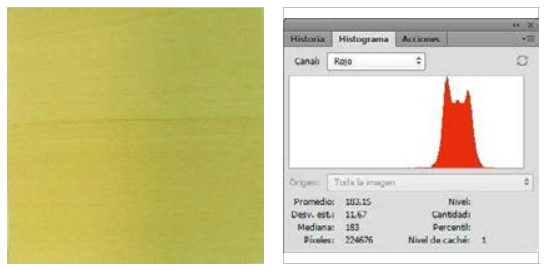

SIN TRATAR (ST): Grafica R (ST)

Valor R(ST):

183,15

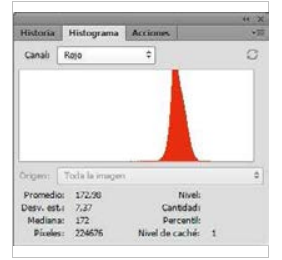

TRATADA (TT): Grafica R (TT)

Valor $\mathrm{R}(\mathrm{TT})$ :

172,98

DIFERENCIA (DF) Grafica R (DF):

Valor DF-R:

10,17

GRAFICA:

\section{LEYENDA}

ST MADERA SIN TRATAR

Grafica R Histograma color Rojo

Grafica G Histograma color Verde

Grafica B Histograma color Azul

Grafica L Histograma Luminosidad

Grafica C Histograma RGB

\section{TT MADERA TRATADA}

Valor R Número pixeles color Rojo

Valor $\mathrm{G}$ Número pixeles color Verde

Valor B Número pixeles color Azul

Valor $\mathrm{L}$ Número pixeles Luminosidad

Valor C Número pixeles RG

DF DIFERENCIA DE VALORES R;G; $\mathrm{DF}=$ Valor $\mathrm{ST}(\mathrm{R} ; \mathrm{G} ; \mathrm{B})$ - Valor TT(R;G;B

\section{MADERA M34/TE/TILO EUROPEO}
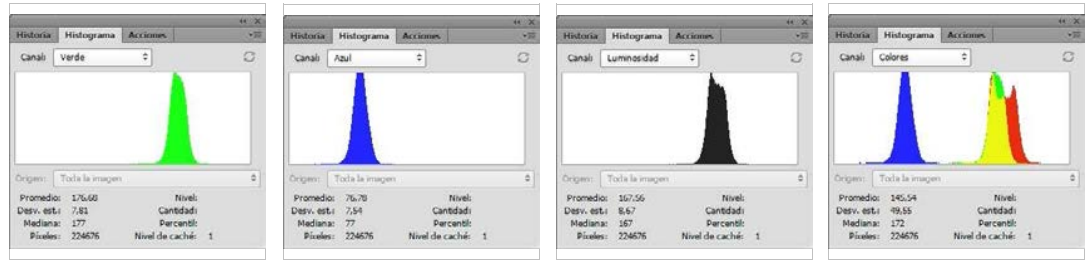

Grafica G (ST)

Grafica B (ST)

Grafica L (ST)

Grafica C (ST)

Valor $\mathrm{G}(\mathrm{ST})$ :

Valor B(ST):

Valor L(ST):

Valor C(ST):

176,78

76,78

167,56

145,54
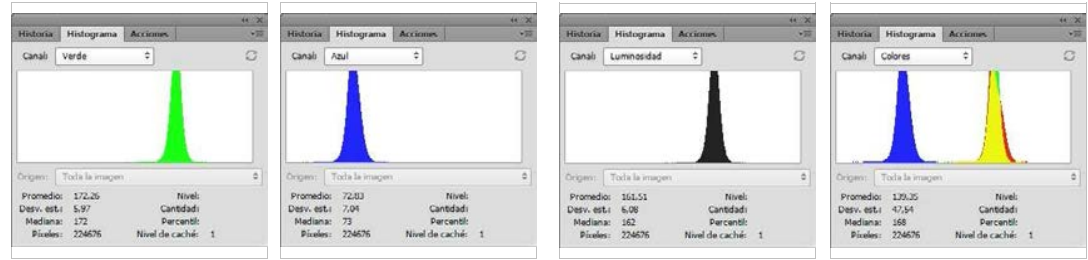

Grafica G (TT)

Grafica B (TT)

Grafica L (TT)

Grafica C (TT)

Valor $\mathrm{G}(\mathrm{TT})$ :

Valor $\mathrm{B}(\mathrm{TT})$ :

Valor L(TT):

Valor $\mathrm{C}(\mathrm{TT})$ :

172,26

72,83

161,51

139,35

Grafica G (DF): Grafica B (DF): Grafica L (DF):

Grafica C (DF):

Valor DF-G: Valor DF-B:

Valor DF-L:

Valor DF-C:

4,52

3,95

6,05

6,19

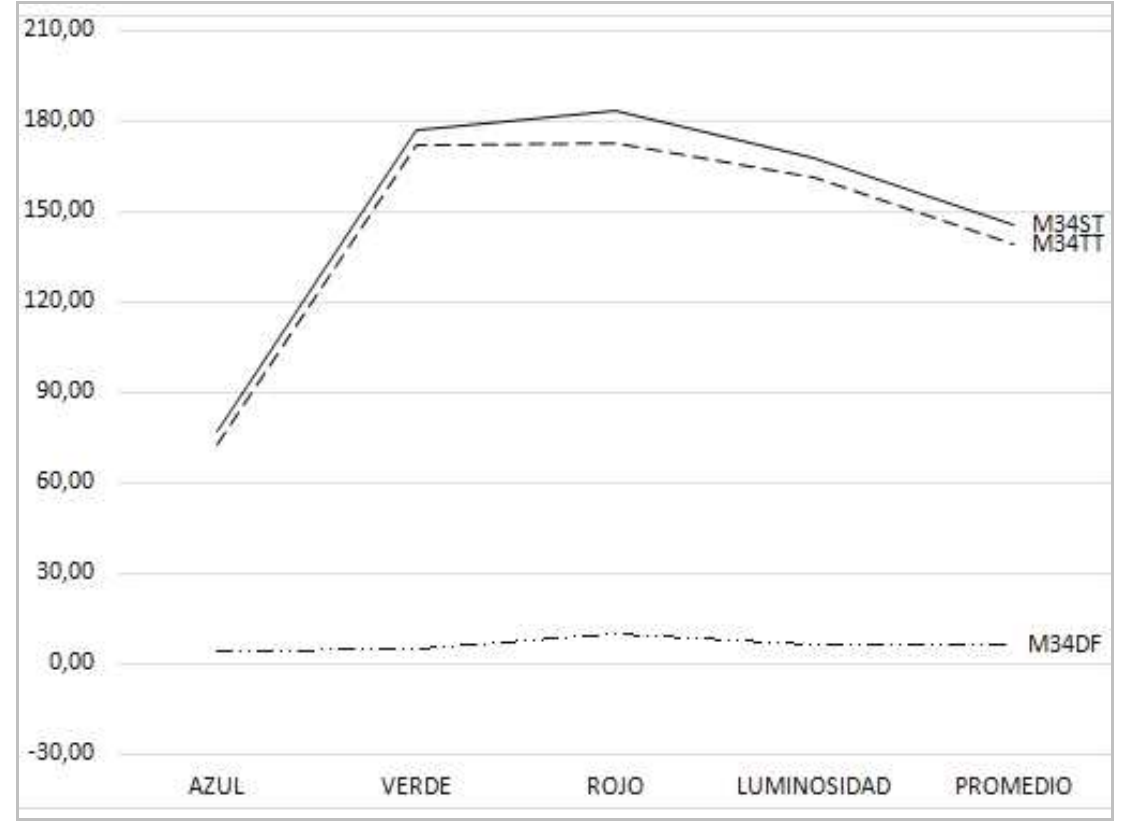

Universidad Politécnica de Madrid - Escuela Técnica Superior de Arquitectura - Departamento de Construcción y Tecnología Arquitectónica Directores: Dr. Alfonso García Santos y Dr. Antonio Rodríguez Rodríguez. Doctorando: D. Francisco Lora Toro 


\section{A06 / ÁCIDO FOSFÓRICO}

\section{FICHA DE ENSAYOS DE MADERA Y ACIDOS}

\section{ACIDO A06/FF/ACIDO FOSFORICO}
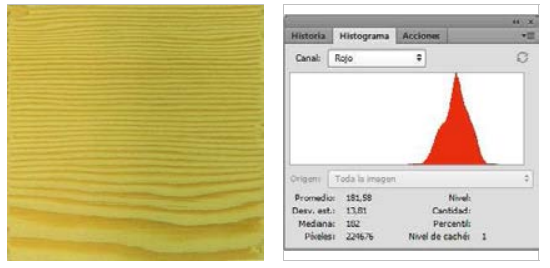

SIN TRATAR (ST): Grafica R (ST)

Valor R(ST):

181,58

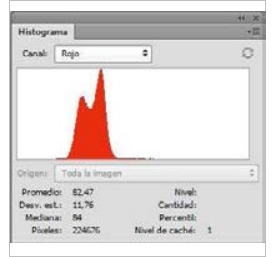

TRATADA (TT): Grafica R (TT)

Valor $\mathrm{R}(\mathrm{TT})$ :

82,47

DIFERENCIA (DF) Grafica R (DF): Valor DF-R: 99,11

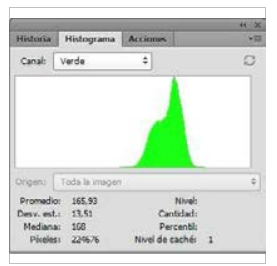

Grafica G (ST)

Valor $\mathrm{G}(\mathrm{ST})$ :

165,93

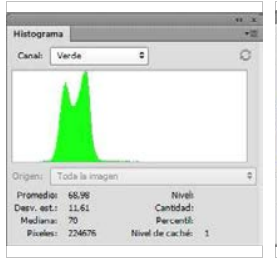

Grafica G (TT)

Valor $\mathrm{G}(\mathrm{TT})$ :

68,98

\section{MADERA M01/AD/ABETO DOUGLAS}

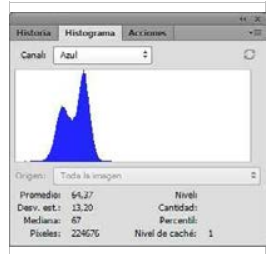

Grafica B (ST)

Valor B(ST):

64,37

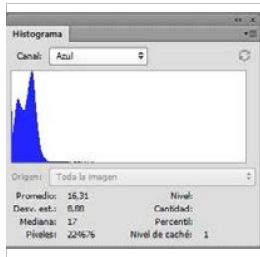

Grafica B (TT)

Valor $\mathrm{B}(\mathrm{TT})$ :

16,31

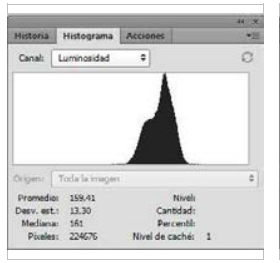

Grafica L (ST)

Valor L(ST):

159,41

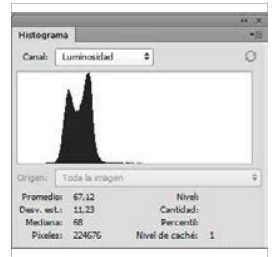

Grafica L (TT)

Valor L(TT):

67,12

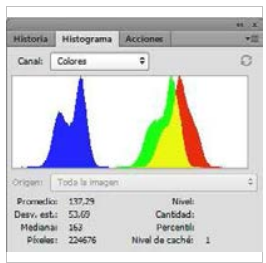

Grafica C (ST)

Valor C(ST):

137,29

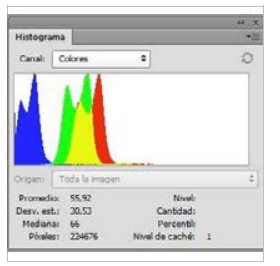

Grafica C (TT)

Valor C(TT):

55,92

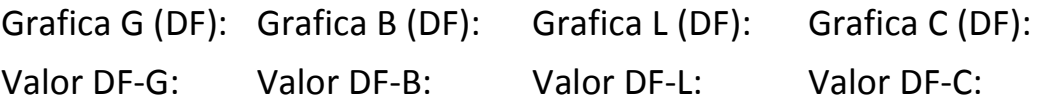

96,95

48,06

92,29

81,37

GRAFICA:

\section{LEYENDA}

ST MADERA SIN TRATAR

Grafica R Histograma color Rojo

Grafica G Histograma color Verde

Grafica B Histograma color Azul

Grafica L Histograma Luminosidad

Grafica C Histograma RGB

\section{TT MADERA TRATADA}

Valor $\mathrm{R}$ Número pixeles color Rojo

Valor G Número pixeles color Verde

Valor B Número pixeles color Azul

Valor L Número pixeles Luminosidad

Valor $C$ Número pixeles RG

DF DIFERENCIA DE VALORES R;G;

$\mathrm{DF}=$ Valor $\mathrm{ST}(\mathrm{R} ; \mathrm{G} ; \mathrm{B})$ - Valor TT(R;G;B

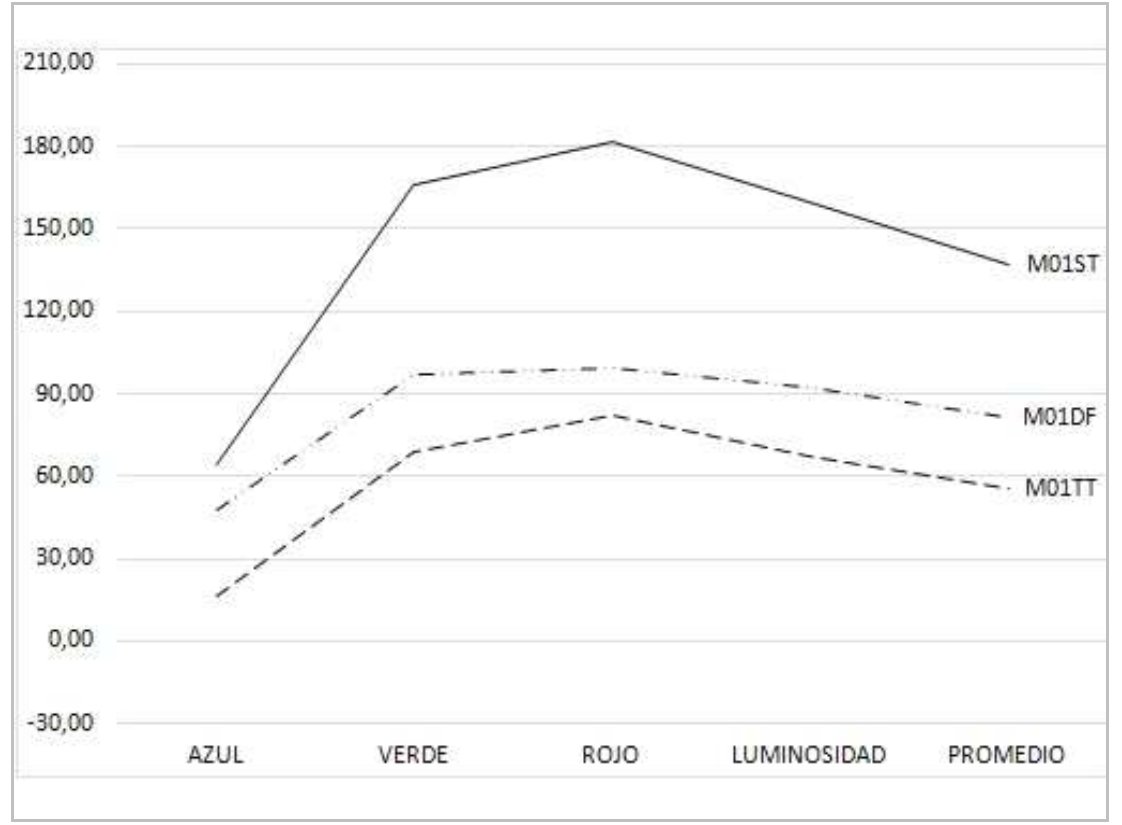

Universidad Politécnica de Madrid - Escuela Técnica Superior de Arquitectura - Departamento de Construcción y Tecnología Arquitectónica Directores: Dr. Alfonso García Santos y Dr. Antonio Rodríguez Rodríguez. Doctorando: D. Francisco Lora Toro 


\section{FICHA DE ENSAYOS DE MADERA Y ACIDOS}

\section{ACIDO A06/FF/ACIDO FOSFORICO}

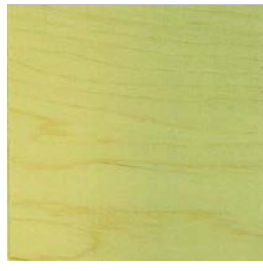

SIN TRATAR (ST): Grafica R (ST)

Valor R(ST):

188,15
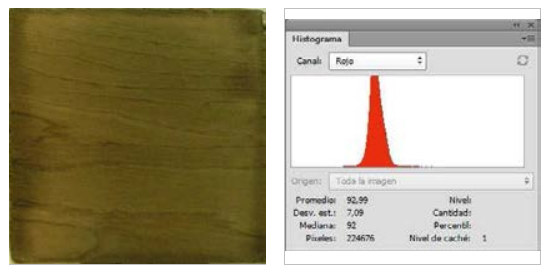

TRATADA (TT): Grafica R (TT)

Valor $\mathrm{R}(\mathrm{TT})$ :

92,99

DIFERENCIA (DF) Grafica R (DF): Valor DF-R: 95,16

GRAFICA:

\section{LEYENDA}

ST MADERA SIN TRATAR

Grafica R Histograma color Rojo

Grafica G Histograma color Verde

Grafica B Histograma color Azul

Grafica L Histograma Luminosidad

Grafica C Histograma RGB

\section{TT MADERA TRATADA}

Valor R Número pixeles color Rojo

Valor G Número pixeles color Verde Valor B Número pixeles color Azul Valor $L$ Número pixeles Luminosidad Valor C Número pixeles RG DF DIFERENCIA DE VALORES R;G; $\mathrm{DF}=$ Valor $\mathrm{ST}(\mathrm{R} ; \mathrm{G} ; \mathrm{B})$ - Valor TT(R;G;B

\section{MADERA M02/ABA/ARCE BLANDO AMERICANO}

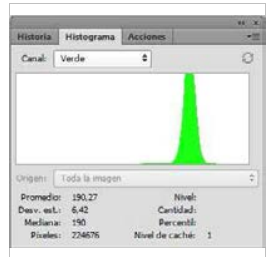

Grafica G (ST)

Valor G(ST):

190,27
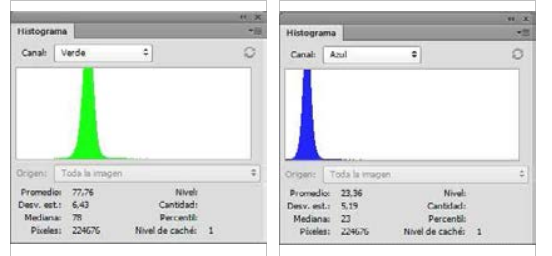

Grafica G (TT)

Grafica B (TT)

Grafica L (TT)

Valor $\mathrm{B}(\mathrm{TT})$ :

23,36

77,76

Grafica G (DF): Grafica B (DF):

Grafica L (DF):

Grafica C (DF):

Valor DF-G:

Valor DF-B:

Valor DF-L:

Valor DF-C:

112,51

85,39

104,29

97,69

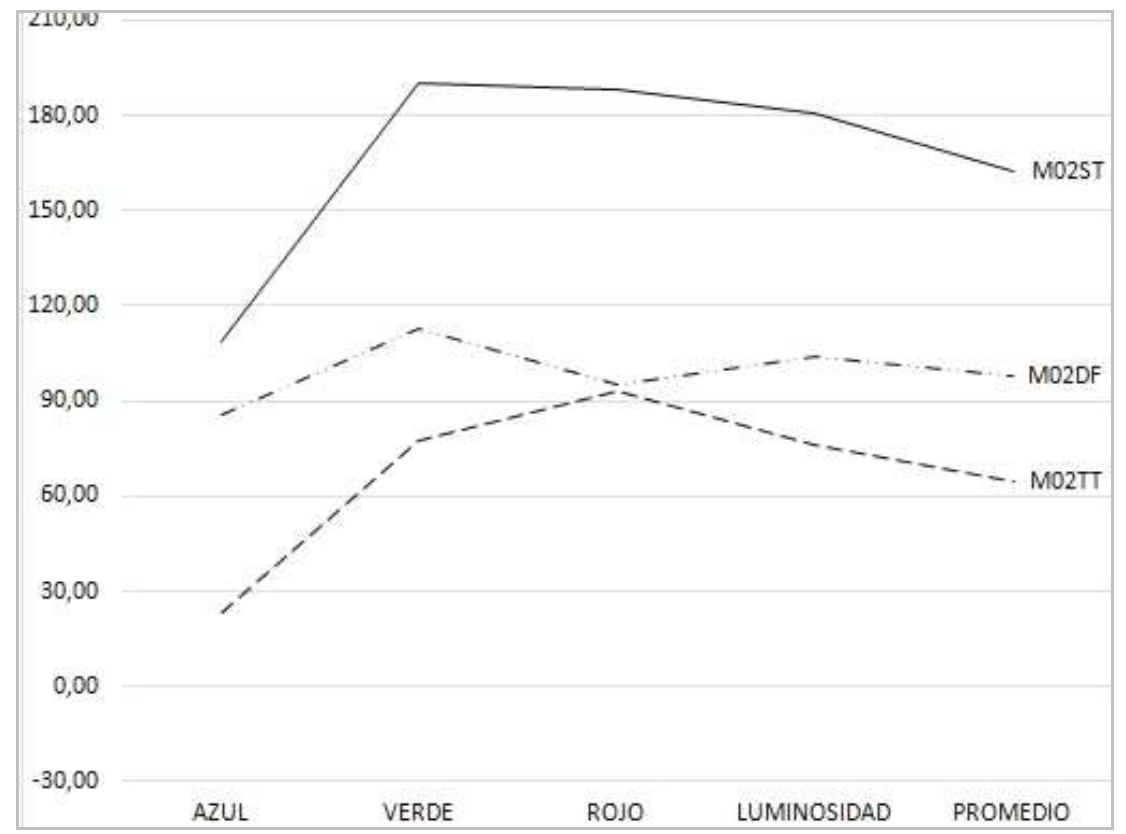

Universidad Politécnica de Madrid - Escuela Técnica Superior de Arquitectura - Departamento de Construcción y Tecnología Arquitectónica Directores: Dr. Alfonso García Santos y Dr. Antonio Rodríguez Rodríguez. Doctorando: D. Francisco Lora Toro 